\title{
Sheila Schneck
}

\section{FORMAÇÃO DO BAIRRO DO BEXIGA EM SÃO PAULO: \\ LOTEADORES, PROPRIETÁRIOS, CONSTRUTORES, TIPOLOGIAS \\ EDILÍCIAS E USUÁRIOS}

(1881-1913)

\author{
Dissertação de Mestrado \\ apresentada ao Programa de Pós-Graduação \\ Faculdade de Arquitetura e Urbanismo \\ Universidade de São Paulo
}

Área de Concentração: História e Fundamentos da Arquitetura e do Urbanismo

Orientador: Profa. Dra. Beatriz Siqueira Bueno

São Paulo 


\section{RESUMO}

De fins do Império aos primeiros anos da República, o Brasil passou por transformações que marcaram definitivamente as suas cidades. Mais do que a substituição de um regime político por outro, tratava-se de um período de transição de uma economia escravocrata para outra capitalista, baseada no trabalho livre, na qual a mão-de-obra imigrante foi fundamental. A cidade de São Paulo, centro de comércio e da indústria nascente, tornou-se foco de atração humana. O fluxo de mão-de-obra imigrante e de ex-escravos para a cidade acarretou grande crescimento populacional e a necessidade de novas moradias, com a consequente ocupação das áreas adjacentes ao centro da cidade.

A proposta deste trabalho é estudar o processo de formação do bairro do Bexiga, como um dos espaços ocupados entre as últimas décadas do século XIX e as primeiras do XX, desde a época da antiga chácara de Antonio José Leite Braga, ainda no Império, passando pelo seu desmembramento em lotes comercializáveis, pela venda dos terrenos e construção dos imóveis e, finalmente, pela ocupação destes por diferentes usuários, já na República. Busca-se, assim, analisar os mecanismos de produção de espaços urbanos pela iniciativa privada, os principais atores sociais envolvidos e as estratégias do poder público para disciplinar o parcelamento do solo e a construção de moradias, via legislação urbanística e sanitária.

Palavras-chave: Arquitetura/Bexiga/Bairros/História/São Paulo/Urbanização 


\title{
FORMATION OF BEXIGA NEIGHBORHOOD IN SÃO PAULO: ENTREPENEURS, OWNERS,BUILDERS, TYPOLOGIES AND \\ USERS (1881-1913)
}

\begin{abstract}
Since the end of the Empire to the early years of the Republic, Brazil has undergone transformations that have marked definitively its cities. More than the replacement of a political regime on the other, it was also a period of transition from an economy based on slavery to another capitalist, based on free work, where immigrant workmanship was fundamental. The city of São Paulo, which was the centre of commerce and a rising industry, became the focus of human attraction. The flow of immigrant workmanship and ex-slaves into the city resulted in the significant growth of population and the need for new homes, with the consequent occupation of the areas adjacent to the centre of the city.

The purpose of this study is to examine the process of formation of Bexiga's district as one of the occupied areas between the last decades of the nineteenth century and the beginning of the twentieth, since the time of the ancient farm of Antonio José Leite Braga - which is still in the Empire - passing to its dismemberment in commercialy viable lots, its sale and the construction of homes and, eventually, its occupation by different people - until it became a Republic. The main objective is to analyse the mechanisms of production of urban areas by the private sector, the main social actors involved, as well as the strategies of public power to organize the division of the land and the construction of homes, through urban and sanitary legislation.
\end{abstract}

Key Words: Architecture/Bexiga/Neighborhoods/History/São Paulo/Urbanization 


\section{LISTA DAS ILUSTRAÇÕES}

Figura 1 - Detalhe da "Planta da Cidade de São Paulo (1881)". Cia. Cantareira e Esgotos, Fonte: Informativo Arquivo Histórico Municipal, 4 (20): set/out.2008, AHMWL

Figura 2 - "São Paulo - Chácaras, sítios e fazendas à volta de São Paulo, desde o século XVIII". Gastão Cesar Bierrembach de Lima, Exposição do IV Centenário de São Paulo. Fonte: Arquivo Aguirra/Museu Paulista/USP

Figura 3 - "Mappa da Cidade de São Paulo e seus Subúrbios (1844-1847)". C. A. Bresser.Fonte: Informativo Arquivo Histórico Municipal, 4 (20): set/out.2008, AHMWL

Figura 4 - Largo da Memória. Detalhe da Ponte do Lorena. Autor: Militão Augusto de Azevedo, 1862. Fonte: Coleção SAN/DIM/DPH/SMC/PMSP

Figura 5 - Largo do Piques. Detalhe de tropeiros. Autoria desconhecida, 1862 Fonte: Coleção SAN/DIM/DPH/SMC/PMSP

Figura 6 - “Mappa da Imperial Cidade de São Paulo (1855)”. Carlos Rath. Fonte: Informativo Arquivo Histórico Municipal, 4 (20): set/out.2008, AHMWL

Figura 7 - "Planta da Cidade de São Paulo (1868)". Atribuída a Carlos Frederico Rath. Fonte: Informativo Arquivo Histórico Municipal, 4 (20): set/out.2008, AHMWL 50

Figura 8 - "Planta da Cidade de São Paulo (1881)". Cia. Cantareira e Esgotos. Fonte: Informativo Arquivo Histórico Municipal, 4 (20): set/out.2008, AHMWL

Figura 9 - "Planta dos Terrenos do Bexiga (1890)". Fernando de Albuquerque. Fonte: Arquivo Aguirra/Museu Paulista/USP

Figura 10 - "Planta da Capital do Estado de São Paulo e seus arrabaldes (1890)". Jules Martin. Fonte: Informativo Arquivo Histórico Municipal, 4 (20): set/out.2008, AHMWL

Figura 11 - “Planta da cidade de São Paulo (1895)”. Ugo Bonvicini. Fonte: Informativo Arquivo Histórico Municipal, 4 (20): set/out.2008, AHMWL

Figura 12 - “Planta Geral da Capital de São Paulo (1897)”. Gomes Cardim. Fonte: Informativo Arquivo Histórico Municipal, 4 (20): set/out.2008, AHMWL

Figura 13 - "Planta Geral da Cidade de São Paulo (1905)". Alexandre M. Coccoci e L. Fructuoso. Fonte: Histórico Demográfico do Município de São Paulo, SEMPLA

Figura 14 - Morro dos Ingleses. Vista do córrego da Saracura. Autoria desconhecida, 1925-1929. Fonte: Coleção SAN/DIM/DPH/SMC/PMSP

Figura 15 - "Planta da Cidade de São Paulo (1913)". Alexandre M. Coccoci e L. Fructuoso. Fonte: Histórico Demográfico do Município de São Paulo, SEMPLA 
Figura 16 - Vale do Anhangabaú. Imagem da Saracura em direção ao Centro.

Figura 17 - Detalhe do "Mappa da Capital da Província de São Paulo" com destaque para a Oficina de Santo Antonio. Fernando de Albuquerque e Jules Martin, 1877. Fonte: Informativo Arquivo Histórico Municipal, 4 (20): set/out.2008, AHMWL 75

Figura 18 - Detalhe da Planta SARA Brasil, contendo a localização da residência de Fernando Albuquerque. 1930. Fl. 37. Fonte: AHMWL

Figura 19 - Rua Fortaleza, “junto ao no 12”. Série Obras Particulares, 1906.

Cx. E1/F1. Fonte: AHMWL

Figura 20 - Rua Fortaleza s/nº. Série Obras Particulares, 1906. Cx. E1/F1-06.

Fonte: AHMWL

Figura 21 - Rua Conselheiro Ramalho no 222. Série Obras Particulares, 1907.

Cx. C2/D1-19. Fonte: AHMWL

Figura 22 - Detalhe da Planta SARA Brasil, contendo a área de atuação de Joaquim Antunes. 1930. Fl. 37. Fonte: AHMWL

Figura 23 - Rua Conselheiro Ramalho no 82. Série Obras Particulares, 1907.

Cx. C2/D1-19. Fonte: AHMWL

Figura 24 - Detalhe da Planta SARA Brasil, contendo a área de atuação da família Passalacqua. 1930. Fl. 37. Fonte: AHMWL

Figura 25 - Detalhe da Planta SARA Brasil, contendo a área de atuação de Paschoal Gazíneo. 1930. Fl. 37. Fonte: AHMWL

Figura 26 - Rua Santo Antonio no 49. Série Obras Particulares, 1912. Cx. S1. Fonte: AHMWL

Figura 27 - Ladeira do Ouvidor. Casa que pertenceu ao Padre Paschoal Gazíneo. Autoria desconhecida, 1900/1910. Fonte: Coleção SAN/DIM/DPH/SMC/PMSP

Figura 28 - Rua Manoel Dutra no 29. Série Obras Particulares, 1906. Cx. M1-09.

Fonte: AHMWL

Figura 29 - Rua Rui Barbosa s/nº. Série Obras Particulares, 1906. Cx. Q1/R1, Fonte: AHMWL

Figura 30 - Rua Major Diogo s/no. Série Obras Particulares, 1906. Cx. M1-09. Fonte: AHMWL

Figura 31 - Rua Santo Antonio, “junto ao 19”. Série Obras Particulares, 1906. Cx. S1-12. Fonte: AHMWL

Figura 32 - Rua 14 de Julho no 46. Série Obras Particulares, 1912. Cx. P4/Q1.

Fonte: AHMWL

Figura 33 - Rua Rui Barbosa n 68. Série Obras Particulares, 1906. Cx. Q1/R1. Fonte: AHMWL 
Figura 34 - Detalhe da "Planta Geral da Capital de São Paulo (1905)", com as ruas do Bexiga envolvidas no perímetro urbano. Coccoci e Fructuoso. Fonte: Histórico Demográfico do Município de São Paulo, SEMPLA

Figura 35 - Rua Santo Amaro no 89. Série Obras Particulares, 1906. Cx. S1. Fonte: AHMWL

Figura 36 - Casa simples, Rua Santo Amaro no 17. Série Obras Particulares, 1906. Cx. S1-12. Fonte: AHMWL

Figura 37 - Casa de fundos, Rua Santo Amaro no 124. Série Obras Particulares, 1907. Cx. 26. Fonte: AHMWL

Figura 38 - Casas em série, Rua Fortaleza, esquina com Rui Barbosa. Série Obras Particulares, 1906. Cx. E1/F1-06. Fonte: AHMWL

Figura 39 - Vila, Rua Fortaleza s/nº. Série Obras Particulares, 1906. Cx. E1/F1. Fonte: AHMWL

Figura 40 - Sobrado com dupla residência, Rua 13 de Maio s/no . Série Obras Particulares, 1913. Cx. T3. Fonte: AHMWL

Figura 41 - Casa de uso misto, Rua Rui Barbosa n 108T. Série Obras Particulares, 1906. Cx. Q1/R1. Fonte: AHMWL

Figura 42 - Casa com mais de 6 cômodos, Rua Major Diogo no 5. Série Obras Particulares, 1910. Cx. M1. Fonte: AHMWL

Figura 43 - Casa com até 3 cômodos, Rua Rui Barbosa no 104T. Série Obras Particulares, 1906. Cx. Q1/R1. Fonte: AHMWL

Figura 44 - Casa com 4 cômodos, Rua da Abolição no 37. Série Obras Particulares, 1906. Cx. 1-01. Fonte: AHMWL

Figura 45 - Casas em série geminadas, com 5 cômodos, Rua São Domingos $n^{\circ} 8$ e 10. Série Obras Particulares, 1906. Cx. S1-12. Fonte: AHMWL

Figura 46 - Casa com 6 cômodos, Rua Conselheiro Ramalho no 106. Série Obras Particulares, 1906. Cx. C2/D1-05. Fonte: AHMWL

Figura 47 - Outra casa com + 6 cômodos, Rua Santo Antonio, "em frente ao no 75". Série Obras Particulares, 1906. Cx. S1-12. Fonte: AHMWL

Figura 48 - Concentração de casas simples, por ruas. Planta SARA Brasil , 1930. Fl. 37. Fonte: AHMWL

Figura 49 - Concentração de casas de fundos, por ruas. Planta SARA Brasil , 1930. Fl. 37. Fonte: AHMWL

Figura 50 - Concentração de casas em série, por ruas. Planta SARA Brasil , 1930. Fl. 37. Fonte: AHMWL

Figura 51 - Concentração de vilas, por ruas. Planta SARA Brasil , 1930. Fl. 37. Fonte: AHMWL 
Figura 52 - Concentração de sobrados com dupla residência, por ruas. Planta SARA Brasil , 1930. Fl. 37. Fonte: AHMWL

Figura 53 - Concentração de casas de uso misto, por ruas. Planta SARA Brasil, 1930. Fl. 37. Fonte: AHMWL

Figura 54 - Vale do Anhangabaú e vista do Bexiga. Foto: Aurélio Becherini, 1911. Fonte: Coleção SAN/DIM/DPH/SMC/PMSP

Figura 55 - Travessa Santo Amaro. Autoria desconhecida, 1911/1912. Fonte:

Coleção SAN/DIM/DPH/SMC/PMSP

Figura 56 - Largo do Riachuelo. Detalhe Rua Santo Amaro. Autoria

desconhecida, 1926. Fonte: Acervo Fundação Energia e Saneamento

Figura 57 - Rua Santo Amaro em direção à Av.Paulista. Detalhe casas. Foto:

Guilherme Gaensly, 1903. Fonte: Acervo Fundação Energia e Saneamento

Figura 58 - Rua Santo Amaro em direção ao Centro. Detalhe casa no barranco. Foto: Guilherme Gaensly, 1903. Fonte: Acervo Fundação Energia e Saneamento

Figura 59 - Avenida Brigadeiro Luiz Antonio e casas da Baronesa de Limeira. Detalhe tilburi e bonde. Foto: Guilherme Gaensly, 1900. Fonte: Coleção SAN/DIM/DPH/SMC/PMSP

Figura 60 - Rua São Domingos. Nos detalhes, Café Soberano e carroças.

Autoria desconhecida, 25/07/1922. Fonte: Divisão do AHMWL/DPH/SMC

Figura 61 - Rua São Domingos. Nos detalhes, casario. Autoria desconhecida, 25/07/1922. Fonte: Divisão do AHMWL/DPH/SMC

Figura 62 - Rua Manoel Dutra. No detalhe, casario. Autoria desconhecida, c.1920. Fonte: Divisão do AHMWL/DPH/SMC

Figura 63 - Rua 13 de Maio. Autoria desconhecida, 30/07/1921. Fonte: Divisão do AHMWL/DPH/SMC

Figura 64 - Largo São Manoel. Autoria desconhecida, 20/08/1930. Fonte: Acervo Fundação Energia e Saneamento

Figura 65 - Cortiço Raphael Pellegrini, Rua Maria José nº 3., Série Obras Particulares, 1906. Cx. M1-09. Fonte: AHMWL

Figura 66 - Cortiço Raphaela Russo, Rua Major Diogo no 85A. Série Obras Particulares, 1900. V.275, p.49. Fonte: AHMWL

Figura 67 - Cortiço Thomazo Lupo, Rua Rui Barbosa n 24. Série Obras Particulares, 1907. Cx. 25. Fonte: AHMWL 
Figura 70 - Cortiço Francisco Perroto, Rua 13 de Maio nº 20. Série Obras

Particulares, 1893. V.20. Fonte: AHMWL

Figura 71 - Cortiço Victor Ricci, Rua Major Diogo no 182. Série Obras

Particulares, 1914. Cx. M1. Fonte: AHMWL

Figura 72 - Antonio Fernandes Pinto, Rua Santo Antonio, esquina com Largo do Riachuelo. Série Obras Particulares, 1913. Cx. S2. Fonte: AHMWL

Figura 73 - Antonio Fernandes Pinto, Rua Santo Antonio nº 6. Série Obras

Particulares, 1906. Cx. S1-12. Fonte: AHMWL

Figura 74 - Localização cortiços e/ou habitações coletivas. Planta SARA Brasil. 1930. Fl. 37. Fonte: AHMWL

Figura 75 - Cortiço Conselheiro Ramalho no 247A. Detalhe crianças.

Foto: Geraldo Paula Souza, c.1919-25. Fonte: Centro de Memória da Saúde Pública/Fac. Saúde Pública/USP

Figura 76 - Cortiço Major Diogo no 114. Foto: Geraldo Paula Souza, c.1919-25.

Fonte: Centro de Memória da Saúde Pública/Fac. de Saúde Pública/USP

Figura 77 - Cortiço Rui Barbosa no 32. Foto: Geraldo Paula Souza, c.1919-25.

Fonte: Centro de Memória da Saúde Pública/Fac. de Saúde Pública/USP

Figura 78 - Ocupação das ruas. Planta SARA Brasil.1930. Fl. 37. Fonte: AHMWL

Figura 79 - Rua da Saracura Grande. Autoria desconhecida, s/data. Fonte: Coleção SAN/DIM/DPH/SMC/PMSP

Figura 80 - Ruas com maior concentração das atividades produtivas. Planta SARA Brasil.1930. Fl. 37. Fonte: AHMWL

Figura 81 - Detalhe do Largo do Riachuelo. Carroças e cocheiros. Autoria desconhecida, 1926. Fonte: Acervo Fundação Energia e Saneamento

Figura 82 - Barrancos Saracura Grande. Foto: Geraldo Paula Souza, s/data. Fonte:

Centro de Memória da Saúde Pública/Fac. de Saúde Pública/USP

Figura 83 - Fundos de cortiço na Saracura Grande. Detalhe estábulo. Foto: Geraldo Paula Souza, s/data. Fonte: Centro de Memória da Saúde Pública/Fac. de Saúde Pública/USP

Figura 84 - Latrina Saracura Grande. Detalhe casinhas. Foto: Geraldo Paula Souza, s/data. Fonte: Centro de Memória da Saúde Pública/Fac. de Saúde Pública/USP

Figura 85 - Detalhe da Planta SARA Brasil, contendo a área de atuação dos irmãos de Franco. 1930. Fl. 37. Fonte: AHMWL 


\section{SUMÁRIO}

\section{VOLUME 1}

INTRODUCÃO - O OBJETO DE ESTUDO

OBJETIVOS

METODOLOGIA

As fontes secundárias - Balanço bibliográfico

As fontes primárias

Delimitação da área de estudo

Periodização - 1881-1913

Procedimentos metodológicos

CAPÍTULO 1 - Atores sociais no processo de formação do bairro do Bexiga: O capital privado e o poder público

1.1 Histórico do bairro nas plantas da cidade

1.2 Empreendedores e especuladores imobiliários $\quad 72$

1.3 O Poder Público $\quad 83$

1.4 Proprietários $\quad 90$

Nacionalidades $\quad 95$

1.5 Construtores $\quad 99$

Nacionalidades 111

1.6 Alguns estudos de caso 113 
CAPÍTULO 2 - As tipologias - Edificações residenciais, de uso misto, fabris, manufatureiras e comerciais

2.1 A Série Obras Particulares: um panorama da atividade construtiva no bairro do Bexiga

2.2 Identificação das tipologias e programas arquitetônicos predominantes

Implantação nos lotes 136

Tipologias edilícias 146

Localização cartográfica das tipologias edilícias 172

Um caso à parte - Os cortiços e/ou habitações coletivas 187

CAPÍTULO 3 - Usuários, principais usos e atividades produtivas

3.1 Uma contribuição especial: as tipologias edilícias na Série Obras Particulares

3.2 A Série Alvará e Licença

Usuários e principais usos

Atividades Produtivas

Nacionalidades e etnias

3.3 Alguns estudos de caso

3.4 Algumas considerações

Mapeamento da ocupação do loteamento

Atuação dos órgãos oficiais em relação à abertura e fiscalização dos negócios 


\section{INTRODUÇÃO - O OBJETO DE ESTUDO}

Como demonstrou Nestor Goulart ${ }^{1}$, o investimento no mercado imobiliário tornou-se um grande negócio a partir do último quartel do século XIX, com o adensamento populacional na cidade de São Paulo. A inserção gradual do imigrante em São Paulo, ao lado da considerável camada de escravos e ex-escravos, assim como de brancos livres em geral, provocou um inchaço populacional significativo, agravado pela falta de moradias. Assim, impôs-se a necessidade de expansão do espaço urbano, de modo a distribuir o imenso número de pessoas que adentrava a capital, e alocar novas atividades econômicas fruto de uma nova ordem capitalista.

Ao lado dos projetos urbanísticos que procuravam dar uma imagem modernizadora à cidade, novos bairros foram abertos, ocupando, inicialmente, as áreas mais próximas do Centro e, depois, outras mais afastadas. O Bexiga formou-se numa daquelas áreas próximas do Centro da cidade.

Para compreendermos melhor a evolução desse processo é necessário levar em conta o histórico da região. Na planta "São Paulo - Chácaras, sítios e fazendas à volta de São Paulo, desde o século XVIII (1800-1990)" 2 encontram-se traçados os limites das chácaras existentes na cidade de São Paulo, entre 1800 e 1900, bem como os nomes dos seus proprietários. No caso em questão, destacam-se, além da região central e da chácara do Bexiga, as chácaras limítrofes à mesma: a do Capão, de propriedade do Major Benedito Antonio da Silva; a do Barão de Limeira; a do Barão de Ramalho; a de Martinho Prado e a de D. Alexandrina.

Em pesquisa preliminar, realizada no Arquivo Aguirra $^{3}$ constatamos que, no início da década de 1880, a Chácara do Bexiga ainda era de propriedade de Thomas Luiz Álvares, mais conhecido como Thomaz Cruz, que a vendeu a Antonio José Leite Braga. Até o ano de 1877 esta chácara ainda aparece nas plantas da cidade como região periférica. Porém, a planta da Cia. Cantareira de Águas e Esgotos, de 1881, já apresenta um loteamento bem definido, com a previsão de implantação dos serviços de água e

\footnotetext{
${ }^{1}$ REIS F ${ }^{\mathrm{o}}$, Nestor Goulart - São Paulo - Vila, Cidade e Metrópole, FAPESP/CNPq/Prefeitura do Município de São Paulo, 2004, p.172-3.

2 "São Paulo - Chácaras, sítios e fazendas à volta de São Paulo, desde o século XVIII (1800-1890)", Engenheiro Gastão Cesar Bierrembach de Lima, Arquivo Aguirra, Museu Paulista/USP.

${ }^{3}$ Fichas catalográficas, Arquivo Aguirra, Museu Paulista.
} 
esgotos, demonstrando que, nesta data, a área já estava incorporada ao mercado imobiliário.

A necessidade de novas moradias não passou despercebida aos agentes imobiliários que, nos anos de 1870, já dispunham do controle sobre as terras loteáveis de São Paulo. Amplas áreas foram adquiridas de seus proprietários originais a preços muito baixos, num processo de fragmentação e loteamento de antigas chácaras, sendo então vendidas a quem se interessasse e pudesse construir para posterior locação, alimentando assim o jogo da especulação imobiliária.

Até o início da expansão urbana, as terras do Bexiga foram, supostamente, ocupadas por integrantes dos segmentos mais pobres da população que, excluídos da região central, procuraram a periferia da cidade. A partir do momento em que se concretizou a expansão dos limites urbanos, alguns aspectos geográficos condicionaram um novo tipo de ocupação. A topografia irregular e a presença de cursos d'água, como o Anhangabaú e os córregos do Saracura e do Bexiga, em área sujeita a constantes inundações, teriam desvalorizado os terrenos da região, abrindo a possibilidade para investimentos mais baratos, destinados a uma fatia relevante do mercado imobiliário, representada pelas camadas mais pobres. Áreas mais altas do bairro, por outro lado, foram ocupadas por gente mais rica.

Paulatinamente, os serviços urbanos mais importantes foram instalados no local, como já apontava a Planta da Cia. Cantareira, valorizando o loteamento e atraindo outros empreendedores imobiliários. Um serviço fundamental para o êxito do empreendimento foi a implantação do transporte urbano, com a inauguração, em 1891, da linha de bonde de tração animal entre o Bom Retiro e a Bela Vista, pela Cia. Ferro Carril de São Paulo. Assim, casas foram sendo levantadas: timidamente por volta dos anos 1870 e 80; mais rapidamente após os anos 90; até que em 1914 o bairro já se apresentava praticamente pronto, urbanizado e povoado.

Tendo em vista o contexto acima descrito, acreditamos que a análise da formação deste bairro possa contribuir para a compreensão do processo mais amplo de transformação da cidade de São Paulo como um todo.

Ao analisarmos os mecanismos de apropriação e produção dos espaços urbanos pela iniciativa privada em meio às estratégias do poder público para disciplinar a construção de moradias no bairro do Bexiga, estamos especulando sobre a natureza do processo de urbanização da cidade de São Paulo no período. 
Atualmente, a cidade ainda acomoda exemplares remanescentes daquele momento. Casarões e palacetes são documentos importantes dos modos de morar, das linguagens arquitetônicas adotadas naquela época e, hoje, testemunham o processo de apropriação e produção do espaço urbano pelas camadas mais altas da sociedade. Ao lado desses bairros mais nobres, desenvolveram-se os bairros habitados pela gente comum, pertencente aos setores médios e baixos da população. $\mathrm{O}$ estudo de um bairro como o Bexiga busca desvendar a parte da cidade mais comum, numa tentativa de tirar essa parcela da população do anonimato a que ficou relegada no processo de construção do próprio ideário paulistano.

Ao percorrer as ruas do Bexiga e observar os exemplares arquitetônicos remanescentes da época da urbanização do bairro, constatamos a presença de casas maiores e menores, indicando que a apropriação e produção desse espaço foi feita por diferentes sujeitos. As casas mais simples, geralmente portadoras de fachada com duas janelas e entrada lateral, de caráter marcadamente popular, são predominantes, mas casarões maiores também pontuam o cenário. O levantamento de fontes primárias e secundárias e a análise das informações obtidas nos remetem a universo mais complexo de múltiplos atores sociais, com resultados materiais heterogêneos, que procuramos aqui investigar.

\section{OBJETIVOS}

A proposta deste trabalho é realizar a análise da formação do Bexiga de um ponto de vista pouco explorado, o da apropriação e produção do espaço urbano, com foco tanto nos atores sociais como nas evidências materiais, lote a lote.

Para esta investigação, levamos em consideração os seguintes aspectos:

a) Identificação da área investigada

b) Legislação sanitária e urbanística balizadora das ações de iniciativa privada

c) Atuação da iniciativa privada no processo de formação do bairro

d) Identificação das tipologias e programas arquitetônicos predominantes

e) Identificação dos usuários e usos predominantes das edificações

Ainda que o Bexiga conserve um razoável conjunto arquitetônico remanescente não há como não constatar a fragilidade desta permanência. Hoje, é possível perceber 
que embora alguns trechos do bairro (entre as ruas Conselheiro Carrão, Rui Barbosa, 13 de Maio, dos Ingleses e a Praça Dom Orione) se mostrem relativamente bem cuidados, com alguma preocupação de manutenção da arquitetura original, outros (imediações da rua Jaceguai, Major Diogo e viaduto Júlio de Mesquita) apresentam-se claramente deteriorados.

Assim, se colocam algumas questões. Embora esteja em parte degradada, tratase de uma das regiões da cidade que mantém um conjunto urbano e arquitetônico significativo para a história da cidade. Por outro lado, o tombamento do bairro, conforme a Resolução $n^{\circ}$ 22/2002 do CONPRESP, foi uma iniciativa fundamental no sentido de fortalecer as iniciativas de preservação daquele espaço.

Apesar do tombamento, se mantêm as intervenções nos imóveis, de maneira a adequá-los às necessidades de seus atuais usuários, sejam eles os proprietários de algum tipo de negócio, sejam os moradores dos "novos cortiços" ou habitações coletivas. Embora o tombamento garanta, ao menos, a certeza de não haver novas demolições, não garante a preservação de fato dos programas originais dos imóveis. Nosso estudo, com base nos projetos arquitetônicos antigos, poderá permitir a compreensão da natureza das transformações hoje em curso, subsidiando futuras políticas de preservação.

\section{METODOLOGIA}

Como nossa pesquisa não é uma história de bairro tradicional, partimos das fontes secundárias para delimitar o "Estado da Arte" sobre o bairro do Bexiga e justificar nossa contribuição, nos valendo essencialmente de fontes primárias para a configuração de uma nova linha de abordagem.

\section{As fontes secundárias - Balanço bibliográfico}

Em relação às fontes secundárias, foram consultados obras de memorialistas, histórias do bairro, bibliografia sobre urbanização, teses e dissertações de mestrado.

Alguns autores foram fundamentais para a elaboração preliminar do projeto de pesquisa, e posteriormente, para o desenvolvimento do trabalho. Entre eles, mereceram especial atenção os memorialistas. Haim Grünspun escreveu Anatomia de um bairro. $O$ Bexiga, em 1979. Era filho de uma família judia que imigrou para o Brasil no início dos 
anos de 1930, passando parte da infância no Bexiga, até se mudar para o lado oposto da Avenida 9 de Julho, o que, nas palavras do autor, "significava a saída do verdadeiro Bexiga”. Durante a adolescência continuou frequentando a região como mascate, o que lhe permitiu o acesso à intimidade dos moradores e, portanto, aos espaços invisíveis da vida cotidiana para o pesquisador contemporâneo mais desatento. A opção por Grünspun levou em conta o domínio do autor sobre o território e sobre os personagens do bairro. Embora possa trazer incoerências e imprecisões, seu texto humaniza e torna vivas as informações transmitidas, permitindo-nos uma aproximação afetiva do objeto de pesquisa. Por outro lado, apesar do autor ter vivido no bairro cerca de 20 anos após o período escolhido para este trabalho, a cidade ainda não havia sofrido o processo de transformação visceral ocorrido pós anos 1950.

Se o Bexiga dos "primeiros tempos" não correspondia exatamente à descrição de Grünspun, através dele obtivemos informações preciosas tanto sobre atores sociais como sobre a infra-estrutura do bairro, por exemplo, sobre os serviços de transporte, energia elétrica, água e esgoto e telefonia, dando-nos pistas sobre as lógicas do seu funcionamento.

Outro memorialista consultado foi Armando Puglisi, o Armandinho do Bixiga. Em depoimento a Júlio Moreno, ele nos dá a conhecer o Bixiga dos anos de 1940 a meados de 1990, permitindo que tenhamos acesso a algumas curiosidades do bairro. Também nos utilizamos de outros autores em nossa busca por informações preliminares sobre o bairro, tais como Jorge Americano ${ }^{4}$ e A. Paim Vieira ${ }^{5}$.

Outra linha de investigações que subsidiaram o nosso trabalho foram as histórias do bairro. Célia Toledo de Lucena, autora de Bixiga, Amore Mio, de 1981, trata, particularmente dos antecedentes da formação da cidade até enquadrar o advento da Chácara do Bexiga no decorrer do século XIX. Caracteriza a fisionomia do bairro nas últimas décadas do século XIX e a entrada dos italianos nesse cenário, analisando as transformações ocorridas em sua conformação no decorrer do século XX. A autora

\footnotetext{
${ }^{4}$ AMERICANO, Jorge - “O Padre Gazineu”. In: São Paulo naquele tempo (1895-1915). São Paulo: Samambaia, 1957. p. 180-181.

${ }^{5} \mathrm{O}$ autor é descendente da família Paim, proprietária da antiga Chácara do Capão, comprada do Major Benedicto Antonio da Silva, em abril de 1880. A chácara fazia limite com a Chácara do Bexiga e, parte de seus domínios foi ampliada com a compra de "certas porções de terra que, no atual bairro do Bexiga penetrava como uma aleta pelos seus domínios perturbando-lhe a urbanização”. A compra foi efetuada junto “à Dona Eugênia Pereira Braga pelo preço de 21 contos em 21 de agosto de 1880” - VIEIRA, A. Paim - Chácara do Capão. Separata da Revista do Arquivo, $\mathrm{n}^{\circ}$ CXLVIII, Departamento de Cultura, São Paulo, 1952. P. 116 a 118.
} 
apoiou-se em extensa bibliografia, sobretudo em cronistas e memorialistas, em documentos do Arquivo Histórico Municipal, do Arquivo do Estado de São Paulo e jornais antigos, assim como em depoimentos de antigos moradores do bairro. Sua leitura se mostrou importante na medida em que forneceu, junto aos memorialistas, os primeiros subsídios para nosso trabalho.

Com perfil semelhante, o livro de Nádia Marzola, Bela Vista ${ }^{6}$, escrito para a série História dos bairros de São Paulo e publicado em 1979, também foi utilizado. O grande mérito dos dois trabalhos reside no esforço em registrar a história de um bairro "comum", ocupado por pessoas "comuns".

Numa linha diferente da história de bairros, pela ótica dos próprios agentes produtores, insere-se a dissertação de mestrado de Luciana Além Gennari, As casas em série do Brás e da Mooca: um aspecto da constituição da cidade de São Paulo, defendida em 2005, na FAUUSP. A autora estudou a construção das casas em série para venda ou aluguel, durante as primeiras décadas do século $\mathrm{XX}$, nos bairros do Brás e da Mooca. Embora se trata de outra região, o processo de estruturação de certos espaços urbanos de São Paulo, entre o final do século XIX e o início do XX, apresentou vários pontos em comum: "Uma parte da cidade foi erguida e reerguida nos moldes da Mooca e do Brás. Não necessariamente parecida morfologicamente, mas talvez metodologicamente sim" 7 . As duas regiões possuem em comum a localização próxima a cursos d'água - o Anhangabaú e seus afluentes, Saracura e Bexiga (Bexiga) e o Tamanduateí (Brás e Mooca) - o que as tornam sujeitas a cheias constantes e mais desvalorizadas em relação a outras áreas da cidade. Se tornaram acessíveis a diversos tipos de empreendimentos, desde aqueles feitos por grandes capitalistas, passando por indivíduos que desejavam diversificar seus negócios, até aqueles mais pobres que viam no investimento imobiliário a possibilidade de aumentar seus rendimentos. No processo de compra de terrenos e construção das casas, esses bairros efetivamente foram ocupados por pessoas de diferentes segmentos sociais.

O acompanhamento do processo de estruturação dos bairros do Brás e da Mooca foi fundamental para a formulação das nossas primeiras hipóteses sobre o Bexiga, bem como para a escolha das fontes a serem investigadas. A leitura do universo descrito por

\footnotetext{
${ }^{6}$ MARZOLA, Nádia - História dos bairros de São Paulo, v. 15. DPH/SEC/Prefeitura de São Paulo, dez/1979. p. 16.

${ }^{7}$ GENNARI, Luciana Alem, As casas em série do Brás e da Mooca: um aspecto da constituição da cidade de São Paulo, dissertação de mestrado, FAUUSP, defendida em 2005, p.293.
} 
Gennari permitiu que traçássemos um paralelo entre o processo de formação dos dois bairros, com suas diferenças e semelhanças, ampliando assim nossas perspectivas sobre o processo de produção e urbanização da cidade.

Semelhante é o caso da tese de doutorado da historiadora Maria Luiza Ferreira de Oliveira, Entre a casa e o armazém. Relações sociais e experiência de urbanização: São Paulo, 1850-1900, defendida em 2003, na FFLCH/USP e publicada em 2005. A autora estudou o papel dos setores médios e intermediários da sociedade na urbanização de São Paulo. Seu estudo centra-se na consulta e análise dos inventários post-mortem do período de 1874 a 1901. Com base nos inventários dos setores médios da população paulistana, pouco contemplados até o presente, Maria Luiza Oliveira constatou a instabilidade que marcou a existência dessas camadas no período, e ao traçar seu perfil, nos remeteu necessariamente aos usuários do bairro do Bexiga. Da mesma forma que os ocupantes das casas situadas na Várzea do Carmo, os moradores do Bexiga também devem ter se visto às voltas com problemas de insolvência - a falta de dinheiro para o pagamento das prestações da casa ou os aluguéis atrasados, para o pagamento das contas do armazém, para a prestação do mascate... E quanto às relações de solidariedade entre vizinhos, fossem credores ou não, terão ajudado essas pessoas a sobreviver por mais uma semana, mais um mês?... Desta forma, a leitura de seu trabalho, aliada a depoimentos como os de Grünspun, foram de extrema valia para a compreensão dos diversos atores sociais no Bexiga; atores que representavam papéis diferentes, no mesmo cenário, alguns mais simpáticos, outros nem tanto. Quando aprofundamos o estudo do caso de Paschoal Gazíneo, descobrimos que o padre, além de ser proprietário e viver "de rendas", explorava a forma mais pobre de moradia, os cortiços. Fazia isso, aparentemente, sem problemas de consciência cristã, já que ao ouvir uma inquilina devedora dizer que não tinha dinheiro para o pagamento a ameaçou de despejo ${ }^{8}$.

Embora as informações contidas na Série Obras Particulares não demonstrem quem eram os usuários das casas edificadas, um dado nos chamou a atenção: a frequência com que, exatamente no mesmo endereço e em um curto espaço de tempo, encontrávamos diferentes pessoas como proprietárias do imóvel. Sabendo que se tratava de um bairro ocupado, sobretudo, por pessoas mais pobres, nos ocorreu que tais casos se referissem a pessoas que, talvez por problemas financeiros, não tenham conseguido manter a propriedade. Concluímos que esta é uma hipótese difícil de comprovar, mas,

\footnotetext{
${ }^{8}$ AMERICANO, Jorge - Op. Cit., p. 181.
} 
diante da realidade desta região, como daquela analisada por Maria Luiza, não é uma idéia absurda. De todo modo, a tese desenvolvida pela autora vem colaborando para o aprofundamento das questões colocadas pelos documentos, como que nos propondo um "mergulho" para além da superfície "fria" dos mesmos.

Para o estudo das tipologias urbanísticas e arquitetônicas predominantes no bairro, partimos dos trabalhos de Nestor Goulart Reis Filho - Quadro da Arquitetura no Brasil (1970) e São Paulo, Vila, Cidade e Metrópole (2004). No primeiro livro, o autor analisa o urbanismo e a arquitetura residencial brasileira, desde a colônia até meados do século XX, com base na lógica de implantação dos edifícios no lote urbano. O segundo trabalho aborda questões mais abrangentes sobre o processo de urbanização de São Paulo. Nas duas ocasiões, o autor forneceu informações e conceitos fundamentais para a realização do estudo dos casos exemplares contemplados neste trabalho.

Não nos limitamos a essas publicações. As monografias desenvolvidas para algumas das disciplinas cursadas no decorrer do mestrado impuseram a necessidade de buscarmos outros trabalhos de Nestor Goulart que permitissem o aprofundamento de questões inerentes ao estudo do processo de transformação urbana de São Paulo. Foi o caso dos textos Cultura e estratégias do desenvolvimento e Habitação popular no Brasil: 1880-1920 ${ }^{9}$, ambos publicados nos Cadernos de Pesquisa do LAP.

Os livros de Carlos Alberto C. Lemos - Cozinhas, etc., (1976), Alvenaria Burguesa (1985) e A República ensina a morar (melhor) (1999) - são referências indispensáveis para a compreensão da arquitetura no período. A leitura dos trabalhos de Lemos nos possibilitou explorar os aspectos mais técnicos da arquitetura da cidade. Em Cozinhas, etc. o autor propõe o estudo das soluções desenvolvidas na casa popular, "para ver como as funções da habitação foram e estão sendo exercidas no espaço arquitetônico" ${ }^{10}$. Em Alvenaria Burguesa, discorre sobre a prática da arquitetura, o uso dos materiais, das técnicas e dos sistemas construtivos em São Paulo, desde seus primórdios até a modernização da cidade e a introdução de novas linguagens estéticas. Por fim, em A República ensina a morar (melhor), analisa "como a legislação republicana interferiu [...] no planejamento de novas residências [...]”, através dos Códigos de Posturas e do Código Sanitário de 1894, todos feitos com o intuito de normatizar as construções, conforme os conceitos de higiene então vigentes. Além da

\footnotetext{
${ }^{9}$ Cadernos de Pesquisa do LAP. Série Urbanização e Urbanismo, no 2, FAUUSP, São Paulo, 1994.

${ }^{10}$ LEMOS, Carlos A.C. - Cozinhas, etc., São Paulo: Perspectiva, 1976, p.12.
} 
leitura dos trabalhos do autor, cursamos as disciplinas Arquitetura do Café ${ }^{11}$ e Técnicas Construtivas Tradicionais Paulistas, ambas ministradas por Lemos, quando tivemos a oportunidade de desenvolver monografias que enriqueceram nosso repertório, de maneira a melhor analisar os projetos arquitetônicos contidos na Série das Obras Particulares.

No que se refere à história da arquitetura paulistana e à identificação dos profissionais que atuaram na construção civil da cidade no período anterior à República, a tese de doutorado de Eudes Campos, Arquitetura paulistana sob o Império. Aspectos da formação da cultura burguesa em São Paulo (1997) foi fundamental. O mesmo ocorreu com os textos desenvolvidos para o Informativo Histórico Municipal, do AHMWL ${ }^{12}$, nos quais demonstra um amplo e profundo conhecimento De diversos aspectos da cidade. Desde a arquitetura praticada na cidade, passando pelo papel desempenhado pelas famílias da aristocracia agrária paulista nas transformações urbanas, assim como o próprio processo de elaboração da legislação sanitária que norteou a atividade construtiva. Graças à leitura desses trabalhos foi possível esclarecer dúvidas e desfazer interpretações equivocadas a que estamos sujeitos no decorrer desse tipo de trabalho. De outro lado, conseguimos localizar informações preciosas sobre alguns dos atores sociais enfocados nos nossos estudos de caso, tais como Alexandre Albuquerque e o Padre Paschoal Gazíneo.

A presença de formas diferenciadas de habitações populares no bairro investigado demandou leituras específicas, tais como a tese de doutorado de Lilian Fessler Vaz, Uma história da habitação coletiva na cidade do Rio de Janeiro - Estudo da modernidade através da moradia (1994). Neste trabalho a autora aborda a transformação da moradia "multifamiliar”, desde aquelas com caráter de habitação coletiva promíscua, características da segunda metade do século XIX, aos modernos apartamentos contemporâneos. Entre os aspectos desenvolvidos pela autora, foi de particular importância para nós a análise dessa tipologia no período que antecedeu a República, assim como no período imediatamente posterior. A definição do significado de habitação coletiva e a distinção entre as modalidades desse tipo de moradia forneceram os subsídios conceituais que viabilizaram a análise de nosso próprio objeto de pesquisa.

\footnotetext{
${ }^{11}$ Disciplina cursada como aluna especial, no segundo semestre de 2004.

${ }^{12}$ Trata-se de uma publicação eletrônica, acessível aos interessados na história da capital paulista e aos pesquisadores em geral.
} 
Por fim, nossa pesquisa se insere numa linha de investigação nova proposta pelos estudos de três autores. José Eduardo Léfèvre - De beco a avenida: A história da Rua São Luiz (2006); Heloisa Barbuy - A Cidade-Exposição. Comércio e Cosmopolitismo em São Paulo, 1860-1914 (2006); e Beatriz Bueno - Aspectos do Mercado Imobiliário em perspectiva histórica: São Paulo (1809-1950) (2008). Esses autores buscaram analisar a dinâmica de transformação da cidade de São Paulo através de fragmentos - uma rua, um bairro, a área central -, investigando lote a lote os atores sociais envolvidos e as tipologias arquitetônicas construídas.

Até o momento, os poucos trabalhos a abordar o Bexiga têm sido feitos, basicamente, do ponto de vista de sua trajetória histórica e das influências do imigrante italiano sobre o seu caráter cultural, o que induz ao senso comum de se tratar de um bairro eminentemente italiano. Dessa maneira, ainda que se saiba da presença do negro, o "caráter" do bairro é dado pela presença italiana. Nosso trabalho pretendeu desconstruir esse "mito", questionando alguns pontos fundamentais, tais como:

- Quem foram os empreendedores a realizar o loteamento?

- Quem foram os proprietários que, de posse dos lotes adquiridos, construíram as casas?

- Quem foram os profissionais responsáveis pela edificação das casas?

- Em que medida predominaram as casas populares ${ }^{13}$ ?

- Quem foram os usuários e, em que medida, houve o predomínio dos imigrantes, sobretudo os italianos?

O Bexiga é usualmente associado à idéia de bairro popular, ocupado por cortiços e casas "operárias", contudo, em toda a sua extensão encontramos uma diversidade de exemplares que, como já nos referimos anteriormente, certamente serviram a outros segmentos sociais. Em estudo de caso realizado para a disciplina "Técnicas Construtivas Tradicionais" ${ }^{14}$, constatamos, por exemplo, a presença no Bexiga, de membro de uma tradicional família paulista, os Almeida Nogueira. Tratava-se de uma família de cafeicultores de Bananal, no Vale do Paraíba, proprietária de algumas fazendas, a Luanda e a Boa Vista, além da Restauração, na cidade de Queluz. José Luiz de Almeida Nogueira, morador na rua Major Diogo $n^{\circ}$ 5, era um advogado formado pela

\footnotetext{
${ }^{13}$ Os requerimentos contidos na Série Obras Particulares frequentemente se referem à construção de “casas operárias". No entanto, a análise dos projetos arquitetônicos demonstra que esse nem sempre é o caso. Dessa maneira, optamos por trabalhar com o conceito de "casa popular" como aquela voltada aos setores médios e baixos da sociedade, que julgamos ser mais de acordo com a proposta deste trabalho. 14 “Arquitetura Eclética no Bexiga - Estudo de caso: Rua Major Diogo, 91”, FAUUSP, nov/2005.
} 
Faculdade de Direito do Largo São Francisco, tendo sido Senador da República entre 1898 e 1900, catedrático da Faculdade de Direito, e autor da obra de caráter memorialista, Tradições e reminiscencias: estudantes, estudantões, estudantadas. Em suma, ele era, senão um típico representante da oligarquia cafeeira paulista, um profissional liberal bem sucedido. Dessa maneira, em face da visão de conjunto do bairro, a presença desta residência nos colocou a pergunta: que motivos levariam pessoas com alto poder aquisitivo a viver em áreas menos nobres, a viver ao lado dos segmentos mais pobres?

Haim Grünspun, ao discorrer sobre os moradores do bairro na década de 30 do século passado, nos diz que "Na linha esquerda do bonde, a começar dos cortiços da Marques Leão, viviam na maioria italianos e seus descendentes, seguidos de mulatos, negros, espanhóis, fazendo a mescla brasileira do Bexiga" ${ }^{15}$. Mesmo levando em conta a defasagem de tempo entre o Bexiga daqueles anos e o período contemplado pelo nosso trabalho, o texto demonstra que a ocupação do bairro foi feita por vários grupos sociais.

$\mathrm{Na}$ análise das nacionalidades dos proprietários, construtores e usuários do Bexiga, tivemos a oportunidade de comprovar a presença, ainda que reduzida, de indivíduos oriundos de outros países, além dos italianos. Portugueses certamente havia muitos, mas, ao lado deles identificamos também espanhóis, alemães, franceses, judeus e turcos. De outro lado, a (aparente) ausência de indivíduos da raça negra pode ser questionada, a partir da noção de "invisibilidade" lançada por Carlos José Ferreira dos Santos ${ }^{16}$, em relação à intenção (ideológica) de branqueamento:

"Assim, se a Europa e sua população eram perseguidas como sinônimo de civilização, desenvolvimento e progresso, a cidade de São Paulo era vista como a que mais se civilizava, desenvolvia elou progredia na Federação, porque também era a que supostamente mais se europeizava."

Na sequência, o autor ao analisar o discurso do Dr. Rubião Meira (de 1906), destaca que:

“" Formando a nossa nacionalidade" e "construindo a nossa raça" sugere um desejo latente: o de reconstruir a Paulicéia inferiorizando, silenciando e excluindo aqueles que estivessem fora dos parâmetros socioculturais desejados ou que fossem vinculados a aspecto de um passado que se desejava apagar - entre esses os nacionais pobres." 17

\footnotetext{
${ }^{15}$ GRÜNSPUN, Haim - Anatomia de um bairro - O Bexiga, São Paulo: Cultura, 1979, p. 22.

${ }^{16}$ SANTOS, Carlos José Ferreira dos - Nem tudo era italiano. São Paulo e pobreza (1890-1915). São Paulo: Annablume, 1998.

${ }^{17}$ SANTOS, Carlos José Ferreira dos - Op. Cit., p. 42.
} 
Não temos dúvidas que a suposta ausência de negros no Bexiga deve-se muito ao ideário "europeizante" proposto pelo autor, justificando assim, que adotemos essa hipótese como nossa. $\mathrm{O}$ fato é que a tendência de desvalorização do nacional em favor do italiano se estendeu ao longo do século XX, legando um conceito/valor preconceituoso e segregacionista. Hoje, é principalmente sobre os moradores do bairro que incide o "mito" estigmatizante de ser um bairro italiano, em detrimento do segmento negro - cuja presença numérica e influência cultural são extremamente significativas, mas, prioritariamente valorizadas apenas em relação à sua produção musical, o que lhe confere um caráter "folclórico", no sentido mais pejorativo.

As hipóteses acima levantadas tratam de questões dinâmicas que se interrelacionam em maior ou menor medida, a depender do momento e da relação entre os atores sociais envolvidos. Assim, somente uma análise mais profunda poderá levar a respostas mais conclusivas acerca da comprovação ou não de nossas hipóteses.

Tendo em vista as questões abordadas, ao reconstruir o cenário de um fragmento da cidade, esperamos que os resultados de nosso trabalho possam colaborar para a compreensão de alguns enigmas sobre a cidade de São Paulo, trazendo novas luzes aos esforços já realizados por autores que de alguma maneira buscaram compreender o nosso processo de urbanização.

\section{As fontes primárias}

Nossa maior contribuição reside na variada documentação primária mobilizada para a reconstituição dos diferentes aspectos da história do bairro do Bexiga, orquestrada com metodologia inédita, especialmente desenvolvida para estudos dessa natureza.

\section{- Cartografia antiga}

As plantas da cidade foram os primeiros documentos a serem investigados. Elaboradas ao longo do século XIX, registraram as transformações ocorridas no espaço urbano da cidade. De acordo com o momento de sua elaboração, detalham aspectos variados: o processo de expansão dos limites do núcleo urbano; a extensa rede hidrográfica que marcava a paisagem paulistana; o traçado viário e as vias de 
comunicação com outras regiões do estado e do país; a implantação da estrada de ferro e do sistema de transporte urbano; alguns dos edifícios públicos construídos durante a $1^{\mathrm{a}}$ República; a localização dos bairros novos e o processo de parcelamento e ocupação dessas áreas.

A utilização dos documentos cartográficos obedeceu a uma ordem cronológica:

1. “Mappa da Cidade de São Paulo e seus Subúrbios (1844-1847)”. Engenheiro Civil C. A. Bresser.

2. “Mappa da Imperial Cidade de São Paulo” (1855). Por Carlos Rath.

3. "Planta da Cidade de São Paulo” (1868). Atribuída a Carlos Frederico Rath.

4. "Planta da Cidade de São Paulo" (1881). Levantada pela Cia. Cantareira e Esgotos, Henry B. Joyner, Engenheiro em Chefe.

5. "Planta da Capital do Estado de São Paulo e seus arrabaldes" (1890). Desenhada e publicada por Jules Martin.

6. "Planta da cidade de São Paulo" (1895). Ugo Bonvicini.

7. “Planta Geral da Capital de São Paulo" (1897). Organizada sob a direção do Dr. Gomes Cardim, Intendente de Obras.

8. "Planta Geral da Cidade de São Paulo" (1905). Adotada pela Prefeitura Municipal para uso de suas Repartições, Alexandre Mariano Coccoci e Luís Fructuoso e Costa.

9. "Planta da Cidade de São Paulo" (1913). Levantada e organizada por Alexandre M. Coccoci e L. Fructuoso e Costa.

Como forma de introdução ao objeto da pesquisa, utilizamos o mapa "São Paulo, chácaras e sítios e fazendas ao redor do Centro”, organizado pelo Engenheiro Gastão Cesar Bierrembach de Lima, para a exposição do IV Centenário de São Paulo, em 1954. Utilizamos a "Planta dos terrenos do Bexiga" (1980), croqui delineado pelo Engenheiro Fernando de Albuquerque para o loteamento, para reconhecer a configuração pretendida para o empreendimento. Ambas as plantas integram a coleção do Arquivo Aguirra, do Museu Paulista, USP.

As plantas relativas aos anos de 1847, 1855, 1868, 1881, 1890 e 1897, fazem parte do álbum de plantas históricas São Paulo Antigo: Plantas da Cidade, publicado em 1954, pela Comissão do IV Centenário. Esta documentação está disponibilizada online pela Divisão do Arquivo Histórico Municipal Washington Luís, DPH/SMC, através do Informativo Arquivo Histórico Municipal, ano 4, $\mathrm{n}^{\mathrm{o}} 20$, de 2008. Com 
relação às plantas de 1905 e 1913, também utilizamos material disponibilizado na internet, desta vez, no Histórico Demográfico do Município de São Paulo, pela SEMPLA.

\section{- Legislação}

A legislação sanitária e urbanística foi decisiva para o conhecimento das normas estabelecidas para controlar as ações da iniciativa privada. O Código Sanitário de 1894, de maneira especial, ao introduzir os preceitos modernos de higiene nos espaços públicos e privados, determinou como e onde construir, condicionando, de certa maneira, a própria configuração urbana. De outro lado, ao estabelecer os critérios para a localização das diferentes tipologias, em diferentes espaços da cidade, também colaborou para a sedimentação da segregação social. Ao Código Sanitário, foram introduzidos, posteriormente, "aditivos" sob a forma de leis complementares, de maneira a aperfeiçoar aspectos que, porventura, se mostrassem falhos. No caso do primeiro documento, trabalhamos com o exemplar pertencente ao Arquivo do Estado. Já o acesso a diversos atos complementares foi permitido pela Série das Obras Particulares, do AHMWL, onde os requerimentos para edificação e/ou reforma, frequentemente, contêm exemplares dessas leis.

Os Códigos de Posturas, anteriores ao Código Sanitário, foram consultados através dos trabalhos de Carlos Lemos (1999) e Eudes Campos (1997). Ambos analisaram a legislação sanitária de forma profunda e detalhada, assim como a sua influência, não apenas sobre o ato de construir, como também sobre o ato de morar.

\section{- Almanaques}

Os Almanaques foram uma das principais fontes a fornecer informações sobre a atuação da iniciativa privada no processo de formação dos bairros paulistanos. Um exemplo é o Almanach da Província de São Paulo, Administrativo, industrial ou comercial para 1887. No item "Principais habitantes da capital", identificamos dois atores sociais com participação efetiva no primeiro momento do empreendimento do Bexiga: Domingos José Coelho da Silva, proprietário de serraria mecânica no Largo do Riachuelo, e o engenheiro Fernando de Albuquerque. Já o Almanak Laemmert ${ }^{18}$,

\footnotetext{
${ }^{18}$ De acordo com o site www.jangadabrasil.com.br, voltado à divulgação da cultura popular, o Almanak Laemmert, publicado entre 1844 e 1889, foi apenas um dos títulos publicados pela Livraria Universal,
} 
publicado no Rio de Janeiro, se mostrou mais rico em informações. Embora publicado na Capital da República, continha "encartes" especiais dedicados aos demais estados. No caso dos exemplares de 1909 e 1910, os encartes eram extremamente completos, chegando a relacionar, inclusive, os nomes de todos os componentes da Diretoria de Obras, tais como Victor da Silva Freire e Arthur Saboya. Observamos a mesma preocupação no arrolamento dos serviços públicos oferecidos à cidade, como também no item "Commercio, Industria e Profissões", dedicado aos profissionais das mais variadas ocupações. Nestas relações encontramos desde empresas famosas, como a Adolpho Schrizmeyer \& Cia., fabricante de chapéus, até pequenos negociantes anônimos do Bexiga, como José Falcone, proprietário de um pequeno açougue, na rua 13 de Maio. Falcone foi apenas um entre os vários personagens do Bexiga identificados no Almanach Laemmert.

O Almanak Laemmert foi consultado na biblioteca do Museu Paulista, da USP; já o Almanach da Província de São Paulo, foi localizado na Seção de Obras Raras, da Biblioteca Municipal Mário de Andrade.

\section{- Jornais}

A imprensa da época também foi uma fonte de informações esclarecedoras. Através dos jornais A Província de São Paulo e, posteriormente, O Estado de São Paulo, envolvendo um período de aproximadamente treze anos (de 1878 a 1891), tivemos contato com os primeiros sinais dos empreendimentos imobiliários ali realizados. Ainda que a baliza inicial deste trabalho tenha sido dada pela planta da Cia. Cantareira, de 1881, levamos em conta o anúncio publicado em 10 de maio de 1878. Naquela data, proprietários de terras no bairro, anunciaram que "mandaram levantar um plano geral de arruamento" com vistas à comercialização de lotes. Em janeiro de 1881, anunciava-se a conclusão da "grande rua que comunica o bairro da Consolação com o do Bexiga" ${ }^{19}$. Neste ano, os anúncios se referiam, em sua maioria, à venda de terrenos. Entretanto, em 27 de abril, encontramos o anúncio indicando a realização do primeiro leilão de "terrenos prontos para edificar situados no Bexiga, junto ao Tanque

fundada por Eduard Laemmert, em 1833. A livraria fechou suas portas em 1909, após um incêndio, quando os direitos de publicação foram negociados com a Francisco Alves e, o almanaque acabou sendo vendido a Manuel José da Silva. Este manteve o título até 1942, quando um novo incêndio interrompeu definitivamente a publicação.

${ }^{19}$ A Província de São Paulo, 10/05/1878. Arquivo do Estado, Microfilme 01.01.004. 
do Reúno" ${ }^{20}$. Em janeiro de 1883, encontramos os primeiros casos de construção no interior do loteamento. Tratava-se do anúncio para locação do "chalé $2^{o}$ do Monte de Ouro (Bexiga), com bastante comodos, água, quintal, e gozando de ótima vista” ${ }^{21}$. Em 1890, outro anúncio demonstra a continuidade do empreendimento: “duas moradas de casa com porta e janela cada uma, e terreno bastante fundo, situadas à rua dos Valinhos [...], rua em que passará a linha de bonds do Bom Retiro à Bela Vista” ${ }^{22}$. O anúncio não só indica a ocupação do bairro, como também a previsão do transporte urbano, o que efetivamente ocorreu naquele ano. Daí por diante, até os últimos exemplares consultados, os anúncios para venda de lotes e casas se sucederam.

Ao lado dos anúncios para venda ou locação de casas, se destacaram aqueles publicados pelos profissionais que de alguma maneira atuaram na construção civil. Foi o caso de M. Haussler, que anunciava seus préstimos para "fazer medições, levantar plantas, fazer orçamentos e construir casas, jardins, etc., tanto por empreitada como por administração” ${ }^{23} \mathrm{ou}$, da Carpintaria e Marcenaria a Vapor de G. Sydow \& C., anunciando a venda de "cal hidráulica" ${ }^{24}$ própria para a construção civil.

\section{- A Série das Obras Particulares - AHMWL}

Tendo em vista a proposta de análise do bairro do ponto de vista da apropriação e produção do espaço, a identificação dos atores sociais envolvidos nesse processo foi fundamental. Dessa maneira, priorizamos a investigação dos processos e projetos arquitetônicos contidos na Série das Obras Particulares, do Arquivo Histórico Municipal Washington Luís, órgão subordinado ao Departamento do Patrimônio Histórico. Este conjunto documental envolve os imóveis submetidos à aprovação da Prefeitura, por particulares, por ocasião da sua construção, acréscimo, demolição ou reforma. Os processos de solicitação de licença para construção fornecem, além dos nomes dos principais atores envolvidos - proprietários e construtores -, os projetos arquitetônicos encaminhados à municipalidade, documentos que permitiram a identificação e análise das tipologias edilícias adotadas no bairro. Através da investigação dos projetos arquitetônicos contidos na Série das Obras Particulares, obtivemos informações acerca de aspectos importantes para compreensão da

\footnotetext{
${ }^{20}$ A Província de São Paulo, 27/04/1881. Arquivo do Estado, Microfilme 01.01.007

${ }^{21}$ A Província de São Paulo, 17/01/1883. Arquivo do Estado, Microfilme 01.01.007

${ }^{22}$ O Estado de São Paulo, 25/01/1890. Arquivo do Estado, Microfilme 01.01.016

${ }^{23}$ A Província de São Paulo, -2/11/1881. Arquivo do Estado, Microfilme 01.01.007

${ }^{24}$ A Província de São Paulo, jun-jul/1881. Arquivo do Estado, Microfilme 01.01.007
} 
configuração do bairro do Bexiga, desde a identificação das formas de implantação nos lotes às tipologias predominantes. No entanto, a análise dos dados teria sido inviável sem a leitura dos trabalhos de Nestor Goulart Reis e Carlos Lemos. O primeiro, fornecendo o referencial teórico para uma abordagem crítica do objeto de investigação e, o segundo, fornecendo os fundamentos conceituais básicos sobre a prática de construção e habitação dos imóveis.

A análise de casos específicos, como os cortiços (inclusive a própria conceituação do termo) demandou um esforço à parte: a leitura da legislação sanitária e urbanística, bem como dos livros de Carlos Lemos, Sidney Chalhoub e Lilian Fessler Vaz.

No que diz respeito ao estudo dos casos exemplares, recorremos, basicamente, aos projetos arquitetônicos cujas plantas, elevações e cortes demonstrassem a diversidade tipológica encontrada no bairro. Não foram esquecidos os aspectos indicativos das tendências dadas pelo momento histórico, implicando em rupturas e permanências.

\section{- Atas da Câmara}

Além das fontes citadas, contamos com alguns números da Revista do Arquivo Municipal contendo as Atas da Câmara da Cidade de São Paulo para obter informações complementares sobre o período e a área em questão. Um bom exemplo foi a notícia, localizada no volume LXIX das Atas, relativa aos anos de 1883-1884, e publicada em 1951, sobre a existência de um abaixo assinado visando a mudança do nome do bairro, de "Bexiga" para "Bella Vista". Em relação a esse documento, tivemos a oportunidade de consultar o original em volume dos Papéis Avulsos (AHMWL).

\section{- Arquivo Aguirra - Museu Paulista/USP}

Um acervo interessante para a história da cidade de São Paulo e seus atores sociais é o Arquivo Aguirra. Trata-se de uma coleção de documentos organizada por João Baptista de Campos Aguirra, que integra o acervo do Serviço de Documentação Textual e Iconográfica do Museu Paulista/USP. De acordo com o artigo desenvolvido por Walter Pires para os Anais do Museu Paulista ${ }^{25}$, entre as atividades exercidas por

\footnotetext{
${ }^{25}$ PIRES, Walter - “Arquivo Aguirra. Fonte documental sobre a formação territorial de São Paulo”. In Anais do Museu Paulista, ano/vol. 10, n 11, São Paulo. p. 61-78.
} 
Aguirra como pesquisador da história paulista, está o trabalho para a empresa Informação Aguirre. Informações sobre títulos de propriedades imobiliárias. O trabalho naquela empresa "corresponde à atividade comercial e arquivística que passou a ser conhecida como Arquivo Aguirra”. Ainda conforme Walter Pires, a coleção envolve, entre outros documentos, uma coleção de fichas, mapas, cadastros, livros e fotografias.

Num primeiro momento, tendo em vista o extenso volume de informações disponibilizadas, procuramos racionalizar a pesquisa. Partimos de uma relação prédefinida, contendo 15 nomes selecionados nas séries documentais do AHMWL. Infelizmente obtivemos poucas informações que se referissem diretamente aos nossos personagens. Foram contemplados apenas os proprietários Joaquim Antunes dos Santos, João Passalacqua, Rocco de Franco e Fernando de Albuquerque. No caso de João Passalacqua e Rocco de Franco, conseguimos, além da localização do cartório onde foram realizados seus inventários post-mortem, as datas de falecimento, nomes dos herdeiros, bens inventariados e dívidas. Sobre Joaquim Antunes dos Santos não encontramos nenhuma menção aos inúmeros imóveis relacionados no banco de dados, apenas os nomes dos herdeiros. Curiosamente, à exceção de um certo João Antunes dos Santos, os demais possuem sobrenomes diferentes do seu.

\section{- Série Alvará e Licença - AHMWL}

Já as informações dos usuários das casas, ou seja, daqueles que efetivamente se apropriaram do espaço, foram obtidas através da Série Alvará e Licença, do AHMWL. Tão importante quanto a série precedente, esses documentos contêm os processos de solicitação de licença para a abertura de negócios, comerciais ou de serviços, entre 1906 e 1921. De uma maneira geral, fornecem informações sobre a abertura de negócios; nomes dos interessados; tipos de negócios, endereço; mudança e/ou transferência de endereço do negócio; mudança de proprietário; colocação de letreiros; licenças para funcionamento fora dos dias e horários previstos pela lei.

\section{- A iconografia antiga}

As fotos recolhidas nos acervos da Divisão de Arquivos e Museus/Museu da Cidade de São Paulo/DIM, Fundação Patrimônio Histórico da Energia e Saneamento, Centro de Memória da Saúde Pública/Faculdade de Saúde Pública/USP e Divisão do Arquivo Histórico/DPH completam a documentação consultada, permitindo visualizar aspectos de ruas, casas e a vida cotidiana do bairro. 


\section{MÉTODOS}

Com base nas fontes primárias e secundárias buscamos responder as hipóteses e objetivos da pesquisa. Procuramos desmistificar certos "chavões" referentes à história do bairro, bem como, através de certas amostragens, conhecer aspectos do seu processo de formação e transformação. Nesse sentido, não se trata de fazer uma história tradicional de bairro, mas, a partir de vestígios materiais e fontes documentais primárias, recolhidas nos acervos da cidade, reconstituir um cenário, com foco nos atores sociais envolvidos.

A consulta às fontes primárias foi fundamental para o desenvolvimento deste trabalho. Porém, para que a análise das informações ali obtidas atingisse um resultado satisfatório, foi decisivo o diálogo constante com os autores que de alguma forma, direta ou indiretamente, abordaram o objeto de pesquisa. De um lado, os memorialistas, transmitindo a vivência afetiva e efetiva dos fatos, impossível de ser obtida através do olhar contemporâneo; de outro, os autores que, guardada a distância temporal do objeto, pensaram as questões envolvidas no processo de apropriação e produção do espaço urbano, fornecendo subsídios conceituais e analíticos.

\section{Delimitação da área de estudo}

Tendo em vista que o foco deste trabalho é o estudo da formação e ocupação do bairro, priorizamos a investigação da área envolvida pelo loteamento original. Para isso, partimos da análise comparativa das plantas da cidade de São Paulo, contemplando as diferentes etapas de transformação da região até o momento em que o empreendimento se mostrou consolidado. Após uma criteriosa comparação entre os sucessivos exemplares organizados entre 1844 e 1916, optamos pela "Planta da Cidade de São Paulo”, de 1913, levantada e organizada por Alexandre M. Coccoci e L. Fructuoso F. Costa, quando o Bexiga já apresentava uma configuração bastante próxima da atual mantendo, porém, o traçado original. 
Dois aspectos foram fundamentais para a conformação do que viria a ser o loteamento do Bexiga: os caminhos tradicionalmente utilizados pelos moradores da cidade, e os limites geográficos.

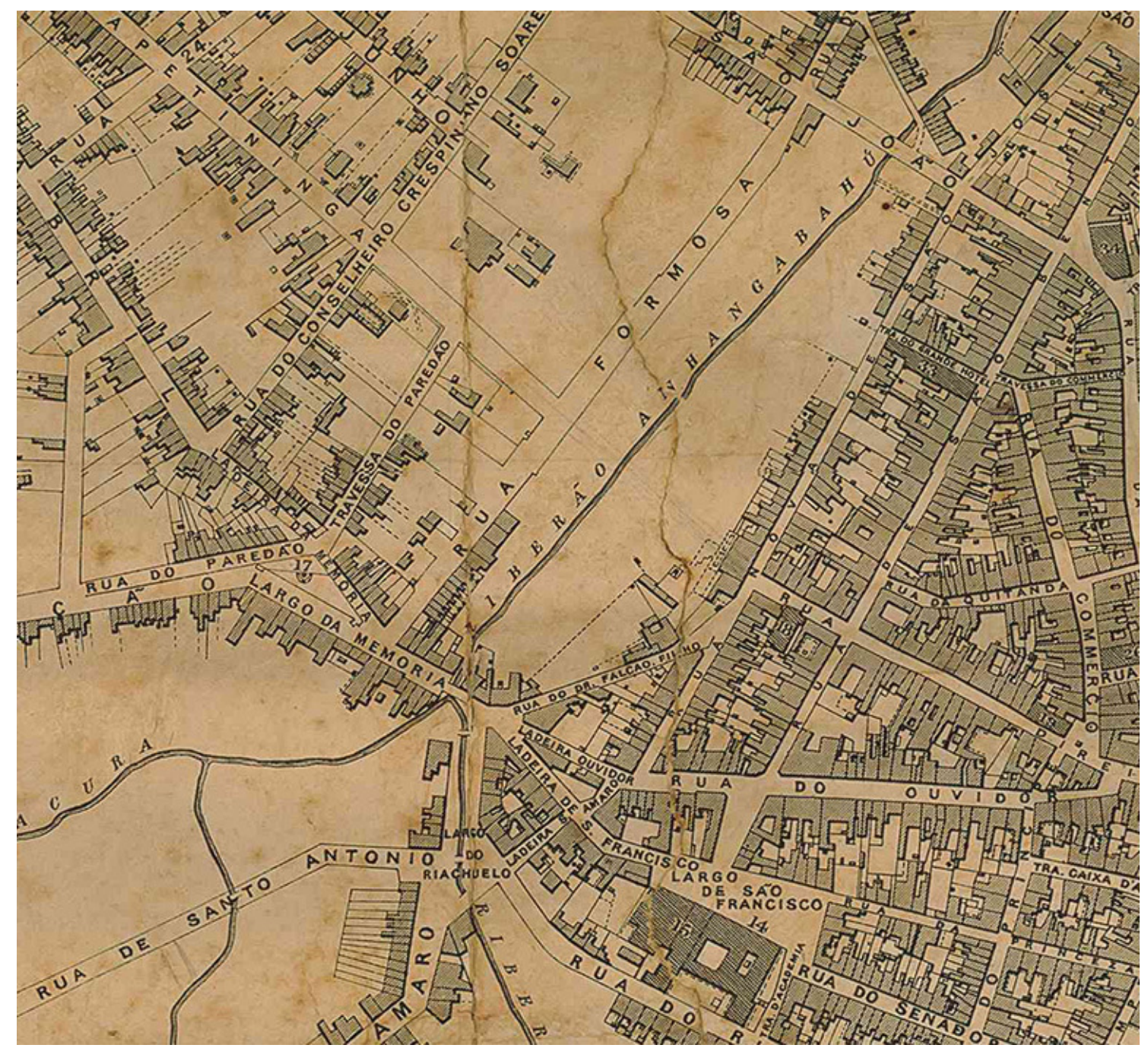

Figura 1 - No detalhe da planta da Cia Cantareira, vemos a rua do Dr. Falcão Filho, entre a rua Nova de São José e o Largo do Riachuelo. Abaixo, à esquerda do largo temos a rua Santo Antonio, e à direita a rua Santo Amaro. Entre o Largo da Memória e a rua de Santo Antonio, vemos o encontro dos córregos do Saracura e Bexiga, os limites naturais que delimitaram o loteamento. Fonte: "Planta da cidade de São Paulo”, Cia. Cantareira e Esgotos, 1881. AHMWL

No primeiro caso temos, de um lado, a rua Santo Antonio que originalmente se chamava rua Vale do Andorra ${ }^{26}$. De acordo com Célia Toledo de Lucena, “a rua Vale do Andorra originou-se de um caminho já aberto para encurtar distâncias entre pontos

\footnotetext{
${ }^{26}$ Conforme MARQUES, Gabriel - Ruas e tradições de São Paulo. Uma história em cada rua, São Paulo: Conselho Estadual de Cultura, 1966, p. 208; e SANT'ANNA, Nuto - São Paulo histórico (Aspectos, Lendas e Costumes), v. I, São Paulo: Departamento de Cultura, 1937, p. 154.
} 
essenciais da Paulicéia. Mais tarde, foi denominada 'Rua Dr. Falcão Filho' [...]” 27 . A julgar pela descrição da autora, os "pontos essenciais" realmente correspondem ao trajeto da atual rua Dr. Falcão Filho, localizada entre a rua Nova de São José (atual Líbero Badaró) e o Largo do Riachuelo. Não conseguimos localizar outras fontes que confirmem essa afirmação, assim como também não confirmamos se os nomes Vale do Andorra, Dr. Falcão Filho e Santo Antonio correspondem à mesma via que em momento posterior teria originado diferentes logradouros ${ }^{28}$. Mas a idéia lançada pela autora, de ligação entre "pontos essenciais" parece fazer bastante sentido se pensarmos que aquela pequena via realmente conectou o triângulo original aos arrabaldes dos Campos do Bexiga.

De outro lado, há o caminho que, na altura do Largo do Piques, dividia-se em dois: o Peabirú, que através da atual rua da Consolação, dirigia-se a Sorocaba; e o caminho de Santo Amaro, que percorrendo o percurso formado pela rua do mesmo nome e a atual Avenida Brigadeiro Luís Antonio, ia em direção a Jundiaí ${ }^{29}$. Contíguo ao Piques, o Largo do Bexiga (transformado em Riachuelo, em 1865) era o ponto de intersecção dos dois caminhos. Ali se realizava o comércio de escravos ${ }^{30}$, de madeira trazida da Vila de Santo Amaro e ficava a hospedaria do Bexiga, pouso de viajantes vindos do sul.

Não por acaso, esses caminhos coincidiram com os limites geográficos do loteamento, impostos pelos cursos d'água. A barreira natural representada pelos córregos forçava a busca por acessos que facilitassem o tráfego de pessoas, carros e animais. Assim, os limites geográficos do loteamento foram, pelo menos no primeiro momento, determinados pelos obstáculos físicos impostos pelos córregos do Saracura e do Bexiga, com encostas típicas de regiões ribeirinhas, e pelo espigão da Paulista, ainda conhecido como Morro do Caaguassú.

\footnotetext{
${ }^{27}$ LUCENA, Célia Toledo de - Bixiga, amoré mio, São Paulo: Parnatz, 1981, p. 60 e 62.

${ }^{28}$ A pesquisa realizada no Dicionário de Ruas se não desmentiu também não confirmou essa versão. Conforme o texto exibido no site, "Esse pequeno trecho em curva, desde a Igreja e até o Anhangabaú, recebeu então a primitiva denominação de Travessa de Santo Antonio. Em meados do século XIX, a população à ela se referia como Ladeira do Dr. Falcão, uma vez que ali residia o Dr. Clemente Falcão Filho. Entretanto, no dia 28/11/1865, por proposta do vereador Malaquias Rogério de Salles, o nome da rua foi oficializado como Ladeira de Santo Antonio. Aos 16 de Agosto de 1877 [...], foi apresentada na Câmara Municipal um requerimento assinado por vários membros da sociedade solicitando que fosse dado à rua onde residia "o Dr. Falcão Filho, o nome deste illustre paulista. Este requerimento foi aprovado por unanimidade ". Disponível em: http://www.dicionarioderuas.com.br/consulta.html ${ }^{29}$ CAMPOS, Eudes - "A vila de São Paulo do Campo e seus caminhos", In Revista do Arquivo Municipal - 30 anos de DPH, $\mathrm{n}^{\circ}$ 204, São Paulo, 2006. p. 28.

${ }^{30}$ MARQUES, Gabriel. Op.cit., p. 145 a 151.
} 
Como ocorrido em toda a cidade, o aumento populacional, a especulação imobiliária, e a superação das dificuldades de transposição dos obstáculos físicos, levaram o bairro a expandir seus limites. Assim, é necessário levar em consideração as diferenças entre o loteamento conhecido como Bexiga, e o bairro tal como conhecemos atualmente - a Bela Vista -, com limites bem mais amplos do que aqueles propostos nas origens. De acordo com a delimitação dada pelo CONPRESP ${ }^{31}$, o bairro da Bela Vista compreende, aproximadamente, os logradouros localizados entre a Praça da Bandeira, ao Norte; a Avenida Nove de Julho em direção ao bairro da Consolação, à Oeste; a Avenida Radial Leste, em direção ao bairro da Liberdade, à Leste; e a Avenida Paulista e Paraíso, ao Sul.

Dessa maneira, a área investigada foi definida pelo traçado original do loteamento: ao Norte, pelo antigo Largo do Bexiga (posteriormente, Largo do Riachuelo, e agora, Praça da Bandeira), e as ruas Santo Antonio e Santo Amaro; dos lados, intermediariamente, pelo córrego do Saracura (Avenida Nove de Julho) e pela Avenida Brigadeiro Luís Antonio; e ao Sul, no encontro da Avenida Brigadeiro Luís Antonio com a rua Treze de Maio.

\section{Periodização}

Da mesma forma que a área de estudo, a periodização foi definida a partir do levantamento cartográfico. A baliza cronológica inicial foi definida a partir do momento em que o loteamento apareceu nos mapas como um empreendimento imobiliário definido. Até o ano de 1868, o Bexiga aparece nas plantas da cidade apenas como região periférica ao Centro, enquanto que na planta de 1881 encontramos o loteamento definido e com arruamento previsto ${ }^{32}$. A "Planta dos terrenos do Bexiga", croqui elaborado pelo Engenheiro Fernando de Albuquerque, data de 1890, e apresenta o traçado original do que viria a ser o bairro, assim como a planta de Jules Martin que,

\footnotetext{
${ }^{31}$ Prefeitura do Município de São Paulo/Secretaria Municipal de Cultura/Departamento do Patrimônio Histórico. CONPRESPP - Resolução 22/2002, p. 1 e 2. Disponível em: http://www.prefeitura.sp.gov.br/cidade/upload/49c99_22_T_Bairro_da_Bela_Vista.pdf ${ }^{32}$ É bem verdade que o anúncio publicado no jornal A Província de São Paulo, em $\mathbf{1 8 7 8}^{32}$, demonstra que a idéia do empreendimento era anterior à planta organizada pela Cia. Cantareira de Água e Esgotos. No entanto, nos parece que este foi apenas o primeiro sinal do empreendimento, que somente viria a se concretizar após 1881, com o lançamento do leilão de Roberto Tavares, conforme os anúncios publicados em 27,28 e 29 de abril de 1881.
} 
mais detalhada, mostra um loteamento demarcado e com ruas nomeadas. Em 1897, o mapa de Gomes Cardim demonstra que num espaço de apenas sete anos o loteamento do Bexiga se ampliou, com a abertura de novas ruas e a renomeação de outras.

Para o estabelecimento da baliza final contávamos com dois mapas: a "Planta da Cidade de São Paulo”, de 1913, levantada e organizada por Alexandre M. Coccoci e L. Fructuoso e Costa; e a "Planta da Cidade de São Paulo" (1916), elaborada pela Divisão Cadastral da Diretoria de Obras e Viação da Prefeitura Municipal. Ambas demonstram o bairro como um empreendimento consolidado. No entanto, a planta de 1916, ao apontar a expansão do empreendimento, com a abertura de novas ruas e ocupação das áreas vizinhas, extrapola o objetivo deste trabalho que é trabalhar com o traçado original, tal como representado na planta da Cia. Cantareira. Assim, optamos pela planta de Coccoci e Fructuoso, de 1913, como baliza cronológica final.

Como segundo critério, partimos do raciocínio de Maria Luiza F. de Oliveira ${ }^{33}$ ao adotar um período de investigação que abrangesse duas fases políticas do país. Tratava-se de um período de transição, entre os últimos anos do Império escravista e os primeiros da República, mas, sobretudo, de transição entre diferentes "modos" de morar e viver. Assim, em face das necessidades mais complexas impostas pelo aumento populacional, a própria administração municipal necessitou criar mecanismos de adequação da atividade construtiva. A compreensão dessa conjuntura mais ampla, certamente elucida sobre o processo de construção das casas do Bexiga - num primeiro momento, em fins do Império, de forma mais ou menos aleatória, nem sempre obedecendo os preceitos indicados pelos Códigos de Postura e, no momento seguinte, após a proclamação da República, partindo do Código Sanitário, seja por intenção dos construtores, seja por força da fiscalização mais efetiva do poder público.

\section{Procedimentos metodológicos}

O cumprimento dos objetivos propostos envolveu os seguintes procedimentos:

a) Identificação espacial da área investigada. Após o levantamento cartográfico das plantas e mapas da cidade eleitos para o estudo, localizamos em cada um dos

\footnotetext{
${ }^{33}$ OLIVEIRA, Maria Luiza F. - Entre a casa e o armazém - Relações sociais e experiência da urbanização: São Paulo, 1850-1900, São Paulo: Alameda, 2005, p.20.
} 
documentos os aspectos que se mostravam relevantes, nos diferentes momentos históricos. A cada ano, buscamos registrar em ilustrações específicas, os sinais indicativos de tendências ou de mudanças efetivas. Nesse sentido, a disponibilização eletrônica dos exemplares digitalizados foi fundamental, como também o foram os programas digitais que permitiram a introdução, nos documentos, dos apontamentos em questão.

b) Análise da legislação sanitária e urbanística, balizadora das ações da iniciativa privada. Segundo Lemos (1999) e Eudes Campos (1996), até o Código de Posturas, de 1886, as posturas municipais nem sempre eram cumpridas, devido à fiscalização deficiente e ao desinteresse da comunidade. Porém, a partir do Código Sanitário, de 1894, a legislação sanitária se tornou, não somente mais detalhada e exigente, como também, mais abrangente. A partir desse momento toda ação no sentido de construir ou reformar qualquer tipo de edificação ficou sujeita ao controle e fiscalização do município. As investigações realizadas demonstraram que, num primeiro momento, houve uma eventual inobservância da legislação, principalmente por parte dos pequenos construtores, mas à medida que a expansão urbana avançou, a fiscalização se tornou mais efetiva, determinando os modos de construir. A consulta aos projetos arquitetônicos possibilitou, de um lado, a identificação do momento em que a lei realmente passou a ser cumprida e, de outro, a percepção das dificuldades encontradas pelo poder público para fazer valer a lei, e pelos próprios construtores, para se adaptar às novas regras.

c) Análise da atuação da iniciativa privada no processo de formação dos bairros paulistanos. A proposta de modernização da cidade implicou na expansão de seus limites e o papel da iniciativa privada foi fundamental nesse processo. Destacam-se os empreendedores, responsáveis pelos loteamentos e arruamento dos lotes, assim como pela abertura de vias de comunicação para outras áreas da cidade; as empresas que realizaram a implantação da infra-estrutura e dos serviços básicos; e, os atores sociais envolvidos no processo de construção dos imóveis particulares ou ligados a empresas da construção civil. No que diz respeito aos empreendedores, o trabalho de identificação dos atores sociais foi possível graças à consulta às Atas da Câmara, dos almanaques e dos anúncios publicados nos jornais "A Província de São Paulo" e, posteriormente, "O Estado de São Paulo”. Essas mesmas publicações, aliadas à leitura dos autores que estudaram esse período, nos auxiliou na localização dos serviços de infra-estrutura 
implantados e, na identificação do momento de sua implantação, assim como das empresas que realizaram tais serviços.

d) Identificação dos atores sociais envolvidos no processo de produção do bairro. Esta questão foi abordada, basicamente, a partir do levantamento dos processos de solicitação de licença para construção e/ou reforma de imóveis do bairro do Bexiga, contidos na Série Obras Particulares do AHMWL. Trata-se de uma documentação bastante extensa, envolvendo trinta e três anos de atividades. O levantamento completo dos documentos relativos à periodização proposta inicialmente se mostrou inviável. Assim, utilizamos um critério de amostragem que possibilitasse abranger todo o período, de 1881 a 1913. A cada três anos pesquisados foram pulados outros três, consecutivamente. No último triênio decidimos contemplar também o ano de 1914, de maneira a, eventualmente, confirmar as tendências dadas pelos anos anteriores. Dessa maneira, a partir de 1907, foram saltados quatro anos, contemplando-se então os anos de 1912, 1913 e 1914. Tendo em mãos os dados obtidos, montamos um banco de dados, priorizando as informações relevantes, organizadas em campos específicos, a saber:

- Data de entrada do processo

- Endereço do imóvel

- Nome do requerente, proprietário e construtor

- Histórico do processo

- Descrição do projeto arquitetônico

- Identificação da localização do documento no AHMWL

e) Identificação das tipologias e programas arquitetônicos predominantes, com espacialização no mapa-base SARA Brasil, de 1930. Embora a literatura sobre o bairro forneça indícios de que se tratava de região ocupada basicamente por "casas operárias" e cortiços habitados pelas camadas sociais mais pobres, observamos, através dos exemplares remanescentes, a presença de casas claramente destinadas à moradia de classe média. Em razão das profundas transformações ocorridas a partir da segunda metade do século XX, grande parte desse casario teve suas características e usos originais alterados por novas necessidades.

A investigação dos projetos arquitetônicos, anexos aos processos de solicitação de licença para construção (Série Obras Particulares), forneceu as informações quanto às $\underline{\text { formas de implantação nos lotes, aos programas de necessidades e às tipologias }}$ predominantes. Os trabalhos de Nestor Goulart Reis (1970/2004) e Carlos Lemos 
(1999) forneceram as categorias de análise fundamentais para o exame dos documentos, assim como a leitura de Sidney Chalhoub (1996) e Lilian Fessler Vaz (1994) o foi para a interpretação dos cortiços. O Código Sanitário, de 1894, e as leis complementares publicadas na primeira década do século XX, forneceram os parâmetros oficiais que, confrontados com os casos investigados, indicaram a medida da observância ou não da legislação.

Para o estudo dos casos exemplares foram selecionados os projetos arquitetônicos representativos das diversas categorias tipológicas elencadas.

f) Identificação dos usuários, e usos predominantes das edificações, com a respectiva espacialização no mapa-base SARA Brasil, de 1930. Com o intuito de caracterizar os moradores do bairro, consultamos a Série Alvará e Licença, parte do Grupo Polícia Administrativa e Higiene, do AHMWL. Esta coleção contém os processos de solicitação de Alvará e Licença para a abertura de negócios comerciais e/ou de serviços, encaminhados à municipalidade, entre 1906 e 1921. Após os primeiros levantamentos para averiguação do material contido na Série, concluímos ser possível localizar os usuários - aqueles que exerceram atividades produtivas no bairro - e, em decorrência das atividades produtivas identificadas, alguns dos principais usos dos espaços construídos.

Infelizmente, no caso dos documentos anteriores a 1906, as informações que seriam úteis indicam apenas os nomes dos requerentes, sem quaisquer referências a endereços ou tipo de negócio proposto. Assim, decidimos trabalhar somente com o período documentado até 1914. Como na Série Obras Particulares, optamos por um critério aleatório de seleção, elegendo os anos de 1906, 1907, 1910, 1911 e 1914.

A partir das informações obtidas, montamos um banco de dados, mantendo a mesma lógica utilizada para a Série das Obras Particulares.

- Data de entrada do processo

- Endereço do imóvel

- Nome do requerente, proprietário e construtor

- Assunto, com o tipo de negócio proposto

- Histórico da solicitação

- Identificação da localização do documento no AHMWL

A se levar em conta que o Bexiga foi um dos novos bairros da cidade a abrigar especialmente as camadas populares, a questão era saber de que maneira elas se 
apropriaram daquele lugar, ajudando a construir o que Gennari chamou de "imaginário social”, incorporando as formas de morar e viver possíveis, dadas pelo espaço construído, numa relação de reciprocidade, se fazendo "incorporar" e aceitar através das práticas culturais de convivência. Em relação ao uso predominante, de uma maneira geral, as construções destinadas à moradia mostraram-se ser a maioria. Entretanto, um pequeno comércio e oficinas de prestadores de serviço, em geral, pontuaram todo o bairro, indicando que ali também se exerciam atividades profissionais. No que diz respeito ao foco deste trabalho, a questão era saber em que medida a construção dos imóveis previa a inclusão desses negócios; se isso implicava na alteração do programa ou se esse também era um caso de adaptação, onde a sala da frente ou o porão transformaram-se em oficina de costura, sapataria, etc.

O confronto entre a Série Alvará e Licença e a Série Obras Particulares foi decisivo para os resultados finais, ora viabilizando o aprofundamento de algumas questões, ora complementando informações, por vezes, apenas sugeridas por uma ou outra fonte. Os projetos arquitetônicos das Obras Particulares foram um instrumento importante para avaliarmos até que ponto tais projetos realmente já previam outros usos que não fossem aqueles residenciais. No Almanak Laemmert, de 1910, confirmamos a presença de um número razoável de comerciantes identificados na série Alvará e Licença. Por exemplo, o quitandeiro Francisco Amadei que, em 1910 vendia frutas no Mercado da 25 de Março. Em 26/01/1914, ele viria a solicitar licença para abertura de negócio na rua Santo Antonio $\mathrm{n}^{\mathrm{o}} 4^{34}$. Outros comerciantes dedicados ao comércio de "gêneros alimentícios", foram Antonio Bruno, rua Major Diogo $\mathrm{n}^{\circ} 79$, Bernardo Pfaff, rua Conselheiro Ramalho $n^{\circ}$ 158, José Tosti, rua Major Diogo no 43 e, Raphael Scaglione, rua Conselheiro Ramalho $\mathrm{n}^{\text {o }} 189{ }^{35}$. No ramo das "quitandas" apareceram, além do próprio Amadei, Carmela Petrone, na rua Conselheiro Ramalho n 226 e Generoso Rubino, na rua Conselheiro Ramalho $n^{\circ}$ 83. Coincidentemente, entre os 13 nomes identificados na edição de 1910 do Almanaque, sete deles também se mostraram presentes na Série Obras Particulares como requerentes ou proprietários dos imóveis em questão. Esse fato pode comprovar nossa hipótese de que os negociantes do Bexiga

\footnotetext{
${ }^{34}$ Almanak Laemmert do Brasil, “Estado de São Paulo”. Rio de Janeiro, 1910. p. 37; Série Alvará e Licença. AHMWL, 26/01/1914. Cx. 1303/4.

${ }^{35}$ Almanak Laemmert do Brasil, “Estado de São Paulo”. Rio de Janeiro, 1910. p. 38-40 e 47; Série Alvará e Licença. AHMWL, anos de 1906, 1910 e 1914.
} 
foram proprietários das edificações onde exerceram suas atividades produtivas e, provavelmente, tais imóveis também tenham sido utilizados como moradia.

Assim, em relação aos usos que se fizeram no bairro, tudo indica que tenha havido uma mescla de situações, onde cada ator social podia representar diferentes papéis ao mesmo tempo. Eventualmente, a depender da situação financeira do indivíduo, esses papéis podiam se inverter: um pequeno comerciante, locatário, cujo negócio tivesse "dado certo", podia transformar-se no futuro proprietário do imóvel ou mesmo adquirir outro maior.

g) Estudos de casos. A seleção dos indivíduos alvo dos estudos de caso foi uma consequência da própria análise das fontes investigadas - as Séries Obras Particulares e Alvará e Licença -, de acordo com os procedimentos relatados acima. De modo geral, fatores como a presença recorrente numa ou noutra série, sua permanência no tempo e no espaço, e alguma especificidade que destacasse o indivíduo em relação aos demais, determinaram a inclusão da pessoa no grupo alvo de uma investigação mais detalhada. De outro lado, nomes reconhecidamente vinculados ao processo de transformação urbana, fossem eles empreendedores ou profissionais da construção civil, também foram alvo de aprofundamento das investigações.

De uma maneira geral, as informações adicionais sobre nossos personagens foram colhidas nos jornais e almanaques da época, e no Arquivo Aguirra. Nesse mesmo sentido, os sites de busca da Internet se mostraram uma ferramenta valiosa, esclarecendo dúvidas e fornecendo pistas sobre pessoas e fatos relevantes. Este foi o caso, por exemplo, de Louise Bierbrauer, para quem Victor Dubrugas desenvolveu projeto de duas casas à rua Santo Antonio, em 1898; Francisco Henzler, parceiro de Dubugras no mesmo trabalho; ou ainda o construtor Júlio Saltini.

h) Identificação do espaço-cenário, vivenciado e apropriado pela população do bairro, através do testemunho dos casos exemplares. A forte presença do imigrante italiano, seguida pela presença do segmento negro, marcou definitivamente a vida cultural paulistana. Esses atores sociais, ao se apropriarem do espaço, com seus sotaques, tradições culturais e maneiras de lidar com o cotidiano, imprimiram um traço diferencial aos espaços da cidade. Ainda que a arquitetura praticada no Bexiga também possa ser encontrada em outras áreas da cidade, aqui ela foi vivenciada de uma maneira especial, "incorporando as formas de morar e viver possíveis, dadas pelo espaço construído e, numa relação de reciprocidade, se fazendo 'incorporar" e aceitar através das práticas sócio-culturais de convivência”. 
Os resultados das investigações realizadas comprovaram a presença predominante do italiano. $\mathrm{O}$ mesmo não se verificou em relação à presença do negro no bairro, já que raramente encontramos menções explícitas a esse segmento. A exceção ficou por conta de dois processos encontrados nas Obras Particulares. Ali, localizamos, em 1886, um certo Tristão Antonio Congo, proprietário de um terreno à rua Vale do Andorra s/n $\mathrm{n}^{\circ}$. De acordo com a descrição do imóvel, este dividia "a direita com Maria Congo e à esquerda com o próprio" ${ }^{36}$. No Caaguassú, não sabemos em que altura da antiga estrada de Santo Amaro, encontramos, em 1890, um Joaquim Mina ${ }^{37}$. A única forma de identificação possível desses atores foi através dos sobrenomes que indicavam a origem étnica.

\section{ESTRUTURAÇÃO DO TRABALHO}

Estruturamos o trabalho em três capítulos. O primeiro capítulo intitula-se “Atores sociais no processo de formação do bairro do Bexiga: o capital privado e o poder público”. Nele analisamos a formação do bairro, a partir das plantas da cidade, bem como os empreendedores e especuladores imobiliários, proprietários e construtores, responsáveis pelo loteamento e edificação dos imóveis, em paralelo à legislação sanitária e urbanística, balizadora das ações da iniciativa privada. Introduzimos alguns estudos de casos exemplares, de maneira a obtermos uma aproximação dos perfis dos sujeitos em ação e do papel do poder público na orquestração das iniciativas individuais.

O segundo capítulo intitula-se "As tipologias - edificações residenciais, de uso misto, fabris, manufatureiras e comerciais". Nele, com base na Série das Obras Particulares, do Grupo Diretoria de Obras e Viação (1906-1921), do Arquivo Histórico Municipal Washington Luís/DPH, procedemos à análise das tipologias edilícias e programas arquitetônicos predominantes no bairro e das diferentes formas de implantação dos edifícios nos lotes. Para cada uma das tipologias identificadas, procedemos ao estudo dos casos exemplares e à sua localização na cartografia do

\footnotetext{
${ }^{36}$ Obras Particulares, processo de 21/05/1886. v. 24, p. 236.

${ }^{37}$ Obras Particulares, processo de 21/05/1890. v. 34, p.77.
} 
período. Por fim, analisamos os cortiços e/ou habitações coletivas em sub-item à parte, dada a especificidade do caso.

No terceiro capítulo, “Os usuários, principais usos e atividades produtivas”, também com base na Série das Obras Particulares, analisamos a distribuição das edificações para moradia e/ou negócios, obtendo a distribuição espacial dos diferentes níveis de riqueza. Em paralelo, a Série Alvará e Licença, do Grupo Polícia Administrativa e Higiene (1906-1921), do AHMWL/DPH, forneceu o perfil dos usuários, os principais usos dos imóveis edificados e as atividades produtivas características do bairro. Estudos de caso permitiram aprofundar certos perfis dos usuários investigados.

Nas considerações finais alinhavamos as conclusões alcançadas no decorrer do trabalho. Embora esta análise forneça apenas um retrato parcial e nebuloso do bairro que conhecemos hoje, essas questões já apontam para tendências que vieram a se consolidar nas décadas seguintes. 


\section{ATORES SOCIAIS NO PROCESSO DE FORMAÇÃO DO BAIRRO DO BEXIGA: O CAPITAL PRIVADO E O PODER PÚBLICO}

\subsection{Histórico do bairro através das plantas da cidade}

Nádia Marzola e Célia Toledo de Lucena ${ }^{38}$, baseadas em autores como Nuto Sant'Anna e Ernani Silva Bruno, desenvolveram trabalhos visando traçar um histórico da região onde se localiza o bairro do Bexiga. Entre os autores citados, Nuto Sant'Anna parece ter sido o que investigou mais a fundo as origens do bairro do Bexiga, desde o ano de 1559, quando a região era parte da sesmaria do Capão. Entretanto, ainda que tenha desenvolvido um histórico possível, parte das suas conclusões são hipóteses a serem comprovadas, tarefa que extrapola o objetivo proposto por este trabalho. Por outro lado, essas informações não foram ignoradas, já que ofereceram pistas importantes, basicamente, no que toca aos primeiros empreendedores que atuaram na região. Assim, optamos por nos basear nos fatos relacionados pelo autor, aqueles que tiveram implicações no processo de formação do bairro, de maneira a obtermos um painel cronológico, dos primórdios da colonização às últimas décadas do século XIX.

De acordo com o histórico traçado por Nuto Sant' $\mathrm{Anna}^{39}$, em 1559, a região que originalmente "faria parte da sesmaria do Capão", pertencia a "Antonio Pinto, tabelião em Santos” (SANT'ANNA). Aproximadamente dois séculos depois, em 1750, a região "seria conhecida por chácara da Samambaia, propriedade agrícola de Pedro Taques, o historiador" (SANT'ANNA). Data de 1794 o registro da venda realizada por Melchior Pereira à Antonio Soares Calheiros e Abreu, de "uma chácara nesta cidade na paragem Anhangabahú, denominada vulgarmente Bexiga” (SANT'ANNA). Beatriz

\footnotetext{
${ }^{38}$ MARZOLA, Nádia - “Bela Vista”, Série História dos Bairros de São Paulo, v. 15, São Paulo: DPH, 1979; e, LUCENA, Célia Toledo de - Bexiga, Amore Mio, São Paulo: Pannartz, 1983.

${ }^{39}$ SANT'ANNA, Nuto - São Paulo Histórico (Aspectos, Lendas e Costumes), v. I, Departamento De Cultura, São Paulo, 1937. P. 153 a 162.
} 
Bueno ao investigar a "Décima Urbana" de 1809, identificou o mesmo Antonio Soares Calheiros como proprietário das 12 casas que compunham o Largo do Bexiga, residindo no n.1, num sobrado de 1 loja e 1 lanço ${ }^{40}$.

A presença de Antonio Calheiros, ou Antonio Bexiga foi confirmada por SaintHilaire na sua primeira visita a São Paulo, em 1819, ocasião em que o viajante pernoitou por algumas noites na "[...] hospedaria de um tal Bexiga, que possuía, dentro de São Paulo, vastas pastagens" ${ }^{41}$. Quase quarenta anos depois, o registro dos sepultamentos da Igreja de Santo Antonio, em Santos, identificava a morte de Antonio Bexiga (ou Antonio Soares Calheiros) em 13 de junho de 1857, na cidade de São Paulo (SANT'ANNA). A próxima notícia sobre a chácara data de 1878, quando consta a venda da propriedade, realizada por Thomaz Luís Álvares (ou Thomaz Cruz) a Antonio José Leite Braga. No mesmo ano de 1878 seriam publicados os primeiros anúncios para a venda de terrenos no Bexiga. Certamente se referindo a esse período são as notas de João Baptista de Campos Aguirra sobre a transação: “24 de março de 1878 (7\$500 Benedito Antonio Nascimento comprou de (...) Antonio José Leite Braga (terreno) com 5 braças (à) Rua Antonio Prado (no Bexiga 9...)" ${ }^{42}$.

Por fim, em 1880, a oficina de moveis de propriedade de Antonio José Leite Braga, localizada no Largo do Bexiga, foi vendida "por trinta contos de réis", ao seu sócio, Domingos José Coelho da Silva (SANT’ANNA). A Fábrica de Santo Antonio, como identificada em diversos anúncios publicados nos jornais da época, desempenhou um papel importante no início do loteamento, funcionando tanto como ponto de referência para a venda dos primeiros lotes do bairro, como também como principal local de comercialização da madeira necessária à edificação dos novos prédios.

O objetivo de nosso trabalho, mais do que rever a mera sucessão dos fatos que marcaram a história do bairro, é analisar os mecanismos de produção desse espaço urbano específico, visto como parte do processo de transformação por que passou a cidade de São Paulo. Nesse sentido, é que levantamos e analisamos as diversas plantas da cidade de São Paulo realizadas no decorrer do século XIX e nas primeiras décadas do século XX, procurando destacar os elementos que denunciassem as transformações ocorridas na região. Essas plantas, ao registrar os diferentes momentos da história da

\footnotetext{
${ }^{40}$ BUENO, Beatriz Siqueira - Aspectos do mercado imobiliário em perspectiva histórica. São Paulo 1809-1950, São Paulo, FAUUSP, 2008. p. 36-37.

${ }^{41}$ SAINT-HILLAIRE, Auguste de - Viagem à Província de São Paulo, São Paulo: EDUSP, 1976. P. 121-122.

${ }^{42}$ Arquivo Aguirra. Museu Paulista/USP.
} 
cidade, funcionam como uma radiografia urbana, permitindo a visualização das alterações dos "micro-espaços", que nunca se mostram isolados mas, sempre em consonância com o todo.

Utilizamos o mapa "São Paulo - Chácaras, sítios e fazendas à volta de São Paulo, desde o século XVIII" ${ }^{43}$ como uma referência dos atores sociais, anônimos ou reconhecidos, que de alguma maneira interferiram no processo de construção da cidade (Figura 2). Organizado a partir do "triângulo histórico", tudo indica que foi feito com a intenção de registrar as propriedades fundiárias além do perímetro urbano, em diferentes momentos, entre os séculos XVIII e o XIX. Sua importância para nós está em fornecer os nomes de proprietários de áreas relativamente extensas que deram origem aos primeiros empreendimentos imobiliários de São Paulo, particularmente aqueles de nossa área de estudo.

Além do registro das propriedades fundiárias, fica clara a intenção do engenheiro em destacar os nomes dos proprietários dessas áreas. Ali temos pessoas que no período de aproximadamente um século tiveram o domínio das terras ao redor do "triângulo histórico" da cidade. O mapa não deixa pistas quanto à forma de aquisição dessas terras - aquelas que teriam sido compradas (e de quem) e aquelas que, eventualmente, teriam sido concedidas pela Câmara, através da doação de datas de terra. De qualquer modo, através dele percebemos, de um lado, a presença de famílias tradicionais paulistas que tiveram influência decisiva nos rumos políticos e econômicos da cidade, representadas por Martinho Prado e pelo Barão de Limeira; de outro, áreas ocupadas por personagens "mais ou menos" anônimos, como é o caso da própria Chácara do Bexiga, sem identificação do proprietário. Ao que parece, Bierrembach buscou na visita de Saint-Hilaire a referência à Chácara de propriedade de "um tal de Bexiga”, aquele que foi identificado por Beatriz Bueno como Antonio Soares Calheiros, proprietário de algumas casinhas e de "vastas pastagens". Infelizmente, o documento não dá informações acerca do período a que corresponde aquela propriedade.

O “Mappa da Cidade de São Paulo e seus Subúrbios (1844-1847)” "(Figura 3) é a primeira planta cadastral da cidade e, entre outros documentos cartográficos, o ponto de partida deste trabalho. De acordo com Nestor Goulart Reis, a planta é "um

\footnotetext{
${ }^{43}$ De acordo com Roberto Mônaco (1991), a planta foi “organizada pelo Engenheiro Gastão Cesar Bierrembach de Lima, para a exposição do IV Centenário de São Paulo”, em 1922. Original pertence ao Arquivo Aguirra, do acervo do Museu Paulista/USP.

${ }^{44}$ Original do Museu Paulista/USP. Reprodução do álbum São Paulo Antigo: Plantas da Cidade, publicado pela Comissão do IV Centenário, em 1954. CAMPOS, Eudes (2008).
} 
trabalho de cadastramento de todos os lotes ocupados”, representando toda a área englobada pela cidade na década de 1840, lote a lote. Nela estão demarcados os caminhos de acesso a outras regiões do estado e do país: à Noroeste, o caminho que

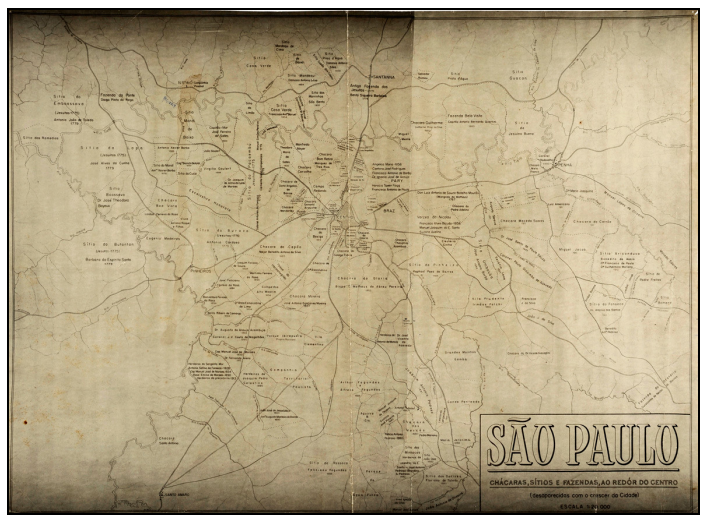

“Chácaras, sítios e fazendas à volta de São

Paulo, desde o século XVIII”. Mapa

organizado pelo Eng. Gastão Cesar

Bierrembach de Lima, para a exposição do IV

Centenário de São Paulo.

Fonte: Arquivo Aguirra. Museu Paulista/USP.

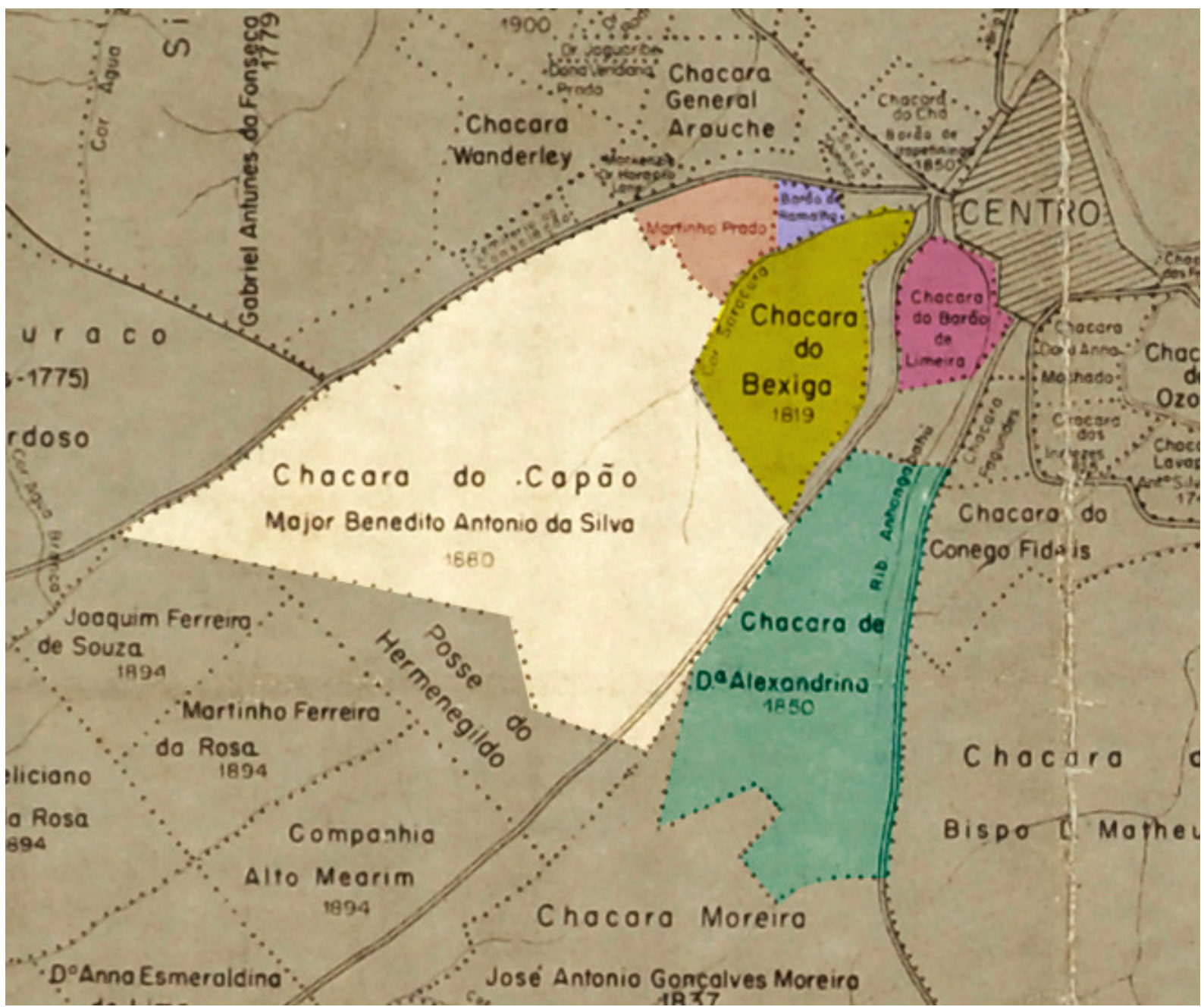

Figura 2 - Em destaque temos a chácara do Bexiga, e à direita, as chácaras do Barão de Limeira (em rosa) e de Da. Alexandrina (em verde); à esquerda, a Chácara do Barão de Ramalho (em roxo), de Martinho Prado (em ocre), seguido da chácara do Capão, do Major Benedito Antonio da Silva (em branco). 


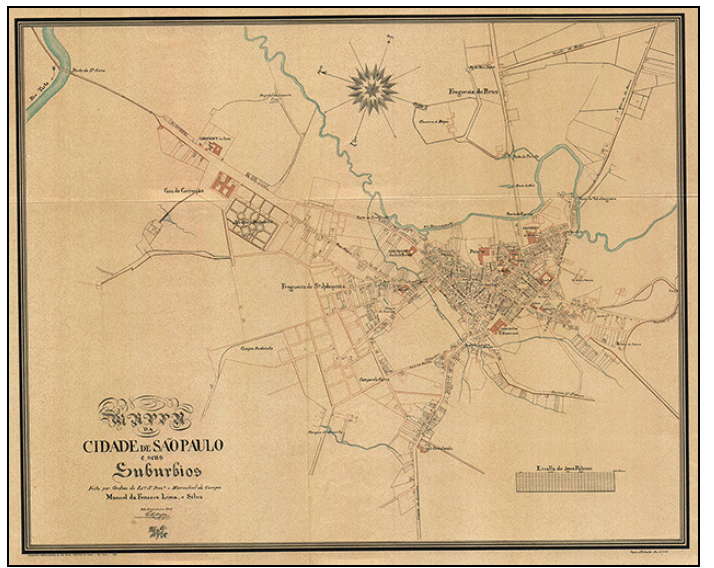

"Mappa da Cidade de São Paulo e seus Subúrbios (1844-1847)”. Engenheiro Civil C.

A. Bresser.

Fonte: Informativo Arquivo Histórico

Municipal, 4 (20):

set/out.2008<http://www.arquivohistorico.sp.go v.br. Consulta em 22/05/2009.

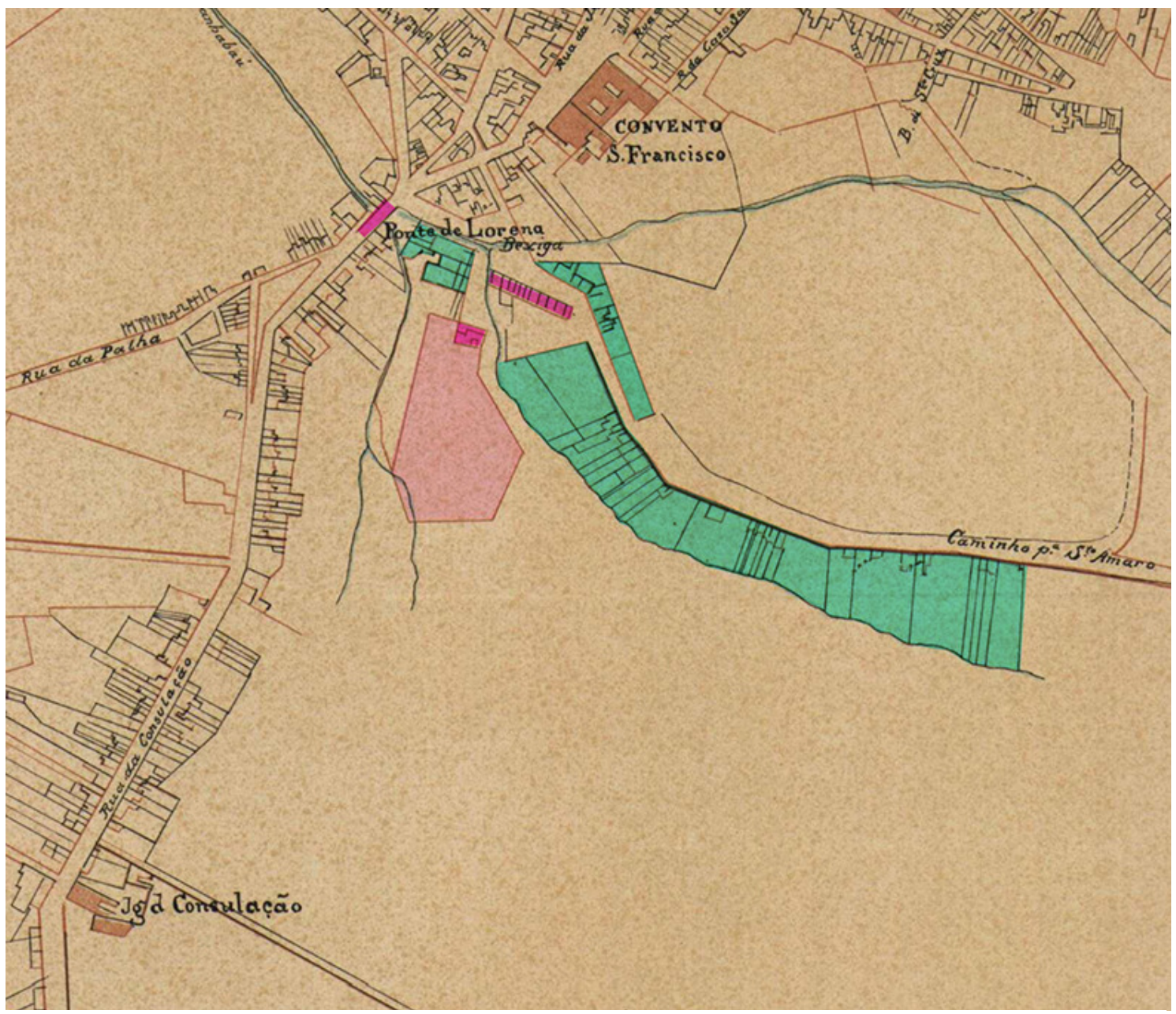

Figura 3 - A planta registra os lotes ocupados nas imediações do Caminho de Santo Amaro, mais densamente na margem direita e menos na esquerda, além de uma série de edificações não identificadas (todos destacados em verde escuro). Destacamos em rosa, a Ponte do Lorena e as casinhas citadas por Beatriz Bueno que, correspondem aos poucos imóveis indicados na "Décima Urbana" de 1809, como pertencentes a Antonio Soares Calheiros, o Antonio Bexiga. Na mesma cor, destacamos a grande área "cercada", que julgamos ser o albergue e as pastagens do Bexiga, a que se referiu Saint-Hilaire, em 1817. A rua da Consolação até a altura da igreja apresenta uma ocupação razoável. 
atravessa a Ponte de Sant'Anna, sobre o Rio Tietê; à Nordeste, o Caminho da Mooca e a Estrada da Mooca, ambos atravessando o Rio Tamanduateí, em direção ao Rio de Janeiro; ao Sul, a partir da rua da Consolação, o Caminho de Sorocaba; e à Sudeste, os caminhos para Santos e Santo Amaro.

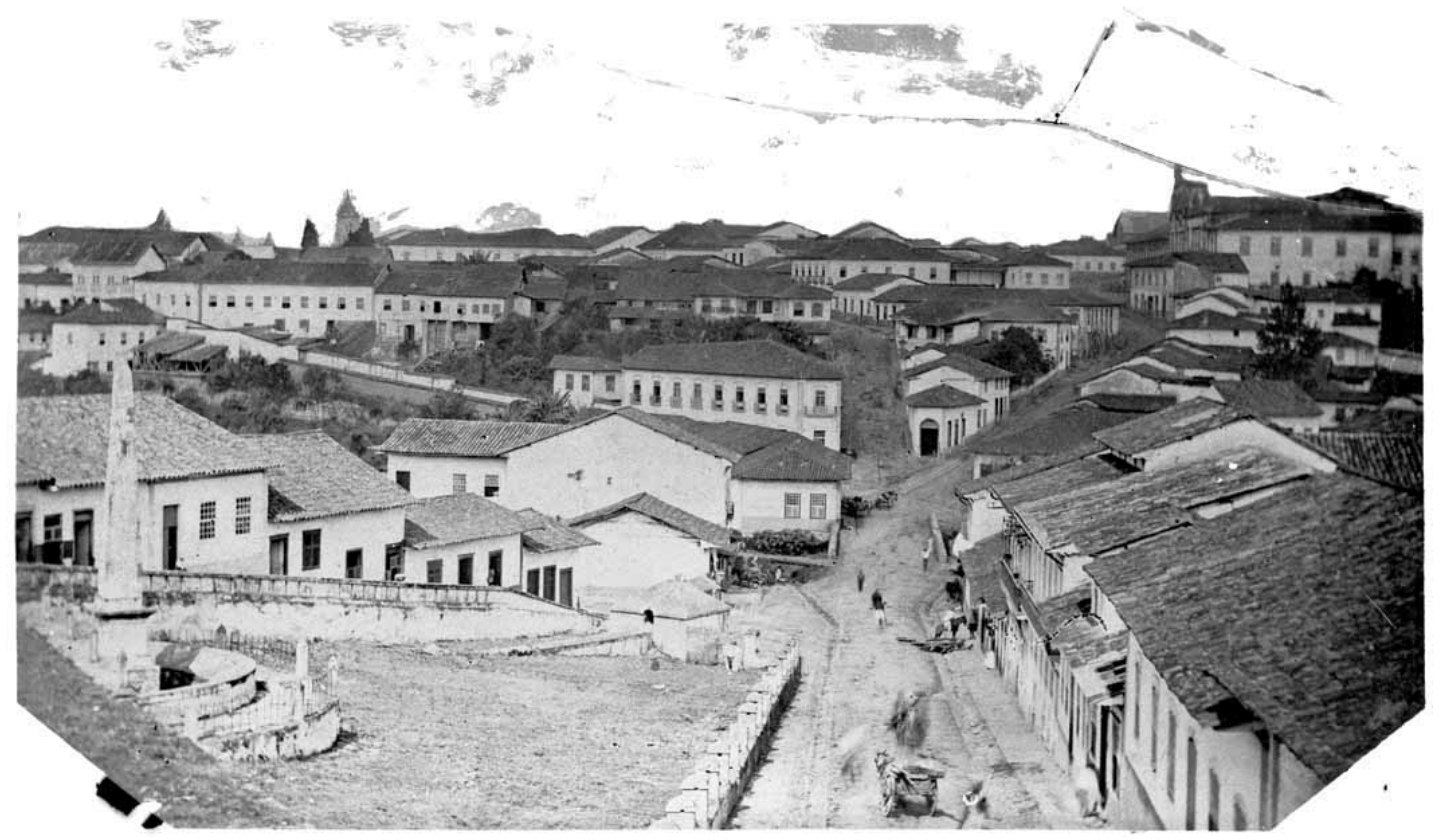

Figura 4 - Em primeiro plano, o Largo da Memória e a Ladeira do Piques, em direção da Ponte do Lorena, à direita da foto. Em frente à ponte, visualizamos a confluência das Ladeiras de Santo Antonio, Ouvidor e São Francisco. Foto: Militão Augusto de Azevedo, 1862. Fonte: Coleção SAN/DIM/DPH/SMC/PMSP.

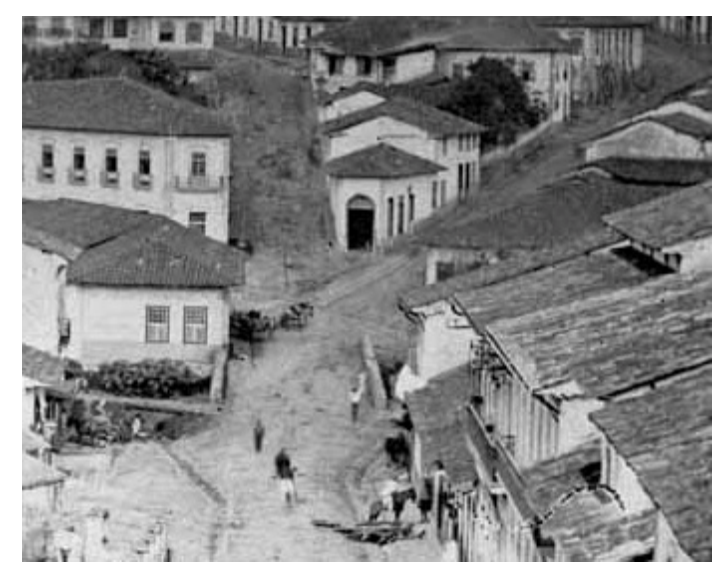

No detalhe da foto de Militão temos a Ponte do Lorena, ampliada, dando acesso ao Largo do Bexiga.

A partir da Ponte do Lorena, a rua da Consolação apresenta uma ocupação razoável até a altura da igreja, ressaltando o espaço vazio à sua direita, em direção do Caminho de Santo Amaro. Este caminho nos interessa especialmente já que foi nos 
seus arredores que se formou o bairro do Bexiga. Ali, temos o registro dos lotes ocupados naquele momento, mais densamente na margem direita e menos na esquerda, além de uma série de edificações não identificadas. A Ponte do Lorena e as casinhas citadas por Beatriz Bueno que, correspondem aos poucos imóveis indicados na "Décima Urbana" de 1809 como pertencentes a Antonio Soares Calheiros, alcunhado de Antonio Bexiga, dono da Chácara do mesmo nome; e a grande área "cercada", que julgamos ser o albergue e as pastagens do Bexiga, a que se referiu Saint-Hilaire, em 1817.

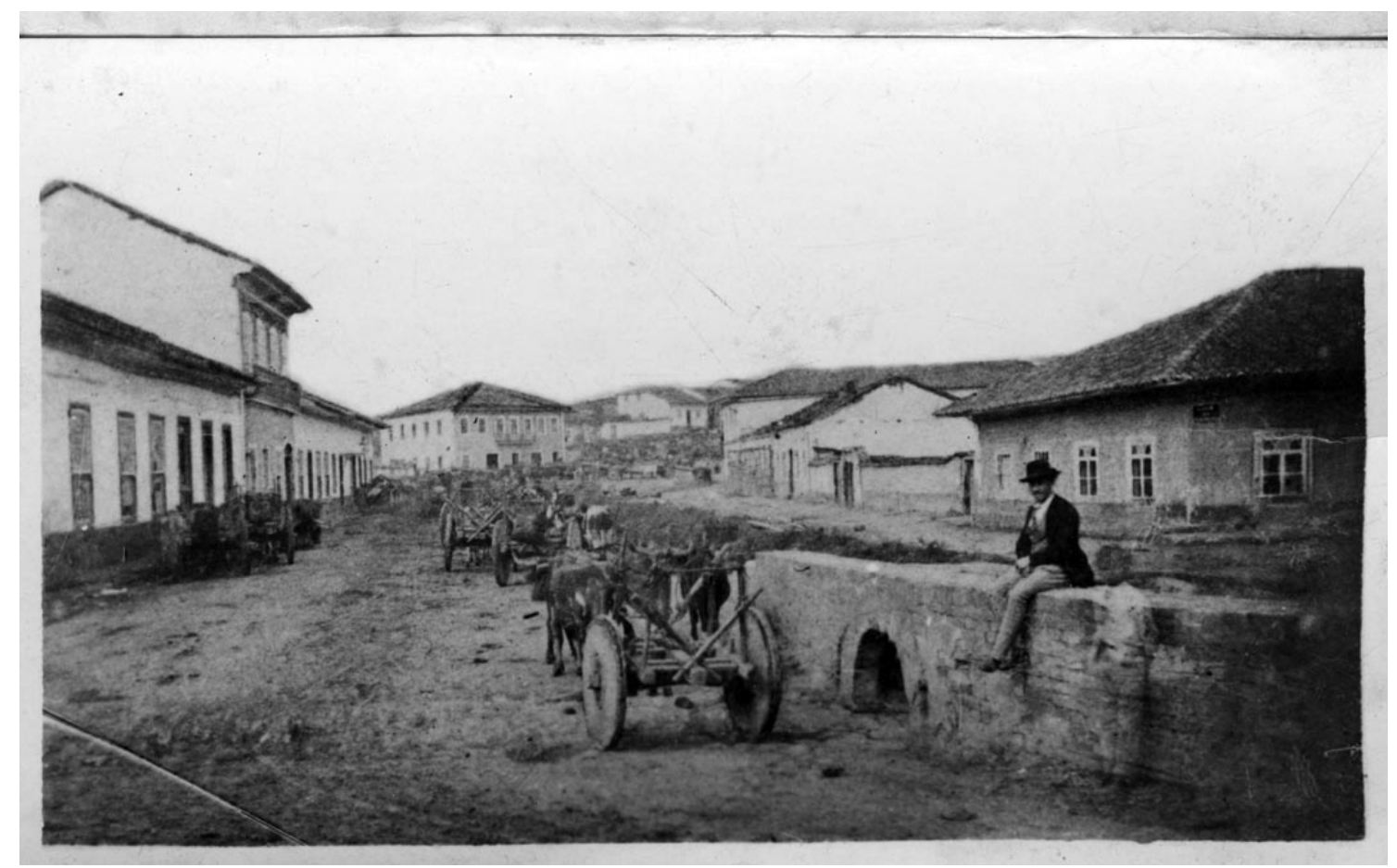

Figura 5 - Nesta imagem, de 1862, observamos a ampla movimentação de tropas no Largo do Bexiga. Foto: Autoria desconhecida. Fonte: Coleção SAN/DIM/DPH/SMC/PMSP.

Outra informação importante que esta planta oferece é a rede hidrográfica que permeia a cidade. $\mathrm{O}$ rio Tamanduateí percorre parte do espaço ocupado pela planta, recebendo as águas do Anhangabaú e se encontrando abaixo com o rio Tietê. O Anhangabaú, por sua vez, é alimentado pelas águas dos ribeirões Itororó, Bexiga e Saracura. Assim, percebemos que o espaço a ser ocupado pelo bairro futuramente seria condicionado pelos limites dados pela rede hidrográfica e pelos caminhos para Sorocaba e Santo Amaro. 
O “Mappa da Imperial Cidade de São Paulo (1855)”, desenvolvido por Carlos Rath (EUDES CAMPOS, 2008) ${ }^{45}$, foi realizado tendo em vista a busca de soluções

${ }^{45}$ Original do Museu Paulista/USP. Reprodução do álbum São Paulo Antigo: Plantas da Cidade, publicado pela Comissão do IV Centenário, em 1954. CAMPOS, Eudes (2008). Op. Cit. 


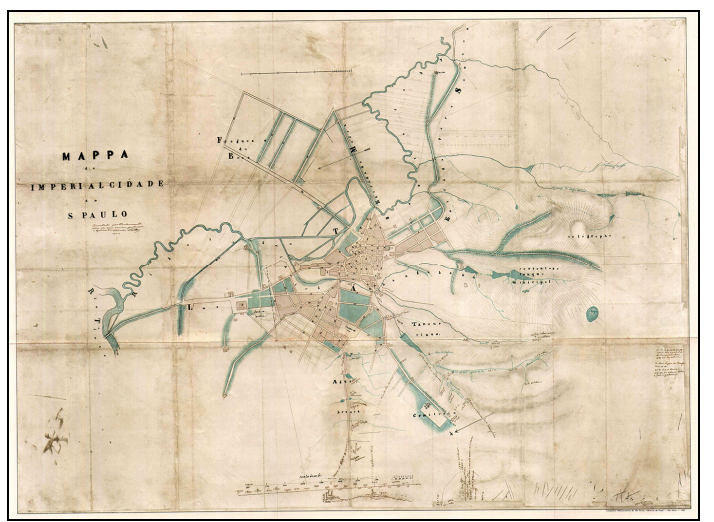

“Mappa da Imperial Cidade de São Paulo"

(1855). Por Carlos Rath.

Fonte: Informativo Arquivo Histórico

Municipal, 4 (20):

set/out.2008<http://www.arquivohistorico.sp.g

ov.br. Consulta em 22/05/2009.

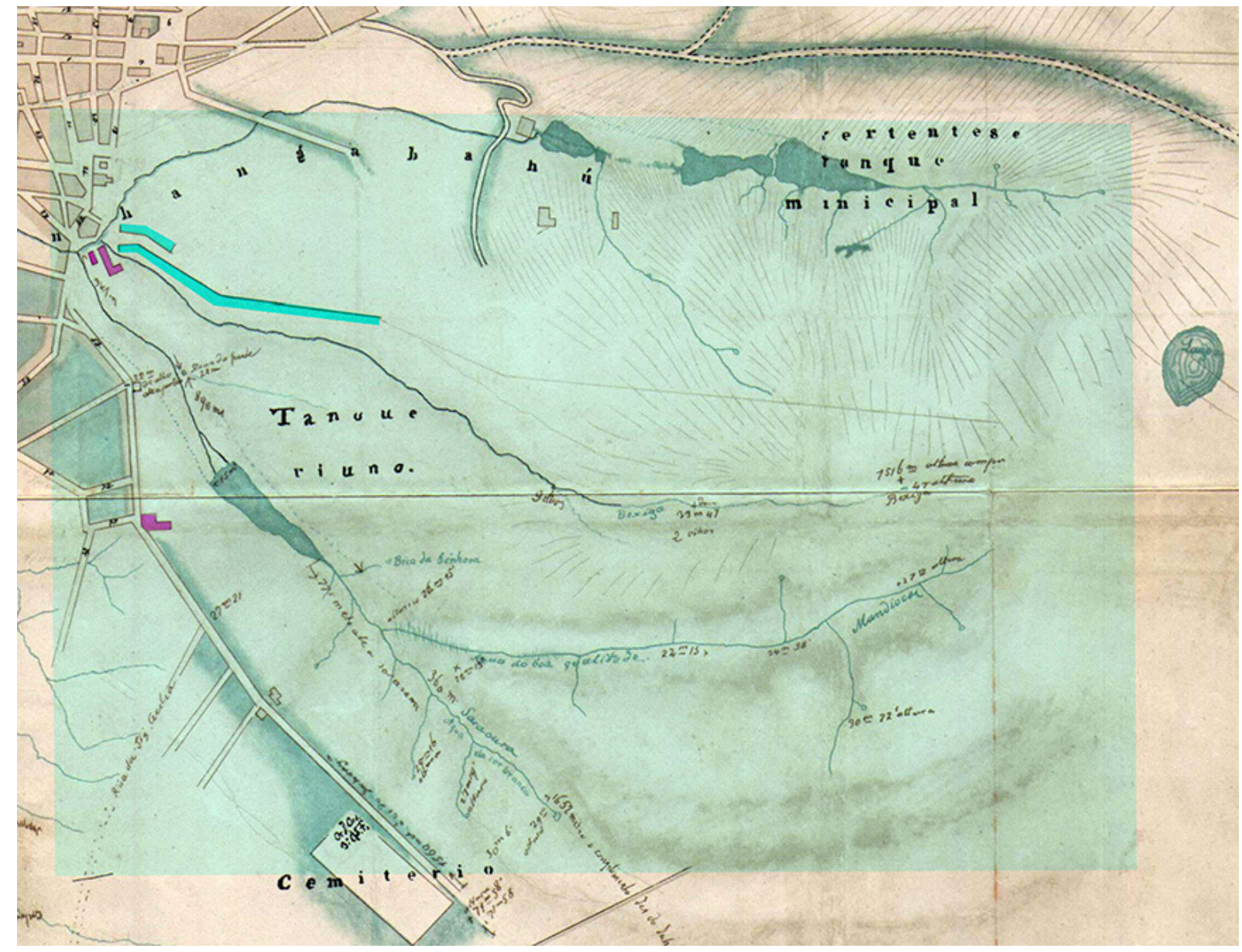

Figura 6 - Destacamos em fundo verde a área onde, aproximadamente se desenvolveu o Bexiga. Próximo ao local onde desaguam os afluentes do rio Anhangabaú, o Saracura, o Bexiga e o Itororó, destacamos, em rosa, uma edificação que julgamos ser a estalagem do Bexiga; à direita, correndo paralelamente ao córrego do Bexiga, o Caminho de Santo Amaro, com destaque em verde para o espaço ocupado pelos lotes e edificações; e abaixo, o Tanque Reúno, localizado no mapa, nas proximidades da Igreja da Consolação. 
para o problema de abastecimento de água potável da cidade. De acordo com Eudes Campos, em 1855, a comissão encarregada de buscar os motivos dos chafarizes da cidade estarem secos, chegou à conclusão que "os Tanques Reúno e das Freiras, também conhecido pelo nome de Santa Teresa, deveriam ser reunidos para aumentar o geral abastecimento de águas potáveis da Capital”. Dessa maneira, Rath foi encarregado de fazer os "melhoramentos do encanamento". O interesse deste trabalho para nós reside, especialmente, na demonstração da área abrangida pelo rio Anhangabaú, seus afluentes Saracura e Bexiga, e o Tanque Reúno, além das inclinações do relevo. A rede hidrográfica, assim como o relevo acidentado, foram fatores determinantes das formas de ocupação da área num momento posterior.

No mapa (Figura 6), destacamos a área onde se desenvolveu o Bexiga. Próximo ao local onde deságuam os afluentes do rio Anhangabaú localizamos uma edificação que julgamos ser a estalagem do Bexiga; à direita, correndo paralelamente ao córrego do Bexiga, o Caminho de Santo Amaro, com destaque para o espaço ocupado pelos lotes e edificações; e abaixo, o Tanque Reúno, localizado nas proximidades da Igreja da Consolação.

A autoria da "Planta da Cidade de São Paulo (1868)" é atribuída ao mesmo Carlos Rath. De acordo com Eudes Campos ${ }^{46}$, esta planta teria sido confeccionada para o uso pessoal do engenheiro, entre 1868 e 1872, quando trabalhava para a Câmara Municipal de São Paulo. Na análise da planta, o autor ressalta a preocupação do engenheiro em registrar os primeiros sinais das transformações que a cidade iria viver dentro de poucos anos, tais como a estrada de ferro e "os arruamentos posteriormente abertos em chácaras situadas nas imediações da Capital, indicadores de uma especulação fundiária tornada visível a partir de meados da década de 1870, e cuja intensidade se fará notar de modo escancarado na Planta de n.11, datada de 1897”. No entanto, ainda que pesem os registros das mudanças, o cuidado de Rath com a “captação de água potável para a Capital” indica que o principal intuito do engenheiro teria sido a busca pela solução desse problema.

Particularmente interessante é a informação sobre o Matadouro Municipal. Ficamos sabendo por Eudes Campos que Carlos Bresser foi o engenheiro responsável pela construção do prédio do matadouro, entre 1849 e 1852. Destacamos, no mapa de

\footnotetext{
${ }^{46}$ Original do Museu Paulista/USP. Reprodução do álbum São Paulo Antigo: Plantas da Cidade, publicado pela Comissão do IV Centenário, em 1954. CAMPOS, Eudes (2008). Op. Cit.
} 


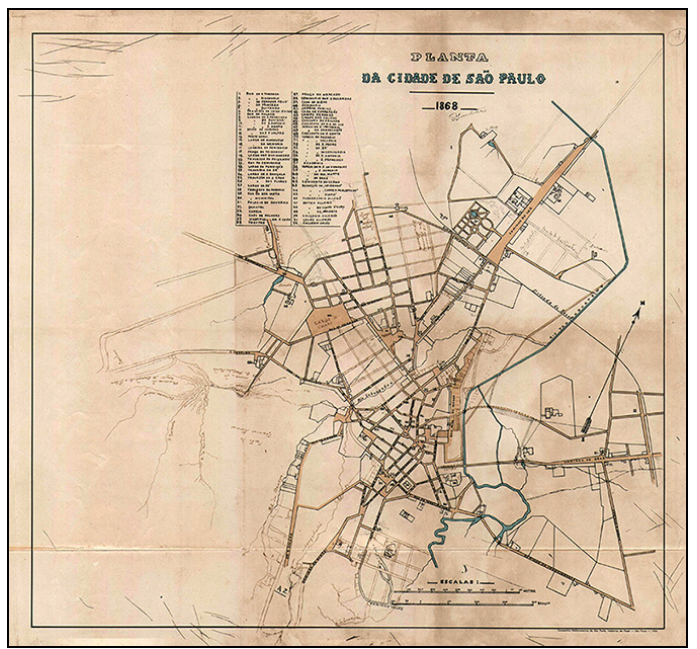

"Planta da Cidade de São Paulo" (1868).

Atribuída a Carlos Frederico Rath

Fonte: Informativo Arquivo Histórico

Municipal, 4 (20):

set/out.2008<http://www.arquivohistorico.sp.g ov.br. Consulta em 22/05/2009.

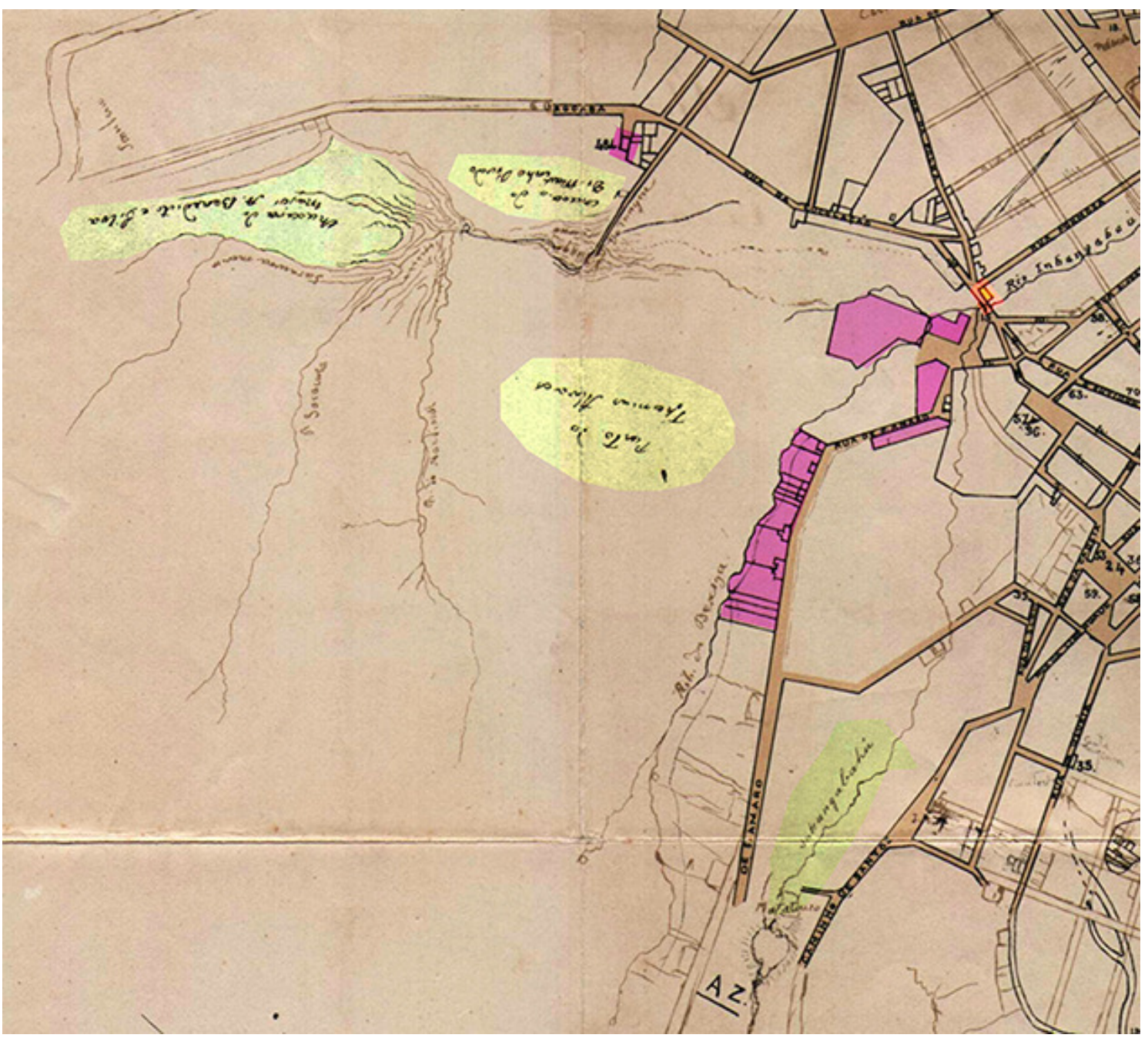

Figura 7 - Ressaltamos os pontos que dizem respeito à área abrangida pela Chácara do Bexiga: em $\underline{\text { rosa }}$, os lotes que julgamos equivaler às casinhas de Antonio Soares Calheiros e aqueles da rua de Santo Amaro, já destacados nas plantas anteriores e, no pequeno quadrado laranja, a novidade introduzida recentemente, o Matadouro Municipal, entre o Caminho de Santo Amaro e o Caminho de Santos. À esquerda da planta, no pequeno aglomerado de edificações à margem da rua da Consolação, destacamos em rosa a Igreja do mesmo nome. Nas manchas em amarelo, destacamos os registros manuscritos realizados por Rath. 
1868 (Figura 7), os pontos que dizem respeito à área abrangida pela chácara do Bexiga: os lotes que julgamos equivaler às casinhas de Antonio Soares Calheiros e aqueles da rua de Santo Amaro, já destacados nas plantas anteriores e, a novidade então introduzida, o Matadouro Municipal, entre o Caminho de Santo Amaro e o Caminho de Santos. Por fim, à esquerda da planta, no pequeno aglomerado de edificações à margem da rua da Consolação, destacamos a Igreja do mesmo nome.

Além dos aspectos levantados por Campos, identificamos, na grande área vazia entre as ruas Santo Amaro e da Consolação, algumas informações interessantes. Tratase de registros feitos à mão, pelo autor, em sentido contrário ao da planta. $\mathrm{O}$ primeiro caso se refere ao "Pasto de Thomas Alvares", entre o ribeirão do Bexiga e a rua da Consolação, certamente o mesmo Thomaz Luís Álvares que, em 1878, vendeu suas terras a Antonio José Leite Braga que, por sua vez, deu início ao empreendimento do Bexiga.

O segundo caso se refere à "Chácara do Major A. Benedicto e Silva” ou, de acordo com a planta "São Paulo - Chácaras, sítios e fazendas à volta de São Paulo, desde o século XVIII”, à Chácara do Capão, de propriedade do Major Benedicto Antonio da Silva. Quanto à referência ao “córrego do Dr. Martinho Prado”, próximo ao Tanque Reúno, ela assinala, pela primeira vez, a presença da família Prado na região. Essa informação corresponde à área indicada pelo mapa de Bierrembach, onde localizamos a Chácara de Martinho Prado, à esquerda da Chácara do Bexiga, e logo acima da Chácara do Capão.

Embora a cidade de São Paulo apresentasse uma ampla rede hidrográfica, o problema de abastecimento de água para a população se arrastava havia muitos anos. $\mathrm{Na}$ medida em que a comercialização da produção cafeeira em terras paulistas apresentou papel de destaque na economia brasileira, a capital da Província assumiu gradativamente o papel de referência, atraindo novos habitantes, fato potencializado pela implantação da linha ferroviária, em 1867. Em pouco tempo a estrutura urbana da cidade se mostrou insuficiente para dar conta do crescimento demográfico e do processo de expansão de seus limites. A proliferação desordenada de moradias sem condições de salubridade, terreno fértil para os surtos epidêmicos, impôs a necessidade de criação de uma infra-estrutura condizente com o processo de urbanização, traduzida pelo saneamento dos rios e várzeas da capital, pelo fornecimento de água e pela instalação da rede de esgotos. Foi neste cenário que, em 1877, “o governo provincial 
contratou uma empresa privada, a Companhia Cantareira \& Esgotos, responsável pela construção e administração desse sistema" ${ }^{47}$.

Tendo em vista o mapeamento da cidade para o cumprimento de seus objetivos, em 1881, a Cia. Cantareira \& Esgotos publicou a "Planta da Cidade de São Paulo (1881)” (Figura 8) ${ }^{48}$. De acordo com Eudes Campos, esta que foi a segunda planta cadastral de São Paulo, e evidencia as transformações sofridas pela cidade:

"[...] abarca a total área urbanizada da cidade. [...] Ainda em 1887 a planta da Cantareira era vista na Câmara como um documento muito útil, por trazer uma parte do cadastro da cidade e parte dos arrabaldes. [...] A antiga Cidade Nova já apresentava na época grande número de construções, em especial, construções residenciais, entre elas, amplas sedes de chácaras isoladas no meio de extensos terrenos. [...] O bairro dos Campos Elísios [...] estava ainda desocupado, tal como o bairro da Bela Vista, criado, no mesmo ano, na antiga Chácara do Bexiga pelo proprietário da época, o português Antônio José Leite Braga, então recentemente falecido."

Entre os sinais de mudança, observamos a presença das Estradas de Ferro Sorocabana e Santos-Jundiaí; o inicio de expansão em direção à Santana, pelo menos até o rio Tamanduateí; a ocupação por novas edificações de parte do que conhecemos atualmente como o bairro da Liberdade; o arruamento previsto para novos loteamentos, no Brás, Campos Elíseos e Bexiga. Aliás, é na Planta da Cia. Cantareira que, pela primeira vez, aparece o traçado do que viria a ser o bairro do Bexiga.

A julgar pelo anúncio no jornal A Província de São Paulo ${ }^{49}$, o loteamento do Bexiga já era uma realidade, desde 1878:

\section{“TERRENOS DO BEXIGA}

Os proprietários destes terrenos mandaram levantar um plano geral de arruamento e expor à venda em lotes e às braças, à vontade do comprador.

As pessoas que desejarem possuir algumas braças de terrenos próprios, com excelente vista, água nascente e livre de qualquer ônus podem desde já examinar e dar as suas encomendas no escritório deste jornal a Emílio Rangel Pestana, ou nas oficinas de Santo Antonio (no Bexiga) aos proprietários dos referidos terrenos que facultarão aos srs. compradores a entrada e exame dos mesmos. ${ }^{50}$

Em 17/01/1881, o mesmo jornal anunciava a conclusão da "grande rua que comunica o bairro da Consolação com o Bexiga". Ao analisar a planta elaborada por

\footnotetext{
${ }^{47}$ CAMPOS, Cristina - “A promoção e a produção das redes de águas e esgotos na cidade de São Paulo, 1875-1892”, Anais do Museu Paulista, vol. 13, n 2, São Paulo, 2005. P. 189.

${ }^{48}$ Cópia pertencente ao Museu Paulista/USP. Reprodução do álbum São Paulo Antigo: Plantas da Cidade, publicado pela Comissão do IV Centenário, em 1954. CAMPOS, Eudes (2008). Op. Cit

${ }^{49}$ Jornal A Província de São Paulo, 10/05/1878, Arquivo do Estado, Microfilme 01.01.004.

${ }^{50}$ A Província de São Paulo, 10/05/1878, p. 2. Arquivo do Estado.
} 


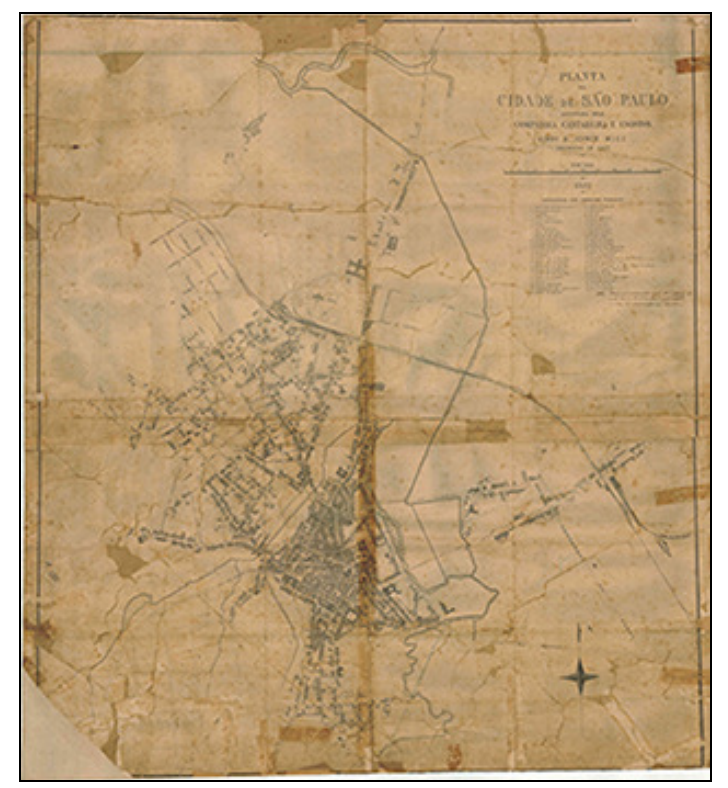

“Planta da Cidade de São Paulo" (1881).

Levantada pela Cia. Cantareira e Esgotos, Henry B. Joyner, Engenheiro em Chefe Fonte: Informativo Arquivo Histórico Municipal, 4 (20):

set/out.2008<http://www.arquivohistorico.sp.g ov.br. Consulta em 22/05/2009.

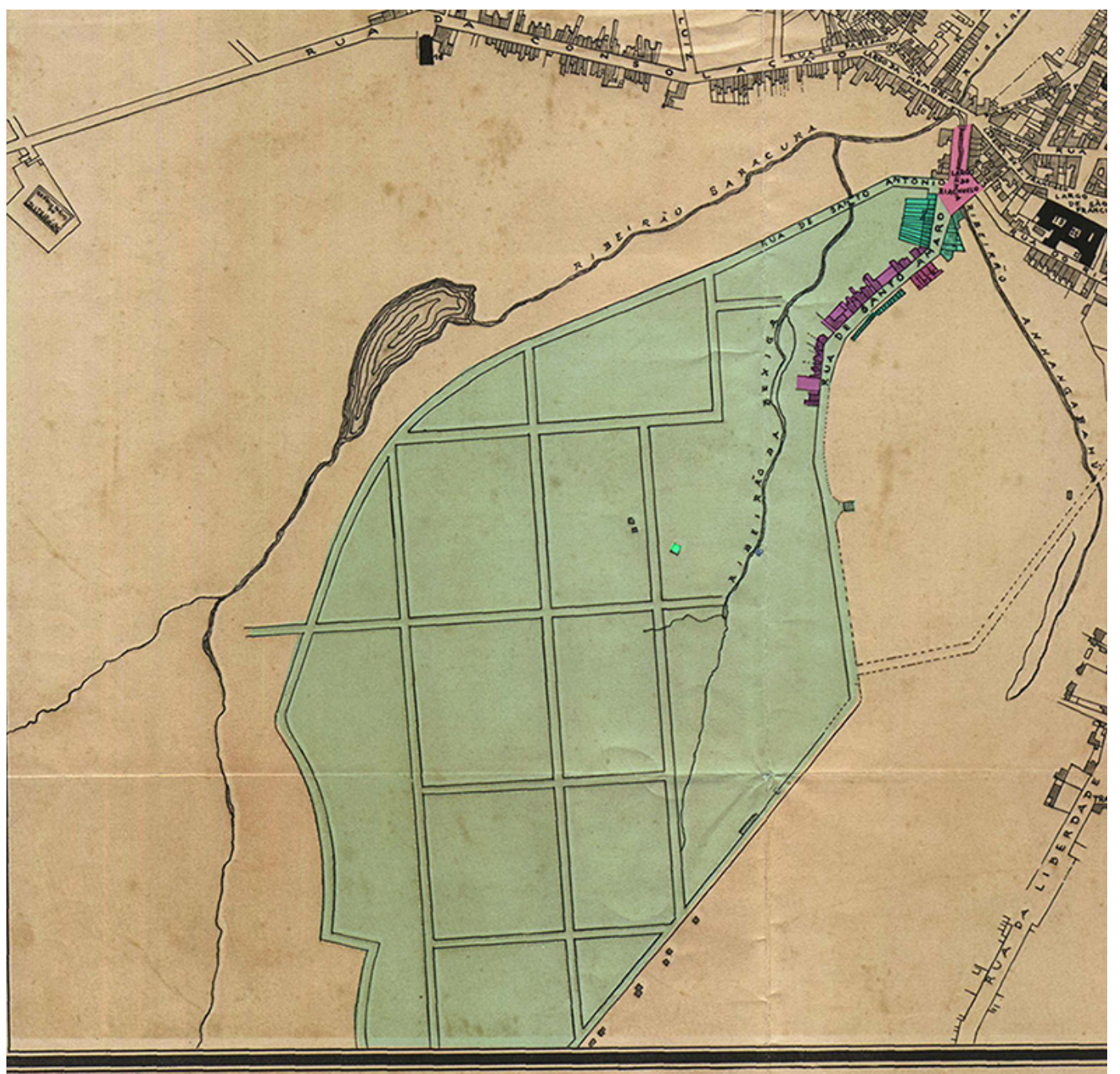

Figura 8 - As ruas projetadas para o loteamento não possuíam nome. A planta indica, quando da sua elaboração, que o empreendimento ainda era uma promessa. Há umas raras edificações dispersas por toda a área do loteamento. Uma delas, um pequeno ponto verde claro identificado na planta, que supomos tratar-se da Casa de Dona Yayá, na época ainda uma chácara, provavelmente, construída por volta dos anos 1870 . 
Jules Martin em 1890, visualizamos uma via - "Aterrado da Bella Vista” - que, saindo da rua da Consolação do lado direito da Igreja, une esta rua à rua Santo Antonio. Tudo indica que essa fosse a rua Martinho Prado.

As ruas projetadas para o loteamento não possuíam nome. A planta indica, quando da sua elaboração, que o empreendimento ainda era uma promessa. Há umas raras edificações dispersas por toda a área do loteamento, entre elas, aquela que supomos tratar-se da Casa de Dona Yayá, na época ainda uma chácara, provavelmente, construída por volta dos anos $1870^{51}$. A casa localiza-se à rua Major Diogo, entre as ruas Manoel Dutra e São Domingos. Na planta, a posição das ruas não é exatamente a mesma encontrada nas plantas posteriores. Algumas foram prolongadas, outras foram abertas, cortando quadras ao meio e, outras foram criadas, de maneira a alargar os limites do bairro, à esquerda e à direita.

A seguir, temos a “Planta dos Terrenos do Bexiga (1890)", realizada pelo engenheiro Fernando de Albuquerque (Figura 9). Trata-se, na verdade, de um croqui, apresentando um loteamento cujo arruamento já se mostra praticamente igual àquele encontrado nas plantas posteriores. Contudo, a nomeação das ruas difere completamente da nomeação futura, à exceção da rua do Conselheiro Carrão. Por outro lado, a rua ali identificada como Santo Amaro, na realidade é a rua Santo Antonio - a rua Santo Amaro inexiste neste mapa.

Alguns aspectos do documento nos chamam a atenção. As anotações acerca das “linha(s) de bonde(s) projectada(s)" para a Avenida Celeste (atual rua Major Diogo) e rua Santo Amaro (na verdade, Santo Antonio) indicam a intenção de implementação do serviço de transporte público, fator que condicionou a valorização do empreendimento. Também encontramos ali alguns nomes de prováveis proprietários de lotes: Luiz Americano, Lourenço Cruz, Lourenço Carmo, Maria de Paula, Francisco Gullo, Alexandrina Maria do E.S ${ }^{52}$ e Antonio Sotero. Aliás, com relação à Alexandrina Maria do Espírito Santo, na Série Obras Particulares, no ano de 1888, seu nome foi dado como referência para alinhamento, em requerimento encaminhado à Diretoria de Obras

\footnotetext{
${ }^{51}$ KATINSKY, Júlio Roberto - “Casa de Dona Yayá - Uma apreciação”, in: A casa de Dona Yayá/Comissão de Patrimônio Cultural da USP, $2^{\text {a }}$ Edição, São Paulo: Edusp/Imprensa Oficial, 2001 Cadernos CPC, p. 87 a 96.

${ }^{52}$ Identificamos a mesma Alexandrina Maria do E. S., como Alexandrina Maria do Espírito Santo, vizinha do proprietário Silvério Lavarito, no Morro do Caaguaçú., Série Obras Particulares, 02/03/1888, v. 30, f. 35 .
} 
por Silvério Lavarito ${ }^{53}$. Em 02 de março daquele ano, Lavarito entrou com um pedido de alinhamento para edificação no morro do Caaguassú. De acordo com o processo, seu lote "Divide de um lado com Alexandrina Maria do Espírito Santo e de outro com o próprio”. Assim como D. Alexandrina, Lourenço Cruz também comparece na Série Obras Particulares. Em 10 de setembro de 1887, José Bernardino Queiroga solicitou alinhamento para edificação, à rua Santo Amaro n¹24. Seu lote dividia "de um lado com Lourenço Cruz e de outro com Domingos Antonio Pacheco" ${ }^{54}$. Durante a década de 1880, o próprio Fernando de Albuquerque comparece, na categoria "vizinhança", em pelo menos seis ocasiões. Dessa maneira, deduzimos que as pessoas mencionadas naquela planta realmente eram proprietárias.

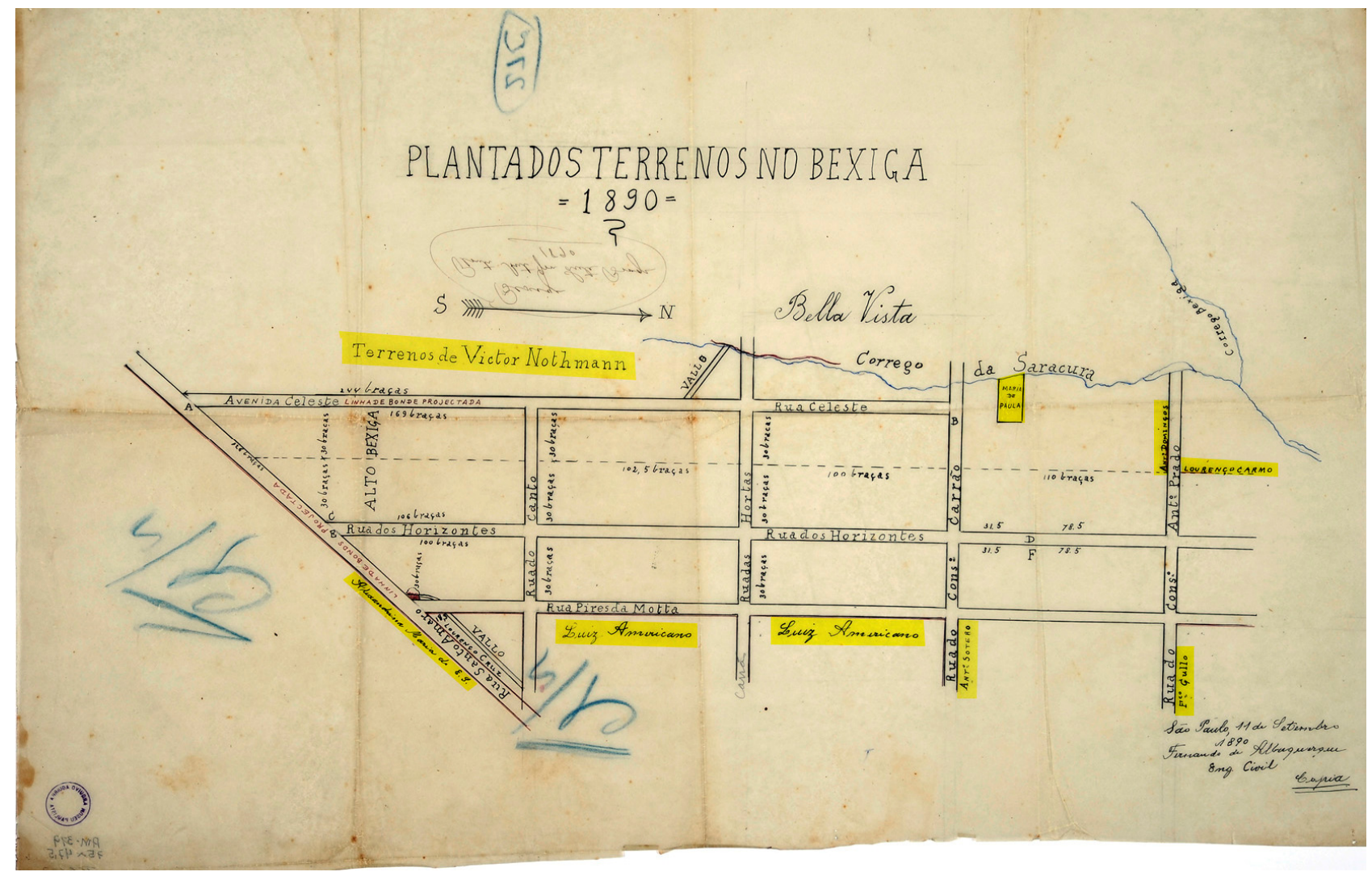

Figura 9 - "Planta dos Terrenos do Bexiga" (1890). Fernando de Albuquerque, engenheiro civil Fonte: Arquivo Aguirra/Museu Paulista/USP.

Acima da Avenida Celeste, à esquerda do croqui, temos a menção a "Terrenos de Victor Nothmann”, o que indica que Victor Nothmann também investiu em terrenos nessa área da cidade, além dos investimentos correspondentes ao bairro de Campos Elíseos. Enfim, todos estes aspectos evidenciam que esse empreendimento estava em

\footnotetext{
53 Obras Particulares, 02/03/1888, v. 30, f. 35.

${ }^{54}$ Obras Particulares, 10/09/1887, v. 27, f. 45.
} 
perfeita sintonia com o momento de crescimento e transformação vivido pela capital paulista.

Embora não se trate de uma planta com caráter oficial, acreditamos que sua análise seja importante, na medida em que documenta um dos primeiros empreendimentos realizados nos subúrbios da capital. Os anúncios investigados nos jornais A Província de São Paulo e O Estado de São Paulo procuram chamar a atenção para o fato de se tratar de "belíssimos terrenos", chegando, em alguns casos mesmo a trocar o nome "pejorativo" de Bexiga pelas alcunhas, mais interessantes, de Monte de Ouro e Bela Cintra. Vejamos abaixo, um ótimo exemplo da tentativa de "dourar a pílula" do empreendimento.

"TERRENOS - É hoje o melhor emprego de capitais, mas cumpre ainda fazer-se boa escolha do local, para duplicar as vantagens do emprego, isto é, que a localidade ao menos, seja salubre; mas que salubridade podem oferecer essas várzeas que rodeiam esta capital?... Que não há entre esses paludosos terrenos e os da Bela Cintra?... Nesses não só há a reconhecida salubridade da terra e deslumbrante vista; além disso quem há aí que faça tantas vantagens ao comprador como a Bela Cintra?... Aqui se vendem os terrenos baratíssimos, concede-se algum prazo para a metade do pagamento deles, aqui há matas, que só delas se tira o valor do terreno, e há grande pastaria grátis; e para provar que a descrição está muito abaixo da realidade, o seu proprietário convida os srs. pretendentes a virem percorrer este bairro em antes de fazerem por aí alguma compra de afogadilho, que depois se arrependam. Entende-se por Bela Cintra, desde a rua da Consolação até a rua de Santo Amaro, inclusive o Bexiga de outrora" ${ }^{55}$

Tratava-se de empreendimento voltado para pequenos e médios investidores. As condições para o empreendimento, de certa maneira, já se esboçavam no Mappa da Imperial Cidade de São Paulo, de 1855, na qual a área do futuro loteamento se destaca pela presença dos cursos d'água e do relevo acidentado.

Não sabemos para que fins o croqui foi elaborado. É provável que quando se quisesse iniciar um empreendimento fosse necessário enviar o projeto para avaliação da Prefeitura, e este documento fosse uma espécie de "rascunho", se não o próprio original. Se o compararmos à planta da Cia. Cantareira, vemos que lá o traçado do loteamento já estava praticamente definido, diferindo muito pouco do croqui, realizado $\underline{\text { nove anos depois. }}$

\footnotetext{
${ }^{55}$ Jornal A Província de São Paulo, 22, 23 e 26/07/1881, Arquivo do Estado, Microfilme 01.01.007.
} 
De acordo com o relatado por Eudes Campos, na "Planta da Capital do Estado de São Paulo e seus arrabaldes (1890)” (Figura 10) desenhada e publicada por Jules $\operatorname{Martin}^{56}$ :

"Temos agora sob os olhos a primeira carta paulistana executada após a Proclamação da República [...] os limites da planta de 1890 mostram avanço com relação aos da planta de 1881 [...] a Rua Pedroso partia da Rua de Santo Amaro (atual Avenida Brigadeiro Luís Antônio) [...] Também a identificação das ruas nessa parte da cidade se apresenta de modo confuso. [...] Podemos identificar quase todas as construções assinaladas nesta planta, obras em sua maioria recém-construídas ou em fase de conclusão. [...] a Escola de Primeiras Letras da Rua de Santo Amaro, humilde prédio construído no Bexiga entre 1877 e 1878 [...] “

Nesta planta, pela primeira vez, o bairro do Bexiga se apresenta como um fato consumado, pelo menos do ponto de vista do projeto de Fernando Albuquerque. Quase todas as ruas existentes possuem nomes, ainda que nem todos definitivos. Horizontalmente, temos as rua Conselheiro Antonio Prado e da Horta que deram lugar às ruas Manoel Dutra e Fortaleza. Perpendicular a estas, temos as ruas Pires da Motta, dos Valinhos e da Misericórdia que, por sua vez, deram lugar às ruas Treze de Maio, Major Diogo e Abolição. No ponto de encontro entre as ruas Santo Antonio e São Domingos, vemos o caminho do "aterrado da Bella Vista", em direção da rua da Consolação que a partir da planta de 1895 seria identificado como rua Martinho Prado.

É curioso pensar nos critérios que nortearam a escolha deste ou aquele bairro para homenagear personagens ou fatos históricos relevantes. No caso das ruas Pires da Motta e Conselheiro Antonio Prado, por exemplo. Pires da Motta, entre outros cargos, desempenhou a função de Vice-Presidente da Província em diversas ocasiões, a última delas em 1871. Seu nome deixou de figurar no Bexiga e passou a constar do logradouro localizado entre o Cambuci e a Aclimação. Antonio Prado, membro de uma das famílias mais influentes da oligarquia paulistana, veio a ser o primeiro prefeito da cidade de São Paulo, entre 1899 e 1911. O nome desse personagem "migrou" para o Centro da cidade, vindo a alcunhar a praça que substituiu o antigo Largo do Rosário, locação talvez mais "de acordo" com a posição de prefeito.

De outro lado, temos a introdução de nomenclaturas alusivas à Abolição da Escravidão: a rua da Abolição relacionada ao fato em si e, a rua Treze de Maio, relacionada à data. Qual teria sido a intenção? Demarcar o fato de caráter político?

\footnotetext{
56 “Planta da Capital do Estado de São Paulo e seus arrabaldes (1890” - Original do Museu Paulista/USP. Reprodução do álbum São Paulo Antigo: Plantas da Cidade, publicado pela Comissão do IV Centenário, em 1954. CAMPOS, Eudes (2008). Op. Cit
} 


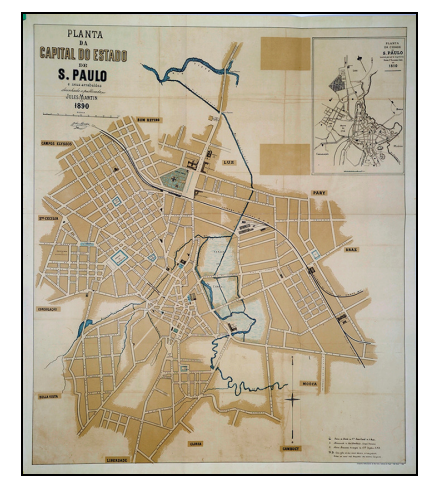

"Planta da Capital do Estado de São Paulo e seus arrabaldes" (1890). Desenhada e publicada por Jules Martin.

Fonte: Informativo Arquivo Histórico

Municipal, 4 (20):

set/out.2008<http://www.arquivohistorico.sp.g ov.br. Consulta em 22/05/2009

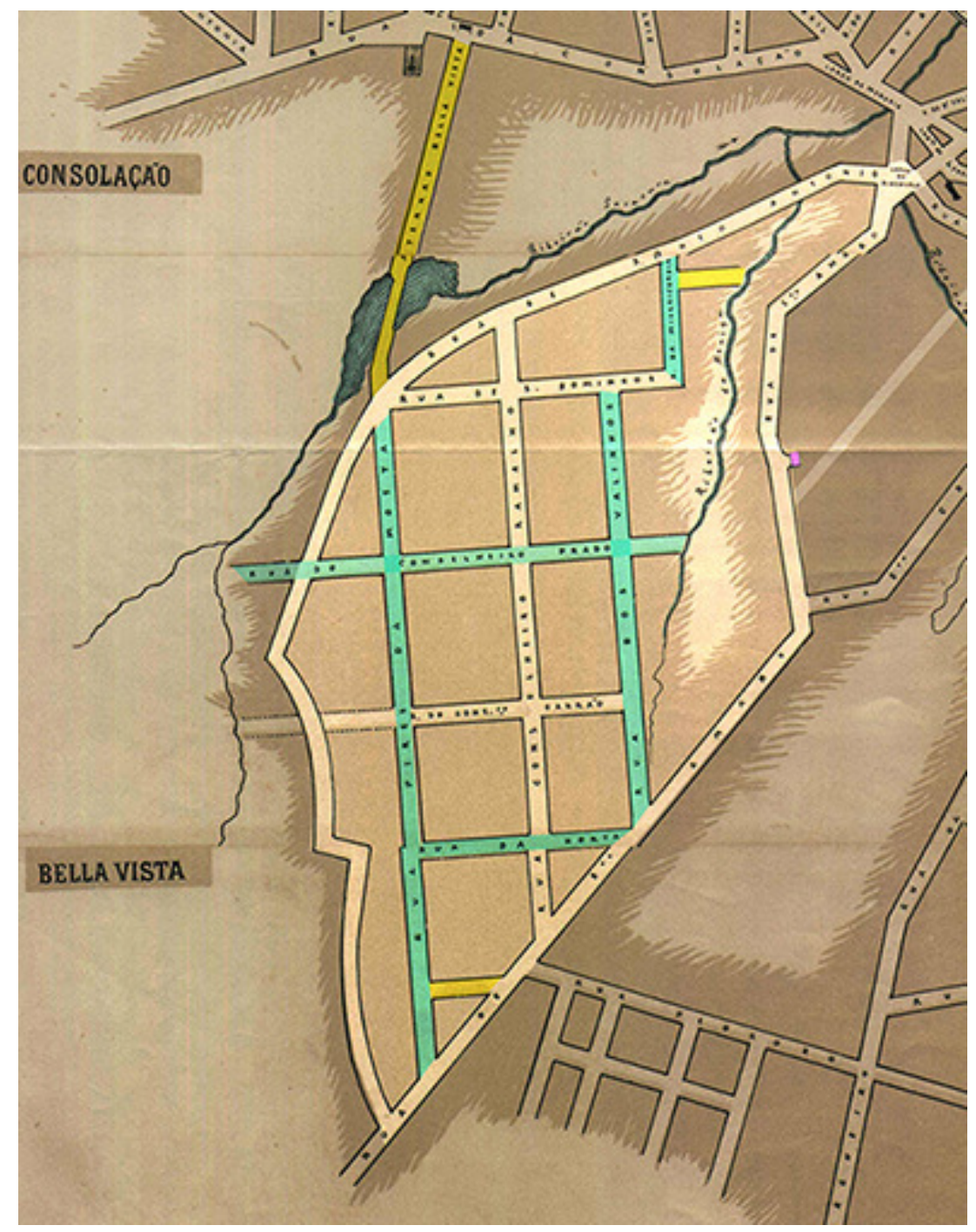

Figura 10 - Aqui, quase todas as ruas existentes possuem nomes, ainda que nem todos definitivos. É o caso das ruas destacadas em verde. Horizontalmente, temos as rua Conselheiro Antonio Prado e da Horta que deram lugar às ruas Manoel Dutra e Fortaleza. Perpendicular a estas, temos as ruas Pires da Motta, dos Valinhos e da Misericórdia que, por sua vez, deram lugar às ruas Treze de Maio, Major Diogo e Abolição. No ponto de encontro entre as ruas Santo Antonio e São Domingos, vemos o caminho do “aterrado da Bella Vista”, em direção da rua da Consolação que, a partir da planta de 1895 seria identificada como rua Martinho Prado. Em amarelo, temos duas ruas ainda sem nome, que deram origem às futuras ruas Jacareí e Fortaleza. Por fim, destacada em rosa, temos a Escola de Primeiras Letras, na margem direita da rua Santo Amaro, entre a "rua Santa Cruz" e o "Largo do Riachuelo". 
Homenagear o segmento liberto das "amarras" do Império? Ou, simplesmente, se tratava de substituir um nome pelo outro?

Acima, nos reportamos à presença das Chácaras de Martinho Prado e do Barão de Limeira nas proximidades da Chácara do Bexiga. A julgar pelos anos em que viveu Martinho Prado (1843-1906), acreditamos que tenha sido contemporâneo do loteamento do bairro, a partir de 1878. A presença da família Prado marcou pelo menos duas vias nas proximidades do Bexiga: a própria rua Martinho Prado, fazendo a ligação entre o bairro e a Consolação, e a rua Caio Prado, entre a rua Frei Caneca e a rua da Consolação.

As famílias Pais de Barros e Souza Queiroz também deixaram suas marcas. A chácara localizada à direita do Bexiga, pertenceu ao Barão de Limeira, Vicente de Souza Queiroz (1813-1872). Parte do que hoje conhecemos como o amplo bairro da Bela Vista, em direção do bairro da Liberdade, estava sob a área de atuação dessas famílias. O que se confirma através de praticamente todas as ruas ali localizadas: as ruas Genebra, Francisco Aguiar de Barros, Maria Paula, Francisca Miquelina, além da óbvia Avenida Brigadeiro Luís Antonio. Dentro dos limites do loteamento original, o próprio Major Diogo Antonio de Barros veio a dar nome a uma de suas ruas ${ }^{57}$.

Uma informação de particular interesse que essa planta oferece é a presença da Escola de Primeiras Letras, na rua Santo Amaro. O imóvel, ainda existente, foi tombado pelo CONDEPHAAT, em 1992 e, pelo CONPRESP em $2002{ }^{58}$. De acordo com o histórico do processo de tombamento pelo órgão estadual, o prédio da escola foi construído em 1877, em terreno doado pela Baronesa de Limeira, na atual rua Aguiar de Barros $\mathrm{n}^{\circ}$ 160, na Bela Vista. Tratava-se de uma iniciativa do governo imperial, estranhamente em "área não urbanizada".

Conforme o histórico fornecido pelo órgão:

\footnotetext{
${ }^{57}$ Conforme a pesquisa documental, realizada para o tombamento do prédio sito à Avenida Brigadeiro Luiz Antonio, 42 e atual sede do CEJUR - Centro de Estudos Jurídicos da Procuradoria Geral do Município: "Quase ao término do século XIX, aos 16/05/1894, a Baronesa de Limeira abriu a rua Brigadeiro Luís Antonio nos terrenos de sua propriedade, bem como várias ruas adjacentes". Disponível em: http://www2.prefeitura.sp.gov.br/secretarias/negocios juridicos/pgm/cejur/0002. Sobre o processo de tombamento, de acordo com o Artigo $1^{\circ}$, da Resolução 03/88, ficou decidido que: "Fica tombado como bem de interesse histórico, cultural e ambiental o imóvel da Avenida Brigadeiro Luiz Antonio, 42, exemplar tipológico de "casa de aluguel”, inserido no Conjunto Arquitetônico do Largo de São Francisco”. Disponível em: http://www.prefeitura.sp.gov.br/cidade/upload/aa6de_03_T_Av_Brigadeiro_Luiz_Antonio_42.pdf ${ }^{58}$ Conselho Municipal de Preservação do Patrimônio Histórico, Cultural e Ambiental da Cidade de São Paulo - CONPRESP. Resolução no. 08/2002. Disponível em: http://www.prefeitura.sp.gov.br/cidade/upload/acaf0_08_T_Escola_de_Primeiras_Letras.pdf.
} 
"O edifício construído pelo governo imperial, em 1877, para sediar a Escola de Primeiras Letras, fez parte, juntamente com outros dois, de uma ação governamental para prover de escolas públicas a Província de São Paulo.

O terreno utilizado para a construção da escola, doado pela baronesa de Limeira, à época localizava-se em área ainda não urbanizada. Trata-se de um edifício em alvenaria de tijolos, de pequenas dimensões, com apenas duas salas de aula de $6 \times 9 \mathrm{~m}$, com acessos independentes para cada sexo, segundo determinações da época e que perdurariam durante toda a República Velha. A cobertura é em quatro águas e o beiral encontra-se escondido por um pequeno arremate de tijolos, sugerindo uma platibanda." (grifo nosso)

Ainda que a planta de Jules Martin não explicite de que maneira se deu a ocupação do bairro, o fato do prédio ter sido construído entre 1877 e 1878 e se localizar “em área não urbanizada” pode indicar que a região já possuía então uma população razoável, justificando-se assim a instalação desse tipo de serviço. Por outro lado, atitudes de membros de famílias influentes como a doação feita pela Baronesa de Limeira do terreno para a Escola de Primeiras Letras podem ser interpretadas como uma forma de colaboração com a cidade e o poder público, mas, sobretudo como uma demonstração do prestígio e do poder exercido pela elite cafeeira sobre os rumos da cidade.

Outro trabalho desenvolvido nesse período foi a "Planta da cidade de São Paulo (1895)”, realizada por Ugo Bonvicini ${ }^{59}$ (Figura 11). Não sabemos precisar os motivos que levaram à sua organização, mas de acordo com Nestor Goulart Reis, as plantas de 1891 e 1894, organizadas pelo mesmo Ugo Bonvicini, tiveram objetivos comerciais $^{60}$. Talvez também seja o caso desta planta, contudo, ela se mostra mais elaborada do que as outras. Como se fosse um "guia urbano", as informações contidas na planta aparentam querer facilitar ao público a locomoção através de uma cidade modificada, quase estranha à população ainda atônita com as rápidas transformações ocorridas nas últimas décadas.

Nesta planta, a área ocupada pelo loteamento se mostra concentrada entre as ruas Santo Antonio (ao Norte), Major Diogo (à direita) e Santo Amaro (ao Sul). As áreas que extrapolam esses limites, caracterizadas pela presença de vegetação, demonstram amplas porções de terrenos ainda vazios. Os sinais da futura ocupação são dados pelos caminhos tracejados, denominados então de Caminho da Fonte, Monte

\footnotetext{
59 “Planta da cidade de São Paulo (1895)”. Original do Museu Paulista/USP. Reprodução do álbum São Paulo Antigo: Plantas da Cidade, publicado pela Comissão do IV Centenário, em 1954. CAMPOS, Eudes (2008). Op. Cit

${ }^{60}$ REIS, Nestor Goulart - São Paulo-Vila, Cidade, Metrópole, Prefeitura de São Paulo, 2004. p. 246.
} 


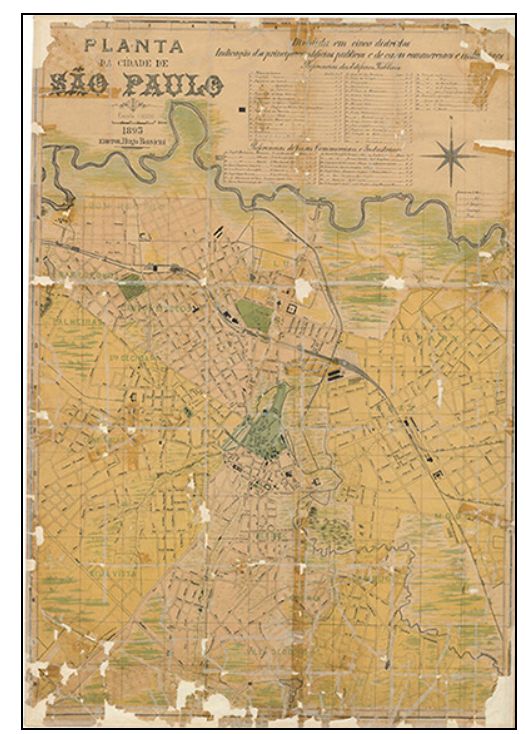

“Planta da cidade de São Paulo" (1895). Ugo Bonvicini. Fonte: Informativo Arquivo

Histórico Municipal, 4 (20):

set/out.2008<http://www.arquivohistorico.sp.g ov.br. Consulta em 22/05/2009.

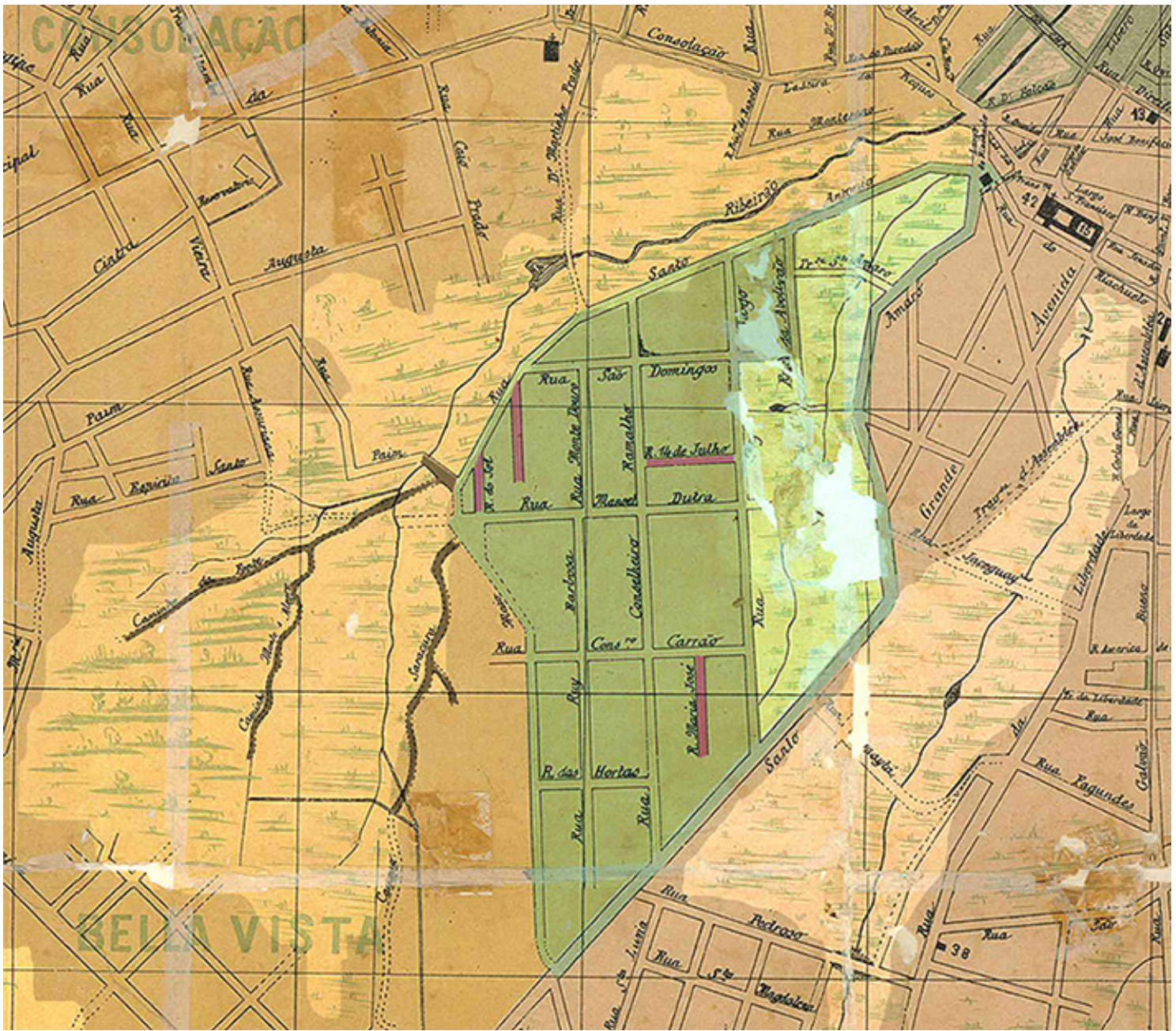

Figura 11 - Nesta planta, a área ocupada pelo loteamento se mostra concentrada entre as ruas Santo Antonio, Major Diogo e Santo Amaro. As áreas que extrapolam esses limites, caracterizadas pela presença de vegetação, demonstram amplas porções de terrenos ainda vazios, destacados em amarelo claro. Os sinais da futura ocupação são dados pelos caminhos tracejados, denominados de Caminho da Fonte, Monte Alegre e Saracura, todos à esquerda da rua Santo Antonio. Além das ruas Santo Antonio e Santo Amaro, anteriores ao loteamento, as vias propostas no loteamento ali estão, quase todas, com seus nomes atualizados. Observe-se as novas vias introduzidas no loteamento, após 1890, destacadas em rosa: as ruas Maria José e Quatorze de Julho, além de outras duas sem denominação. 
Alegre e Saracura, todos à esquerda da rua Santo Antonio. Além das ruas Santo Antonio e Santo Amaro, anteriores ao loteamento, as vias propostas no loteamento ali estão, quase todas, com seus nomes atualizados.

No sentido vertical, da esquerda para a direita, temos parte da rua Treze de Maio, uma rua sem nome (rua do Sol, atual Dr. Luiz Barreto), Rui Barbosa, Monte de Ouro (atual João Passalacqua), Conselheiro Ramalho, Maria José, Major Diogo e Abolição. No sentido longitudinal, aparecem a travessa Santo Amaro e as ruas São Domingos, Quatorze de Julho, Manoel Dutra, Conselheiro Carrão e da Horta (atual Fortaleza). Observamos as novas vias introduzidas no loteamento, após 1890: as ruas Maria José e Quatorze de Julho, além de outras duas sem denominação. Ambas se referem, respectivamente, à rua do Sol e à parte da rua Treze de Maio, ainda não denominada.

Aqui ainda é possível visualizar os cursos d'água originais que devem corresponder aos ribeirões do Itororó, Bexiga e Saracura. O Itororó, à direita, entre as ruas da Liberdade e a Santo Amaro. O Bexiga, entre as ruas Santo Amaro e Major Diogo; e o Saracura, à esquerda da rua Santo Antonio, ambos definindo os limites do loteamento original. Acreditamos que a presença desses rios deva explicar a ausência de ocupação a que nos referimos acima, já que na época a cidade ainda não havia sido beneficiada pelas obras de canalização dos rios, o que somente viria a ocorrer na primeira década do século XX. Por fim, de acordo com nossas investigações na Série Obras Particulares, desde 1893 o bairro vinha registrando um aumento de edificações. Para termos uma idéia do ritmo de crescimento, constata-se 13 solicitações de alinhamento e licença para edificação registradas em 1889, e 41 em 1895. Assim, temos, no espaço de apenas seis anos, dados que revelam que a atividade construtiva quase que dobrou. Contudo, esse seria um crescimento relativo se comparado ao que viria a acontecer nos próximos dez anos.

Em relação as obras de canalização dos rios, é importante destacar que há muito as áreas inundáveis da cidade se configuravam como um problema a pedir soluções urgentes. No decorrer de todo o século XIX, há registros da utilização dos rios como local de despejo do lixo doméstico, sendo que o Anhangabaú também recebia os dejetos do Matadouro Municipal e os resíduos químicos de uma indústria de chapéus, provavelmente a fábrica de chapéus de Adolfo Schrizmeyer. Assim, é compreensível que as regiões ribeirinhas tenham se tornado focos de sujeira, mosquitos e toda sorte de mazelas originárias dos usos que se fazia dos rios da cidade. 
O problema foi agravado com a entrada contínua de imigrantes a partir dos anos de 1870. De acordo com Nabil Bonduki,

“[...] havia em São Paulo, no final do século, um evidente processo de deterioração das condições sanitárias, problema que tinha de ser enfrentado pelo poder público. $O$ crescimento da capital e de outros núcleos urbanos no interior, ocasionado por levas ininterruptas de imigrantes que aqui chegavam após longas viagens na terceira classe dos navios, onde muitas vezes grassavam doenças contagiosas; o intenso fluxo de trabalhadores entre Santos, São Paulo e o interior; os alojamentos coletivos e desprovidos de saneamento básico nos quais esta população era obrigada a viver; $\underline{a}$ falta de drenagem das várzeas; e, por fim a precariedade do serviço sanitário até a década de 1890 - tudo isso contribuiu para aumentar o temor da eclosão de epidemias" (grifos nossos) ${ }^{61}$

As condições expressas pelo autor são confirmadas pelos sucessivos surtos epidêmicos, dos quais, os mais graves foram: a varíola, no decorrer de todo o século XIX, as epidemias de febre amarela e cólera, nas últimas décadas do século, e a gripe espanhola, na década de 1910. A disseminação das doenças representava então uma ameaça real ao processo de desenvolvimento urbano, impondo a necessidade de intervenções drásticas por parte das autoridades municipais, entre elas, o saneamento e drenagem das baixadas.

A “Planta Geral da Capital de São Paulo (1897)” sucede dois anos mais tarde a anterior, e foi realizada com outros propósitos, sob a direção do Intendente de Obras, Dr. Gomes Cardim ${ }^{62}$. Talvez a maior importância deste trabalho esteja no fato de abranger, de forma organizada e completa, um maior leque de informações sobre a cidade. Isso se deve, com certeza, ao fato de ter sido realizada pela Intendência de Obras, demonstrando o empenho da administração municipal em lidar com a complexidade do espaço urbano em crescimento.

Na Planta de 1897 (Figura 12), observamos a expansão da área urbanizada da cidade, com o preenchimento dos vazios visíveis nas plantas anteriores. Os bairros antigos e aqueles de ocupação recente apresentam nomenclatura atualizada de suas ruas, assim como o prolongamento previsto para umas ou a abertura de outras, o mesmo sucedendo com os novos loteamentos. No entanto, persistem certas imprecisões quanto à localização e nomeação de algumas ruas.

\footnotetext{
${ }^{61}$ BONDUKI, Nabil - Origens da habitação social no Brasil, arquitetura moderna, Lei do inquilinato e difusão da casa própria, São Paulo: Estação Liberdade/FAPESP, 1998, p. 29.

${ }^{62}$ Exemplar pertencente ao Museu Paulista/USP. Reprodução do álbum São Paulo Antigo: Plantas da Cidade, publicado pela Comissão do IV Centenário, em 1954. CAMPOS, Eudes (2008). Op. Cit.
} 


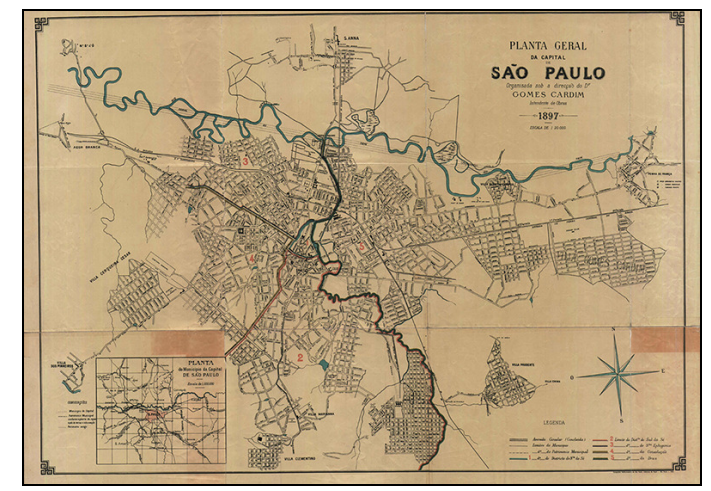

“Planta Geral da Capital de São Paulo"

(1897). Organizada sob a direcção do Dr.

Gomes Cardim, Intendente de Obras

Fonte: Informativo Arquivo Histórico

Municipal, 4 (20):

set/out.2008<http://www.arquivohistorico.sp.g ov.br. Consulta em 22/05/2009.

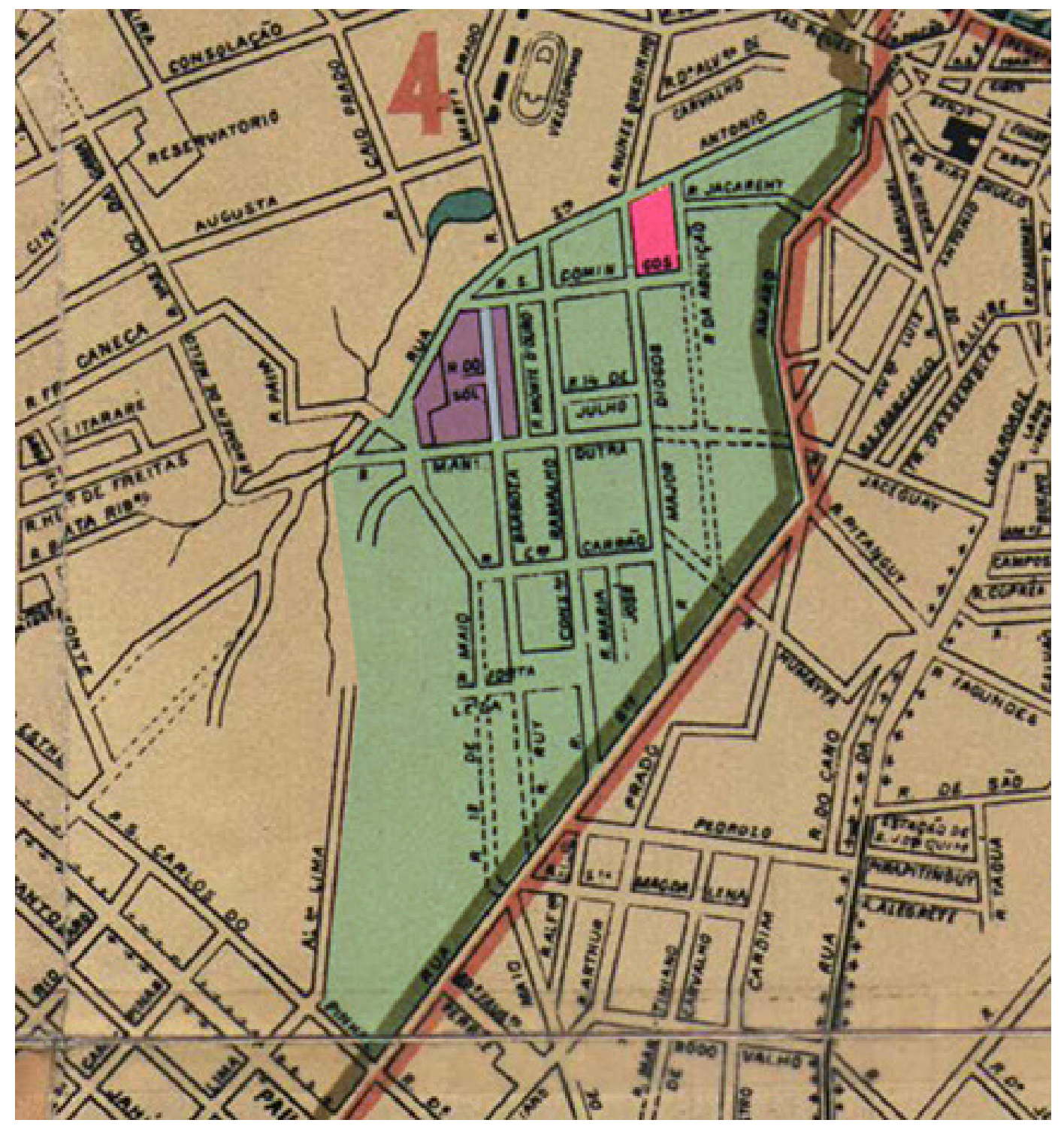

Figura 12 - As ruas do loteamento mantêm praticamente a mesma nomenclatura encontrada na planta de 1895, com exceção da pequena travessa Santo Amaro que passou a se chamar rua Jacarehy. Contudo, nesta planta persistem certas imprecisões quanto à localização e nomeação de algumas ruas. Na área destacada em roxo (entre as ruas Monte de Ouro e Treze de Maio), localizamos uma pequena rua sem saída, denominada rua do Sol. Esta via não existiu e rua do Sol é a via em tom mais claro, que corta a quadra, entre as ruas São Domingos e Manoel Dutra. À esquerda das ruas Santo Antonio e Treze de Maio, ainda temos um espaço vazio, aberto para uma ocupação futura. No destaque rosa, está a quadra doada por Antonio José Leite Braga para a construção da sede da Santa Casa de Misericórdia. 
De acordo com Eudes Campos:

"A planta de 1897 apresenta limites extraordinariamente expandidos [...] tornaram-se comuns os loteamentos particulares, sobretudo em conseqüência da crise inflacionária de 1875. E por essa mesma época, fizeram-se igualmente freqüentes as manobras executadas pelas elites para atrair o desenvolvimento urbano para suas terras. [...]". Componentes da "família Pais de Barros [... f forçaram, em 1880, a instituição a transferir o seu hospital, que ia ser construído no bairro da Bela Vista, na zona sul da cidade, para um lote por eles adquirido nos altos de Santa Cecília [...] Concomitantemente, iam os loteamentos particulares tomando o lugar das antigas chácaras. [...] Os mais desfavoráveis eram os situados em regiões ribeirinhas, inundáveis durante o periodo das chuvas, em parte adquiridos pelas companhias ferroviárias que por aí estenderam suas linhas. [...]"

Das questões apontadas pelo autor, nos interessa, sobretudo, aquela acerca da pressão por parte da família Pais de Barros para que o hospital fosse construído no bairro de Santa Cecília. De acordo com Antonio Egydio Martins, a sede do hospital da Santa Casa de Misericórdia estava prevista para ser construída no terreno doado pela firma Antonio José Leite Braga \& Cia., “uma quadra de terrenos com 8.475 braças quadradas, que ficava entre as atuais ruas de Santo Antonio, Abolição, São Domingos e Major Diogo" ${ }^{63}$. A idéia teria sido abandonada em virtude do parecer contrário "dos médicos desta Capital”.

Campos $^{64}$ acrescenta:

"outros membros da família desenvolviam estratégias para provocar a valorização fundiária das terras nas quais os Barros tinham interesse, num exemplo de como agiriam, a partir de então, diferentes setores da camada dominante ao promover o processo de expansão do ramo imobiliário paulistano".

A “Planta Geral da Cidade de São Paulo (1905)” foi realizada por Alexandre Mariano Coccoci e Luís Fructuoso e Costa ${ }^{65}$, provavelmente a pedido da Prefeitura de São Paulo, "para uso de suas Repartições". Mais detalhada que aquela de 1897, esta planta contém uma informação interessante: a relação dos logradouros da cidade, organizados em ordem alfabética, onde fica evidente a preocupação em fornecer à população uma orientação eficiente.

Conforme Nestor Goulart Reis, "Esta planta mostra todas as áreas edificadas da cidade em 1905. [...] A planta indica na cor cinza as quadras já edificadas, o que

\footnotetext{
${ }^{63}$ MARTINS, Antonio Egydio - São Paulo antigo - 1554 a 1910, São Paulo: Paz e Terra, 2003, p. 153154.

64 “Os Pais de Barros e a Imperial Cidade de São Paulo", trabalho realizado para o Informativo Arquivo Histórico Washington Luís, onde o autor reconstitui "a saga familiar desses ituanos, que por um longo período de tempo dominaram a sociedade, a política e a economia paulista”, n. 16, jan/fev. 2008.

Disponível em: http://www.fotoplus.com/dph/info16/i-logra.htm

${ }^{65}$ Histórico Demográfico do Município de São Paulo. Disponível em:

http://sempla.prefeitura.sp.gov.br/historico.
} 
nos permite compreender a expansão dos loteamentos periféricos, nessa época, à espera de construções. [...]" 66

Elaborada cerca de vinte anos após o lançamento do empreendimento, a planta de Coccoci e Fructuoso (Figura 13), foi a primeira a registrar o processo de crescimento do bairro do Bexiga de maneira mais eficiente. De forma geral, a planta demonstra que a ocupação do loteamento se fez de maneira desigual. Algumas das principais ruas do bairro parecem estar ocupadas em toda a sua extensão, tais como as ruas Santo Antonio, Conselheiro Ramalho, Jacareí e São Domingos. Outras, como as ruas Treze de Maio e a Major Diogo, apresentam ocupação em apenas um dos lados. Já as ruas da Abolição, Conselheiro Carrão e Maria José, ainda não possuíam seus trajetos prolongados. Aliás, em nossas investigações na Série Obras Particulares, em algumas ocasiões, encontramos solicitações de licença para construção que foram negadas justamente em virtude dos prolongamentos não terem sido ainda aprovados ${ }^{67}$. As ruas do Sol e Monte de Ouro mantinham a nomenclatura antiga, e as ruas São Vicente e Dr. Ricardo Batista ainda não haviam sido abertas.

\footnotetext{
${ }^{66}$ REIS, Nestor Goulart (2004). Op. Cit. p. 249.

${ }^{67}$ Obras Particulares, Rua da Abolição, Processo de 30/09/1907, Cx. A/1; Rua Conselheiro Carrão, Processo de 22/10/1912, Cx. C/5; Rua do Sol, Processo de 22/02/1912, Cx. C/55; Rua Santo Antonio, Processo de 16/11/1912, Cx. S/1.
} 


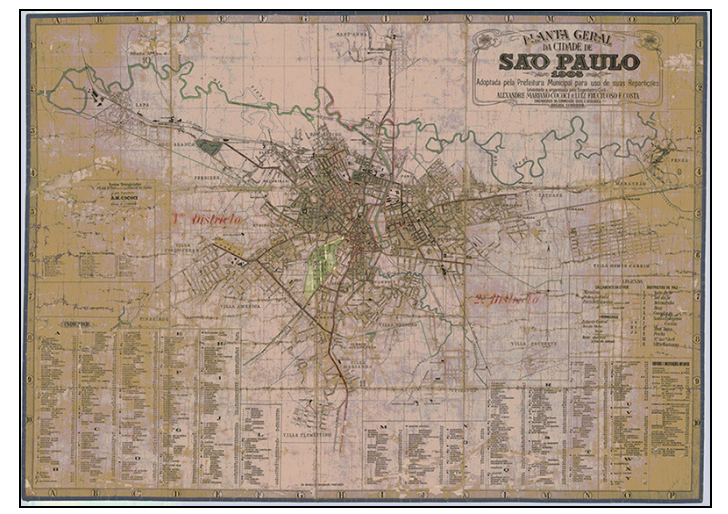

“Planta Geral da Cidade de São Paulo"

(1905). Adotada pela Prefeitura Municipal para uso de suas Repartições, Alexandre Mariano Coccoci e Luís Fructuoso e Costa.

Fonte: Histórico Demográfico do Município de São Paulo, SEMPLA. Disponível em:

http://sempla.prefeitura.sp.gov.br/historico/. Consulta em: 18/11/2009.

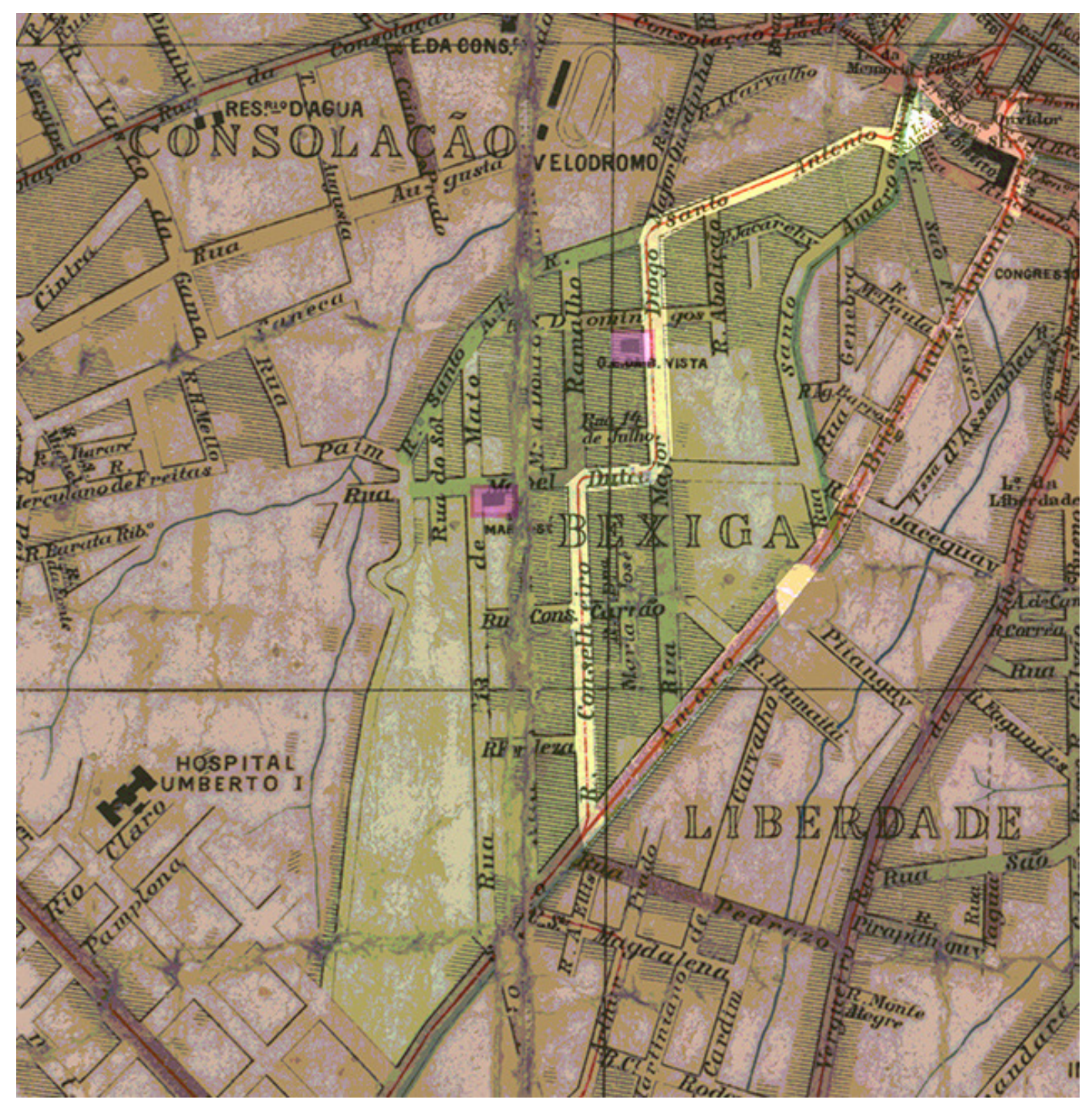

Figura 13 - De forma geral, a planta demonstra que a ocupação do loteamento se fez de maneira desigual. Selecionamos toda a extensão do bairro em um tom mais claro de verde. Em tom mais escuro, destacamos as quadras edificadas que permitem perceber a ocupação do bairro. Duas edificações voltadas ao ensino público se destacam no bairro: o Grupo Escolar da Bela Vista, na rua Major Diogo, próximo da rua São Domingos e outra escola, localizada na esquina da rua Treze de Maio com a rua Manoel Dutra, ambas destacadas em rosa. Infelizmente não encontramos sinais da Escola de Primeiras Letras, na rua Santo Amaro, na altura da rua Jaceguai. Entre todas as informações fornecidas pela planta, a mais significativa é a presença da linha de bondes, cujo percurso está destacado em amarelo. 


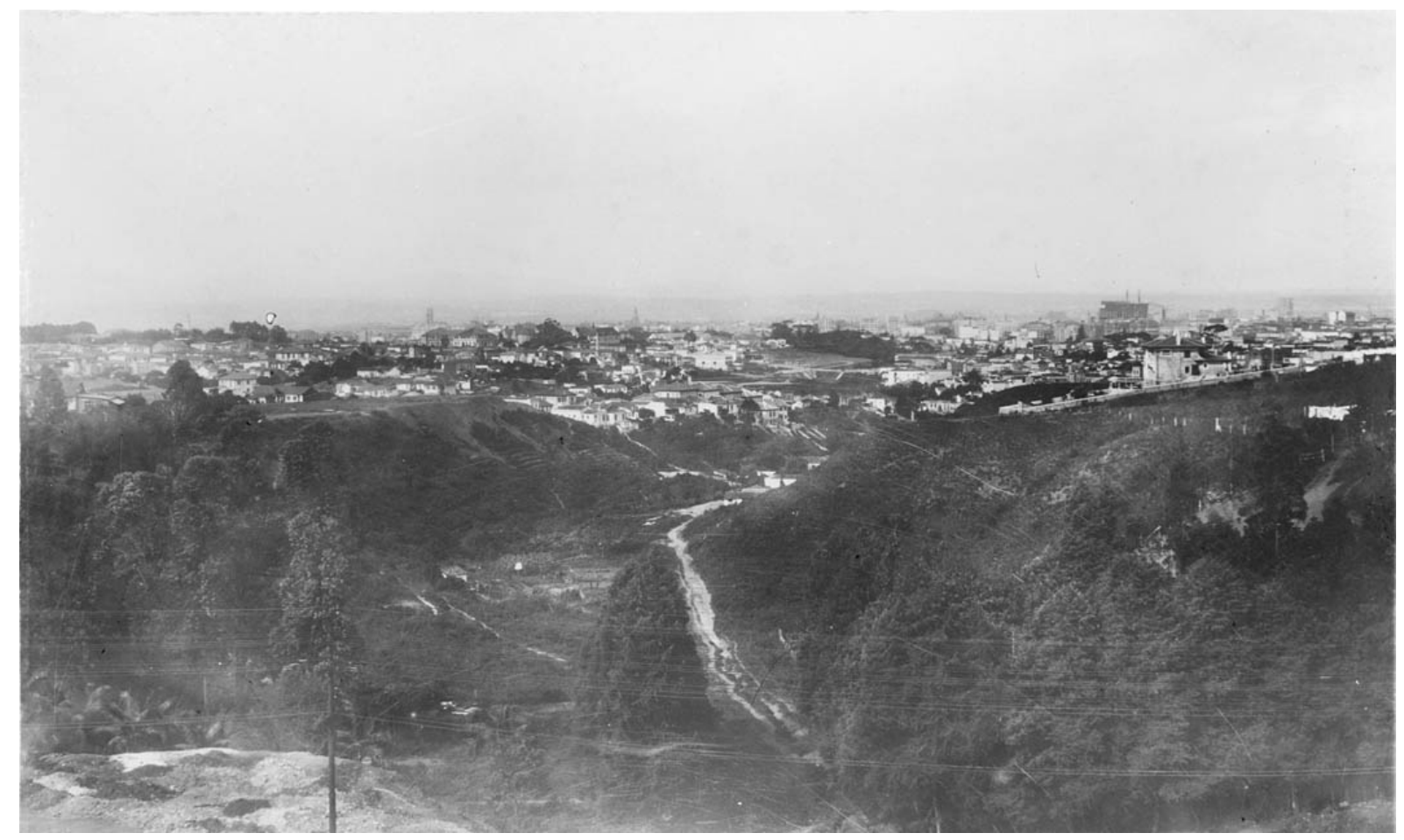

Figura 14 - Foto tomada do alto do Trianon em direção ao Centro da cidade. No centro da foto visualizamos o córrego da Saracura. A imagem, embora posterior a 1914, dá uma idéia do que era a Chácara do Bexiga nos anos de 1880, fornecendo a dimensão dos obstáculos físicos que restringiram a expansão do loteamento até a década de 1930. Foto: Autoria desconhecida, 1925/1929. Fonte: Coleção SAN/DIM/DPH/SMC/PMSP.

Se o "miolo" do bairro mostra uma ocupação mais densa, o mesmo não ocorre na área próxima ao leito do Saracura. Essa região apresenta dois dos maiores problemas para uma ocupação efetiva: além das várzeas do córrego, sujeitas a alagamentos, era a zona de relevo mais acidentado. Essa foi a área ocupada mais tardiamente, fato confirmado por nossas investigações.

Duas edificações destinadas ao ensino público se destacam: o Grupo Escolar da Bela Vista, na rua Major Diogo com a rua São Domingos, e a Escola Maria José, na esquina das ruas Manoel Dutra e 13 de Maio.

Entre todas as informações fornecidas por essa planta para o bairro do Bexiga, a mais significativa é a presença da linha de bondes ${ }^{68}$. Vindo do Largo da Memória, a

\footnotetext{
${ }^{68}$ De acordo com o projeto educacional São Paulo, 450 anos, desenvolvido por ocasião do aniversário da cidade (2204), pelo CEDAC e pela SME, “Em 1889, estabeleceu-se uma linha que partia da Sé e terminava na Colina do Ipiranga, e outras duas que se dirigiam aos bairros do Bom Retiro e Bela Vista.estabeleceu-se uma linha que partia da Sé e terminava na Colina do Ipiranga, e outras duas que se dirigiam aos bairros do Bom Retiro e Bela Vista”. Disponível em: http://www.aprenda450anos.com.br/450anos/index.asp .
} 
linha seguia pela rua Santo Antonio, até a rua Major Diogo, de onde seguia até a Manoel Dutra. Na rua Manoel Dutra o trajeto era curto, percorrendo apenas um quarteirão para, em seguida, entrar à esquerda, na rua Conselheiro Ramalho. Ali, ela seguia até a rua Santo Amaro, de onde fazia o caminho de volta, passando pela Avenida Brigadeiro Luiz Antonio, até chegar ao Largo do Riachuelo e dali voltar ao Centro. O percurso percorrido pelo bonde por algumas das principais vias do bairro (área de ocupação mais densa), indica que, naquele momento, o bairro do Bexiga já se incorporava à cidade, articulando-se ao Centro.

Fechamos o período investigado com a "Planta da Cidade de São Paulo (1913)”, dos mesmos Alexandre Mariano Coccoci e Luiz Fructuoso F. Costa. Trata-se de um trabalho particular realizado para a Companhia Litographica HartmannReichenbach ${ }^{69}$.

Na Figura 15, os contornos dos quarteirões estão demarcados por uma cor mais escura, indicando os terrenos construídos. As poucas exceções, na rua da Abolição e à esquerda da rua Treze de Maio, permitem constatar que naquele momento o loteamento original do Bexiga já estava totalmente consolidado. Como novidade temos, à esquerda do antigo Bexiga, o Largo São Manoel (atual Praça 14 Bis) e a partir deste o prolongamento da rua Manoel Dutra, em direção à Bela Cintra, com o nome de rua Barata Ribeiro; do mesmo largo, em direção ao Sul, define-se a rua Rocha ${ }^{70}$. À direita e à esquerda desta rua se delineiam os caminhos da Saracura. Anos mais tarde eles originariam a Avenida Nove de Julho e a rua Dr. Plínio Barreto. A presença desses novos logradouros indica que a trama urbana em direção ao bairro da Consolação começava a se fechar. Entretanto, ainda havia que se transpor os limites do Saracura.

Disponível em: http://br.geocities.com/zostratus15/sp-bonde-00.htm.

${ }^{69}$ Histórico Demográfico do Município de São Paulo - SEMPLA. Disponível em: http://sempla.prefeitura.sp.gov.br/historico.

${ }^{70}$ Em 07/11/1912, quando esta rua ainda não era oficializada, localizamos um pedido de aprovação de projeto arquitetônico por Horácio Nogueira, na Série Obras Particulares. 


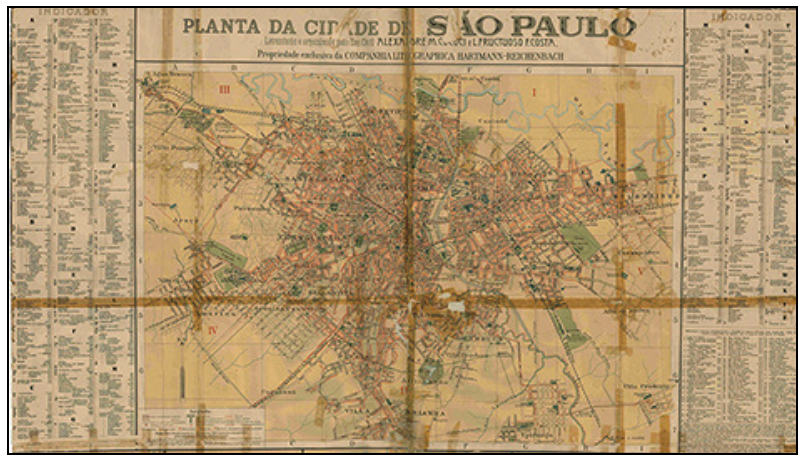

“Planta da Cidade de São Paulo" (1913). Alexandre M. Coccoci e L. Fructuoso F. Costa Fonte: Histórico Demográfico do Município de São Paulo, SEMPLA. Disponível em: http://sempla.prefeitura.sp.gov.br/historico/. Consulta em: 18/11/2009.

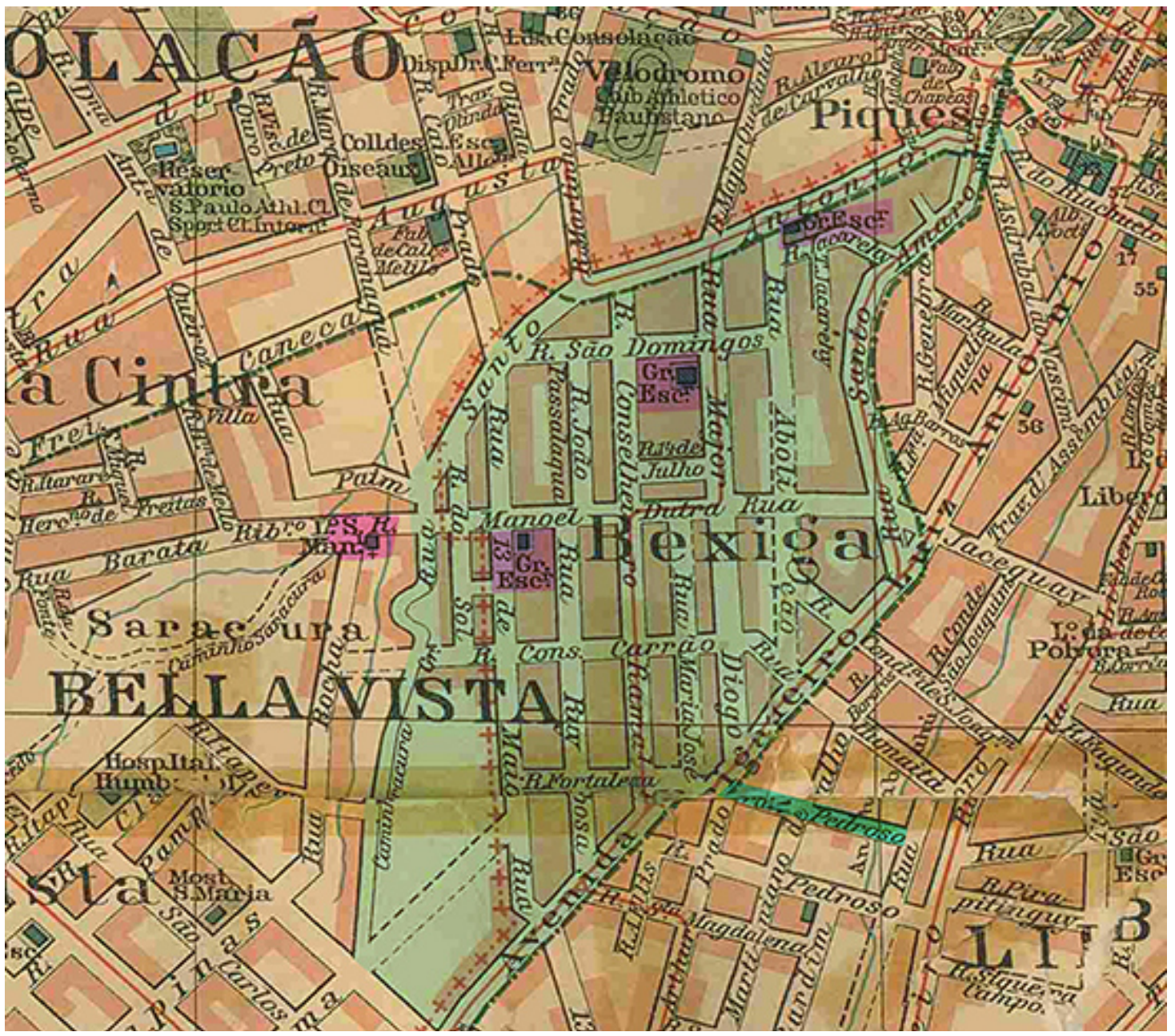

Figura 15 - Nesta planta, os quarteirões do Bexiga demarcados em tons mais escuros indicam que se trata de quadras já ocupadas por edificações. As poucas exceções ficam por conta do prolongamento da rua da Abolição, marcado por uma linha tracejada, à esquerda da via; e na quadra compreendida pelas ruas Treze de Maio e Caminho da Saracura, entre a rua Conselheiro Carrão e a via tracejada abaixo, provavelmente a Alameda Lima (atual Alameda Joaquim Eugênio de Lima). À direita da rua Santo Amaro e da Avenida Brigadeiro Luiz Antonio, o núcleo original do Bexiga se expande em direção ao bairro da Liberdade, conformando parte do que conhecemos como Bela Vista. Nas áreas em roxo, destacam-se as três escolas públicas do bairro: o Grupo Escolar de Santo Antonio (rua Santo Antonio), o Grupo Escolar da Bela Vista (rua Major Diogo) e a Escola Modelo Maria José (rua Treze de Maio, esquina com Manoel Dutra). Por fim, na área rosa, temos o Largo São Manoel, atual Praça 14 Bis, estabelecendo a comunicação entre as ruas Manoel Dutra e Barata Ribeiro. 
À direita do antigo Bexiga, entre a rua da Abolição e a Avenida Brigadeiro Luiz Antonio (no limite com o bairro da Liberdade), definiram-se as ruas Jacareí, Asdrúbal do Nascimento, Genebra, Maria Paula, Aguiar de Barros, Francisca Miquelina, além da Travessa Jacareí.

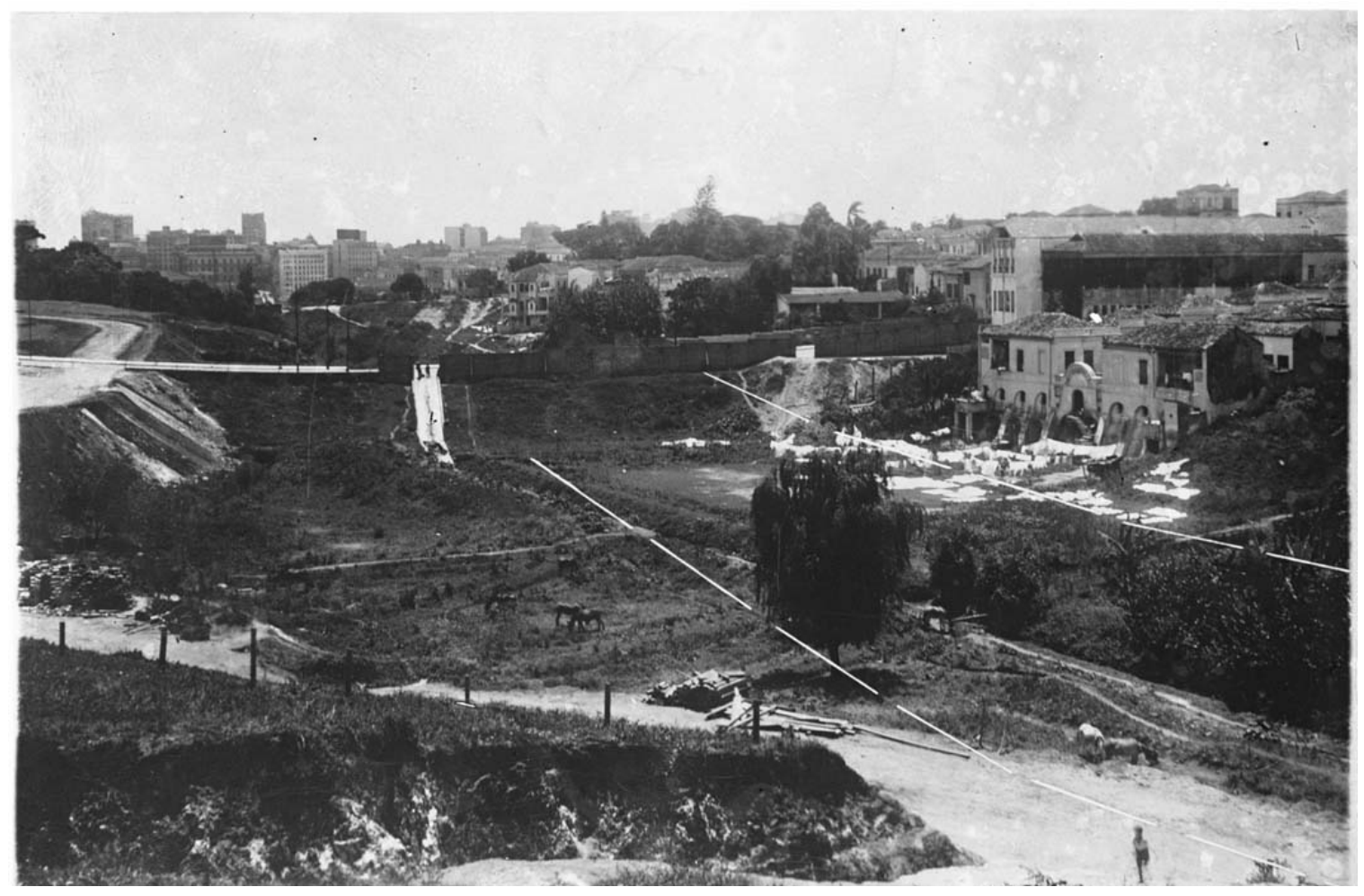

Figura 16 - Imagem da Saracura em direção ao Centro da cidade. A montagem da foto parece ter sido feita em função da abertura da Avenida 9 de Julho. À direita, visualizamos os fundos de prédios da rua Santo Antonio; à esquerda é possível ver animais pastando e uma vegetação de porte razoável. Foto: Autoria desconhecida, s/data. Fonte: Coleção SAN/DIM/DPH/SMC/PMSP.

O córrego do Saracura ainda corre à céu aberto, desaparecendo sob a rua Martinho Prado, em direção ao Norte, indicando que o trecho compreendido entre essa rua e o Anhangabaú já estava canalizado. O mesmo acontece com o Tanque Reúno que, na planta de 1905, ainda se localizava entre as ruas Caio Prado e Martinho Prado.

Uma informação interessante refere-se à presença dos dois nomes pelos quais o bairro é conhecido: Bexiga, em letras menores, identificando a área do loteamento original; Bella Vista, em letras maiores, identificando parte da área à esquerda do córrego, e parte do próprio Bexiga. Temos notícias que, desde $1883^{71}$, havia tentativas de alterar o nome do bairro, o que só ocorreu em 1910. Assim, a presença dos dois

\footnotetext{
${ }^{71}$ De acordo com o Abaixo assinado encaminhado à Câmara na Sessão Ordinária de 27/06/1883. Atas da Câmara da Cidade de São Paulo, v. 69-70 (1883-1884), Divisão do Arquivo Histórico, vol. LXIX, Departamento de Cultura, 1951, p. 31 . O documento original do abaixo assinado encontra-se nos Papéis Avulsos.
} 
nomes parece indicar um fato, ao que parece, incontornável: a impossibilidade de apagar do imaginário popular o nome original pelo qual a região ficou conhecida.

\subsection{Empreendedores e especuladores imobiliários}

Como metonímia da própria lógica de transformação da cidade, elegemos o bairro do Bexiga, procurando inicialmente investigar os atores sociais envolvidos na sua produção. O trabalho de identificação dos atores sociais direta ou indiretamente envolvidos na construção do bairro do Bexiga obedeceu à própria ordem cronológica dos acontecimentos, assim, iniciamos com a investigação dos personagens que alavancaram o loteamento, através do levantamento da propaganda imobiliária. No Arquivo do Estado, consultamos os jornais A Província de São Paulo, de 1878 até a República, em 1899, e O Estado de São Paulo, a partir daquela data até 1891. O levantamento foi feito no sentido de acompanhar, através dos anúncios publicados, a primeira fase do processo de compra de terrenos na região, assim como seu parcelamento, loteamento e venda final dos lotes.

Estabelecemos o ano de 1881 para o início de nossas investigações, partindo do momento em que o empreendimento do Bexiga se configurou na planta da Cia. Cantareira. No entanto, uma citação de Célia Toledo de Lucena ${ }^{72}$ sobre a venda de terrenos de propriedade de Antonio José Leite Braga, no jornal A Província de São Paulo, nos remete a 1878, quando se anunciava que os proprietários dos terrenos do Bexiga “[...] mandaram levantar um plano geral de arruamento[...]”. Tratava-se do primeiro passo do empreendimento. Em 1881, já se anunciava a conclusão da rua “[...] que comunica o bairro da Consolação com o do Bexiga[...]”. De 1878 até 1891, foi possível observar que o processo de comercialização dos terrenos andou rápido, já contando inclusive com vários anúncios para venda e locação de casas prontas.

O material recolhido no Arquivo do Estado apontou informações que, aliadas às fontes secundárias, forneceram pistas sobre a atuação dos diversos agentes imobiliários na região. A começar do primeiro anúncio, de 10 de maio de 1878, onde “[...] As pessoas que desejarem possuir algumas braças de terrenos próprios [...] podem desde já examinar e dar as suas encomendas no escritório deste jornal a Emílio Rangel

\footnotetext{
${ }^{72}$ LUCENA (1983), Op.cit., p.50.
} 
Pestana, ou nas oficinas de Santo Antonio (no Bexiga) aos proprietários dos referidos terrenos $[\ldots]$ ". 73

Emílio Rangel Pestana era membro da família de Francisco Rangel Pestana um dos proprietários daquele jornal (aproximadamente entre 1882 e 1888) e de fazenda de café no Oeste paulista, além de ter ocupado cargos públicos nos últimos anos do Império e durante o governo de Deodoro da Fonseca ${ }^{74}$. Rangel Pestana assinou, além deste, mais anúncios de venda de terrenos e casas no Bexiga, além de outros empreendimentos na cidade.

As "oficinas de Santo Antonio", citadas no anúncio eram de propriedade de Antonio José Leite Braga em sociedade com Domingos José Coelho da Silva, ambos portugueses. Maria Luiza Ferreira de Oliveira fornece informações interessantes sobre Antonio Braga, a partir dos levantamentos dos inventários que recolheu no Arquivo do Poder Judiciário de São Paulo ${ }^{75}$. De acordo com a autora, Braga era um comerciante português razoavelmente bem sucedido. Além da Fábrica de Santo Antonio, onde funcionava a "carpintaria e serraria a vapor, que vendia madeiras e móveis", possuía uma “casa de ferragens, tintas e objetos de armarinho na rua Direita”, e uma olaria na cidade de Avaré. Também diversificou seus investimentos com a venda de terrenos no Bexiga, onde se localizava a dita oficina.

Ao morrer, em 1879, Braga deixou filhos e cremos que um deles tenha sido o proprietário de um imóvel localizado na esquina da rua da Abolição com a rua Santo Antonio (junto ao $\mathrm{n}^{\circ} 83$ ), exatamente no local onde se localizava a casa de Fernando de Albuquerque (ver Figura 22) ${ }^{76}$. Chamava-se Antonio José Leite Braga, como o pai, e possuía outros imóveis no bairro: quatro casas na rua Major Diogo, $\mathrm{n}^{\circ} 14$, e outra casa na rua da Abolição, “junto ao 37” 77 . Esses requerimentos, que datam de 1907 e 1914, demonstram, de certa maneira, a permanência dos Braga no bairro.

Através dos manuscritos de Aguirra, localizamos a primeira referência a Fernando de Albuquerque, no jornal A Província de São Paulo, de 24/12/1876: “Chegou pelo (...) o Dr. Fernando de Albuquerque que ultimamente concluiu seus estudos de engenharia

\footnotetext{
${ }^{73}$ Grifo nosso. In: A Província de São Paulo, 10/05/1878. Microfilme 01.01.004. Arquivo do Estado.

${ }^{74}$ Verbete temático sobre o jornal “O Estado de São Paulo”, in Dicionário Histórico-Biográfico Brasileiro - CPDOC - Fundação Getulio Vargas. Disponível em: <http://www.cpdoc.fgv.br.

${ }^{75}$ OLIVEIRA, Maria Luiza Ferreira de - Entre a casa e o armazém, São Paulo: Alameda, 2005. p. 218 a 220.

${ }^{76}$ Neste processo, o proprietário, “desejando construir um quarto para chofer junto à garagem existente, solicita licença”. Obras Particulares, 13/08/1913, Cx. A1.

${ }_{77}$ Obras Particulares, processos de 14/02/1907, Cx. L1/M1; e 06/04/1907, Cx. A1-15.
} 
nos Estados Unidos. (...) o quanto honrou esse distinto santista (...)”. Realmente, tratava-se de um engenheiro, natural de Santos, um dos primeiros profissionais brasileiros a estudar nos Estados Unidos, tendo se formado na Universidade de Easton, na Pensilvânia. No ano seguinte à sua volta ao Brasil, Fernando de Albuquerque trabalhou com Jules Martin na elaboração do "Mapa da Capital da Província de São Paulo”, de $1877{ }^{78}$. Talvez não por acaso, constatamos neste mapa a presença da Oficina Santo Antonio, visível no detalhe à esquerda (Figura 17).

Também foi administrador da Santa Casa de Misericórdia, além de ter participado do Conselho de Intendência que governou a cidade de São Paulo, em 1891. Por fim, um detalhe relevante de sua atuação profissional foi revelado pela historiadora Elisângela Maria da Silva. Ao investigar os Papéis Avulsos, no AHMWL, a pesquisadora localizou Fernando de Albuquerque trabalhando como fiscal para a Intendência Municipal de Obras, nos anos de 1880 e $1881^{79}$. Nesse cargo, pelo menos uma de suas funções consistia em demarcar datas de terra para aqueles que as solicitavam à Câmara Municipal. No caso dos três documentos, tratava-se de reclamações encaminhadas à Câmara por requerentes insatisfeitos com os resultados as demarcações haviam sido feitas, porém, as terras foram concedidas a outros interessados. Esta informação é no mínimo instigante, pois aponta para práticas pouco éticas por parte do engenheiro. É o que parece ter acontecido com Manoel Dias da Cruz e D. Ana Cândida de Oliveira (1880), como se pode depreender do texto dos reclamantes: “Acontece ter o mesmo Engenheiro trocado essas datas, a seu bel prazer, e isto sem o consentimento dos suppes (...) e não tendo o Engenheiro autoridade para declarar as datas em comisso; e sendo certo que na posse d'ellas pretende acomodar amigos ou parentes". Caso semelhante foi o de Benedicto Baunilha (1881): "acontece porem que, depois de ter o supplicante feito despesas com títulos e alinhamento, que pagou ao secretário d'esta Camara apresentou-se o mesmo Engenheiro e exijio a entrega da referida data a outrem...”. Albuquerque não foi muito feliz em sua resposta

\footnotetext{
${ }^{78}$ Dicionário de Ruas. Disponível em: http://www.dicionarioderuas.com.br.; Informativo Arquivo Histórico Municipal, PMSP/SMC/DPH, São Paulo, set-out/1905, ano 1, nº 2. Disponível em: http://www.fotoplus.com/dph/info02/index.html.

${ }^{79}$ Ver "Datas de terras", Papéis Avulsos, v. 2, 1880; e "Datas de terras", Papéis Avulsos, v. 1, pgs. 1013 e pgs. 57 e subsequentes, 1881. Elisângela Maria da Silva foi pesquisadora no projeto de pesquisa “Arquivo Histórico Municipal Washington Luís - A cidade de São Paulo e sua Arquitetura”, parceria entre o AHMWL com a FAUUSP, financiado pela FAPESP. Atualmente, desenvolve dissertação de mestrado na FAUUSP, sobre a concessão de datas de terras, na segunda metade do século XIX.
} 
- ao defender-se das acusações de Baunilla, referiu-se ao mesmo como sendo "pobre, analfabeto e preto".

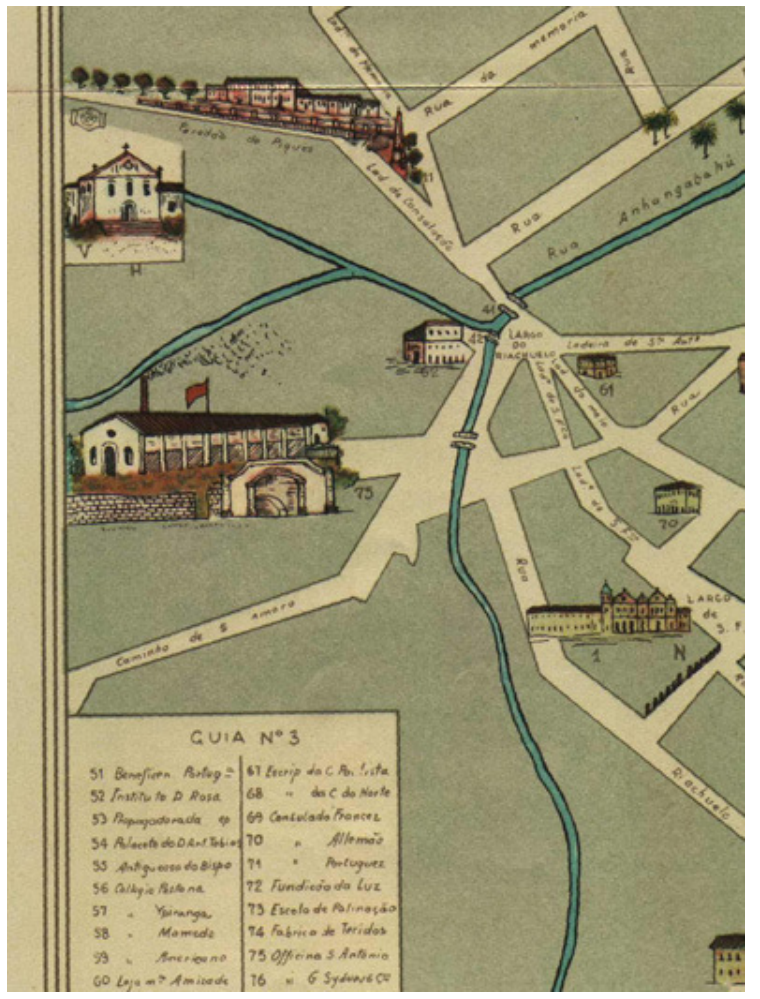

Figura 17 - Detalhe do "Mappa da Capital da Província de São Paulo, publicado por Fernando de Albuquerque e Jules Martin em julho de 1877". À esquerda do mapa, a Oficina de Santo Antonio, entre a Rua da Consolação e o Caminho de Santo Amaro. Fonte: Informativo Arquivo Histórico Municipal, 4 (20): set/out. 2008<HTTP://www.arquivohistorico.sp.gov.br. Consulta em 25/08/2009.

O que chama mais a atenção é o acesso facilitado que o engenheiro possuía em relação às terras públicas. Como engenheiro encarregado de fazer a medição de terras, detinha informações valiosas quanto aos melhores e piores terrenos, nas melhores e piores regiões da cidade. Isso demonstra o tipo de papel exercido pelo engenheiro num momento em que as terras municipais eram alvo de cobiça por parte de potenciais especuladores imobiliários. Hoje, chamaríamos isso de "tráfico de influências"... De outro lado, a atuação como administrador da Santa Casa de Misericórdia e a participação no Conselho de Intendência de São Paulo, ainda que anos mais tarde, pode sugerir a hipótese de que o convívio com pessoas de influência social e política, viabilizado por essas atividades, teria sido resultado da eventual "troca de favores" do período em que trabalhou para a Intendência de Obras. Embora estas sejam apenas especulações, a pedir investigações mais profundas, elas indicam que o engenheiro que a princípio nos parecia ser um simples coadjuvante no cenário da urbanização paulistana, desempenhou papel mais decisivo do que imaginávamos. 


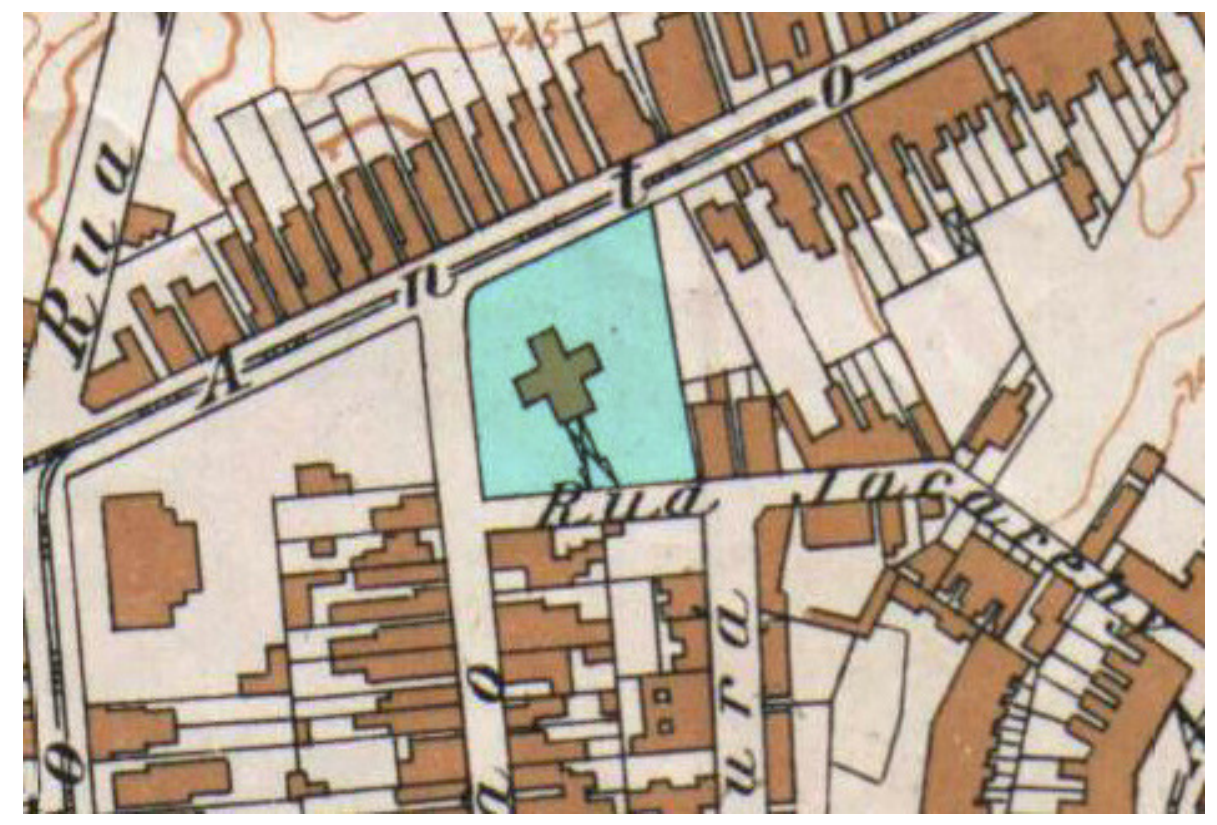

Figura 18 - No detalhe da Planta SARA Brasil, a localização da residência de Fernando de Albuquerque, construída em 1887, no no 83 da rua Santo Antonio. Planta SARA Brasil, 1930, Bairro do Bexiga. Fl. 37. AHMWL

Através dos anúncios, também é possível constatar a presença de agentes que apenas intermediavam os negócios. Nesse sentido, além de Emílio Rangel Pestana, outros nomes aparecem de forma mais ou menos constante nesses anúncios: o já citado Domingos José Coelho da Silva, Antonio Proost Rodovalho, Roberto Tavares (com anúncios diretos de venda de terrenos, ou ainda no papel de leiloeiro), os escritórios comerciais Sá \& Andrade e Henrique Wright \& Comp., entre outros.

Com relação a Domingos José Coelho da Silva, encontramos, no jornal $A$ Província de São Paulo, um anúncio interessante, que embora não se relacione com o nosso assunto pode esclarecer um pouco mais sobre alguns dos atores sociais que atuaram no primeiro momento do empreendimento.

\section{“CAIXA EMANCIPADORA LUIZ GAMA}

Para conhecimento dos senhores associados e mais interessados, se faz público que a tesouraria desta instituição se acha a cargo do segundo tesoureiro Domingos José Coelho da Silva, na Fábrica de Santo Antonio, ao Largo do Riachuelo.São Paulo, 22 de novembro de 1881. Domingos José Coelho da Silva, 24 de novembro" ${ }^{80}$.

Em 1881, alguns anos antes da Abolição, a Caixa Emancipadora Luiz Gama, instituição criada com a intenção de arrecadar fundos para a compra de alforrias de escravos, tinha como segundo tesoureiro o próprio Domingos José Coelho da Silva, um

\footnotetext{
${ }^{80}$ A Província de São Paulo, anúncios em novembro e dezembro de 1881. Arquivo do Estado.
} 
dos proprietários da Fábrica de Santo Antonio, localizada no Largo do Riachuelo, praticamente à "porta de entrada" do bairro ${ }^{81}$.

Tendo em vista a ampliação das informações sobre os primeiros atores sociais a atuar na área abrangida pelo loteamento do Bexiga, buscamos algumas outras fontes primárias no AHMWL, tais como as Atas da Câmara Municipal de São Paulo e os Papéis Avulsos. O acesso a um documento especialmente importante, o abaixoassinado encaminhado à Câmara, em 1883, foi possibilitado pela informação valiosíssima do historiador do AHMWL, Luís Soares de Camargo.

O abaixo-assinado foi encaminhado por proprietários de terras da região ao Presidente da Câmara e aos demais Vereadores da Câmara Municipal de São Paulo ${ }^{82}$. Naquele documento, os proprietários solicitaram “a mudança do nome de Campo do Bixiga para o de Campo da Bella Vista, visto como aquelle nome nenhuma tradição nos faz recordar".

Entre as 51 pessoas a assinar o documento, alguns sobrenomes se destacam: Albuquerque, Marques, Tavares, Araújo e Clark, sendo que neste último caso, contamos inclusive, com a sugestiva presença de uma senhora, Marietta de Albuquerque Clark ${ }^{83}$. A família Albuquerque soma sete assinaturas que, acrescidas dos Clark, Marques e Tavares, chegam a vinte pessoas. Além desses nomes, encontramos outras 24 pessoas, algumas delas bem conhecidas, como é o caso de Tobias de Aguiar. Chamam a atenção os quatro nomes de origem nórdica ou escandinava - Barnabé Fuller(?), Christiana Nielsen, Adelheid Paulsen e Pedro F. Rohde - sobrepondo-se a apenas dois italianos - Carlos Biagini e Raimundo Gurgetti(?) - o que pode ser facilmente explicável pelo ainda pequeno impulso da imigração italiana até aquele momento. A análise suscinta desse abaixo-assinado evidencia as ligações familiares dessas pessoas e, por extensão, dos interesses entre esses atores sociais.

Com o objetivo de confirmar a possível permanência dessas pessoas durante o processo de consolidação do bairro, tivemos o cuidado de comparar esses nomes com

\footnotetext{
${ }^{81}$ A partir desse anúncio é possível depreender que alguns dos mesmos personagens que investiram no desenvolvimento da cidade também estiveram envolvidos com o movimento abolicionista.

${ }^{82}$ Atas da Câmara da Cidade de São Paulo, Op. Cit., p. 31.

${ }^{83}$ Nada descobrimos acerca dos indivíduos da família Clark, apontados no abaixo-assinado. Conforme Suzigan e Szmrecsányi, "Por seu lado, a Clark \& Co, britânica, que já vinha operando no país, no comércio de importação de calçados, decidiu instalar uma fábrica de calçados no Brasil a fim de importar sem as barreiras tarifárias à importação”. A fábrica foi construída no bairro da Mooca e inaugurada em 1904. SUZIGAN Wilson e SZMRECSÁNYI, Tamás - "Os investimentos estrangeiros no início da industrialização do Brasil”. In: História Econômica da Primeira República, São Paulo: EDUSP/Imprensa Oficial/Ed. Hucitec, 2002. p. 265.
} 
aqueles identificados nos processos da Série Obras Particulares. O único nome efetivamente confirmado por esta fonte foi o de Fernando de Albuquerque. Em 1906 encontramos a última referência a Albuquerque, que nessa data apresentou um requerimento, solicitando alvará de licença para reconstrução de muro e colocação de portão $^{84}$ em terreno de sua propriedade. A breve presença desses atores sociais no cenário do Bexiga, saindo de "cena" tão logo o empreendimento se firmou, aponta para a inexistência de vínculos com o bairro, confirmando a área como objeto de puro investimento imobiliário.

O texto do documento deixa bem claro as intenções dos peticionários: a mudança do nome do bairro significava revesti-lo de uma nova conotação e valor supostamente impossível de obter com a alcunha pejorativa de "Bexiga", fosse esse realmente o apelido de um antigo proprietário - Antonio Soares Calheiros, o Antonio Bexiga -, fosse um nome dado à área em razão da varíola ou das "bexigas de boi" encontradas no Matadouro Municipal. Partindo do pressuposto de que as pessoas que assinaram o documento eram proprietárias de terras na região, interessadas em participar do "boom" imobiliário em curso na cidade, é compreensível que quisessem "agregar valor" ao empreendimento. Independentemente de sabermos se a mudança de nome realmente atingiu o objetivo de valorização formal, o fato é que "Pela Lei $n^{o}$ 1.242 de 1910, o antigo Bexiga [...] passou a constituir um único bairro com o nome que conserva até hoje - Bela Vista” ${ }^{85}$. Após a mudança, o processo de comercialização continuou, e dez anos depois não encontramos mais aqueles personagens. Isso nos leva a concluir que a primeira etapa do empreendimento havia sido cumprida.

De janeiro a dezembro de 1881, o jornal A Província de São Paulo publicou diversos anúncios para venda de casas e terrenos no Bexiga. Entre todos eles, alguns chamaram especialmente a nossa atenção. O primeiro, anunciando o leilão de "terrenos prontos para edificar",

“UMA PECHINCHA LUCRATIVA!!! ROBERTO TAVARES - Vende em leilão, sábado, às 5 horas da tarde por conta e ordem de quem pertencer, terrenos prontos para edificar situados no Bexiga, junto ao Tanque do Reúno, a 5 minutos da cidade. N.B. - Para melhor orientação do pretendente podem seguir para os terrenos, saindo no Piques junto à Fábrica Santo Antonio, tomando sempre à direita, ou então mais

\footnotetext{
${ }^{84}$ Obras Particulares, 23/06/1906, Cx. S1-12.

${ }^{85}$ ALAMBERT, Clara Correia d' e FERNANDES, Paulo Cesar Gaioto - "Bela Vista: a preservação e o desafio da renovação de um bairro paulistano”, Revista do Arquivo Municipal, no 204, São Paulo: DPH, 2006. p. 152.
} 
facilmente pela rua da Consolação, entrando pela rua do Tanque que é contígua ao Colégio Morton. No portão está hasteada uma bandeira.

SÁBADO, ÀS 5 HORAS”. (27, 28 e 29/04/1881)

O segundo, publicado em 22, 23 e 26 de julho do mesmo ano, aparentemente nos remete a outro bairro conhecido, a Bela Cintra. Entretanto, a última frase, grifada por nós, esclarece que se tratava de área abrangida inclusive pelo "Bexiga de outrora".

"TERRENOS - É hoje o melhor emprego de capitais, mas cumpre ainda fazer-se boa escolha do local, para duplicar as vantagens do emprego, isto é, que a localidade ao menos, seja salubre; mas que salubridade podem oferecer essas várzeas que rodeiam esta capital?... Que não há entre esses paludosos terrenos e os da Bela Cintra?... Nesses não só há a reconhecida salubridade da terra e deslumbrante vista; além disso quem há aí que faça tantas vantagens ao comprador como a Bela Cintra?... Aqui se vendem os terrenos baratíssimos, concede-se algum prazo para a metade do pagamento deles, aqui há matas, que só delas se tira o valor do terreno, e há grande pastaria grátis; e para provar que a descrição está muito abaixo da realidade, o seu proprietário convida os srs. pretendentes a virem percorrer este bairro em antes de fazerem por aí alguma compra de afogadilho, que depois se arrependam. Entende-se por Bela Cintra, desde a rua da Consolação até a rua de Santo Amaro, inclusive o Bexiga de outrora”. (22, 232 26/07/1881)

Em 1882 e 1883, outros anúncios se destacam, e ali novamente encontramos o bairro com outra nomenclatura:

"TERRENOS BARATOS À VENDA - Vendem-se diversos lotes de terrenos, no Monte de Ouro (antigo Bexiga), com pontos de vista esplendidos; para tratar na Fábrica de Santo Antonio com o dono da mesma”. ( jan/1882)

“Aluga-se o chalé $2^{\circ}$ do Monte do Ouro (Bexiga), com bastantes comodos, água, quintal, e gozando de ótima vista; para tratar na Fábrica de Santo Antonio (Piques). Anúncio em 17/jan (p.3) durante o mês". (jan/1883)

Não é possível ter uma idéia clara sobre as facilidades ou dificuldades de comercialização dos terrenos nos primeiros anos, mas durante todo o levantamento dos jornais no Arquivo do Estado tivemos a impressão de que a pretensa mudança de nome indicava uma intenção de valorizar o empreendimento. De 1878 até ocorrerem os anúncios de leilão daquelas terras em 1883, diversos outros foram publicados, quase sempre de uma maneira muito simples, com apenas a indicação dos endereços onde deveriam ser tratados os negócios. A nosso ver, mesmo que o empreendimento não apresentasse grandes dificuldades de comercialização, também não deve ter tido o sucesso de vendas esperado pelos capitalistas envolvidos. Apesar das vantagens anunciadas, não se tratava de lotes tão perfeitos, pois estavam localizados em região de difícil acesso, com as baixadas sujeitas a enchentes frequentes dos cursos d'água ali existentes. Por outro lado, diversos autores se referem ao fato daquela região ser 
"refúgio de escravos fugidos" e de "vagabundos e meretrizes". Maria Cristina C. Wissenbach traça o seguinte perfil do Bexiga:

“[...] Área de ocupação antiga e historicamente demarcada pela existência de redutos de escravos fugidos, forros e africanos livres da época do Império, nos inícios do século conviviam com os moradores originais com os recém-chegados que aí se estabeleceram em razão da barateza dos terrenos [...]" ${ }^{86}$.

Dessa maneira, a mudança de nome desvinculava o bairro da tradição "pouco recomendável", ao mesmo tempo em que valorizava o empreendimento, algo que confirma a hipótese levantada referente ao objetivo do abaixo-assinado enviado à Câmara em 1883. Os signatários do abaixo-assinado, provavelmente, fazem parte do time de capitalistas que atuou na cidade nas últimas décadas do século XIX - alguns possivelmente vinculados à aristocracia paulistana, outros à indústria nascente, como é o caso da família Clark, proprietária da conhecida fábrica de calçados que se instalou no bairro da Mooca em 1904.

Cabe destacar outra informação fornecida por Maria Luiza F. de Oliveira, talvez a mais interessante. Trata-se da associação, após a morte de Braga em 1879, de sua viúva, Eugenia Pires com Victor Nothmann, ocasião em que "fizeram um loteamento com o plano de uma linha de bondes e ganharam bastante dinheiro" ${ }^{87}$. Isso, além de explicar o porquê do nome de Nothmann constar na Planta dos Terrenos do Bexiga (ver Figura 12), nos fez rever alguns fatos. Braga comprou a chácara de Thomaz Luiz Álvares em $1878^{88}$, com o objetivo de lucro rápido, já que data do mesmo ano o primeiro anúncio para venda dos terrenos. Não sabemos se a intenção da associação com Nothmann é anterior à morte de Braga ou é "fruto" da união da viúva com o engenheiro Fernando de Albuquerque ${ }^{89}$. O caso é que a oficialização do empreendimento ocorreu somente em 1890, onze anos após a morte de Braga, conforme atesta o croqui elaborado pelo engenheiro, sugerindo que foi sob a influência de Nothmann e Albuquerque que o empreendimento tomou as proporções que conhecemos.

\footnotetext{
${ }^{86}$ WISSENBACH, Maria Cristina Cortes - "Da escravidão à liberdade: dimensões de uma privacidade possivel", in História da Vida Privada no Brasil, v. 3, São Paulo: Cia.das Letras, 1998, p.115-117. ${ }^{87}$ OLIVEIRA, Maria Luiza F. de - Op. Cit., p. 220.

${ }^{88}$ (S. P. A., 1, 109, p. 16). In SANT'ANNA, Nuto - São Paulo histórico (Aspectos, lendas e costumes), V. 1, Volume 16 da Coleção. Depto. de Cultura, São Paulo, 1937. p. 161.

${ }^{89}$ Não sabemos exatamente de quando data essa união, mas, em 1884, quatro anos após a morte de Antonio José Leite Braga, a viúva Eugenia Pires, agora casada com Fernando de Albuquerque, aparece doando o grande terreno no Bexiga, para a edificação do novo prédio da Santa Casa (SANT'ANNA).
} 
Não era mais o caso da venda de lotes e casas esparsos pela extensa área da chácara como demonstram os anúncios dos jornais A Província e $O$ Estado de São Paulo. Até 1882, a maioria dos anúncios publicados naqueles jornais se utilizava de referências bastante vagas para designar o local dos imóveis, tais como "morro do Bexiga", "Monte de Ouro", ou apenas "Bexiga". Nos casos mais específicos, os endereços eram aqueles nas ruas mais antigas, Santo Amaro e Santo Antonio. Já em 1890 e 1891, talvez até como reflexo dos esforços empreendidos pelos proprietários (a exemplo do abaixo-assinado), diversas ruas são dadas como referência das possibilidades de "bons negócios", agora preferencialmente nos "campos da Bela Vista": rua dos Valinhos, rua Conselheiro Ramalho, rua Conselheiro Carrão, rua Rui Barbosa, rua Antonio Prado, rua São Domingos e rua Monte de Ouro. Um anúncio de 1890, em especial, dá o "tom” das mudanças que viriam a ocorrer:

"Por [...] vendem-se duas moradas de casa com porta e duas janelas cada uma, e terreno bastante fundo, situadas à rua dos Valinhos (Bexiga); rua em que passará a linha de bonds do Bom Retiro à Bela Vista" 90

Era a nova fase do empreendimento, aquela registrada por Maria Luiza F. de Oliveira, a partir do inventário de Antonio José Leite Braga. Ele saíra de cena; entraram Victor Nothmann e Fernando de Albuquerque. É possível que o primeiro não tenha se demorado muito por ali já que não encontramos outras referências a seu respeito. Quanto a Fernando de Albuquerque, talvez os laços familiares o tenham mantido no então bairro da Bela Vista, pelo menos até a data de seu último registro nas Obras Particulares, em 23/06/1906 ${ }^{91}$.

Ao lado dos anúncios para venda de imóveis, os jornais apresentam outros empreendimentos que pretendem explorar as supostas potencialidades econômicas do bairro. Aparentemente, o maior deles foi a "Carpintaria e Marcenaria a Vapor denominada Fábrica Santo Antonio”, de propriedade de Domingos José Coelho da Silva e Antonio José Leite Braga.

"O proprietário deste bem montado estabelecimento tem a honra de comunicar a todos os seus amigos e freguezes tanto desta capital quanto do interior, que acaba de fazer uma grande redução de preços nos diferentes ramos de serviço de sua fábrica, pelo que pode garantir não haver mais barato nem mais perfeito em qualquer outro estabelecimento. Além do aparelho de batentes, soalho, forro e molduras, fabrica janelas, portas, caixilhos, lambrequins, balaustradas, colunas, armações, balcões,

\footnotetext{
${ }^{90}$ O Estado de São Paulo”, 25/01/1890. p. 4. Arquivo do Estado, filme 01.01.016.

${ }^{91}$ Obras Particulares, 23/06/1906, Cx. S1-12.
} 
vitrinas e bem assim trabalhos de recorte... Largo do Riachuelo”. (maio, junho e julho/1881)

A Fábrica Santo Antonio veio a atender às necessidades de material de construção, apontando esse tipo de comércio como um dos mais valorizados nesse momento. Tendo em vista o mercado da construção, outros serviços também eram oferecidos, a saber:

"CONSTRUÇÕES - Toma-se, por empreitada, ou não, a construção de casas, chalés e toda e qualquer obra. Trata-se na rua da Liberdade n.27. Domingo até 30”. (04/07/1883 e durante os meses seguintes)

\section{"PARA CONSTRUÇÕES}

O abaixo assinado oferece-se para fazer medições, levantar plantas, fazer orçamentos e construir casas, jardins, etc., tanto por empreitada como por administração. Para informações em casa do senhor A.C. Rocha Júnior, à rua da Imperatriz n.39. São Paulo, 2 de novembro de 1881. M. Haussler" $(02 / 11 / 1891)^{92}$

"Para abrir latrinas e poços de água e limpeza dos mesmos, oferece-se um moço. Na rua de Santo Antonio, 8”. (17/07/1891)

Ainda nos anos de 1890, já encontramos anúncios de atividades produtivas exercidas nas novas ruas do Bairro:

"Leite puro na chácara Talon à rua dos Valinhos A5, vende-se de manhã e de tarde, bom leite a $200 \$$ a garrafa”. (07/01/1890)

"Oferece-se uma ama de leite, rua Conselheiro Ramalho, 19. Bexiga". (21/04/1891 e durante o mês de maio)

Por fim, de 1881 até 1891, ao lado dos anúncios para venda de casas e terrenos, algumas casas para aluguel eram anunciadas, nas ruas Monte de Ouro, Santo Amaro e São Domingos. Dessa maneira é possível depreender que, nos seus dez primeiros anos, o empreendimento imobiliário já estava avançado e apontava para a exploração locatícia das casas construídas. Configurava-se dessa maneira uma tendência que iria se confirmar na primeira década do século seguinte.

\footnotetext{
${ }^{92}$ Tudo indica que "M. Haussler" é o mesmo Matheus Haussler que, de acordo com Salmoni \& Debenedetti realizou projetos para Elias Chaves, entre outros. SALMONI \& DEBENEDETTI. Op. Cit., p. 36 .
} 


\subsection{O poder público}

A transformação de antigas residências em cortiços, na região central, e a instalação desordenada nos novos bairros pelas populações de baixa renda, estimulada pela ação especuladora dos agentes imobiliários, condicionou edificações precárias e baratas para locação, ampliando dessa maneira o risco de incidência das doenças epidêmicas. O Relatório da Comissão de Exame e Inspecção das Habitações Operárias e Cortiços no Discricto de Santa Iphigênia ${ }^{93}$ é um bom exemplo das condições de moradia dos segmentos pobres na cidade. Nabil Bonduki considera que, "Embora abrangendo somente alguns quarteirões de Santa Iphigênia, é possível extrapolar as informações do Relatório para outros bairros ocupados por moradias populares" 94. Paulo Cesar Garcez também demonstrou que a instalação dos cortiços não se restringiu aos bairros centrais. Nas palavras do autor:

"As precárias condições sanitárias presentes nas casas dos bairros de imigrantes, juntamente com as encontradas nos cortiços espalhados por quase toda a cidade, justificaram a expansão do aparelho oficial de fiscalização higiênica, cujos resultados antecederam os que seriam alcançados no Rio de Janeiro na primeira década do século XX" 95.

Impunha-se para a administração pública a necessidade de medidas que atuassem diretamente no problema, entre essas, a criação de leis que regulamentassem onde e como construir.

Eudes Campos elabora uma análise criteriosa dos códigos de posturas que buscaram disciplinar o ato de construir. Conforme o autor:

"O primeiro código de posturas da cidade de São Paulo foi aprovado pela Assembléia Provincial em 14 de maio de 1873. Considerado muito rigoroso e injusto, sofreu enorme oposição por parte da população paulistana [...] Sensíveis à opinião pública, os vereadores paulistanos solicitaram a suspensão imediata do código, mas a presidência da Província informou que só tinha poder para aprovar provisoriamente as posturas municipais, e não para revogá-las. A solução era manter o código em vigor e substituí-lo o mais breve possível por outro, mais adequado. Foi então nomeada uma comissão revisora [...], responsáveis pela versão que substituiria em $\underline{31}$ de março de 1875 o código rejeitado.

Com o rápido desenvolvimento da capital paulista [...], onze anos foram suficientes para fazer envelhecer, aos olhos dos edis paulistanos, a apresentação do código de

\footnotetext{
${ }^{93}$ Ver em SAMPAIO, Maria Ruth Amaral de (Coordenação) - Habitação e Cidade, LEMOS, Carlos A. C. - “Os primeiros cortiços paulistanos”, São Paulo: FAUUSP/FAPESP, 1998. p. 19 a 37.

${ }^{94}$ BONDUKI, Nabil - Origens da habitação social no Brasil, São Paulo: Estação Liberdade/FAPESP, 1998, p. 22.

${ }^{95}$ MARINS, Paulo Cesar Garcez - "Habitação e vizinhança: limites da privacidade no surgimento das metrópoles brasileiras”, in História da Vida Privada no Brasil, v. 3, São Paulo: Cia. das Letras, 2001, p.173.
} 
1875, tido agora como uma compilação de normas municipais de confusa e simplória redação. [...] Convém chamar a atenção aqui para o fato de que o chamado código de 1886 não era na verdade um novo código, e sim mera recodificação do código de 1875 , não tendo sido necessário cumprir alguns trâmites oficiais para a sua entrada em vigência [...]. Foi simplesmente aceito pela Câmara Municipal em 6 de outubro de 1886 e entrou em vigor imediatamente" ${ }^{96}$ (grifo nosso).

No Código de Posturas de 1886, a edificação de habitações coletivas foi tolerada, desde que realizada fora dos limites centrais, ou seja, nos novos bairros, permitindo assim que se continuasse a construir como se quisesse ou pudesse. No entanto, alguns parâmetros foram colocados de maneira a disciplinar a construção de tais moradias. Destes, os mais importantes foram:

- A obrigatoriedade de porão com alturas mínimas, de forma a isolar as residências da umidade do solo;

- Altura mínima também para o pé-direito dos cômodos internos;

- Utilização da alvenaria de tijolos em substituição ao uso da taipa;

- A "conveniência do corredor lateral descoberto que permitisse a iluminação direta dos cômodos”.

Em 1894, já na República, foi promulgado o Código Sanitário. Nesse documento, são terminantemente proibidas as alcovas e as latrinas com acesso direto aos dormitórios, ou os dormitórios com acesso direto às cozinhas. Como colocado por Lemos ${ }^{97}$, até o Código de Posturas de 1886 não ficam claros nos documentos oficiais as definições que caracterizariam a priori o que seria um cortiço. Somente em $\mathbf{1 8 9 6}$ seria elaborada uma conceituação mais objetiva, mas nem por isso mais eficiente:

"A Lei n. 286 daquele ano dizia em seu artigo 13 que 'entende-se por cortiço o conjunto de duas ou mais habitações que se comuniquem com as ruas públicas por uma ou mais entradas comuns para servir de residências a mais de uma família'[...] 'compreende-se também como cubículos de cortiços os cômodos de casas que não sejam cortiços, mas que estejam divididos em diferentes fogões e os que lhes forem acrescidos nas mesmas condições. ", 98

Nabil Bonduki destaca que:

“[...] para compreender o significado dessa intervenção estatal na Primeira República (1889-1930), é preciso ter em mente que o Estado liberal relutava ao máximo em interferir na esfera privada. [...] Na habitação, porém, o Estado foi obrigado a atuar de forma mais vigorosa. A (ir)racionalidade da produção capitalista de edifícios, $o$ loteamento indiscriminado e a precariedade dos serviços de água e esgoto, a cargo de

\footnotetext{
${ }^{96}$ CAMPOS, Eudes. “Casas e vilas operárias paulistanas”. Informativo Arquivo Histórico Municipal, 4 (19): jul/ago.2008 http://www.arquivohistorico.sp.gov.br.

${ }^{97}$ LEMOS, Carlos A. C. - Alvenaria Burguesa, São Paulo: Nobel, 1985. p. 69-70.

${ }^{98}$ LEMOS, Carlos A.C - "Os primeiros cortiços paulistanos”, in SAMPAIO, Maria Ruth Amaral de (coord.) - Habitação e cidade, São Paulo: FAPESP/FAUUSP, 1998, p.14.
} 
empresas privadas, entre outros, passaram a constituir séria ameaça à saúde pública. Por isso, o controle estatal da produção do espaço urbano não só foi aceito como também reivindicado [...] Nos últimos quinze anos do século XIX, higienistas, médicos e engenheiros já começaram a clamar pela criação de leis e serviços sanitários [...] E, tendo obtido o apoio da opinião pública, conseguiram fazer com que o Estado desse prioridade à questão. " 99

Desde a instauração da República, a administração pública esteve sujeita a diversas modificações em busca de um modelo político-administrativo que satisfizesse as necessidades de cidades em franco processo de crescimento. Em São Paulo, em 27 de fevereiro de 1896, foi promulgada a Lei $n^{\circ}$ 203, estabelecendo que "o poder executivo seria exercido por quatro Intendências":

- de Polícia e Higiene

- de Justiça

- de Obras

- de Finanças" 100.

Através dessa lei, além da Intendência de Obras, encarregada da verificação da observância das normas construtivas, estabelecia-se uma outra instância reguladora das condições de higiene na cidade, sob a responsabilidade da Intendência de Polícia e $\underline{\text { Higiene }}$ - mediante a fiscalização das condições de funcionamento das atividades comerciais e da conformação dos diferentes tipos de negócio às normas urbanas. A partir da Lei no 374, de 19 de dezembro de 1898, o Poder Executivo Municipal passou a ser exercido por um Prefeito, ao qual as antigas Intendências - agora transformadas nas Seções de Justiça, Polícia e Higiene, Obras e Finanças -, se subordinavam. Assim, entre as gestões dos prefeitos Antonio da Silva Prado (07/01/1899 a 15/01/1911) e Raimundo da Silva Duprat (16/01/1911 a 14/01/1914) $)^{101}$, a administração pública municipal paulistana foi sendo aprimorada de maneira a responder às necessidades mais complexas impostas pelo crescimento da cidade.

Independentemente do alcance das medidas implementadas pelo poder público nas ações relativas ao disciplinamento do construir, morar e trabalhar, o fato é que cada vez mais ele se mostrou presente na cidade de São Paulo. Com maior ou menor grau de eficiência, as intervenções realizadas naquele momento moldaram os espaços urbanos

\footnotetext{
${ }^{99}$ BONDUKI - Op. Cit. p.27 e 28.

${ }^{100}$ Guia Arquivo Histórico Municipal Washington Luís - 100 Anos (1907-2007), Prefeitura da Cidade de São Paulo, Departamento do Patrimônio Histórico/DPH, 2007, p. 30 a 32.

${ }^{101}$ São Paulo (SP). Prefeitura - O poder em São Paulo: história da administração pública da cidade, 1554-1992, São Paulo: Cortez Ed., 1992, p. 157.
} 
da cidade de acordo com as necessidades de segmentação social pretendida pelas classes dominantes.

Enquanto os cortiços multiplicavam-se entre os bairros destinados às camadas baixas da população, nos bairros nobres foram edificadas as residências destinadas às camadas mais altas da sociedade. Se no caso dos primeiros a busca por moradias em espaços possíveis foi condicionada pelo baixo custo dos aluguéis e pela proximidade dos locais de trabalho, a ocupação de bairros destinados às camadas mais altas obedeceu a questões menos práticas e mais valorizadas socialmente. A boa localização, com melhores condições de salubridade, a possibilidade de desfrutar dos equipamentos urbanos mais modernos, a implantação de infra-estrutura mais completa, tudo a custos impensáveis para os primeiros, foi determinante para a ocupação de bairros como Higienópolis, Vila Buarque, Avenida Paulista e Morro dos Ingleses.

A ação fiscalizadora do poder público no bairro da Bela Vista, enredo de nossa pesquisa, se fez sentir principalmente através da aplicação de multas, intimações e embargos. Entre o início da pesquisa, em 1881, e o ano de 1894, passados 17 anos, encontramos apenas seis processos que de alguma forma implicaram na ação fiscalizadora e reguladora do poder público em vista da inobservância ou desrespeito da legislação urbanística, apenas 5,50\% dos 109 casos em que ficou comprovada a presença fiscalizadora municipal.

De acordo com a Tabela 1, nós verificamos que, a partir de 1899, a cada ano aumentam as ações oficiais, seja através de intervenções repressivas ainda durante a edificação, seja para corrigir distorções já concretizadas, ou mesmo para prevenir possíveis infrações.

Como demonstram os trechos a seguir transcritos:

- Um "Pedido de vistoria e demolição para prédio em ruínas, por infringir o Art. 20 da Lei 220 de 10/11/1896" $" 102$.

- Processo para construção de uma cocheira: "pode-se conceder a licença, obrigando-se (o proprietário) a construir o pavimento impermeável e a revestir as paredes até 1,5m de altura, pelo menos, com argamassa de cimento e a dar fácil escoamento às águas” 103

\footnotetext{
102 Solicitação de vistoria de 22/02/1899, acerca do prédio de Manoel Salgado, à rua Santo Antonio, 125. Obras Particulares, v. 251, p.70.

${ }^{103}$ Processo de 14/04/1899, em nome de Ignácio Mamanna (?), rua Maria José, pegado ao nº 25. Obras Particulares, v. 244, p.44.
} 
- Pedido de vistoria de obra embargada por construção em desacordo com a planta aprovada: “[...] no número 28 existe um cortiço composto de 7 cômodos, 4 dos quais ainda em construção. Os outros 3 são habitados cada um por uma família, e não são assoalhados mas sim, cimentados [...]" 104 .

- Intimação para mandar “[...] no prazo de 10 dias mandar fazer os reparos... caiar, pintar e colocar clarabóia nos quartos de dormitório[....]" 105.

- Ofício solicitando providências da Secretaria: “[...] em relação aos prédios citados, que apresentam vícios radicais de construção[...] a casa 194 é excessivamente baixa, com 2,70m do solo ao forro. Há um quarto dormitório sem abertura alguma exterior e com a área de 5,60m. O primeiro cômodo é cimentado e os outros atijolados. A construção é de 0,15 de espessura nas paredes externas. Está, todavia em muito bom estado de segurança. O prédio 196 e contíguo ao 194 e tem a mesma divisão e está igualmente no mesmo estado[...] tem a seu favor a área do quarto dormitório que é superior a 7,50m[...]". Conforme parecer do engenheiro, de 19/12/1900, em relação aos números 208 e 210 “[...] os prédios são ainda mais baixos que os precedentes, pois tem apenas 2,25m de altura; constam de sala, quarto e cozinha, são de páu-a-pique e os dormitórios, exceto o do n. 210 quanto à área, são mal arejados e de área insuficiente. Além disso não oferecem segurança" ${ }^{106}$.

- Solicitação de vistoria de casa em construção, de 22/12/1905. Conforme parecer do fiscal, "o proprietário construiu os dois primeiros quartos de acordo com a planta, porém, alegando não poder concluir as obras... começou a construir dois pequenos quartos logo em seguida aos dois já referidos[...] destinados à cozinha e ao depósito de lenha; (as paredes) são de meio tijolo e em completo desacordo com o padrão municipal[...], acho que essas alterações em construções não devem ser permitidas, mesmo a título do provisório, a fim de não alterar o padrão municipal e as condições higienicas exigidas". Em 24/01/1906, "já haviam sido demolidos os quartos"107.

- A assinatura do Termo de Compromisso: "Tendo projeto aprovado para construção de uma vila de oito casas, em frente a outro grupo chamado de "Villa Casilda", também de sua propriedade, formando-se assim uma rua particular, deve pagar

\footnotetext{
${ }^{104}$ Processo de 08/11/1899, em nome de Affonso Cocci, rua Santo Amaro, no 28. Obras Particulares, v. 282, p.128.

105 Intimação de 27/07/1900, para a rua Conselheiro Carrão, nº 50. Obras Particulares, v. 265, p.215.

${ }^{106}$ Ofício de 15/01/1901, para os prédios localizados na rua Santo Antonio, no 194, 196, 208 e 210. Obras Particulares, v. 312, p.1.

${ }^{107}$ Solicitação de 22/12/1905 para a obra da rua Santo Antonio, 19. Obras Particulares, v. 422.
} 
importância de 2:827\$000 para garantir o calçamento, solicita assinar um termo de responsabilidade" ${ }^{108}$.

\begin{tabular}{|c|c|c|c|c|}
\hline ANO & $\begin{array}{c}\text { DOCUMENTOS } \\
\text { OFICIAIS }\end{array}$ & REQUERIMENTOS & TOTAL & $\%$ \\
\hline $\mathbf{1 8 8 7}$ & 1 & - & 1 & - \\
\hline $\mathbf{1 8 9 1}(*)$ & - & 1 & 1 & - \\
\hline $\mathbf{1 8 9 3}$ & 1 & - & 3 & - \\
\hline $\mathbf{1 8 9 4}$ & 1 & 2 & $\mathbf{6}$ & $\mathbf{5 , 5 0}$ \\
\hline SUBTOTAL & $\mathbf{3}$ & $\mathbf{3}$ & 8 & - \\
\hline $\mathbf{1 8 9 9}$ & 2 & 6 & 17 & - \\
\hline $\mathbf{1 9 0 0}$ & 8 & 9 & 9 & - \\
\hline $\mathbf{1 9 0 1}$ & 8 & 1 & $\mathbf{3 4}$ & $\mathbf{3 1 , 2 0}$ \\
\hline SUBTOTAL & $\mathbf{1 8}$ & $\mathbf{1 6}$ & 2 & - \\
\hline $\mathbf{1 9 0 4}(*)$ & - & 2 & 5 & - \\
\hline $\mathbf{1 9 0 5}$ & 1 & 4 & 5 & - \\
\hline $\mathbf{1 9 0 6}$ & - & 5 & 6 & - \\
\hline $\mathbf{1 9 0 7}$ & 1 & 5 & 13 & - \\
\hline $\mathbf{1 9 1 2}$ & 5 & 8 & 19 & - \\
\hline $\mathbf{1 9 1 3}$ & 11 & 8 & 19 & - \\
\hline $\mathbf{1 9 1 4}$ & 9 & 10 & $\mathbf{6 9}$ & $\mathbf{6 3 , 3 0}$ \\
\hline SUBTOTAL & $\mathbf{2 7}$ & $\mathbf{4 2}$ & $\mathbf{1 0 9}$ & $\mathbf{1 0 0 \%}$ \\
\hline TOTAL & $\mathbf{4 8}$ & $\mathbf{6 1}$ & & \\
\hline
\end{tabular}

Tabela 1 - Incidência da ação fiscalizadora da municipalidade

Conforme visto na tabela, dividimos o período investigado em três fases distintas, onde encontramos somente seis casos de intervenção oficial, até 1894. Já o triênio de 1899 a 1901, demonstra a presença mais constante da ação fiscalizadora municipal, com 34 ocorrências. Por fim, entre 1904 e 1914, ocorreram 69 casos, ou 63,30\% dos 109 casos. Ainda que os levantamentos realizados não tenham envolvido a totalidade dos projetos arquitetônicos apresentados no período em questão, não resta dúvida sobre o aumento da ação do poder público a partir da década de 1890. Isso nos leva a pensar criticamente sobre certas assertivas feitas por alguns autores que escreveram sobre o bairro. É o caso de Nádia Marzola, que ao discorrer sobre o crescimento do bairro, afirma:

"A massa compacta do casario modesto foi surgindo sem qualquer projeto, da forma mais empírica possível. As residências era desenhadas pelos 'capomastri', arquitetos que não usavam planta, ou arquitetos de 'ponta de guarda-chuva', para usar a expressão utilizada pelo Arquiteto Benedito Lima de Toledo. A planta era riscada no chão e as paredes levantadas a partir desse desenho (grifos nossos)." 109

O mesmo se verifica em Lucena:

\footnotetext{
${ }^{108}$ Processo de 12/08/1913, referente à edificação de uma vila, à rua Major Diogo, 42, em nome de José Galvão de Albuquerque. Obras Particulares, Cx. M1.

${ }^{109}$ MARZOLA, Nádia - "Bela Vista”, in História dos Bairros de São Paulo, v.15, Depto. do Patrimônio Histórico/Secretaria da Cultura/Prefeitura de São Paulo, 1979, p.63.
} 
"Os calabreses, que foram comprando seus lotes e quintas nas baixadas do Bexiga, projetaram suas residências, esses conhecidos por 'capomastri', construtores italianos, que desenhavam o sobrado com a ponta do guarda-chuva em terra batida no chão." 110

Ainda que pesem os esforços empreendidos pelas autoras no sentido de traçar um retrato mais completo do bairro, sem sombra de dúvida fruto da leitura de ampla documentação, acreditamos que tais afirmações podem gerar uma imagem equivocada do que teria sido o processo construtivo na região - aleatório e sem vínculos com as normas construtivas da época. Conforme Eudes Campos ${ }^{111}$, foi justamente tendo em vista a construção de moradias para as camadas mais pobres da população que os Códigos de Posturas de 1886, 1889 e, mais tarde, o Código Sanitário de 1894 foram elaborados, contendo exigências que garantissem um mínimo de habitabilidade civilizada. As camadas mais ricas tinham consciência dos benefícios oferecidos pelos novos padrões, adotando-os para suas próprias residências. Porém, ao construírem imóveis para alugar, sempre que fosse possível, evitavam investir em materiais, equipamentos ou mesmo em extensões de terrenos que implicassem em maiores gastos. Assim, acreditamos que nos primeiros anos de ocupação do bairro as regras construtivas tenham sido realmente ignoradas, porém, na medida em que a fiscalização se tornou mais rígida, acarretando multas e, às vezes, até a demolição e reconstrução de obras já concluídas, a sujeição aos padrões construtivos impostos pelo poder público se mostrou um "mal necessário". Do total de 91 processos investigados, entre 1900 e 1904, pelo menos $52(57,14 \%)$ se referem a medidas corretivas em virtude de algum tipo de intimação recebida pelos proprietários de imóveis.

Se de um lado a presença da fiscalização é um fato comprovado pela constância dos embargos às obras em desacordo com a legislação, de outro, essa mesma constância fiscalizadora parece significar a reincidência de comportamentos abusivos. Encontramos alguns processos que entre "idas e vindas", chegaram a levar mais de um ano até a solução final, demonstrando uma tendência à "desobediência". Foi o caso de Franklin Antão Pedroso, proprietário que, em 02/09/1901, “Querendo mandar levantar platibanda na sua casa à rua de Santo Amaro, $n^{o} 86$, solicitava a necessária autorização[...]" ${ }^{112}$. Tratava-se de um processo iniciado ainda em setembro de 1899, quando o proprietário havia sofrido embargo em virtude de obra começada sem a

\footnotetext{
${ }^{110}$ LUCENA, Célia Toledo de - Bixiga, amore mio, São Paulo: Parnatz, 1983, p.86.

${ }^{111}$ CAMPOS JR., Eudes de Mello - Arquitetura paulistana sob o Império, "Os novos conceitos de higiene e conforto aplicados aos edifícios residenciais” , v.3, pg.426-487.

${ }^{112}$ Obras Particulares, v.311, p.88 a 108.
} 
apresentação do projeto arquitetônico à Prefeitura. A autorização foi negada e, conforme um parecer do dia 23 de setembro, a edificação foi demolida entre os dias 21 e 22 desse mês.

Outro exemplo, é o prédio 28, à rua de Santo Amaro, de propriedade de Affonso Cocci que, em 08/11/1899, já havia sido alvo de um pedido de vistoria para acompanhamento das obras, embargadas no dia 14 do mesmo mês. Seis dias depois, o requerente apresentou outra solicitação, aparentemente mais de acordo com as normas, onde dizia que "Desejando aumentar seu prédio[...] conforme a planta junta, pede aprovação da mesma.” A aprovação foi dada, porém, em 24/04/1900 encontramos outro embargo em decorrência da "construção em desacordo com a planta aprovada[...]”, tendo o proprietário “[...]prazo de 24 horas[...] para demolir as obras. $" 113$

Citamos apenas dois exemplos, mas são inúmeros os casos de tentativas por parte de proprietários e construtores de burlar a legislação reguladora do ato de construir. O fato é que esses exemplos fornecem bem a medida das dificuldades enfrentadas pelo poder público que, ao legislar em prol de interesses coletivos, frequentemente teve que lidar com as resistências de uma população que não estava habituada a seguir regras.

\subsection{Proprietários}

Tendo em vista a identificação dos proprietários dos imóveis, foram investigados os processos para autorização de construção, constantes na Série das Obras Particulares, no AHMWL. Dada a obrigatoriedade, a partir de 1893, de licença da Prefeitura para a construção e/ou reforma de edificações, assim como para qualquer tipo de intervenção nos imóveis, esses documentos são fundamentais como fonte de informações sobre os atores que encabeçaram a construção de novos imóveis no espaço urbano.

Nesse caso, foi utilizado um critério de amostragem que possibilitasse abranger todo o período, de 1881 a 1914. Assim, a cada três anos pesquisados foram pulados

\footnotetext{
${ }^{113}$ Obras Particulares, v.282, p.128, 130 e 131.
} 
outros três, consecutivamente. Somente no último triênio, após 1907, foram saltados quatro anos, de maneira a contemplarmos os anos de 1912, 1913 e 1914.

Os levantamentos realizados envolveram a consulta a $\mathbf{1 . 1 7 0}$ documentos e abrangeram um período que vai de $\mathbf{1 8 8 2}$ - quando estes passam a se mostrar mais detalhados em relação aos processos, inclusive com projetos arquitetônicos - até meados da década de 1910, quando a ação fiscalizadora do poder público se fez sentir de forma mais contundente.

Além das edificações para moradias, simples ou mistas, que são o alvo principal de nosso estudo, os processos contêm registros de outras solicitações de licenças importantes que implicavam em:

- construção de edifícios para fábricas e/ou manufaturas;

- construção de edifícios para comércio ou outro tipo de negócio;

- reformas e acréscimos em construções existentes (para moradia ou negócio);

- intervenções externas nos imóveis, como a construção de cocheiras, barracões para depósitos, muros, passeios, colocação de portões, etc;

- toda ação relativa ao poder público, tais como queixas dos moradores e proprietários, multas, embargos, etc.

- finalmente, no âmbito das ações ligadas à municipalidade, os pedidos de licença para abertura de valas nas ruas, visando à instalação da rede de águas e esgotos.

Os dados obtidos a partir das investigações na Série Obras Particulares foram organizados por data, em um banco de dados, de maneira a permitir os cruzamentos necessários à análise das informações; e, as principais informações contidas nesse banco foram sistematizadas e sintetizadas na Tabela 2. Cada requerimento pode conter ou não o nome do proprietário e do construtor responsável, sendo que o único nome que se mostra realmente obrigatório é aquele do requerente da ação. De maneira geral, nos parece que proprietários e construtores se alternaram no papel de requerentes dos processos, porém em alguns casos aparecia uma terceira pessoa quando o interessado não soubesse escrever ou, por algum outro motivo, não pudesse estar presente.

Nos três casos - dos requerentes, proprietários e construtores - foram montadas, a partir do banco de dados original, bancos de dados específicos, relativos a cada um 
desses atores sociais, sendo que em cada um deles constam os nomes, $\underline{\text { as datas dos }}$ processos e os endereços dos imóveis correspondentes ${ }^{114}$.

\begin{tabular}{|c|c|c|c|c|c|c|c|c|c|}
\hline DATA & $\begin{array}{l}\text { ALINHAM. } \\
\text { RESIDÊNCIAS }\end{array}$ & $\begin{array}{l}\text { FÁBRICAS E } \\
\text { MANURAT. }\end{array}$ & $\begin{array}{c}\text { COM. E } \\
\text { SERVIÇOS }\end{array}$ & $\begin{array}{c}\text { REFORMAS } \\
\text { E ACRÉSC. } \\
\text { MORADIA }\end{array}$ & $\begin{array}{l}\text { REFORMAS } \\
\text { E ACRÉSC. } \\
\text { NEGÓCIOS }\end{array}$ & $\begin{array}{c}\text { INTERV. } \\
\text { EXTERNAS NOS } \\
\text { IMÓVEIS }\end{array}$ & $\begin{array}{c}\text { REDE ÁGUA } \\
\text { E ESGOTO }\end{array}$ & $\begin{array}{l}\text { RELAÇÕES } \\
\text { C/ PODER } \\
\text { PÚBLICO }\end{array}$ & TOTAL \\
\hline 1882 & 5 & - & - & - & - & - & - & - & 5 \\
\hline 1883 & 1 & - & - & - & - & - & - & - & 1 \\
\hline 1886 (*) & 2 & - & - & - & - & - & - & - & 2 \\
\hline 1887 & 13 & - & - & - & - & - & - & 1 & 14 \\
\hline 1888 & 10 & - & - & 1 & - & - & - & - & 11 \\
\hline 1889 & 13 & - & - & - & - & - & - & - & 13 \\
\hline $1890(*)$ & 7 & - & - & - & - & - & - & - & 7 \\
\hline $1891(*)$ & 9 & - & - & - & - & 1 & - & - & 10 \\
\hline $1892(*)$ & 1 & - & - & - & - & 1 & - & - & 2 \\
\hline 1893 & 27 & 1 & 1 & 7 & 2 & - & - & 2 & 40 \\
\hline 1894 & 25 & - & 2 & 10 & 4 & 12 & - & 1 & 54 \\
\hline 1895 & 37 & 1 & 3 & 11 & 2 & 4 & - & - & 58 \\
\hline $1896(*)$ & 1 & - & - & 1 & - & 1 & - & - & 3 \\
\hline 1897 (*) & 1 & - & - & 1 & - & - & - & - & 2 \\
\hline $1898(*)$ & 9 & 3 & - & 2 & - & 1 & - & - & 15 \\
\hline 1899 & 32 & 2 & - & 14 & 4 & 12 & - & 2 & 66 \\
\hline 1900 & 12 & 1 & - & 17 & 1 & 8 & - & 8 & 47 \\
\hline 1901 & 11 & 1 & - & 10 & 3 & 4 & - & 7 & 36 \\
\hline $1902(*)$ & 1 & - & 1 & - & - & - & - & - & 2 \\
\hline $1903(*)$ & - & - & - & 2 & - & - & - & 1 & 3 \\
\hline $1904(*)$ & 2 & - & - & 1 & - & - & - & - & 3 \\
\hline 1905 & 44 & 1 & 1 & 21 & 5 & 14 & - & 1 & 87 \\
\hline 1906 & 41 & 1 & - & 23 & 1 & 16 & 1 & - & 83 \\
\hline 1907 & 33 & 1 & - & 20 & 10 & 12 & 2 & 1 & 79 \\
\hline 1912 & 77 & 5 & 1 & 30 & 4 & 21 & 1 & 6 & 145 \\
\hline 1913 & 93 & 14 & 1 & 54 & 13 & 19 & 3 & 10 & 207 \\
\hline 1914 & 61 & 6 & 1 & 40 & 22 & 30 & 6 & 9 & 175 \\
\hline TOTAL & $568^{115}$ & 37 & 11 & 265 & 71 & 156 & 13 & 49 & 1.170 \\
\hline
\end{tabular}

(*) Anos e registros fora da amostra selecionada.

Tabela 2 - Universo investigado. Ocorrências da Série Obras Particulares, por ano

Observa-se todo tipo de ação, de simples pedidos de alinhamento, passando a solicitações de licença para novas edificações, para acréscimos de cômodos, construção de cercas ou muros, o recebimento de multas, questionamento de embargos em virtude de construções em ruas ainda não oficializadas pela Prefeitura, etc. Mesmo que o total das informações obtidas não tenha sido utilizado de maneira sistemática neste trabalho,

\footnotetext{
${ }^{114}$ Os nomes, por ordem alfabética, e sempre que houvesse mais de um processo em nome da mesma pessoa, foram ordenados cronologicamente. Obtivemos assim um panorama amplo da ação dos atores sociais desde o início da formação no bairro, acompanhando os primórdios de sua atuação, processos em que estiveram envolvidos e a área de abrangência de sua atuação. Contudo, ao realizarmos as primeiras leituras das listagens, percebemos diferentes grafias para os mesmos nomes. Se simplesmente aceitássemos os dados classificados pelo programa do computador utilizado, ele nos levaria a um número de agentes maior do que o ocorrido, induzindo a erros de interpretação. O problema foi contornado a partir de leituras sucessivas e criteriosas de todos os nomes, buscando agrupar aqueles que parecessem se referir às mesmas pessoas. Posteriormente, esses dados foram confrontados com os endereços fornecidos, de forma a checarmos identificações e endereço. Por fim, os nomes foram reagrupados, segundo as prováveis identidades dessas pessoas, chegando a uma relação final.

${ }^{115}$ Deste total, $\mathbf{6 6}$ se referem a alinhamentos e, $\mathbf{5 0 2}$ se referem a edificações.
} 
visto que focamos fundamentalmente os pedidos para novas edificações, a própria recorrência de processos em nome de uma mesma pessoa, às vezes envolvendo toda uma família no decorrer de longos períodos de tempo e em diferentes espaços do bairro, mostrou que aqueles documentos podiam fornecer pistas importantes para a avaliação da importância desses atores na história do bairro.

Entre os 1.170 processos levantados, encontramos $\underline{552 \text { proprietários }}$ identificados como tal, representando $47,17 \%$ da amostra total. Desses nomes destacamos os requerimentos para novas edificações, chegando a 344 proprietários ou $62,31 \%$ da amostra de 552 indivíduos.

\begin{tabular}{|c|c|c|c|c|}
\hline $\mathbf{N}^{\circ}$ & PROPRIETÁRIOS & NOVAS EDIFICAÇÕES & $\begin{array}{c}\text { REFORMAS/ } \\
\text { INTERVENÇÕES }\end{array}$ & TOTAL \\
\hline 1 & JOAQUIM ANTUNES DOS SANTOS & 21 & 1 & 22 \\
\hline 2 & JOSÉ MARIA PASSALACQUA & 1 & 14 & 15 \\
\hline 3 & BELARMINO BARBOSA & 12 & 1 & 13 \\
\hline 4 & GIUSEPPE FALCONE & 9 & - & 9 \\
\hline 5 & ALBERTO PEREIRA BORGE & 8 & - & 8 \\
\hline 6 & JOSÉ GALVÃO DE ALBUQUERQUE & 8 & - & 8 \\
\hline 7 & PASCOAL GAZINEO (PADRE) & 4 & 4 & 8 \\
\hline 8 & FERNANDO DE ALBUQUERQUE & 4 & 2 & 6 \\
\hline 9 & ANTONIO NAZZARO & 5 & - & 5 \\
\hline 10 & CORONEL (?) ANTONIO ERNESTO DA SILVA & 5 & - & 5 \\
\hline 11 & FRANCISCO PINTO MOREIRA & 5 & - & 5 \\
\hline 12 & HORÁCIO SANTALÚCIA & 5 & - & 5 \\
\hline 13 & PINHEIRO \& CIA. & 5 & - & 5 \\
\hline 14 & JOSÉ CREDÍDIO & 3 & 2 & 5 \\
\hline 15 & AGOSTINHO FERNANDES PINTO & 4 & - & 4 \\
\hline 16 & ALBERTO BOZZONI & 4 & - & 4 \\
\hline 17 & ELIAS NÁPOLI & 4 & - & 4 \\
\hline 18 & GENEBRA DE SOUZA BARROS & 4 & - & 4 \\
\hline 19 & MATTEO CIANCIARULO & 4 & - & 4 \\
\hline 20 & MICHELE CORRADINE & 4 & - & 4 \\
\hline 21 & NICOLAU REA & 4 & - & 4 \\
\hline 22 & MIGUEL CORRADO (MICHELE CORZADO) & 3 & 1 & 4 \\
\hline 23 & NICOLANGELO MARONNA & 3 & 1 & 4 \\
\hline 24 & RAPHAEL BRINGATE & 3 & 1 & 4 \\
\hline 25 & RAPHAEL PELLEGRINI & 3 & 1 & 4 \\
\hline 26 & AMARO RODRIGUES DA SILVA & 2 & 2 & 4 \\
\hline 27 & JOÃO CALDARELLI (OU CARDARELLA) & 2 & 2 & 4 \\
\hline 28 & A. POZZO \& G. BIANCHI & 3 & - & 3 \\
\hline 29 & ANTONIO PANGARDI & 3 & - & 3 \\
\hline 30 & FRANCISCO PERROTA (OU PERROTO VARIO) & 3 & - & 3 \\
\hline 31 & JOÃO FERRACIANO & 3 & - & 3 \\
\hline 32 & JOSÉ BOMFIM & 3 & - & 3 \\
\hline 33 & JOSÉ CYPRIANO LAUZAN & 3 & - & 3 \\
\hline 34 & JÚLIO PEREIRA DOS SANTOS & 3 & - & 3 \\
\hline 35 & LEOPOLDINA DE ARAÚJO CINTRA & 3 & - & 3 \\
\hline 36 & MARIO PAULETTI & 3 & - & 3 \\
\hline 37 & ANTONIO CURTO & 2 & 1 & 3 \\
\hline 38 & JOÃO AQUILINO & 2 & 1 & 3 \\
\hline 39 & JOSÉ BASSOTI & 2 & 1 & 3 \\
\hline 40 & JOSÉ EGNER (?) & 2 & 1 & 3 \\
\hline 41 & NICOLAU CINISIO (OU SINIZI) & 2 & 1 & 3 \\
\hline 42 & ROCCO DE FRANCO & 2 & 1 & 3 \\
\hline 43 & VITO MAMMANA & 2 & 1 & 3 \\
\hline
\end{tabular}

Tabela 3 - Proprietários com mais de três propriedades.

Nota: Somente foram computados os imóveis com diferentes endereços, sendo que os demais foram ignorados. 
Elaboramos a Tabela 3, contendo os nomes de todos os proprietários com mais de três imóveis. Foram ao todo 43 proprietários $(12,05 \%$ ), num universo de 344 pessoas.

De acordo com esses dados, excetuando-se os casos extremos - como o da família Passalacqua -, tivemos apenas seis pessoas que concentravam mais de oito propriedades em seu nome; os $87,05 \%$ restantes pertenciam a pequenos proprietários e/ou investidores:

- Belarmino Barbosa, com treze propriedades;

- Giuseppe Falcone, com nove propriedades

- José Galvão de Albuquerque, com oito propriedades

- Padre Pascoal Gazíneo, com oito propriedades

- Joaquim Antunes, com o maior número de imóveis, num total de $\underline{22}$.

Os dados apresentados acima nos autorizam a concluir que o bairro foi construído, predominantemente, por e/ou para proprietários de pequeno e médio porte. Pessoas comuns na sua grande maioria, imigrantes ou descentes, que de algum modo conseguiram se firmar como proprietários de bens de raiz. Constituem, enfim, parte do imenso universo de anônimos que contribuíram para a produção do espaço urbano paulistano, não importa para onde dirijamos nosso olhar. É o que demonstram as fontes investigadas. No entanto, notamos alguns "personagens" que parecem insistir em estar em todos os espaços, ainda que à primeira vista sua presença num bairro supostamente popular possa parecer sem sentido. É o caso de duas mulheres das famílias Pais de Barros e Souza Queiroz. Em 1888 e 1889, Francisca de Paula Souza, a Baronesa de Limeira, viúva de Vicente de Souza Queiroz (o Barão de Limeira) compareceu na qualidade de "vizinha" de João Ferraz de Campos ${ }^{116}$, no Largo do Riachuelo s/no, e de Albertina de Souza Guimarães por ocasião do alinhamento solicitado por esta para a rua Monte de Ouro $\mathrm{s} / \mathrm{n}^{\mathrm{o}}$. Neste caso, no parecer do engenheiro responsável, consta que o “alinhamento será dado pela casa da Sra. Baronesa de Limeira, dos dois lados” 117. Anos mais tarde, em 28/02/1913, foi a vez de Genebra de Souza Barros. Nessa ocasião, Manoel Asson entrou com uma solicitação de licença para a construção de quatro casas para aquela senhora, na rua Santo Amaro $\mathrm{n}^{\mathrm{o}} 81,81$ A, 81 B e 83, certamente para

\footnotetext{
${ }^{116}$ Solicitação de 22/10/1888, em nome de João Ferraz de Campos, solicitando alinhamento para

“levantar um muro que caiu”, no Largo do Riachuelo, s/no, Série Obras Particulares, v. 30. p. 15. Em razão da localização fora da área investigada, o requerimento não entrou na amostra.

${ }^{117}$ Processo de 10/03/1889, Série Obras Particulares, v. 32, p. 41.
} 
locação. No ano seguinte, a própria D. Genebra assina o pedido de alinhamento para a rua Santo Amaro n ${ }^{\circ}$ 85, na esquina com a rua Aguiar de Barros ${ }^{118}$. Já em 22/03/1895, Francisco Xavier Pais de Barros, o Barão de Tatuí, apresentara, através da firma Domingos Ferreira Bento \& Cia, um pedido de licença para construção de uma casa na rua Santo Amaro, s/no ${ }^{119}$. Talvez de família menos influente que os Pais de Barros e os Souza Queiroz, Leopoldina de Araujo Cintra, descendente de tradicional família originária da região de Atibaia, encarregou a firma Mello \& Cia. da construção de três sobrados providos de mansardas, à rua São Domingos $n^{\mathbf{o}} 72^{120}$. Se de um lado a presença desses personagens, mesmo que ocasionalmente, demonstra que não apenas as camadas médias e baixas investiram nos bairros populares, de outro, demonstra que para os representantes das classes altas, não importava onde investir, mesmo que se tratasse de um espaço de segregação.

\section{Nacionalidades}

A superioridade numérica dos italianos sobre o total da população que vivia na cidade de São Paulo é senso comum. Tendo em vista confirmar ou não este dado, julgamos conveniente realizar uma análise mais detalhada dos números de estrangeiros na cidade, no período em questão. A partir dos dados fornecidos pela EMPLASA, elaboramos duas tabelas simplificadas referentes à Participação de brasileiros $e$ estrangeiros na composição da população paulistana, nos anos de 1886 e 1920.

\begin{tabular}{|c|c|c|c|c|c|c|c|}
\hline BRASILEIROS & ItALIANOS & PORTUGUESES & $\begin{array}{c}\text { ALEMÃES E } \\
\text { AUSTRÍACOS }\end{array}$ & AFricANOS & ESPANHóIS & OUtros & TOTAL (*) \\
\hline 35.407 & 5.717 & 3.502 & 1.527 & 960 & 379 & 205 & 47.697 \\
\hline $74,23 \%$ & $11,98 \%$ & $7,34 \%$ & $3,20 \%$ & & $3,23 \%$ & & $100 \%$ \\
\hline
\end{tabular}

(*) Incluindo São Bernardo

Tabela 4 - Participação de brasileiros e estrangeiros na composição da população paulistana, $1886^{121}$

\footnotetext{
${ }^{118}$ Processos de 28/02/1913 e 12/02/1914, Série Obras Particulares, Caixas S2.

${ }^{119}$ Processo de 22/03/1895, Série Obras Particulares, v. 93, p. 136.

${ }^{120}$ Processo de 04/09/1912, Série Obras Particulares, Cx. S2.

121 Tabela 39, "Cidade de São Paulo e seus arredores. Participação de brasileiros e estrangeiros na composição da população: 1886”, EMPLASA - Memória Urbana: a Grande São Paulo até 1940, v. 2 , São Paulo: Arquivo do Estado/Imprensa Oficial, 2001, p.46.
} 


\begin{tabular}{|c|c|c|c|c|c|c|c|c|}
\hline BRASILEIROS & ItALIANOS & PORTUGUESES & ESPANHÓIS & $\begin{array}{c}\text { ALEMÃES E } \\
\text { AUSTRÍACOS }\end{array}$ & TurCos & JAPONESES & OUtROS & TOTAL \\
\hline 372.376 & 91.544 & 64.687 & 24.902 & 6.237 & 5.983 & 966 & 10.836 & 577.621 \\
\hline $64,46 \%$ & $15,84 \%$ & $11,19 \%$ & $4,31 \%$ & $1,07 \%$ & & $3,07 \%$ & $100 \%$ \\
\hline
\end{tabular}

Tabela 5 - Participação de brasileiros e estrangeiros na composição da população paulistana,1920 ${ }^{122}$

Embora essas informações não envolvam o exato período de nossa pesquisa, acreditamos que sejam suficientes para nos dar uma noção numérica da presença dos estrangeiros na cidade, entre os últimos anos do Império e as primeiras décadas da República. De acordo com a Tabela 4, três anos antes da Proclamação da República, os indivíduos oriundos da península itálica formavam o maior contingente de estrangeiros na cidade, seguidos dos portugueses e germânicos. Perfazem assim, 11,98\% do total de 47.697 habitantes da capital paulista.

Ainda de acordo com os dados da EMPLASA para 1920, em plena vigência da Primeira República (Tabela 5), a população italiana se mantinha como a maior colônia estrangeira em São Paulo, perfazendo 15,84\%. Na sequência, vinham portugueses $(11,19 \%)$, espanhóis $(4,31 \%)$ e os indivíduos de origem germânica $(3,07 \%)$ - todos em meio a 372.376 brasileiros $(64,46 \%)$, numa população total de 577.621 habitantes.

A comparação dos dados apresentados nas duas tabelas demonstra que no decorrer desses trinta e quatro anos ocorreram algumas mudanças. A primeira delas é que a população de origem africana foi incorporada à população dita "brasileira"; além disso, temos uma diminuição do número de alemães ou austríacos, em favor do aumento de espanhóis. Por fim, constatamos a entrada de japoneses e sírios libaneses. Em nenhum dos dois momentos podemos afirmar o predomínio de italianos em relação aos brasileiros, que sempre se mantiveram numericamente na frente. Acreditamos, sim, que houve uma diferente distribuição dos segmentos estrangeiros pelos bairros da cidade, com o predomínio de um ou outro grupo, neste ou naquele bairro.

Tendo como base o banco de dados das informações obtidas na Série das Obras Particulares, organizamos diferentes listagens, contendo os nomes dos proprietários, de acordo com o seu país de origem. Tivemos algumas dificuldades para estabelecer corretamente a origem dos nomes encontrados, devido à dificuldade de leitura dos textos manuscritos. Certamente, a comunicação entre requerentes estrangeiros e os

\footnotetext{
${ }^{122}$ Tabela 49, "Cidade de São Paulo e seus arredores. Participação de brasileiros e estrangeiros na composição da população: 1920”, EMPLASA - Memória Urbana: a Grande São Paulo até 1940, v. 2, São Paulo: Arquivo do Estado/Imprensa Oficial, 2001, p.52.
} 
funcionários da Diretoria de Obras não devia ser tarefa fácil. De um lado, os imigrantes tentando se fazer compreender no seu próprio idioma, de outro, os agentes da municipalidade tentando interpretar o que diziam os primeiros. Muitas vezes, o requerente, mesmo sendo brasileiro, mal sabia escrever. Dessa maneira, agrupamos numa mesma categoria - Não identificados - todos os casos em que a leitura do nome era impossível ou quando não conseguíamos identificar a sua origem.

A partir dessas relações, elaboramos a Tabela 6, com os números e percentuais relativos à presença de estrangeiros no bairro do Bexiga.

\begin{tabular}{|l|c|c|}
\hline \multicolumn{1}{|c|}{ SUPOSTAS NACIONALIDADES DE PROPRIETÁRIOS } & No & $\%$ \\
\hline BRASILEIROS E/OU PORTUGUESES & 143 & 25,91 \\
\hline ITALIANOS & 360 & 65,22 \\
\hline GERMÂNICOS & 19 & 3,44 \\
\hline $\begin{array}{l}\text { OUTROS (ESPANHOIS, FRANCESES, NÓRDICOS, POLONESES, } \\
\text { AFRICANOS, GREGOS, ÁRABES E ANGLO-SAXÕES) }\end{array}$ & 16 & 2,90 \\
\hline NÃO IDENTIFICADOS & 14 & 2,53 \\
\hline TOTAL PROPRIETÁRIOS & $\mathbf{5 5 2}$ & $\mathbf{1 0 0 \%}$ \\
\hline
\end{tabular}

Tabela 6 - Percentual das nacionalidades predominantes entre os proprietários

A tabela demonstra um claro predomínio dos italianos sobre a totalidade dos proprietários do bairro, 65,22\% de um total de 552 pessoas, confirmando a hipótese levantada acima. Infelizmente, no caso de brasileiros e portugueses, com $25,91 \%$ dos terrenos e casas, não podemos afirmar, com certeza, quem era o que.

Além da presença predominante de italianos no bairro, o que se destaca aqui, acima de tudo, é o fato de eles concentrarem a propriedade da maior parte dos imóveis em forma de lotes ou edificações, o que não quer dizer, contudo, concentração de riqueza. Zuleika Alvim, em seu trabalho sobre a imigração italiana no Estado de São Paulo, chamou a atenção para o significado da propriedade urbana em mãos italianas:

"Embora meu objetivo principal não seja o de demonstrar o processo de proletarização sofrido pelo grupo, mas o tipo de resistência oferecida à proletarização nas cidades, considero importante analisar os índices de propriedades nas mãos de italianos nos centros urbanos. Porque, entre os estrangeiros, eles ocupam o primeiro lugar como proprietários de imóveis urbanos [...] Se, porém, analisarmos o valor desses imóveis, a posição dos italianos cai para oitavo lugar, numa lista de onze nacionalidades identificadas. Quero ainda lembrar que a grande maioria das propriedades italianas concentrava-se nos bairros pobres de São Paulo, Brás, Bom Retiro, Barra Funda, Belenzinho e Bela Vista, habitados quase que exclusivamente por italianos [...] $]^{, 123}$

\footnotetext{
${ }^{123}$ ALVIM, Zuleika M. F. - Brava gente! Os italianos em São Paulo. 1870-1920, São Paulo: Brasiliense, 1986, 2ª Edição, p. 142.
} 
Valor dos Imóveis urbanos nas mãos de estrangeiros em $1910^{124}$

\begin{tabular}{l|cc}
\hline NACIONALIDADE & $\begin{array}{c}\boldsymbol{N}^{\circ} \boldsymbol{D E} \\
\text { PROPRIEDADES }\end{array}$ & $\begin{array}{c}\text { VALOR } \\
\text { DO IMÓ VEL }(*)\end{array}$ \\
\hline $1^{\circ}$ ingleses & 80 & $59 \$ 000.000$ \\
$2^{\circ}$ franceses & 464 & $15 \$ 600.000$ \\
$3^{\circ}$ alemães & 3.498 & $12 \$ 000.000$ \\
$4^{\circ}$ portugueses & 12.834 & $9 \$ 000.000$ \\
$5^{\circ}$ espanhóis & 1.488 & $5 \$ 800.000$ \\
$6^{\circ}$ austro-húngaros & 139 & $5 \$ 500.000$ \\
$7^{\circ}$ sírios & 619 & $5 \$ 200.000$ \\
$\mathbf{8}^{\circ}$ italianos & 23.520 & $\mathbf{4} \$ 800.000$ \\
$9^{\circ}$ americanos & 43 & $4 \$ 400.000$ \\
$10^{\circ}$ suíços & 71 & $3 \$ 800.000$ \\
$11^{\circ}$ belgas & 18 & $2 \$ 000.000$ \\
$12^{\circ}$ diversos & 1.156 & $11 \$ 000.000$ \\
\hline
\end{tabular}

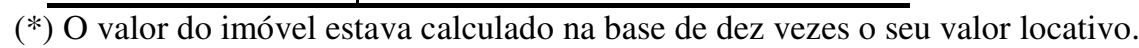

Acima transcrevemos a tabela elaborada pela autora, onde estão relacionadas as nacionalidades, o número de propriedades concentradas por grupo. Esses dados são interessantes e podem ajudar a pensar como nossos atores sociais inseriram-se nos padrões de riqueza urbanos.

Retomamos os números obtidos na Tabela 3, onde estão agrupadas as 42 pessoas com três ou mais imóveis, perfazendo um total de 219 propriedades. Ali, após reorganizar os dados a partir da nacionalidade dos proprietários, chegamos aos seguintes números:

\begin{tabular}{ccccc}
\hline & BRASILEIROS E/OU & OtALIANOS & OUTRAS & TOTAL \\
& PORTUGUESES & NACIONALIDADES & \\
No IMÓVEIS & 93 & 115 & 11 & 219 \\
\hline
\end{tabular}

Os italianos, proprietários de três ou mais imóveis, realmente, eram a maioria. Esses dados coincidem com aqueles apresentados por Zuleika Alvim em quantidade, embora em termos do valor dos imóveis a autora coloque os italianos em oitavo lugar. Ressaltamos nossa hipótese inicial sobre a diferente distribuição dos segmentos

\footnotetext{
${ }^{124}$ Os dados da tabela foram extraídos, pela autora, do levantamento sobre propriedades urbanas nas mãos de estrangeiros, "realizado pela Secretaria da Agricultura e Obras Públicas do Estado de São Paulo em 1910, catalogando 111 dos seus 175 municípios, de acordo com o número de proprietários estrangeiros. In "Proprietá urbane appartenenti a stranieri nello Stato di San Paolo", in: Italia e Brasile. São Paulo, (5): 190-195, maio de 1911; P.S., "Le proprietà urbane degli stranieri nello stato di San Paolo”, in: Bollettino della Società Geografica. Roma, série IV, XII (9): 1167, set. de 1911. P. 141.

${ }^{125}$ Grifo nosso.
} 
estrangeiros pelos bairros da cidade, na medida em que os imóveis dos italianos se concentravam em determinados bairros da cidade e, também, a presença de pequenos investidores entre a maioria dos proprietários. Essa questão será retomada adiante, quando falarmos sobre as tipologias e a inserção social dos atores sociais que atuaram no bairro do Bexiga.

\subsection{Construtores}

Antes de iniciarmos a análise dos dados relativos aos construtores que atuaram na conformação física do bairro, é necessário fazer algumas observações. No início das investigações realizadas junto à Série das Obras Particulares, partimos do pressuposto de que os nomes que surgissem nos processos, e que não se identificassem como proprietários ou simplesmente pessoas que por qualquer motivo assinavam os requerimentos (os requerentes), correspondiam aos construtores dos imóveis. Posteriormente, ao trabalhar no projeto Arquivo Histórico Municipal Washington Luís: A Cidade de São Paulo e sua Arquitetura ${ }^{126}$, tivemos a oportunidade de confirmar, ao menos parcialmente, essa hipótese. Ali, encontramos um grande número daqueles atores sociais identificados no Bexiga, atuando em outras áreas da cidade. Essa experiência permitiu que tivéssemos melhores condições de avaliar o papel daquelas pessoas que, até então tratávamos como construtores. Percebemos, por exemplo, que pessoas que teoricamente respondiam por projetos arquitetônicos no bairro do Bexiga, faziam-no, ao mesmo tempo, em outros bairros. Ora, seria possível que uma pessoa pudesse estar, ao mesmo tempo, em todos esses lugares, a não ser que fossem responsáveis somente pelo projeto e não pela obra em si? Em outras ocasiões, nomes que por vezes eram interpretados como autores dos projetos, em outros momentos dão a perceber que eram responsáveis pelas obras, como mestres de obras ou empreiteiros.

\footnotetext{
126 “Arquivo Histórico Municipal Washington Luís: A Cidade de São Paulo e sua Arquitetura” - Projeto de informatização de parte da Série das Edificações Particulares. Parceria entre a Faculdade de Arquitetura e Urbanismo (FAUUSP) e o Arquivo Histórico Municipal Washington Luís, sob a coordenação do Prof. Dr. Nestor Goulart Reis Filho e Beatriz Bueno, financiado pela FAPESP, de 2006 a 2010. Este trabalho abrange todos os processos de edificação, entre 1906 e 1920. A nossa participação como membro da equipe que alimenta o banco de dados SIRCA - Sistema de Registro, Controle e Acesso ao Acervo (ISAD-G), permitiu o acesso a documentos pertencentes a outros anos que não aqueles contemplados pela amostra deste trabalho. Dessa maneira, pudemos constatar a presença de agentes atuantes no bairro do Bexiga em outras regiões, assim como ter uma visão do processo de construção da cidade no longo prazo.
} 
Por outro lado, em diversos processos, quando por algum motivo se fazia necessário adicionar um "termo de compromisso" por parte do proprietário, era muito comum que fossem avalizados por uma ou mais pessoas. Entre essas pessoas encontramos, frequentemente, os nomes de José Kanz e Raul dos Santos Oliveira, além de outros que não atuaram no bairro.

De qualquer maneira, acreditamos que a categoria genericamente chamada de construtores, deva ser pensada em termos das diferentes funções exercidas por tais atores sociais, envolvendo possíveis fases distintas do processo de construção de um edifício, nem sempre claras nos documentos analisados.

a) Elaboração do projeto (engenheiro, arquiteto, prático-licenciado ou o próprio requerente)

b) Contratação de mão de obra e supervisão do processo construtivo (empreiteiro ou o próprio requerente)

c) Trabalho de construção (desenvolvido por pedreiros, carpinteiros, etc. $)^{127}$

Com o objetivo de enriquecer a análise sobre os profissionais da construção buscamos apoio em autores que, de alguma forma, tivessem abordado a presença desses atores sociais na construção da cidade de São Paulo. A tese de doutorado de Eudes Campos $^{128}$ foi valiosa, na medida em que esclareceu o funcionamento das relações profissionais dentro do processo construtivo no Império. Tendo o autor investigado a Série das Obras Particulares, desde o início dos registros de pedidos de licença para construção (1870), a tese nos forneceu, ao mesmo tempo, os nomes dos construtores que atuaram na fase de transição entre o Império e a República, foco deste trabalho.

Outro autor consultado foi Heloisa Barbuy $^{129}$, que também sistematizou as informações sobre os prédios reformados ou construídos nas principais ruas do Centro da cidade no "Anexo 2 - Tabela de Obras Particulares realizadas nas ruas 15 de Novembro, Direita e São Bento, 1886-1914”. Os nomes apresentados por Barbuy permitiram, sempre que possível, estabelecer um parâmetro de comparação com os

\footnotetext{
${ }^{127}$ Lindener Pareto Jr. realiza pesquisa de mestrado para a FAUUSP, na qual estuda os práticoslicenciados que atuaram na cidade de São Paulo: "O quotidiano em construção - Práticos-licenciados em São Paulo (1870-1933)”. Esse trabalho deverá esclarecer muitas das dúvidas levantadas no decorrer da pesquisa ora realizada no AHMWL.

${ }^{128}$ CAMPOS, Eudes - Arquitetura paulistana sob o Império, tese de doutorado, FAUUSP, v., I, 1997. p. 170-209.

${ }^{129}$ BARBUY, Heloisa - A Cidade-Exposição. Comércio e cosmopolitismo em São Paulo, 1860-1914, São Paulo: Edusp, 2006.
} 
nossos personagens, viabilizando assim, conclusões mais fundamentadas. Permitiram, inclusive, perceber a atuação mais contundente de engenheiros e arquitetos no Centro, em oposição a presença predominante de práticos-licenciados nos novos bairros mais modestos da cidade. Outros nomes, não contemplados neste trabalho, puderam ser localizados em Salmoni e Debenedetti ${ }^{130}$.

Entre os 1.170 processos analisados, optamos por destacar aqueles em que estivesse explícita a presença de profissionais envolvidos com edificações, reformas e/ou acréscimos em geral, perfazendo um total de $\mathbf{1 . 1 1 6}$ projetos. Desse total, em somente 108 casos, ou aproximadamente 9,67\% da amostra, foi possível identificar o nome dos profissionais que, teoricamente, seriam responsáveis pela obra. Entre os nomes ali relacionados, conseguimos identificar 16 pessoas por categoria profissional, restando 92 casos, com a categoria bastante vaga de "construtores responsáveis", o que representa 85,18\% dos $\mathbf{1 0 8}$ projetos. Na verdade, na maioria das vezes nem essa referência há e temos somente o nome do requerente.

Assim, partindo dos $\mathbf{1 0 8}$ projetos com profissionais identificados, temos a seguinte distribuição dos envolvidos:

\begin{tabular}{|l|c|c|}
\hline \multicolumn{1}{|c|}{ CATEGORIAS PROFISSIONAIS } & $\begin{array}{c}\text { PROJETOS } \\
\text { REALIZADOS }\end{array}$ & $\%$ \\
\hline ARQUITETOS & 8 & $\mathbf{7 , 4 1}$ \\
\hline ENGENHEIROS & 4 & $\mathbf{3 , 7 0}$ \\
\hline EMPREITEIROS & 3 & $\mathbf{2 , 7 8}$ \\
\hline CONSTRUTORES & 1 & $\mathbf{0 , 9 2}$ \\
\hline PROFISSIONAIS SEM ESPECIFICAÇÃO DEFINIDA & 92 & $\mathbf{8 5 , 1 9}$ \\
\hline PROFISSIONAIS IDENTIFICADOS & $\mathbf{1 0 8}$ & $\mathbf{1 0 0 \%}$ \\
\hline
\end{tabular}

Tabela 7 - Categorias profissionais e percentuais correspondentes

Entre estes profissionais, os percentuais de atuação em relação aos trabalhos realizados são:

\begin{tabular}{|l|c|c|}
\hline \multicolumn{1}{|c|}{ PROFISSIONAIS COM } & $\begin{array}{c}\text { PROJETOS } \\
\text { REALIZADOS }\end{array}$ & $\%$ \\
\hline COM APENAS UM PROJETO & 75 & $\mathbf{6 9 , 4 4}$ \\
\hline COM ATÉ DOIS PROJETOS & 18 & $\mathbf{1 6 , 6 7}$ \\
\hline COM TRÊS OU MAIS PROJETOS & 15 & $\mathbf{1 3 , 8 9}$ \\
\hline PROFISSIONAIS IDENTIFICADOS & $\mathbf{1 0 8}$ & $\mathbf{1 0 0 \%}$ \\
\hline
\end{tabular}

\footnotetext{
${ }^{130}$ SALMONI, Anita e DEBENEDETTI, Emma - Arquitetura italiana em São Paulo, São Paulo: Perspectiva, 1981.
} 
Tabela 8 - Trabalhos realizados e percentuais correspondentes

Se a ausência de referências aos profissionais encarregados da construção nos impede de fazer afirmações conclusivas acerca da maior parte dos projetos, ela aponta para a possibilidade dos agentes envolvidos nas construções serem ao mesmo tempo proprietários e construtores dos imóveis. Analisamos um processo cujo requerente, Camillo Amadio, também era proprietário do imóvel. Neste processo, datado de 18/03/1914 e destinado à construção de um sobrado com instalação de armazém no térreo, à rua do Sol, na esquina com a rua Santo Antonio, encontramos o seguinte parecer técnico do engenheiro Arthur Saboya: “[...] o proprietário assinará a planta como construtor responsável; não o conhecendo no caráter de construtor nada posso dizer quanto a sua idoneidade” ${ }^{131}$. Esse parecer, embora seja o único nesses termos, pode demonstrar que essa não era uma prática incomum - a do proprietário assinar a planta como construtor responsável.

Entre os construtores vinculados apenas a um ou dois projetos, encontramos alguns poucos exemplos de profissionais reconhecidamente ligados à história da arquitetura da cidade. Há um caso extremo, de um único projeto assinado pelo arquiteto Victor Dubugras, aparentemente, em parceria com Francisco Henzler, na rua Santo Antonio $n^{\circ} 53$, e das duplas Novaes \& Saltini e Rossi \& Brenni, com dois projetos cada um. Dubrugas e Henzler construíram duas casas, em 1898, para um casal aparentemente, de origem alemã, Luise Bierbrauer e Gustavo Chiele ${ }^{132}$. Se levarmos em consideração as informações sobre Luise, fazia dezoito anos que ela chegara ao Brasil e, seja onde for que tenha desembarcado, agora iria viver no Bexiga. Francisco Henzler, na verdade, não era arquiteto, mas sim desenhista. De acordo com o que pudemos apurar, por volta de 1896, ele teria desempenhado esta função na Repartição de Agricultura de São Paulo, junto ao engenheiro Sá Rocha ${ }^{133}$. O francês Victor

\footnotetext{
${ }^{131}$ Obras Particulares, 18/03/1914, Cx. S3.

132 Aqui, cabem alguns esclarecimentos acerca da cliente de Dubugras. Investigando na Internet, obtivemos algumas informações que, se não "definitivas", são curiosas e podem lançar alguma luz sobre esses atores sociais. Louise (e não Luise) Bierbrauer era uma polonesa que, viajando no navio Valparaiso, teria desembarcado no Brasil, em 20 de outubro de 1880, vindo de Hamburgo, na Alemanha. No site constam os seguintes dados: "BIERBRAUER, Louise: 43 anos, Joinville, Brasil, casada, protestante, $3^{a}$ classe, pagou passagem integral”. Infelizmente não foi possível saber em que cidade brasileira Louise desembarcou. Disponível em: http://www.polonesesnobrasil.com.br. Consulta em 21/04/2009.

${ }^{133}$ De acordo com o Histórico desenvolvido para a Escola Superior de Agricultura Luiz de QueirozESALQ, "Durante o mês de agosto de 1896, chegara (a Piracicaba) de São Paulo, como enviado do governo para avaliação das construções, o engenheiro Sá Rocha, acompanhado do desenhista Henzler”. Marly Therezinha Germano Perecin confirma e complementa essa informação "O desenhista da
} 
Dubugras, formado em arquitetura na Argentina, chegou a São Paulo em 1891, tendo sido professor de Desenho Arquitetônico na Escola Politécnica da USP, de 1894 até 1927. Ao lado dos projetos particulares pelos quais se notabilizou, também projetou edifícios públicos, como funcionário do Departamento de Obras Públicas do Estado de São Paulo ${ }^{134}$.

Rossi \& Brenni, em 10/06/1895, apresentaram projeto para acréscimo de uma “cozinha para família”, à rua 14 de Julho, sem número, e apenas uma semana depois apresentaram projeto para construção de uma casa para Mathias de Castro Leite, à rua 14 de Julho, sem número. O último projeto assinado por eles data de 03/02/1905, quando se propuseram a "construir um puxado em continuação do prédio existente”, na rua Santo Antonio n ${ }^{\circ}$ 74, para Manoel André Gaspar ${ }^{135}$. Heloisa Barbuy demonstra que a dupla desenvolveu diversos projetos no Centro da cidade, no decorrer da última década do século XIX. Ali, constatamos a sua presença, entre 1894 e 1905. Em 1912, ainda temos José Rossi como responsável por alguns projetos nas ruas São Bento, Quintino Bocaiúva e Direita ${ }^{136}$. Os processos da Série das Obras Particulares indicam que esses profissionais não tinham problemas em realizar obras, aparentemente "menores", em bairros populares.

Novaes \& Saltini foram responsáveis por dois projetos, um de construção de um prédio, e outro de acréscimo de cômodos. O primeiro, para Julia Anantona, em 31/05/1898, e o segundo para Marcos di Capri, em 22/02/1899. No caso das pessoas para quem esses engenheiros trabalharam, não havíamos encontrado quaisquer referências a outros processos construtivos, o mesmo ocorrendo com o Novaes da referida dupla. Júlio Saltini, entretanto, é citado por algumas fontes como arquiteto ${ }^{137}$.

Repartição da Agricultura, Francisco Henzler, permaneceu algum tempo em Piracicaba para efeito de passar à tinta diversas plantas e fazer as fachadas do colégio-internato."

Disponível em: http//www.esalq.usp.br/instituicao/historico.html; e, PERECIN, Marly Therezinha Germano Memória e Saber Agronômico. O edifício-sede da ESALQ em seu primeiro centenário. http://www.esalq.usp.br/acom/artigo_edificiocentral.pdf. Consulta em 21/04/2009.

${ }^{134}$ Artigos desenvolvidos pelo Jornal da USP, por ocasião do lançamento do livro Victor Dubugras Precursor da arquitetura moderna na América Latina, de Nestor Goulart Reis Filho, São Paulo: Quota de Arte/Edusp/ Via das Artes, 2005.

135 Obras Particulares, 03/02/1905, v. 422, p. 85.

${ }^{136}$ BARBUY. Op.cit., p. 259 a 285.

${ }^{137}$ Curiosamente, ao buscarmos na Internet, informações que fornecessem mais pistas sobre Saltini, encontramos indícios seus e, do "cliente" Marcos di Capri, na cidade de Osasco, na primeira década do século XX. Ao que parece, Júlio Saltini foi responsável pela elaboração do "único mapa de uma proposta de loteamento [...] entre 1907 ou 1908”; e o último teria sido um dos "italianos que quiseram sair do Brasil ou dividir suas heranças, como ocorreu com os herdeiros de Marco de Capri (?)”. Disponível em: http://www.camaraosasco.sp.gov.br/osasco/historia/index4.htm. Consulta em 21/04/2009. 
Para conhecer melhor esses atores, elaboramos a Tabela 9 abaixo, contendo apenas os profissionais que trabalharam em dois ou mais projetos, individualmente ou em parceria com outros.

É flagrante a presença de José Kanz, envolvido em 37 obras realizadas nesse período no bairro, isso sem falar nos anos que ficaram fora da amostra, quando, com toda certeza também atuou. Observamos sua presença a partir de janeiro de 1900, quando fez o acréscimo de uma sala para o proprietário Vito Santorio. Naquele ano ele trabalhou em cinco projetos e, em 1906 (ano em que mais se mostrou presente), apareceu como responsável por quinze obras. No trabalho de Heloísa Barbuy, o vimos numa única ocasião, em 1905, como responsável por “construção de prédio” no Largo do Rosário ${ }^{138}$. A última notícia que tivemos desse personagem foi em 13 de agosto de 1913, data em que respondeu pela edificação de "um quarto para chofer", na rua da Abolição.

\begin{tabular}{|c|c|c|c|}
\hline $\mathbf{N}^{\circ}$ & PROFISSIONAIS & $\begin{array}{l}\text { CATEGORIA } \\
\text { PROFISSIONAL }\end{array}$ & $\begin{array}{l}\text { TOTAL DE } \\
\text { PROJETOS }\end{array}$ \\
\hline 1 & JOSÉ KANZ & NÃO CONSTA & 37 \\
\hline 2 & CARLOS MiLanese & ARQUITETO & 35 \\
\hline 3 & MIGUEL MARZO & ARQUITETO & 21 \\
\hline 4 & BENEDICTO BETTOI & NÃO CONSTA & 11 \\
\hline 5 & JOSÉ PUCCI & NÃO CONSTA & 9 \\
\hline 6 & FERNANDO SIMÕES & NÃO CONSTA & 7 \\
\hline 7 & FRANCISCO POMPEU & NÃO CONSTA & 7 \\
\hline 8 & AFFONSO TOSTA & NÃO CONSTA & 6 \\
\hline 9 & ANTONIO BRUNO DA ROSA & NÃO CONSTA & 5 \\
\hline 10 & JÚLIO SALTINI & ARQUITETO & 5 \\
\hline 11 & JOAQUIM CARLOS AUGUSTO CAVALHEIRO & NÃO CONSTA & 4 \\
\hline 12 & EUGENIO RAISIN & ARQUITETO & 4 \\
\hline 13 & FRANCESCO MANCINI & NÃO CONSTA & 4 \\
\hline 14 & LEOPOLDINO ANTONIO DOS PASSOS & NÃO CONSTA & 3 \\
\hline 15 & ROSSI \& BRENNI & NÃO CONSTA & 3 \\
\hline 16 & $\begin{array}{l}\text { ADELARDO IVAN CAIUBY } \\
\text { (OU SOARES CAIUBY) }\end{array}$ & NÃO CONSTA & 2 \\
\hline 17 & ALBERTO BOZZONI & ENGENHEIRO & 2 \\
\hline 18 & ANTONIO ROBERTI (OU ROSERTI) & NÃO CONSTA & 2 \\
\hline 19 & (?) DOS SANTOS & NÃO CONSTA & 2 \\
\hline 20 & FERNANDO ALBUQUERQUE & ENGENHEIRO & 2 \\
\hline 21 & GUILHERME NICOLA & NÃO CONSTA & 2 \\
\hline 22 & JOÃO LONGO & NÃO CONSTA & 2 \\
\hline 23 & JOÃO REICH & NÃO CONSTA & 2 \\
\hline 24 & JOAQUIM DE QUADROS GUIMARÃES & NÃO CONSTA & 2 \\
\hline 25 & JOSÉ FERREIRA DA ROCHA & EMPREITEIRO & 2 \\
\hline 26 & JOSÉ FRANCISCO LOPES BRAGA & NÃO CONSTA & 2 \\
\hline 27 & JOSÉ JOAQUIM LOPES BRAGA & NÃO CONSTA & 2 \\
\hline 28 & JOSÉ MASTRANGELLO & NÃO CONSTA & 2 \\
\hline 29 & MANOEL FRANCISCO DIAS & NÃO CONSTA & 2 \\
\hline 30 & NOVAES \& SALTINI & $\begin{array}{l}\text { ENGENHEIROS } \\
\text { "CONSTRUTORES" }\end{array}$ & 2 \\
\hline 31 & RAUL (?) SANTOS & NÃO CONSTA & 2 \\
\hline 32 & SANTOS OLIVEIRA & NÃO CONSTA & 2 \\
\hline
\end{tabular}

Tabela 9 - Construtores por categorias profissionais, com mais de dois projetos 
Como já citado acima, ao realizar pesquisa no AHMWL, constatamos que José Kanz atuou em muitos outros bairros da cidade, durante longo tempo. Nesse sentido, acreditamos que ele estaria entre os agentes envolvidos na categoria dos pequenos investimentos em construção na cidade. Não o encontramos em grandes projetos, ou ligado à profissionais de renome, ao contrário, seu nome aparece sempre sozinho. Por outro lado, nesses outros projetos é possível identificá-lo como empreiteiro de obras, ou seja, não era um mero pedreiro, mas também um agenciador de mão de obra e coordenador do trabalho nos canteiros espalhados pela cidade. Seu nome também está presente em diferentes processos ao mesmo tempo, o que confirma seu papel de coordenador das empreitadas construtivas.

Aqui é importante definir o papel que esses atores sociais desempenharam no mercado da construção civil. Paulo César Xavier Pereira, ao estudar as "transformações pelas quais passaram o construir e o morar na cidade de São Paulo no último quarto do século XIX e nas primeiras décadas do século XX” e o papel do imigrante como mão de obra supostamente mais qualificada em relação à nacional, indica os pressupostos das relações entre proprietário ou contratante do trabalho, o empreiteiro e as atividades construtivas. Ao analisar os motivos da preferência por trabalhadores de origem estrangeira, especialmente italianos, ele acredita que o monopólio dos preços exercido pelos capitalistas que investiram na construção civil permitiu "ajustes de conveniência" entre estes e os trabalhadores da construção. Apoiando-se em Yvoty Macambira ${ }^{139}$, o autor conclui que essa importância deveu-se, principalmente, à precariedade da mão de obra não especializada na cidade, como também pela farta oferta desse tipo trabalho, tornando "uma espécie de 'faz tudo' o mestre de obras, que chegava a essa posição depois de ser pedreiro e de ter adquirido prática suficiente para coordenar uma construção”:

"[...] era a partir desses ajustes entre proprietários de imóveis e empreiteiro que se encontrava a possibilidade de maior remuneração do trabalho de construir, uma vez que a generalização da produção por encomenda, na construção de palacetes $e$ moradias de aluguel (grifo nosso), se apoiava fundamentalmente em profissionais que exerciam pessoalmente a ocupação e o comando do processo produtivo da construção. Esse era o trabalhador principal, um "capomastro" que obtinha o contrato para a realização da obra com o cliente [...]". ${ }^{140}$

\footnotetext{
${ }^{139}$ MACAMBIRA, Y. de M.P. - Os mestres da fachada, São Paulo: CCSP, 1985, p. 38, In PEREIRA, Paulo César Xavier - São Paulo - a construção da cidade: 1872-1914, São Paulo:RiMa/FAPESP, 2004, p.76-77.

${ }_{140}$ PEREIRA, Op. Cit., p.77.
} 
Quando das greves ocorridas na cidade, durante o ano de 1911, os "ajustes de conveniência" entre empreiteiros e os contratantes de seus serviços parecem ter colocado esses profissionais do lado oposto do movimento grevista. Paula Beiguelman, em Os companheiros de São Paulo, extraiu do jornal Correio Paulistano (02/08/1911) a informação de que "vários empreiteiros e mestres de obras (grifo nosso), em conferência com o dr. João Baptista de Souza, $4^{o}$ delegado, obtêm o 'compromisso de que a polícia dará inteira garantia a todo o pedreiro que se conserve estranho ao movimento" ${ }^{141}$. A tomada de posição ao lado dos interesses patronais vem indicar o caminho trilhado por esses atores, não apenas como profissionais da construção civil, mas principalmente como empreendedores que também investiram no mercado imobiliário.

José Kanz, como muitos outros profissionais que desempenharam a função de “coordenador" de obras de construção civil, conseguiu se destacar tecendo uma espécie de rede pela cidade, a partir dos projetos e obras que realizou. Além dele, outro construtor de destaque foi Carlos Milanese, com boa parte das obras durante a última década do século XIX. A partir de 1900 os registros em seu nome se tornam mais escassos, até o último processo encontrado, em 1905. Na busca por nomes ligados à construção civil durante essa época na Internet, este foi um dos poucos agentes contemplados pelos sites e links relacionados à história da urbanização paulistana. Ao que parece, Milanese era, de fato, um "prático-licenciado", porém, ali ele comparece como autor do projeto arquitetônico do atual Instituto Pasteur de São Paulo, na Avenida Paulista, conforme pesquisa realizada por Maria Regina Cardoso Sandoval, arquiteta daquela instituição ${ }^{142}$. Via de regra, seu nome esteve associado à categoria de "arquiteto", apresentando, eventualmente, o endereço de seu escritório, à rua Líbero Badaró $\mathrm{n}^{\circ}$ 17. O caso de Milanese ilustra a referência de Paulo César Xavier Pereira (2004, p. 20) sobre a autopromoção que esses agentes faziam de si mesmos. Ali o autor se utiliza das palavras de Salmoni \& Debenedetti, onde por meio "de uma curiosa autopromoção, as mesmas pessoas que assinam os primeiros pedidos com uma letra

\footnotetext{
${ }^{141}$ BEIGUELMAN, Paula - Os companheiros de São Paulo, São Paulo: Ed. Símbolo, 1977, p.57.

${ }^{142}$ Conforme a pesquisadora, a planta do prédio, de 1895, estava relacionada originalmente à construção de uma casa de saúde. Em 1903 o imóvel foi comprado e adaptado para a instalação do Instituto. " $O$ projeto, do arquiteto Carlos Milanese, tem forte influência da arquitetura neoclássica italiana. O edifício passou por uma reforma em 1903, mas manteve seu estilo original até a reforma de 1917-1918, quando foi adaptado ao estilo eclético, em moda na época.” In TEIXEIRA, L.A.; SANDOVAL, M.R.C.; e TAKAOKA, N.Y. - Instituto Pasteur de São Paulo: cem anos de combate à raiva, Scielo - Scientific Electronic Libray Online, p.10. Disponível em: http//www.scielo.br.
} 
rabiscada, com a incerta grafia do principiante, nos anos sucessivos passam a acrescentar ao próprio nome a especificação de: 'mestre de obras', 'construtor' $e$, enfim, 'arquiteto'”.

Carlos Milanese frequentemente trabalhou com outros profissionais; Miguel Marzo parece ter sido seu principal parceiro. Ambos realizaram seis projetos durante o ano de 1895. Entre 1899 e 1907, o nome de Marzo comparece em cinco projetos de reforma ou acréscimo em prédios existentes, assim como na "construção de um sobrado", todos no Centro da cidade ${ }^{143}$. Através da leitura da tese de Barbuy, tudo indica que a grande maioria dos trabalhos de Marzo foi realizada para médios e pequenos proprietários, na linha dos proprietários do bairro do Bexiga. Esse profissional, atuando em parceria ou sozinho, respondeu por 21 dos projetos arquitetônicos do bairro, sendo um dos três profissionais com presença mais marcante. Embora na Série das Obras Particulares seja comum encontrarmos o carimbo com os dizeres "Miguel Marzo - Architecto-Constructor, Rua Capitão Salomão 42 - S. Paulo”, na verdade, como outros tantos, ele era um empreiteiro. Em relação aos construtores, em seu trabalho de mestrado, Lindener Pareto se propõe a "estudar a atuação profissional dos práticos licenciados, construtores populares sem diploma de engenheiro elou arquiteto, entre 1870 e 1933”. De acordo com as investigações até agora realizadas por Pareto, foi a partir de 1934 que a legislação municipal tornou obrigatória a regulamentação da profissão de construtor, "com a criação da Escola Politécnica e do Mackenzie em São Paulo”, qualificando este profissional como "prático-licenciado", apto a desenvolver as atividades relacionadas à profissão de arquiteto. Assim, ao que tudo indica, até a institucionalização do ensino da profissão de engenheiro-arquiteto temos a convivência entre os profissionais qualificados pela experiência com aqueles qualificados por instituições de ensino superior.

Outro caso interessante foi o de Leopoldino Antonio dos Passos, que além de construtor também se apresentava como proprietário. Foram identificados quatro processos, nos quais se apresentava ao mesmo tempo como requerente e construtor; sendo que em três desses, também comparecia como proprietário. Trata-se de um único exemplo desse tipo de situação, mas cremos que aponta para o acúmulo de atividades e diversificação de investimentos por parte dos agentes transformadores da paisagem urbana paulistana. Esse personagem provavelmente aplicou parte dos lucros auferidos

${ }^{143}$ BARBUY, Op. Cit., p. 263 a 279. 
no exercício da profissão, na compra de novos lotes e na construção de novas casas, provavelmente para fins locatícios, contribuindo assim para o crescimento da cidade até a segunda década do século XX. Porém, os investimentos de Leopoldino não se limitaram à especulação imobiliária. Maria Luiza F. de Oliveira identificou, em inventário de 1899, um processo em que ele constava como credor de D. Joaquina Rosa da Silva, por ter “fornecido 1:500\$000 com letra ao falecido marido" 144. Aproximadamente dez anos após os seus trabalhos no bairro do Bexiga, Leopoldino Antonio dos Passos consta da relação de Empreiteiros do Almanach Laemmert de 1910, com escritório à rua Amaral Gurgel no $91^{145}$.

João Reick teve uma participação modesta na construção do bairro do Bexiga. Nós o encontramos apenas duas vezes, em junho e julho de 1894, na qualidade de requerente e construtor de duas casas à rua Santo Antonio. Nas duas ocasiões tratava-se de construções modestas de "casas para operários" ${ }^{146}$. Salmoni e Debenedetti se referem a ele como um dos "outros nomes de construtores alemães, cujas obras seriam menos significativas [...]" 147 .

\begin{tabular}{|c|c|c|}
\hline CONSTRUTORES \& ASSOCIADOS & ANOS & No PROJETOS \\
\hline $\begin{array}{l}\text { CARLOS MILANESE (ARQUITETO) E } \\
\text { ANTONIO MOSTO (CONSTRUTOR) }\end{array}$ & 1893 & 1 \\
\hline $\begin{array}{l}\text { CARLOS MILANESE (ARQUITETO) E } \\
\text { JOSÉ FERREIRA DA ROCHA (EMPREITEIRO DE OBRAS) }\end{array}$ & 1901 & 1 \\
\hline CARLOS MILANESE E JÚLIO SALTINI (ARQUITETOS) & 1895 & 1 \\
\hline $\begin{array}{l}\text { CARLOS MILANESE E MIGUEL MARZO (ARQUITETOS) } \\
\text { RUA LÍBERO B ADARÓ, } 17\end{array}$ & 1895 & 6 \\
\hline $\begin{array}{l}\text { ESCRIPTÓRIO TÉCHNICO BENTO CAMARGO FILHO \& } C \text {. } \\
\text { RuA JOSÉ BONIFÁCIO, } 39^{\mathrm{a}}\left(1^{\circ} \mathrm{A}\right)\end{array}$ & 1913 & 1 \\
\hline $\begin{array}{l}\text { EUGENIO RAISIN (ARQUITETO) E } \\
\text { (?) PINTO (EMPREITEIRO) }\end{array}$ & 1893 & 2 \\
\hline $\begin{array}{l}\text { EUGENIO RAISIN (ARQUITETO) E } \\
\text { PAULO VICTOR LANZONI (EMPREITEIRO) }\end{array}$ & 1893 & 1 \\
\hline $\begin{array}{l}\text { LUIZ GONZAGA DA SILVA LEME (ENGENHEIRO) E } \\
\text { JOAQUIM ANTUNES (CONSTRUTOR) }\end{array}$ & 1905 & 1 \\
\hline NOVAES \& SALTINI & 1899 & 2 \\
\hline MELLO \& CIA. & 1912 & 1 \\
\hline ROSSI \& BRENNI & 1895 E 1905 & 3 \\
\hline \begin{tabular}{|l|l} 
VITOR DUBUGRAS E FRANCISCO HENSZLER \\
\end{tabular} & 1898 & 1 \\
\hline
\end{tabular}

Tabela 10 - Construtores por trabalhos realizados em parceria com outros profissionais

\footnotetext{
${ }^{144}$ OLIVEIRA, Maria Luiza Ferreira de - Entre a casa e o armazém. Relações sociais e experiência da urbanização. São Paulo, 1850-1900, São Paulo: Alameda, 2005. p. 189-190.

${ }^{145}$ Almanach Laemmert, Rio de Janeiro, 1910, p. 35.

${ }^{146}$ Obras Particulares, 27/06/1894 e 03/07/1894, v. 70, p. 40 e 42.

${ }^{147}$ SALMONI E DEBENEDETTI, Op. Cit., p. 36.
} 
Entre os 32 profissionais relacionados, destacamos aqueles que em algum momento de sua vida profissional realizaram projetos em parceria com outros profissionais no bairro do Bexiga.

Nesta tabela procuramos, sempre que houvesse a informação, inserir os endereços dos escritórios fornecidos pelos agentes. O fato de estarem estabelecidos comercialmente num endereço determinado diz muito sobre a forma como viam a si mesmos, ao mesmo tempo em que avalizava sua capacidade técnica e experiência de trabalho, qualificando-os como profissionais da construção civil, aptos a realizarem outros trabalhos.

Outra informação importante a ser destacada acerca desses atores sociais é o tipo de projeto desenvolvido por eles. Levando em conta os profissionais que mais se sobressaíram na construção do bairro, envolvidos que estiveram em mais de seis processos construtivos durante o período investigado, montamos a Tabela 11. A esses nomes acrescentamos outros de arquitetos e engenheiros com atuação supostamente reconhecida como tal.

Aqui observamos que de uma maneira geral os profissionais que mais projetos desenvolveram no bairro estavam envolvidos com todo tipo de trabalho, desde construção de novas casas para moradia, passando pelas edificações com fins mistos ou comerciais, reformas e acréscimos, até a construção de simples muros ou passeios. De qualquer maneira, a maioria dos casos parece se relacionar a práticos-licenciados, justamente aquele tipo de profissional referido por Xavier Pereira. Assim, é possível concluir e compreender que, empreiteiros e mestres de obras, profissionais de pequeno e médio porte, aceitassem qualquer tipo de trabalho. Por outro lado, mesmo pessoas como o engenheiro Luis Gonzaga da Silva Leme e o arquiteto Maximilian Hehl se ocuparam de reformas em casas existentes, atividades talvez consideradas menos "nobres". É bem verdade que, no último caso, se tratava de um cliente especial, o Monsenhor Camillo Passalacqua $^{148}$.

\footnotetext{
148 A família Passalacqua foi um dos casos investigados no item "Alguns estudos de Caso". Ver p. 109 a 113.
} 


\begin{tabular}{|c|c|c|c|c|c|c|}
\hline CONSTRUTORES $^{149}$ & $\begin{array}{l}\text { EDIFICAÇÕES } \\
\text { RESIDENCIAIS }\end{array}$ & $\begin{array}{l}\text { EDIFICAÇÕES } \\
\text { MISTAS }\end{array}$ & $\begin{array}{c}\text { FÁBRICAS, } \\
\text { MANUFATURAS } \\
\text { E NEGÓCIOS }\end{array}$ & $\begin{array}{c}\text { COCHEIRAS, } \\
\text { BARRACÕES } \\
\text { E MUROS }\end{array}$ & $\begin{array}{l}\text { ACRÉSCIMOS } \\
\text { E REFORMAS }\end{array}$ & $\begin{array}{c}\mathrm{N}^{\circ} \\
\text { PROJETOS } \\
\text { (INDIVIDUAIS } \\
\text { OU EM } \\
\text { PARCERIA) } \\
\end{array}$ \\
\hline JOSÉ KANZ - CONSTRUTOR (?) & 17 & 3 & - & 6 & 11 & 37 \\
\hline $\begin{array}{l}\text { CARLOS MILANESE - PRÁTICO } \\
\text { LICENCIADO }(*)\end{array}$ & 15 & 6 & 4 & 2 & 8 & 35 \\
\hline $\begin{array}{l}\text { MIGUEL MARZO - PRÁTICO } \\
\text { LICENCIADO }(*)\end{array}$ & 6 & 7 & 1 & - & 7 & 21 \\
\hline $\begin{array}{l}\text { BENEDICTO BETTOY - PRÁTICO } \\
\text { LICENCIADO }(*)\end{array}$ & 3 & 1 & 1 & 1 & 4 & 10 \\
\hline JOSÉ PUCCI - CONSTRUTOR (?) & 7 & - & - & 1 & 1 & 9 \\
\hline $\begin{array}{l}\text { FRANCISCO POMPEU - } \\
\text { CONSTRUTOR (?) } \\
\end{array}$ & 1 & 1 & 1 & 2 & 2 & 7 \\
\hline AFFONSO TOSTA (?) & 2 & 1 & - & 1 & 2 & 6 \\
\hline $\begin{array}{l}\text { FERNANDO SIMÕES - PRÁTICO } \\
\text { LICENCIADO }(*)\end{array}$ & - & 1 & 1 & - & 5 & 6 \\
\hline $\begin{array}{l}\text { ANTONIO BRUNO DA ROSA - } \\
\text { CONSTRUTOR }(*)\end{array}$ & 2 & - & - & - & 3 & 5 \\
\hline JÚLIO SALTINI - ARQUITETO & 2 & - & - & - & 3 & 5 \\
\hline EUGENIO RAISIN - ARQUITETO & 3 & - & - & - & 1 & 4 \\
\hline $\begin{array}{l}\text { ROSSI \& BRENNI - } \\
\text { EMPREITEIROS (*) }\end{array}$ & 1 & - & - & - & 2 & 3 \\
\hline $\begin{array}{l}\text { ABELARDO IVAN [SOARES] } \\
\text { CAIUBY - CONSTRUTOR (?) }\end{array}$ & 2 & - & - & - & - & 2 \\
\hline $\begin{array}{l}\text { FERNANDO DE ALBUQUERQUE - } \\
\text { ENGENHEIRO CIVIL }\end{array}$ & 1 & - & - & - & 1 & 2 \\
\hline $\begin{array}{l}\text { ALBERTO BOZZONI - } \\
\text { ENGENHEIRO }\end{array}$ & 1 & - & - & 1 & - & 2 \\
\hline $\begin{array}{l}\text { LUÍS GONZAGA DA SILVA LEME } \\
\text { - ENGENHEIRO }\end{array}$ & 1 & - & - & - & 1 & 2 \\
\hline $\begin{array}{l}\text { MAXIMILIAN HEHL - } \\
\text { ENGENHEIRO -ARQUITETO }\end{array}$ & - & - & - & - & 1 & 1 \\
\hline $\begin{array}{l}\text { VITOR DUBUGRAS - } \\
\text { ENGENHEIRO }\end{array}$ & 1 & - & - & - & - & 1 \\
\hline
\end{tabular}

Tabela 11 - Relação de construtores, por tipo de projetos realizados

Analisamos, basicamente, a atuação dos construtores que mais se destacaram, seja pelo número de projetos que desenvolveram, seja pela notoriedade de seus nomes. No caso dos proprietários analisados acima, vimos que a configuração do bairro foi marcada, principalmente, pela presença de pequenos e médios proprietários. Aqui não foi diferente. O papel dos construtores, representantes de pequenas e médias iniciativas profissionais também foi decisivo. As 92 pessoas que, de alguma maneira, responderam pela construção dos prédios no bairro significaram nada menos que 85,19\% dos 108 casos em que conseguimos identificar a sua presença. Essa constatação só vem confirmar o Bexiga como um bairro construído pelos e para os segmentos médios e baixos da população paulistana.

\footnotetext{
${ }^{149}$ As qualificações indicadas com asterisco (*) foram baseadas em informações obtidas posteriormente ao levantamento de dados, a partir de relação fornecida pelo pesquisador Lindener Pareto Jr., enquanto que aquelas com ponto de interrogação (?) se relacionam às informações obtidas através dos processos da Série Obras Particulares e sujeitas à confirmação.
} 


\section{Nacionalidades}

Se na análise do papel representado pelos atores sociais que possuíram imóveis no bairro confirmamos uma maioria esmagadora dos indivíduos de origem italiana, o mesmo não ocorreu no caso dos construtores. Organizamos os nomes desses profissionais num banco de dados à parte, procurando agrupá-los por nacionalidade: brasileiros e/ou portugueses; italianos; germânicos; supostos espanhóis e franceses; e, não identificados. O resultado quanto à presença das diferentes nacionalidades está sintetizado na tabela abaixo.

\begin{tabular}{|l|c|c|}
\hline \multicolumn{1}{|c|}{ PROFISSIONAIS } & No & $\boldsymbol{\%}$ \\
\hline BRASILEIROS E/OU PORTUGUESES & 41 & $\mathbf{3 7 , 9 7}$ \\
\hline ITALIANOS & 48 & $\mathbf{4 4 , 4 4}$ \\
\hline GERMÂNICOS & 5 & $\mathbf{4 , 6 3}$ \\
\hline OUTROS (SUPOSTOS ESPANHÓIS E FRANCESES) & 6 & $\mathbf{5 , 5 6}$ \\
\hline NÃO IDENTIFICADOS & 8 & $\mathbf{7 , 4 0}$ \\
\hline TOTAL DE PROFISSIONAIS IDENTIFICADOS & $\mathbf{1 0 8}$ & $\mathbf{1 0 0 \%}$ \\
\hline
\end{tabular}

Tabela 12 - Percentagem dos profissionais, de acordo com as diferentes origens

Dos 108 nomes identificados, 48 são de nacionalidade italiana e 41 são brasileiros e/ou portugueses. Dessa maneira, constatamos que a tendência dos primeiros dominarem o controle do processo produtivo fica relativizada.

Os dados apresentados na tabela contradizem, ao menos aparentemente, as considerações de Xavier Pereira, acerca da preferência geral pelos estrangeiros nos primeiros anos do século XX. Ali constatamos que, no nível da "empreitada", brasileiros (e/ou portugueses) e italianos praticamente se equiparavam. Contudo, esta é uma questão a ser pensada com cuidado. Entre os construtores identificados como "brasileiros e/ou portugueses", não há como definir quem era uma coisa ou outra. Este problema parece incontornável. Eudes Campos, na sua tese de doutorado, já havia constatado a dificuldade: "Sabemos que eram numerosos os lusitanos no ramo da construção civil em São Paulo, a dificuldade no entanto reside na distinção da nacionalidade pelo sobrenome, para não confundi-los com os brasileiros ${ }^{„ 150}$.

Se nessa categoria se tratar predominantemente de portugueses, aí sim se confirma a tese de Xavier Pereira sobre a preferência pela mão de obra estrangeira, caso contrário, as dúvidas se mantêm.

${ }^{150}$ CAMPOS, Eudes (1996). Op. Cit. V. 1, p. 180. 
A preferência por profissionais de outras nacionalidades tem precedentes na história brasileira. Eudes Campos se refere a exemplos de contratação de europeus para trabalhar nas estradas provinciais, nos anos 1830 e $1850^{151}$. Entre os operários que entraram no país na segunda ocasião, o autor sugere que Valentino Kanz "talvez fosse um desses operários alemães”. Seria esse um antepassado de José Kanz? ${ }^{152}$.

O mesmo autor observou que, por volta dos anos de 1870, pelo menos no que se refere às obras públicas, ficava evidente "a estreita ligação existente entre a presença de projetistas, empreiteiros e mão-de-obra qualificada de origem estrangeira e as primeiras manifestações do Ecletismo em São Paulo" ${ }^{153}$.

$\mathrm{Na}$ tentativa de identificar mais detalhadamente a relação entre a atuação dos profissionais brasileiros e estrangeiros e as rupturas políticas e sociais atravessadas pelo país, com a Abolição da Escravidão (1888) e a Proclamação da República (1889), elaboramos a Tabela 13, abaixo, onde relacionamos a presença dos construtores passíveis de identificação de acordo com os anos que atuaram no bairro.

\begin{tabular}{|c|c|c|c|c|c|c|}
\hline ANO & $\begin{array}{l}\text { BRASILEIROS E/OU } \\
\text { PORTUGUESES }\end{array}$ & $\begin{array}{c}\text { NÃO } \\
\text { IDENTIFICADOS }\end{array}$ & GERMÂNICOS & ITALIANOS & OUTROS & $\begin{array}{c}\text { TOTAL } \\
\text { ESTRANGEIROS }\end{array}$ \\
\hline 1887 & 1 & - & - & - & - & - \\
\hline 1889 & 1 & - & - & 1 & - & 1 \\
\hline 1893 & 3 & - & - & 5 & 1 & 6 \\
\hline 1894 & 3 & - & 1 & 4 & - & 5 \\
\hline 1895 & 6 & 1 & - & 11 & - & 11 \\
\hline 1897 & 1 & - & - & 1 & - & 1 \\
\hline 1898 & 2 & - & 2 & 2 & 2 & 6 \\
\hline 1899 & 2 & - & - & 2 & - & 2 \\
\hline 1900 & - & - & 1 & 3 & 1 & 5 \\
\hline 1901 & 2 & - & - & 2 & - & 2 \\
\hline 1902 & 1 & - & - & - & - & - \\
\hline 1905 & 2 & - & 1 & 4 & 1 & 6 \\
\hline 1906 & - & - & 1 & 2 & - & 3 \\
\hline 1907 & - & - & 2 & 1 & - & 3 \\
\hline 1912 & 4 & 1 & - & 5 & - & 5 \\
\hline 1913 & 14 & 4 & 1 & 8 & 1 & 10 \\
\hline 1914 & 8 & 3 & - & 17 & - & 17 \\
\hline
\end{tabular}

Tabela 13 - Presença de profissionais brasileiros elou portugueses X estrangeiros

A partir do universo de estrangeiros identificados nos processos da Série Obras Particulares pudemos observar nesta tabela que em apenas uma ocasião, em 1913, o número de construtores brasileiros e/ou portugueses superou os demais. Nos anos de 1895, 1898, 1900, 1905 e 1914 o número de profissionais de outras nacionalidades, basicamente italianos, chegou a dobrar em relação àquele de brasileiros e/ou

${ }^{151}$ CAMPOS, Eudes. Op. Cit., v. 1, p. 175 a 180.

152 De acordo com o autor, essa informação foi retirada das Atas, 1856, p. 59.

153 Grifo nosso; CAMPOS, Eudes. Op. Cit., v. I, p. 193. 
portugueses. Justamente nesses anos a construção civil no bairro viveu suas duas primeiras fases de crescimento. A primeira, entre 1882 e 1899, atingindo o auge no ano de 1895; a segunda, de 1905 a 1914, atingindo o auge nos anos de 1913 e 1914. Logicamente que esses picos implicaram no aumento da demanda por mão de obra, qualificada ou não, mas indicam, sobretudo, o aumento do contingente de profissionais de origem italiana. Ao lado deles, a presença de poucos profissionais de origem germânica, tão importantes numérica e qualitativamente no decorrer do século que acabava de terminar, parece apontar para o seu desaparecimento gradual.

Infelizmente, nada podemos afirmar acerca dos pedreiros. Em nenhum documento investigado encontramos qualquer menção a essa mão de obra anônima.

\subsection{Alguns estudos de caso}

\section{Joaquim Antunes dos Santos}

Joaquim Antunes dos Santos se mostrou um caso exemplar, já que, além de se destacar pelo número de imóveis em seu nome, também se destacou pelo tempo de atuação no bairro: aproximadamente treze anos. Se considerarmos todos os requerimentos em nome de uma mesma pessoa, o maior proprietário, dentro da amostragem investigada, foi ele.

\begin{tabular}{|c|l|l|l|}
\hline \multicolumn{1}{|c|}{ DATA } & \multicolumn{1}{|c|}{ ENDEREÇO } & \multicolumn{1}{c|}{ HISTÓRICO } & \multicolumn{1}{c|}{$\begin{array}{c}\text { POSIÇÃO } \\
\text { DO AGENTE }\end{array}$} \\
\hline $10 / 04 / 1899$ & RUY BARBOSA, S/N ${ }^{\circ}$, PEGADO AO 27 & 2 CASAS & REQUERENTE \\
\hline $18 / 07 / 1906$ & FORTALEZA, JUNTO DO 12 & 6 CASAS, SENDO UMA COM ARMAZÉM & PROPRIETÁRIO \\
\hline $28 / 08 / 1906$ & FORTALEZA, S/N $\mathrm{N}^{\circ}$ & 4 CASAS & PROPRIETÁRIO \\
\hline $24 / 10 / 1906$ & RUY BARBOSA, S/N & 1 CASA & REQUERENTE \\
\hline $22 / 01 / 1907$ & RUY BARBOSA, 83 TINTA, PRÓXIMO RUA FORTALEZA & $\begin{array}{l}\text { ACRÉSCIMO DE COZINHA, VARANDA E } \\
\text { LATRINA }\end{array}$ & PROPRIETÁRIO \\
\hline $19 / 11 / 1907$ & CONSELHEIRO RAMALHO, JUNTO AO 204 & 1 CASA & REQUERENTE \\
\hline $17 / 121907$ & CONSELHEIRO RAMALHO, 222 & 2 CASAS & PROPRIETÁRIO \\
\hline $20 / 01 / 1912$ & RUY BARBOSA, JUNTO AO 143 & 2 CASAS & PROPRIETÁRIO \\
\hline $26 / 01 / 1912$ & FORTALEZA, 13 & 2 CASAS & PROPRIETÁRIO \\
\hline $21 / 02 / 1912$ & FORTALEZA, 11 & OFICINA DE MARCENARIA & PROPRIETÁRIO \\
\hline TOTAL DE IMÓVVIS & & $\mathbf{2 2}$ \\
\hline
\end{tabular}

Tabela 14 - Propriedades em nome de Joaquim Antunes dos Santos

Entre os dez processos em seu nome, em três deles, Joaquim Antunes consta como requerente, sendo que apenas um dos projetos arquitetônicos apresentados o indica como proprietário. Também excluímos a possibilidade de se tratar de um construtor, já que em nenhuma ocasião ele aparece nessa categoria. Assim, acreditamos que ele realmente fosse o proprietário de todos os imóveis. 
Desde o primeiro registro em seu nome, datado de 10/04/1899 ${ }^{154}$, quando solicitou licença para a construção de duas casas, à “rua Ruy Barbosa, pegado ao 27”, e o último, de 03/10/1912 $2^{155}$, no qual se referia à construção de um muro à rua "Ruy Barbosa, junto ao 143", se passaram treze anos. Durante esse tempo ele construiu e reformou diversas casas, em três ruas diferentes, porém próximas: Rui Barbosa, Fortaleza e Conselheiro Ramalho. Entre julho e agosto de 1906, Joaquim Antunes solicitou licença para construir dez casas na rua Fortaleza: primeiro, seis casas "junto ao número 12”, e em seguida, mais quatro casas, sem identificação de número. Ao que tudo indica eram casas vizinhas.

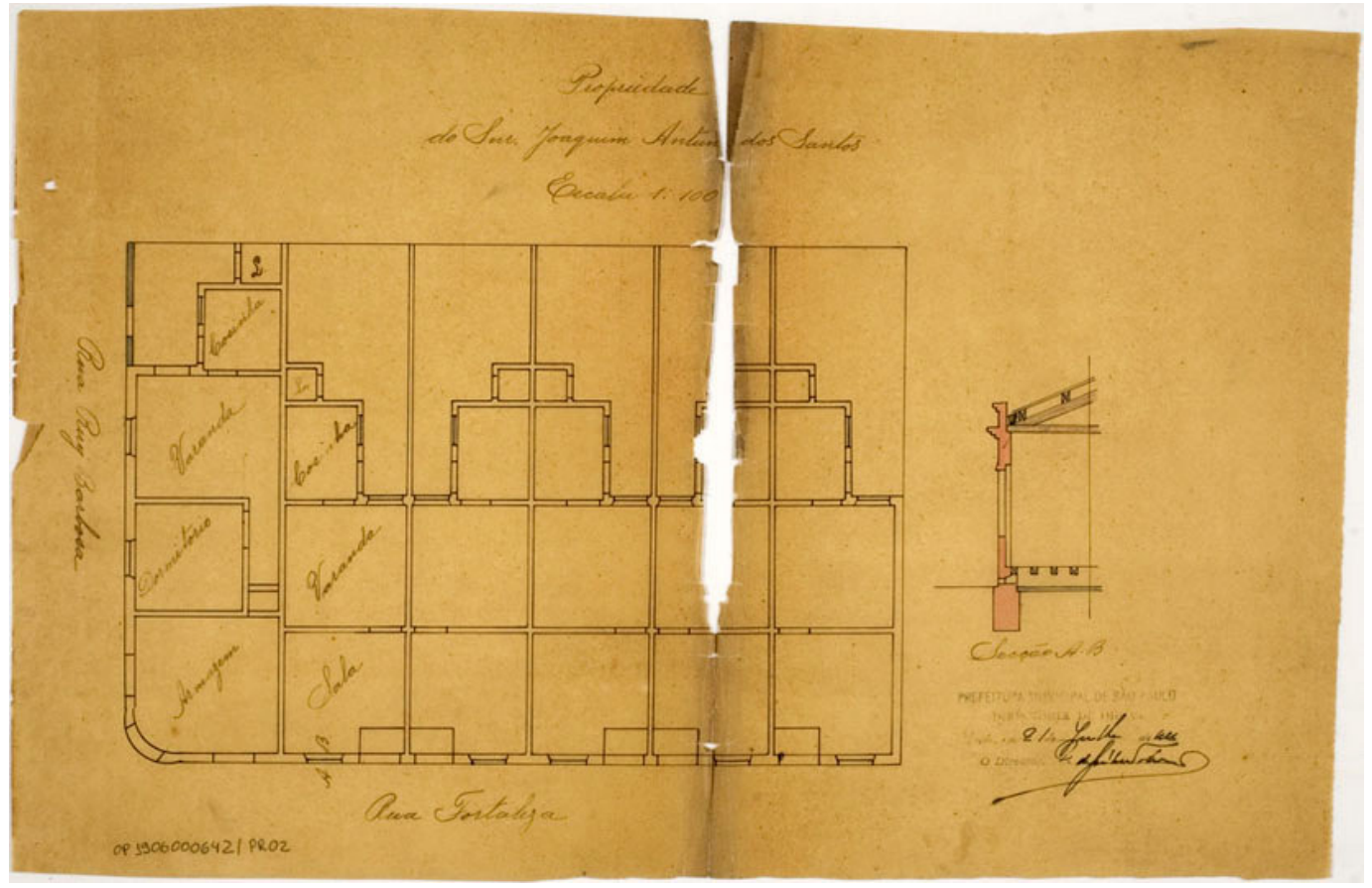

Figura 19 - Rua Fortaleza, “junto ao 12” 156

Na Série Alvará e Licença ${ }^{157}$ do AHMWL há um registro em seu nome, datado de 24/10/1911, para os imóveis sitos à rua Fortaleza, números 7 e 10. Embora essa Série trate basicamente dos atores sociais envolvidos com algum tipo de negócio, o processo em nome de Joaquim Antunes não acusou vínculos comerciais com o bairro. Por outro

\footnotetext{
${ }^{154}$ Obras Particulares, Processos de 10/04/1899, v.249, p. 216; 03/10/1912, Cx. R1.

155 Obras Particulares, Processo de 03/10/1912, Cx.R1.

${ }^{156}$ Obras Particulares, Processo de 18/07/1906, Cx.E1/F1-06.

${ }^{157}$ Série Alvará e Licença, Arquivo Histórico Municipal Washington Luiz, 24/10/1911, Cx. 721. Essa coleção contém os processos de solicitação de Alvará e Licença para a abertura de negócios comerciais e/ou de serviços, entre 1906 e 1921.
} 
lado, confirmou a hipótese de que o mercado locatício estava, pelo menos, entre as suas principais fontes de renda. No processo, que vale a pena ser reproduzido, ele:

"Vem dizer que não se responsabiliza por nenhuma indústria colocada em suas propriedades - como sejam cocheiras, fornos para cozinha [...] bem como curtume e "salga" de couros. Vem fazer este aviso a fim de "colectar" os inquilinos que exercem qualquer dessas profissões em sua propriedade". Em anexo, os avisos 31 (ua Joly), 54 e 55 (Rua Fortaleza, 7 e 10) referentes às cocheiras".

Conforme o parecer de 21 de fevereiro, o pedido foi indeferido, já que, "de acordo com a lei é o proprietário responsável pelo imposto sobre cocheiras, embora estejam elas alugadas a terceiros [...]" (grifos nossos).

Se atentarmos para a segunda planta, veremos que se trata de casas a serem construídas nos fundos do terreno. A planta ainda indica que a entrada da "vila" estava entre dois terrenos de "propriedade do mesmo". Há uma grande possibilidade da casa de número 10 , mencionada no texto acima, se referir ao terreno localizado à esquerda da entrada da "vila". Seis anos mais tarde, em 1912, Joaquim Antunes construiria mais duas casas e uma oficina para marcenaria, respectivamente nos números 13 e 11, da mesma rua.

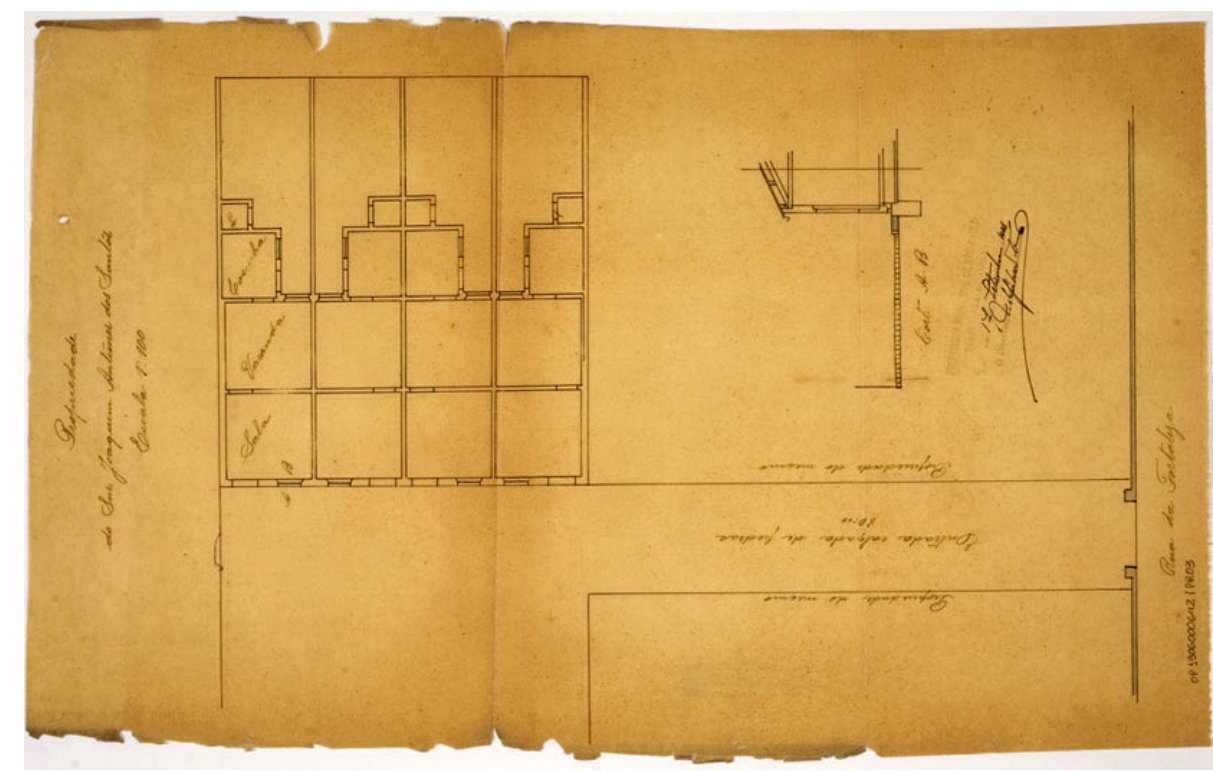

Figura 20 - Rua Fortaleza, s/nº. ${ }^{158}$

Um outro exemplo interessante dos empreendimentos de Joaquim Antunes está no processo de 17/12/1907. Ali, o requerente diz que sendo "proprietário de uma cocheira nos fundos da rua Conselheiro Ramalho, 222, e desejando transformá-la em

${ }^{158}$ Obras Particulares, Processo de 28/08/1906, Cx. E1/F1-06. 
duas habitações para operário, conforme a planta junta, solicita a licença necessária”"159.

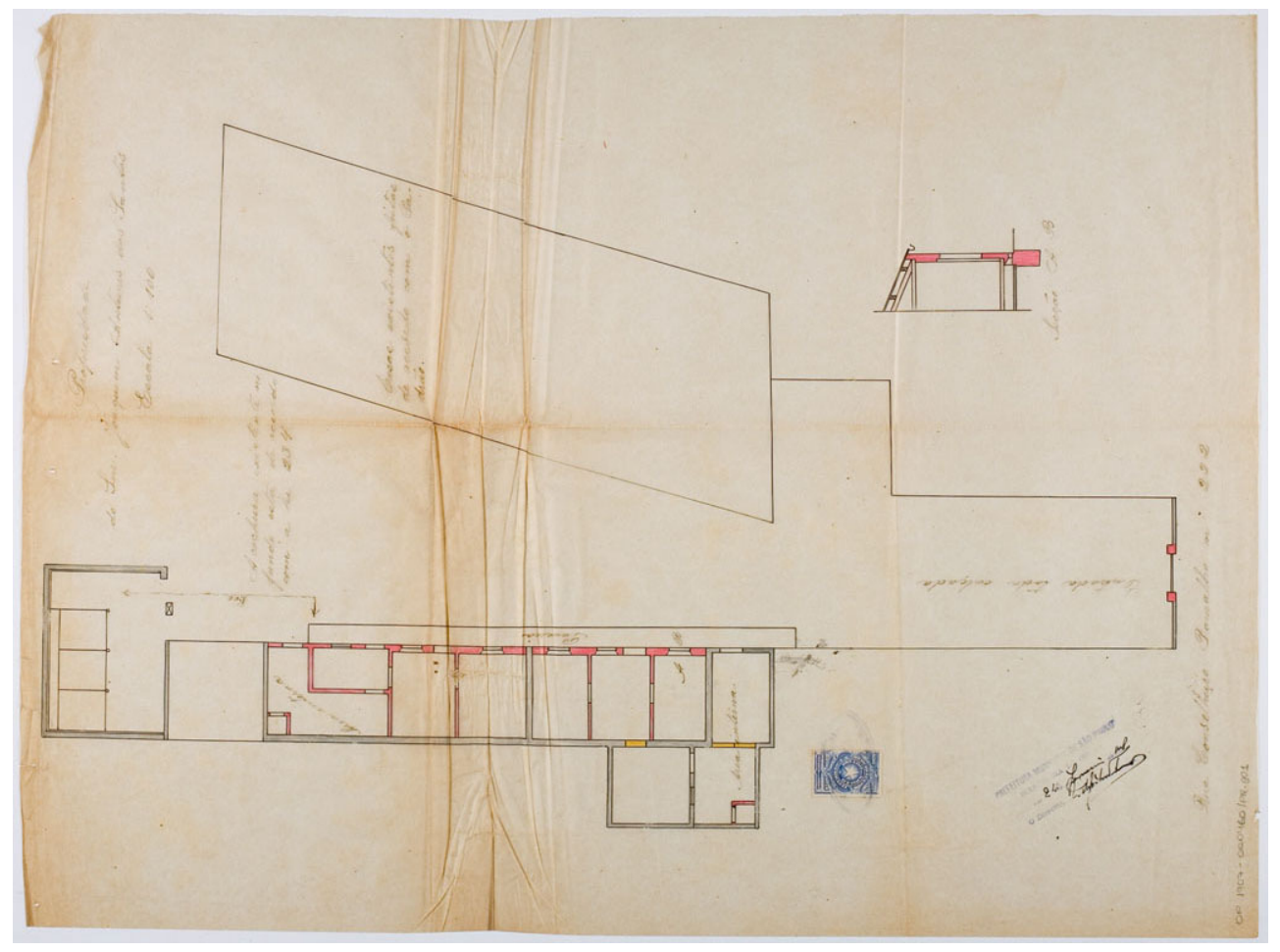

Figura 21 - Rua Conselheiro Ramalho, 222

O projeto arquitetônico apresenta entrada larga, calçada, dando acesso ao interior da "vila". À direita do pátio interno, temos "edificações existentes", sem definição dos espaços, possivelmente pertencentes ao mesmo proprietário ${ }^{160}$. À esquerda, as duas casas a serem edificadas, foram organizadas como um corredor de cômodos enfileirados. A primeira, aparentemente, conta com quatro cômodos; a segunda tem três cômodos; cada uma delas tem uma "área interna", com latrina própria. Nos fundos do terreno, à esquerda, há uma cocheira, com três baias. De acordo com o requerimento, todo o espaço das casas havia sido originalmente ocupado por uma cocheira, porém, o projeto não permite saber se esta é a mesma edificação, já que ali, "a cocheira existente nos fundos está de acordo com a lei 234". Aparentemente, Joaquim Antunes não teve problemas para a aprovação do projeto, já que o parecer técnico elaborado pela Diretoria de Obras não acusa nada. Contudo, não fosse a presença de latrinas em cada uma das casas, diríamos que se trata de um cortiço. Não foi esse o caso. De qualquer

\footnotetext{
${ }^{159}$ Obras Particulares, Processo de 17/12/1907, Cx. C2/D1-19.

${ }^{160}$ Em 19 de novembro do mesmo ano, Joaquim Antunes solicitara licença para construir uma casa, na rua Conselheiro Ramalho, “junto ao 204”. Pode ser que se trate da mesma edificação. Obras Particulares, Cx. C2.
} 
maneira, a análise dos projetos arquitetônicos demonstrou que Joaquim Antunes dos Santos construiu para famílias pertencentes às camadas baixas da população, sobretudo pequenas casas, geralmente com três cômodos, no máximo quatro.

Uma outra informação no texto transcrito acima ${ }^{161}$ que nos chamou a atenção: além das cocheiras existentes na rua Fortaleza, havia mais duas, nos números 54 e 55 , da rua Joly. Descobrimos, assim que Joaquim Antunes possuía terrenos não apenas no Bexiga, mas também no Brás. Finalmente, a confirmação de sua atuação como empreendedor imobiliário foi dada pela investigação que realizamos no Arquivo do Estado, onde consultamos o Índice das Escrituras do $2^{\circ}$ Cartório de Notas. Ali, em 1898, o encontramos na condição de "outorgante" de um terreno para a São Paulo Railway Co., e de outro terreno, em 1907, para C. A. Zickho S/C. ${ }^{162}$

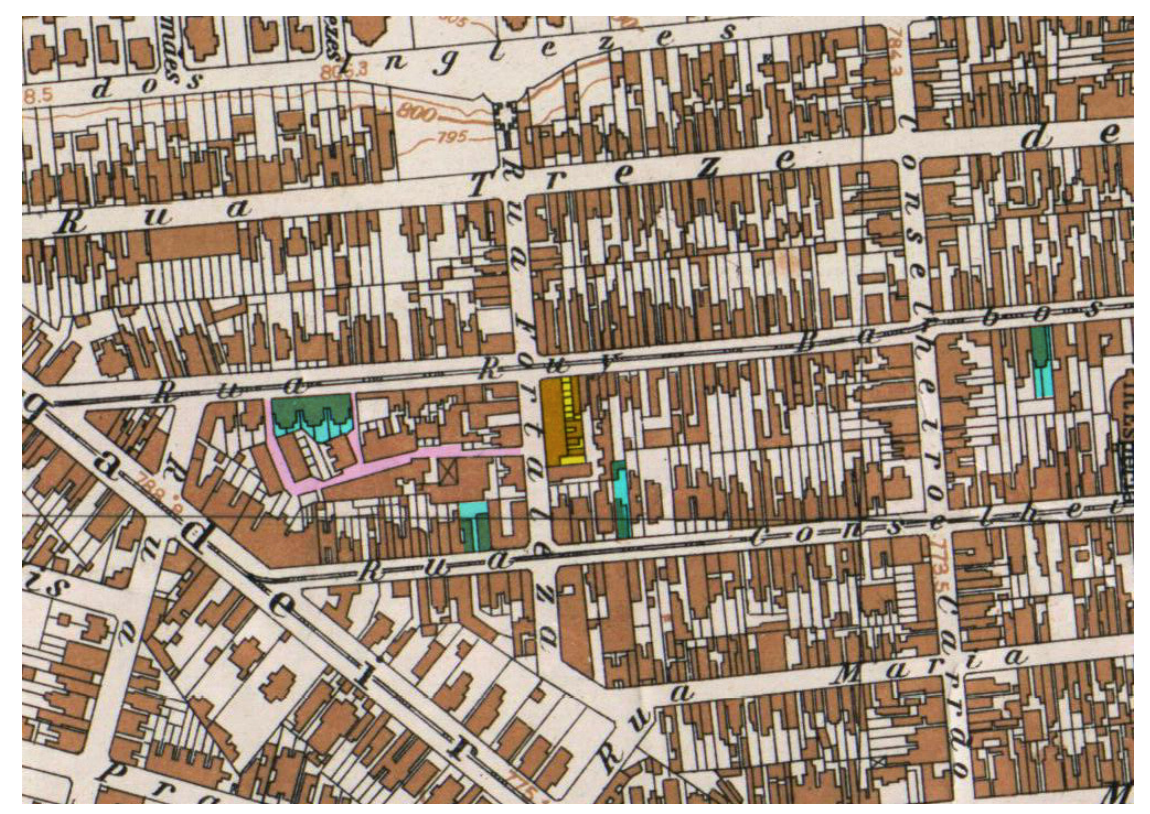

Figura 22 - Localização da área de atuação de Joaquim Antunes dos Santos. O único imóvel que temos certeza ter pertencido a Joaquim Antunes está destacado em amarelo. No caso dos demais, destacados em verde, calculamos a localização aproximada, a partir da análise dos projetos arquitetônicos e dos endereços fornecidos. Um detalhe interessante é a "rua interna", destacada em rosa, onde observamos um acesso entre as ruas Rui Barbosa e Fortaleza. Esta rua corresponde, atualmente, à Travessa dos Arquitetos. Planta SARA Brasil, 1930, Bairro do Bexiga. Fl. 37. AHMWL

Com o objetivo de ampliar o perfil desse personagem, buscamos outras informações no Arquivo Aguirra. Descobrimos que Joaquim Antunes dos Santos faleceu a 20 de abril de 1913, cerca de um ano após a última solicitação encaminhada à Diretoria de Obras. Como prováveis herdeiros constam: “João Antunes dos Santos,

\footnotetext{
${ }^{161}$ Processo de 24/11/1911, Série Alvará e Licença.

162 Índice das Escrituras do $2^{\circ}$ Cartório de Notas, Livro 12.065, Fl. 181; e Livro 205, Fl. 54.
} 
Maria Espírito Santo Mathias (casada com Luís Mathias), Maria Angélica Conceição Dias (Mel. Dias Anastácio), e Anna (?) Piedade"163. Conforme os processos arrolados na Tabela 14, localizamos a área na qual Joaquim Antunes atuou no Bexiga. O trecho compreendido pelas ruas Rui Barbosa, Conselheiro Carrão, e Fortaleza, concentra suas propriedades no bairro.

Ainda que o caso de Joaquim Antunes seja o único exemplo de locação de imóvel citado nos registros investigados, ele só vem confirmar uma realidade conhecida e relatada por diversos autores. Beatriz Piccolotto Siqueira Bueno ${ }^{164}$ constatou esse fato, ainda na primeira década do século XIX. "Ao espacializarmos uma documentação inédita, a Décima Urbana de 1809 [...] verificamos que boa parte do tecido urbano era produto da iniciativa privada e $50 \%$ das casas destinadas à renda de aluguel". Maria Luiza Ferreira de Oliveira, ao estudar a forma como as camadas médias e baixas da população paulistana vivenciavam o processo de urbanização da cidade, na segunda metade do século XIX, demonstrou que o investimento no mercado imobiliário pelos setores médios da população também era usual ${ }^{165}$. No decorrer do capítulo "Modos de viver" a autora traz diversos exemplos de pessoas que viviam da renda auferida com o aluguel de casas ou mesmo de cômodos. Ao citar o espanhol José Fernandes de Castro, morto em 1899, ela diz que "Ele, como outros remediados de setores médios da sociedade paulistana, tinha pequenas casas de aluguel”. O mesmo sucedeu com José Bento Rodrigues, um português que morava na rua 25 de Março. “José Bento apostara diretamente no mercado para as populações pobres que São Paulo não parava de receber [...]”. Embora as investigações realizadas pela autora enfoquem basicamente a região central da cidade, o cenário que forneceu pode ser estendido para as regiões circundantes, que tiveram sua expansão justamente nessa época. José Bento Rodrigues apresentava casas de aluguel no Brás, e Joaquim Antunes dos Santos, no Brás e no Bexiga. Ambos são atores sociais que desempenharam o mesmo papel em diferentes espaços da cidade.

\footnotetext{
${ }^{163}$ Cartório do $1^{\text {o }}$ Ofício, Maço 361, 1913. In: Arquivo Aguirra. Museu Paulista.

${ }^{164}$ BUENO (2005), Op.cit., p.60.

${ }^{165}$ OLIVEIRA, Maria Luiza Ferreira de - Entre a casa e o armazém. Relações sociais e experiência da urbanização. São Paulo, 1850-1900, São Paulo: Alameda, 2005. p.33 a 65.
} 


\section{Família Passalacqua}

Constantemente encontramos diferentes agentes portando o mesmo sobrenome e acreditamos na possibilidade de que pessoas de uma mesma família, especialmente aquelas de origem italiana, tenham comprado terrenos no bairro. $\mathrm{O}$ exemplo mais sintomático é o da família Passalacqua, conforme a tabela seguinte.

\begin{tabular}{|c|c|c|c|}
\hline DATA & NOME & ENDEREÇO & $\begin{array}{c}\text { HISTÓRICO } \\
\text { OCORRÊNCIAS }\end{array}$ \\
\hline $23 / 11 / 1891$ & JOSÉ MARIA PASSALACQUA & MAJOR DIOGO, S/Nº -ESQ. CONS.CARRÃO & ALINHAMENTO PARA EDIFICAÇÃO \\
\hline $05 / 12 / 1894$ & JOSÉ MARIA PASSALACQUA & CONSELHEIRO RAMALHO, 84 & REFORMA E ACRÉSCIMO \\
\hline $19 / 08 / 1895$ & JOSÉ MARIA PASSALACQUA & CONSELHEIRO RAMALHO, 76 & ABERTURA JANELAS \\
\hline $04 / 05 / 1899$ & JOÃO PASSALACQUA & CONSELHEIRO RAMALHO, 82 & ABERTURA PORTÃO \\
\hline $11 / 07 / 1899$ & JOÃO PASSALACQUA & MONTE DE OURO, 45 & ACRÉSCIMO "PUCHADO" \\
\hline $04 / 09 / 1907$ & CAMILLO PASSALACQUA & CONSELHEIRO RAMALHO, 82 & REFORMA \\
\hline $10 / 02 / 1912$ & CAMILLO PASSALACQUA & JOÃO PASSALACQUA, 67 & ACRÉSCIMO SALA BANHO E DESPENSA \\
\hline $10 / 02 / 1912$ & CAMILLO PASSALACQUA & MANOEL DUTRA, 42 & ACRÉSCIMO SALA DE BANHO E DESPENSA \\
\hline $21 / 10 / 1912$ & JOSÉ MARIA PASSALACQUA & JOÃO PASSALACQUA, 17 & CONSTRUÇÃO DE GARAGEM \\
\hline $07 / 02 / 1913$ & JOSÉ MARIA PASSALACQUA & MAJOR DIOGO, 152 - ESQ.CONS.CARRÃO & REFORMA PARA COMÉRCIO \\
\hline $17 / 11 / 1913$ & JOSÉ MARIA PASSALACQUA & CONSELHEIRO RAMALHO, 82 & REFORMA PARA COMÉRCIO \\
\hline 1914 & JOSÉ MARIA PASSALACQUA & MARIA JOSÉ, S/Nº - PRÓX. RUA FORTALEZA & ALINHAMENTO E NIVELAMENTO \\
\hline $20 / 01 / 1914$ & JOSÉ MARIA PASSALACQUA & ABOLIÇÃO, 6 & ACRÉSCIMO CÔMODOS COMÉRCIO \\
\hline $29 / 01 / 1914$ & JOSÉ MARIA PASSALACQUA & MAJOR DIOGO, 154 & ACRÉSCIMO EDÍCULA E GARAGEM. \\
\hline $17 / 06 / 1914$ & JOSÉ MARIA PASSALACQUA & CONSELHEIRO RAMALHO, 247 & TRANSF. JANELAS P/ PORTAS COMÉRCIO \\
\hline $02 / 07 / 1914$ & JOSÉ MARIA PASSALACQUA & CONSELHEIRO RAMALHO, 161 & ABERTURA PORTAS PARA COMÉRCIO \\
\hline $11 / 07 / 1914$ & JOSÉ MARIA PASSALACQUA & RUY BARBOSA, 131 & CORTIÇO - ACRÉSCIMO \\
\hline $25 / 07 / 1914$ & JOSÉ MARIA PASSALACQUA & CONSELHEIRO RAMALHO, 249 & MODIFICAÇÃO DE 3 PORTAS E 2 PILARES \\
\hline $15 / 10 / 1914$ & JOSÉ MARIA PASSALACQUA & CONSELHEIRO RAMALHO, 82 & TRANSF. JANELAS EM PORTAS COMÉRCIO \\
\hline $10 / 12 / 1914$ & JOSÉ MARIA PASSALACQUA & CONSELHEIRO RAMALHO, 69 & ACRÉSCIMO E TRANSF. JANELA P/PORTA \\
\hline $15 / 12 / 1914$ & JOSÉ MARIA PASSALACQUA & CONSELHEIRO RAMALHO, 80 & ABERTURA PORTA PARA COMÉRCIO \\
\hline
\end{tabular}

Tabela 15 - Propriedades em nome da família Passalacqua

O primeiro registro encontrado, em nome de José Maria Passalacqua, data de 23 de novembro de 1891, e está relacionado a um pedido de "alinhamento para edificação", à rua Major Diogo, esquina com a rua Conselheiro Carrão. João Passalacqua, em 04 de maio de 1899, encaminhou à Diretoria de Obras um requerimento referente à "abertura de um portão" no muro da propriedade, à rua Conselheiro Ramalho, ${ }^{\circ}$ 82. No mesmo ano, em 11 de julho, o mesmo solicita licença para aumentar "um puchado" na casa da rua Monte de Ouro, $\mathrm{n}^{\circ} 45$. Em 04 de setembro de 1907, Camillo Passalacqua (o Monsenhor) pede licença para reformar a casa da rua Conselheiro Ramalho, $\mathrm{n}^{\circ}$ 82. Esse pedido será seguido de outros dois, em 10 de fevereiro de 1912, para as ruas João Passalacqua e Manoel Dutra. Esses dois agentes já indicam que a família possuía diferentes imóveis no bairro.

Entretanto, o caso que mais chama a atenção é o de José Maria. Sozinho, ele apresenta 15 imóveis em seu nome:

- oito propriedades à rua Conselheiro Ramalho

- três à rua Major Diogo;

- uma à rua João Passalacqua; 
- uma à rua da Abolição;

- uma à rua Maria José;

- uma à rua Rui Barbosa.

É interessante observar que o imóvel sito à rua Conselheiro Ramalho $n^{\circ} 82$ apresenta três proprietários da mesma família, o que pode significar transmissão por herança, ou mesmo uma espécie de "administração conjunta" do imóvel. Somente a título de ilustração, na pesquisa que realizamos no AHMWL ${ }^{166}$ na mesma Série das Obras Particulares, encontramos dois requerimentos em nome do Major José Maria Passalacqua, contendo projetos para acréscimos em edificações existentes, à rua Maria Antonia, números 59 e 60. No bairro da Consolação, não muito longe do Bexiga, o nosso personagem volta a aparecer. Decididamente esse foi um homem que investiu na especulação imobiliária! Aliás, um detalhe merece destaque no caso do imóvel da Rua Rui Barbosa: tratava-se de um cortiço. A leitura do projeto arquitetônico (planta baixa) permite constatar uma série de quatro cômodos no alinhamento, sem portas ou janelas, e definidos como "construção antiga". Do lado direito da edificação há uma entrada larga dando acesso a uma grande área vazia; no fundo do terreno, consta o acréscimo de cozinha, banheiro e dois tanques. O processo teve início em 11/07/1914 e prolongou-se até pelo menos 15/03/1917, quando um parecer do engenheiro Saboya deixa claro que se tratava de "aumento de cortiço existente, em desacordo com o Código de Posturas, Artigo 20, não sendo pela lei $n^{o}$ 1788, Art. 5\%, então vigente, tolerados novos cortiços e, consequentemente, aumento dos existentes" 167.

A análise desses processos não deixa dúvidas quanto à exploração locatícia dos imóveis. Se não toda a família, pelo menos José Maria construiu e reformou para alugar, e fez isso atendendo aos diversos usos possíveis dos imóveis. Das quinze edificações registradas em seu nome, oito indicam uso comercial, e as sete restantes destinavam-se a moradia, com o detalhe que uma delas era um cortiço. Digamos que ele não apenas explorou o mercado de locação, mas levou essa exploração às últimas consequências.

\footnotetext{
${ }^{166}$ Projeto Arquivo Histórico Municipal "Washington Luís” - A cidade de São Paulo e sua Arquitetura, 2007 a 2010.

${ }^{167}$ Obras Particulares, 11/07/1914, Cx. R2.
} 


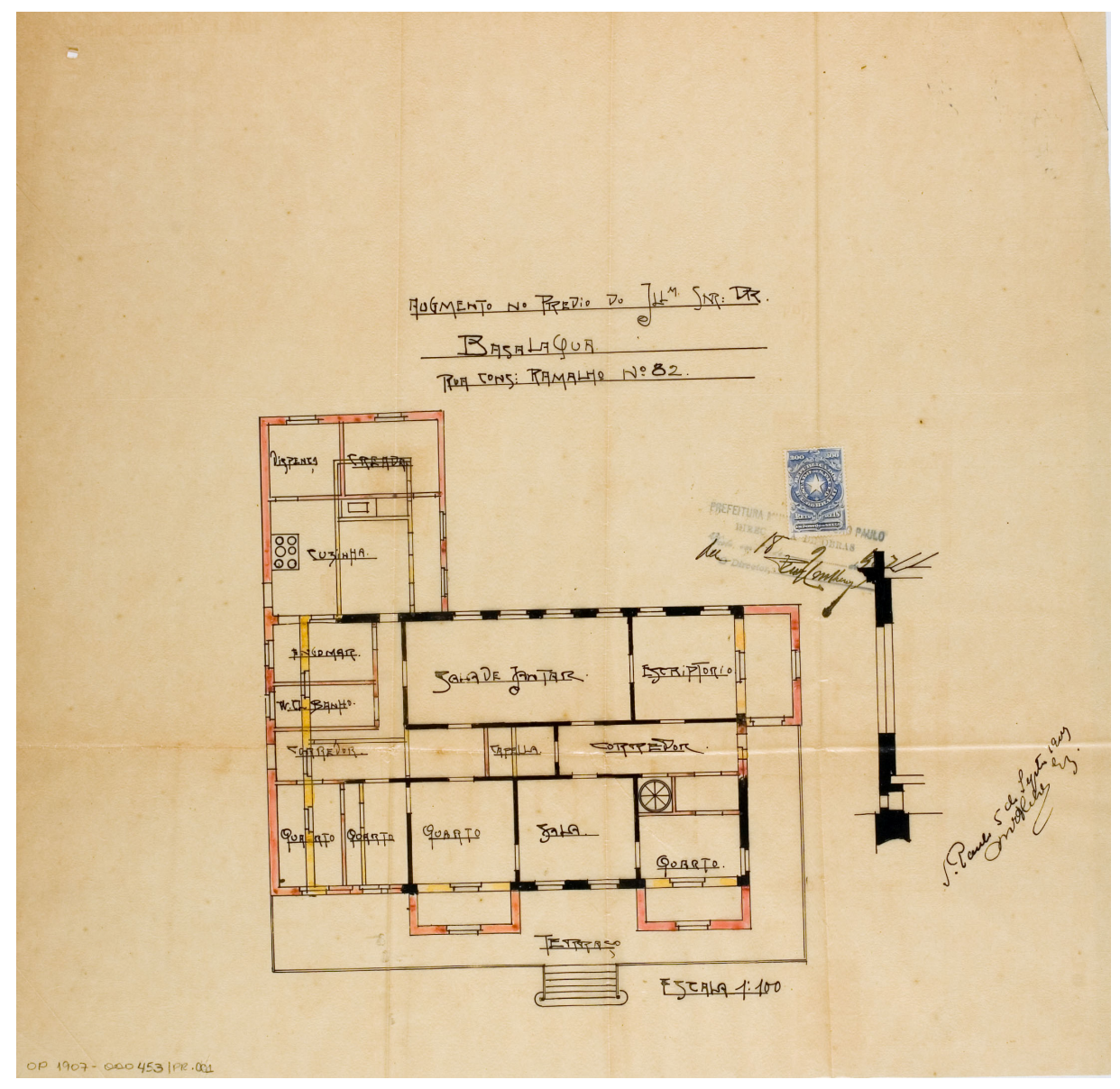

Figura 23 - Processo de 04/09/1907, para acréscimo e reforma do imóvel localizado à rua Conselheiro Ramalho $\mathrm{n}^{\circ}$ 82, em nome de Camillo Passalacqua. Projeto assinado pelo arquiteto Maximilian Hehl. Tudo indica que esse imóvel tivesse sido residência da família. De acordo com o inventário do patriarca da família, João Passalacqua, em 1903, esta foi, justamente, a casa deixada como herança à família. Mais tarde, em 17/11/1913, encontramos uma solicitação de reforma com objetivo de "comércio".

Os Passalacqua deixaram alguns legados no bairro da Bela Vista. Duas ruas tiveram seus nomes originais substituídos em homenagem a dois membros da família: a rua Monte de Ouro veio a se chamar João Passalacqua, através da Lei $\mathrm{n}^{\circ} 1108$, em 30/07/1908; e a Travessa Pedroso, nos limites da Bela Vista e da Liberdade, por força do Ato $\mathrm{n}^{\circ}$ 1584, de 13/06/1921, passou a se chamar rua Monsenhor Passalacqua. Infelizmente, sobre o Colégio João e Raphaela Passalacqua, vinculado à Associação Beneficente das Irmãs de São Vicente de Paula de Gysegem, e localizado na mesma rua João Passalacqua, pouco conseguimos apurar. De qualquer modo tanto a escola como as ruas demonstram a importância da família, nos levando a investigar esses personagens.

Sobre o patriarca da família, João Passalacqua, ficamos sabendo que:

“João Crisóstomo Passalacqua nasceu em Scaléa, antigo reino de Nápoles, em 16 de abril de 1833. Chegou ao Brasil em 1867. Com algumas economias, comprou terrenos no então bairro do Bexiga. Fundou uma associação de caridade a então chamada 
sociedade São Vicente de Paula que funcionava em uma sala do antigo Palácio do Bispo, na Rua do Carmo. Faleceu em 24 de outubro de 1901" 168.

Consultando a documentação do Arquivo Aguirra ${ }^{169}$, identificamos alguns dados de seu inventário, onde consta que ele era casado com “D. Raphaela Bello Passalacqua [...], falecida em 15 de março de 1903 [...]" ${ }^{170}$. O casal deixou os filhos: “Camillo Passalacqua, Monsenhor; José Maria Passalacqua, casado; Maria Luiza Passalacqua Botelho, casada com o Dr. (Urcas) Mello Botelho; e Paulo (Américo) Passalacqua [...]”. Como herança, deixaram uma casa, à rua Conselheiro Ramalho, número 82, justamente o imóvel que, em diferentes momentos, esteve em mãos de três pessoas da família. Como havíamos pensado, tratava-se mesmo de um caso de transmissão por herança.

Sobre Camillo Passalacqua, obtivemos poucas informações. Sabemos que "foi durante muitos anos catedrático da Escola Normal de São Paulo e diretor espiritual da Casa Pia de São Vicente de Paula" ${ }^{171}$, além de autor do livro A Pedagogia e Methodologia, publicado em 1887. Entretanto, ao consultar a Série Alvará e Licença no AHMWL, encontramos uma informação curiosa a seu respeito. Em 04 de novembro de 1914, um certo Sescrim Castanhos solicitou, sem definir o objetivo do requerimento, uma “certidão com relação dos nomes e residências de todos os particulares possuidores de automóveis, assim como as garagens existentes nesta capital" ${ }^{172}$. O pedido foi deferido. Dessa relação, destacamos as pessoas com endereço no Bexiga: Belarmino Barbosa, rua Major Diogo no 6 (automóvel particular); Luiz Martella, rua Major Diogo no 41 (automóvel de aluguel); e, Camillo Passalacqua, rua Conselheiro Ramalho $n^{\circ} 86$ (automóvel de aluguel).

A citação do requerimento pode parecer desprovida de sentido porém, dada a importância da posse de um automóvel naquele momento da história da cidade e, acreditando que ele possa nos ajudar a conhecer a posição social deste personagem decidimos pela sua inclusão. Não sabemos definir com precisão o sentido do termo "aluguel" utilizado no texto, mas a legislação municipal registrava, desde 1893, a existência de "carros de praça" como veículo de aluguel para transporte de passageiros

\footnotetext{
${ }^{168}$ Disponível em: http://www.dicionarioderuas.com.br. Departamento do Patrimônio Histórico/DPH.

${ }^{169}$ Correio de São Paulo, 25/10/1901, in Arquivo Aguirra, Museu Paulista.

${ }^{170}$ Inventário de João Passalacqua, Cartório do $3^{\circ}$ Ofício Civil, Maço 2, 1903. Ficha catalográfica, manuscrita, Arquivo Aguirra, Museu Paulista.

${ }^{171}$ Disponível em: http://www.dicionarioderuas.com.br. Departamento do Patrimônio Histórico/DPH.

${ }^{172}$ Série Alvará e Licença, Cx. 1300.
} 
e, em 1906, o artigo 19 da Lei no 956 regulamentava o "imposto de veículos" para os possuidores de "automóvel de praça ou de aluguel para condução pessoal" ${ }^{173}$. Deduzimos assim, que sendo proprietário de um automóvel, o Monsenhor provavelmente se utilizasse dos serviços de um chauffeur para explorar esse ramo de atividade.

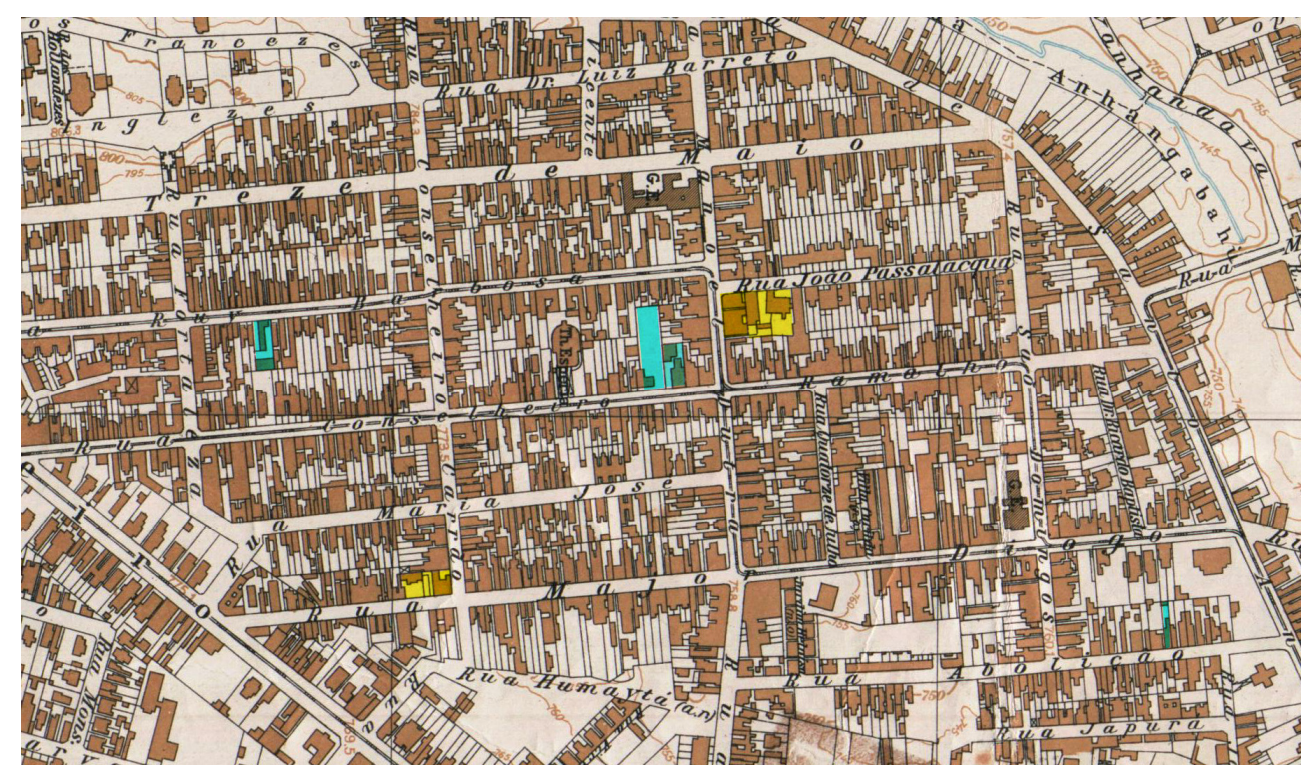

Figura 24 - Localização da área de atuação da família Passalacqua. Os únicos casos que destacamos foram aqueles passíveis de identificação aproximada, sendo que os destacados em amarelo, são os únicos que, seguramente, pertenciam a membros da família. Os casos destacados em verde foram selecionados a partir da confrontação dos projetos e dos endereços fornecidos. Planta SARA Brasil, 1930, Bairro do Bexiga. Fl. 37. AHMWL

Quantos aos outros filhos do casal Passalacqua, não obtivemos nenhuma informação. São poucas as notícias sobre a família, entretanto são suficientes para concluirmos que o grande "capitalista" da família foi José Maria. Ele esteve presente em 23 dos 33 anos abrangidos pela nossa pesquisa, e ainda que seu nome não tenha "batizado" nenhuma rua, sua presença, certamente, influenciou a vida de moradores do bairro que alugaram suas casas.

\footnotetext{
${ }^{173}$ MENDES, Ricardo. "Táxi - veículos de aluguel em São Paulo (1892-1930) e os marcos regulatórios", in. Informativo Arquivo Histórico Municipal, 3 (13): julho/agosto 2007 $<$ http://www.arquivohistorico.sp.gov.br>
} 


\section{Padre Paschoal Gazíneo}

Temos a presença do Padre Gazíneo no bairro do Bexiga por um período relativamente longo, aproximadamente 27 anos, sempre na rua Santo Antonio. Os endereços fornecidos à Diretoria de Obras parecem indicar que todos os imóveis de sua propriedade se localizavam no início da rua, sempre do lado esquerdo, nas proximidades do Centro.

\begin{tabular}{|c|c|c|c|}
\hline DATA & ENDEREÇO & HISTÓRICO & $\begin{array}{c}\text { POSIÇÃO } \\
\text { DO AGENTE }\end{array}$ \\
\hline $23 / 08 / 1887$ & SANTO ANTONIO, S/N ${ }^{\circ}$ & ALINHAMENTO PARA CONSTRUÇÃO DE 1 CASA & REQU/PROPRIET. \\
\hline $06 / 10 / 1899$ & SANTO ANTONIO, 27 E 27 A & 2 CASAS & REQU/PROPRIET. \\
\hline $26 / 02 / 1901$ & SANTO ANTONIO, 29 & INTIMAČ̃̃O PARA LEVANTAR MURO E FAZER CAIACCÃO & PROPRIETÁRIO \\
\hline $14 / 05 / 1912$ & SANTO ANTONIO, 49 & REFORMA DE CASA & PROPRIETÁRIO \\
\hline $11 / 03 / 1913$ & SANTO ANTONIO, 51 & PEDIDO DE CÓPIA DE PLANTA & PROPRIETÁRIO \\
\hline $11 / 10 / 1913$ & SANTO ANTONIO, $51 \mathrm{~A}$ & ACRÉSCIMO DE 1 CÔMODO & PROPRIETÁRIO \\
\hline $23 / 03 / 1914$ & SANTO ANTONIO, $53(\mathrm{~T})$ & LICENÇA PARA A RECONSTRUÇÃO DE UM PILAR & PROPRIETÁRIO \\
\hline
\end{tabular}

Tabela 16 - Propriedades em nome do Padre Paschoal Gazíneo

Não é possível saber com certeza se ele também viveu no bairro, em algum dos imóveis que ali possuía. Porém, no requerimento encaminhado à municipalidade, em 30/12/1886, por Antonio Ferreira de Sampaio, seu nome é citado como referência de divisa de lotes: "Divide à direita com o padre Paschoal e à esquerda com Placidina Leme" ${ }^{174}$, o que poderia, talvez, caracterizá-lo como morador.

Em 23 de agosto do ano seguinte, pela primeira vez, o padre aparece como requerente de uma licença para alinhamento e construção de prédio em terreno de sua propriedade, na rua Santo Antonio sem número, dividindo “à direita com Jacob e à esquerda com o requerente”. Daí por diante, temos sua presença esporádica, até a década de 1910, quando se torna mais assíduo.

Embora tenhamos obtido poucas informações sobre o Padre Paschoal Gazíneo, estas demonstram se tratar de uma figura, no mínimo, de caráter discutível, principalmente se levarmos em conta que era um representante da Igreja. Jorge Americano traça um retrato nada simpático a seu respeito ${ }^{175}$ : “Era italiano. Não sei se estava privado de ordens [...] Na baixada sobre a qual passa hoje o viaduto Jacareí, o padre Gazineu possuía um imenso cortiço. Além do cortiço, era dono de casinholas na rua Senador Feijó, em cujas janelas [...] apareciam, a contar do meio-dia, senhoras "de cor", encamisoladas em cetineta decotada cor-de-rosa, azul, verde ou lilás". Adiante, o autor relata a rotina diária do padre, quando ele saía em busca do pagamento

\footnotetext{
${ }^{174}$ Obras Particulares, 30/12/1886, v. 27, p. 55.

175 AMERICANO, Jorge - “O Padre Gazineu”, São Paulo naquele tempo (1895-1915), São Paulo: Saraiva, 1957. p. 180/181.
} 
dos aluguéis em seus cortiços sendo que num deles, aparentemente, funcionava um bordel.

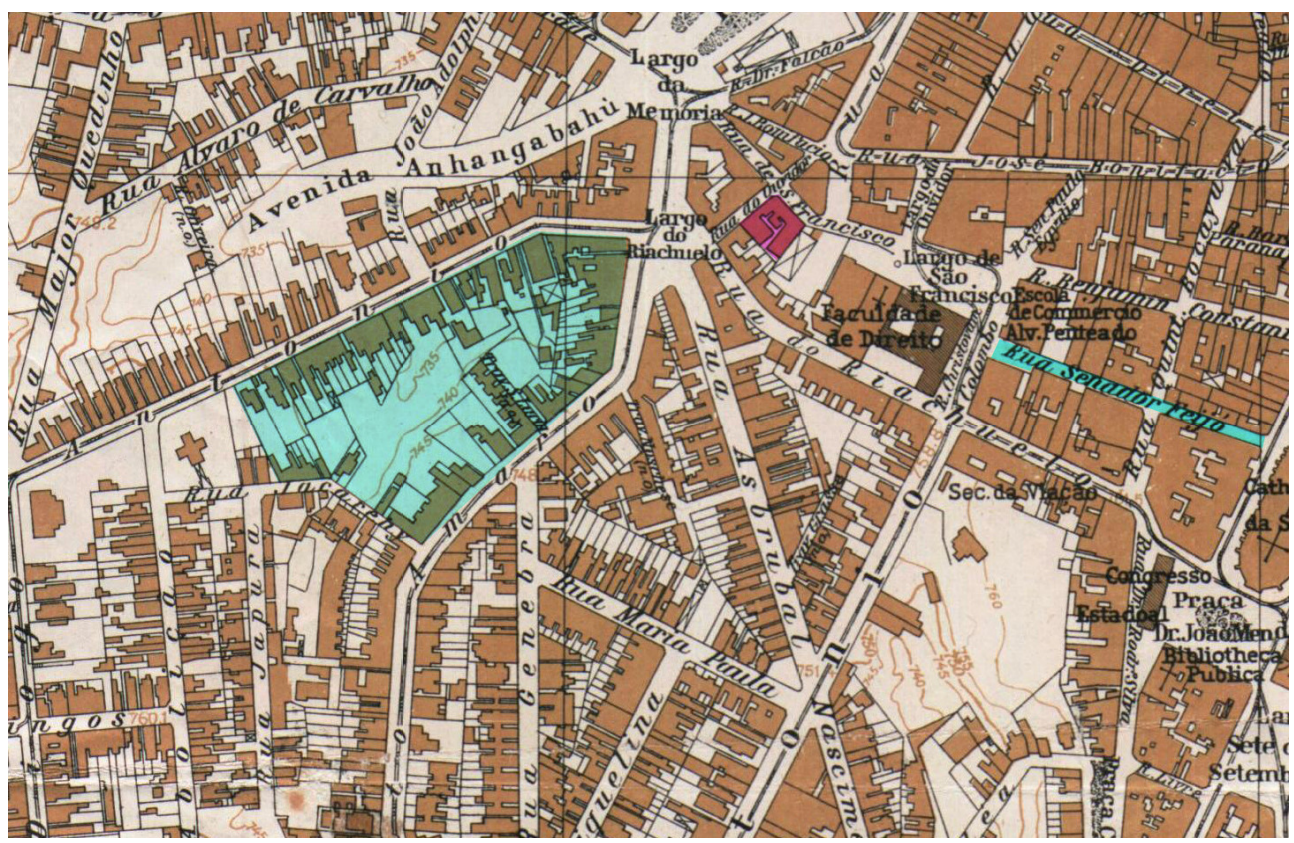

Figura 25 - Localização aproximada da área de atuação do Padre Paschoal Gazineo. Foi possível localizar somente o chalé citado por Eudes Campos, destacado em rosa. Acreditamos que os projetos apresentados à Diretoria de Obras se localizem na área destacada em verde, entre o Largo do Riachuelo e a rua da Abolição. Na mesma área, na direção das ruas Jacareí e Santo Amaro, deviam estar os cortiços a que Jorge Americano se referiu. Também assinalamos a rua Senador Feijó, local de outro cortiço do Padre Paschoal. Planta SARA Brasil, 1930, Bairro do Bexiga. Fl. 37. AHMWL

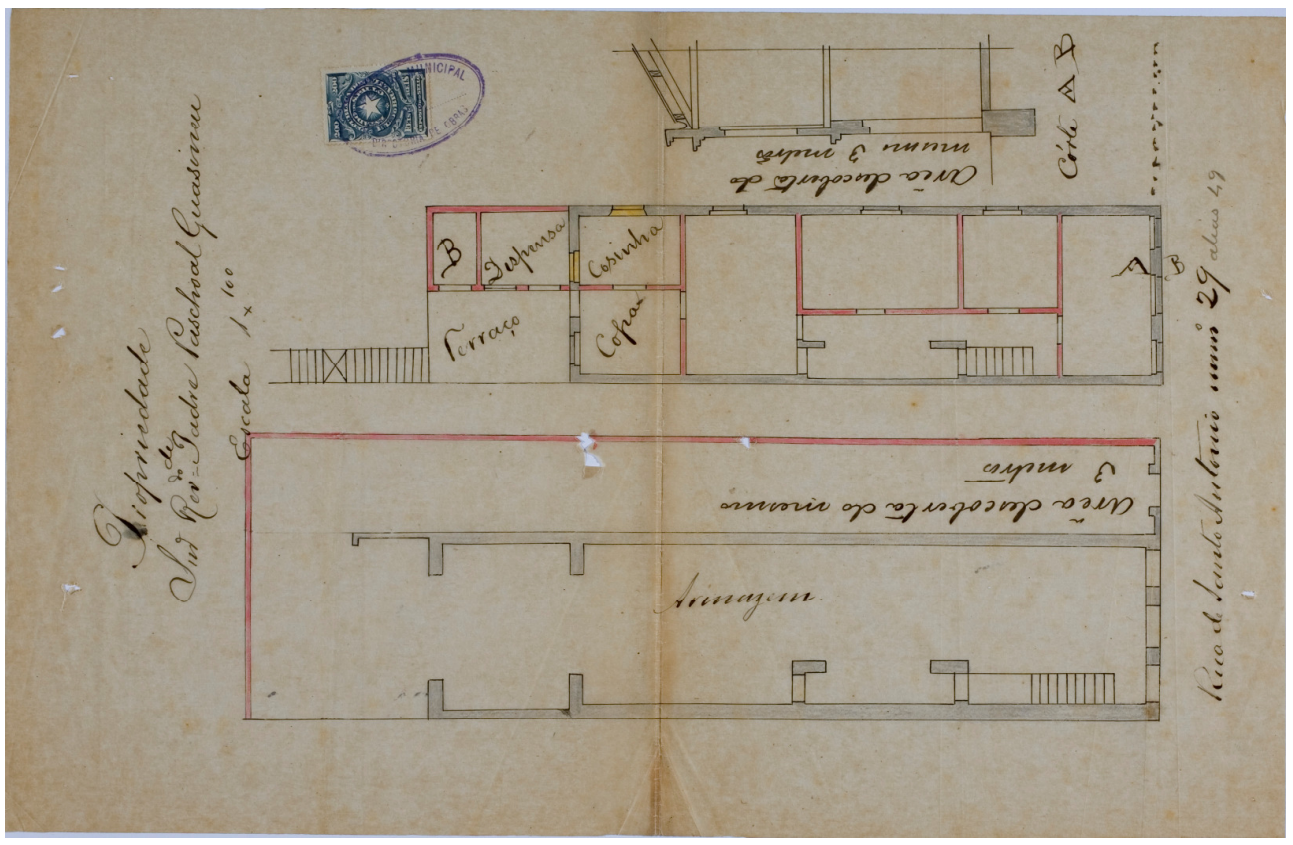

Figura 26 - Projeto de 14/05/1912, para acréscimo e reforma de casa, à rua Santo Antonio n 49. Este foi o único caso de planta identificada em nome do Padre Paschoal Gazíneo. 
Eudes Campos localizou o padre Gazíneo como proprietário de um chalé construído "entre as ladeiras que conduziam do Centro ao antigo Piques, antigas ruas do Meio (ladeira do Ouvidor) e de São Francisco. No Arquivo Histórico Municipal deparamo-nos com um auto de alinhamento lançado em 17 de junho de1886 referente a essa construção [...]" 176 .

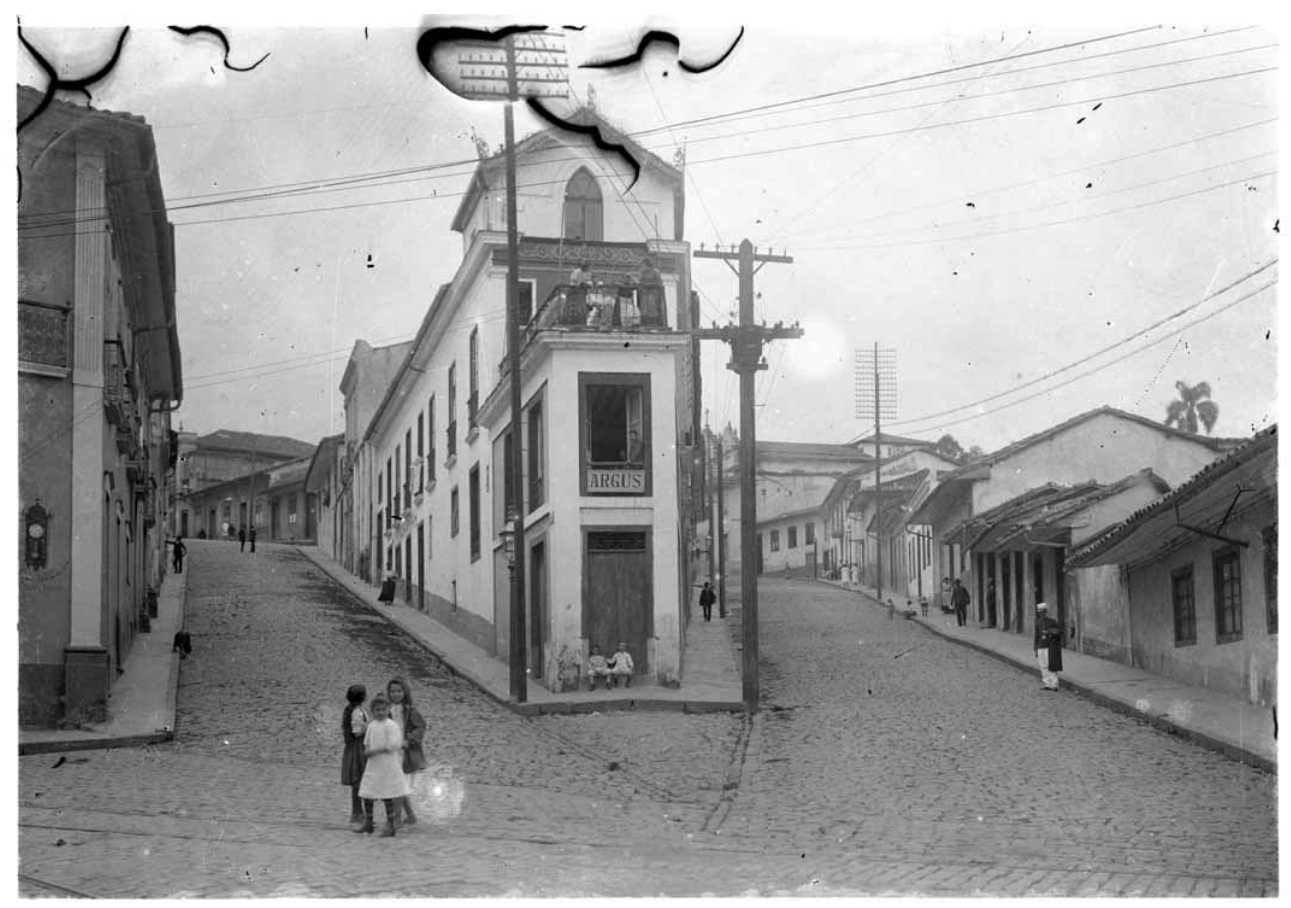

Figura 27 - Conforme as referências de Eudes Campos, o prédio construído entre 1886 e 1887, e demolido no final da década de 1950, pertenceu a Paschoal Gazineo. Localizava-se no canto das antigas Ladeiras do Ouvidor e São Francisco. Autoria desconhecida, 1900-1910. Fonte: Coleção SAN/DIM/DPH/SMC/PMSP.

Nada garante que os imóveis nos endereços acima relacionados tenham permanecido sempre em mãos dos mesmos proprietários, ou que tenham sido comercializados posteriormente à sua construção ou reforma. Mas o fato de que, em longos espaços de tempo, diferentes propriedades tenham estado nas mãos dessas pessoas confere às mesmas uma posição diferenciada em relação à grande maioria dos proprietários do bairro.

O fato de $87,05 \%$ dos imóveis do Bexiga pertencerem a pequenos e médios proprietários vem confirmar o que Luciana Gennari, em seu trabalho sobre a construção das casas em série nos bairros do Brás e da Mooca, demonstrou:

"A cidade de São Paulo foi construída pelas mãos de diferentes grupos de empreendedores regidos pelos mais diversos interesses. Sua constituição, consolidação

\footnotetext{
${ }^{176}$ CAMPOS, Eudes - “Chalés Paulistanos”, Anais do Museu Paulista, Ano/vol. 16, nº 1, Universidade de São Paulo/Museu Paulista, jan/jun 2008. p. 83 a 85.
} 
e transformação ocorreram tanto por intermédio de grandes capitais, que de uma vez formaram áreas inteiras, como também por investimentos de menor vulto, que inúmeras vezes significavam a negociação de pequenas áreas como lotes de diferentes dimensões. [...] Essas pequenas ações tinham participação nos meandros das grandes transformações, posto que as ações locais particulares compreendiam uma grande diversidade de investidores por não exigirem necessariamente grandes capitais iniciais nem outros envolvimentos organizados de qualquer ordem." 177

Homens como Joaquim Antunes dos Santos, José Maria Passalacqua e o Padre Paschoal Gazíneo que, visivelmente, investiram na construção e manutenção de edificações com o objetivo de locação para terceiros, podem ter possuído o controle locatício de diversos imóveis no bairro. Embora o resultado desse último procedimento por nós elaborado seja elucidativo do "poder de fogo" dos médios empreendedores, ele também confirma a preponderância dos pequenos investidores nesta região da cidade. Por outro lado, assim como os grandes investidores, eles também tinham como objetivo principal extrair de seus imóveis o máximo de renda possível.

O diferencial entre os dois tipos de investidores estava não somente no montante do capital investido, que eventualmente podia influenciar na qualidade, número e dimensão dos imóveis oferecidos para locação, como dependia basicamente do poder aquisitivo das pessoas que procuravam o bairro para viver. A análise dos projetos arquitetônicos apresentados por Joaquim Antunes dos Santos durante o ano de 1906, por exemplo, demonstrou projetos onde a tônica era dada por casas com três cômodos - sala, varanda e cozinha -, além da latrina contígua à última. Portanto, tratava-se de casas voltadas para as camadas mais pobres da sociedade. Assim, o atendimento às demandas desse mercado é que devia nortear a ação construtiva dos empreendedores imobiliários, fossem pequenos ou médios. Adiante, ao analisarmos as tipologias edilícias identificadas no Bexiga, veremos essa e outras formas de investimentos realizados para atingir o objetivo de lucro e atender a demanda por moradias.

A partir das informações obtidas é possível depreender que, no caso do Bexiga, a grande maioria das propriedades do bairro estava dispersa em mãos de pequenos e médios empreendedores. Talvez, gente que dispondo de poucos recursos se sujeitasse a viver em condições difíceis, morando de aluguel e procurando, através do trabalho familiar, acumular algum capital que propiciasse a compra de um lote. Quando

\footnotetext{
${ }^{177}$ GENNARI, Luciana Alem - As casas em série do Brás e da Mooca: um aspecto da constituição da cidade de São Paulo, p.34-35. Dissertação de Mestrado apresentada à FAUUSP, 2006.
} 
conseguissem fazer essa aquisição construiriam os três cômodos mínimos exigidos pela municipalidade, caso contrário, aguardariam mais algum tempo até que isso fosse possível, e assim por diante. Primeiro a compra do lote, posteriormente a construção dos primeiros cômodos, e com o passar do tempo o acréscimo de outros - esse processo é claramente visível nos processos encontrados em nome da mesma pessoa, no mesmo endereço. Após os pedidos de alinhamento para construção, quase que invariavelmente se sucederam os pedidos de licença para acréscimos. Alguns anos mais tarde, surgem os pedidos de licença para construção nos fundos do terreno, visando a locação para terceiros e, logicamente, mais alguma renda para a família. Isso, quando ao lado dos acréscimos para moradia também não apareciam os acréscimos para abertura de negócios, como mais uma forma de aumentar os rendimentos familiares. É muito provável que muitos desses atores sociais, ao construírem para a própria família, adquiriam um "saber fazer" construtivo, terminando por trabalhar para outras pessoas. 


\section{AS TIPOLOGIAS - EDIFICAÇÕES RESIDENCIAIS, DE USO} MISTO, FABRIS, MANUFATUREIRAS E COMERCIAIS

\subsection{A Série Obras Particulares: um panorama da atividade construtiva no bairro do Bexiga}

O conjunto documental da Série Obras Particulares, do AHMWL, envolve os imóveis submetidos à aprovação da Prefeitura, por particulares, por ocasião da sua construção, demolição ou reforma - prédios de uso residencial, comercial, de prestação de serviços, fabris e manufatureiros, etc. ${ }^{178}$. Os levantamentos realizados envolveram a consulta a 1.170 documentos e abrangeram um período entre 1881 e 1914, no qual a ação fiscalizadora do poder público se fez sentir de forma mais contundente.

Os dados básicos do levantamento, organizados na Tabela 2 - Universo Investigado, por ano, foram sintetizados na Tabela 17, a seguir.

\begin{tabular}{|l|c|c|}
\hline \multicolumn{1}{|c|}{ TIPOS DE SOLICITAÇÕES } & \multicolumn{1}{c|}{$\begin{array}{c}\text { NÚMERO DE } \\
\text { SOLICITAÇÕES }\end{array}$} & \% \\
\hline ALINHAMENTOS & 66 & $\mathbf{5 , 6 4}$ \\
\hline NOVAS EDIFICAÇÕES - RESIDÊNCIAS SIMPLES E MISTAS & 502 & $\mathbf{4 2 , 9 0}$ \\
\hline NOVAS EDIFICAÇÕES - FÁBRICAS E MANUFATURAS & 37 & $\mathbf{3 , 1 7}$ \\
\hline NOVAS EDIFICAÇÕES - COMÉRCIO E SERVIÇOS & 11 & $\mathbf{0 , 9 4}$ \\
\hline REFORMAS E ACRÉSCIMOS - PARA MORADIA & 265 & $\mathbf{2 2 , 6 5}$ \\
\hline REFORMAS E ACRÉSCIMOS - PARA COMÉRCIO & 71 & $\mathbf{6 , 0 7}$ \\
\hline INSTALAÇÃO REDE DE ÁGUA E ESGOTOS & 13 & $\mathbf{4 , 1 9}$ \\
\hline $\begin{array}{l}\text { RELAÇÕES COM O PODER PÚBLICO (INTIMAÇÕES, MULTAS, } \\
\text { EMBARGOS, QUEIXAS DE MORADORES, ETC.) }\end{array}$ & 49 & $\mathbf{1 3 , 3 3}$ \\
\hline $\begin{array}{l}\text { INTERVENÇÕES EXTERNAS NOS IMÓVEIS (MUROS, PASSEIOS, } \\
\text { FACHADAS, COCHEIRAS, TELHEIROS, BARRACÕES, ETC.) }\end{array}$ & 156 & $\mathbf{1 0 0 \%}$ \\
\hline TOTAL & $\mathbf{1 . 1 7 0}$ & \\
\hline
\end{tabular}

Tabela 17 - Relação percentual entre as solicitações e o universo investigado (1882-1914)

Dos 1.170 documentos:

- 952 se referem diretamente às edificações e reformas $(81,36 \%$ do universo investigado).

- 616 processos versam sobre novas edificações, aproximadamente 52,64\% da amostra total .

\footnotetext{
${ }^{178}$ De 1870 até 1906 , esse conjunto documental encontra-se encadernado e organizado por ano. A consulta é feita pelo nome do logradouro, em ordem alfabética. Entretanto, há alguns volumes especiais que envolvem anos diferentes, deixando perceber que se trata de documentos que, por algum motivo, escaparam da idéia inicial de agrupamento, tendo sido assim reunidos em volumes extras. Tais volumes, por vezes, continham documentos de outros anos, além daqueles contidos na amostra selecionada. Nesses casos decidimos pela inclusão desses documentos na amostra. São apenas 47 casos e acreditamos que pouco alteraram os resultados finais.
} 
- 156 processos versam sobre intervenções externas nos imóveis, entendidas como cercamento de terrenos ou levantamento de muros, calçamento de passeios, construção de cocheiras, barracões para depósito, etc.

- 13 processos versam sobre levantamento de calçadas, visando a instalação dos serviços de água e esgotos.

- 49 processos versam sobre "relações com o poder público", nos casos dos documentos oriundos da municipalidade com o objetivo de intimar, multar, embargar, etc.

\begin{tabular}{|c|c|c|c|c|c|}
\hline DATA & ALINHAMENTOS & RESIDÊNCIAS & $\begin{array}{c}\text { FÁBRICAS E } \\
\text { MANUFATURAS }\end{array}$ & $\begin{array}{l}\text { COMÉRCIO E } \\
\text { SERVIÇOS }\end{array}$ & TOTAL \\
\hline 1882 & 5 & - & - & - & 5 \\
\hline 1883 & 1 & - & - & - & 1 \\
\hline $1886(*)$ & 2 & - & - & - & 2 \\
\hline 1887 & 13 & - & - & - & 13 \\
\hline 1888 & 10 & - & - & - & 10 \\
\hline 1889 & 12 & 1 & - & - & 13 \\
\hline $1890(*)$ & 7 & - & - & - & 7 \\
\hline $1891(*)$ & 9 & - & - & - & 9 \\
\hline $1892(*)$ & - & 1 & - & - & 1 \\
\hline SUB TOTAL & 59 & 2 & - & - & 61 \\
\hline 1893 & 3 & 24 & - & 1 & 28 \\
\hline 1894 & 1 & 24 & - & 2 & 27 \\
\hline 1895 & - & 37 & 1 & 3 & 41 \\
\hline $1896(*)$ & - & 1 & - & - & 1 \\
\hline $1897(*)$ & - & 1 & - & - & 1 \\
\hline $1898(*)$ & - & 9 & 3 & - & 12 \\
\hline 1899 & - & 32 & 2 & - & 34 \\
\hline SUB TOTAL & 4 & 128 & 6 & 6 & 144 \\
\hline 1900 & 1 & 11 & 1 & - & 13 \\
\hline 1901 & 1 & 10 & 1 & - & 12 \\
\hline $1902(*)$ & - & 1 & - & 1 & 2 \\
\hline $1903(*)$ & - & - & - & - & - \\
\hline $1904(*)$ & - & 2 & - & - & 2 \\
\hline SUB TOTAL & 2 & 24 & 2 & 1 & 29 \\
\hline 1905 & - & 44 & 1 & 1 & 46 \\
\hline 1906 & - & 41 & 1 & - & 42 \\
\hline 1907 & - & 33 & 1 & - & 34 \\
\hline 1912 & - & 77 & 5 & 1 & 83 \\
\hline 1913 & - & 93 & 15 & 1 & 109 \\
\hline 1914 & 1 & 60 & 6 & 1 & 68 \\
\hline SUB TOTAL & 1 & 348 & 29 & 4 & 382 \\
\hline TOTAL & 66 & 502 & 37 & 11 & 616 \\
\hline
\end{tabular}

(*) Anos e registros fora da amostra selecionada.

Tabela 18 - Solicitações de licença para novas edificações, por anos de ocorrência

Destacamos, na Tabela 18, os processos correspondentes às solicitações de autorização para construção de edifícios destinados a residências simples e mistas, fábricas e manufaturas ou negócios em geral. Dos $\mathbf{6 1 6}$ processos referentes às novas edificações destacamos, particularmente, aqueles $\mathbf{5 0 2}$ relacionados a edificações para moradias simples ou mistas. Contudo, os dados sobre as reformas e acréscimos em edificações existentes são demasiado significativos para serem ignorados, principalmente aqueles correspondentes ao período de 1905 a 1914 , quando o processo 
de construção de imóveis no bairro se torna mais intenso. Juntas, as solicitações de licença para acréscimos em prédios residenciais e mistos somam 336 processos, o que significa $28,71 \%$ da amostra de $\mathbf{1 . 1 7 0}$ documentos.

Se pensarmos que os acréscimos visavam, sobretudo, aumentar a área construída das casas, seja para melhor acomodar os moradores, seja para possibilitar o exercício de atividades produtivas, a sua análise fornece informações elucidativas sobre a vida dos seus ocupantes. Dessa maneira, sempre que tais informações se mostraram importantes para esclarecer qualquer questão, foram utilizadas.

Na Tabela 19, destacamos os processos relativos às reformas e acréscimos.

\begin{tabular}{|c|c|c|c|}
\hline DATA & $\begin{array}{c}\text { REFORMAS E ACRÉSCIMOS } \\
\text { PARA MORADIA }\end{array}$ & $\begin{array}{c}\text { REFORMAS E ACRÉSCIMOS } \\
\text { PARA NEGÓCIOS }\end{array}$ & TOTAL \\
\hline 1882 & - & - & - \\
\hline 1883 & - & - & - \\
\hline $1886(*)$ & - & - & - \\
\hline 1887 & - & - & - \\
\hline 1888 & 1 & - & 1 \\
\hline 1889 & - & - & - \\
\hline 1890 (*) & - & - & - \\
\hline $1891(*)$ & - & - & - \\
\hline $1892(*)$ & - & - & - \\
\hline 1893 & 7 & 2 & 9 \\
\hline 1894 & 10 & 4 & 14 \\
\hline 1895 & 11 & 2 & 13 \\
\hline $1896(*)$ & 1 & - & 1 \\
\hline 1897 (*) & 1 & - & 1 \\
\hline $1898(*)$ & 2 & - & 2 \\
\hline 1899 & 14 & 4 & 16 \\
\hline 1900 & 17 & 1 & 18 \\
\hline 1901 & 10 & 3 & 13 \\
\hline $1902(*)$ & - & - & - \\
\hline 1903 (*) & 2 & - & 2 \\
\hline $1904(*)$ & 1 & - & 1 \\
\hline 1905 & 21 & 5 & 26 \\
\hline 1906 & 23 & 1 & 24 \\
\hline 1907 & 20 & 10 & 30 \\
\hline 1912 & 30 & $4^{179}$ & 34 \\
\hline 1913 & 54 & $13^{180}$ & 67 \\
\hline 1914 & 40 & 22 & 62 \\
\hline TOTAL & 265 & 71 & 336 \\
\hline
\end{tabular}
ocorrência

Tabela 19 - Solicitações de licença para realização de reformas e acréscimos, por anos de

Como já mencionado, os pedidos de licença para edificação de moradias portadoras das mais diversas tipologias somam 502, com um percentual de $81,49 \%$ sobre o total dos 616 processos construtivos. As edificações para uso exclusivamente fabril ou manufatureiro somam 37 casos, aproximadamente $6 \%$ da amostra de 616; e aquelas de uso comercial e/ou destinadas à prestação de serviços somam 11 casos, apenas $1,78 \%$ desse total.

\footnotetext{
${ }^{179}$ Uma reforma para instalação de cinema.

${ }^{180}$ Um acréscimo para instalação de uma escola.
} 


\begin{tabular}{|c|c|c|}
\hline USOS & UNIDADES & $\%$ \\
\hline MORADIA & 502 & 81,49 \\
\hline FÁBRICAS & 37 & 6 \\
\hline COMÉRCIO & 11 & 1,78 \\
\hline
\end{tabular}

Tabela 20 - Percentual dos usos, em relação ao total de edificações

Através dos dados apresentados na Tabela 2, onde estão contabilizados os pedidos de alinhamento que indicam a intenção de edificar sem quaisquer especificações, percebemos que da primeira década do loteamento até 1889 houve um crescimento moderado de, no máximo, 13 novas edificações por ano. Esse processo começou a se intensificar em 1893, com 28 novas edificações, até $\mathbf{1 8 9 5}$, quando foi atingida a cifra de 41 edificações/ano. Em 1899 o número de construções decaiu para 34 novas edificações, chegando a apenas 12 em 1901 e voltando a subir a partir de 1905, agora num movimento quase sempre ascendente, chegando ao número máximo de 109, em 1913.

A análise das Tabelas 18 e 19 revela que em 1914 houve um decréscimo no número das novas construções para moradia ou negócio. A paralisação do setor que há anos apresentava um crescimento contínuo deve ser analisada sob um ponto de vista mais abrangente. Desde 1913, o agravamento da crise econômica mundial com a consequente paralisação do mercado do café refletiu-se nos setores produtivos nacionais, trazendo recessão, alta de preços e desemprego. O problema se agravaria com a Primeira Guerra Mundial, em 1914, e a indústria da construção civil não ficaria imune. Castellucci, ao abordar as implicações das "flutuações econômicas e da crise política" no decorrer da Primeira República na Bahia, revela que no caso da construção civil:

"Em 1914, os recursos foram se tornando mais escassos e os materiais começaram a faltar, além de estarem cada vez mais caros e só poderem ser pagos à vista. As obras, então, tornaram-se mais lentas e algumas foram suspensas ou paralisadas [...] $O$ enorme contingente operário, contratado e estabelecido na cidade nos anos anteriores, rapidamente converteu-se num grande exército industrial de reserva e um período de desemprego, subemprego [...]" 181

Significativamente, no mesmo ano de 1914, o único setor a apresentar alta na atividade construtiva no Bexiga foi aquele dedicado às reformas e acréscimos para negócios, o que nos leva a pensar na hipótese de que em tempos de alta de preços e

\footnotetext{
${ }^{181}$ CASTELLUCCI, Aldrin A. S. - "Flutuações econômicas, crise política e greve geral na Bahia da Primeira República”, in Revista Brasileira de História, vol.25 n. 50 São Paulo, Jul/Dez. 2005. Disponível em: http://redalyc.uaemex.mx
} 
desemprego reformar a casa para abrir um negócio podia ser uma solução viável para escapar da crise; ou que os pequenos e médios empreendedores que ainda dispusessem de algum capital preferissem investir em negócios próprios e menos arriscados.

Esse panorama suscinto configura duas fases de apogeu do crescimento do bairro, a primeira, de 1882 até 1899; a segunda, de 1905 até 1914, último ano por nós investigado. Parece-nos que as duas últimas décadas do século XIX assistiram ao primeiro surto construtivo vivido pela cidade ainda em fins do Império. Desde os anos 1870, São Paulo iniciou sua expansão urbana. O crescente afluxo de estrangeiros a partir de 1880/1890 implicou na demanda por novas moradias e novos bairros foram se formando. Prova disso são os inúmeros anúncios nos jornais da época, alardeando as vantagens desse ou daquele empreendimento nos novos bairros. Porém, num primeiro momento isso ocorreu numa intensidade mais ou menos estável, excetuando-se o ano de 1895, quando esse ritmo intensificou-se mais. Conforme os dados fornecidos pela EMPLASA $^{182}$, a população total de São Paulo e seus arredores pulou de 47.697 habitantes, em 1886, para 239.820, em 1900. Ou seja, o número de habitantes cresceu mais de $500 \%$ num período de apenas 14 anos! Segundo Zuleika Alvim ${ }^{183}$, no decênio compreendido entre 1880 e 1889, chegaram cerca de 144.654 imigrantes italianos para o estado de São Paulo. Esse número subiu para 430.243 indivíduos, na década seguinte, caindo para 174.634, entre os anos 1900/1909. No total, durante esses anos, teriam entrado em território paulista aproximadamente 749.531 italianos. Não vamos nos arriscar a estabelecer algum prognóstico sobre o número de pessoas que foi viver no Bexiga a partir desses dados, até porque não foram apenas imigrantes italianos que o ocuparam. Os números apresentados pela autora se referem a todo o estado, não sendo possível dimensionar os imigrantes que ficaram na cidade, ou que para cá vieram após alguns anos de trabalho no campo, e menos ainda quantos foram viver no Bexiga. Porém, os dados são suficientes para termos uma noção do crescimento populacional da cidade e do que isso pode ter significado em termos da ocupação do bairro.

Retomando as edificações, constatamos que a grande maioria das edificações para moradia, simples ou mistas, foi construída no último período, entre 1905 e 1914.

\footnotetext{
${ }^{182}$ EMPLASA - Memória Urbana, a grande São Paulo até 1940, vol.2, Tabela 11, Arquivo do Estado/Imprensa Oficial, 2001. p.29.

${ }^{183}$ ALVIM, Zuleika - Brava Gente! Os italianos em São Paulo, 1870-1920, Brasiliense: São Paulo, 1986, $2^{\mathrm{a}}$. Edição, p.120.
} 


\begin{tabular}{|c|c|c|}
\hline ANOS & $\begin{array}{c}\text { PRÉDIOS SIMPLES } \\
\text { E MISTOS }\end{array}$ & PERCENTUAL \\
\hline $\mathbf{1 8 8 2} / \mathbf{1 8 9 9}$ & 130 & $\mathbf{2 5 , 9 0}$ \\
\hline $\mathbf{1 9 0 0 / 1 9 0 4}$ & 24 & $\mathbf{4 , 7 8}$ \\
\hline $\mathbf{1 9 0 5 / 1 9 1 4}$ & 348 & $\mathbf{6 9 , 3 2}$ \\
\hline TOTAL & $\mathbf{5 0 2}$ & $\mathbf{1 0 0 \%}$ \\
\hline
\end{tabular}

Tabela 21 - Percentual de edificaçõe,s para uso residencial e misto

Quanto às edificações para fins comerciais, foi também nesse período que se concentrou o maior número de solicitações. Se relacionarmos o número dessas edificações (48) com o total das novas edificações (616), a relação percentual será de apenas $7,79 \%$. Entretanto, embora o número de prédios comerciais tenha sido muito menor do que os residenciais, seu ritmo de crescimento se manteve coerente à tendência delineada por aqueles.

\begin{tabular}{|c|c|c|c|c|}
\hline ANOS & $\begin{array}{c}\text { FÁBRICAS E } \\
\text { MANUFATURAS }\end{array}$ & $\begin{array}{c}\text { COMÉRCIO E } \\
\text { SERVIÇOS }\end{array}$ & TOTAL & PERCENTUAL \\
\hline $\mathbf{1 8 8 2 / 1 8 9 9}$ & 6 & 6 & 12 & $\mathbf{2 5}$ \\
\hline $\mathbf{1 9 0 0 / 1 9 0 4}$ & 2 & 1 & 3 & $\mathbf{6 , 2 5}$ \\
\hline $\mathbf{1 9 0 5 / 1 9 1 4}$ & 29 & 4 & 33 & $\mathbf{6 8 , 7 5}$ \\
\hline TOTAL & $\mathbf{3 7}$ & $\mathbf{1 1}$ & $\mathbf{4 8}$ & $\mathbf{1 0 0 \%}$ \\
\hline
\end{tabular}

Tabela 22 - Percentual de edificações para uso comercial

O primeiro ponto a nos chamar a atenção na leitura dos processos para edificação, refere-se à quase absoluta ausência de projetos arquitetônicos nos primeiros dez anos do loteamento do bairro. Entre 1882 e 1914, encontramos 66 requerimentos cuja solicitação se referia a "alinhamento para edificação", sem nenhuma especificação sobre o imóvel ${ }^{184}$. Desses, até 1892, havia $\mathbf{5 9}$ solicitações de alinhamento

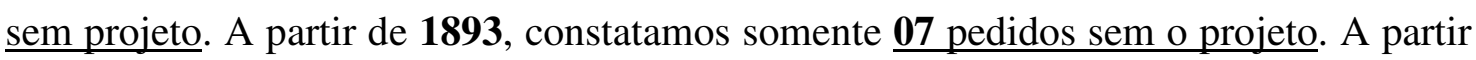
de 1893, na cidade de São Paulo, se tornou obrigatória a aprovação das plantas dos edifícios a serem construídos, exigência que se estenderia ao nível estadual no ano seguinte $^{185}$, com a criação do primeiro Código Sanitário.

\begin{tabular}{|c|c|}
\hline ANO & 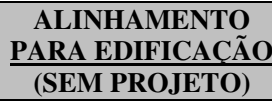 \\
\hline $1882 / 1892$ & 59 \\
\hline 1893/1914 & 7 \\
\hline TOTAL & 66 \\
\hline
\end{tabular}

Tabela 23 - Pedidos de alinhamento para edificação, sem projeto arquitetônico

\footnotetext{
${ }^{184}$ É importante destacar que esses requerimentos podem se referir a edificações para moradia (de uso simples ou misto) e para instalação de qualquer tipo de negócio (comércio, serviço, fabril e manufatureiro). Portanto, os 66 requerimentos sem identificação de uso se relacionam ao conjunto de 616 requerimentos para algum tipo de edificação.

${ }^{185}$ CAMPOS, Eudes - Arquitetura paulistana sob o Império. Aspectos da formação da cultura burguesa em São Paulo. Tese apresentada à FAUUSP, v.3, p. 580-612.
} 
De 1893 a 1914, os projetos arquitetônicos se tornam presentes em praticamente todos os processos.

\subsection{Identificação das tipologias e programas arquitetônicos predominantes}

A leitura dos processos da Série das Obras Particulares do AHMWL, assim como dos projetos arquitetônicos ali contidos, demonstrou que o bairro do Bexiga apresenta um universo bem mais complexo do que aquele relatado por Carlos Lemos em A República ensina a morar (melhor) (1999) e por Luciana Gennari em As casas em série do Brás e da Mooca (2005). No início da análise dos processos acreditávamos que os critérios metodológicos utilizados por esses autores seriam suficientes para o nosso trabalho. Porém, ao tentarmos identificar as formas de ocupação do espaço, com base na implantação dos imóveis nos lotes, das tipologias edilícias e dos programas arquitetônicos predominantes, nos deparamos com uma certa diversidade de soluções que, embora de número restrito, era impossível de ser ignorada. O aproveitamento de terrenos irregulares, através da "reinvenção" de tipologias usuais, adequando as necessidades programáticas às condições dos terrenos, bem como a introdução das casas tipo "apartamento" ${ }^{186}$, otimizando o aproveitamento do espaço, foram exemplos da diversidade encontrada no bairro. Ainda que essas soluções não fossem a regra, levantaram questões sobre o construir por parte de uma parcela dos produtores daquele espaço, dando origem ao que chamaríamos de traços de individualidade do bairro, traços estes relacionados à diversidade social dos atores que ali atuaram.

A ocupação da área abrangida pelo bairro do Bexiga foi condicionada por alguns aspectos geográficos determinantes: a topografia irregular e de difícil acesso e a proximidade dos rios Anhangabaú, Saracura e Bexiga, onde as baixadas, próximas aos cursos d'água e sujeitas a constantes cheias e inundações na época das chuvas, foram marcadas por más condições de salubridade e pela dificuldade natural de acesso a outras regiões da cidade. Esses fatores, de certa maneira, determinaram o direcionamento do empreendimento a uma parcela da população de baixo poder aquisitivo e com poucas chances de escolha. Nesse sentido é que o imigrante italiano de

\footnotetext{
${ }^{186}$ Sobrados contendo duas habitações unifamiliares: uma no térreo e outra no pavimento superior.
} 
poucas posses mostrou-se como o sujeito ideal para ocupar o loteamento, seja construindo, seja vivendo nas casas ali construídas. Não apenas italianos ali se encontraram. Também os negros e mulatos egressos da escravidão, sem inserção no mercado formal de trabalho, viveram no bairro, principalmente na região do Saracura $^{187}$, nas proximidades da rua da Saracura Grande - ocupada atualmente pelo leito da avenida Nove de Julho (altura aproximada das atuais ruas Almirante Marques Leão, Una e Rocha, e da praça 14 Bis). Essa foi uma das áreas mais prejudicadas, tanto pelas condições topográficas como pela ausência de infra-estrutura urbana, que só chegaria ali anos mais tarde, a partir do prolongamento da rua Conselheiro Carrão e da abertura das vias apontadas acima.

Enfim, para compreender como esses atores sociais se apropriaram do bairro, nessas condições específicas, foi necessário pensar em outras formas de abordagem que abarcassem a complexidade do universo investigado. Primeiro, identificamos as formas de implantação nos lotes; em seguida, detalhamos as tipologias edilícias adotadas e organizadas pelo número de cômodos construídos; por fim, analisamos o caso especial dos cortiços. Inserimos cópias de alguns projetos, de modo a contemplar os casos exemplares.

\section{Implantação nos lotes}

Durante os primeiros anos do loteamento, a ocupação dos lotes se mostrou bastante "tradicional", caracterizando-se basicamente por:

a) Lotes de testada estreita e compridos, possuindo aproximadamente $5 \mathrm{~m}$ de frente por $50 \mathrm{~m}$ de fundo. Podiam ocorrer lotes menores, com um mínimo de até 4 metros de frente, ou ainda lotes que ultrapassavam essas medidas, com uma média de 6 a 7 metros de frente. Em relação à profundidade dos terrenos, com o avançar dos anos, percebemos uma certa tendência para a construção no fundo dos lotes, especialmente a partir da década de 1910, implicando na consequente diminuição das áreas livres destinadas aos quintais. Dentro das casas, encontramos uma forma típica de

\footnotetext{
${ }^{187}$ WISSENBACH, Maria Cristina Cortez. Ritos de Magia e Sobrevivência - Sociabilidades e práticas mágico-religiosas no Brasil (1890-1940). Tese de Doutorado, São Paulo, FFLCH/USP, Depto. de História, 1997, p. 78. In KOGURUMA, Paulo - A saracura: ritmos sociais e temporalidades da metrópole do café (1890-1920), Revista Brasileira de História, v.19, n 38, São Paulo, 1999.
} 
distribuição espacial dos cômodos: todos enfileirados, desde a sala da frente até a cozinha nos fundos, à exemplo da Figura 28.

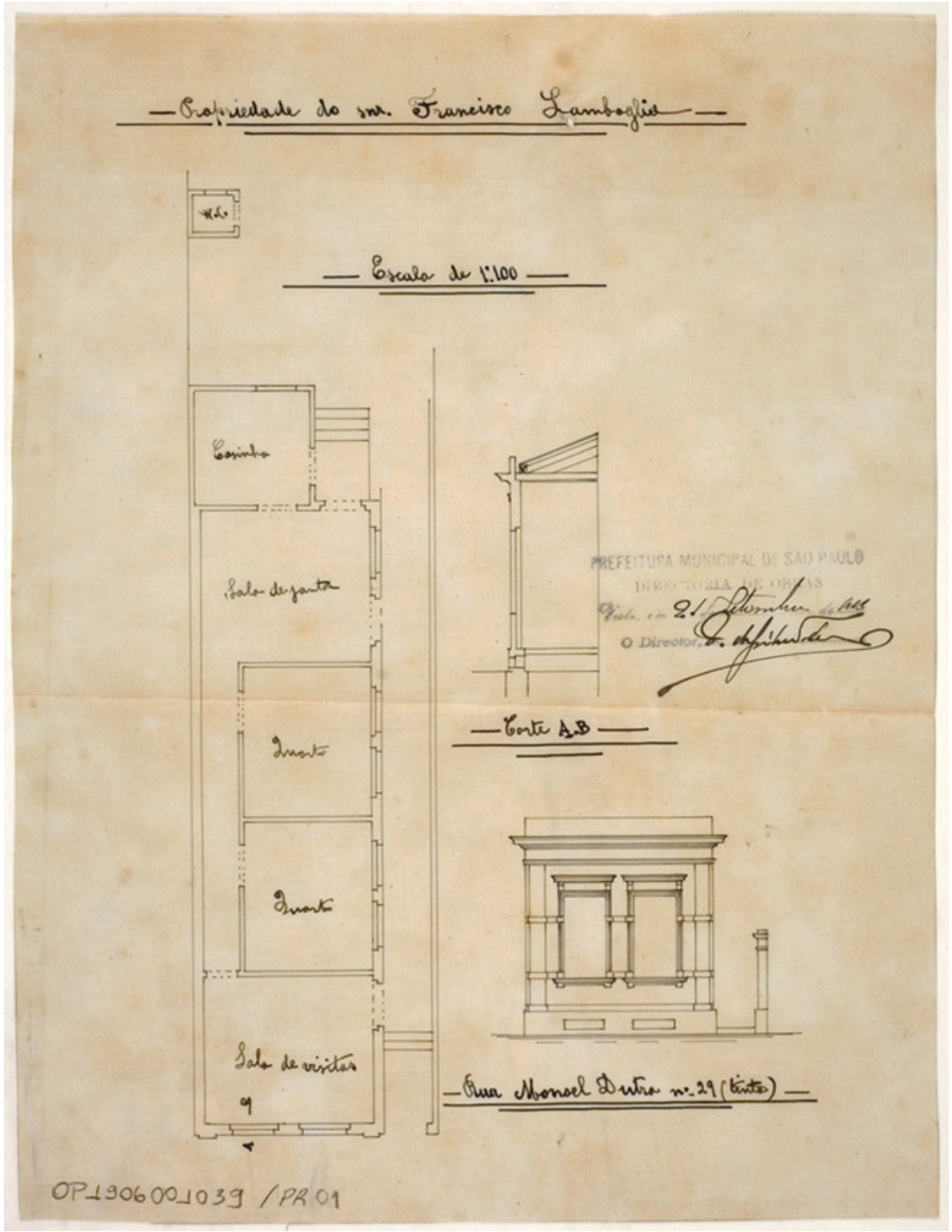

Figura 28 - Esta planta se refere a uma casa a ser construída à rua Manoel Dutra ${ }^{\circ} 29$ (tinta), para Francisco Lamboglia, em 1906. Ela nos mostra uma forma tradicional de implantação no lote. Construída no alinhamento, a casa térrea sobre porão apresenta fachada com duas janelas voltadas para a rua e um corredor lateral de onde se tem acesso ao interior da residência através de duas portas, uma na sala de visitas e outra na sala de jantar. O corredor lateral também leva ao quintal. Nos fundos do quintal, à esquerda, a latrina. Internamente, da sala de visitas parte um corredor, dando acesso a dois quartos e à sala de jantar que se comunica com a cozinha. Nos quartos e na sala de jantar abrem-se janelas para o corredor lateral e, da cozinha para o quintal. Embora não seja possível identificar a proporção exata dos cômodos, devida à ausência de escala gráfica, as informações contidas no respectivo processo informam tratar-se de uma casa com 6,40m de frente e área construída total de $95 \mathrm{~m} 2$. O corte indica a cobertura e a platibanda, bem como o afastamento do assoalho do solo, aparentemente inferior a $50 \mathrm{~cm}$; pé direito por volta de 4m. Fonte: Obras Particulares, Processo de 18/09/1906, Cx. M1-09. AHMWL. 
Diversas plantas demonstram que em casos de terrenos de difícil aproveitamento se procurou tirar partido do espaço disponível. As Figuras 29, 30 e 31 , a seguir, ilustram alguns desses casos.

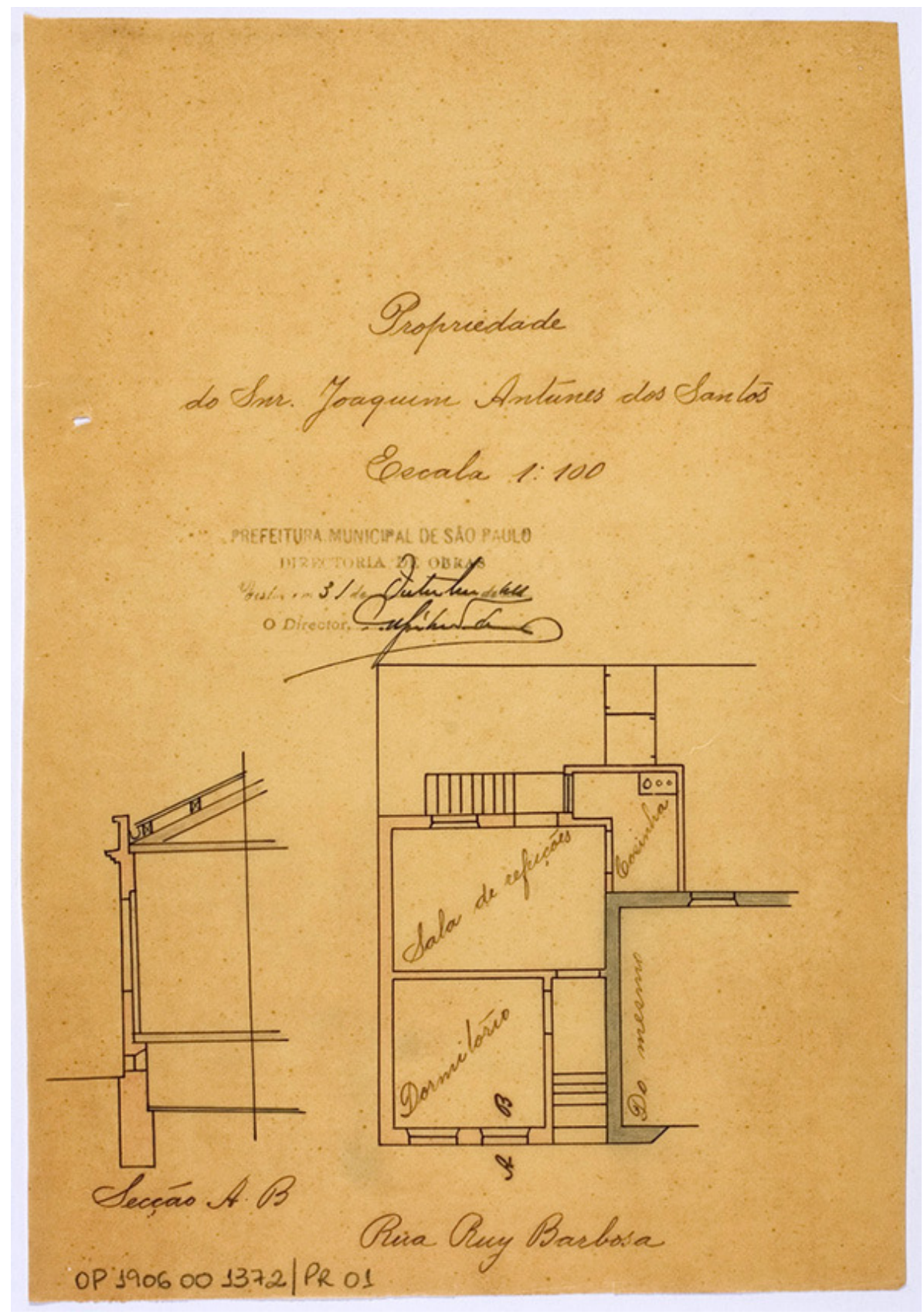

Figura 29 - Projeto de uma casa à rua Rui Barbosa $s / n^{\circ}$, de Joaquim Antunes dos Santos. Ali temos o aproveitamento de pequena área ao lado e atrás de outra propriedade "do mesmo" dono. No alinhamento, dormitório com janelas para a rua; entrada lateral, através de um pequeno corredor, com portas para o dormitório e para a "sala de refeições". Não há ligação interna entre esses cômodos, apenas a sala possui portas para a cozinha e para a escada que dá acesso aos fundos do lote. A cozinha, em forma de $\underline{L}$, não possui janela para o exterior, apenas uma porta para os fundos. No quintal há duas latrinas, uma com porta para esta casa, e outra para a casa vizinha. O corte indica a cobertura e a platibanda, bem como o porão. Não há detalhamento sobre as medidas do pé direito da casa e do porão. O corte também aponta as alturas mínimas exigidas: $4 \mathrm{~m}$ de pé direito e $50 \mathrm{~cm}$ de distância entre o assoalho e o solo. Fonte: Obras Particulares, Processo de 24/10/1906. Cx. Q1-R1. AHMWL. 


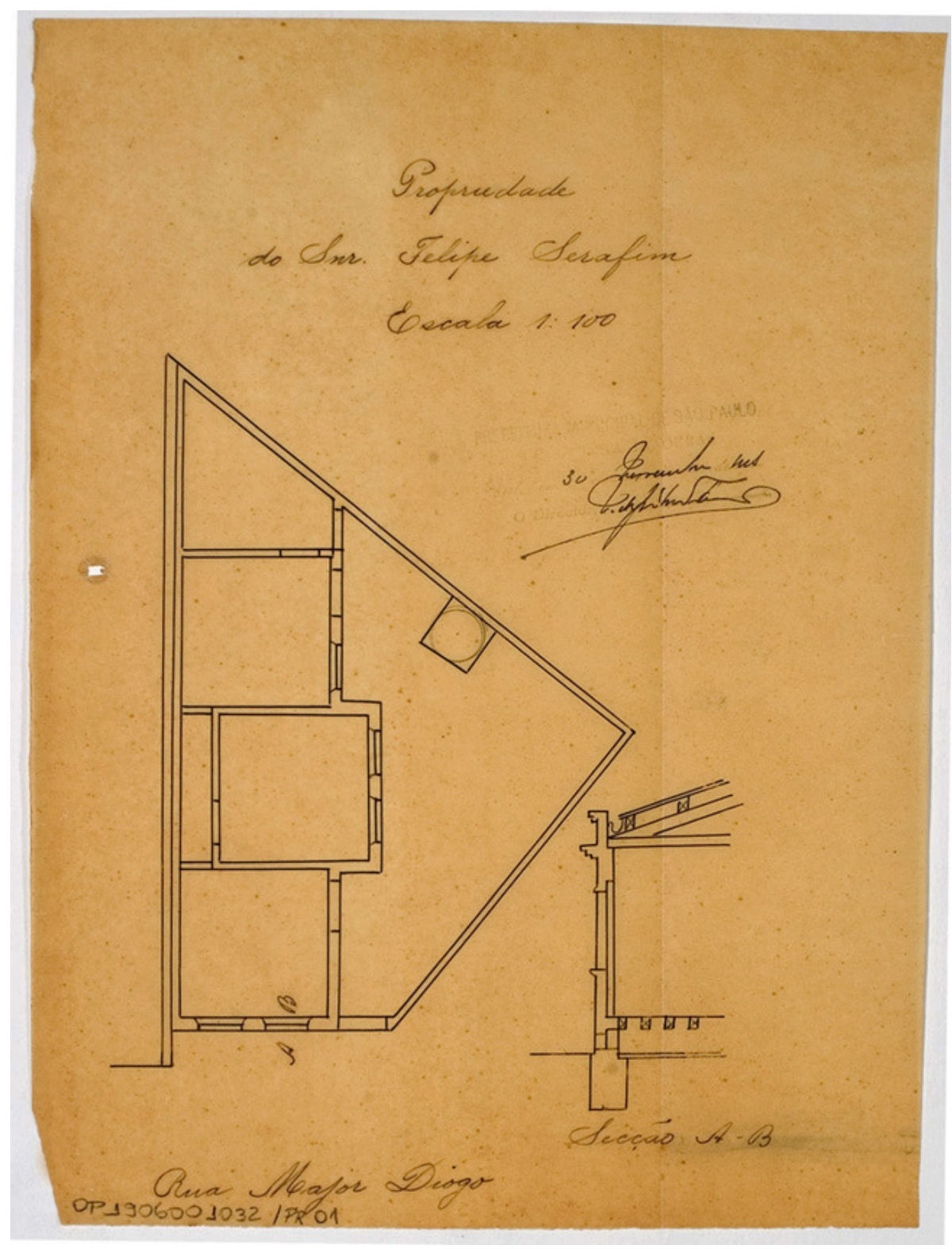

Figura 30 - Projeto de casa para Phelipe Serafim, à rua Major Diogo s/no (junto ao 121). Ali a implantação não chega a ser muito diferente do modelo tradicional, se destacando pelo formato do quintal, em "triângulo". O quintal lateral é amplo e com latrina. Internamente, quatro cômodos poderiam ser interpretados como sala, quarto, sala de jantar e cozinha; o quarto e a sala de jantar abrem janelas para o quintal. Ligação entre a primeira sala e o restante da casa através de estreito corredor interno. No provável quarto, a parede voltada para o quintal parece tentar recuperar a área perdida com a introdução do corredor interno. A provável cozinha aproveita o canto posterior do triângulo, no final da edificação, e não possui janela, apenas uma porta para o quintal. A casa tem $5,60 \mathrm{~m}$ de frente e área construída de 65 $\mathrm{m} 2$. O corte, além de indicar cobertura e a platibanda, aponta para as alturas mínimas exigidas: 4m de pé direito e 50cm de distância entre o assoalho e o solo. Fonte: Obras Particulares, Processo de 17/11/1906. Cx. M1-09. AHMWL. 


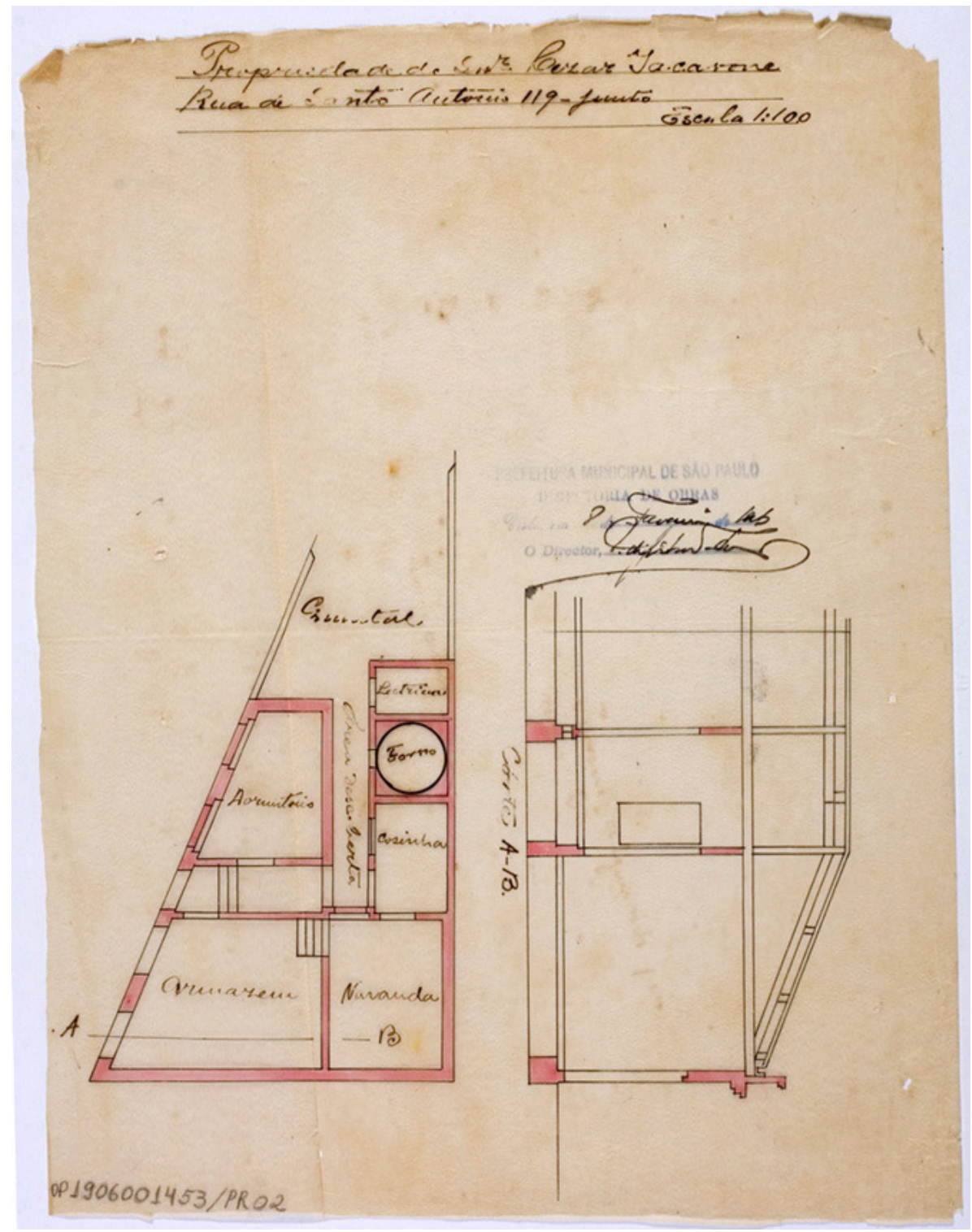

Figura 31 - Projeto para construção de casa com armazém, para Cezar Tacavone, à rua Santo Antonio, junto ao $n^{\circ} 119$. A implantação desse prédio difere em tudo da Figura 30, apresentando lote no formato de uma espécie de trapézio. No alinhamento de 11,40m, armazém, com duas portas para a rua, dormitório (também com janelas para a rua) e o quintal. Entre os dois cômodos, corredor com acesso ao interior e à uma "área descoberta". O acesso à varanda, à cozinha, ao forno e à latrina também é feito através do corredor descoberto. $\mathrm{O}$ único acesso ao dormitório é aquele através do corredor de entrada. O corte indica a cobertura e a platibanda; o porão, com cerca de $50 \mathrm{~cm}$, abrange apenas a área íntima da casa, sendo que o armazém deve ser construído sobre o solo. O pé direito da residência deve ter por volta de 4,50m. Área construída de 82,42 m2. Observa-se que este projeto, como o anterior, demonstra formas de aproveitamento de lotes irregulares. Fonte: Obras Particulares, Processo de 29/01/1906. Cx. S1-12. AHMWL. 
b) Casas construídas no alinhamento, por vezes um pouco recuadas, o que no caso do bairro naquele período nem sempre traduzia a intenção de um jardim, mas, mais frequentemente, a intenção de dar espaço a uma futura sala ou ainda a um posterior salão de negócios. Um caso típico de acréscimo para introdução de cômodos, data de 16/08/1912, na rua Quatorze de Julho, nº 46, quando Donato Picasso solicitou licença para "construir dois cômodos em sua casa, conforme a planta junta" (Figura 32).

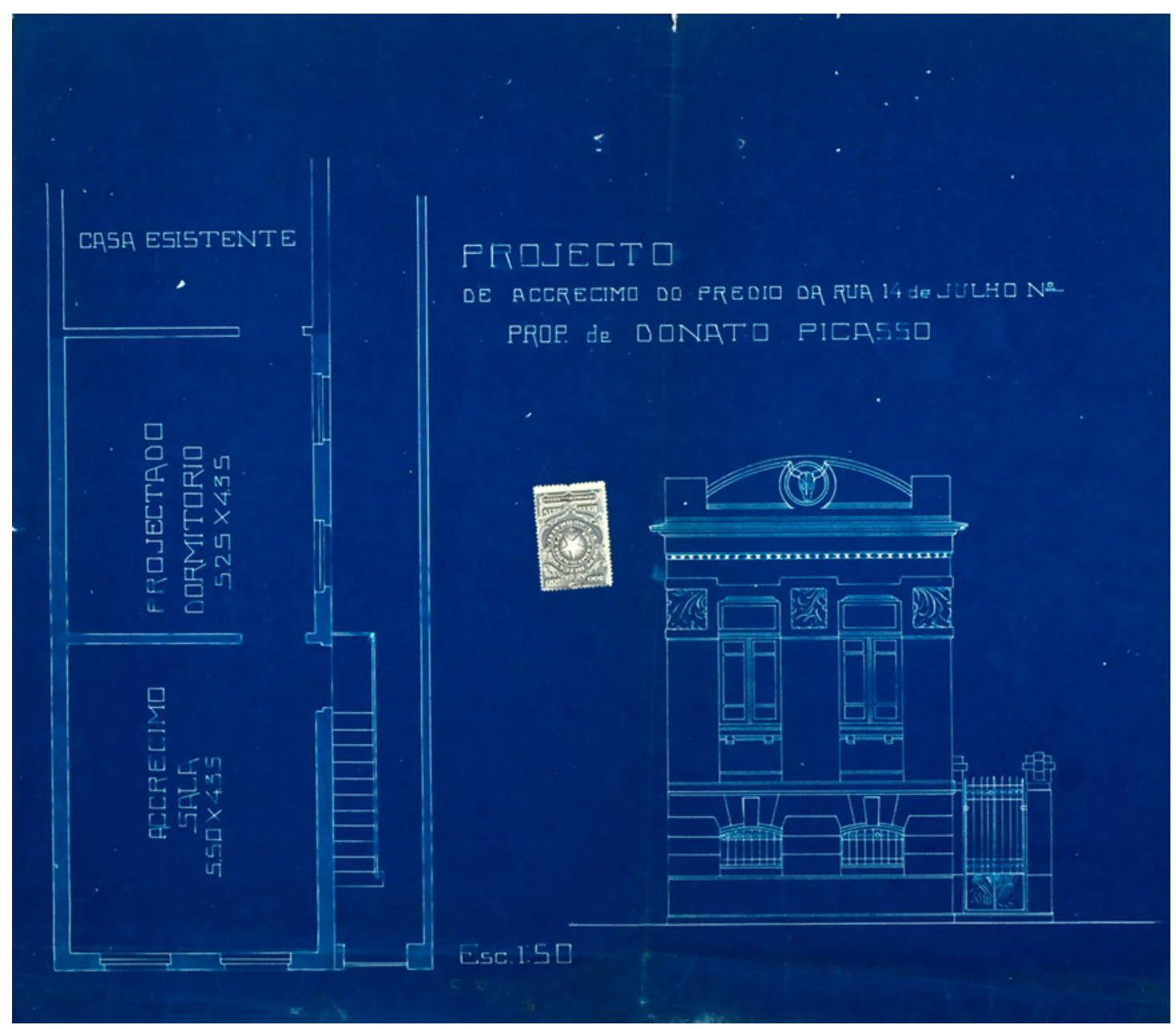

Figura 32 - O projeto de Donato Picasso apresenta parte de uma casa existente, distante cerca de $10,75 \mathrm{~m}$ do alinhamento. A planta indica o acréscimo, no alinhamento, de uma sala, com 5,50m x 4,35m, seguida de um dormitório, com 5,25m x 4,35m. O acesso à sala e, provavelmente, aos fundos da residência deveria ser feito através de corredor descoberto, para onde também davam as janelas dos cômodos posteriores. A circulação passava, necessariamente, pelo interior dos cômodos, já que não havia corredor interno. A elevação, além de demonstrar duas janelas voltadas para a rua, platibanda e porão, aponta para pé direito de aproximadamente 4,40m e cerca de 50cm de porão. Fonte: Obras Particulares, 16/08/1912, Cx. P4/Q1. AHMWL. 
Também foi muito comum encontrarmos pessoas pedindo licença para acrescentar uma pequena "sala de negócios" à edificação existente, tal como Vicente Policastro que, em 06/05/1914, pediu licença para aumentar o prédio da rua Santo Antonio $\mathrm{n}^{\mathrm{o}} 254^{188}$. Porém, mais comuns foram os casos de acréscimo nos fundos de "casa existente", onde os requerentes pretendiam aumentar o espaço doméstico da edificação. Um bom exemplo disso é a Figura 33, onde o projeto arquitetônico propõe tal tipo de acréscimo.

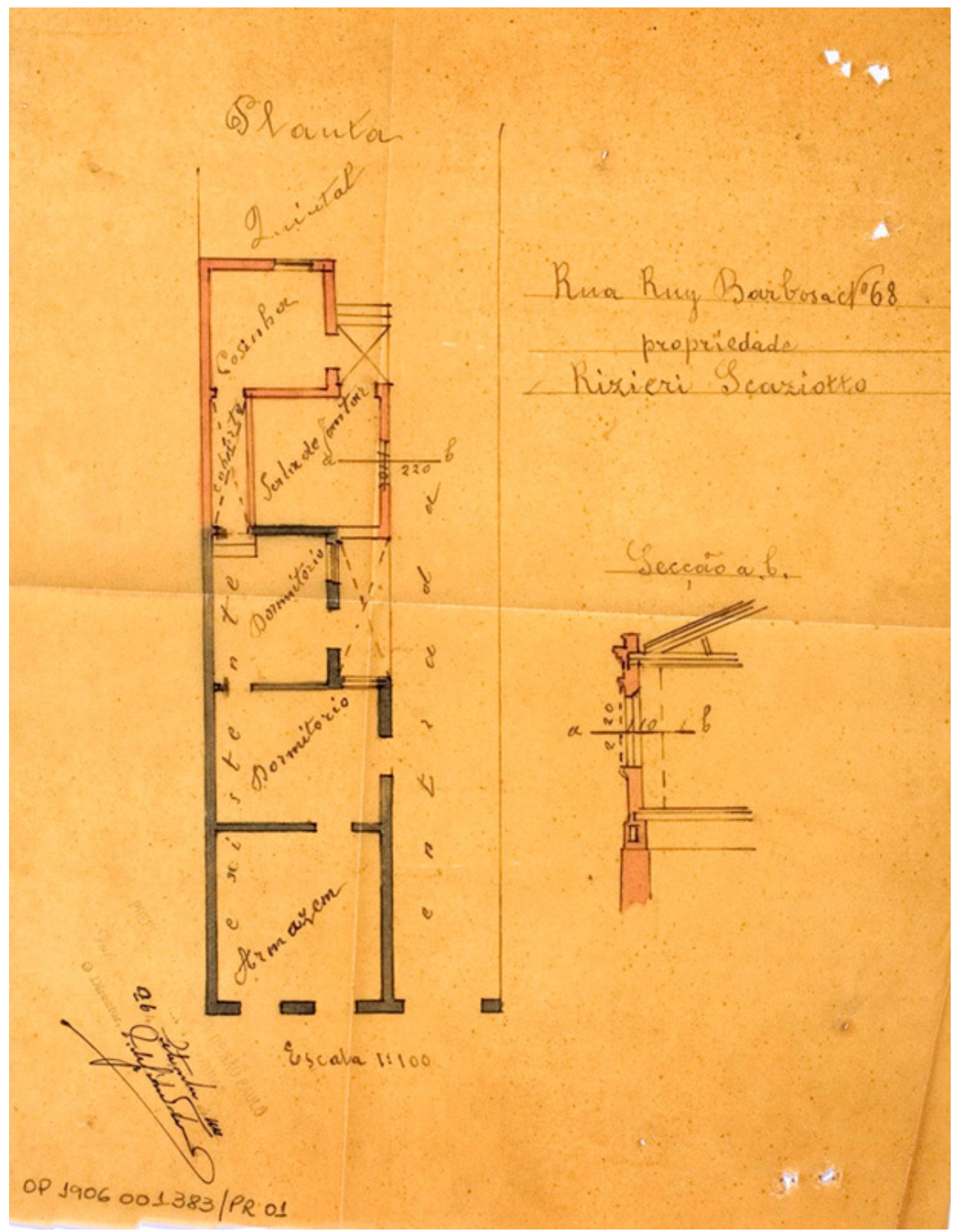

Figura 33 - Projeto de acréscimo para a casa à rua Rui Barbosa, 68, de propriedade de Rizieri Scaziotto. $\mathrm{O}$ acréscimo proposto consta de sala de jantar e cozinha, nos fundos da casa. A partir do último dormitório há um pátio de iluminação levando à cozinha que, por sua vez, dá acesso à sala de jantar. Os dormitórios possuem janelas para outro pátio de iluminação; a sala de jantar para o corredor lateral; e a cozinha, para o quintal. O corte demonstra a presença da platibanda. Embora a planta não defina as alturas da residência, tudo parece indicar estarem dentro dos padrões previstos: mínimo de $50 \mathrm{~cm}$ de porão e $4 \mathrm{~m}$ de pé direito. Fonte: Obras Particulares, 04/09/1906, Cx. Q1/R1. AHMWL. 
É importante destacar que em nenhum momento encontramos qualquer indicação nos pareceres técnicos elaborados pela municipalidade sobre a obrigatoriedade de se construir no alinhamento. Por outro lado, em processo de 1913, encontramos uma situação inversa. Nele, Joaquim Fernandes Pinto solicita licença para construção de oito casas na esquina das ruas do Sol (atual Dr. Luís Barreto), nº 69, e Conselheiro Carrão ${ }^{189}$. Conforme o parecer do engenheiro responsável, “nas ruas novas abertas no Morro dos Ingleses as construções devem ficar afastadas do alinhamento 5 metros [...]”. Essa recomendação indica que as intenções para a ocupação daquela área visavam uma implantação diferenciada, se pensada em termos do bairro da Bela Vista. Aqui se tratava de estabelecer a obrigatoriedade de um recuo mínimo de 5 metros. Atualmente, a região compreendida pelo Morro dos Ingleses ruas dos Ingleses, Franceses, Belgas, Holandeses e Alemães - se distingue pela presença de algumas casas de classe média alta, remanescentes daquela época e, ali o recuo do alinhamento é constante. Entretanto, as recomendações da municipalidade não chegaram a atingir os arredores, já que o projeto apresentado por Fernandes Pinto, para a construção das casas no alinhamento, terminou sendo aprovado.

De qualquer maneira, sentimos necessidade de esclarecer a questão, buscando informações na legislação reguladora das atividades construtivas. Em 14 de dezembro de 1900 , foi publicada a Lei n.498 ${ }^{190}$, estabelecendo "prescripções para construcção de casas de habitação operaria". Ainda que nem todos os processos analisados correspondam à construção de "casas operárias", acreditamos que três artigos do documento se mostram especialmente esclarecedores:

"Art. $1^{\circ}$ - Na construcção de casas para habitação de família de operarios, fora do perímetro urbano marcado na presente lei, serão observadas as seguintes prescripções:

Art $2^{\circ}$ - As casas a que se refere a presente lei não poderão ser construídas no alinhamento das ruas, mas afastadas della pelo menos 5 metros.

Art. $8^{\circ}$ - O perímetro urbano a que se refere o art. $1^{\circ}$ é o seguinte: rua da Figueira, esquina da avenida Rangel Pestana, ruas Santa Rosa, Paula Souza, via Tamanduatehy até a linha ingleza, por esta até as alamedas Antonio Prado, Barão de Limeira, Nothmann, rua das Palmeiras, largo de Santa Cecilia, ruas d.Veridiana, Maria

\footnotetext{
189 Obras Particulares, Processo de 04/04/1913, de propriedade de Alberto Pereira Borge, Cx S5. Além deste processo, entre os anos de 1912 e 1913, encontramos outros requerimentos, cuja aprovação dependia de decisão da Câmara sobre o prolongamento de certas ruas, como as mesmas ruas do Sol, Conselheiro Carrão, e a Santo Antonio, exatamente no trecho próximo ao Morro dos Ingleses: os processos de 24/04/1912, em nome de Jacinto Paris, à rua Conselheiro Carrão, $n^{\circ}$ 81, esquina com a rua do Sol (Cx. C5); de 22/10/1912, em nome de José Scigliano, na Conselheiro Carrão, no 70 , esquina com a Treze de Maio (Cx. C5); e de 16/11/1912, em nome de Pedro Chitarra, na Santo Antonio, 249, cujo parecer dizia que "não é oficial o prolongamento da rua de Santo Antonio, além da rua São Vicente”. ${ }^{190}$ Grifo nosso. Localizamos este documento em alguns dos processos da Série Obras Particulares.
} 
Antonia, Consolação, Major Quedinho, Major Diogo, Santo Amaro, Riachuelo, largos Municipal, Sete de Setembro, ruas da Gloria, São Paulo, Glycerio, Hospicio, Vinte e Cinco de Março, aterrado do Carmo até o ponto de partida."

$\mathrm{O}$ artigo $1^{\circ}$ estabelecia prescrições para casas "operárias" "fora do perímetro urbano". De acordo com o artigo $8^{\circ}$ e a planta abaixo, o trecho do bairro inserido no perímetro urbano compreendia parte das ruas Santo Antonio, Major Diogo, São Domingos, Santo Amaro, assim como as ruas Abolição, Japurá e Jacareí. Dessa maneira, praticamente todas as ruas do bairro do Bexiga, alvo do presente estudo, estavam fora do perímetro urbano. A exceção parece ter ficado por conta das ruas indicadas nos processos de Joaquim Fernandes Pinto, Alberto Pereira Borge, Jacinto Paris, José Scigliano e Pedro Chitarra, nas proximidades do Morro dos Ingleses. Conforme o artigo $3^{\circ}$, as casas "operárias" deveriam ser construídas, pelo menos, a 5 metros do alinhamento. Ora, uma grande maioria, senão a maior parte dos projetos arquitetônicos, indica casas a serem construídas no alinhamento, sem provocar objeções por parte da Diretoria de Obras. Assim, persistem nossas dúvidas acerca da obrigatoriedade, de fato, de se construir no alinhamento ou distante dele.

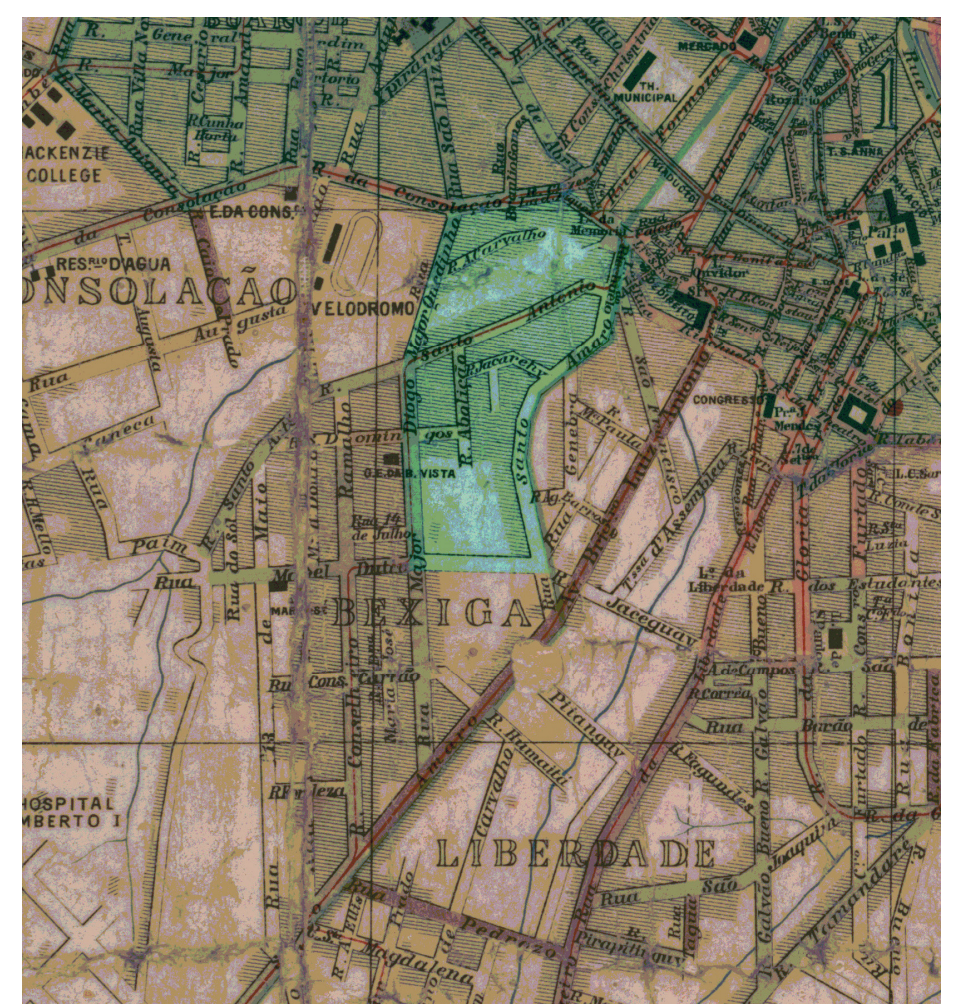

Figura 34 - "Planta Geral da Capital de São Paulo” (1905), Alexandre Mariano Coccoci e Luís Fructuoso e Costa. Destacado em verde temos o trecho do bairro, cujas ruas localizam-se dentro do perímetro urbano, tal como foi definido pela Lei $\mathrm{n}^{\circ} 498$, de 14 de dezembro de 1900. Fonte: Histórico Demográfico do Município de São Paulo. Disponível em:

<http://www.sempla.prefeitura.sp.gov.br/historico> Consulta em 18/11/2009 
c) Algumas casas apresentaram uma porta de entrada junto ao alinhamento. A iluminação dos cômodos era feita através de um pátio de iluminação. A Figura 35 demonstra esta implantação, em virtude da pequena largura do lote, inexistindo o corredor lateral externo e circulação interna através de cômodos enfileirados.

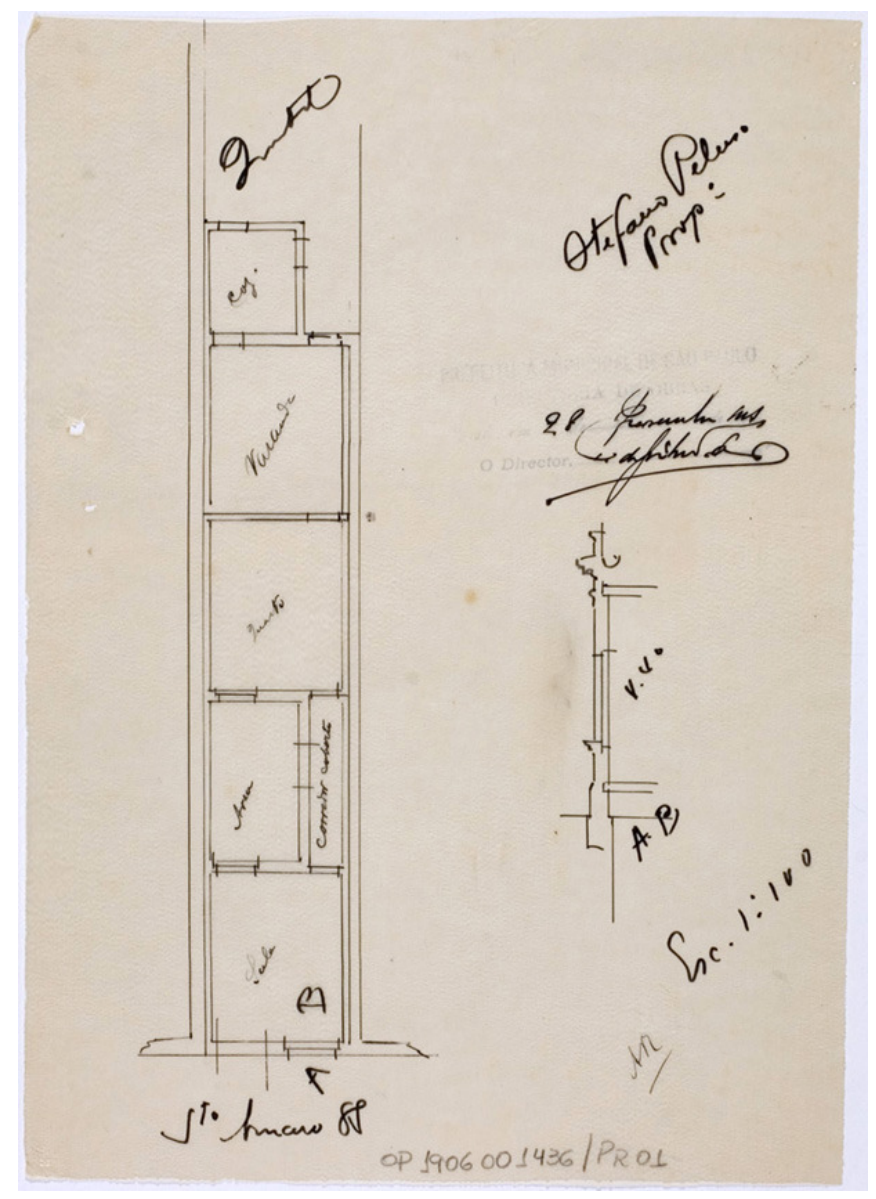

Figura 35 - Projeto em nome de Stephano Peluso, para construção de casa à rua Santo Amaro, 89. A testada do imóvel possui somente $3,20 \mathrm{~m}$ e a área a ser construída contava com 55,50 m2. Casa com distribuição sequencial dos cômodos. Sala e quarto com janelas para o pátio; varanda com porta para o pátio e o quintal. O corte demonstra a existência de platibanda e porão, e pé direito de 4,40m para o interior da residência. Fonte: Obras Particulares, Processo de 17/11/1906, rua Santo Amaro, 88. Cx. S1. AHMWL.

d) Quintal ocupando os fundos do terreno ou a lateral do lote. Nos primeiro anos, invariavelmente, encontramos as latrinas no fundo do quintal, sempre bem longe da casa.

Essa típica implantação da edificação nos lotes do Bexiga respondeu às exigências do Código de Posturas de 1886 e, mais tarde, do Código Sanitário de 1894 que, de resto, parece não se diferenciar muito do que ocorreu em outros bairros mais modestos da cidade, como descrito por Carlos Lemos (1999): 
"[...] a partir da legislação de 1886, nasceu a nova tipologia da casa paulistana, novo partido arquitetônico derivado, em resumo, da obrigatoriedade do alinhamento do lote [...]; da obrigatoriedade de porão que às vezes ficava bastante alto, pois nem todos os lotes eram em nivel; da obrigatoriedade da platibanda e da conveniência de corredor lateral descoberto que permitisse a iluminação direta dos cômodos.

Enquanto a classe abastada assim procedia, a classe média, atendendo às rigorosas exigências do 'Padrão Municipal de 1886, continuou por muitos e muitos anos a levantar casas no alinhamento[...]”. ${ }^{191}$

Realmente, os porões são uma constante em todas as plantas analisadas, sejam eles com a altura mínima exigida, de $50 \mathrm{~cm}$, ou os mais constantes, com alturas que variavam de 2 a 2,5 metros. Nos casos de alturas superiores a 2,50 metros, frequentemente encontramos a previsão de algum tipo de uso especial para esses espaços, geralmente como depósitos. Podiam conter, inclusive, até uma outra residência. Embora esse tipo de residência tenha aparecido definido em plantas aprovadas pela municipalidade em algumas poucas ocasiões, achamos por bem inventariá-las, já que apontam para uma possível tendência nos anos posteriores ao período investigado.

Quanto às platibandas, nem sempre é possível confirmar sua existência, já que nem todos os projetos possuem os respectivos cortes ou elevações. Foi possível constatar a intenção de colocação de platibandas em edificações já existentes, através de pedidos de autorização para reforma da fachada dos imóveis.

\section{Tipologias edilícias}

Como vimos acima, de 1880 a 1893, consultamos 66 solicitações sem quaisquer referências a projetos arquitetônicos, que apenas citam o fato do requerente querer edificar, solicitando alinhamento. A maior parte desses casos (59) está diretamente relacionada a um período em que não era obrigatória a apresentação dos projetos arquitetônicos junto aos requerimentos, envolvendo processos anteriores a 1893.

Por outro lado, na análise do conjunto de $\mathbf{5 0 2}$ pedidos de licença de edificação para moradia, mesmo após 1893, percebemos um número considerável de processos (68) nos quais as plantas estão ausentes. Infelizmente, não é possível saber os motivos disso, mas as solicitações e os pareceres demonstram claramente que foram

\footnotetext{
${ }^{191}$ Op.Cit., p. 22. Grifos nossos.
} 
apresentadas, já que esses requerimentos contêm, invariavelmente, textos mencionando-as: "fulano de tal, querendo edificar um prédio, conforme a planta junta, solicita licença e alinhamento". Eventualmente, em alguns casos de solicitações indeferidas, consta, nos pareceres técnicos, a informação de que foram devolvidas aos requerentes, mas a grande maioria parece ter se extraviado em algum momento impossível de se averiguar.

A Tabela 24, a seguir, contém as categorias tipológicas adotadas neste trabalho, arroladas em função da sua incidência no decorrer do período estudado, entre 1881 e 1914.

\begin{tabular}{|c|c|c|c|c|c|c|c|}
\hline ANO & $\begin{array}{c}\text { CASAS } \\
\text { SIMPLES }\end{array}$ & $\begin{array}{c}\text { CASAS DE } \\
\text { FUNDO }\end{array}$ & $\begin{array}{c}\text { CASAS } \\
\text { EM SÉRIE }\end{array}$ & VILAS & $\begin{array}{l}\text { SOBRADOS } \\
\text { COM DUPLA } \\
\text { RESIDÊNCIA } \\
\end{array}$ & $\begin{array}{c}\text { CASAS } \\
\text { MISTAS }\end{array}$ & TOTAL \\
\hline 1882 & - & - & - & - & - & - & - \\
\hline 1883 & - & - & - & - & - & - & - \\
\hline $1886(*)$ & - & - & - & - & - & - & - \\
\hline 1887 & - & - & - & - & - & - & - \\
\hline 1888 & - & - & - & - & - & - & - \\
\hline 1889 & - & - & 1 & - & - & - & 1 \\
\hline $1890(*)$ & - & - & - & - & - & - & - \\
\hline $1891(*)$ & - & - & - & - & - & - & - \\
\hline $1892(*)$ & - & - & 1 & - & - & - & 1 \\
\hline 1893 & 12 & - & 5 & - & - & 7 & 24 \\
\hline 1894 & 17 & - & 3 & - & - & 4 & 24 \\
\hline 1895 & 35 & - & - & - & - & 2 & 37 \\
\hline $1896(*)$ & - & - & - & - & - & 1 & 1 \\
\hline $1897(*)$ & - & - & 1 & - & - & - & 1 \\
\hline $1898(*)$ & 5 & - & 2 & - & - & 2 & 9 \\
\hline 1899 & 20 & - & 7 & - & - & 5 & 32 \\
\hline 1900 & 7 & - & - & - & - & 4 & 11 \\
\hline 1901 & 5 & - & 2 & - & - & 3 & 10 \\
\hline $1902(*)$ & 1 & - & - & - & - & - & 1 \\
\hline $1903(*)$ & - & - & - & - & - & - & - \\
\hline $1904(*)$ & 2 & - & - & - & - & - & 2 \\
\hline 1905 & 29 & 2 & 8 & - & - & 5 & 44 \\
\hline 1906 & 26 & - & 9 & 1 & - & 5 & 41 \\
\hline 1907 & 22 & 2 & 4 & 1 & - & 4 & 33 \\
\hline 1912 & 47 & 3 & 12 & 2 & 4 & 9 & 77 \\
\hline 1913 & 53 & 6 & 17 & 3 & 4 & 10 & 93 \\
\hline 1914 & 18 & 9 & 13 & 3 & 7 & 10 & 60 \\
\hline TOTAL & 299 & 22 & 85 & 10 & 15 & 71 & 502 \\
\hline
\end{tabular}

(*) Anos e registros fora da amostra selecionada.

Tabela 24 - Solicitações quanto às tipologias adotadas, por anos de ocorrência

Tendo em vista que a análise de dados deveria ser realizada a partir de fatos documentados, agrupamos as edificações, por tipologias predominantes. Dessa maneira, a partir das $\mathbf{5 0 2}$ solicitações de licença para edificação de casas para moradia, simples ou mistas, excluímos aquelas que, embora possuíssem um texto definidor da tipologia (o próprio requerimento), não possuíam a respectiva planta, como demonstrado na tabela seguinte. Dessa maneira, a amostra real analisada envolveu 434 solicitações: 86,45\% das $\mathbf{5 0 2}$ solicitações são para edifícios residenciais e mistos, como demonstra a próxima tabela. 


\begin{tabular}{|l|c|c|c|}
\hline \multicolumn{1}{|c|}{ TIPOLOGIA } & $\begin{array}{c}\text { SOLICITAÇÕES } \underline{\text { COM }} \\
\text { PROJETOS } \\
\text { ARQUITETÔNICOS }\end{array}$ & $\begin{array}{c}\text { SOLICITAÇÕES SEM } \\
\text { PrOJETOS } \\
\text { ARQUITETÔNICOS }\end{array}$ & $\begin{array}{c}\text { TOTAL } \\
\text { SOLICITAÇÕES }\end{array}$ \\
\hline CASAS SIMPLES & 242 & 57 & 299 \\
\hline CASAS DE FUNDOS & 20 & 2 & 22 \\
\hline $\begin{array}{l}\text { CASAS } \\
\text { EM SÉRIE }\end{array}$ & 79 & 6 & 10 \\
\hline VILAS & 10 & - & 15 \\
\hline $\begin{array}{l}\text { SOBRADOS COM } 2 \\
\text { RESIDÊNCIAS }\end{array}$ & 15 & - & 71 \\
\hline CASAS MISTAS & 68 & 3 & $\mathbf{5 0 2}$ \\
\hline TOTAL & $\mathbf{4 3 4}$ & $\mathbf{6 8}$ & \\
\hline
\end{tabular}

Tabela 25 - Total de solicitações acompanhadas pelas respectivas plantas

As solicitações relacionadas na Tabela 25 não levam em conta o número real de unidades residenciais a serem construídas. As casas em série, as vilas e mesmo sobrados com dupla residência, implicam em um maior número de unidades residenciais. Esses três tipos de casas somam 110 das solicitações, perfazendo aproximadamente $25,40 \%$ do total de $\mathbf{4 3 4}$.

\begin{tabular}{|l|c|c|c|}
\hline \multicolumn{1}{|c|}{ TIPOLOGIA } & $\begin{array}{c}\text { SOLICITAÇÕES } \\
\text { ORIGINAIS }\end{array}$ & $\begin{array}{c}\text { DIFERENÇA } \\
\text { SOLICITAÇÕES }\end{array}$ & $\begin{array}{c}\text { TOTAL } \\
\text { A CONSTRUIR }\end{array}$ \\
\hline CASAS SIMPLES & 242 & - & $\mathbf{2 4 2}$ \\
\hline CASAS DE FUNDOS & 20 & - & $\mathbf{2 0}$ \\
\hline CASAS EM SÉRIE & 79 & 129 & $\mathbf{2 0 8}$ \\
\hline VILAS & 10 & 36 & $\mathbf{4 6}$ \\
\hline $\begin{array}{l}\text { SOBRADOS COM DUPLA } \\
\text { RESIDÊNCIA }\end{array}$ & 15 & 16 & $\mathbf{6 8}$ \\
\hline CASAS MISTAS & & & $\mathbf{6 1 5}$ \\
\hline TOTAL & 68 & - & $\mathbf{1 8 1}$ \\
\hline
\end{tabular}

Tabela 26 - Solicitações originais e unidades( reais), a serem edificadas

De uma maneira geral, as tipologias adotadas se definem por algumas características particulares, destacadas nas Figuras 36, 37, 38, 39, 40 e 41 : 
- Casas simples - As casas térreas e os sobrados destinados exclusivamente à moradia, com fachada voltada para a rua.

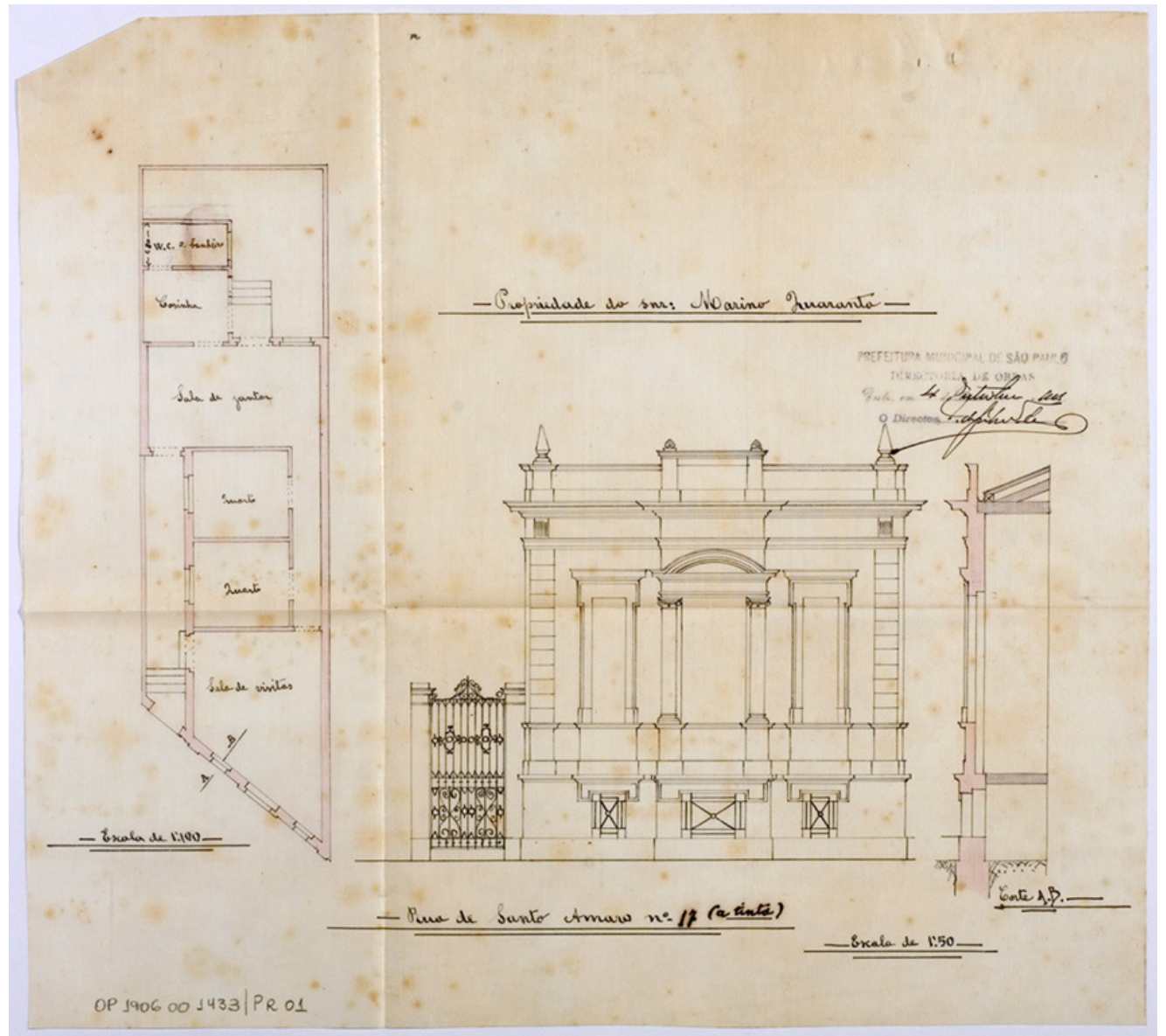

Figura 36 - Casa térrea simples, de propriedade de Marino Quaranta, destinada à moradia, à Rua Santo Amaro $\mathrm{n}^{\circ} 17$ (tinta). O projeto demonstra casa com sala de visitas, dois quartos, sala de jantar, cozinha, "WC e banheiro". Corredor descoberto com portas para as salas de visitas e de jantar. Da sala de visitas, observa-se acesso, através de corredor interno, aos quartos e à sala de jantar. Esta última possui uma porta para a cozinha, outra para o quintal, além de janela, para o mesmo quintal. A cozinha não tem janelas, mas porta para o quintal, e, ao contrário do que rezava a lei, tem acesso direto ao banheiro. A elevação demonstra a presença da platibanda, das janelas voltadas para a rua e, dos gradis do porão.A escala 1:50 indica um pé direito de 4,50m no interior da residência e $50 \mathrm{~cm}$ para o porão. Fonte: $O b r a s$ Particulares, 27/09/1906, Cx.S1-12. AHMWL. 
- Casas de fundo - Da mesma forma que as casas simples, também podiam ser térreas ou sobrados, porém, eram instaladas no fundo dos terrenos.

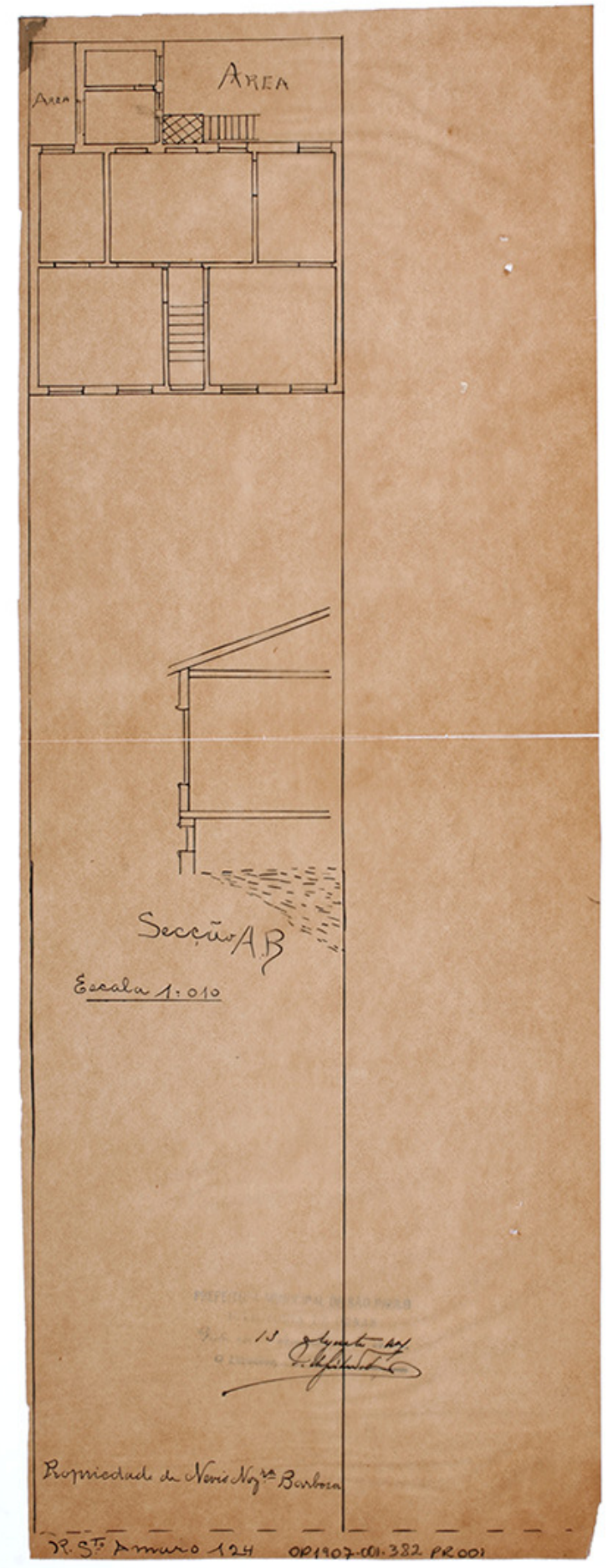

Figura 37 - Casa de fundos. Projeto em nome de Nevio Nogueira Barbosa, a ser construído nos fundos do $n^{\circ} 124$, da rua Santo Amaro. Entrada da residência através de corredor central, com acesso para os cômodos da frente e à provável sala de jantar. Esta sala está localizada entre dois cômodos menores (todos com janelas voltadas para "áreas" externas). $\mathrm{Na}$ sequência desses três cômodos, há outros dois (talvez uma cozinha e um banheiro), com acesso direto para "área" externa. O corte demonstra a ausência de platibanda e as aparentes alturas: cerca de $4 \mathrm{~m}$ de pé direito e $50 \mathrm{~cm}$ de porão. De acordo com o processo, esta casa teria $100 \mathrm{~m} 2$ de área construída. Fonte: Obras Particulares, 02/08/1907, Cx.26. AHMWL. 
- Casas em série - Essas casas muitas vezes são geminadas e podem contar com duas ou mais moradias. Embora basicamente possuam plantas iguais, eventualmente, algumas unidades também podem apresentar um salão destinado a uso comercial, o que é comum ocorrer em terrenos de esquina.

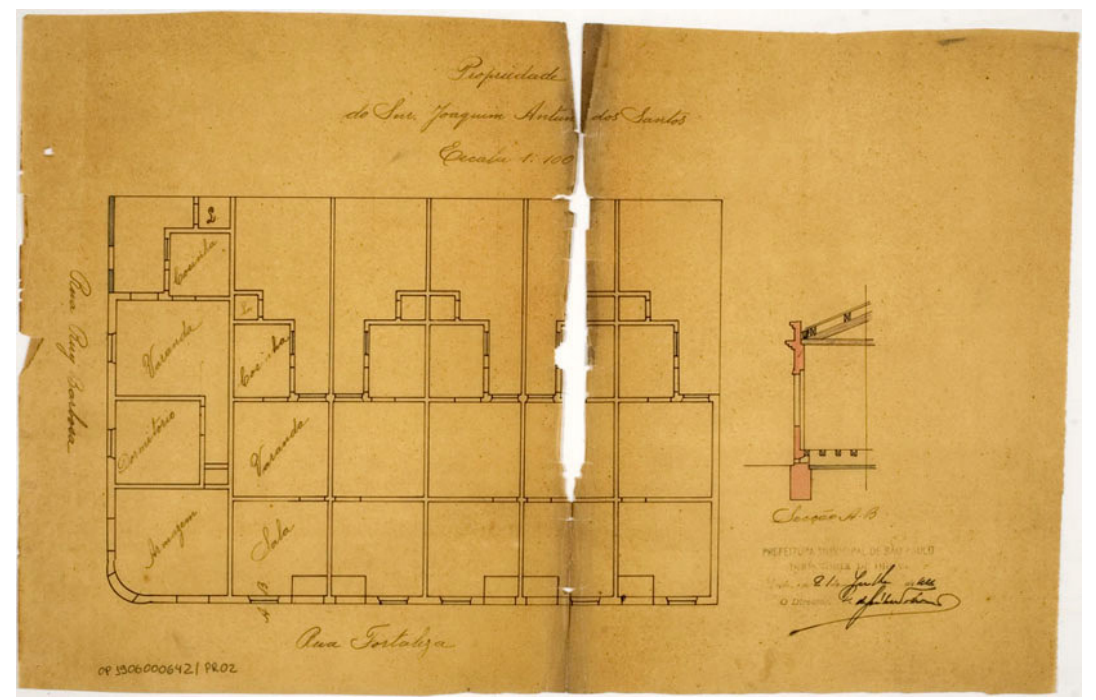

Figura 38 - Casas em série, de propriedade de Joaquim Antunes dos Santos na Rua Fortaleza, esquina com a Rui Barbosa. Com exceção da casa da esquina, com quatro cômodos, além de um armazém, as demais possuem três cômodos e latrina. Acesso direto ao interior através da porta da sala. A circulação interna passa por todos os cômodos: da sala para o quarto (dormitório) e, deste para a cozinha. Cozinha e latrina com portas voltadas para o quintal. Presença de platibanda; porão; e pé direito com cerca de $4 \mathrm{~m}$. $\mathrm{O}$ armazém com portas para as duas ruas, pode enquadrar a casa na categoria de uso misto. Fonte:Obras Particulares, 18/07/1906, Cx. E1-F1-06. AHMWL.

- Vilas - As casas em série construídas no interior de lotes maiores, com rua interna.

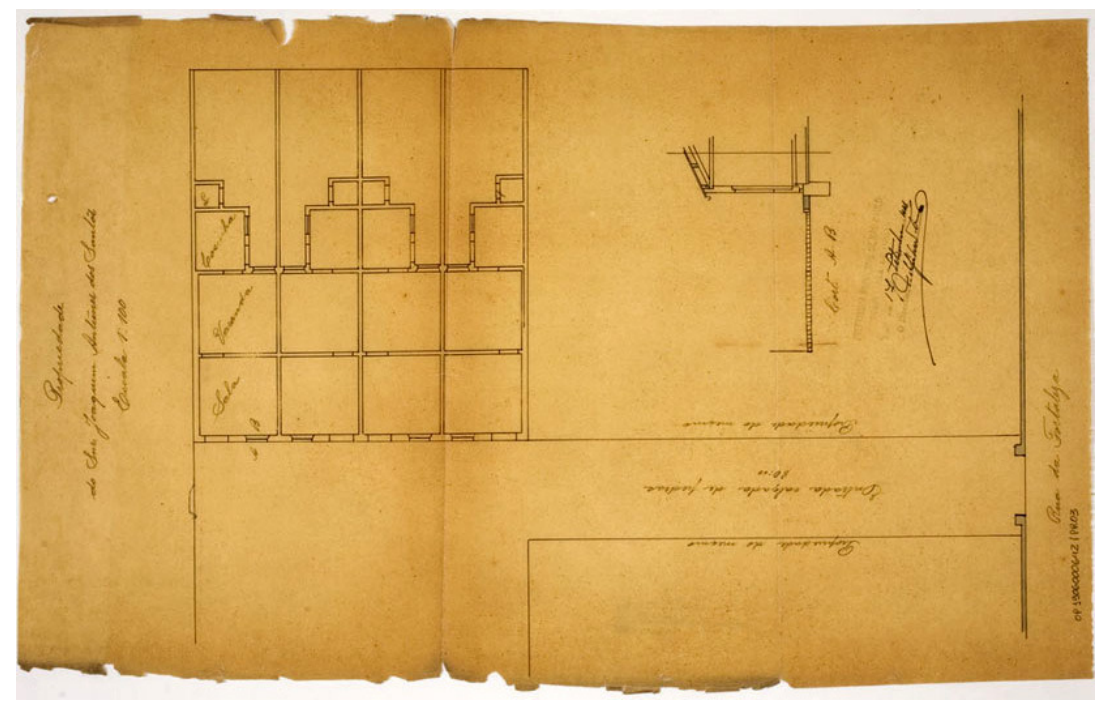

Figura 39 - Vila de propriedade do mesmo Joaquim Antunes dos Santos, a construir nos fundos do lote à Rua Fortaleza, $\mathrm{s} / \mathrm{n}^{\mathrm{o}}$. A planta baixa e o corte dessas casas demonstram projetos exatamente iguais ao caso anterior (localizado na mesma rua), configurando "casas operárias". Note-se que a área defronte da vila nos fundos do lote ainda está vazia, certamente aguardando o momento de novas edificações, e que o terreno vizinho à entrada também pertencia a Antunes. O processo indica que a área construída de cada moradia era de 48,28 m2. Fonte: Obras Particulares, 28/08/1906, Cx. E1-F1-06. AHMWL. 
- Sobrados com dupla residência, uma no pavimento térreo e outra no pavimento superior. Eventualmente, o cômodo frontal, no térreo, também era ocupado por alguma atividade comercial.

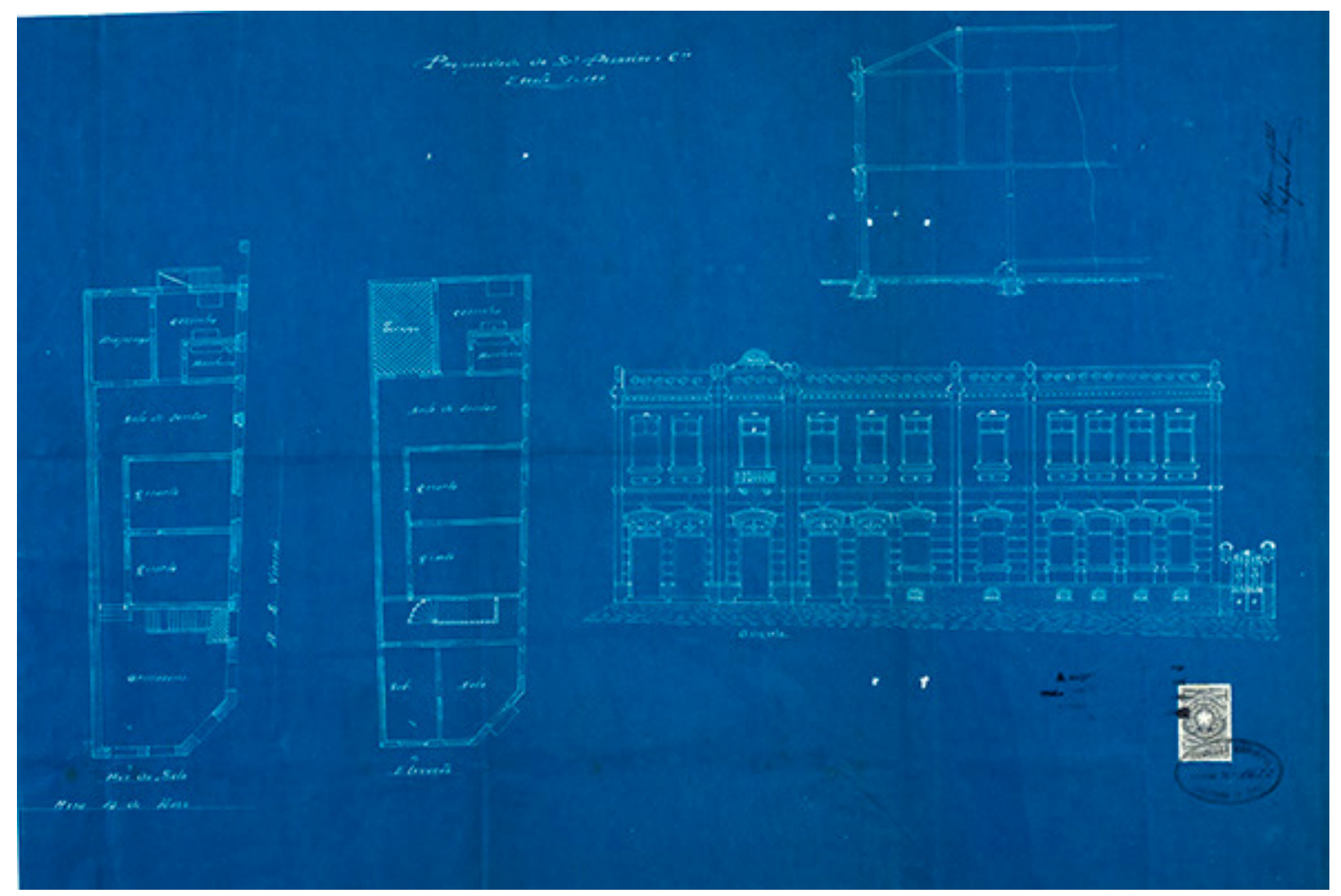

Figura 40 - Sobrado com dupla residência, de propriedade de Pinheiro \& Cia., à rua Treze de Maio, s/no (esquina com a rua São Vicente, 68). A planta baixa demonstra uma primeira residência, no térreo, com espaço para armazém no alinhamento, seguido de dois quartos, sala de jantar, banheiro, cozinha e despensa. Acesso à residência através do armazém e, aos demais cômodos, através de corredor interno; a sala de jantar possui porta para a despensa e para um pequeno corredor de distribuição, por onde se vai ao banheiro e à cozinha. Nesta há uma porta, provavelmente para um quintal. Todos os cômodos possuem janelas para o exterior, os primeiros para a rua São Vicente, a despensa para o quintal. Conforme o corte, o porão (ocupando somente a área da residência) deve ter cerca de $50 \mathrm{~cm}$, e o pé direito mais de $4 \mathrm{~m}$. A entrada para a residência do piso superior é feita pela rua São Vicente, através de uma escada, logo após o armazém, que chega a um corredor de distribuição. A planta demonstra a presença de sala e gabinete, na altura do alinhamento. Com exceção da despensa, aqui substituída por um terraço, o restante da casa possui planta igual à do piso inferior. Fonte: Obras Particulares, 19/04/1913, Cx. T3. AHMWL. 
- Casas de uso misto - Aqui se trata de edificações planejadas e construídas com a finalidade de abrigarem residências e atividades comerciais.

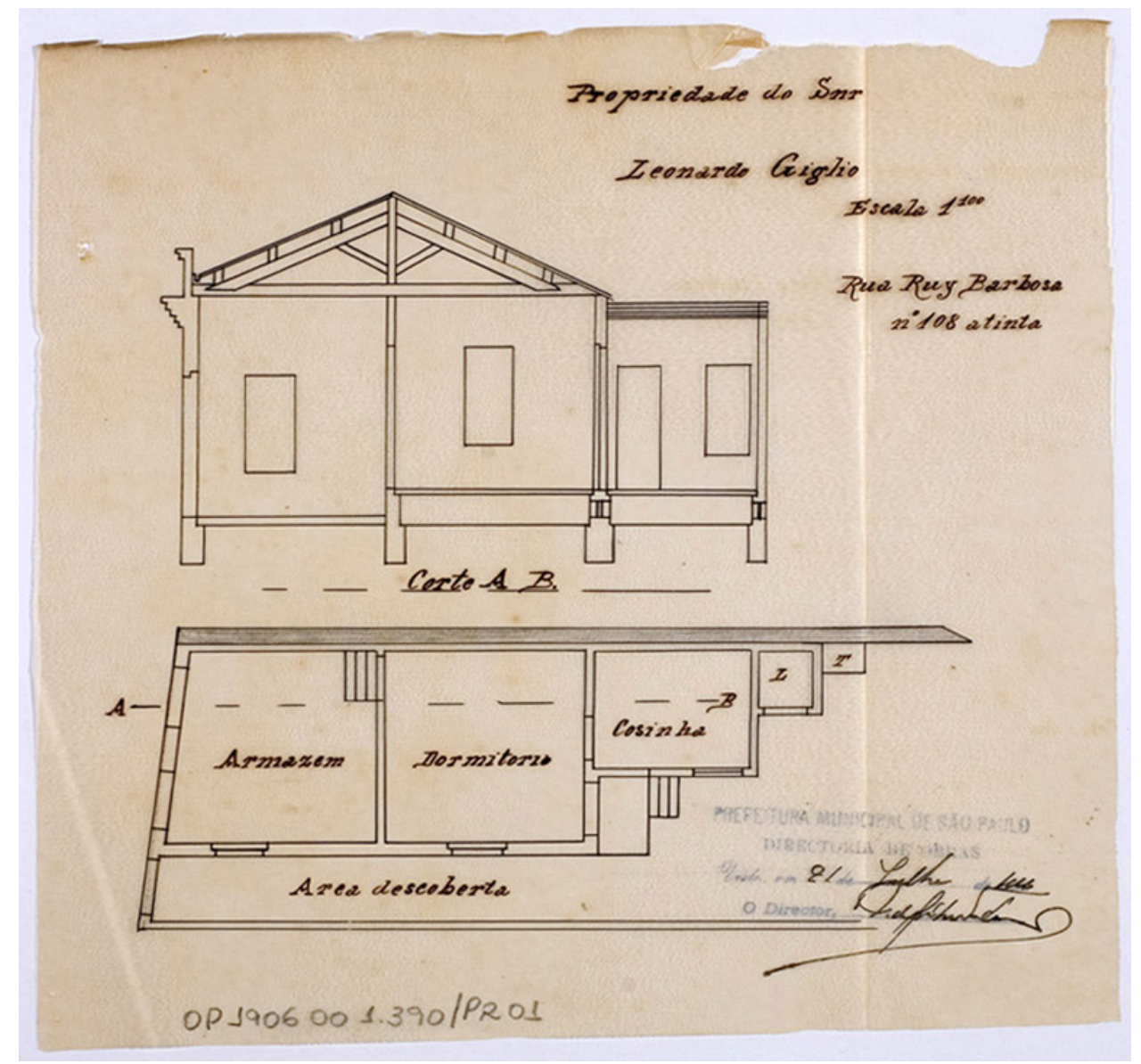

Figura 41 - Casa de uso misto, de propriedade de Leonardo Giglio, na rua Rui Barbosa 108T (ou 114). Trata-se de uma pequena casa, com apenas dois cômodos, além do armazém na frente do prédio. O acesso à residência pode ser feito através do próprio armazém, ou na parte posterior do edifício através da cozinha. Latrina externa, instalada na parede contígua à cozinha, com entrada independente. O corte, abrangendo toda a edificação, indica a presença de porão somente para os cômodos a serem ocupados pela residência. Excepcionalmente neste caso, podemos ver toda a estrutura do telhado escondida pela platibanda. Pé direito de aproximadamente $4 \mathrm{~m}$ e porão com cerca de $50 \mathrm{~cm}$. Fonte: Obras Particulares, 12/06/1906, Cx. Q1-R1. AHMWL.

- Cortiços - Configuram uma tipologia com programa específico, e serão alvo de uma análise à parte.

O início dos empreendimentos imobiliários no Bexiga, conforme as pesquisas realizadas nos jornais A Província e O Estado de São Paulo, ocorreu no final dos anos 1880, e pelo menos até o final do século XIX as casas foram construídas alinhadas às ruas. Com o passar do tempo, por volta dos anos 1900, os fundos dos terrenos começaram a ser ocupados por novas casas. A aquisição de dois ou mais lotes, geralmente pela mesma pessoa, deu ensejo à construção de vilas ou mesmo de 
pequenos aglomerados de duas ou três casas nesses fundos de terreno, construídas em tempos diferentes. Era muito comum encontrarmos solicitações para acréscimo de novas casas em um terreno já edificado.

A análise das plantas durante todo o período deixa perceber que a partir dessa época houve o que hoje chamaríamos de otimização do espaço, ou seja, todo e qualquer pedaço de terreno passou a ser aproveitado, de maneira que mais unidades residenciais se multiplicassem ${ }^{192}$. Foi o caso não somente das vilas, construídas no interior dos terrenos, mas também dos sobrados. Ainda que em pequeno número, chamam atenção as plantas envolvendo duas unidades residenciais diferentes, uma no andar térreo e outra no pavimento superior, remetendo à idéia contemporânea de "apartamento". A opção por tal tipo de moradia, certamente, estava longe de implicar em conceitos préelaborados sobre soluções alternativas para a questão habitacional. Porém, nossa hipótese parece se comprovar à luz da descrição de Lilian Fessler Vaz ${ }^{193}$ sobre a continuidade de certos tipos de habitações coletivas que adentraram os anos 30, na cidade do Rio de Janeiro:

"Os sobrados [...] também mostravam indícios de mudanças, inclusive em termos de coletivização. Depois que se difundiram os sobrados com uma habitação no térreo e outra no pavimento superior, surgiram também as habitações com três pavimentos, havendo em cada um, uma moradia, e sobrados com maior número de domicílios. Muitos pequenos 'prédios para renda' do início do século não diferiam muito dos sobrados, com sua distribuição dos espaços condicionada pela forma do lote."

Embora estejamos versando sobre duas realidades distintas, cada uma com suas peculiaridades, estamos lidando com mudanças estruturais que se operaram nos grandes centros urbanos sujeitos a adensamento populacional, à carência de moradias e à especulação imobiliária durante esse período. As soluções para a questão habitacional nas cidades de São Paulo e Rio de Janeiro parecem ser bastante semelhantes. A descrição de Lilian Vaz nos autoriza a afirmar que se trata da mesma solução "sobrados com uma habitação no térreo e outra no pavimento superior" -, presente lá e cá. Assim, decidimos criar a tipologia específica dos sobrados com dupla residência, que diferem dos sobrados unifamiliares, conforme demonstrado na Figura 40. Nesta

\footnotetext{
${ }^{192}$ A definição do conceito de "unidade residencial" adotado neste trabalho obedeceu ao critério de moradia possuidora de pelo menos os 3 cômodos exigidos pela lei, aí incluída a cozinha, e servida por instalações sanitárias próprias, teoricamente ocupada por apenas uma família, independentemente da tipologia identificada.

${ }^{193}$ VAZ, Lílian Fessler - Uma história da habitação coletiva na cidade do Rio de Janeiro - Estudo da Modernidade através da moradia, Tese de doutorado apresentada à FAUUSP, 1994, p.129 (grifos nossos).
} 
categoria também foram incorporados casos de prédios com porão utilizável. Ambos contabilizaram apenas 15 solicitações da nossa amostragem de $\mathbf{5 0 2}$ imóveis, porém, implicaram em $\mathbf{3 1}$ unidades residenciais ou moradias diferentes a serem construídas.

Na Tabela 10 observamos o predomínio das casas simples, com 242 unidades, ou aproximadamente 39,34\% das $\mathbf{6 1 5}$ casas a serem edificadas. As casas em série vêm em seguida, somando 208 unidades $(33,82 \%)$. Embora as casas de uso misto totalizem apenas 68 exemplares $(11,05 \%)$, é importante destacar que tanto as casas em série como os sobrados com dupla residência (com 31 unidades ou 5,04\%), via de regra, apresentavam espaços destinados à implantação de negócios. Por outro lado, como já referido, nosso trabalho está enfocando basicamente os projetos que envolveram a construção de novas edificações. Assim, não estamos levando em conta as reformas que implicaram em acréscimos de cômodos para uso comercial. Contudo, se acrescentarmos os $\mathbf{7 1}$ casos de pedidos de licença nesta categoria, teremos então um total de $\mathbf{1 3 9}$ prédios de uso misto.

É claro que toda essa situação estava sujeita a alterações. As casas simples térreas poderiam vir a se transformar em casas com dupla residência, com uma posterior ocupação do porão, ainda que de forma ilegal, podendo até dar origem a futuros cortiços. Quanto mais passou o tempo e se foram os testemunhos vivos dessa realidade, mais diminuíram nossas certezas acerca das intenções e usos reais que se fizeram das edificações da cidade. Não podemos nos esquecer que estamos trabalhando com um período em que o bairro estava se formando, cuja configuração ainda está muito longe da atual. O processo de configuração espacial de um bairro não é algo estanque e está sujeito às constantes transformações no tempo. Assim ocorreu com o Bexiga, pelo menos até os anos de 1950. Ainda que na aparência de suas ruas e fachadas o Bexiga da década de 1910 seja o mesmo daquele dos anos 30, a ocupação e o uso das edificações se alterou muito no decorrer de 20 anos; prova disso são as frequentes solicitações apresentadas, com o objetivo de reforma e acréscimo de novos comodos.

A entrada maciça de gente na cidade durante as últimas décadas do século XIX (ex-escravos, imigrantes europeus, etc.) aumentou a demanda por moradias, propiciando a formação de um mercado consumidor formado pelos setores médios e baixos dessa "nova" população. Para quem quisesse investir no mercado locatício gastando menos, o Bexiga era um bairro ideal, já que os terrenos ali eram baratos para todo tipo de investidor. Porém, o número de terrenos disponíveis, com o passar dos 
anos, certamente se reduziu. Até mesmo aquelas pessoas que dispunham de poucas posses podiam investir na compra de um terreno de $5 \mathrm{~m}$ x $50 \mathrm{~m}$ e, com o passar do tempo, construir uma casa nos fundos ou um sobrado de duas residências ou mesmo as duas coisas. O fato é que as formas de ocupação dos terrenos foram se intensificando, sempre de maneira a aproveitar melhor cada pedaço de chão disponível.

\begin{tabular}{|c|c|c|c|c|c|c|c|}
\hline ANO & $\begin{array}{l}\text { CASAS } \\
\text { SIMPLES }\end{array}$ & $\begin{array}{c}\text { CASAS DE } \\
\text { FUNDO }\end{array}$ & $\begin{array}{c}\text { CASAS } \\
\text { EM SÉRIE }\end{array}$ & VILAS & $\begin{array}{l}\text { SOBRADOS } \\
\text { COM DUPLA } \\
\text { RESIDENCIA }\end{array}$ & $\begin{array}{c}\text { CASAS } \\
\text { MISTAS }\end{array}$ & TOTAL \\
\hline 1882/1904 & 103 & - & 22 & - & - & 28 & 153 \\
\hline $1905 / 1914$ & 195 & 22 & 63 & 10 & 15 & 43 & 348 \\
\hline TOTAL & 299 & 22 & 85 & 10 & 15 & 71 & 502 \\
\hline
\end{tabular}

Tabela 27 - Total de solicitações quanto às tipologias adotadas, por anos de ocorrência

Acima, o resumo da Tabela 24, contendo as solicitações organizadas por tipologias, permite observar que, até 1904, não encontramos nenhuma solicitação para casas de fundo, vilas ou sobrados com dupla residência. Já, de 1905 a 1914, ainda que em número reduzido, as solicitações para outros tipos de edificações passam a ser presença mais constante.

Os projetos encaminhados à municipalidade propõem um determinado número de cômodos para as edificações a serem construídas. Acreditamos que o arrolamento e detalhamento desses cômodos, assim como de seus possíveis usos, possam dizer algo mais sobre os usuários das casas construídas no bairro. Dessa maneira, estabelecemos categorias diferenciadas, pelo número de cômodos propostos pelos construtores e proprietários na elaboração dos projetos arquitetônicos.

\begin{tabular}{|l|c|c|c|}
\hline \multicolumn{1}{|c|}{ TIPOLOGIAS } & $\begin{array}{c}\text { COM } \\
\text { BANHEIRO }\end{array}$ & $\begin{array}{c}\text { SEM } \\
\text { BANHEIRO }\end{array}$ & TOTAL \\
\hline CASAS SIMPLES & 152 & 90 & $\mathbf{2 4 2}$ \\
\hline CASAS DE FUNDOS & 11 & 9 & $\mathbf{2 0}$ \\
\hline CASAS EM SÉRIE & 145 & 63 & $\mathbf{2 0 8}$ \\
\hline VILAS & 44 & 2 & $\mathbf{4 6}$ \\
\hline $\begin{array}{l}\text { SOBRADOS COM } \\
\text { DUPLA RESIDÊNCIA }\end{array}$ & 29 & 2 & $\mathbf{3 1}$ \\
\hline CASAS MISTAS & 40 & 28 & $\mathbf{6 8}$ \\
\hline TOTAL & $\mathbf{4 2 1}$ & $\mathbf{1 9 4}$ & $\mathbf{6 1 5}$ \\
\hline
\end{tabular}

Tabela 28 - Total de casas a serem construídas, com e sem banheiro

Antes de prosseguirmos com a análise da organização interna das edificações, queremos destacar outra questão correlata a esta: a inexistência de instalações sanitárias em pouco mais de $35 \%$ da amostra investigada. De acordo com a Tabela 28 , entre os 615 prédios a serem construídos, as edificações sem a presença de instalações sanitárias somam 194, perfazendo $31,54 \%$ da amostra de solicitações devidamente documentadas. 
Contudo, nestes casos é simplesmente impossível afirmar que elas não existiam. A consulta dos Artigos 77 e 78 do Código Sanitário de $1894^{194}$, que tratam especificamente das latrinas, trouxe algumas informações que nos ajudam a esclarecer esta questão.

"Artigo 77. Na falta de galeria de esgotos, deverão ser toleradas as fossas fixas; Artigo 78. Essas fossas deverão ser construídas sempre fora das habitações e não deverão ter mais de um metro cúbico de capacidade”.

Ora, se o próprio Código admitia a possibilidade das fossas negras (ou fixas) na falta da rede de esgotos, é porque esses serviços ainda não estavam disponíveis para todos os bairros. Embora o bairro do Bexiga conste da "Planta da Cidade de São Paulo”, levantada pela Cia. Cantareira de Águas \& Esgotos em 1881, sabemos que a companhia não conseguiu cumprir as metas estabelecidas quando do contrato com o Governo Provincial, tendo sido encampada pelo Estado em 1892 $2^{195}$. Apenas um ano depois ocorreu a criação da Repartição Técnica de Águas e Esgotos, quando o saneamento passou a ser responsabilidade do Estado. De acordo com Cristina de Campos, após a encampação, o Relatório da Superintendência de Obras Públicas, de 1895, informava que "Sobre a rede de esgotos [...] a situação teve bom andamento nos bairros da Consolação, Santa Cecília, Campos Elíseos, Bom Retiro, Luz, Liberdade e Bela Vista, estando nos primeiros terminados os serviços de ligação às casas [...]” 196. A julgar pelo Relatório da Superintendência, o último bairro a ser beneficiado pelos serviços de água e esgoto foi justamente a Bela Vista, de onde se infere que naquele ano ainda não havia disponibilidade (pelo menos total) dos serviços.

Para esclarecer melhor essa questão, selecionamos, nos próprios processos das Obras Particulares as informações relativas à instalação da rede de água e esgotos, localizando alguns requerimentos dirigidos à municipalidade, solicitando licença para “levantamento da calçada para instalação da rede de água e esgotos”.

São bem poucos esses requerimentos: apenas treze pessoas solicitaram esses serviços. Isso fornece alguns indícios interessantes: primeiro, na amostragem estudada, data somente de 1906 a primeira solicitação de licença para "levantamento do calçamento", o que nos leva a pensar que antes desse ano a população residente no

\footnotetext{
${ }^{194}$ Código Sanitário, 1894, Capítulo II, Das habitações em geral, p.79 a 81.

195 CAMPOS, Cristina de - “A promoção e a produção das redes de águas e esgotos na cidade de São Paulo. 1875-1892”, in Anais do Museu Paulista, jul-dez/2005, Ano 13, v.2, p.208. Disponível em: http://redalyc.uaemex.mx/redalyc.

${ }^{196}$ CAMPOS, Cristina - Relatório da Superintendência, 1895, p.210.211.Op.cit., p.224.
} 
bairro não podia contar com água encanada, nem com rede de esgoto ${ }^{197}$; segundo, a partir de 1906, com certeza, os serviços de água e esgoto já estavam disponíveis, pelo menos em algumas ruas, envolvendo custo para a população.

\begin{tabular}{|c|c|c|}
\hline ENDEREÇO & DATA & $\begin{array}{c}\text { HISTÓRICO } \\
\text { DA SOLICITAÇÃO } \\
\end{array}$ \\
\hline $\begin{array}{l}\text { CONSELHEIRO CARRÃO, } \\
30\end{array}$ & $11 / 09 / 1907$ & $\begin{array}{l}\text { PRECISANDO LIGAR A ÁGUA PELA CONSTRUÇÃO DE SEU PRÉDIO, SOLICITA LICENÇA } \\
\text { PELO LEVANTAMENTO DA CALÇADA. }\end{array}$ \\
\hline MAJOR DIOGO, 108A & 24/10/1906 & $\begin{array}{l}\text { DESEJANDO LEVANTAR O CALÇAMENTO, PARA LIGAÇÃO DE ÁGUA E ESGOTO, SOLICITA A } \\
\text { NECESSÁRIA LICENÇA. }\end{array}$ \\
\hline $\begin{array}{l}\text { MAJOR DIOGO, } 16 \\
\text { (TINTA) }\end{array}$ & $12 / 08 / 1907$ & $\begin{array}{l}\text { JÁ TENDO PLANTA APROVADA PARA O TERRENO, E OCORRENDO QUE A REPARTIÇÃO DE } \\
\text { ÁGUAS E ESGOTOS SE RECUSA A FAZER AS LIGAÇÕES SEM A LICENÇA DA CÂMARA } \\
\text { PARA LEVANTAMENTO DO CALÇAMENTO, SOLICITA OFICIAL PARA REFERENDAR. }\end{array}$ \\
\hline QUATORZE DE JULHO, 11 & $10 / 09 / 1912$ & $\begin{array}{l}\text { DESEJANDO ABRIR UMA VALA NA FRENTE DE SEU TERRENO PARA FAZER LIGAÇÃO DE } \\
\text { ÁGUA, PARA A CONSTRUÇÃO DE UMA CASA, SOLICITA ALVARÁ DE LICENÇA. }\end{array}$ \\
\hline SANTO AMARO, 80 & $27 / 11 / 1914$ & PEDIDO DE LICENÇA DE ABERTURA DE VALETA PARA LIGAÇÃO DA REDE DE ÁGUAS. \\
\hline SANTO ANTONIO, 205A & 13/08/1914 & LICENÇA PARA ABERTURA DE CALÇADA PARA INSTALAÇÃO DA REDE DE ESGOTOS. \\
\hline SANTO ANTONIO, 256 & $23 / 11 / 1913$ & $\begin{array}{l}\text { SOLICITAÇÃO DE LICENÇA E ISENÇÃO DE IMPOSTO PARA LEVANTAMENTO DO } \\
\text { CALÇAMENTO, PARA LIGAÇÃO DE ÁGUA E ESGOTO. }\end{array}$ \\
\hline SANTO ANTONIO, 256 & $10 / 01 / 1914$ & LEVANTAMENTO DO CALÇAMENTO PARA INSTALAÇÃO REDE DE ESGOTOS. \\
\hline TREZE DE MAIO, 15 & $11 / 12 / 1913$ & LEVANTAMENTO DE CALÇADA PARA INSTALAÇÃO DA REDE DE ÁGUA E ESGOTOS. \\
\hline $\begin{array}{l}\text { TREZE DE MAIO, 15A E } \\
15 \mathrm{~B}\end{array}$ & $05 / 02 / 1914$ & $\begin{array}{l}\text { SOLICITAÇÃO DE LICENÇA PARA ABERTURA DE VALAS, PARA INSTALAÇÃO REDE } \\
\text { ÁGUAS }\end{array}$ \\
\hline TREZE DE MAIO, 53 E 55 & 08/04/1914 & $\begin{array}{l}\text { AUTORIZAÇÃO DE ABERTURA DO CALÇAMENTO PARA INSTALAÇÃO DA REDE DE ÁGUA } \\
\text { NAS CASAS EM CONSTRUÇÃO. }\end{array}$ \\
\hline TREZE DE MAIO, 55 E 57 & 1914 & AUTORIZAÇÃO DE ABERTURA DO CALÇAMENTO PARA INSTALAÇÃO DA REDE DE ÁGUAS. \\
\hline $\begin{array}{l}\text { TREZE DE MAIO, S/N } \\
\text { ESQUINA SÃO VICENTE }\end{array}$ & $17 / 12 / 1913$ & LEVANTAMENTO DO CALÇAMENTO PARA INSTALAÇÃO DE ÁGUA. \\
\hline
\end{tabular}

Tabela 29 - Rede de Água e Esgotos no bairro do Bexiga (1882-1914)

Não sabemos se esse custo era alto ou baixo, e se as pessoas se dispunham a pagar os preços cobrados. Certamente era bem mais cômodo contar com água corrente e esgoto, mas não podemos nos esquecer que, até há bem pouco tempo, a água fornecida pelos chafarizes da cidade, ainda que insuficiente, era gratuita. Quanto às vantagens dos esgotos, ainda eram uma novidade para a população de poucos recursos que vivia no bairro, mas, uma novidade que custava dinheiro. Dessa maneira, seria compreensível que ainda que esses serviços significassem uma maior comodidade, pouca gente se dispusesse a pagá-los por não estarem habituados, a não ser que obrigados a isso. Por outro lado, não sabemos se todos os pedidos de licença para instalação da rede passaram necessariamente pelo setor de Obras Públicas do município, ou se poderiam ser encaminhados diretamente para a Repartição Técnica de Águas e Esgotos.

$\mathrm{Na}$ verdade, os casos acima se referiam à abertura de valas em calçamentos já feitos, o que requeria a necessidade de licença da Câmara e pagamento de taxas extras. De qualquer maneira, essas informações elucidam, ao menos, algumas das ruas por

\footnotetext{
${ }^{197}$ É difícil fazer afirmações a esse respeito, mas o fato de haverem tão poucas solicitações nos anos seguintes (três em 1913, e seis em 1914), pode ser significativo.
} 
onde passava a rede: Conselheiro Carrão, Major Diogo, 14 de Julho, Santo Amaro, Santo Antonio e 13 de Maio. Na maior parte, trata-se em geral de ruas longas, que atravessavam o bairro de norte a sul. No entanto, também se nota menções a ruas de percursos mais curtos, como a 14 de julho e a Conselheiro Carrão. Provavelmente, em 1914, a rede já envolvesse todo o bairro.

É evidente que, em qualquer situação, haveria um espaço nas residências destinado ao uso sanitário, nem que fosse apenas uma fossa negra nos fundos dos terrenos, citada por Carlos Lemos (1999) para as casas com apenas dois cômodos, e ausente nos projetos arquitetônicos: “[...] (a fossa negra escavada no fundo do quintal é sempre ignorada, nunca mencionada nos desenhos levados à aprovação pela prefeitura)". Conforme o Artigo 77 do Código Sanitário, as fossas seriam toleradas, desde que não houvesse serviço de esgotos. Por outro lado, a única ocasião em que encontramos referências à obrigatoriedade de construção desse cômodo, data justamente de 1914, quando João Pangela pede licença para reformar uma casa à rua da Abolição, $n^{\circ} 47$ (23/06/1914). Nesse processo, o parecer elaborado pelo engenheiro da Seção de Obras Públicas dizia que "se tratava de duas habitações diferentes, uma no térreo e outra no alto, (e) deve haver latrina independente para cada uma delas"198. Este parecer se refere especificamente à obrigatoriedade da latrina para todas as residências, porém, o conjunto dos processos investigados não evidencia a obrigatoriedade da definição de banheiros no projeto arquitetônico. $\mathrm{Na}$ verdade, a grande porcentagem de projetos apresentados, e via de regra aprovados, representam edificações desprovidas desse cômodo. Aliás, como projetar este cômodo em época que a rua era desprovida do serviço público de água e esgoto encanado?

A Tabela 30 contém os dados relativos à ocorrência de edificações com e sem instalações sanitárias, entre $1892^{199}$ e 1914. Ela demonstra que em dois períodos distintos, em 1899 e a partir de 1905, a relação entre os projetos construtivos sem banheiros mudou significativamente. Enquanto em 1899, 88,57\% dos projetos não apresentava banheiro, a partir de 1905 essa porcentagem diminuiu gradativamente, até alcançar o menor índice em 1914, com apenas 13,82\% dos projetos sem esse cômodo. Assim, se pensarmos que a rede de esgotos pode ter sido instalada no bairro por volta

\footnotetext{
198 Obras Particulares, 1914, Cx. A1.

${ }^{199}$ Data desse ano a primeira solicitação acompanhada de projeto arquitetônico.
} 
de 1906, esses índices fazem bastante sentido e explicam, em parte, o baixo percentual de edificações desprovidas de banheiro ou latrina.

\begin{tabular}{|c|c|c|c|c|}
\hline ANO & $\begin{array}{c}\text { COM } \\
\text { BANHEIRO }\end{array}$ & $\begin{array}{c}\text { SEM } \\
\text { BANHEIRO }\end{array}$ & TOTAL & $\begin{array}{c}\text { PERCENTUAL } \\
\text { /ANO }\end{array}$ \\
\hline $1892(*)$ & - & 2 & 2 & $\mathbf{1 0 0}$ \\
\hline 1893 & 4 & $\mathbf{2 8}$ & $\mathbf{3 2}$ & $\mathbf{8 7 , 5}$ \\
\hline 1894 & 3 & $\mathbf{7}$ & $\mathbf{1 0}$ & $\mathbf{7 0}$ \\
\hline 1895 & 6 & $\mathbf{1 0}$ & $\mathbf{1 6}$ & $\mathbf{6 2 , 5}$ \\
\hline $1896(*)$ & - & $\mathbf{1}$ & $\mathbf{1}$ & $\mathbf{1 0 0}$ \\
\hline $1897(*)$ & 6 & - & $\mathbf{6}$ & - \\
\hline $1898(*)$ & 8 & $\mathbf{3}$ & $\mathbf{1 1}$ & $\mathbf{2 7 , 2 7}$ \\
\hline $\mathbf{1 8 9 9}$ & 4 & $\mathbf{3 1}$ & $\mathbf{3 5}$ & $\mathbf{8 8 , 5 7}$ \\
\hline 1900 & 3 & $\mathbf{8}$ & $\mathbf{1 1}$ & $\mathbf{7 2 , 7 2}$ \\
\hline 1901 & 7 & $\mathbf{6}$ & $\mathbf{1 3}$ & $\mathbf{4 6 , 1 5}$ \\
\hline $1902(*)$ & - & $\mathbf{1}$ & $\mathbf{1}$ & $\mathbf{1 0 0}$ \\
\hline $1903(*)$ & - & - & - & - \\
\hline $1904(*)$ & - & - & - & $\mathbf{3 1 , 3 7}$ \\
\hline 1905 & 35 & $\mathbf{1 6}$ & $\mathbf{5 1}$ & $\mathbf{2 6 , 7 8}$ \\
\hline 1906 & 41 & $\mathbf{1 5}$ & $\mathbf{5 6}$ & $\mathbf{3 5}$ \\
\hline 1907 & 26 & $\mathbf{1 4}$ & $\mathbf{4 0}$ & $\mathbf{2 2 , 3 4}$ \\
\hline 1912 & 73 & $\mathbf{2 1}$ & $\mathbf{9 4}$ & $\mathbf{1 3}, \mathbf{1 4 2}$ \\
\hline 1913 & 124 & $\mathbf{1 3}$ & $\mathbf{9 4}$ & $\mathbf{6 1 5}$ \\
\hline 1914 & 81 & $\mathbf{1 9 4}$ & $\mathbf{6 1 5}$ & \\
\hline TOTAL & 421 & & & \\
\hline & & & & \\
\hline
\end{tabular}

(*) Anos fora da amostra selecionada.

Tabela 30 - Relação percentual dos projetos construtivos, sem banheiros

Acreditamos que essas considerações sobre as instalações sanitárias no bairro do Bexiga sejam importantes para a análise do interior das moradias edificadas. Estando presentes ou ausentes nos projetos arquitetônicos, localizadas dentro ou fora das casas, refletem as transformações ocorridas não apenas no bairro, mas em toda a cidade.

A seguir, arrolamos as edificações residenciais e mistas, conforme o número de cômodos propostos nos projetos e exemplificados nas Figuras 42, 43, 44, 45, 46 e 47. A partir dessa classificação, organizamos os dados referentes às $\mathbf{6 1 5}$ edificações destinadas aos usos residencial e misto ${ }^{200}$, tendo o cuidado de destacar o número e o tipo de cômodos propostos pelos proprietários e/ou construtores. Dessa maneira, obtivemos um novo banco de dados, organizado a partir das seguintes informações:
a) presença e ausência de instalações sanitárias
b) data do processo
c) localização
d) número de cômodos
f) descrição resumida dos cômodos propostos

\footnotetext{
${ }^{200}$ As 615 edificações são resultado de $\mathbf{4 3 4}$ requerimentos originais, acrescidos das $\mathbf{1 8 1}$ unidades residenciais a serem edificadas.
} 
Carlos Lemos, no livro A República ensina a morar (melhor), trabalhou com sete categorias. Para a análise do universo investigado nós utilizamos, basicamente, as definições do autor, porém, dadas as peculiaridades do bairro, optamos por definir outras categorias, de maneira a que enquadrassem melhor o universo estudado, lembrando, inclusive, o alerta de Lemos sobre a dificuldade de estabelecer separações nítidas entre elas. Abaixo reproduzimos o trecho em que o autor detalha as suas categorias :

“[...] cortiços, casas operárias, casas da baixa classe média, casas da classe média propriamente dita, casas de classe média alta, palacetes e soluções mistas [...]. As casas operárias $\boldsymbol{O P}$ abrangeriam as moradias pequenas de até três acomodações, fora o WC de uso exclusivo da família [...]. As residências da classe média baixa $\boldsymbol{C B}$ reuniriam todas as moradias com quatro cômodos e instalações sanitárias. As moradias da classe média propriamente dita $\boldsymbol{C M}$ designariam as casas com qualquer número de dormitórios mas portadoras de duas salas, a de receber, às vezes também chamadas de "gabinete", e a sala de jantar costumeiramente batizada de "varanda, fora a cozinha, tendo ao lado instalações sanitárias completas, incluído banho. As residências ditas de classe média alta $\boldsymbol{C A}$ reuniriam os exemplares com qualquer número de dormitórios, mais sala de visitas, "gabinete", agora com feição de escritório, sala de jantar, copa-cozinha e quarto de empregada. Também podem aparecer uma despensa e um quarto de engomar[...]."

Frequentemente, encontramos a expressão "casa operária" nos processos analisados, porém nem sempre essa nomenclatura se refere às pequenas casas descritas por Lemos, com somente três cômodos, podendo conter até cinco cômodos, se encaixando perfeitamente na categoria "classe média". Diversos projetos, cujas plantas indicam uma sala de visitas, dois dormitórios, sala de jantar, cozinha e instalação sanitária, e que poderiam se classificar até como de "classe média propriamente dita" são apresentados como sendo "casas operárias". Por outro lado, alguns exemplares portadores de "gabinetes" possuem apenas quatro cômodos e poderiam se enquadrar na categoria "classe média baixa". Assim se seguem diversos exemplos, onde ocorre essa "mistura" de categorias, impossibilitando que as utilizemos de forma estanque, relacionada a uma ou outra classe social.

Pudemos perceber, com o avançar da década de 1910, a intenção de especialização do interior das moradias; se nem sempre de fato, ao menos na introdução de nomenclaturas mais de acordo com os padrões modernos nos projetos arquitetônicos. Contudo, também constatamos a permanência de alguns termos, mesmo

\footnotetext{
${ }^{201}$ LEMOS, Carlos - A República ensina a morar (melhor), São Paulo: Hucitec, 1999, p. 33-34. Grifos
} nossos. 
em anos mais avançados. As "varandas" e as "salas de jantar" - cômodos equivalentes - estão presentes em todos os anos investigados, assim como chegamos a encontrar algumas "alcovas". Em 18/06/1901, havia um processo referente a uma edificação à rua Santo Antonio $\mathrm{n}^{\mathrm{o}} 5 \mathrm{C}$, que tinha "sala, alcova, dois dormitórios, varanda, banheiro, despensa e cozinha” ${ }^{\text {,202 }}$. Outro exemplo, já de 02/01/1907, na rua São Domingos, nº 6 A, se refere à uma moradia com apenas "sala, alcova e varanda",203, só que com iluminação direta. Nos dois casos, embora se mantivesse a denominação antiga, remetendo a um período anterior às exigências das posturas municipais, tratava-se na verdade de cômodos com janelas para o exterior.

Em todas essas categorias, mesmo aquelas desprovidas de acomodações sanitárias, eventualmente encontramos a presença de cômodos destinados a usos mais especializados e socialmente valorizados, como vestíbulos, escritórios, quartos de engomar e de criada, despensas e copas, além de eventuais fornos, depósitos, terraços e alpendres. Dessa maneira, na impossibilidade de avaliarmos a utilização efetiva desses espaços pelos seus usuários, para a sua classificação foram mantidos os critérios a partir do número de cômodos encontrados. Apenas os fornos e terraços foram ignorados. No caso dos fornos, isso se justifica por um provável uso vinculado aos hábitos alimentares do imigrante italiano, como já mencionado por Lemos. Quanto aos terraços, frequentemente funcionavam como substitutos de quintais, ou ainda, como áreas para iluminação e circulação de ar.

A seguir, sintetizamos as informações sobre as tipologias identificadas.

\begin{tabular}{|c|c|c|c|c|c|c|}
\hline TIPOLOGIAS & $\begin{array}{c}\text { ATÉ } 3 \\
\text { CôMODOS }\end{array}$ & $\begin{array}{c}4 \\
\text { CôMODos }\end{array}$ & $\begin{array}{c}5 \\
\text { CôMODOS }\end{array}$ & $\begin{array}{c}6 \\
\text { CôMoDos }\end{array}$ & $\begin{array}{l}\text { MAIS DE } 6 \\
\text { CÔMODOS }\end{array}$ & $\begin{array}{c}\text { UNIDADES } \\
\text { RESIDENCIAIS } \\
\text { A CONSTRUIR }\end{array}$ \\
\hline CASAS SIMPLES & 78 & 51 & 43 & 35 & 35 & 242 \\
\hline $\begin{array}{l}\text { CASAS DE } \\
\text { FUNDO }\end{array}$ & 9 & 3 & 5 & 1 & 2 & 20 \\
\hline $\begin{array}{l}\text { CASAS EM } \\
\text { SÉRIE }\end{array}$ & 53 & 50 & 40 & 23 & 42 & 208 \\
\hline VILAS & 15 & 18 & 12 & 1 & - & 46 \\
\hline SOBRADOS & 7 & 4 & 9 & 3 & 8 & 31 \\
\hline CASAS MISTAS & 26 & 19 & 12 & 6 & 5 & 68 \\
\hline TOTAL & 188 & 145 & 121 & 69 & 92 & 615 \\
\hline
\end{tabular}

Tabela 31 - Tipologias, por número de cômodos

Para a elaboração da tabela, partimos dos critérios adotados para a análise das tipologias por número de cômodos:

- casas com até 3 cômodos (2 cômodos e cozinha)

\footnotetext{
${ }^{202}$ Requerimento em nome de Francisco de Mattos Dias, Obras Particulares, v. 312, p. 15.

203 Obras Particulares, 1907, Cx. 26.
} 
- casas com 4 cômodos (3 cômodos e cozinha)

- casas com 5 cômodos (4 cômodos e cozinha)

- casas com 6 cômodos (5 cômodos e cozinha)

- casas com mais de 6 cômodos (mais de 5 cômodos, além da cozinha)

Os números apresentados na tabela indicam o predomínio das casas com até 3 cômodos, num total de 188, ou 30,59\% do total de $\mathbf{6 1 5}$ casas a serem construídas. Excluindo os cortiços, essas casas certamente se destinavam às camadas pobres da população do bairro. Em seguida vêm as casas de 4 cômodos, somando 145 unidades, ou aproximadamente 23,57\% do total; e aquelas de 5 cômodos, com 121 unidades, ou 19,68\%, - os dois casos provavelmente voltados para as camadas médias. As casas com 6 cômodos contam com apenas 69 unidades, ou 11,21\% do universo estudado, e demonstram se tratar de moradores com mais posses, pertencentes a uma classe média alta. Por fim, no caso daquelas moradias com mais de 6 cômodos (92 unidades, ou $14,95 \%)$, se torna mais difícil definir a que tipo de morador se destinavam.

\begin{tabular}{|l|c|c|}
\hline \multicolumn{1}{|c|}{ NÚMERO DE CÔMODOS } & $\begin{array}{c}\text { CASAS A } \\
\text { CONSTRUIR }\end{array}$ & $\%$ \\
\hline ATÉ 3 CÔMODOS & 188 & $\mathbf{3 0 , 5 9}$ \\
\hline 4 CÔMODOS & 145 & $\mathbf{2 3 , 5 7}$ \\
\hline 5 CôMODOS & 121 & $\mathbf{1 9 , 6 8}$ \\
\hline 6 CÔMODOS & 69 & $\mathbf{1 1 , 2 1}$ \\
\hline MAIS DE 6 CôMODOS & 92 & $\mathbf{1 4 , 9 5}$ \\
\hline TOTAL & $\mathbf{6 1 5}$ & $\mathbf{1 0 0 \%}$ \\
\hline
\end{tabular}

Tabela 32 - Porcentagem de casas a construir, por número de cômodos

A questão é que tanto as casas com 6 cômodos, como aquelas com mais de 6 cômodos, podiam apresentar programas mais complexos. Nos dois casos encontramos a presença de "gabinetes", “vestíbulos”, “despensas”, “copas”, “quartos de criadas”, etc., além das instalações sanitárias, aí já definidas como "banheiros" ou "salas de banho". Entretanto, as moradias maiores, com mais de 6 cômodos, se destacavam pela presença de um número maior de quartos ou dormitórios, assim como por um cuidado especial na distribuição espacial dos cômodos nas plantas. Eventualmente, apresentavam uma implantação no lote que as diferenciava da vizinhança mais pobre. Eram construídas, por vezes, distantes dos alinhamentos, possuindo recuos frontais e laterais, ocupados por jardins. Algumas delas apresentavam-se elevadas em relação ao nível da rua, pela presença de porões mais altos, em geral relacionados à topografia mais propícia. Observamos a coexistência dessas tipologias numa mesma rua, embora houvesse certa concentração de casas mais simples na zona x ou mais complexas na zona y. 
Jacques Le Goff ${ }^{204}$, ao analisar a configuração da "nova sociedade urbana" francesa, no decorrer dos séculos XII ao XIV, nos fala de uma sociotopografia típica das cidades medievais. Assim como na cidade colonial brasileira, na aparente homogeneidade do conjunto, verificava-se, numa mesma rua, a presença de diferentes “dégradés" sociais, dispostos em áreas topograficamente mais e menos valorizadas, ou às vezes coexistindo lado a lado. Um dos objetivos deste capítulo é fornecer um painel da sociotopografia do bairro do Bexiga, entre os anos de 1882 e 1914. Nessa época, de uma maneira geral, São Paulo vivia um momento crucial de transformação, onde observamos a tendência para a concentração de determinadas camadas sociais em determinados bairros/espaços, de acordo com os interesses e conveniências específicos deste ou daquele segmento. Ao contrário da cidade colonial, concentrada na "colina histórica" e aparentemente mais homogênea, apresentando uma sociotopografia menos evidente, a cidade da Primeira República apresentava uma tendência à especialização dos espaços - o Centro, com comércio e serviços; e os bairros residenciais de classe alta, média, baixa; ou bairros industriais, etc.

Realizamos alguns estudos de casos sobre edificações maiores e menores presentes no bairro do Bexiga, a começar pelo exemplar da rua Major Diogo (Figura 42). Nessa residência foi possível perceber que, além do material mais sofisticado utilizado na edificação, a implantação no lote em relação às casas vizinhas fazia toda a diferença $^{205}$. Abaixo, destacamos alguns outros casos exemplares de projetos por número de cômodos, onde procuramos analisar suas principais características, a partir das informações fornecidas pelos respectivos processos.

\footnotetext{
${ }^{204}$ LE GOFF, Jacques - “A nova sociedade urbana”, in O apogeu da cidade medieval, São Paulo: Martins Fontes, 1992, p. 94 a 123. Disponível em: http://groups.google.com.br/group/digitalsource. Consulta em 17/05/2009.

${ }^{205}$ Obras Particulares, Processo de junho de 1900, em nome de Domiciana de Almeida Nogueira. In "Arquitetura Eclética no Bexiga, (A primeira década do século XX - 1910). Estudo de caso Rua Major Diogo, 91”, AUH 5852 - Técnicas Construtivas Tradicionais, novembro/2005.
} 


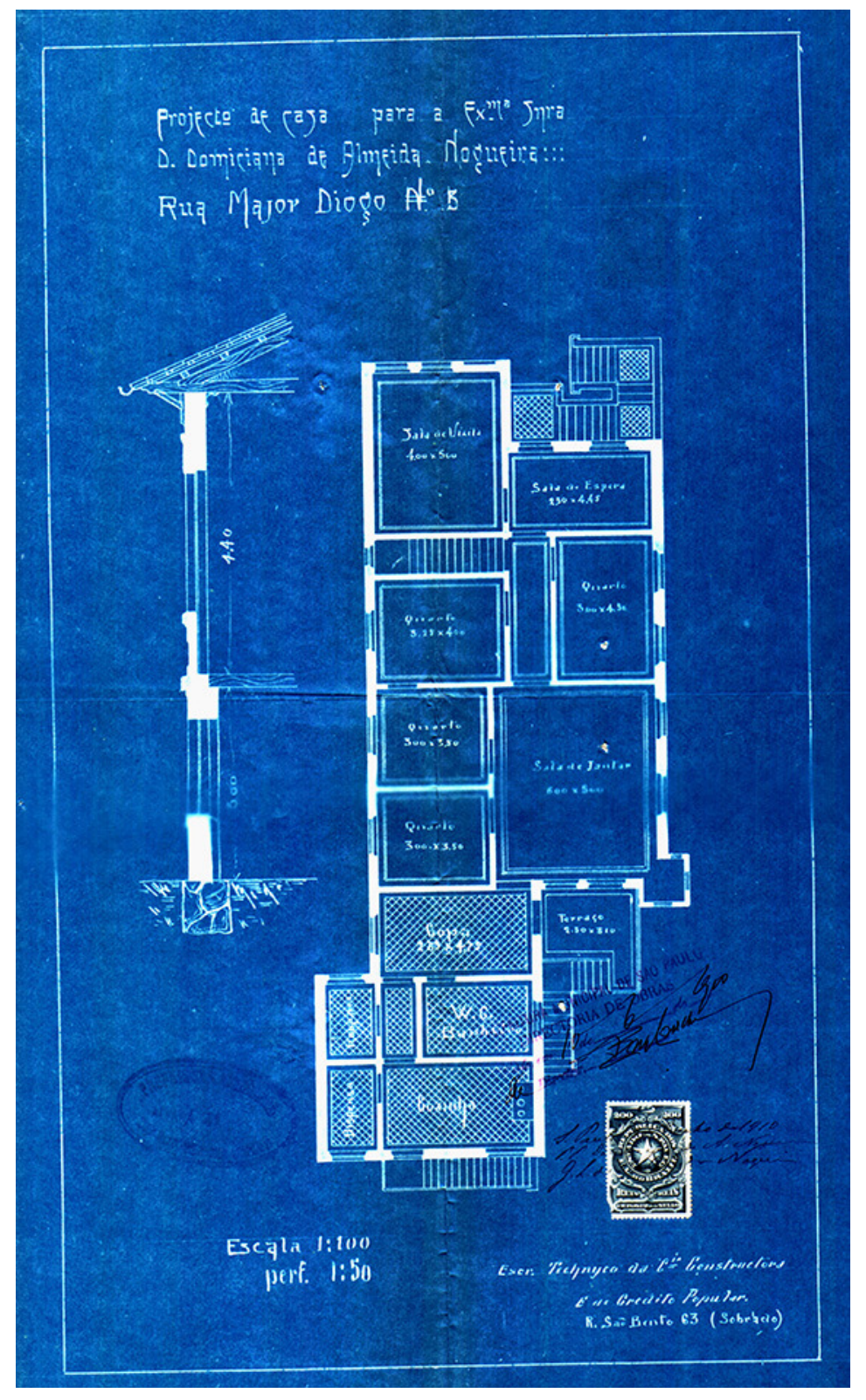

Figura 42 - Projeto de casa com mais de seis cômodos à rua Major Diogo $\mathrm{n}^{\circ}$ 5. O terreno conta com aproximadamente $900 \mathrm{~m} 2(15,40 \mathrm{~m}$ de frente por $60 \mathrm{~m}$ de fundo), sendo que a área construída ocupa cerca de $205 \mathrm{~m} 2$ (aproximados 9,30 x 22m) desse total. Construção praticamente isolada no lote, a não ser pelo espaço ocupado internamente por duas despensas, contíguas ao muro vizinho. O recuo frontal, em relação ao alinhamento é de quase $10 \mathrm{~m}$, ocupado por jardim, escada e caminho em ziguezague, perpendicular ao terreno, conduzindo à residência, que se encontra acima do nível da rua. A lateral esquerda conduz aos fundos, com recuo em relação ao muro vizinho de 3,70m ; a lateral direita, com 2,40m de largura. A casa, com pé direito de 4,40m, possui sala de visitas, sala de espera, quatro quartos, sala de jantar, copa, banheiro, duas despensas, cozinha e dois terraços. O porão, com altura de $3 \mathrm{~m}$, é ocupado, na parte posterior, por três pequenos cômodos que, conforme o proprietário, eram habitados pelos empregados. Na sequência desses cômodos, há mais duas salas, dois quartos, cozinha e banheiro. Por fim, o corte demonstra a inexistência de platibanda. Projeto de autoria do Escritório Technyco da Cia. Constructora e de Credito Popular, com "Lavre-se alvará de 10/06/1910, para construção da casa de Domiciana de Almeida Nogueira. Fonte: Obras particulares, Processo de 04/06/1910, Cx. M1. AHMWL. 


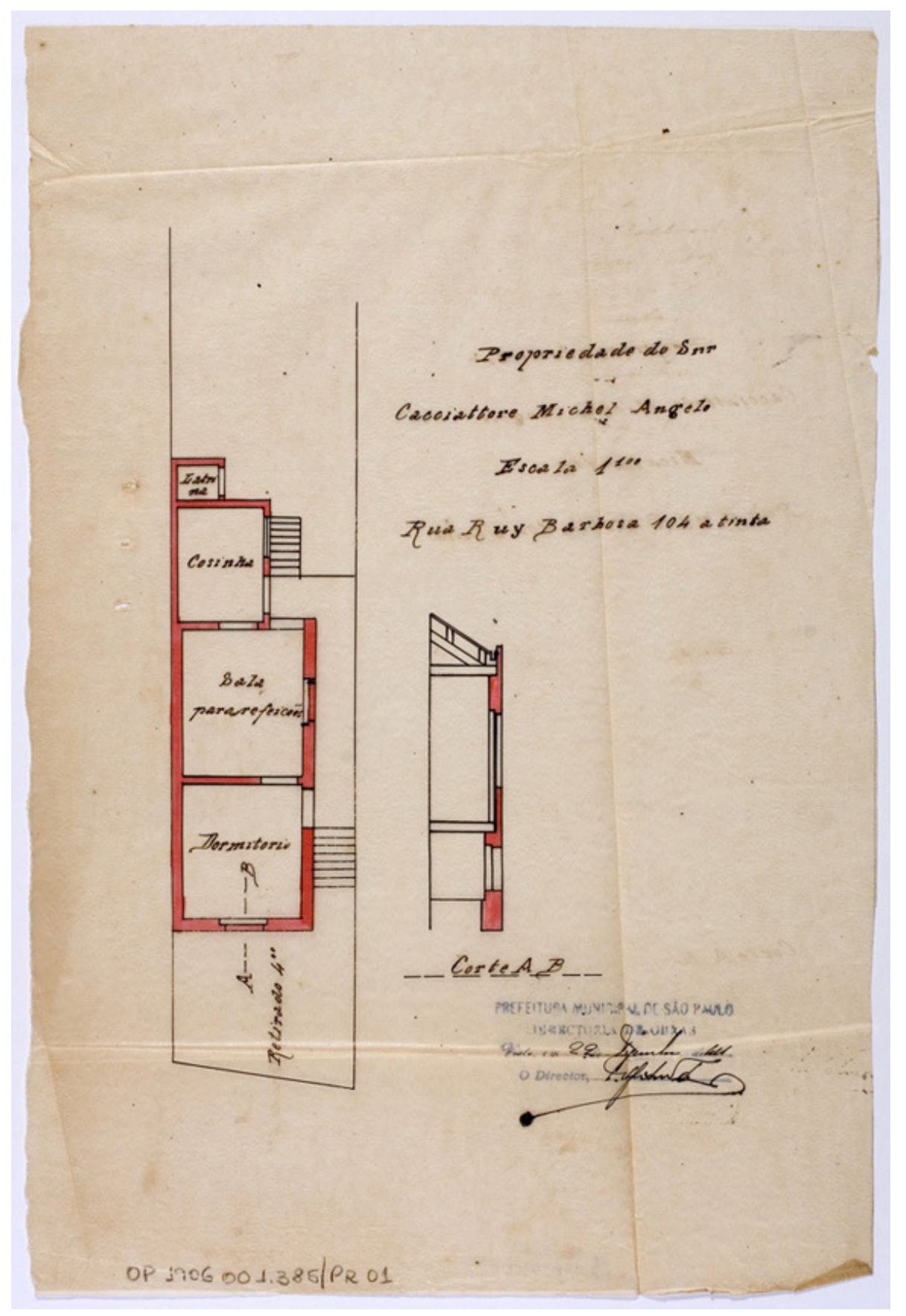

Figura 43 - Casa com até 3 cômodos de propriedade de Cacciattore Michel Ângelo, à rua Ruy Barbosa $\mathrm{n}^{\circ} 104 \mathrm{~T}$ (ou 112). A casa, a ser construída com recuo frontal de 4 metros, contém dormitório, sala para refeições, cozinha e latrina contígua à parede da cozinha. $\mathrm{O}$ acesso ao interior se dá através de corredor descoberto, com portas para o dormitório e a cozinha; a circulação interna passa necessariamente por todos os cômodos. O dormitório possui janela voltada para o terreno fronteiro e, a sala de refeições, para o corredor lateral; a cozinha possui janela e porta para o quintal. O corte demonstra platibanda de dimensões discretas; pé direito com cerca de $4 \mathrm{~m}$, e porão com aproximadamente $50 \mathrm{~cm}$. Esse é um caso típico daqueles que acreditamos possam ter dado origem à construção de uma sala ou salão de negócios no espaço entre o alinhamento e a casa. Conforme o processo de 14/11/1906, possuía 5,50m de alinhamento e área construída de 50 m2. Fonte: Obras particulares, Processo de 14/11/1906, Q-1, R-1. AHMWL. 


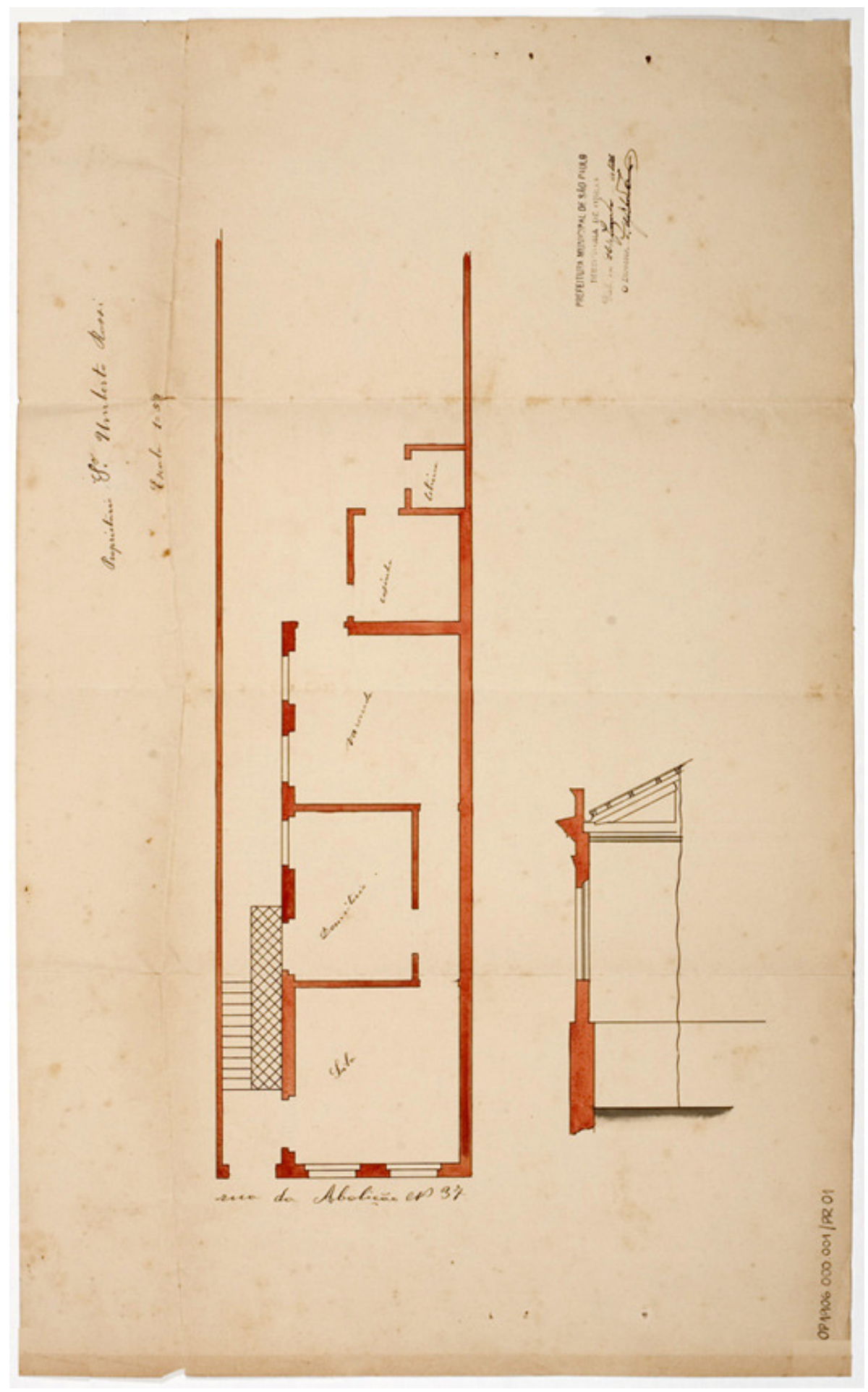

Figura 44 - Casa com 4 cômodos, à rua da Abolição n ${ }^{\circ}$ 37, de propriedade de Umberto Rossi. Contém $\underline{\text { sala, }}$ dormitório, varanda (ou sala de refeições), cozinha e latrina contígua à parede da cozinha. A iluminação de todos os cômodos se dá através das janelas voltadas para o corredor descoberto, à esquerda da edificação. De acordo com o corte, presença de platibanda; o porão parece ter mais de $50 \mathrm{~cm}$, porém não possui gradil para a rua; pé direito com prováveis $4 \mathrm{~m}$. No processo não consta a área construída, somente o alinhamento com 6 metros. Fonte: Obras Particulares, Processo de 21/06/1906. Cx. 1-01. AHMWL. 


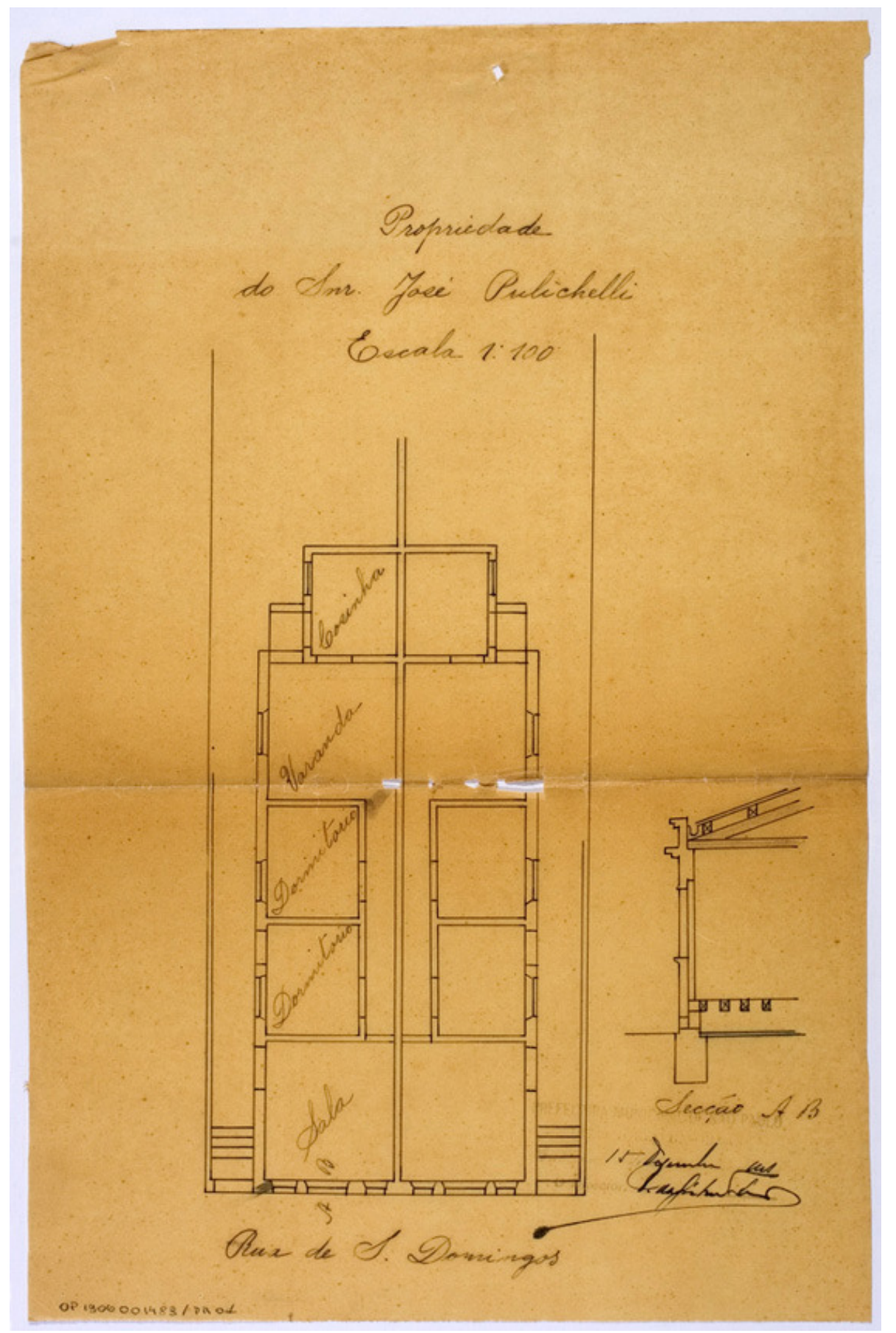

Figura 45 - Casas em série geminadas, com 5 cômodos, à rua São Domingos no 8 e 10, de propriedade de José Pulichelli. Projeto consta de sala, dois dormitórios, varanda e cozinha, além de corredor lateral descoberto, para onde se abrem as janelas. Circulação entre a sala, os quartos e a varanda, através de corredor. Não há sinal de latrina, o que pode indicar uma fossa negra nos fundos do terreno. O corte atesta a existência de platibanda, pé direito com cerca de $4 \mathrm{~m}$ e porão com altura, aparentemente, de $50 \mathrm{~cm}$. Fonte: Obras Particulares, 16/12/1906. Cx. S-1 12. AHMWL. 


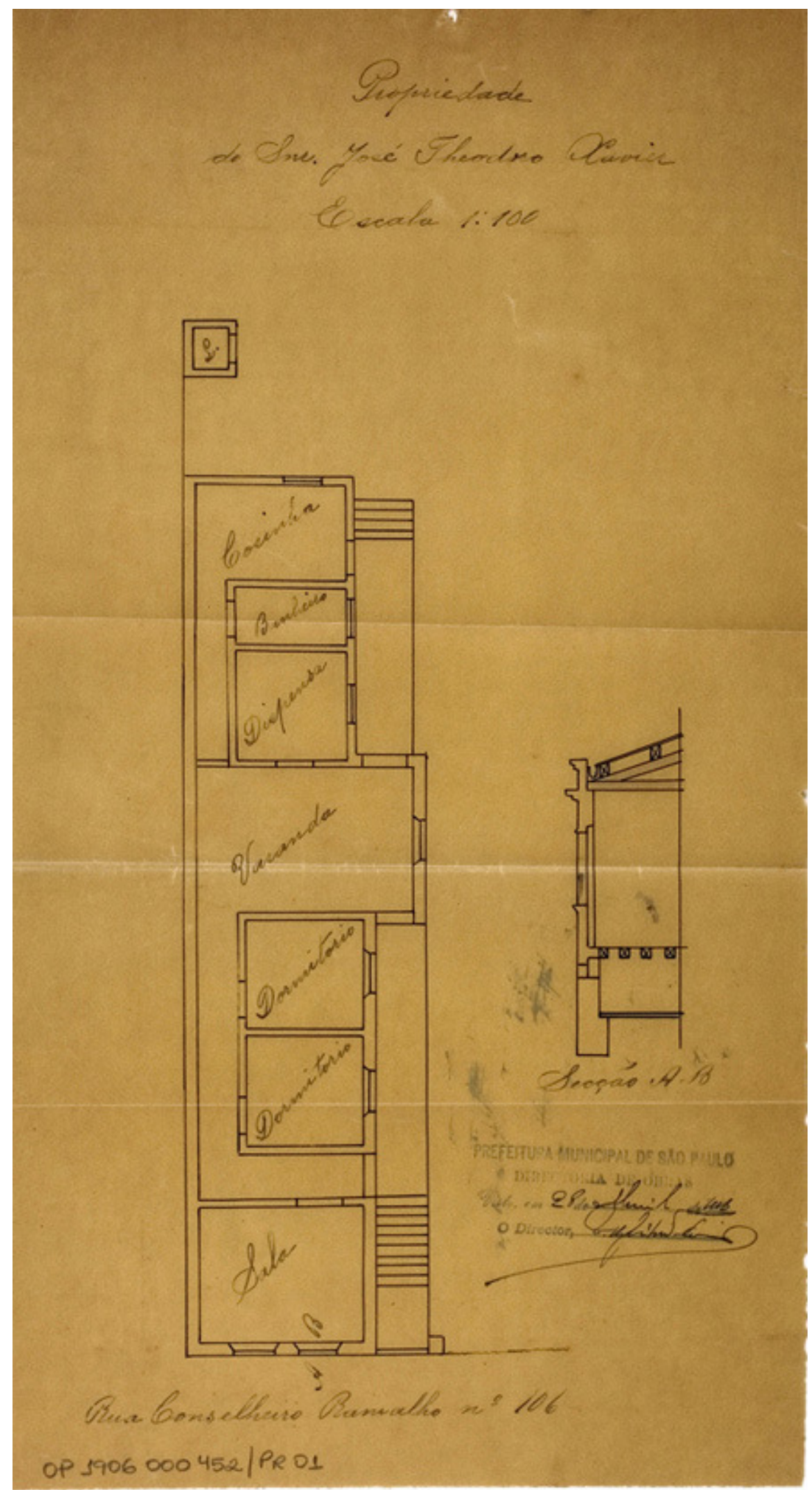

Figura 46 - Casa com 6 cômodos, à Rua Conselheiro Ramalho, 106, de propriedade de José Theodoro Xavier. Possui sala, dois dormitórios, varanda, despensa, cozinha e banheiro, além da latrina no quintal. É um dos casos indicados como "casa operária", o que a planta demonstra não ser verdade - o número de cômodos, a presença de despensa, de banheiro, e latrina externa, indicam uma certa especialização de usos. Acesso ao interior, iluminação e aeração através de corredor descoberto. O corte demonstra a existência de platibanda e porão com cerca de $50 \mathrm{~cm}$; pé direito parece ter por volta de $4 \mathrm{~m}$. Fonte: Obras Particulares, 1906, Cx. C 2 e D1-05. AHMWL. 


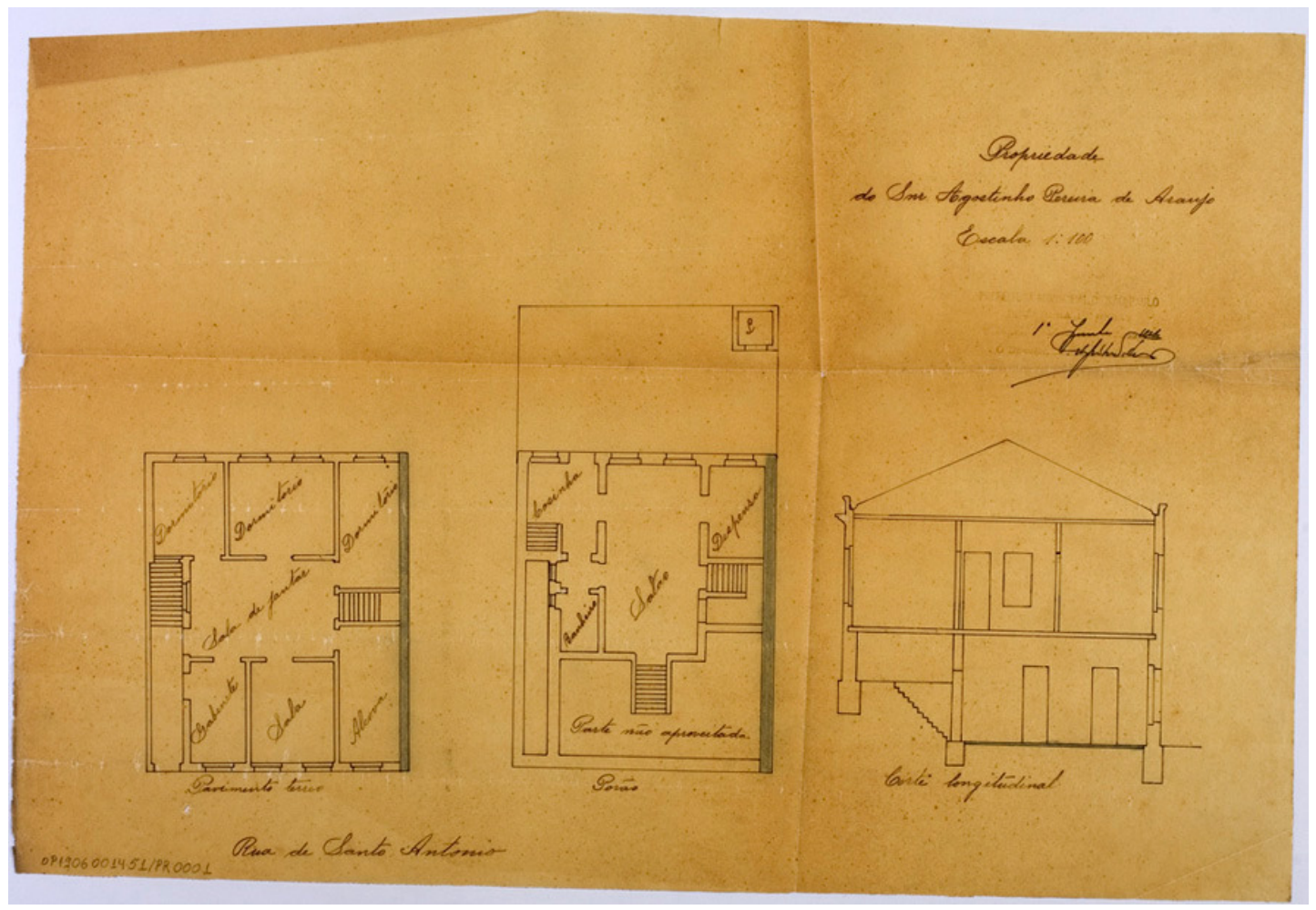

Figura 47 - Projeto de residência com mais de 6 cômodos, para Agostinho Pereira de Araújo, na Rua Santo Antonio, em frente ao $\mathrm{n}^{\circ} \mathbf{7 5}$. Trata-se de uma casa cujo desnível do porão possibilitou o aproveitamento parcial da área, anexada à residência. O "pavimento térreo" apresenta corredor lateral descoberto, com acesso ao interior através do gabinete e da sala de jantar; possui ainda três dormitórios, sala e "alcova" ${ }^{206}$, sendo que esta, além de também possuir janela para a rua, não difere dos outros cômodos com função de repouso. Na sala de jantar há escada para o porão. A frente deste pavimento, de acordo com o corte longitudinal, figura como "parte não aproveitada"; o restante do espaço é ocupado por um salão, cozinha, despensa e banheiro, todos com janelas voltadas para os fundos do terreno. O corte também demonstra platibandas na frente e nos fundos da edificação. No processo consta parecer técnico dizendo que “[...] o porão será aproveitado, assim deverá ter pé direito de 4,40m”, o que indica a mesma altura para o pé direito do piso térreo. Fonte: Obras Particulares, 05/05/1906, Cx. S1-12. AHMWL.

Procuramos buscar, nos casos exemplares analisados até aqui, formas de implantação nos lotes, tipologias, e o número de cômodos típicos, de maneira a obter um panorama de como se construiu e se viveu no bairro nos primeiros trinta anos de sua ocupação. A partir desses exemplos, e tendo como base as conceituações realizadas por Nestor Goulart Reis ${ }^{207}$ e Carlos Lemos ${ }^{208}$, destacamos algumas questões:

a) Manutenção da relação entre arquitetura e lote urbano - Levando em conta as particularidades apresentadas no bairro do Bexiga, onde proprietários e construtores

\footnotetext{
${ }^{206}$ Embora este cômodo possua janela voltada para a rua, consta na planta como sendo uma "alcova”. Isso demonstra a eventual permanência dos termos utilizados para designar os espaços domésticos, como no caso das "varandas", ainda frequentemente encontrados nos projetos arquitetônicos.

${ }^{207}$ REIS, Nestor Goulart - Quadro da Arquitetura no Brasil, São Paulo: Perspectiva, 10ª Edição, 2004, p.43 a 62 .

${ }^{208}$ LEMOS, Carlos A.C. - Cozinhas, etc., São Paulo: Perspectiva, 1976, p.138.
} 
buscaram aproveitar ao máximo os espaços disponíveis, a tendência geral foi a presença de lotes compridos e estreitos, com as casas construídas no alinhamento. Os estreitos recuos laterais significam obediência às exigências municipais. Contudo, também procuramos contemplar as exceções à regra, como no caso da Figura 47, onde houve um outro tipo de aproveitamento do lote, condicionado possivelmente, pela dimensão do terreno e pelas posses de seu proprietário.

b) Manutenção do esquema de distribuição espacial doméstico - com as áreas de receber (salas) na frente, seguidas dos espaços para repouso (quartos ou dormitórios) e as áreas de estar e serviços (varanda ou sala de jantar, copa e cozinha), assim como da circulação doméstica através do corredor lateral externo, ou através de corredores internos. Mesmo nos exemplares de casas construídas para as classes médias e altas, com maior disponibilidade de terreno, esses esquemas pouco variaram, apenas sendo acrescentados outros cômodos mais especializados e de maiores dimensões.

As técnicas, os materiais e os sistemas construtivos proporcionados pelas transformações tecnológicas ocorridas na segunda metade do século XIX, assim como as novas linguagens arquitetônicas adotadas, significaram uma mudança nas formas de morar e construir. Se somarmos as edificações de até 3 cômodos, àquelas com 4 e 5 cômodos, teremos 454 casos, ou 73,82 \% do universo de 615 casas investigadas. A grande maioria das casas foi construída por médios empreendedores, com fins locatícios. Possuíam porão e corredor ou pátio de iluminação, e de três a quatro cômodos. Excetuando-se a cozinha de utilização mais específica, em todos os outros as atividades poderiam se alternar, conforme as necessidades dos moradores - salas "de visitas", podiam converter-se em dormitório, "salas de jantar" em quartos de costura ou de passar, enfim, a superposição de atividades referida por Lemos ${ }^{209}$. A garantia da melhor iluminação, certamente implicava num viver mais saudável, e sobretudo, no uso do dia mais prolongado para o exercício das atividades domésticas. Através do transcorrer dos anos investigados, observa-se a introdução de termos supostamente mais especializados para designar os cômodos das casas, mesmo as mais pobres, demonstrando uma intenção de valorização social do "viver" nessas casas. Por outro lado, pessoas com alto poder aquisitivo, como D. Domiciana de Almeida Nogueira, proprietária da residência na rua Major Diogo, $n^{\circ}$ 5, uma entre as 87 residências com mais de 6 cômodos, só vêm confirmar a persistência dos esquemas compositivos no

${ }^{209}$ LEMOS, Carlos (1999), p.37. 
bairro $^{210}$. Ainda que se trata de uma casa grande, com cômodos de usos bem definidos, ostentando materiais importados e técnicas elaboradas, além de elementos arquitetônicos ecléticos que a distinguiam das demais casas, é mais um exemplo da típica distribuição espacial e circulação doméstica encontradas no bairro.

c) Por fim, ainda que as exceções a essas regras sejam em número restrito, é importante destacar a coexistência entre as edificações onde se manteve uma distribuição espacial tradicional e aquelas às quais os agentes produtores do espaço deram uma feição diferente. Os projetos apresentados por Joaquim Antunes dos Santos para a rua Rui Barbosa (Figura 29) e por Cezar Tacavone para a rua Santo Antonio (Figura 31) são bons exemplos disso.

\section{Localização cartográfica das tipologias edilícias}

Retomando a análise das $\mathbf{4 3 4}$ solicitações de licença para edificação providas do projeto arquitetônico, já nos referimos à coexistência de diferentes tipologias numa mesma rua, ainda que houvesse concentração de uma ou outra, nesta ou naquela rua. Tendo em vista a verificação da distribuição das edificações nas ruas do Bexiga, elaboramos a Tabela 33, onde arrolamos a ocorrência de pedidos de licença para construção em cada logradouro, de acordo com as tipologias.

Num primeiro momento, independentemente das tipologias adotadas, é flagrante a maior concentração de edificações na rua 13 de Maio (68 ou 15,67\% de 434), o que não era de se estranhar já que essa parece ser uma das ruas mais longas do bairro. Por outro lado, é nessa rua que encontramos uma alta concentração de todas as tipologias.

Em seguida, vem a rua Santo Antonio, outra rua longa, com 51 edificações ou 11,76\% do conjunto; e as ruas Conselheiro Ramalho e Major Diogo, cada qual com 41 (9,44\%)

\footnotetext{
${ }^{210}$ De acordo com a entrevista realizada com o atual proprietário, Luiz Carlos Sanson, herdeiro do imóvel, a casa foi construída para servir de residência para a família de José Luiz de Almeida Nogueira, o que efetivamente aconteceu, até 1914. Neste ano, com a morte do mesmo, a família voltou a viver em Bananal, onde possuía fazendas de café, alugando a casa a uma ordem religiosa que ali instalou um colégio. Em 1937, a família retornando a São Paulo, voltou a ocupar a casa. Em 2005, após a morte de uma das últimas pessoas da família, a casa foi cedida à empresa Cia.do Restauro, mediante acordo feito entre o proprietário e herdeiro direto da casa. Nesse acordo, o edifício foi cedido àquela Companhia, por sete anos, renováveis por mais sete, em troca da restauração total do imóvel, e da instalação de uma escola para formação de técnicos especialistas em obras de restauro (pedreiros, carpinteiros, eletricistas, etc.). In "Arquitetura Eclética no Bexiga, (A primeira década do século XX - 1910). Estudo de caso Rua Major Diogo, 91”, AUH 5852 - Técnicas Construtivas Tradicionais, novembro/2005.
} 
e $40(9,21 \%)$ edificações, respectivamente. O menor número de edificações nas demais ruas, provavelmente deve ser creditado às menores extensões das mesmas.

\begin{tabular}{|c|c|c|c|c|c|c|c|c|c|}
\hline $\mathbf{N}^{\circ}$ & RUAS & $\begin{array}{l}\text { CASAS } \\
\text { SIMPLES }\end{array}$ & $\begin{array}{c}\text { CASAS } \\
\text { DE } \\
\text { FUNDOS }\end{array}$ & $\begin{array}{l}\text { CASAS } \\
\text { EM } \\
\text { SÉRIE }\end{array}$ & VILAS & $\begin{array}{c}\text { SOBRADOS } \\
\text { COM DUPLA } \\
\text { RESIDÊNCIA }\end{array}$ & $\begin{array}{c}\text { CASAS } \\
\text { DE } \\
\text { USO } \\
\text { MISTO }\end{array}$ & TOTAL & $\%$ \\
\hline 1 & ABOLIÇÃO & 7 & - & - & - & - & 1 & 8 & 1,85 \\
\hline 2 & CONSELHEIRO CARRÃO & 16 & - & 4 & - & - & 4 & 24 & 5,53 \\
\hline 3 & CONSELHEIRO RAMALHO & 25 & - & 7 & 2 & - & 7 & 41 & 9,44 \\
\hline 4 & FORTALEZA & 3 & - & 3 & 1 & - & - & 7 & 1,61 \\
\hline \multirow{2}{*}{5} & $\begin{array}{l}\text { MONTE DE OURO } \\
\text { (JOÃO PASSALACQUA) }\end{array}$ & 3 & - & - & - & - & 1 & \multirow{2}{*}{14} & \multirow{2}{*}{13,22} \\
\hline & $\begin{array}{l}\text { Jỗo PASSALACQUA/ } \\
\text { (MONTE DE OURO) }\end{array}$ & 7 & - & 1 & 1 & - & 1 & & \\
\hline \multirow{2}{*}{6} & VALINHOS / MAJOR DIOGO & - & - & - & - & - & - & \multirow{2}{*}{40} & \multirow{2}{*}{9,21} \\
\hline & MAJOR DIOGO/VALINHOS & 21 & 3 & 6 & 3 & 1 & 6 & & \\
\hline \multirow{2}{*}{7} & $\begin{array}{l}\text { CONS. ANTONIO PRADO } \\
\text { (MANOEL DUTRA) }\end{array}$ & - & - & - & - & - & - & \multirow{2}{*}{34} & \multirow{2}{*}{7,84} \\
\hline & $\begin{array}{l}\text { MANOEL DUTRA } \\
\text { (CONS. ANTONIO PRADO) }\end{array}$ & 22 & 1 & 4 & 1 & 2 & 4 & & \\
\hline 8 & MARIA JOSÉ & 17 & 2 & 4 & - & - & 2 & 25 & 5,77 \\
\hline 9 & QUATORZE DE JULHO & 1 & - & 1 & - & - & 1 & $\mathbf{3}$ & 0,69 \\
\hline 10 & RUI BARBOSA & 24 & 1 & 5 & 1 & 1 & 4 & 36 & 8,29 \\
\hline 11 & SANTO AMARO & 15 & 3 & 8 & 1 & 1 & 2 & 30 & 6,92 \\
\hline \multirow{2}{*}{12} & VALE DO ANDORRA & - & - & - & - & - & - & - & - \\
\hline & SANTO ANTONIO & 19 & 1 & 10 & - & 2 & 19 & 51 & 11,76 \\
\hline 13 & SÃO DOMINGOS & 7 & 1 & 6 & - & 1 & 2 & 17 & 3,91 \\
\hline 14 & SÃO VICENTE & 3 & 3 & 1 & - & - & 1 & 8 & 1,85 \\
\hline 15 & $\begin{array}{l}\text { SARACURA GRANDE } \\
\text { (NOVE DE JULHO) }\end{array}$ & 1 & 1 & 1 & - & - & - & 3 & 0,69 \\
\hline 16 & $\begin{array}{l}\text { SARACURA PEQUENA } \\
\text { (DR. PLÍnIo BARRETo) }\end{array}$ & 1 & - & - & - & - & - & 1 & 0,23 \\
\hline 17 & DO SOL / DR. LUÍS BARRETO & 12 & - & 7 & - & 2 & 3 & 24 & 5,52 \\
\hline \multirow[t]{2}{*}{18} & TREZE DE MAIO & 38 & 4 & 11 & - & 5 & 10 & 68 & 15,67 \\
\hline & TOTAL & 242 & 20 & 79 & 10 & 15 & 68 & 434 & $100 \%$ \\
\hline
\end{tabular}

Tabela 33 - Distribuição das diferentes tipologias edilícias, por ruas

É importante destacar que, nos casos dos logradouros que tiveram seus nomes alterados (Monte de Ouro, Valinhos e Conselheiro Antonio Prado), somamos os respectivos totais - correspondentes às ruas de nome antigo e novo. Já as ruas Saracura Grande e Saracura Pequena, com menos de $1 \%$ da amostra, são uma exceção. A Saracura Grande veio a configurar parte da atual Avenida 9 de Julho e a Saracura Pequena tornou-se a rua Dr. Plínio Barreto, localizada no lado oposto daquela avenida. Dessa maneira, nenhuma das duas vias foi alvo de levantamentos sistemáticos, justamente por se localizarem fora do perímetro eleito para as nossas investigações.

Para melhor espacializar a distribuição das tipologias utilizamos o Mappa Topographico do Município de São Paulo, de $1930^{211}$. Trata-se de uma planta cadastral que permite a visualização de todos os imóveis existentes naquela data, lote a lote. A idéia inicial de identificação das tipologias por proprietários deveria obedecer a

\footnotetext{
${ }^{211}$ Mappa Topográphico do Município de São Paulo, executado pela empresa SARA BRASIL, a partir de levantamento aerofotogramétrico, F. 37, 1930. Arquivo Histórico Municipal Washington Luís.
} 
sequência lógica da numeração dada pelo processo. Para cada rua, a partir do Centro, contaríamos sequencialmente os lotes: os números ímpares na margem esquerda e os números pares na margem direita, até chegar ao endereço em questão. Entretanto, embora a configuração do bairro, em 1930, não difira muito daquela existente em 1914, percebemos que a quase totalidade dos lotes apresenta-se ocupada por imóveis que devem ter sido construídos no decorrer desses dezesseis anos, o que certamente implicou na alteração da numeração dos edifícios anteriores a esta data. Ao realizarmos o levantamento dos últimos emplacamentos feitos em 1911 e 1912, constatamos que diversas ruas, como a 13 de Maio, Santo Amaro, Rui Barbosa, 14 de Julho, Maria José, Manoel Dutra, Dr. Luiz Barreto (antiga rua do Sol) e Conselheiro Carrão apresentavam muitos lotes desocupados e desprovidos de numeração. Após consultarmos as listas de Emplacamentos, verificamos que cada rua foi alvo de mais de uma alteração de numeração, até 1930, certamente para contemplar os novos imóveis construídos, o que pode ter determinado a mudança dos números originais das casas construídas anteriormente.

Outro problema encontrado se refere às reformas e acréscimos nos imóveis. Ainda que contemos com os projetos arquitetônicos originais para uma comparação com os lotes visualizados no mapa, não sabemos que alterações foram realizadas, modificando a configuração espacial da edificação e impossibilitando o reconhecimento. Em alguns casos, quando se tratava de imóvel localizado numa esquina e o processo fornecia esta informação, foi possível fazer a identificação. Porém, esses exemplos foram muito raros.

Tendo em vista as questões apontadas e para não correr o risco de uma avaliação infundada, montamos diferentes mapas onde a identificação de cada tipologia foi dada por cores diferentes. Sempre que possível, procuramos localizar na planta os exemplares passíveis de identificação.

Como demonstrado pela Tabela 33, observamos sempre diferentes tipologias ocupando uma mesma via, como veremos a seguir. 

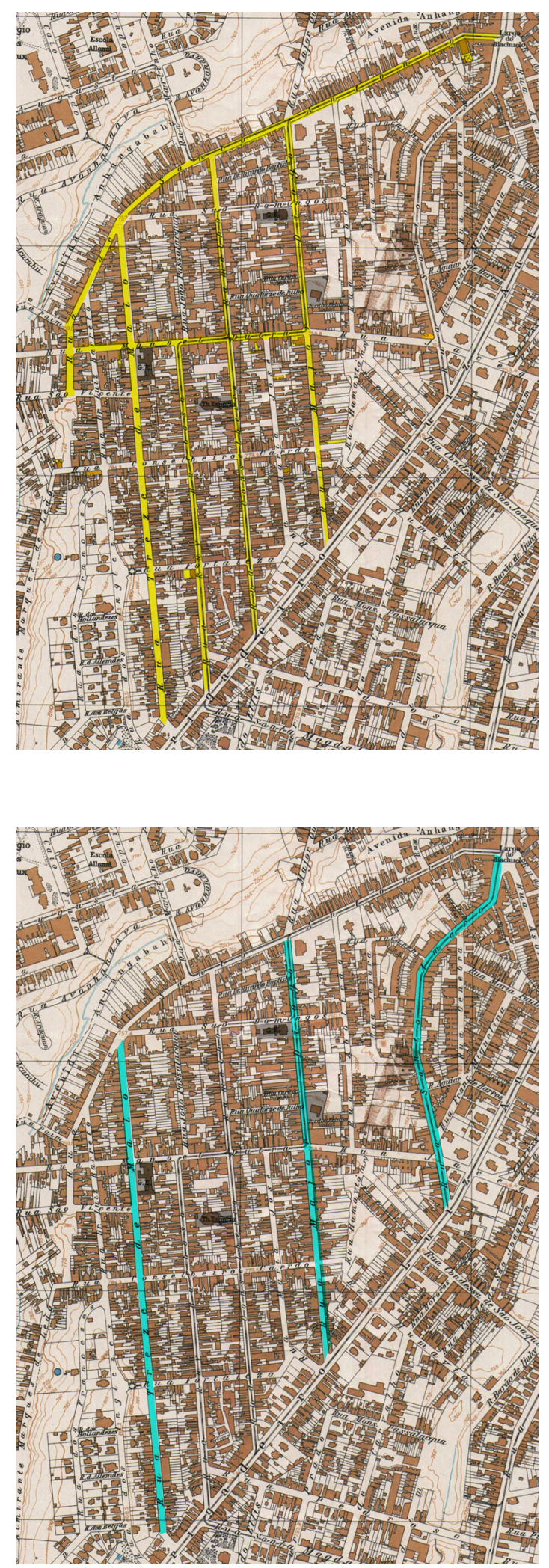

Figura 48 - A tipologia com o maior número de exemplares no bairro, era a das casas simples, concentradas na rua 13 de Maio, seguida das ruas Conselheiro Ramalho, Rui Barbosa, Manoel Dutra, Major Diogo e Santo Antonio, todas totalizando 149 ou 61,57\% de um total de 242 imóveis. Porém ela está presente em todas as vias do bairro.

Fonte: "Mappa Topográphico do Município de São Paulo (1930)”, SARA Brasil, Fl. 37.

AHMWL.

Figura 49 - As casas de fundo, com 20

exemplares, embora fossem pouco numerosas, concentravam-se preferencialmente, nas ruas 13 de Maio, Santo Amaro e Major Diogo. No entanto, esta tipologia também compareceu nas ruas São Vicente, São Domingos, Santo Antonio, Rui Barbosa, Maria José e Manoel Dutra.

Fonte: “Mappa Topográphico do Município de São Paulo (1930)”, SARA Brasil, Fl. 37. AHMWL. 

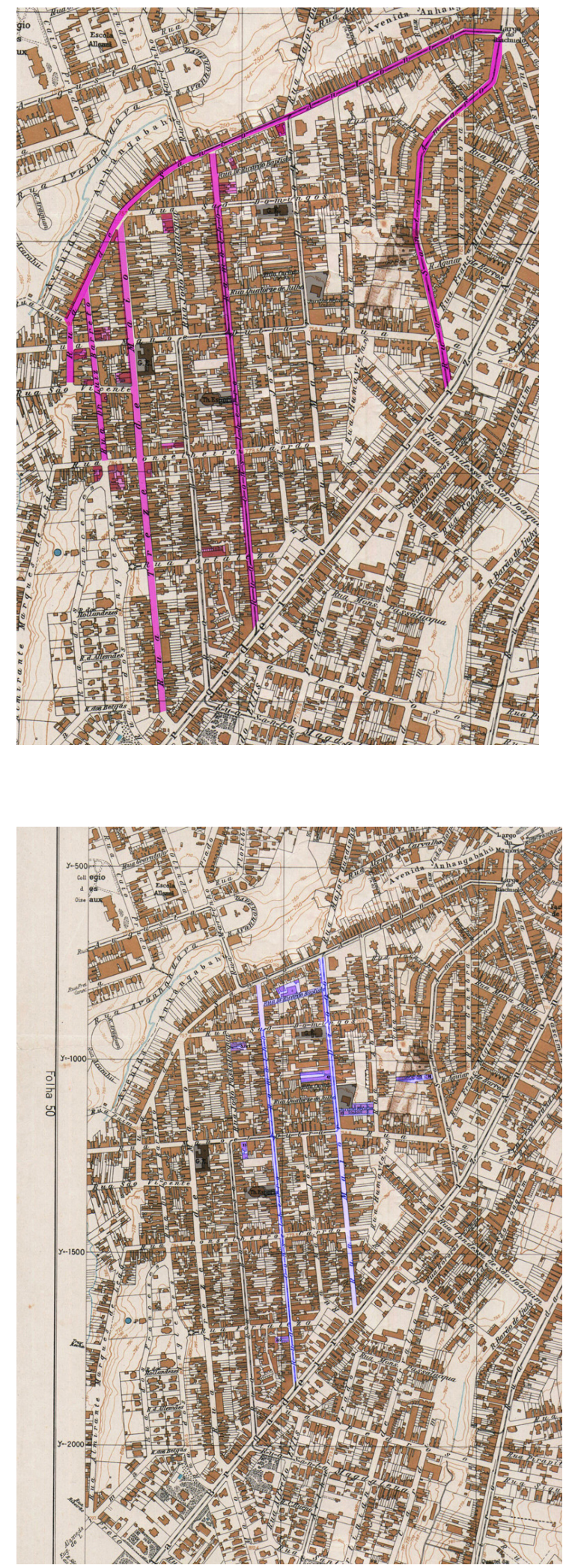

Figura 50 - As casas em série, com 79 pedidos de licença construtiva também se

concentravam, prioritariamente, nas ruas 13 de Maio, Santo Antonio, Santo Amaro, Major Diogo e São Domingos, sendo que esta última era uma das vias com trajeto mais curto.

Porém, localizamos exemplares esparsos nas demais ruas do bairro.

Fonte: "Mappa Topográphico do Município de São Paulo (1930)”, SARA Brasil, Fl. 37.

AHMWL.

Figura 51 - As vilas, com apenas 10

exemplares, não chegavam a se destacar, alcançando o maior número (três) na rua Major Diogo. Excepcionalmente, esta é a única tipologia sem quaisquer exemplares localizados na rua 13 de Maio. Conseguimos localizar com exatidão um caso, na atual rua Dr. Ricardo Batista. Naquela ocasião esta era uma rua particular, cujo endereço fornecido pelo proprietário foi Travessa Major Diogo $n^{\circ} 4$. Outro caso possível de identificar foi aquele à rua João Passalacqua $n^{\circ}$ 5, 7 e 9 fundos. Nos demais casos, fizemos uma localização aproximada, a partir da provável numeração da via, comparada com o projeto arquitetônico. Fonte: "Mappa Topográphico do Município de São Paulo (1930)”, SARA Brasil, Fl. 37. AHMWL. 

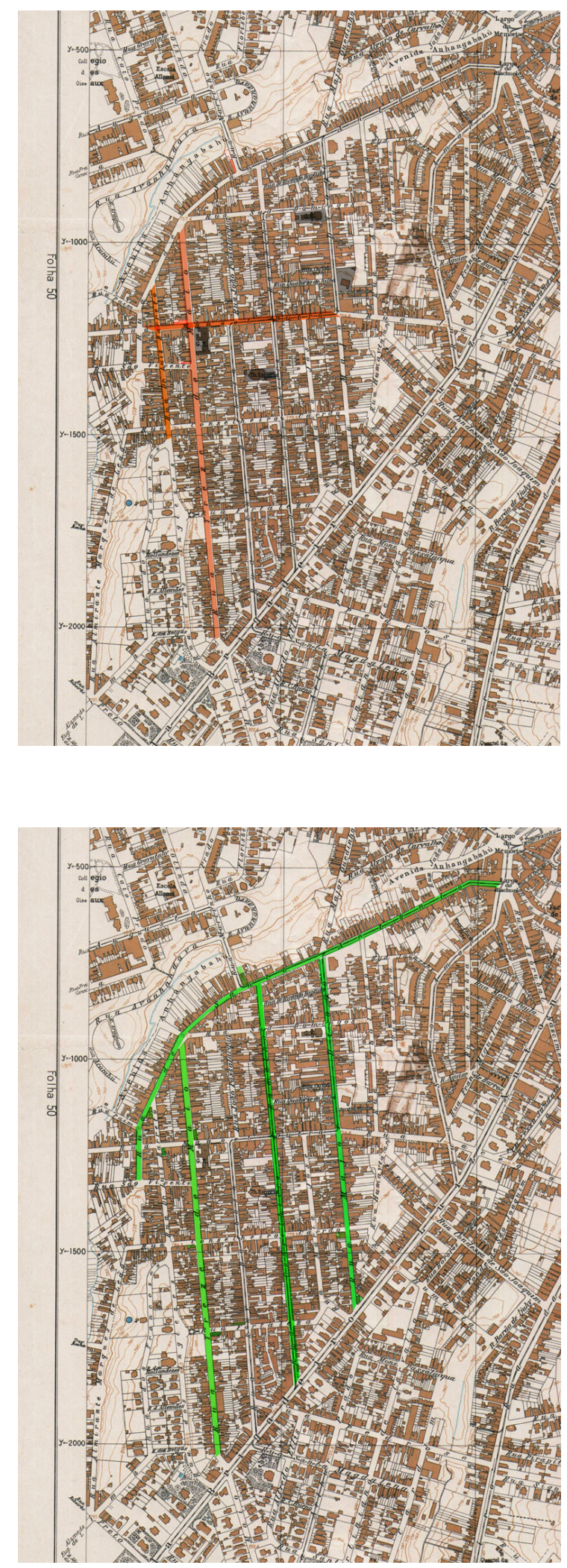

Figura 52 - No caso dos sobrados com dupla residência, com 15 pedidos de licença, temos novamente a rua 13 de Maio, ocupada por cinco dessas edificações. As outras dez distribuem-se pontualmente por outras ruas do bairro: Major Diogo, Manoel Dutra, Rui Barbosa, Santo Amaro, Santo Antonio, São Domingos e do Sol.

Fonte: "Mappa Topográphico do Município de São Paulo (1930)”, SARA Brasil, Fl. 37. AHMWL.

Figura 53 - Por fim, as 68 casas mistas, em número de 68, concentraram-se sobretudo na rua Santo Antonio (19) e nas ruas 13 de Maio, Conselheiro Ramalho e Major Diogo. Contudo, também esta tipologia está presente nas demais ruas do bairro.

Fonte: “Mappa Topográphico do Município de São Paulo (1930)”, SARA Brasil, Fl. 37. AHMWL. 


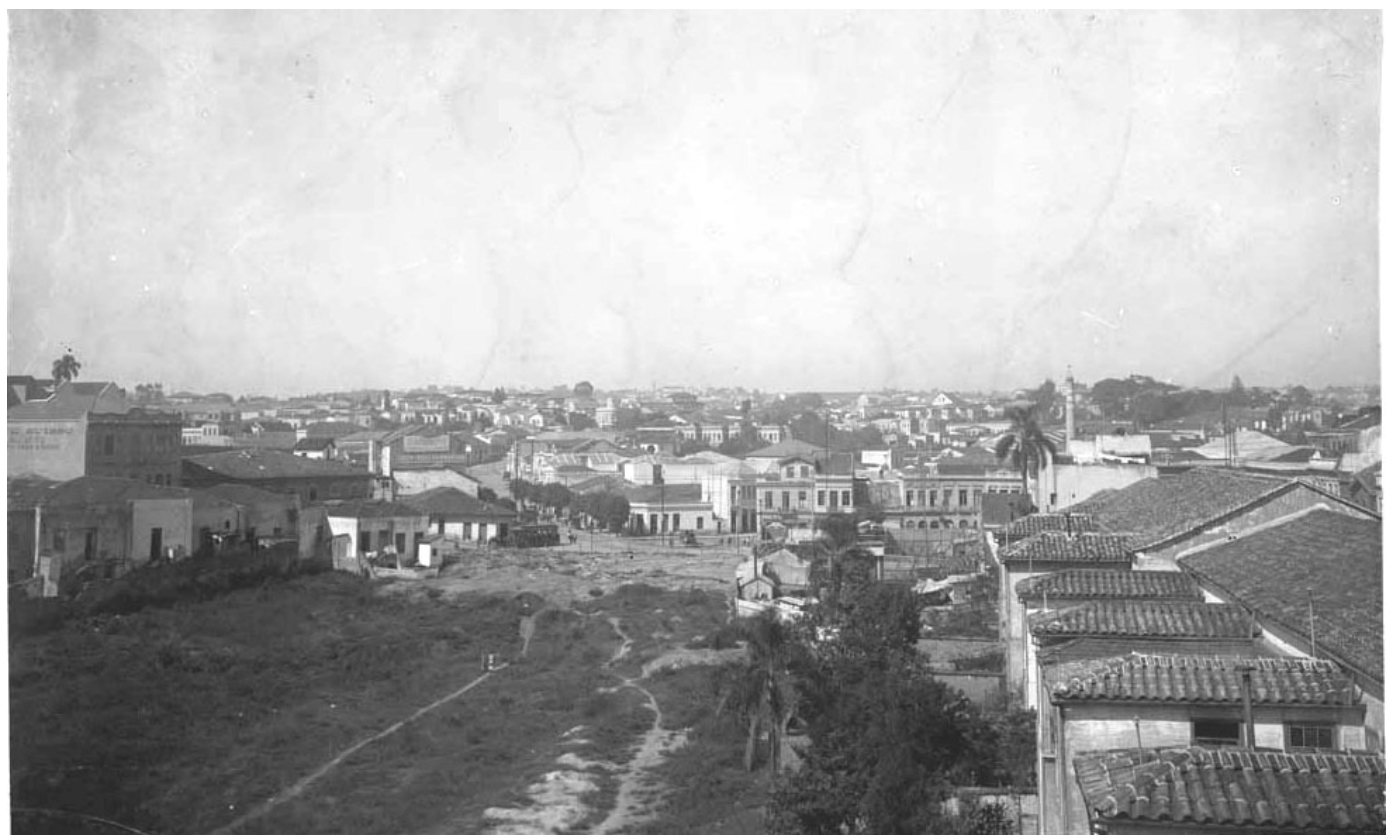

Figura 54 - Desta imagem, tomada do alto do antigo Viaduto do Chá, temos em primeiro plano, o vale do Anhangabaú, e os fundos do casario da rua Formosa. A fotografia, realizada em 1911, permite a visualização, ao fundo, do bairro do Bexiga. Aqui, percebemos um espaço de ocupação bastante densa, demonstrando que a configuração do bairro já era fato concreto. Foto: Aurélio Becherini. Fonte: Coleção SAN/SIM/DPH/SMC/PMSP.

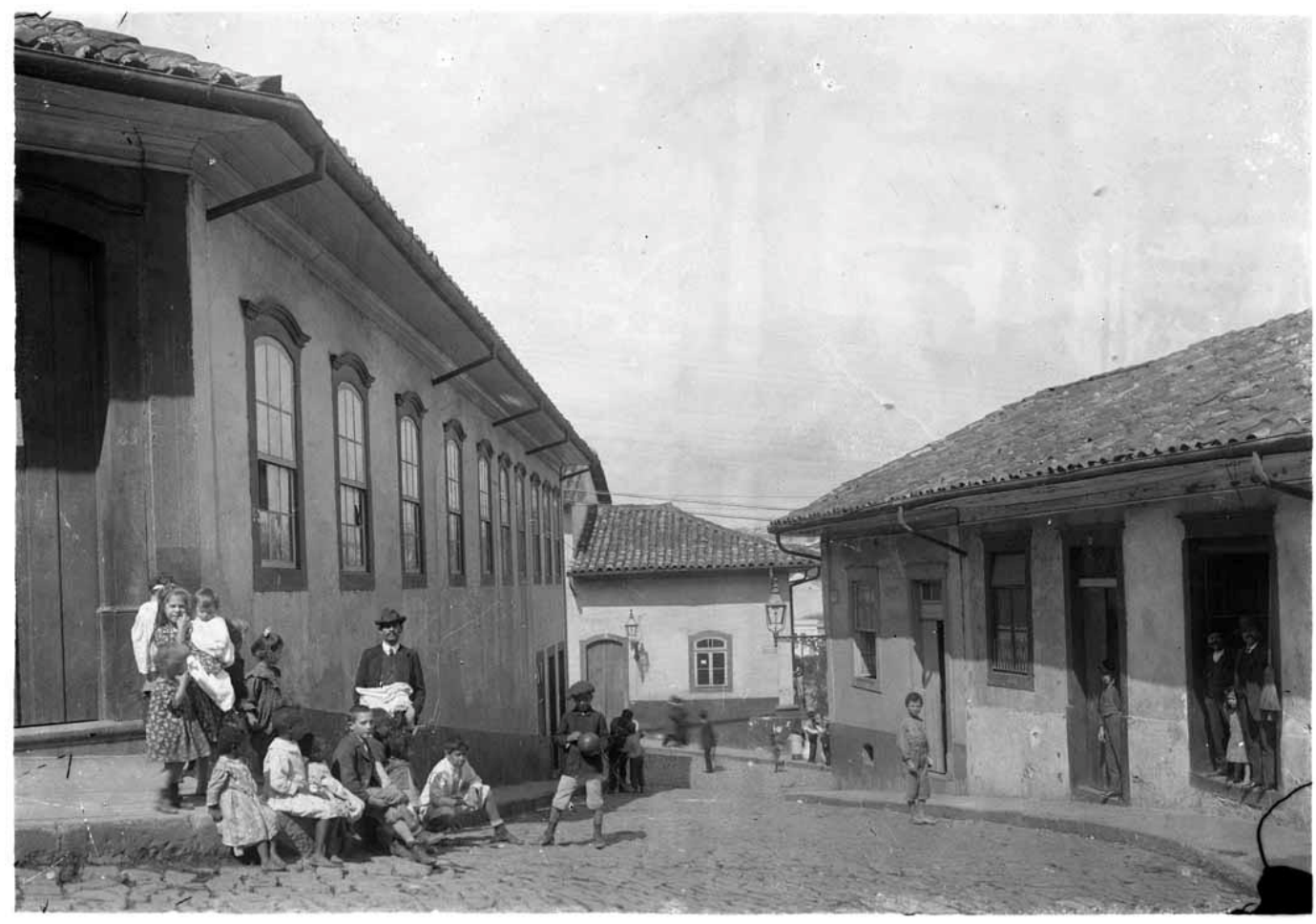

Figura 55 - Travessa Santo Amaro, realizada entre 1911 e 1912. Aparentemente essas casas devem ter sido construídas em taipa, com exceção da casa da esquina, à direita. Apesar do telhado, provavelmente de duas águas, o porão desta casa indica se tratar de casa de tijolos, construída segundo as novas orientações da higiene. A importância desta imagem, tomada nas proximidades do Largo do Riachuelo, está justamente em demonstrar o contraste com as casas construídas no Bexiga, sob o "manto" da Diretoria de Obras Públicas e do Serviço Sanitário. Foto: Autoria desconhecida, 1911/1912. Fonte: Coleção SAN/SIM/DPH/SMC/PMSP. 


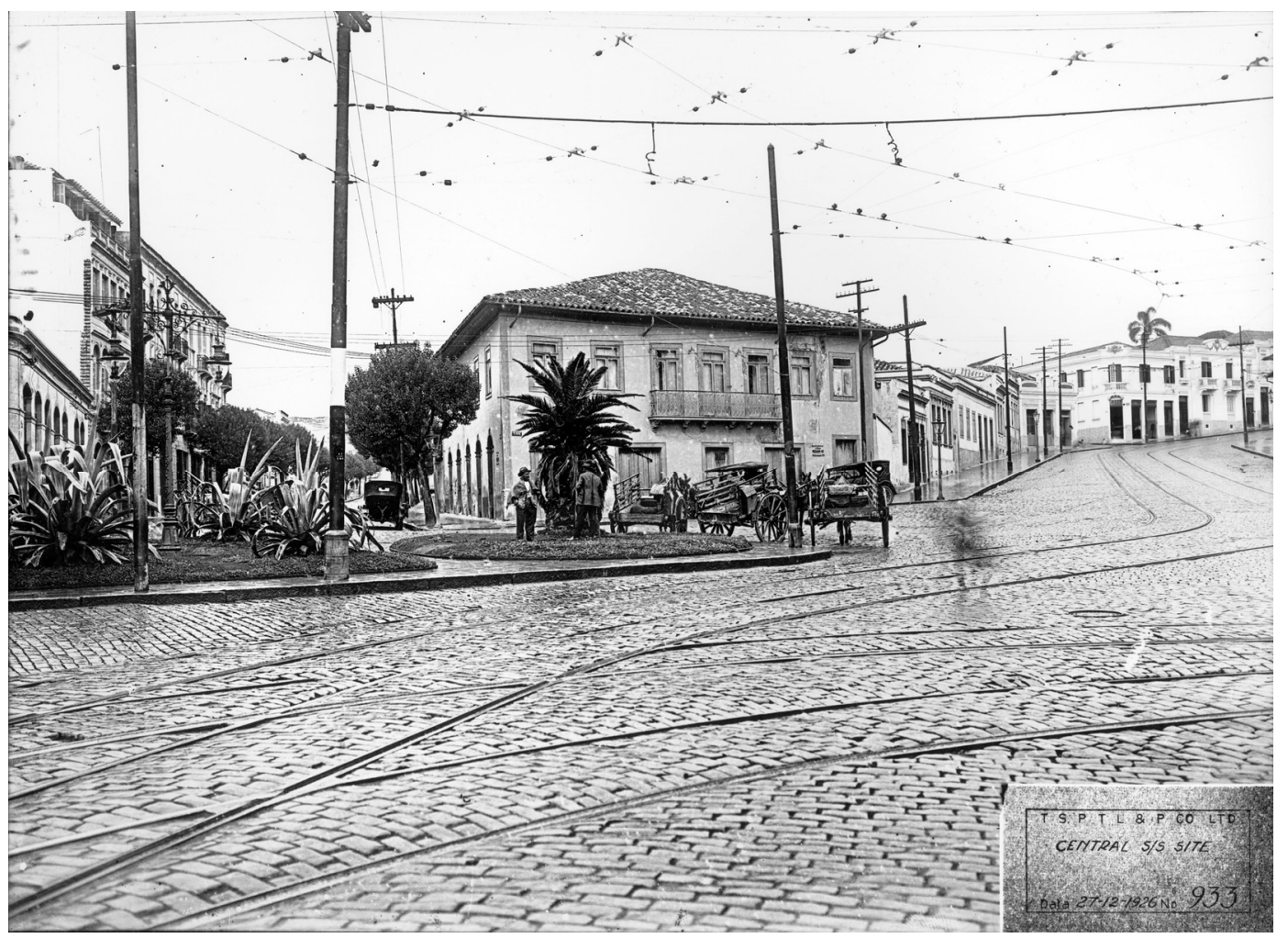

Figura 56 - Largo do Riachuelo, nos anos de 1920. À esquerda da foto, temos a rua Asdrúbal do Nascimento e, à direita, o início da rua Santo Amaro. No centro da imagem, um sobrado, construído provavelmente, nas ultimas décadas do século XIX. Foto: Autoria desconhecida, 1926. Fonte: Acervo Fundação Energia e Saneamento.

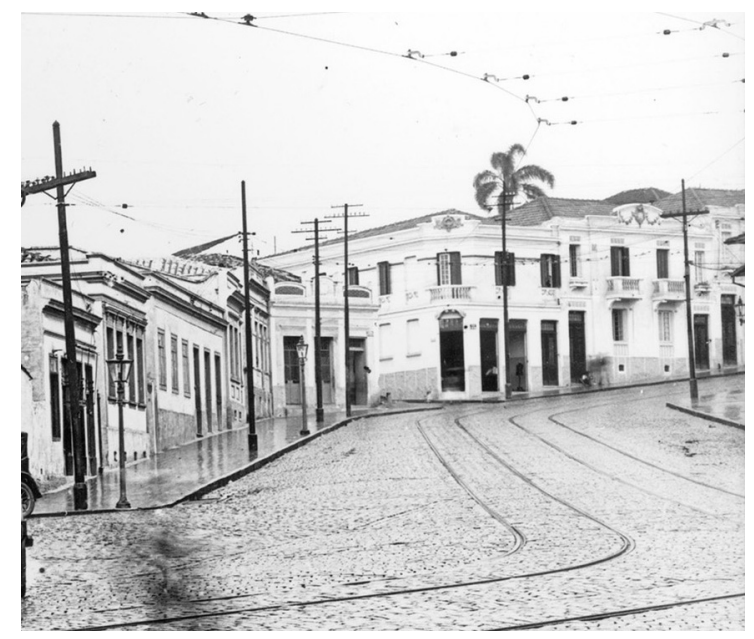

No detalhe da foto é possível perceber, à esquerda, algumas casas térreas, com fachadas simples, platibandas e porões. Na sequência destas, um prédio com três portas, ocupado por comércio. No centro, temos uma típica construção de esquina, onde o pavimento térreo do sobrado frequentemente era utilizado para algum tipo de negócio. Ao lado deste, há outro sobrado residencial. 


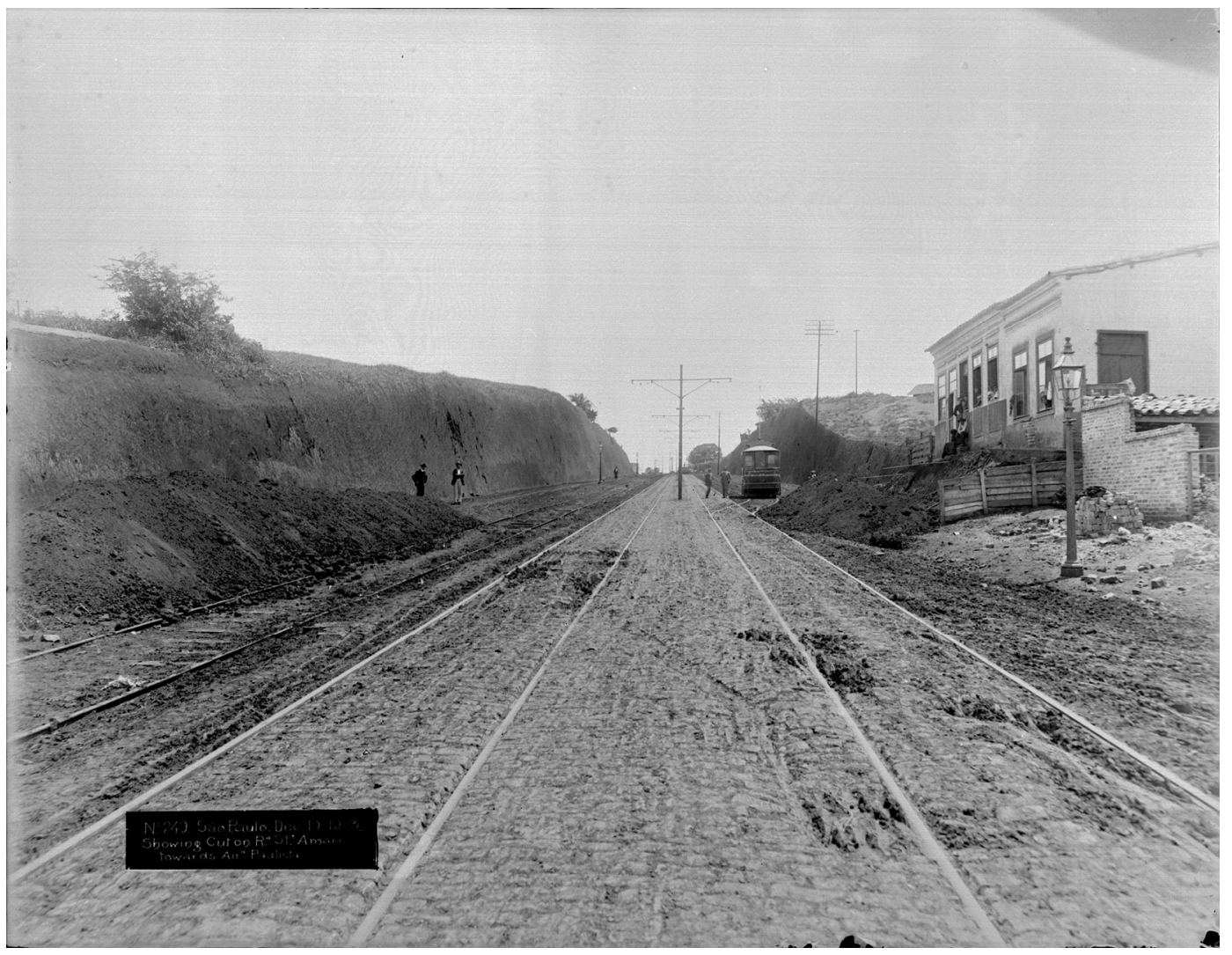

Figura 57 - Trecho da rua Santo Amaro, em direção da Avenida Paulista, apresenta rua calçada e com os trilhos do bonde instalados. Embora a imagem não permita saber a altura da rua em que a foto foi tirada, através dela percebemos que naqueles anos o entorno desta via ainda eram um grande vazio, demonstrando que ainda havia muito a ocupar no loteamento. Foto: Guilherme Gaensly, 1903. Fonte: Acervo Fundação Energia e Saneamento.

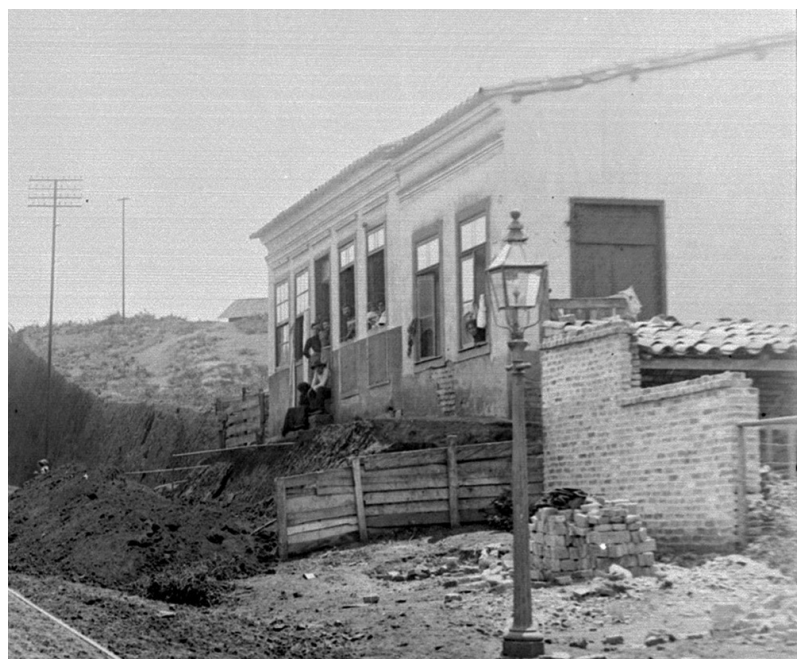

No detalhe da foto anterior, temos duas casas às margens da rua Santo Amaro. Trata-se de típicas casas térreas, construídas aparentemente, sem definição do alinhamento. Note-se a presença do poste de luz, indicando que a iluminação pública era um fato, pelo menos para as vias por onde passava o bonde. 


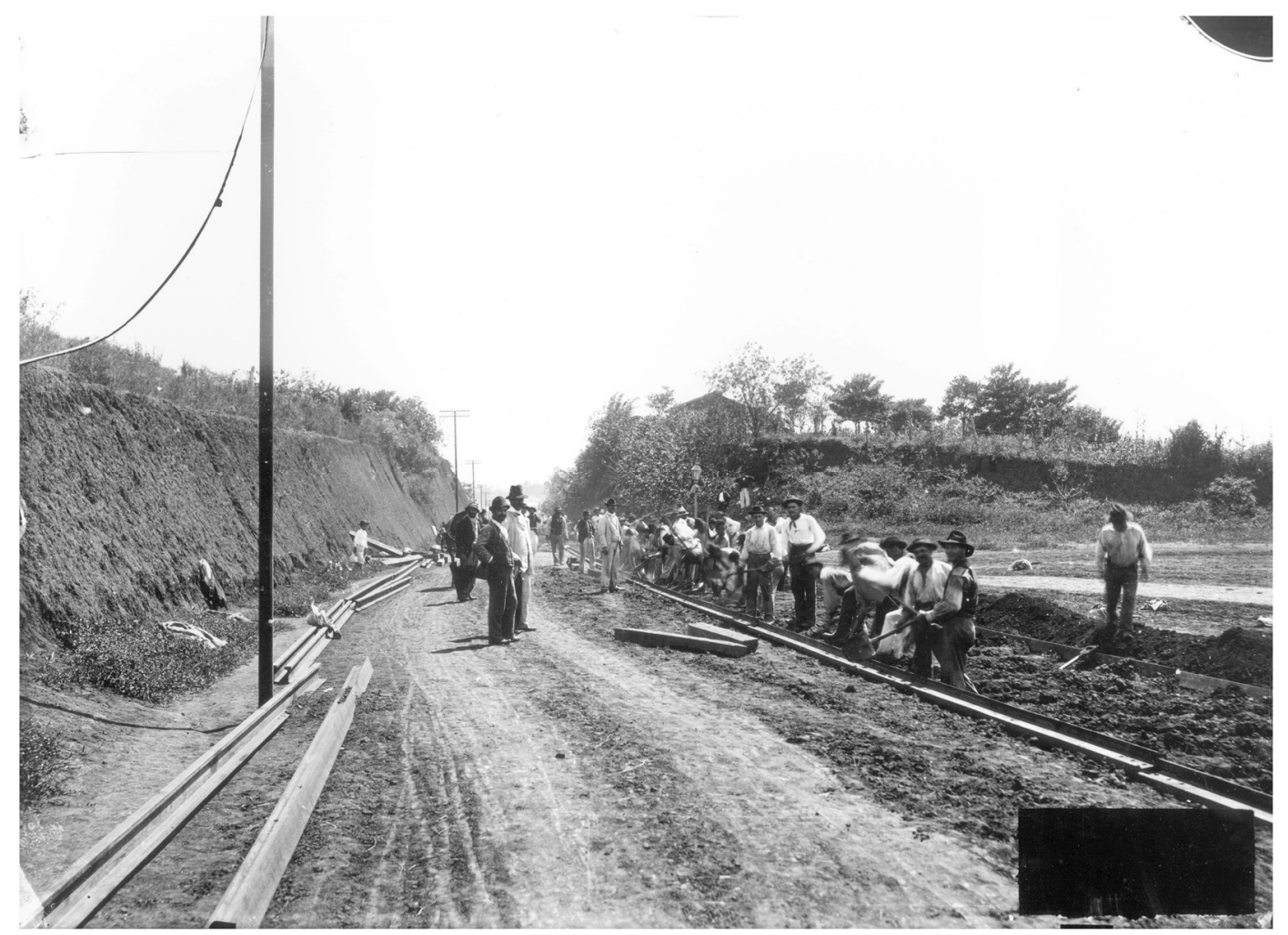

Figura 58 - Implantação dos trilhos do bonde em trecho da rua Santo Amaro, em direção ao Centro, ainda sem calçamento. Reparar, entre as árvores sobre o barranco, à direita, a presença de uma casa. Foto: Guilherme Gaensly, 1900. Fonte: Acervo Fundação Energia e Saneamento.

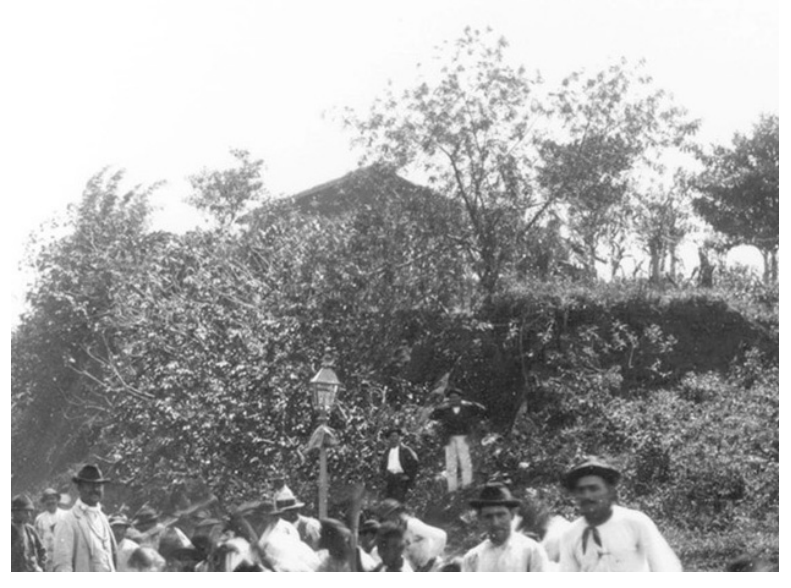

No detalhe, visualizamos melhor a edificação no alto do barranco. O telhado de duas águas parece indicar que se trata de casa antiga, quem sabe anterior ao loteamento. 


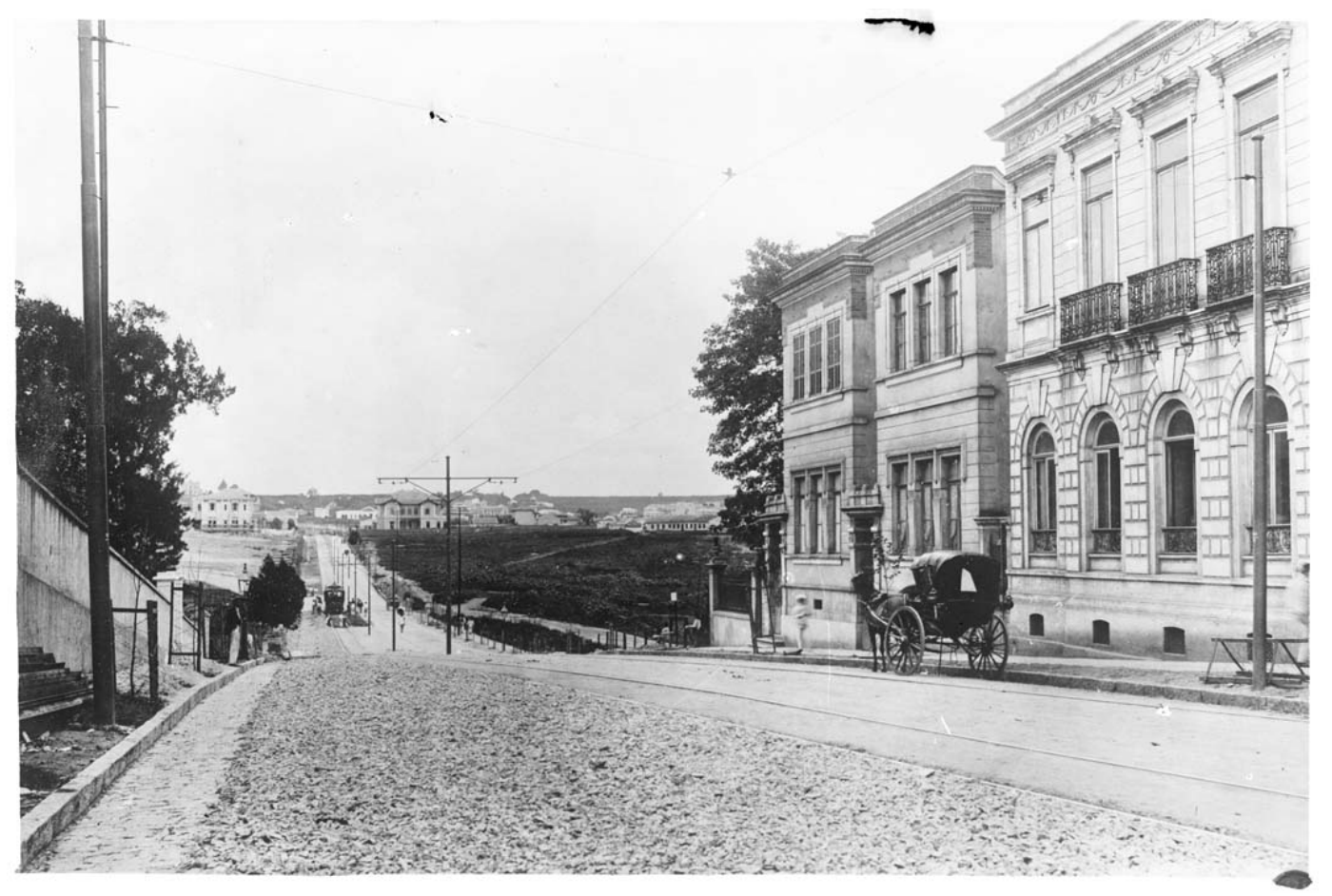

Figura 59 - Foto da Avenida Brigadeiro Luís Antonio, em direção à Avenida Paulista. Os três sobrados à direita eram de propriedade da Baronesa de Limeira, sendo que o primeiro foi sua residência e os demais, conforme Eudes Campos, eram casas para locação. O único exemplar remanescente, a última casa à direita, é atualmente ocupado pela sede do CEJUR. Localizamos, na Série Obras Particulares, a presença desta senhora no Largo do Riachuelo e na rua Monte de Ouro, entre 1888 e 1889, o que leva a crer que estes prédios tenham sido edificados na mesma época. Note-se, na margem direita da avenida, a área compreendida pelo bairro do Bexiga. Embora esta avenida não tenha sido alvo direto das investigações, dois motivos justificam sua inclusão: o fato dela situar-se no limite da área proposta e a percepção que ela possibilita da ocupação rarefeita do bairro naquele momento. Foto: Guilherme Gaensly, $1900^{212}$. Coleção SAN/SIM/DPH/SMC/PMSP.

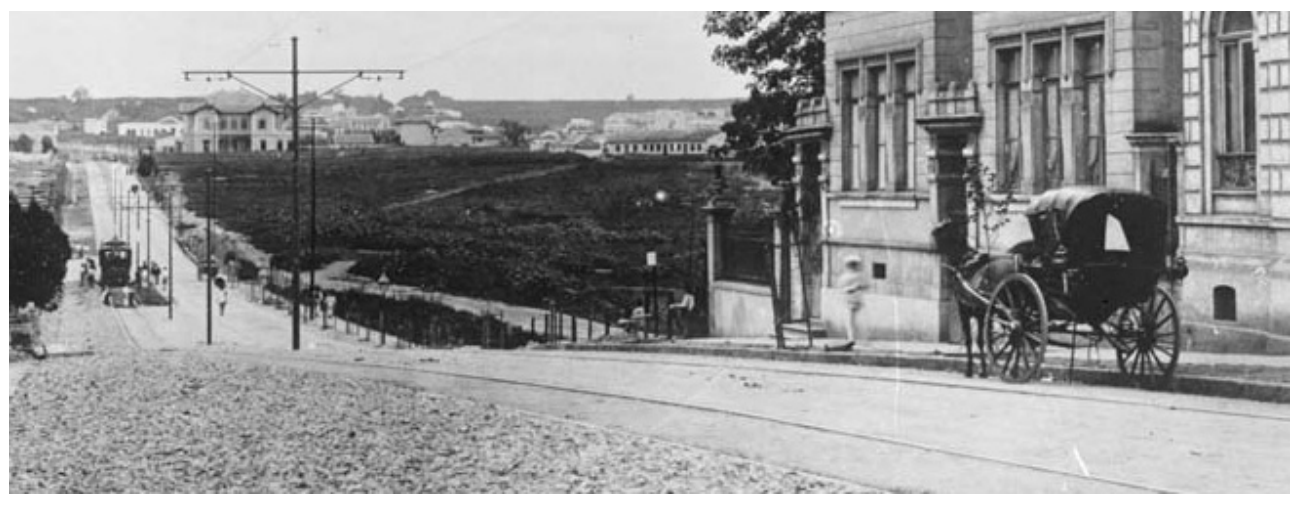

No detalhe, podemos observar a coexistência do antigo tilburi com o moderno bonde, à esquerda da foto.

${ }^{212}$ Localizamos esta imagem no Acervo Fundação Energia e Saneamento, onde confirmamos a autoria de Guilherme Gaensly. O fotógrafo foi contratado pela The São Paulo Railway, Light and Power Co. Ltd., em 1899, "para registrar os trabalhos realizados pela empresa [...] Ele permaneceria como o principal fotógrafo da Light na capital paulista até 1925, três anos antes de sua morte”. In Guilherme Gaensly e Augusto Malta: dois mestres da fotografia brasileira no Acervo Brancan. Exposição comemorativa da doação do Acervo Branscan ao IMS. Rio de Janeiro, São Paulo, Belo Horizonte, Poços de Caldas: IMS, 2003/2004. 


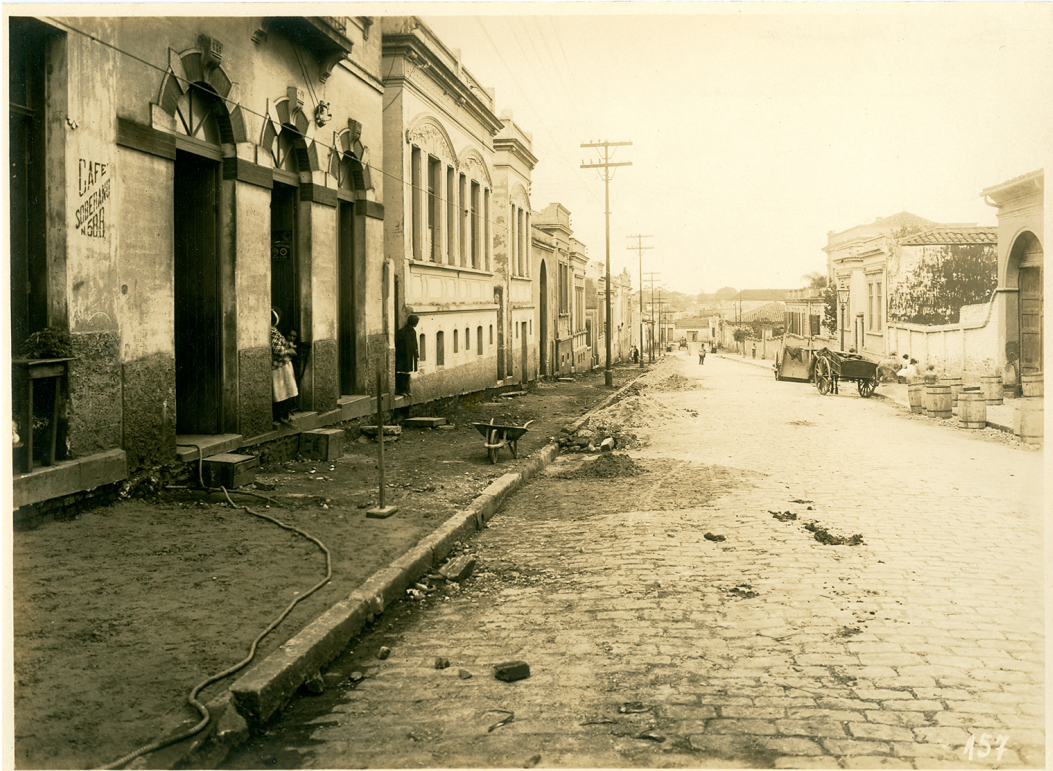

Figura 60 - Imagem da Rua São Domingos, na época do calçamento do passeio. Se a lógica da numeração da rua corresponder àquela utilizada atualmente, o n 588 abaixo do cartaz Café Soberano deve indicar que a via localizada no fundo da foto é a rua da Abolição. Observe-se a presença dos postes de iluminação da Light. Foto: 25/07/1922. Autoria desconhecida. Fonte: AHMWL.

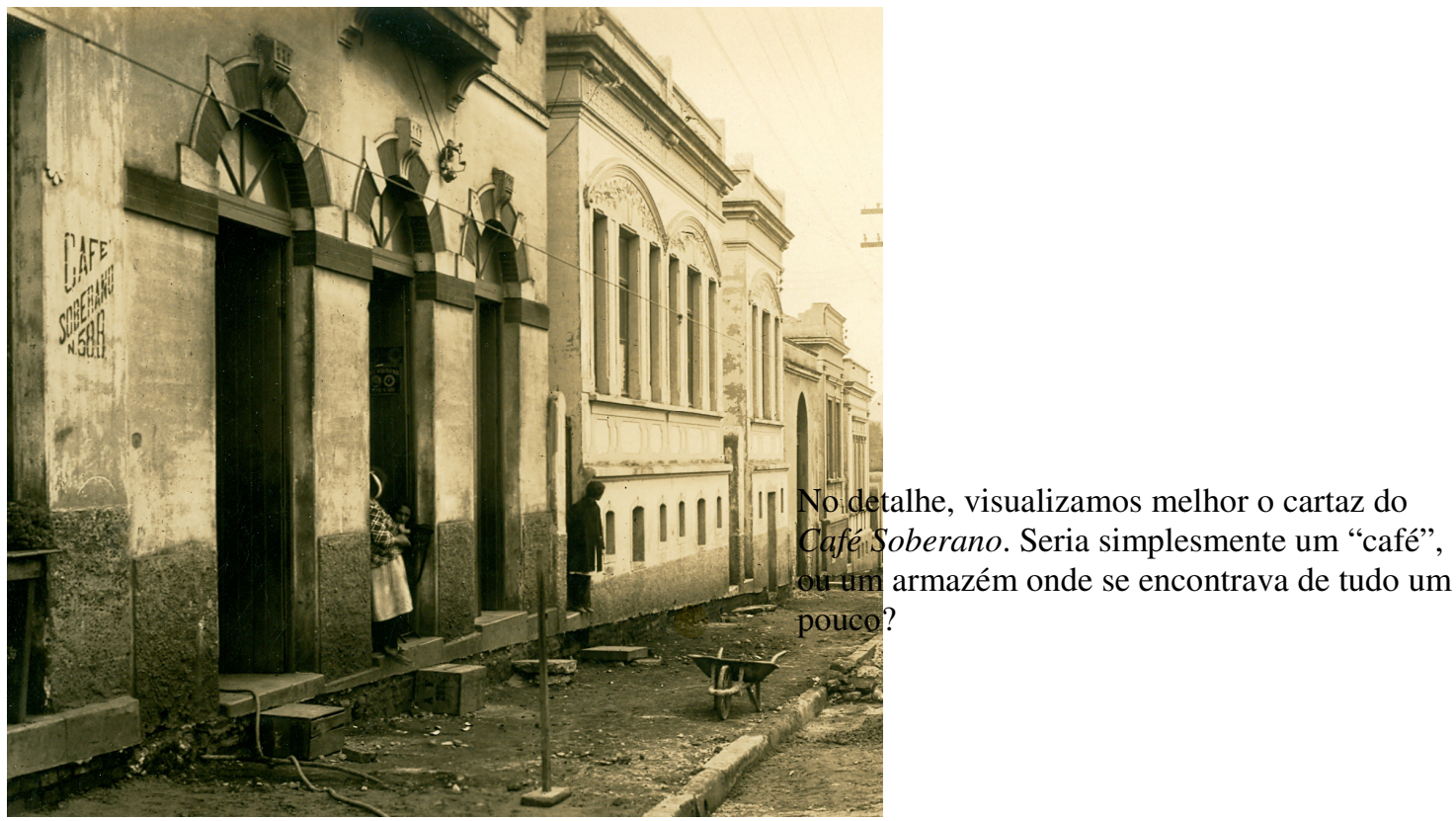

Este outro detalhe permite que visualizemos algumas carroças estacionadas no lado direito da rua para transporte de mercadorias.

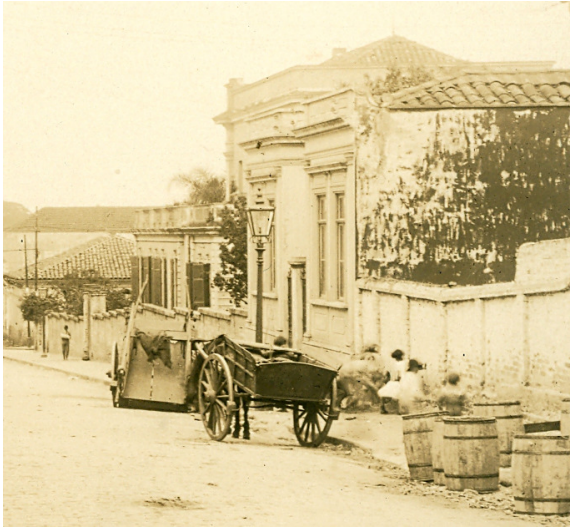




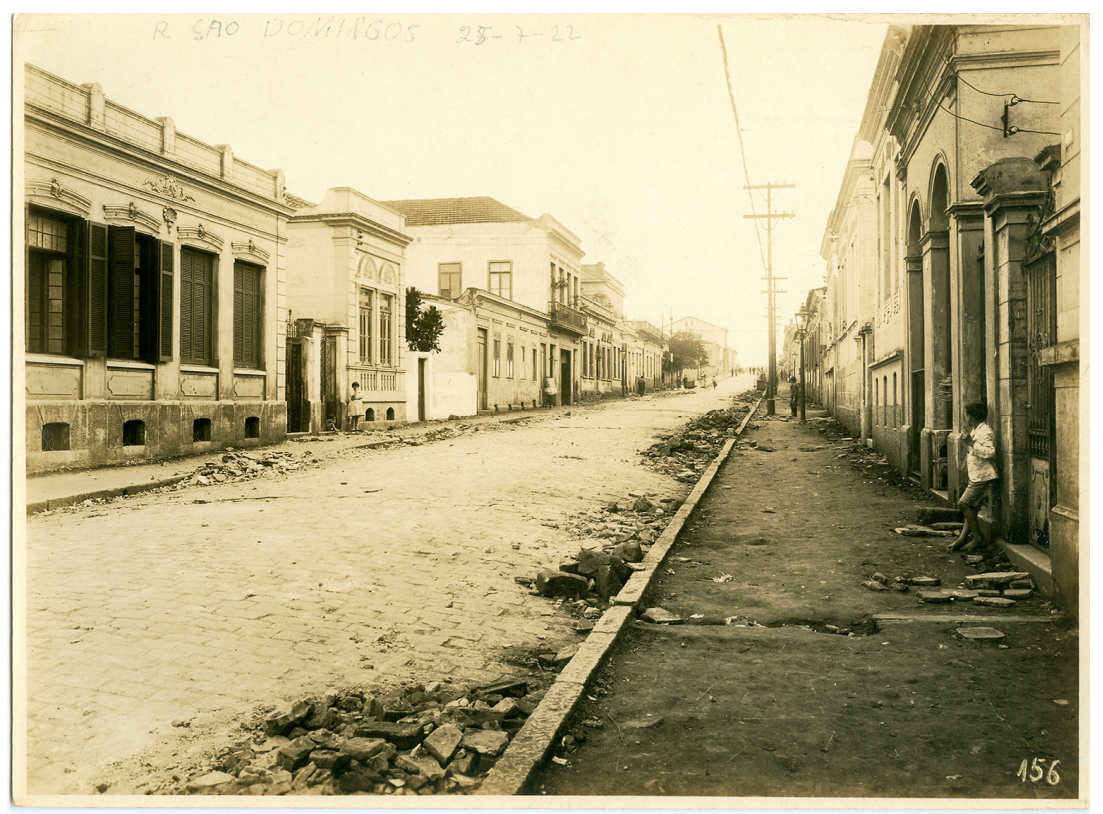

Figura 61 - Aqui, a direção da rua São Domingos se inverte, indicando a rua Santo Antonio no fundo da foto. Foto: 25/07/1922. Autoria desconhecida. Fonte: AHMWL.
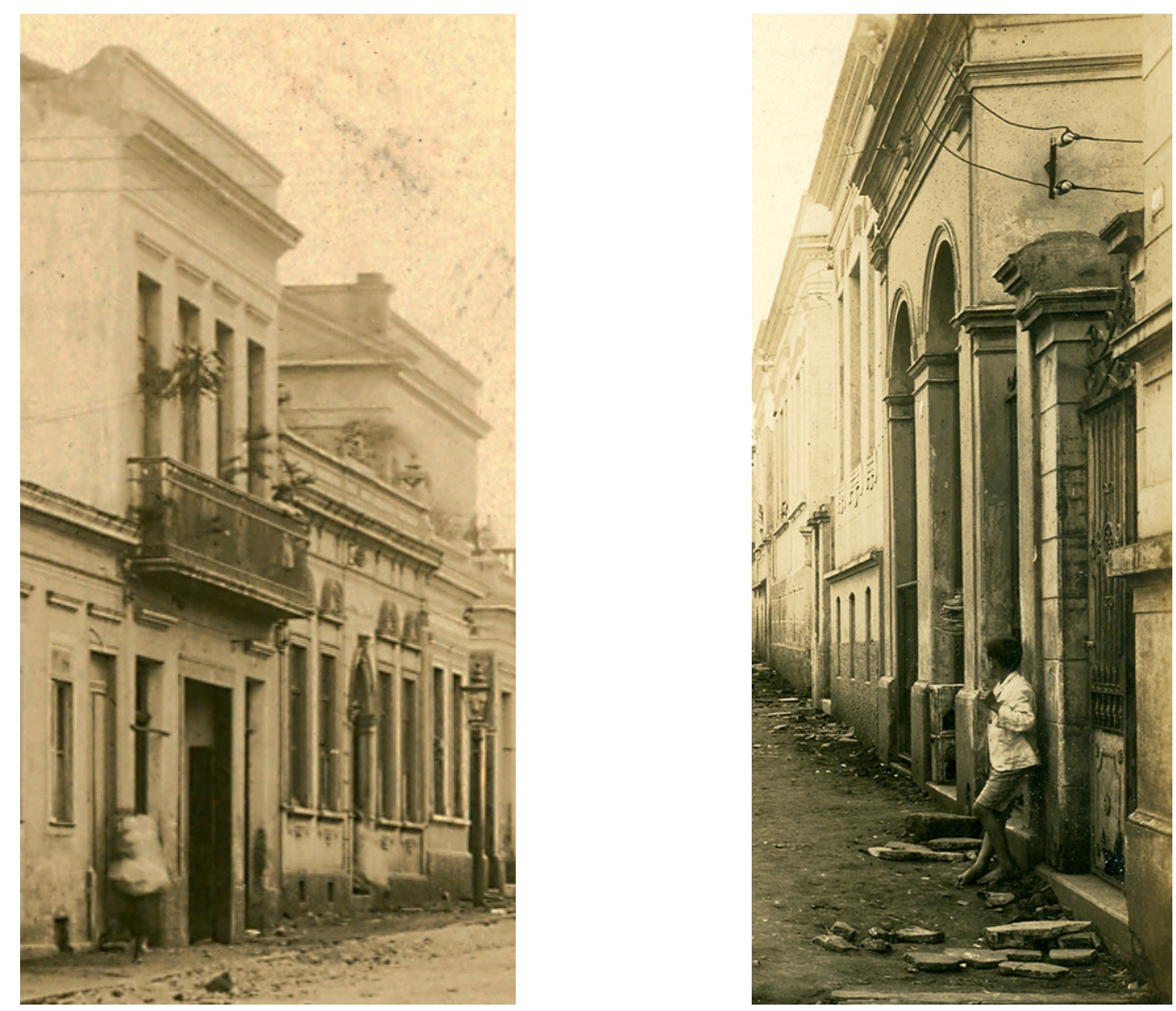

No detalhe, à esquerda, um típico caso de sobrado ocupado por comércio no térreo e por residência no alto. Já no caso da direita temos uma edificação térrea com comércio. Se observarmos com atenção, veremos, entre a criança e as portas da "loja", uma entrada lateral, levando, quem sabe, à residência nos fundos da loja. 


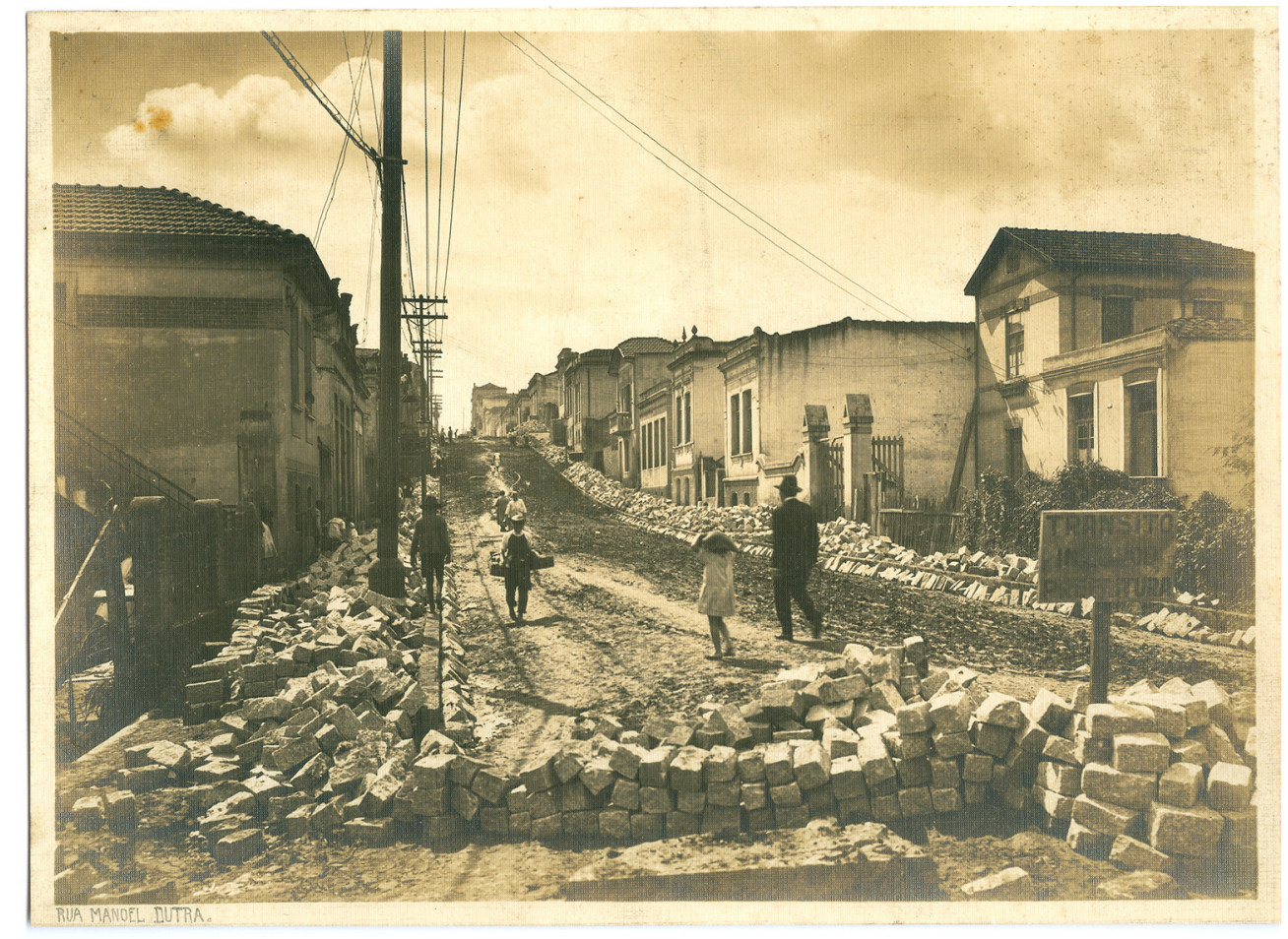

Figura 62 - A rua Manoel Dutra na época de seu calçamento, no início dos anos 1920. Com exceção do sobrado à direita da foto, todas as outras casas foram construídas no alinhamento. Algumas delas demonstram se tratar de típicas construções residenciais edificadas nas duas primeiras décadas do século $\mathrm{XX}$, com fachadas com platibanda, duas janelas, porão e entrada lateral. Observar a declividade da rua. Foto: c. 1920. Autoria desconhecida. Fonte: AHMWL.

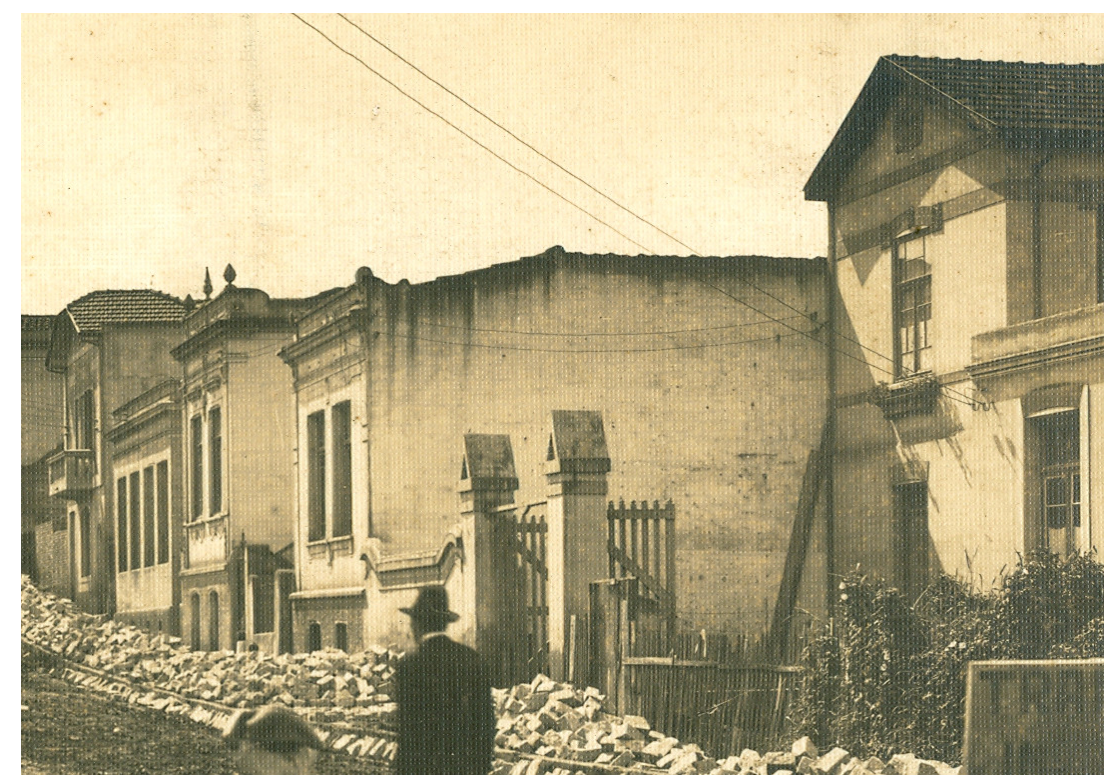

No destaque, o sobrado com uma distância aproximada de $4 \mathrm{~m}$. do alinhamento. Ao seu lado, três casas térreas, seguidas por um sobrado. 


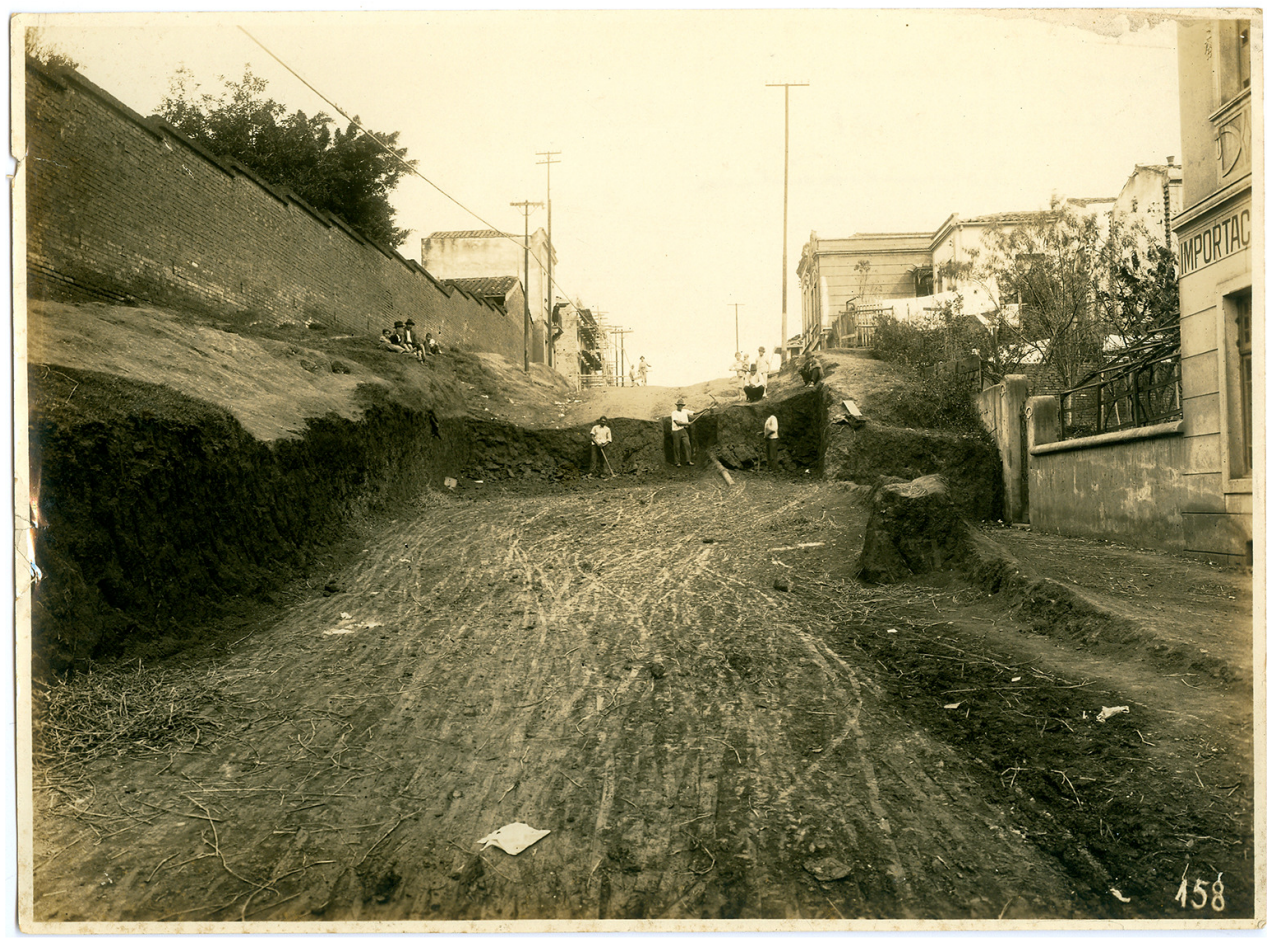

Figura 63 - Nos requerimentos das Obras Particulares nós frequentemente encontramos referências ao nivelamento das ruas junto às soleiras das casas. Este caso, na rua 13 de Maio, demonstra um momento em que o leito da rua está sendo nivelado, para o futuro calçamento. Observe-se a diferença entre o leito original, ainda a ser escavado, e aquele já trabalhado. Foto: 30/07/1921. Autoria desconhecida. Fonte: AHMWL.

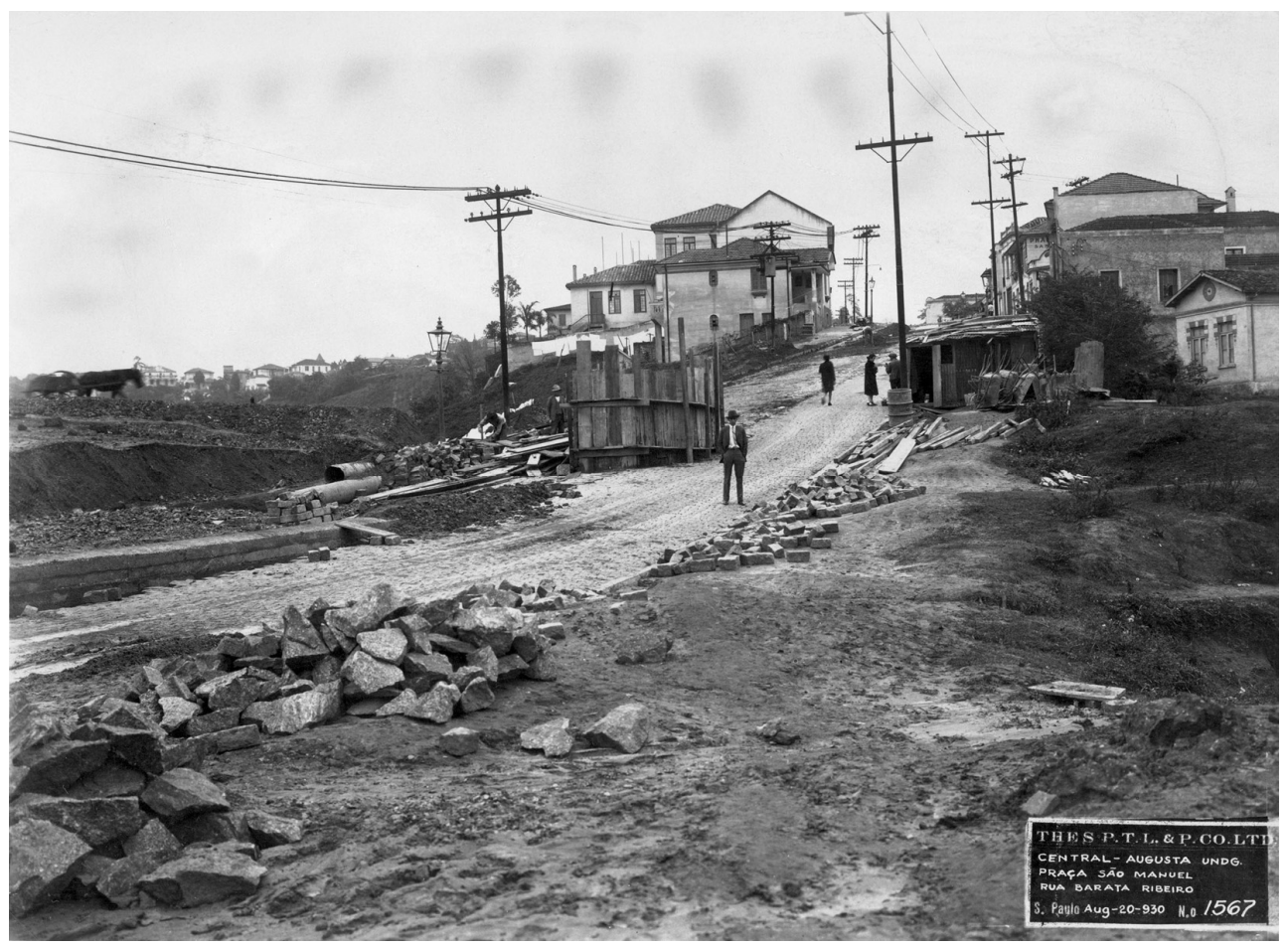

Figura 64 - Vista do Largo São Manoel,atual Praça 14 Bis, em direção à rua Barata Ribeiro. Ainda que se trata de área não abrangida por este trabalho, a imagem permite perceber como, já nos anos de 1930, a região ainda se mantém vazia. Contudo, as pedras quebradas em primeiro plano, demonstram, conforme relatado por Grünspun, que os trabalhos para a construção da Avenida 9 de Julho já estavam em curso. Foto: Autoria desconhecida, 20/08/1930. Fonte: Acervo Fundação Energia e Saneamento. 


\section{Um caso à parte - Os cortiços e/ou habitações coletivas}

As dificuldades em estabelecer critérios para a caracterização dos cortiços parece ser consenso entre os autores que se detiveram nesta questão. Também estamos distantes de chegar a uma definição conclusiva acerca do conceito de cortiço. Assim, decidimos começar a pensar o assunto a partir do Código Sanitário de $1894^{213}$, especialmente com base nos capítulos que envolvam as habitações com diferentes indivíduos ou várias famílias, além daquelas consideradas "das classes pobres".

Do Capítulo III, “Das Habitações Coletivas”, basicamente nos interessam os seguintes artigos:
- Artigo 103 - "São habitações collectivas as que domiciliam grande número de indivíduos";
- Artigo 104 - "Todos os edifícios destinados a conter permanentemente grande número de habitantes deverão ser construídos fóra da agglomeração urbana"; - Artigo 107 - "O princípio dominante na construcção das habitações collectivas e que deve ser observado tanto quanto for possivel - é a multiplicação dos pavilhões com prejuízo dos andares";
- Artigo 114 - "As latrinas e todas as installações hygienicas deverão obedecer aos princípios estabelecidos para as habitações em geral";
- Artigo 115 - "Deverá haver uma latrina para cada grupo de 20 moradores".

De maneira geral, o Capítulo III parece prever a construção de novos edifícios destinados às habitações coletivas, já que coloca parâmetros como:

- a localização fora do perímetro urbano, que envolveria os novos loteamentos nos arrabaldes da cidade;

- construções horizontais, que excluem a ocupação de sobrados e o aproveitamento de porões;

- obediência aos princípios de higiene recomendados para qualquer tipo de habitação;

- instalação de latrinas para um determinado número de pessoas.

No Capítulo IV, “Hotéis e Casas de Pensão”, se destacam os seguintes artigos:

- Artigo 126 - "O edifício para hotel ou casa de pensão deverá ser escrupulosamente escolhido, tendo-se em consideração muito especial a ventilação e illuminação dos aposentos";

- Artigo 127 - "O número de locatarios deverá ser proporcional á capacidade do edifício e não deverão ser permittidos menos de 14 metros cubicos de espaço para cada individuo [...]";

- Artigo 129 - "As paredes divisórias dos aposentos deverão ser impermeaveis, devendo ser terminantemente prohibidas as subdivisões de taboas";

\footnotetext{
${ }^{213}$ DECRETO $n^{o} 233$, de 2 de março de 1894. Estabelece o Código Sanitário, Coleção das Leis e Decretos do Estado de S. Paulo. Tomo IV, 1918, p. 82 a 84. Arquivo do Estado de São Paulo. Grifos nossos.
} 
- Artigo 130 - "A locação ou habitação dos porões deve ser terminantemente prohibida";

- Artigo 133 - “Para cada grupo de 20 habitantes deverá haver uma latrina”.

Neste capítulo está clara a permissão para se utilizarem casas já edificadas para fins de locação de quartos a terceiros, contanto que fosse feita escolha escrupulosa, respeitando-se os princípios da higiene. A possibilidade de aproveitamento de casas existentes indica que subdivisões de madeira seriam proibidas, porém não faz menção a eventuais acréscimos ou divisões de cômodos feitas com alvenaria. Por outro lado, proibia claramente a utilização dos porões como moradia.

Por fim, no Capítulo V, "Habitações das Classes Pobres", destacamos os artigos:

- Artigo 138 - "Deve ser terminantemente prohibida a construcção de cortiços, convindo que as municipalidades providenciem para que desappareçam os existentes"; - Artigo 139 - "Não devem ser toleradas as grandes casas subdivididas, que servem de domicilio a grande numero de indivíduos";

- Artigo 141 - "As villas operarias deverão ser estabelecidas fora da agglomeração urbana";

- Artigo 142 - "As casas para habitação das classes pobres deverão ser construídas em grupos de 4 a 6, no máximo”;

- Artigo 143 - "As installações hygienicas deverão ser particulares para cada caso".

O Capítulo V indica cuidados com a construção de "casas operárias" e "vilas" em geral. Certamente prevendo a utilização dessas casas como cortiços, o capítulo se inicia com a sua proibição, além de indicar a necessidade de se destruir aquelas existentes. Aqui também se mantém uma certa confusão entre o que era cortiço, casa de pensão e habitação para classes pobres, sobretudo no artigo que proíbe a subdivisão de "grandes casas". Afinal, esse não seria um problema pertinente às "casas de pensão"? Como distinguir a "casa de pensão" do cortiço, já que ambos eram ocupados por um número variado de indivíduos? E ainda, como delimitar o número de pessoas que podiam viver na "casa de pensão" ou no cortiço?

De qualquer modo, do ponto de vista do Código, todas essas modalidades de moradia parecem implicar na ocupação por pessoas pobres. Excetuando-se as "casas de pensão", que poderiam ser ocupadas por qualquer tipo de gente - de filhos de fazendeiros ricos que estudavam na Capital a pessoas sozinhas que trabalhavam no comércio, no funcionalismo público, etc. ${ }^{214}-$, cortiços, casas operárias e vilas deviam

\footnotetext{
${ }^{214}$ De acordo com Fessler Vaz, "os quartos de alugar eram fato comum na vida carioca da época, abrigando não apenas os trabalhadores pobres, mas de diferentes faixas de renda, inclusive dos estratos médios”. Op. Cit., p.64.
} 
ficar fora do perímetro urbano. A intenção de segregação é muito clara, o que não fica claro são as definições do que eram cortiços, casas de pensão e habitações das classes pobres, assim como as diferenças entre os tipos de habitação coletiva. De uma maneira geral, foram esses os pontos do Código de Posturas que utilizamos para a identificação e análise dos cortiços no bairro do Bexiga. Ali iremos perceber o quanto essas categorias se misturavam e se confundiam, demonstrando que também para a municipalidade foram pontos obscuros, nem sempre interpretados de forma objetiva.

Buscando esclarecer melhor a questão, recorremos a outros autores que nela se detiveram.

Lemos define cortiço como sendo:

“[...] um programa habitacional inusitado, ou melhor, até então desconhecido: famílias diversas morando em promiscuidade, usando as mesmas instalações sanitárias e lavando a roupa suja nos mesmos tanques. [...] a expressão logo se estendeu a todo tipo de habitação coletiva que possuísse áreas de uso comunitário. Isso nos leva a imaginar inúmeras gradações possiveis desses alojamentos precários ${ }^{215}$.

Lílian Fessler Vaz, por sua vez, fez uma análise detalhada das variantes de habitações coletivas encontradas no Rio de Janeiro na mesma época:

"As habitações coletivas assumiram diversos nomes, correspondendo a diferentes formas arquitetônicas e conteúdos ideológicos distintos - estalagens, casas de cômodos, e posteriormente avenidas. O termo - cortiço - porém, foi o mais generalizado, visto por isso mesmo, como um símbolo dessa época, ${ }^{216}$.

Entre as variantes elencadas por Fessler Vaz, destacamos aquelas que mais se aproximaram dos modelos identificados na realidade paulistana, se não pela nomenclatura, pela descrição física: as estalagens e as casas de cômodos.

- “As estalagens eram grupos de minúsculas casas térreas - os 'quartos' ou 'casinhas' de porta e janela - enfileiradas de um ou dos dois lados dos quintais, formando um pátio ou corredor de acesso, dotadas de instalações sanitárias coletivas".

- "As casas-de-alugar-cômodos, ou casas de cômodos eram térreos ou sobrados subdivididos internamente [...]".

Ao analisar as conceituações de um autor da época, Everardo Backheuser ${ }^{217}$, Sidney Chalhoub ${ }^{218}$ demonstra como cortiços e estalagens podiam se confundir, a depender do ponto de vista e dos interesses do observador.

\footnotetext{
${ }^{215}$ LEMOS, Carlos (1999) - Op. Cit., p.15. Grifos nossos.

${ }^{216}$ VAZ, Lílian Fessler - Op. Cit, p.53 a 56.

${ }^{217}$ Conforme Telma de Barros Correia, Everardo Backheuser foi o engenheiro responsável pela elaboração do "Relatório sobre Habitações Populares", apresentado ao Ministro da Justiça e Negócios
} 


\begin{abstract}
"Os critérios para a identificação dos diferentes tipos de habitação coletiva eram então ainda mais indefinidos, pastosos mesmo, se acomodando aos interesses de ocasião das partes em confronto. Cubículos originados de subdivisões internas num casarão eram cortiços? Quartos construídos no fundo do quintal de uma residência, ou de uma fábrica ou oficina, eram cortiços? Chefes de família que alugavam cômodos em suas casas, às vezes até o sótão e o porão, seriam corticeiros obrigados a pagar impostos à municipalidade? Numa cidade em crescimento acelerado e com déficit crônico de moradias, todos esses expedientes foram bastante utilizados.

Parecia haver algum acordo apenas em torno do que era habitação coletiva, como definia, por exemplo, a postura de 15 de setembro de 1892: 'São todas as que abrigarem sob a mesma cobertura, ou dentro da mesma propriedade, terreno etc., indivíduos de famílias diversas, constituindo unidades sociais independentes, "„19.
\end{abstract}

Os conflitos descritos, e as perguntas feitas por Chalhoub remetem ao Código Sanitário, de 1894. Certamente as imprecisões encontradas na legislação reguladora "do construir e do morar", em São Paulo e no Rio de Janeiro, se relacionam ao desejo de exclusão das chamadas "classes perigosas". Nesse sentido, as recomendações do Código Sanitário para que tais edificações fossem feitas fora das "aglomerações urbanas" são bem claras. Entretanto, pensamos que a forma confusa como os executores da lei - fiscais e engenheiros - lidaram com a questão também resultou do fato de se tratar de uma realidade nova para todos. Até o Império não havia preocupação, por parte da Câmara ou do governo central, de regulamentar a construção e organização interna das moradias ${ }^{220}$. Essa preocupação era recente, principalmente a partir dos anos 1880, devido ao aumento populacional e à demanda por moradia. A ocupação desordenada do espaço urbano ocorrida então, gerando problemas sérios como os surtos epidêmicos, impôs a necessidade urgente de organizar e regulamentar $\mathrm{o}$ ato de construir, e consequentemente de morar, traduzidos nos Códigos de Posturas de 1886, e no Código Sanitário de 1894. Se pensarmos que desde a metade da década de 1880, quando aumentou o número de imigrantes e trabalhadores na cidade ${ }^{221}$, até o ano de elaboração do Código Sanitário, em 1894, se passaram apenas dez anos, podemos compreender que foi muito pouco tempo para que autoridades e habitantes se

Interiores, Dr. J.J.Seabra, em 1906. In A construção do habitat moderno no Brasil - 1870-1950, São Carlos: RiMa, 2004, p.103.

${ }^{218}$ CHALHOUB, Sidney - Cidade febril: cortiços e epidemias na Corte Imperial, São Paulo: Cia. das Letras, 1996, p. 36 a 46.

${ }^{219}$ Códigos de Posturas, leis, decretos, editais e resoluções da Intendência Municipal do Distrito Federal, Rio de Janeiro, 1894, p.338. In CHALHOUB, Sidney - Cidade Febril - Cortiços e Epidemias na Corte Imperial, São Paulo: Cia. das Letras, 1996, p.36-40. Grifos nossos.

${ }^{220}$ LEMOS, Carlos (1999), p.13.

${ }^{221}$ De acordo com os dados elaborados pela EMPLASA, até 1872, a porcentagem da população estrangeira era de 6,4\% em relação ao total de habitantes da cidade. Em 1886, esse número subiu para 25,8\%, chegando a perfazer 55,6\% do total, em 1893. In Memória Paulistana, São Paulo: Imprensa Oficial, 2001, p.47 
adaptassem à nova realidade urbana. De um lado, as autoridades tentando definir parâmetros, que embora "ideais", conformavam-se ao "possível"; de outro, proprietários tirando proveito dos lucros auferidos com a locação de imóveis; por fim, os citadinos todos tendo que se habituar, inclusive culturalmente, às novas normas.

Frente a todas as dificuldades mencionadas e levando-se em conta, sobretudo, que São Paulo vivia um momento de mudanças profundas, para a identificação dos casos que pudessem se configurar na categoria de Cortiços, estabelecemos alguns critérios básicos:

a) Os pareceres técnicos dos fiscais, resultantes de solicitações de licença, ou outras ações do poder público, tais como intimações, multas, embargos, etc., acusando a presença de "prédio com caráter de habitação coletiva";

b) Os pedidos de licença para construção de acréscimos a prédios existentes, já que esses são os principais procedimentos a indicar a transformação de um imóvel em cortiço;

c) Os próprios textos das solicitações, quando eventualmente o requerente deixasse claro que se tratava de habitação coletiva;

c) Análise dos projetos arquitetônicos.

A partir desses critérios, selecionamos $\mathbf{4 3}$ processos que de alguma forma indicassem habitações coletivas. No entanto, entre esses processos, alguns exemplares se relacionavam a um único imóvel, reduzindo assim o número das prováveis habitações coletivas para 39 casos.

\begin{tabular}{|l|c|c|}
\hline \multicolumn{1}{|c|}{$\begin{array}{c}\text { PROCESSOS E ORIGEM DA } \\
\text { IDENTIFICAÇÃO DOS CORTIÇOS }\end{array}$} & No TOTAL & $\%$ \\
\hline $\begin{array}{l}\text { REFORMAS E ACRÉSCIMOS } \\
\text { (INCLUSIVE UMA INTERVENÇÃO MUNICIPAL) }\end{array}$ & 23 & 58,98 \\
\hline NOVAS EDIFICAÇÕES PARA MORADIA & 10 & 25,64 \\
\hline $\begin{array}{l}\text { NOVAS EDIFICAÇÕES PARA COCHEIRA E } \\
\text { BARRACÕES }\end{array}$ & 3 & 7,69 \\
\hline $\begin{array}{l}\text { NOVAS EDIFICAÇÕES PARA INSTALAÇÃO DE } \\
\text { MANUFATURAS }\end{array}$ & 3 & 7,69 \\
\hline TOTAL & $\mathbf{3 9}$ & $\mathbf{1 0 0 \%}$ \\
\hline
\end{tabular}

Tabela 34 - Origem da identificação de cortiços e habitações coletivas

A análise de cada um dos casos confirmou que as reformas e acréscimos a prédios existentes realmente envolviam a maior parte das habitações coletivas. Conforme a Tabela 34, para um total de 39 processos de edificações com caráter coletivo, 23 (ou 58,98\%) se originaram desse procedimento -, inclusive um dos 
processos de pedido de vistoria da Prefeitura se refere ao acréscimo de cômodos destinados a cortiço ${ }^{222}$. O conjunto das novas edificações respondeu por $41,02 \%$ dos casos passíveis de serem interpretados como cortiços: dez solicitações referentes a moradia, simples ou de uso misto; três referentes a uma cocheira e dois barracões para depósitos; e três referentes a prédios destinados à instalação de manufaturas.

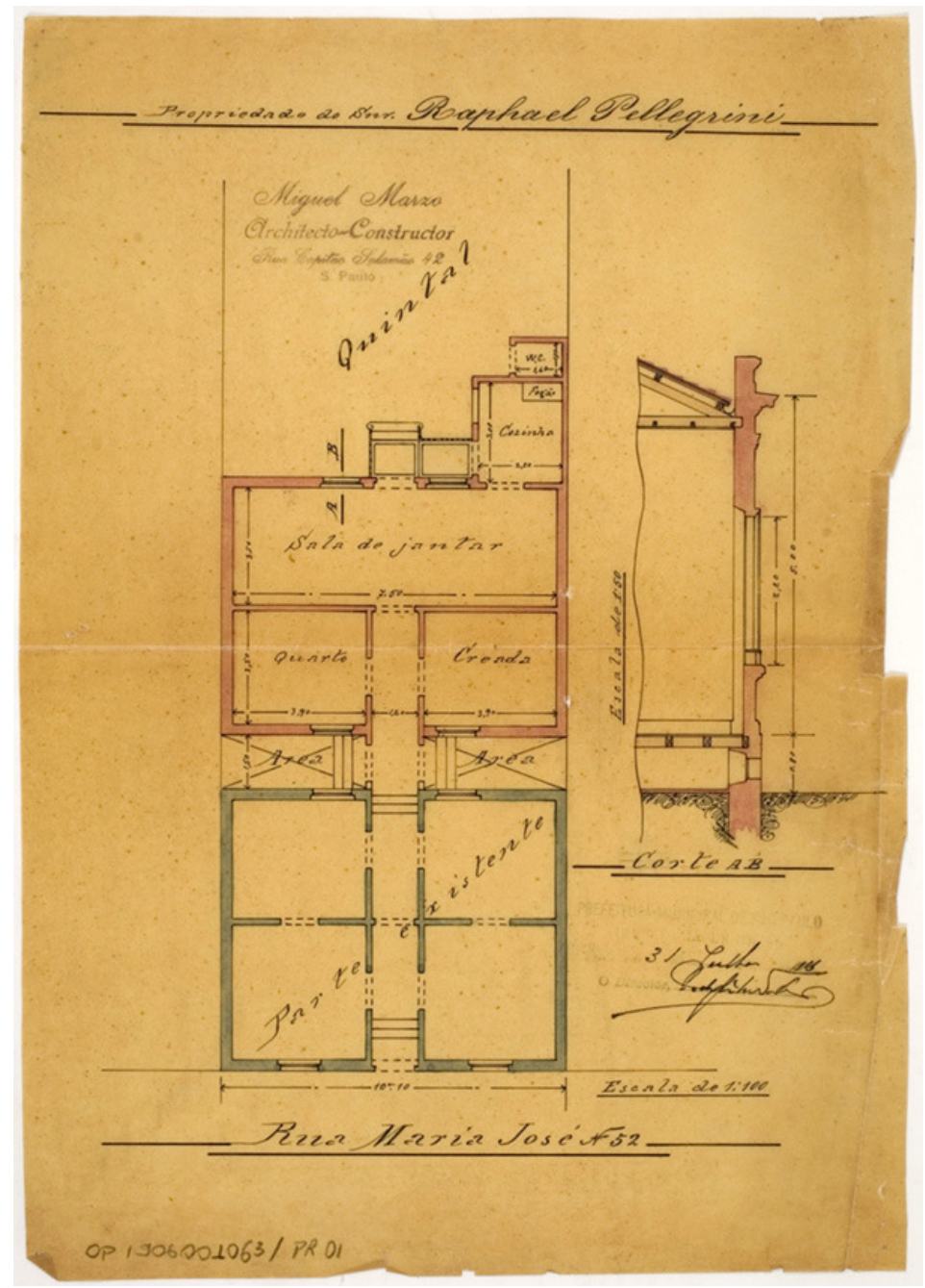

Figura 65 - Processo em nome de Raphael Pellegrini, contendo projeto de acréscimo à uma casa existente. De acordo com a planta da "casa existente", os dois cômodos da frente possuem janela para a rua, e os cômodos seguintes, janelas para os pátios de iluminação propostos. Na sequência dessa casa, os cômodos destinados a "quarto" e "criado" também possuem janelas voltadas para os pátios. O corredor original, prolongado na nova edificação, dá acesso à sala de jantar, que por sua vez, possui portas e janelas para o quintal, além de porta para a cozinha. Esta, conta com acesso independente ao quintal. Por fim, na parede contígua à cozinha, há uma latrina. O corte demonstra alturas de $80 \mathrm{~cm}$ para o porão e $5 \mathrm{~m}$ de pé direito. Fonte: Obras Particulares, 28/06/1906, Cx. M1-09. AHMWL.

Os pareceres técnicos foram bastante úteis já que forneceram as primeiras pistas para localizarmos os imóveis utilizados como habitações coletivas. Contudo, nem

\footnotetext{
${ }^{222}$ Processos de 10/10/1899, 08/11/1899, e 11/06/1900, em nome de Affonso Cocci, à rua Santo Antonio, no 28. Obras Particulares, respectivamente, v. 251, p.27; e v. 282, p.128 e 130.
} 
sempre a leitura das plantas confirmou a avaliação feita pelos fiscais. Esse é o caso, por exemplo, da solicitação feita em 28/06/1906, para a rua Maria José no 52 (Figura 65).

Nesse requerimento, Raphael Pellegrini diz que "Tendo comprado um prédio neste endereço, para transformá-lo em morada de sua família, solicita alvará de licença para construção interna, de acordo com a planta junta”. Conforme o parecer do fiscal, em 04 de julho, "os cômodos existentes são habitados por duas famílias, formando um cortiço”. A planta das alterações a serem realizadas indica uma "construção existente", composta de quatro cômodos, separados por corredor central; os cômodos à direita e à esquerda do corredor têm comunicação entre si, além das portas para aquele corredor. Na sequência, o projeto propõe o acréscimo de duas pequenas áreas para iluminação, um quarto, outro quarto para "criado", sala de jantar, cozinha e latrina externa. Embora não possamos avaliar exatamente qual a utilização dos cômodos da casa da frente, a partir de um olhar contemporâneo, essa planta não nos parece indicativa de construção para habitação coletiva. A recorrência de casos como esse nos leva a pensar numa possível "má vontade" dos agentes encarregados da fiscalização, até porque o requerimento terminou por ser deferido em 31/07/1906.

Ainda que pese uma certa má vontade dos fiscais e dos engenheiros responsáveis, temos que admitir que ninguém melhor do que eles conhecia a realidade da cidade. A leitura exaustiva dos inúmeros pareceres, gerados por processos de difícil solução, deixa bem clara a presença permanente de fiscais nas ruas do bairro. Foi o caso, por exemplo, dos três processos relacionados a um único imóvel, à rua Santo Antonio n ${ }^{\circ} 28$, em nome de Affonso Cocci (ou Tocci). Esses processos envolveram uma infinidade de intimações, embargos e pareceres oficiais, questionando as obras, além de contra-argumentos do proprietário.

O procedimento de vistoria era o seguinte: a partir da entrada dos requerimentos, solicitando aprovação de projetos na Prefeitura, os fiscais percorriam as ruas do bairro, procurando localizar os endereços apresentados, conferindo se os projetos estavam sendo cumpridos à risca ou ainda visando a identificação de quaisquer irregularidades que surgissem - desde a construção e reforma das casas, até as condições de funcionamento de estabelecimentos comerciais, manufatureiros e de cocheiras. Acreditamos que esses procedimentos, desenvolvidos em consecutivos anos de trabalho, em contato direto com os responsáveis pela construção e com os que viviam e trabalhavam no bairro do Bexiga, lhes tenha proporcionado uma visão mais abrangente que os autorizava a opinar com maior propriedade. 


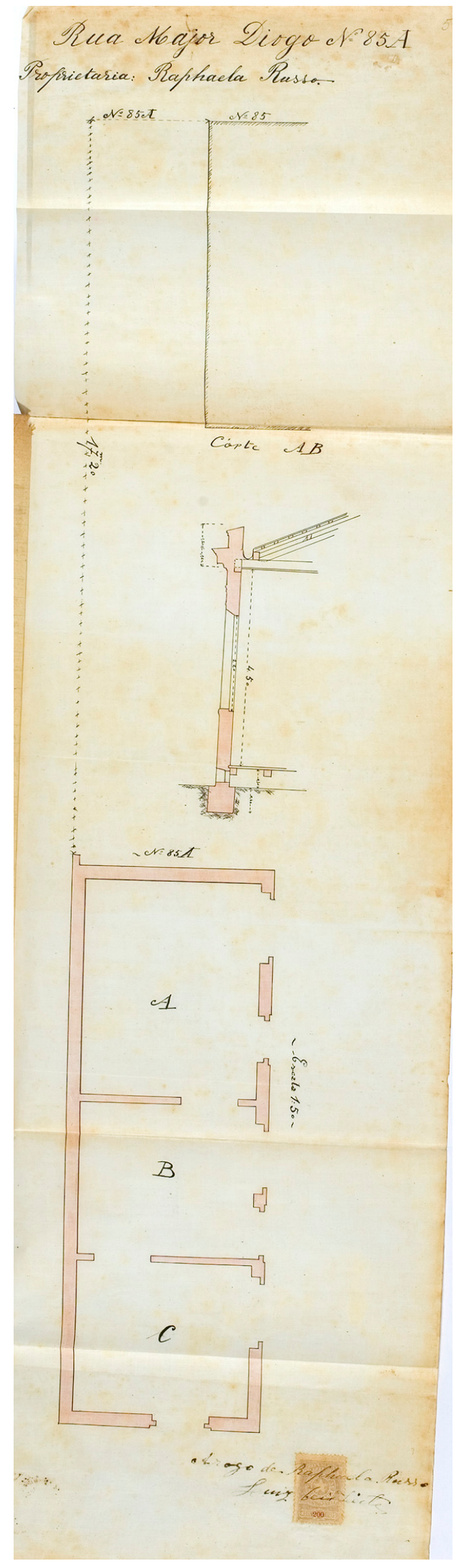

Figura 66 - Processo em nome de Raphaela Russo. Projeto para adequação do imóvel às exigências municipais, à rua Major Diogo $\mathrm{n}^{\circ}$ 85A. Trata-se de uma casa com três cômodos, cujo acesso ao interior pode ser feito através da porta localizada na frente do imóvel. Todos os cômodos possuem portas para um suposto corredor lateral, permitindo o acesso direto ao exterior. Internamente, a casa não possui corredor de circulação, sendo necessário atravessar cada cômodo. Foi a existência dessas portas que, certamente, conferiu à edificação o caráter de cortiço.

O corte demonstra pé direito com 4,50m e porão com $50 \mathrm{~cm}$ de altura, o que aponta para a intenção da proprietária de responder à intimação recebida para "suspender as paredes de mais de 1,50m". Um detalhe interessante: em 14 de dezembro do mesmo ano, seria instituída a Lei no 498, que "Estabelece prescripções para construcções de casas de habitação operaria.", definindo, no Artigo 8', "a altura mínima das paredes, contada do nível superior do pavimento até o frechal será de 3 metros”. Se levarmos em conta o parecer do engenheiro da Prefeitura que dizia "trata-se de um cortiço que o proprietário pretende reconstruir sem satisfazer as condições exigidas", poderíamos concluir que o problema não residia apenas na altura do pé direito da casa mas, principalmente, na presença de cômodos que, fechadas as portas internas, poderiam se caracterizar como espaços independentes entre si, portanto, definíveis como "cortiços". O requerimento foi indeferido em 08 de fevereiro de 1900. Fonte: Obras Particulares, Processo de 27/01/1900, v.275, p. 49. AHMWL. 
- Em 27/01/1900, Raphaela Russo (Figura 66) foi intimada a "suspender as paredes de mais de 1,50m [...]". Conforme o parecer de 07/02/1900, "trata-se de um cortiço que o proprietário pretende reconstruir sem satisfazer as condições exigidas".

Uma outra questão que chama a atenção nos casos de reformas e acréscimos, se refere ao fato de que os cortiços no bairro, não apenas eram tolerados como também eram aceitos, desde que estivessem "de acordo com o padrão das construções coletivas". Alguns processos demonstram a forma como isso se dava. Por exemplo:

- Em 05/06/1905, Galbo Vincenzo entrou com o seguinte requerimento: “Tendo começado a construir uma casa, e não tendo concluído por falta de recursos, solicita licença para a continuação da obra [...]”. Conforme o parecer técnico de 14/06/1905, "Os cômodos prontos indicam se tratar de um cortiço, que não ficará de acordo com o padrão da parte que se refere a construções coletivas [...] Sendo portanto, preciso que os cômodos tenham as portas indispensáveis somente, e que eles se comuniquem entre si por um corredor interno". 223

- Em 27/04/1907, Thomazo Luppo, com casa à rua Rui Barbosa no 24 (Figura 67), "Desejando aumentar mais um quarto nos fundos de seu prédio, solicita licença e aprovação". Curiosamente, todos os cômodos propostos no projeto possuem, além das portas internas de comunicação entre um e outro, portas para um alpendre. Certamente, estas portas configuraram o uso do imóvel como "cortiço", já que permitiriam acesso independente a cada cômodo. Conforme o parecer de 08 de maio de 1907, "O prédio em questão está transformado em cortiço”. Em 11 de junho de 1907, o proprietário foi multado em $100 \$ 000$ “[...] por ter criado cortiço no imóvel”. ${ }^{224}$

\footnotetext{
${ }^{223}$ Obras Particulares, Processo de 05/06/1905, sem projeto construtivo, à rua São Domingos, 24B, v.423, p.118.

${ }^{224}$ Obras Particulares, Processo de 27/04/1907, Cx. 25.
} 


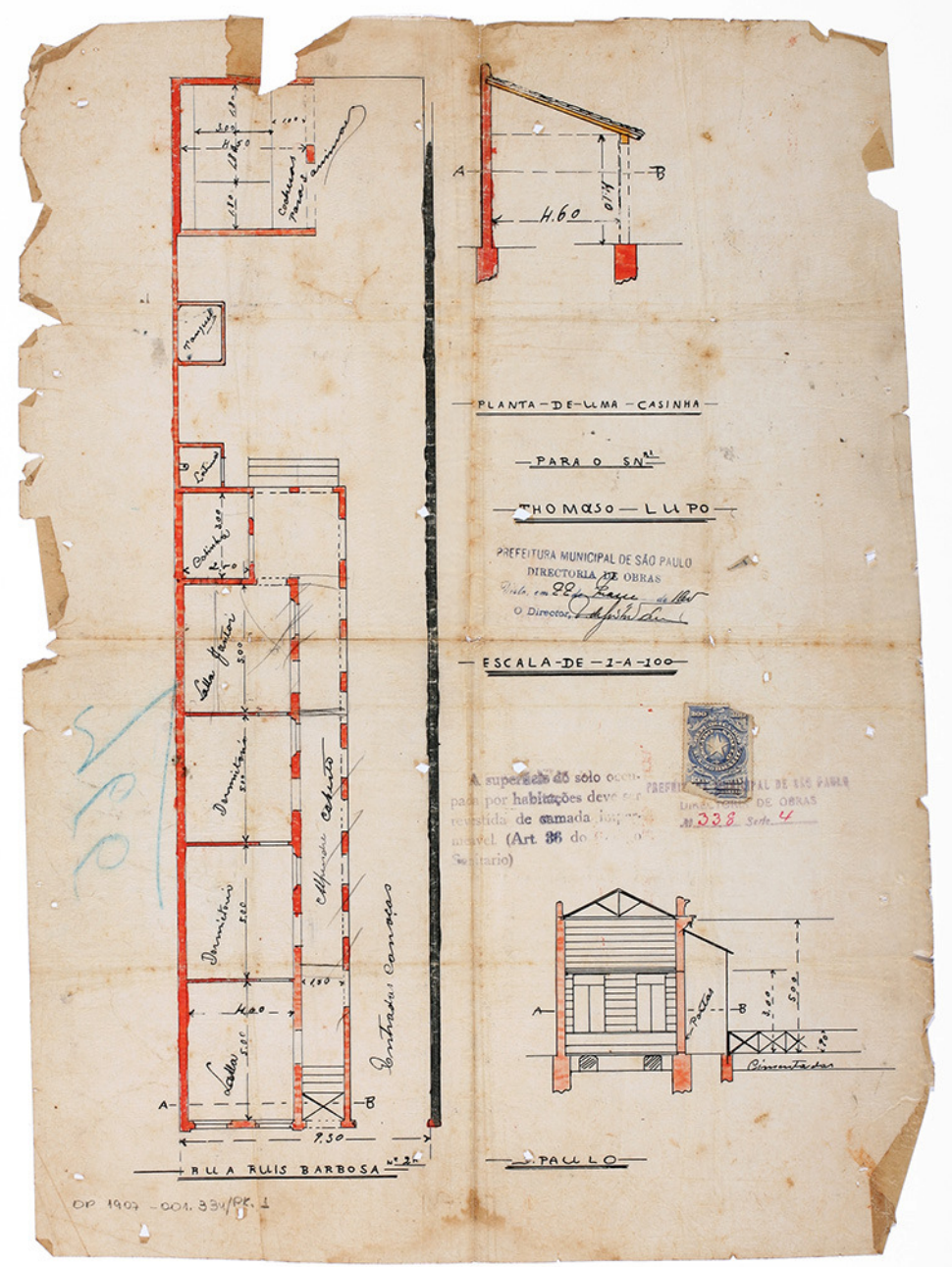

Figura 67 - O projeto contém planta de casa com sala, dois dormitórios, sala de jantar, cozinha e latrina externa; o alpendre lateral acessa um cômodo sem uso definido. Ao lado do alpendre, entrada para "carroças" com cerca de $4 \mathrm{~m}$ de largura. Nos fundos do lote há um tanque e "cocheiras para três animais”. A elevação demonstra a cobertura da casa, a fachada frontal com platibanda, os gradis do porão e, as alturas do pé-direito do edifício (5m), da porta de entrada (3m) e, do balaústre (90cm). As alterações na planta parecem demonstrar que a sala de jantar seria aumentada, incorporando parte do alpendre. Este teria a parede externa derrubada, mantendo-se a cobertura, onde seriam introduzidas duas portas: para a sala e para a sala de jantar.

- Em 07/05/1912, Vicente d'Andréa, “Tendo sido intimado a construir uma cozinha nos baixos da casa existente, solicita aprovação [...]”, merece o parecer em 18 de maio de 1912, "trata-se de prédio de habitação comum, que se acha com caráter de casa coletiva". Em outro parecer, do dia 23 do mesmo mês, o pedido "[...] deve ser indeferido para evitar a permanência e aumento de [...] cortiço”. 


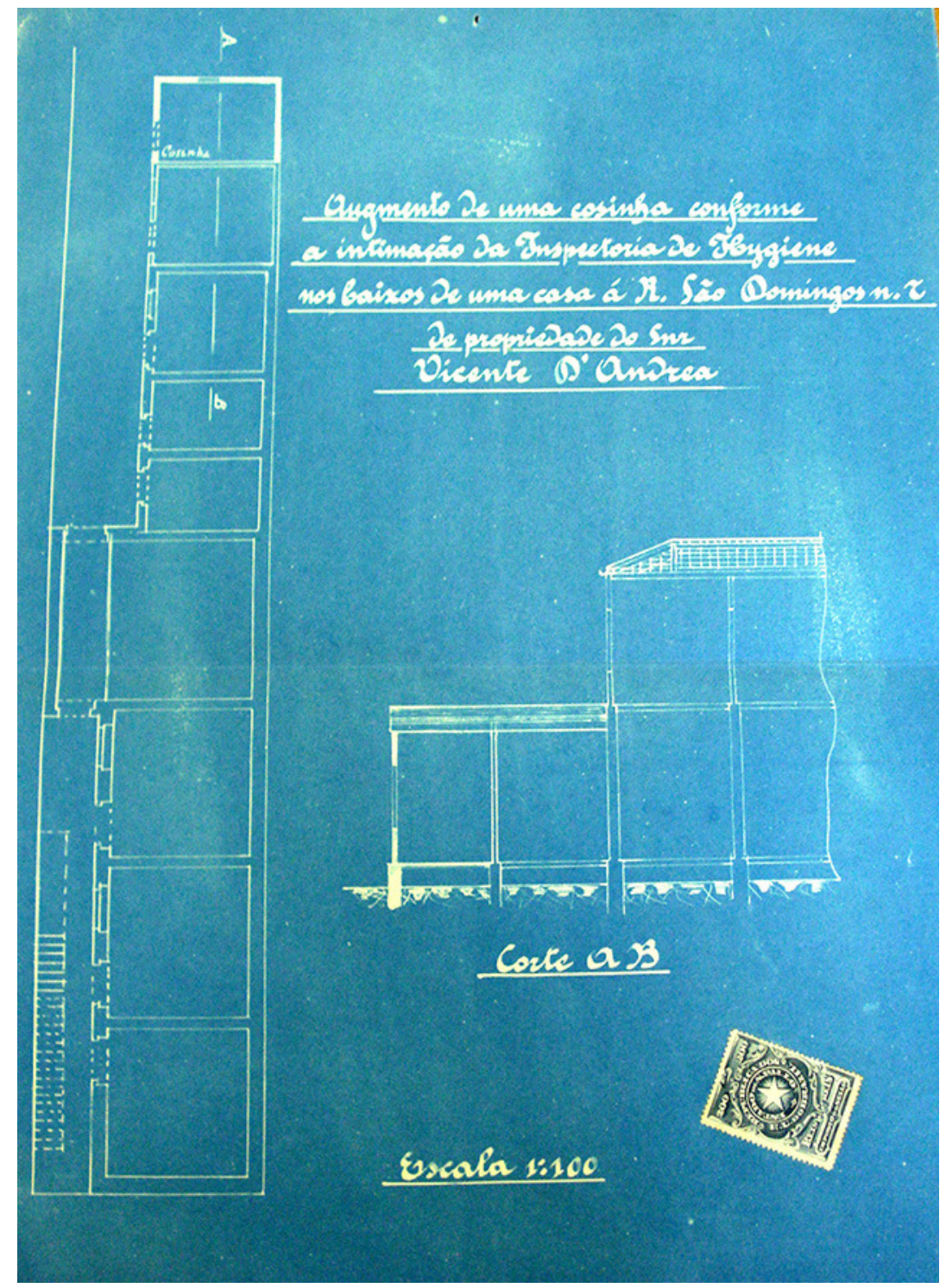

Figura 68 - Processo em nome de Vicente d'Andrea, para acréscimo de cozinha na casa à rua São Domingos $\mathrm{n}^{\circ}$ 7. O projeto indica um sobrado existente, composto no térreo de oito cômodos sequenciais. Os três primeiros não possuem circulação interna, somente portas para o corredor descoberto. Com exceção do primeiro cômodo, que não possui janela alguma, os demais apresentam janelas e portas para o mesmo corredor. O corredor também dá acesso ao quarto cômodo, uma provável sala de jantar. A partir da sala, o corredor alarga prolongando-se para a parte posterior do prédio e, dando acesso a quatro pequenos "quartos", também independentes. Entre estes, apenas o terceiro possui uma janela voltada para fora. Por fim, o último cômodo é provavelmente destinado à cozinha. $\mathrm{O}$ corte se relaciona aos fundos da edificação, demonstrando se tratar de um sobrado. Embora não haja informação explícita, o pé-direito parece ter mais de $4 \mathrm{~m}$ e o porão a altura mínima de $50 \mathrm{~cm}$. Fonte: Obras Particulares, Processo de 07/05/1912, Cx. S2. AHMWL.

É interessante observar que o próprio titulo do projeto, “Augmento de uma cosinha conforme a intimação da Inspetoria de Higyene nos baixos de uma casa á rua São Domingos n.7 de propriedade do Snr. Vicente d'Andrea", denuncia que parte das irregularidades no imóvel já fora detectada pelo serviço de higiene, para o qual parecia 
bastar que se construísse a cozinha. Opinião não compartilhada pela Diretoria de Obras, para a qual tal obra só aumentaria um problema que se queria eliminar.

A partir da década de 1910 se evidencia a tendência, se não de eliminar os cortiços, de evitar que aumentassem de tamanho, o que fica bastante explícito no processo a seguir. Em 1914, o pedido de licença para acréscimo de cozinha, latrina e tanque, para a casa localizada à rua Rui Barbosa nº 131 (Figura 31), cujo requerimento estava em nome de José Maria Passalacqua, gerou um longo processo, que se estendeu até ser indeferido, em 1917.

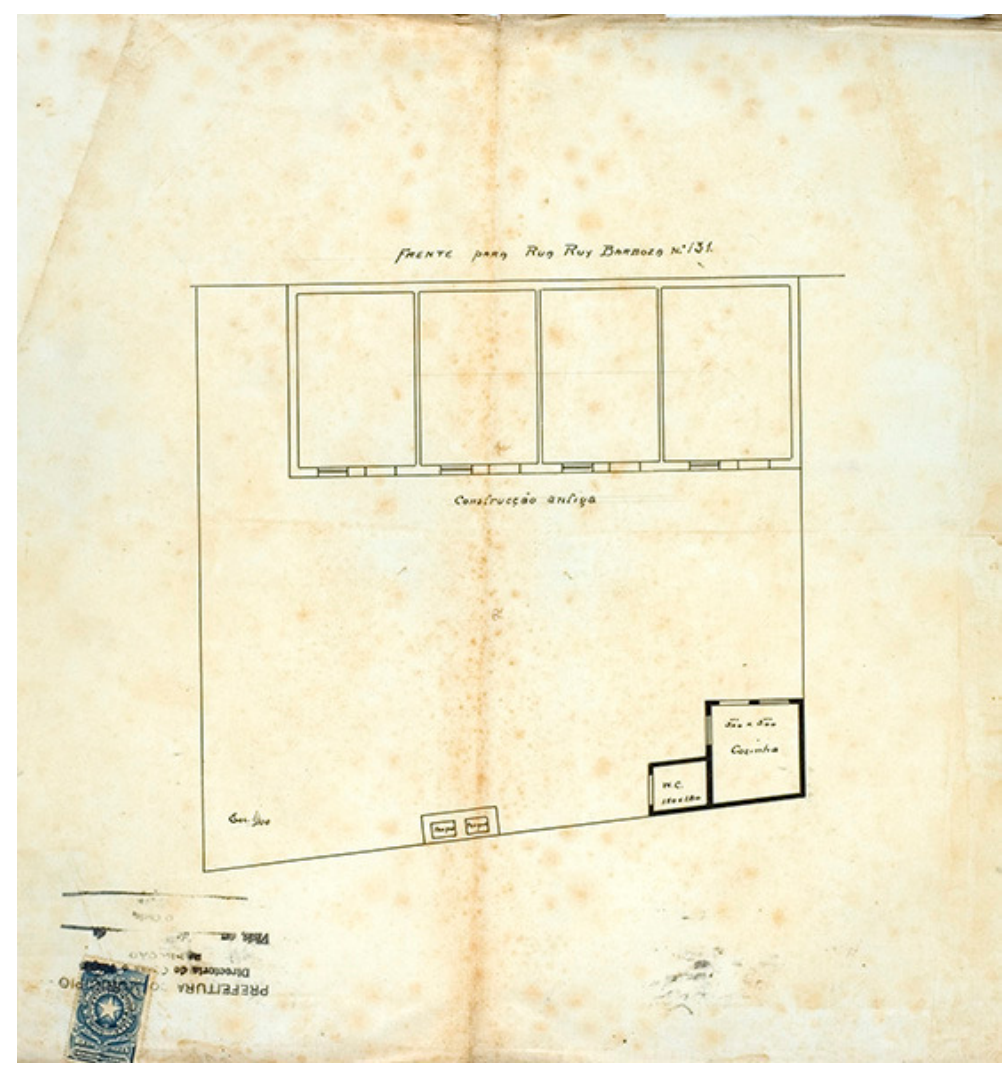

Figura 69 - Processo em nome de José Maria Passalacqua para construção de cozinha, latrina e dois tanques nos fundos de um terreno à rua Rui Barbosa $n^{\circ}$ 131. A planta demonstra uma série de quatro cômodos (de) “frente para Rua Rui Barbosa n $n^{\circ} 131$ ”. Ao lado da edificação há um corredor de acesso ao pátio interno, bastante grande e, nos fundos, os cômodos propostos no projeto. Nenhum dos cômodos existentes possui porta ou janela para a rua! São todos independentes entre si e, seus vãos estão voltados para o pátio comum. A introdução de cozinha, latrina e tanques talvez significasse, para o proprietário, uma forma de não ter problemas com a Inspetoria de Higiene, já que assim estaria "cumprindo" os princípios do artigo 115 do Código Sanitário que rezava que "Deverá haver uma latrina para cada grupo de 20 moradores”. Fonte: Obras Particulares, Processo de 11/07/1914, Cx. R-2. AHMWL.

Nessa ocasião, o parecer do engenheiro Arthur Saboya deixava claro que se tratava de "aumento de cortiço existente, em desacordo com o Código de Posturas, Artigo 20, não sendo pela lei $n^{\circ} 1788$, Art. $5^{\circ}$, então vigente, tolerados novos cortiços $e$, consequentemente, aumento dos existentes”. Este processo bastante complicado, já no 
final do período investigado, indica que por mais que as autoridades municipais se esforçassem, dali em diante, a luta entre o poder público, os proprietários e moradores se intensificava.

Nos casos de novas edificações que teriam originado cortiços ou habitações coletivas, tivemos que recorrer principalmente à interpretação dos projetos arquitetônicos. Foi o caso do projeto em nome de Leopoldino Antonio dos Passos, de $1893^{225}$. Ali, não há processo acompanhando a planta, há apenas o projeto para a construção de quatro casas, cada uma com apenas dois cômodos e sem instalações sanitárias, perfeitamente enquadráveis na categoria de Cortiços.

Outro processo contendo solicitação de licença para construção de uma nova casa ocorreu somente em 1904, e não consta de planta, apenas da solicitação e do respectivo parecer negativo de 20/12/1904, que diz que "a planta não pode ser aprovada, por tratar-se de um verdadeiro cortiço" ${ }^{226}$. Esse certamente é um dos casos indeferidos em que a planta deve ter sido devolvida ao requerente.

Outro caso, datado de 1893, também não consta de processo, apenas da planta indicando a construção de um sobrado de uso misto, com um grande número de cômodos (cinco no térreo e três no sobrado) e uma única latrina (Figura 70). O projeto, com uma certa especialização no uso dos espaços, indica aparentemente, uma residência de classe média. Contudo, o fato de haver apenas uma latrina servindo aos dois pavimentos pode apontar, se não para um cortiço "típico", para uma casa de habitação coletiva ou "casa de cômodos".

\footnotetext{
${ }^{225}$ Obras Particulares, Processo de 17/08/1893, rua Major Diogo, s/nº , v. 10.

${ }^{226}$ Obras Particulares, Processo de 22/12/1904, em nome de Antonio Pangardi, à rua Conselheiro Ramalho, no 100, v.408, . 47.
} 


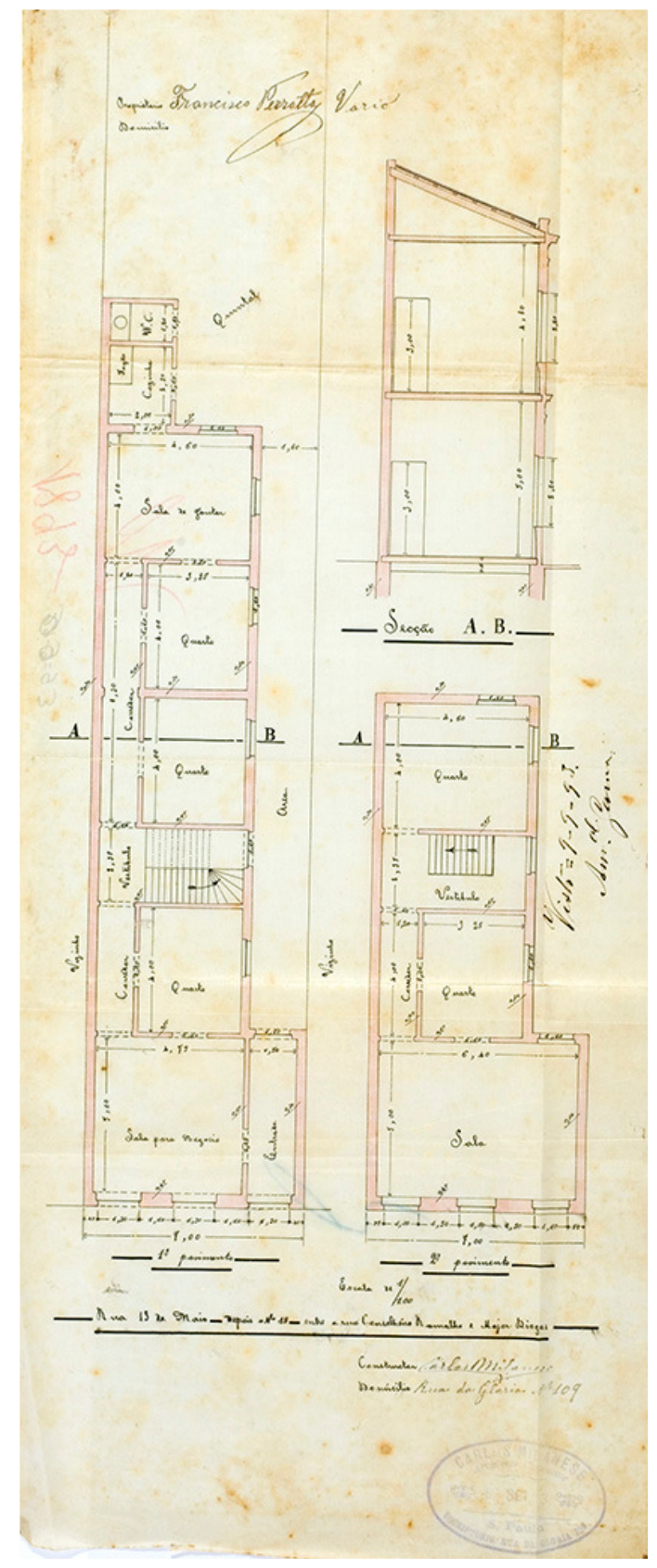

Figura 70 - Projeto arquitetônico em nome de Francisco Perroto Vario, à rua Treze de Maio ${ }^{\circ}$ 20. Embora não haja um requerimento especificando os fins do projeto, tudo leva a crer que se trata da construção de um sobrado de uso misto. No piso térreo temos a "sala para negócios”, instalada no alinhamento, seguida de um quarto, vestíbulo de acesso ao piso superior, mais dois quartos, a sala de jantar, cozinha e WC. O acesso ao interior da residência poderia ser feito através da sala de negócios ou do vestíbulo. No segundo pavimento, ocupando apenas uma parte da edificação, temos uma sala na frente, seguida de quarto, vestíbulo e outro quarto. A circulação, nos dois pavimentos, realiza-se através de corredores internos ou, em alguns casos, de acessos diretos entre diferentes espaços: no térreo, da "loja" para o primeiro quarto; do terceiro quarto para a sala de jantar; e, dessa para a cozinha. No sobrado, da sala para o primeiro quarto. Os dois cômodos localizados na fachada frontal possuem janelas para a rua e para o corredor descoberto; os demais têm suas janelas voltadas para o corredor descoberto ou para o quintal. Por fim, o WC, localizado na parede contígua à cozinha, possui entrada independente da residência. $\mathrm{O}$ corte demonstra alturas de $0,60 \mathrm{~cm}$ para o porão, $5 \mathrm{~m}$ para o primeiro pavimento e, $4,80 \mathrm{~m}$ para o sobrado, todas dentro dos parâmetros estabelecidos pelo Código Sanitário de 1894. Na cobertura, presença de platibanda. Fonte: Obras Particulares, Processo de 09/09/1893, à rua Treze de Maio, no 20, v. 15. AHMWL.

Já nos referimos aos processos relacionados à edificação de barracões em alvenaria, destinados à implantação de manufaturas no fundo de terreno. Num desses projetos, onde o proprietário solicitava licença para construção de "casinha nos fundos da casa”, a planta apresentou um espaço sem definição de uso, na frente do terreno; dentro do terreno, existiam mais duas edificações, erguidas nas divisas dos lotes vizinhos. Este caso foi classificado pelos fiscais como sendo "habitação coletiva" e indeferido. Em seguida, o proprietário entrou com uma nova solicitação, desta vez para a construção de um barracão para "oficina de carpinteiro", que foi aprovado sem 
problemas $^{227}$. Num outro caso, em que o proprietário pedia licença para construir um galpão e uma oficina de marcenaria, o parecer técnico diz que "trata-se de um aumento de uma casa... (para) transformar-se em cortiço". O projeto consta de uma casa existente no alinhamento e de galpão com dois pavimentos, a ser construído nos fundos do lote ${ }^{228}$. A leitura das plantas, nos dois casos, não permitiu a confirmação de que realmente se tratasse de algum tipo de habitação coletiva. Contudo, o indeferimento das solicitações só vem confirmar a preocupação da municipalidade em evitar novos cortiços.

O terceiro caso se refere à uma solicitação de licença para edificação de "um barracão para serralheria”, à rua Major Diogo nº 182 (Figura 71).

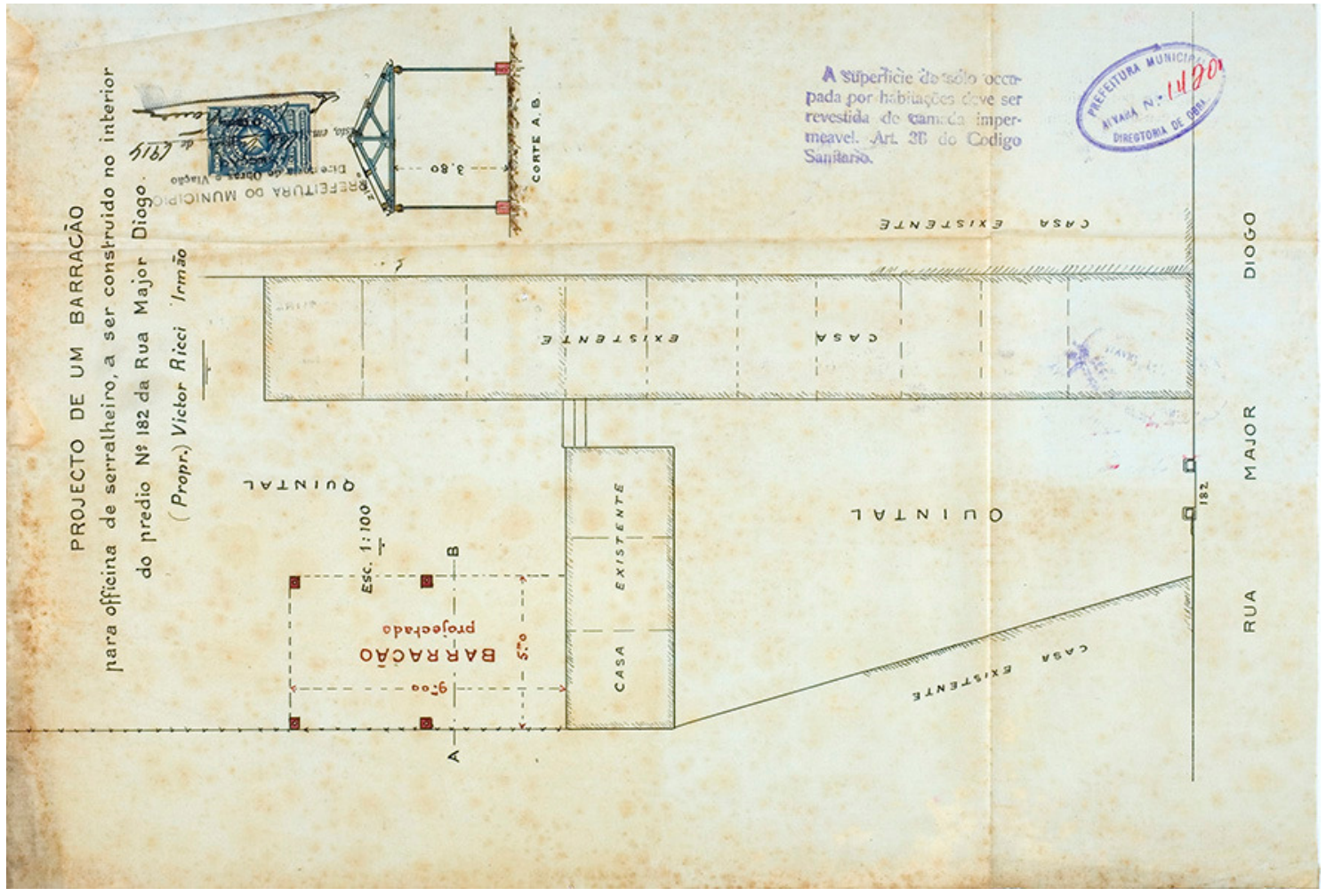

Figura 71 - Projeto em nome de Victor Ricci Irmãos, para construção de "um barracão para officina de serralheiro, a ser construído no interior do prédio no 182 da Rua Major Diogo”. A área total da planta envolve um grande quintal a partir do alinhamento do imóvel número 182, espremido por uma carreira de dez cômodos do lado direito, descritos como "casa existente" e, do lado esquerdo, por outra "casa existente", com três cômodos. O terreno se inicia afunilado no alinhamento e termina por se alargar mais ou menos a partir da metade do lote, na altura da casa menor (em posição paralela à rua). Exatamente na sequência dessa casa seria instalado o barracão para "officina de serralheiro", contendo 9m x 5m. No caso das "casas existentes" não é possível detalhar o seu interior mas, a sequência de cômodos da casa maior pode indicar um possível cortiço. O corte demonstra a armação do telhado, além do pé direito de 3,80m. Fonte: Obras Particulares, Processo de 09/05/1914, Cx. M1. AHMWL.

${ }^{227}$ Obras Particulares, Processo de 05/05/1905, Cx. 416, p.113.

${ }^{228}$ Obras Particulares, Processo de 26/12/1913, Cx. 07. 
Dois requerimentos nos chamaram a atenção de forma especial, ambos referentes à construção de dois sobrados, para a mesma pessoa, Antonio Fernandes Pinto. O primeiro caso, de 23/10/1913, para a rua Santo Antonio, esquina com o Largo do Riachuelo (Figura 72). No segundo, de 15/12/1913, o requerente apresentou um projeto semelhante, agora para o $\mathrm{n}^{\circ} 6$ da rua Santo Antonio (Figura 73).

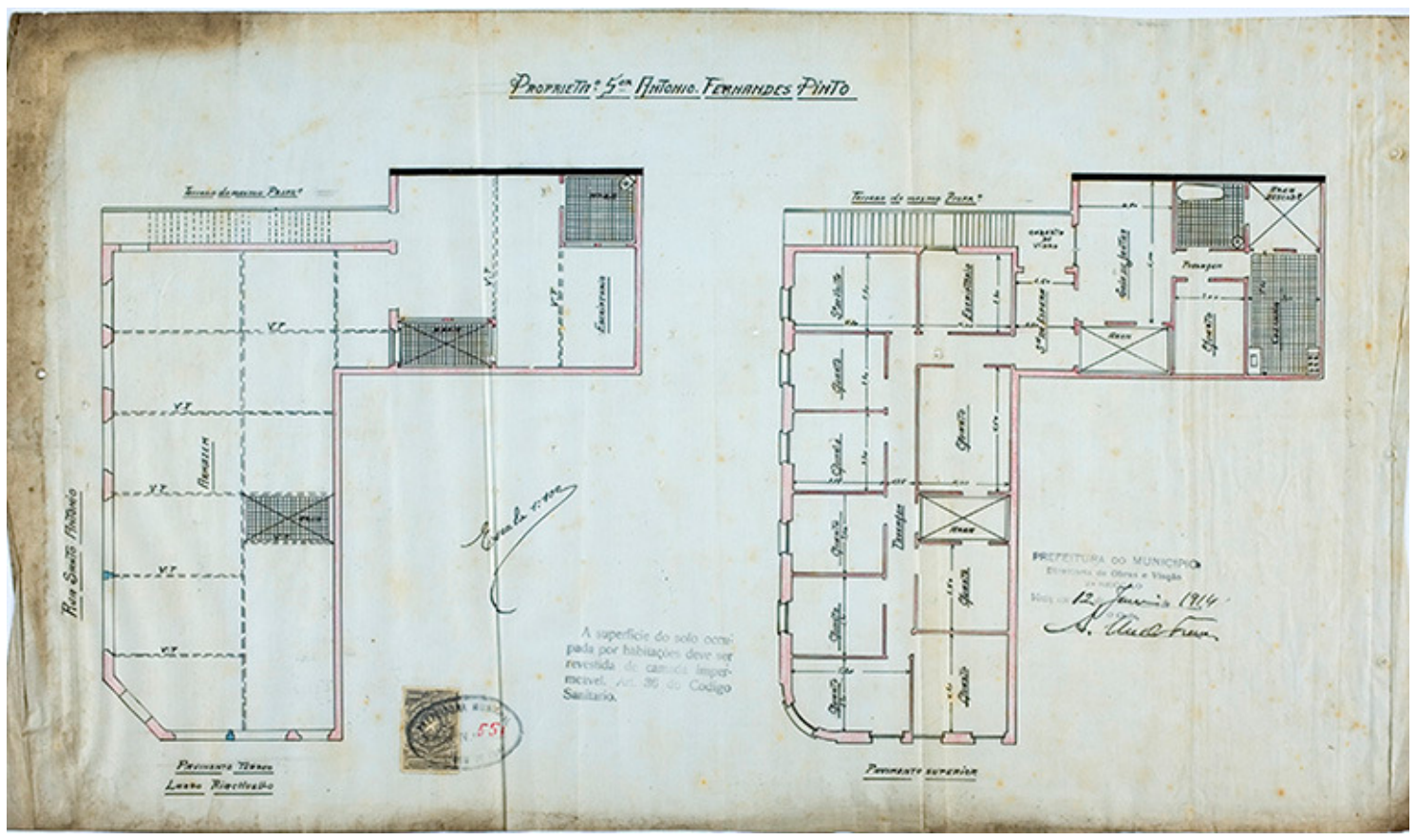

Figura 72 - A planta do piso térreo demonstra ocupação total do lote em forma de "L" invertido, por um armazém, com exceção do escritório nos fundos e de três áreas de iluminação para o piso superior. Acesso independente ao pavimento superior através de escada, localizada nos fundos do prédio. A planta deste piso apresenta, à direita da escada, sala de espera, sala de jantar, um quarto, banheiro e cozinha. Em frente à escada com "coberto de vidro", há uma "sala de espera", através da qual se acessa o escritório (único cômodo com janela para a rua) e a sala de visitas. Todos os cômodos citados recebem iluminação das áreas localizadas no térreo. A área íntima se compõe de cinco quartos, à esquerda, com janelas voltadas para a rua e, três quartos à direita, separados por corredor central. O último quarto da direita possui janela para a rua e, nos quartos seguintes, a janela é voltada para uma das áreas de iluminação localizadas no piso térreo. Fonte: Obras Particulares, 23/10/1913, Cx. S2. AHMWL.

A análise das duas plantas não autoriza a pensar em cortiços, mas, mais provavelmente, em duas pensões ou casas de cômodos - é o que pode indicar a presença de um grande número de quartos nos dois projetos. Por outro lado, o fato das autoridades municipais, tão preocupadas em impedir a construção desse tipo de moradia, não colocarem objeções à edificação proposta, reforça a hipótese de se tratar de pensão. A idéia de edificações com essas características, a serem construídas nas proximidades do Centro e que pudessem servir como pensão para estudantes ou trabalhadores de escritórios, era aceitável, não configurando cortiço. 


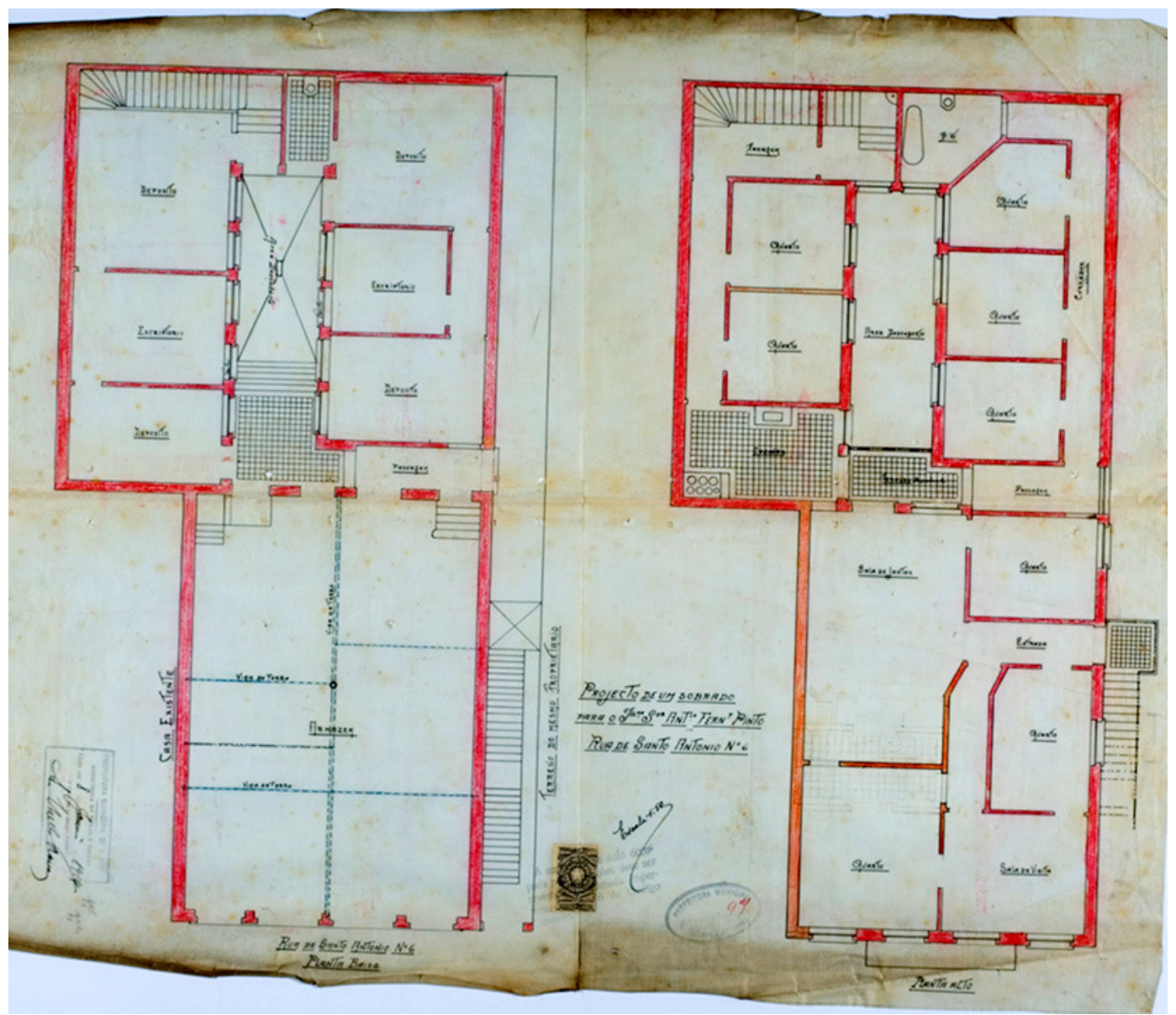

Figura 73 - Projeto do sobrado à rua Santo Antonio no 6. A planta do térreo demonstra ocupação total do lote que divide, do lado esquerdo com uma "casa existente" e, do lado direito, com "terreno do mesmo proprietário". A partir do alinhamento até, aproximadamente, metade da área, o espaço é ocupado por um armazém. A partir daí, temos um pátio de iluminação para o piso superior, ladeado por três depósitos, à esquerda, mais dois depósitos e escritório, à direita. Nos fundos da edificação à esquerda, há escada de acesso ao piso superior. Aliás, o acesso ao sobrado também pode ser feito por escada lateral, à direita da construção, a partir da rua. O piso superior apresenta, a partir da entrada feita pela rua, três quartos, sala de visitas e sala de jantar, exatamente sobre o espaço ocupado no térreo pelo armazém. A partir da sala de jantar, adentrando a construção, temos uma área de distribuição, seguida da área de iluminação fornecida pelo piso inferior. A área de distribuição leva, à esquerda, à cozinha; dali, sai um corredor lateral, com acesso a dois quartos e, nos fundos da edificação, à escada que leva ao térreo. À direita da área de distribuição temos passagem para um corredor lateral direito, com acesso a mais três quartos e ao banheiro. Fonte: Obras Particulares, 15/12/1913, Cx. S2. AHMWL.

Outro exemplo de edificação que poderia se destinar à habitação coletiva ou pensão é o processo de 21/03/1914 ${ }^{229}$, para construção de um sobrado com dupla residência. O pavimento térreo, ocupado por um armazém, se enquadra na categoria de mais de 6 cômodos, possivelmente voltado para a moradia de uma família de classe média. Porém, o piso do sobrado contém sete dormitórios, além de sala, sala de jantar, sala de banho, cozinha e despensa. Não podemos afirmar que se tratasse de casas de

${ }^{229}$ Obras Particulares, Processo em nome de José Mastrangelo, para edificação de sobrado à rua Major Diogo, s/no, Cx. M-1. 
cômodos ou pensão, e ainda que não haja nenhum parecer indicando outro uso que não o residencial, acreditamos que a presença de tantos dormitórios deva ser levada em conta.

É arriscado fazer afirmações categóricas sobre uma realidade que, no período investigado, ainda estava se configurando. As tentativas nesse sentido, a partir de conceitos contemporâneos, podem resultar em idéias estereotipadas sobre o bairro e sobre os atores sociais que ali atuaram, preocupação esta que já apontamos na introdução deste trabalho. Assim, buscamos realizar uma análise exaustiva e criteriosa dos processos para construção e/ou reforma dos imóveis passíveis de serem interpretados como cortiços ou habitações coletivas e os exemplares apontados acima foram os únicos que apresentaram indícios nesse sentido. Se nossa análise e nosso julgamento não estiverem falhos, o número total de processos que envolveram a construção de moradias destinadas a algum tipo de habitação coletiva é muito pequeno quando comparado ao universo investigado - apenas 39 casos entre as $\mathbf{8 8 6}$ solicitações de licença para novas edificações, reformas e/ou acréscimos.

\begin{tabular}{ccccc}
\hline NOVAS & NOVAS & ACRÉSCIMOS & ACRÉSCIMOS & TOTAL \\
EDIFICAÇÕES & EDIFICAÇÕES & RESIDÊNCIAS & NEGÓCIOS & \\
RESIDÊNCIAS & NEGÓCIOS & & & \\
$\mathbf{5 0 2}$ & $\mathbf{4 8}$ & $\mathbf{2 6 5}$ & $\mathbf{7 1}$ & $\mathbf{8 8 6}$ \\
\hline
\end{tabular}

Essa constatação nos leva a questionar a idéia corrente do Bexiga ter sido

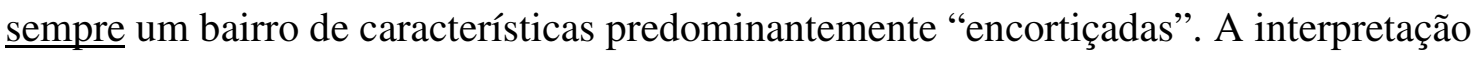
dos dados apresentados pela Série das Obras Particulares permitiu concluir que foi a partir de 1905 que a especulação imobiliária tomou maior impulso, tornando-se mais agressiva nos anos de 1912, 1913 e 1914. Nossa investigação terminou neste último ano, mas tudo indica que o processo de adensamento populacional e o consequente super aproveitamento dos espaços possíveis, com um aumento efetivo do número de cortiços no bairro, tenha se concretizado no decorrer das duas próximas décadas, vindo a transformar o bairro no perfil traçado por Haim Grünspun, em Anatomia de um bairro. O Bexiga ${ }^{230}$ :

"As casas, mesmo, começavam no lado esquerdo das ruas Rocha, Manoel Dutra, Almirante Marques Leão, Santo Antonio e São Vicente. Neste lado baixo do bairro é onde se encontrava o maior número de cortiços, com escadarias sempre afundando para baixo. Em cada patamar, ladeavam portas que se abriam para outras portas. Atrás de cada porta uma família de oito a dez pessoas.

${ }^{230}$ GRÜNSPUN, Haim - Op.Cit. 
O quintal, sempre na descida se alargando para os fundos, apresentava uma ou outra torneira, um ou outro tanque de uso geral e uma ou outra privada, com caixa de descarga, de uso comum." (Grünspun, 1979, pg. 21)

"A entrada pelo portão da esquerda dava para dois quartos enormes, que saiam para um terraço com balaustrada de ferro [...] No portão da direita também de ferro começava uma descida de degraus com patamares. A cada seis ou sete degraus descendo e se afastando da balaustrada, uma porta com um quarto. O primeiro quarto, com janela para a rua ao rés do chão, o segundo quarto, com janela ao lado da porta, ficando alta à medida que se descia pelos degraus, e assim sucessivamente, quatro ou cinco quartos na descida." (Grünspun, 1979, pg. 71)

"Do lado, tinha um portãozinho baixo, direto para uma escadaria que depois formava uma plataforma como rua e ao longo, por trinta metros, portas e mais portas com quartos. O pátio com a entrada pelo portão, era ladeado por tanques e cozinhas, uns três metros abaixo das portas dos quartos." (Grünspun, 1979, pg. 77)

Ao analisar a cidade de São Paulo nos anos de 1920, Nicolau Sevcenko chama a atenção para o fato do crescimento da cidade ter sido desproporcionalmente maior do que as possibilidades de controle por parte do poder público. Apesar do empenho demonstrado pela municipalidade em controlar o crescimento urbano desenfreado através da ação da Diretoria de Obras e da Inspetoria Sanitária, conforme Sevcenko, fatores como os limites orçamentários e a estrutura administrativa enxuta da municipalidade, dificultaram e até impediram quaisquer reações contra a pressão exercida pelas manobras especulativas e contra o descaso por parte daqueles que detinham o controle político e econômico da cidade ${ }^{231}$. A conjugação desses fatores trouxe como consequência funesta a ocupação desenfreada dos espaços possíveis. Enquanto os novos loteamentos envolviam regiões esparsas pela cidade e distantes do Centro, extensas áreas intermediárias eram preservadas em prol da especulação. Nesse contexto de demanda por moradias é que as possibilidades de uso do solo urbano nas áreas mais próximas do Centro foram exploradas exaustivamente, envolvendo todas as possibilidades habitacionais que permitissem a presença de um maior número de pessoas: casas de cômodos, pensões e cortiços.

De qualquer maneira, organizamos os casos analisados, por logradouro e ano de ocorrência, de maneira a traçarmos uma possível concentração dessa tipologia dentro de determinadas áreas do bairro.

\footnotetext{
${ }^{231}$ SEVCENKO, Nicolau - Orfeu extático da Metrópole. São Paulo, sociedade e cultura nos frementes anos 20, São Paulo: Cia. das Letras, 1992. p. 129 a 132.
} 


\begin{tabular}{|c|c|c|c|c|c|c|c|c|c|c|c|c|c|c|}
\hline RUAS & 1893 & 1894 & 1895 & 1899 & 1900 & 1901 & 1904 & 1905 & 1906 & 1907 & 1912 & 1913 & 1914 & TOTAL \\
\hline ABOLIÇÃo & - & - & - & - & - & 1 & - & - & - & - & - & - & 1 & 2 \\
\hline CONSELHEIRo CARRÃo & - & - & - & - & - & - & - & - & - & - & - & 1 & - & 1 \\
\hline CONSELHEIRO RAMALHO & - & - & 1 & - & 2 & - & 1 & - & - & - & - & 1 & - & 5 \\
\hline FORTALEZA & - & - & - & - & - & - & - & - & - & - & - & - & 1 & 1 \\
\hline MAJOR DIOGO/VALINHOS & 1 & - & - & - & 2 & - & - & 2 & - & - & 1 & - & 2 & 8 \\
\hline MARIA JOSÉ & - & - & - & - & - & - & - & - & 1 & - & 2 & - & - & 3 \\
\hline QUATORZE DE JULHO & - & - & - & - & 1 & - & - & - & - & - & - & - & - & 1 \\
\hline RUI BARBOSA & - & - & - & 2 & - & - & - & - & 1 & 1 & - & 1 & 1 & 6 \\
\hline SANTO AMARO & - & - & - & - & - & - & - & - & - & - & 1 & - & - & 1 \\
\hline SANTO ANTONIO & - & 1 & - & - & 1 & - & - & 1 & - & - & - & 2 & 1 & 6 \\
\hline SÃO DOMINGOS & - & - & - & - & - & - & - & 1 & 1 & - & 1 & - & - & 3 \\
\hline TREZE DE MAIO & 1 & - & - & - & - & - & - & - & - & - & - & 1 & - & 2 \\
\hline TOTAL & 2 & 1 & 1 & 2 & 6 & 1 & 1 & 4 & 3 & 1 & 5 & 6 & 6 & 39 \\
\hline
\end{tabular}

Tabela 35 - Mapeamento da ocorrência de possíveis cortiços

Os dados da tabela acima indicam que $\mathbf{2 5}$ dos possíveis casos de cortiços se concentravam nas ruas Major Diogo, Rui Barbosa, Santo Antonio e Conselheiro Ramalho. Os demais casos se distribuíam pontualmente pelas outras ruas do bairro. Com exceção da rua Treze de Maio, aqui parece se repetir o que constatamos na análise das tipologias, sobre a preferência por essas ruas. Resta saber que motivos levariam as pessoas a escolherem essas ruas e não outras para instalar as habitações coletivas, fossem cortiços ou pensões. Haveria algum condicionante que levasse os proprietários a selecionarem ruas determinadas para explorar o "negócio" de locação? Algumas ruas disporiam de "vantagens" suficientes para atrair novos locatários? Algo como a disponibilidade de meios de transporte, como o bonde, a facilidade de acesso ao Centro ou mesmo ao comércio local, etc?

Na tentativa de compreender a "lógica" de distribuição espacial dos cortiços no bairro, voltamos a nos utilizar da cartografia. Para tanto, procuramos localizar no Mappa Topográphico do Município de São Paulo, de 1930 (Figura 74 - Cortiços e habitações coletivas), as ruas onde foram identificados os prováveis cortiços e/ou casas de habitação coletiva. Para isso, tendo em vista as alterações na numeração dos imóveis da cidade no decorrer do último século, e a impossibilidade de localizar os endereços fornecidos pelos requerentes, buscamos no Índice de Emplacamentos da Prefeitura de São Paulo ${ }^{232}$ os dados relativos aos emplacamentos realizados no bairro entre 1908 e 1914, de modo a atualizar a numeração daqueles imóveis. Em seguida, efetuamos a contagem dos lotes com os respectivos imóveis, em cada rua e sempre a partir do Centro, procurando localizar, ainda que aproximadamente, os casos investigados ${ }^{233}$.

\footnotetext{
232 Índice de Registro dos Emplacamentos feito em 16/09/1926. AHMWL.

${ }^{233}$ Para os números pares e ímpares, obedecemos à ordem numérica utilizada oficialmente.
} 
Nem sempre foi possível estabelecer a localização exata e certamente há imprecisões, mas, acreditamos que, de uma maneira geral, o mapa cumpra a função de espacializar a distribuição dos cortiços e habitações coletivas do Bexiga. A primeira impressão é que há cortiços distribuídos por todo o bairro. Percebemos a concentração dessa tipologia predominantemente no "miolo" do bairro, em direção do Centro, a Nordeste. Chegamos assim, à primeira constatação, de que na maioria dos casos, se trata de números baixos, provavelmente localizados mais perto do Centro. Outra constatação é a ocupação preferencial das ruas longitudinais: Rui Barbosa, Conselheiro Ramalho, Maria José, Major Diogo, Abolição e Santo Amaro. As poucas exceções foram as ruas perpendiculares, ocupadas por poucos casos: Fortaleza, Conselheiro Carrão, Quatorze de Julho e São Domingos. A rua Santo Antonio também foi um caso à parte, com cinco casos, alguns muito próximos do Centro. Aliás, aqui é bom lembrar que somente três casos, por se definirem "sem número", não foram localizados no mapa. Por fim, o aspecto provavelmente mais importante: a proximidade das linhas de bonde. $\mathrm{O}$ itinerário da linha de bonde Bom Retiro-Bela Vista percorria, a partir do Largo do $\underline{\text { Riachuelo, }}$, as ruas Santo Antonio, Major Diogo, São Domingos, Conselheiro Ramalho, além de parte da Avenida Brigadeiro Luís Antonio. Daí retornava pelas ruas Rui $\underline{\text { Barbosa, }}$ Manoel Dutra, passando novamente pela Major Diogo e Santo Antonio, para daí, voltar ao ponto inicial, no Largo do Riachuelo. Curiosamente, 28 dos casos de habitações coletivas se localizavam exatamente nessas ruas. Não temos idéia da quantidade de pessoas que viviam nesses cortiços, se trabalhavam no bairro ou distante dele. Porém, se levarmos em conta a inexistência, na região, de indústrias ou firmas de grande porte que dessem emprego a um contingente maior de trabalhadores, é de se supor que os moradores do Bexiga buscassem trabalho em bairros mais afastados. Assim, a proximidade de um meio de transporte coletivo certamente funcionava como um fator de atração importante, se não decisivo, para a escolha do lugar de moradia. 


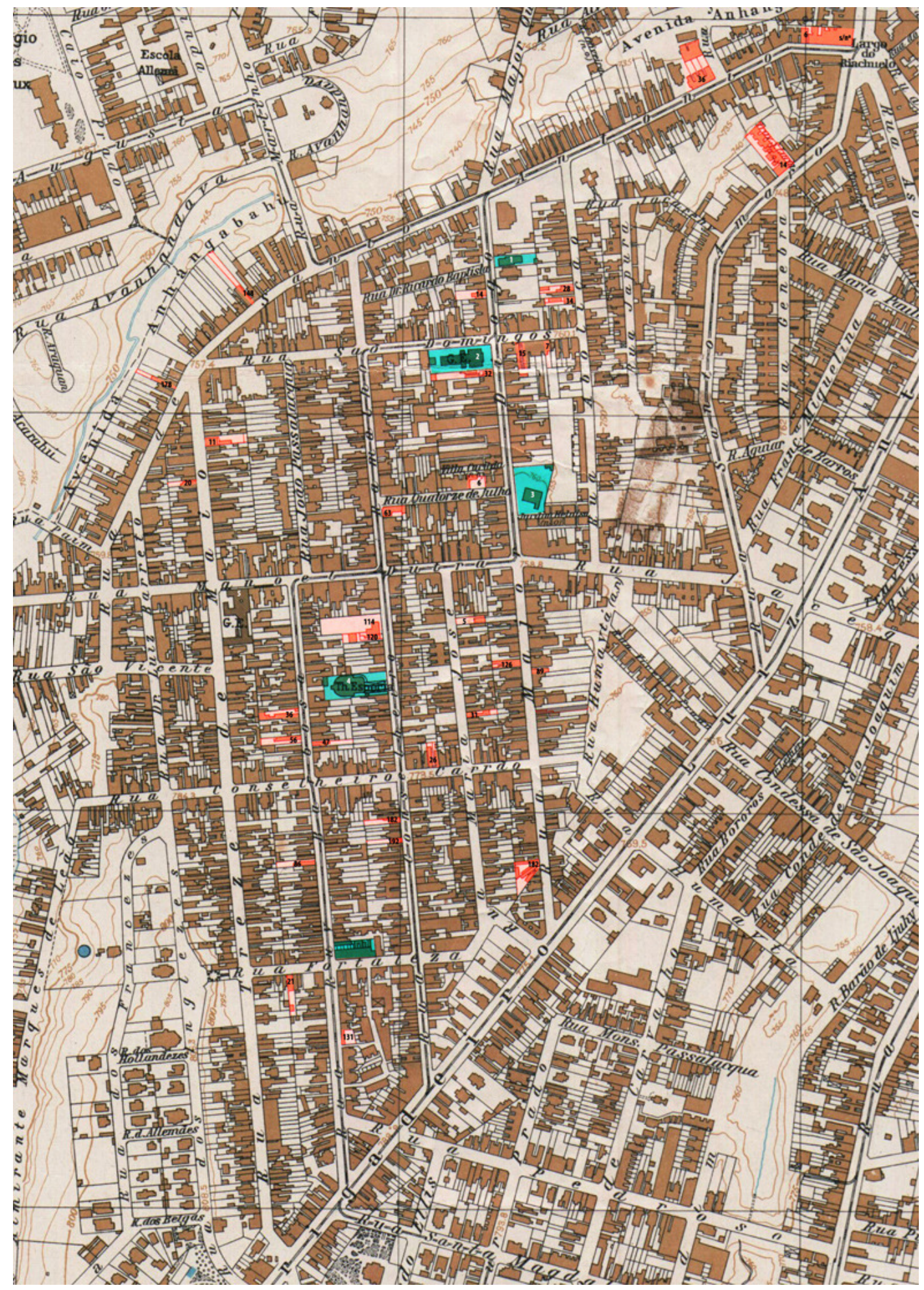

Figura 74 - Localização dos Cortiços e/ou habitações coletivas. É importante destacar que a localização dos exemplares, em vermelho, foi feita de uma forma aproximada, já que não é possivel ter certeza exata da numeração das vias. Procuramos destacar em verde os edifícios que pudessem funcionar como referência: na rua Major Diogo, o ${ }^{\circ} 5$, de propriedade de D. Domiciana de Almeida Nogueira; o Grupo Escolar da Bela Vista; e a casa de D. Yayá, defronte da rua 14 de Julho. Na rua Conselheiro Ramalho $n^{\circ}$ 132, o Theatro Esperia. Por fim, na rua Fortaleza, esquina com a rua Rui Barbosa, as casas de Joaquim Antunes dos Santos. Fonte: "Mappa Topográphico do Município de São Paulo (1930)”, SARA Brasil, Fl. 37. AHMWL. 
Retomando a Tabela 35, observamos momentos de "pico" nas ocorrências de cortiços e/ou habitações coletivas durante os anos de 1900, 1905, 1912, 1913 e 1914, quando registramos $\mathbf{2 3}$ documentos que, de alguma maneira, remetem à presença desse tipo de moradia, o que confirma nossas constatações sobre as fases de aumento populacional no bairro e na cidade. Por exemplo, no Capítulo 1, ao analisarmos a presença de profissionais de origem estrangeira na construção de novos edifícios, constatamos a incidência de um maior número de italianos nos anos de 1895, 1898, 1900, 1905, 1913 e 1914. Ainda que a análise ali realizada se relacione a um segmento específico, ela implica no aumento da presença de elementos estrangeiros na cidade e, em última instância, no aumento de pessoas na cidade, inclusive daquelas em busca de moradias baratas.

A seguir, apresentamos algumas imagens do interior de cortiços no bairro do Bexiga, pertencentes ao acervo do Centro de Memória da Saúde Pública/Faculdade de Saúde Pública da USP. Embora realizadas anos após o período enfocado neste trabalho, as fotografias feitas pelos funcionários do Instituto de Higiene ${ }^{234}$ fornecem um quadro que acreditamos esteja bem próximo da realidade do bairro nas suas primeiras décadas de ocupação.

\footnotetext{
${ }^{234}$ O Instituto de Higiene foi criado por Geraldo Paula Souza, em 1918. De acordo com VASCONCELLOS e RODRIGUES, a produção fotográfica do Instituto de Higiene, da qual fazem parte as imagens aqui reproduzidas, "era parte inerente dos métodos de identificação das condições em que as doenças proliferavam. A força das imagens [...] servia aos objetivos do higienista em dois aspectos complementares: como instrumento de denúncia e como prova documental irrecusável para propor intervenções no espaço urbano junto ao poder público". VASCONCELLOS, Maria da Penha C. e RODRIGUES, Jaime - "A fotografia como instrumento de trabalho do higienista (São Paulo, primeira metade do século XX)", História, Ciência, Saúde-Manguinhos, v. 13, nº 2, Rio de Janeiro, abr-jun/2006. Disponível em: http://www.scielo.br/scielo.
} 


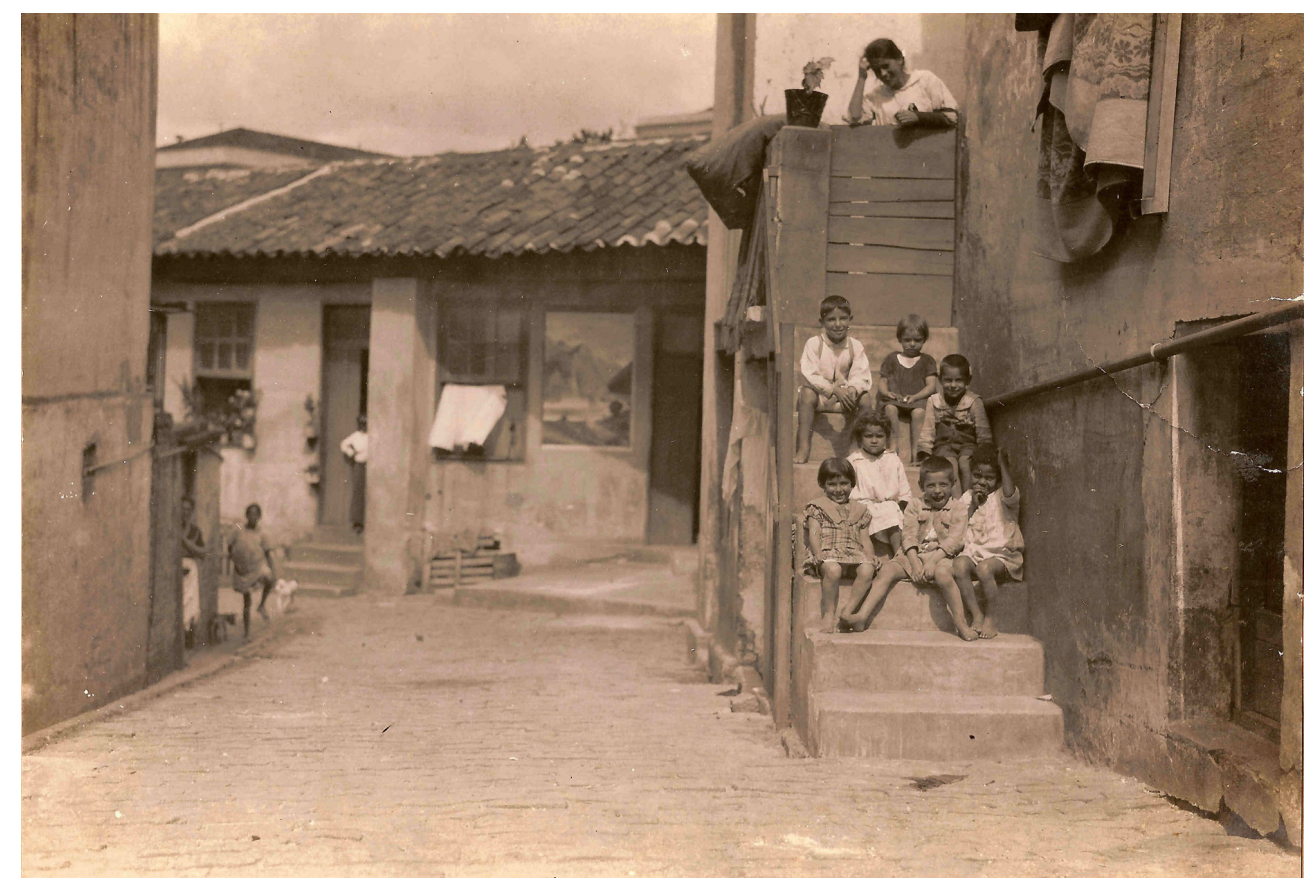

Figura 75 - Interior de cortiço na rua Conselheiro Ramalho, 247 A. Pátio calçado, casas de porta e janela e inúmeras crianças parecem ter sido uma constante naquele cenário. O garoto à esquerda da foto, também parece ser afro-descendente. Foto: Geraldo Horácio de Paula Souza, c. 1919-1925. Fonte: Centro de Memória da Saúde Pública/Faculdade de Saúde Pública/USP.

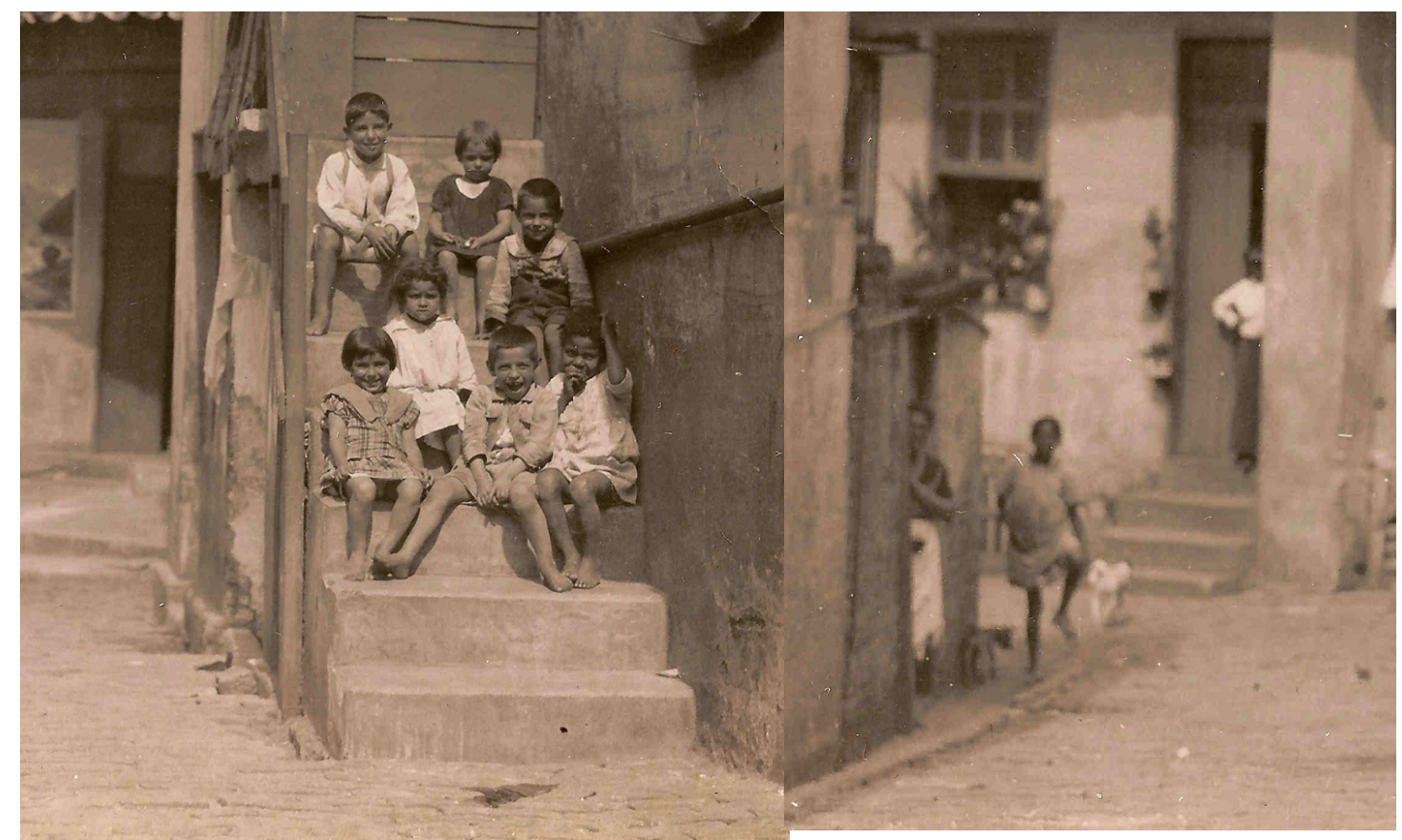

No detalhe à esquerda, vemos entre as crianças uma menina afro-descendente. No detalhe à direita, destacamos um garoto ao lado da mulher e dos cachorros. 


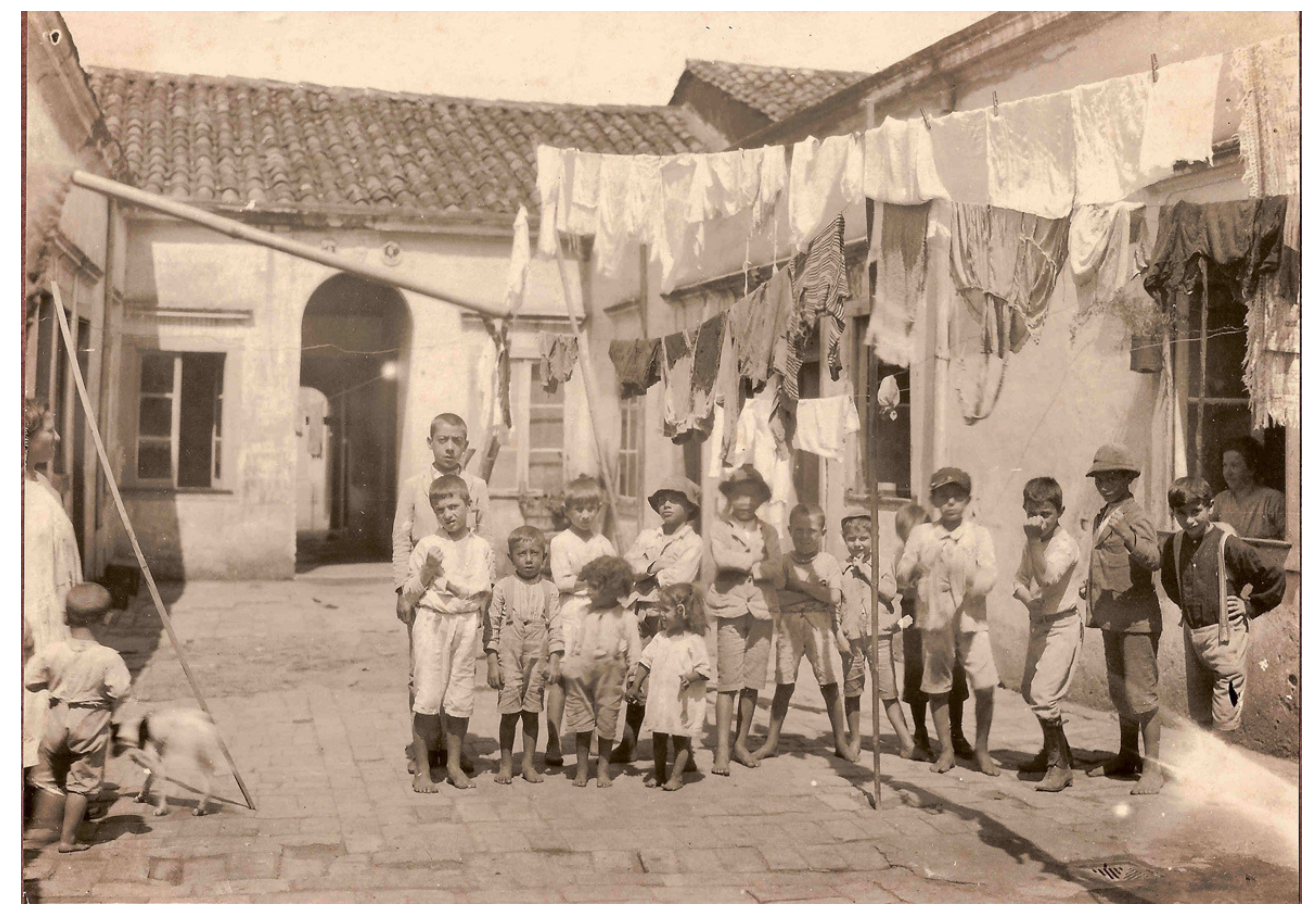

Figura 76 - Cortiço localizado na rua Major Diogo, 114. Em contraste com a foto anterior, aqui não encontramos nenhuma criança afro-descendente; entretanto, nas duas fotos os pés descalços parecem dizer que a pobreza é a mesma. Foto: Geraldo Horácio de Paula Souza, c. 1919-1925. Fonte: Centro de Memória da Saúde Pública/Faculdade de Saúde Pública/USP.

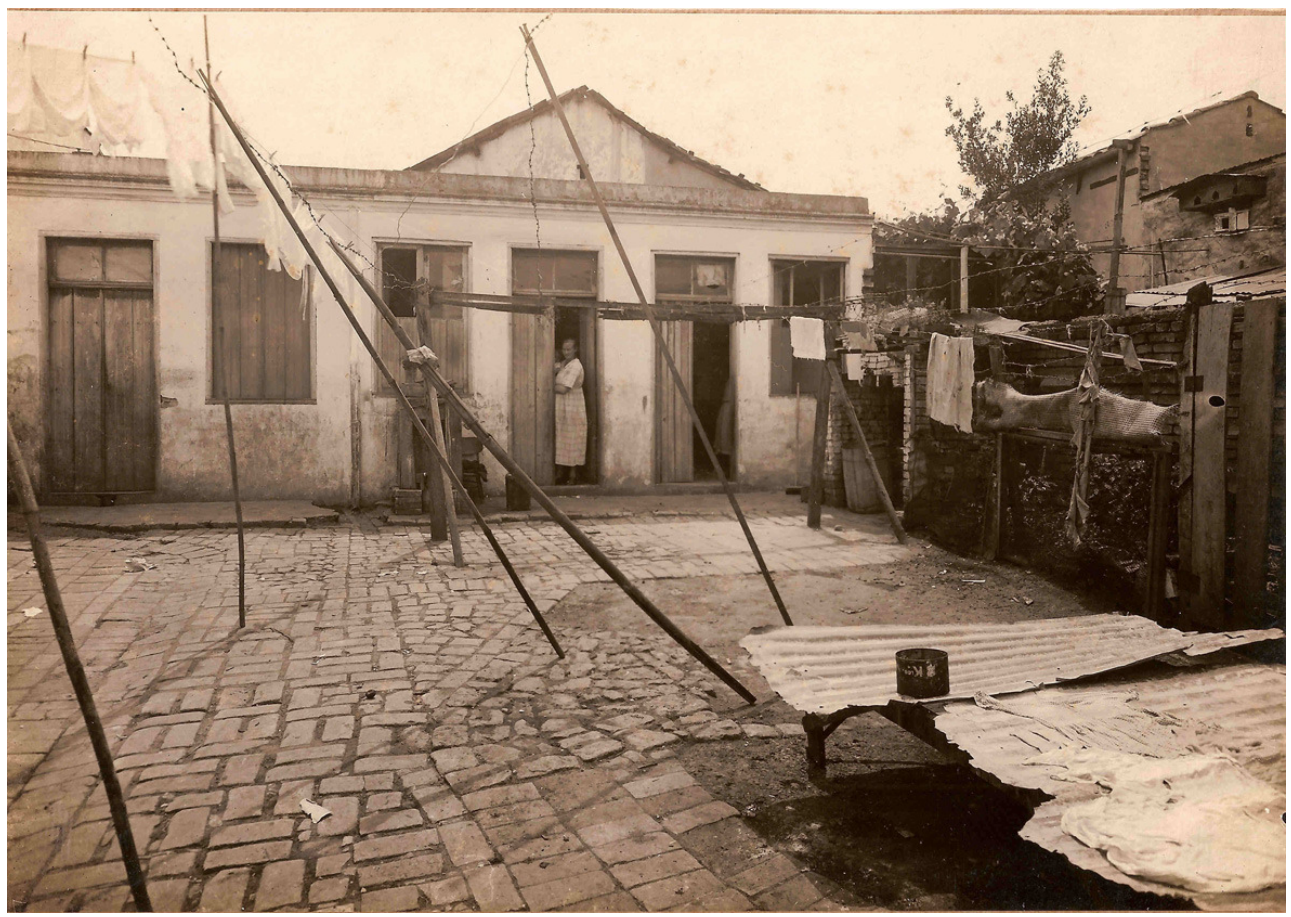

Figura 77 - $\mathrm{O}$ interior desse cortiço na rua Rui Barbosa, 32, apresenta pequenas casas de porta e janela, $\mathrm{o}$ pátio devidamente calçado, de acordo com o "Cap. VI, do Padrão Municipal de 11 de agosto de 1886”. Os varais e os suportes para "quarar" a roupa denunciam a atividade das moradoras, provavelmente lavadeiras. Foto: Geraldo Horácio de Paula Souza, c. 1919-1925. Fonte: Centro de Memória da Saúde Pública/Faculdade de Saúde Pública/USP. 


\section{USUÁRIOS, PRINCIPAIS USOS E ATIVIDADES PRODUTIVAS}

\subsection{Uma contribuição especial: as tipologias edilícias na Série Obras Particulares}

A análise das tipologias edilícias, através do estudo dos processos da Série Obras Particulares, permitiu reconstituir um possível cenário do bairro do Bexiga, entre 1881 e 1914. Saber como as pequenas e grandes construções para moradia e/ou negócios se distribuíram pelas ruas do bairro foi fundamental para espacializar as diferentes faixas de riqueza no Bexiga, até o ano de 1914. Num primeiro momento, organizamos na Tabela $36^{235}$, as informações relativas às tipologias, por ruas.

\begin{tabular}{|c|c|c|c|c|c|c|c|}
\hline RUA & $\begin{array}{l}\text { CASAS } \\
\text { SIMPLES }\end{array}$ & $\begin{array}{c}\text { CASAS } \\
\text { DE } \\
\text { FUNDOS }\end{array}$ & $\begin{array}{c}\text { CASAS } \\
\text { EM } \\
\text { SÉRIE }\end{array}$ & VILAS & $\begin{array}{c}\text { SOBRADOS } \\
\text { COM } 2 \\
\text { RESIDÊNCIAS }\end{array}$ & $\begin{array}{c}\text { CASAS } \\
\text { DE } \\
\text { USO } \\
\text { MISTO }\end{array}$ & TOTAL \\
\hline ABOLIÇão & 7 & - & - & - & - & 1 & 8 \\
\hline $\begin{array}{l}\text { CONSELHEIRO ANTONIO PRADO } \\
\text { (ATUAL MANOEL DUTRA) }\end{array}$ & - & - & - & - & - & - & - \\
\hline CONSELHEIRO CARRÃO & 16 & - & 8 & - & - & 4 & 28 \\
\hline CONSELHEIRO RAMALHO & 25 & - & 17 & 6 & - & 7 & 55 \\
\hline FORTALEZA & 3 & - & 10 & 4 & - & - & 17 \\
\hline $\begin{array}{l}\text { JOÃO PASSALACQUA } \\
\text { (ANTIGA MONTE DE OURO) }\end{array}$ & 7 & - & 3 & 3 & - & 1 & 14 \\
\hline $\begin{array}{l}\text { MAJOR DIOGO } \\
\text { (ANTIGA VALINHOS) }\end{array}$ & 21 & 3 & 16 & 25 & 2 & 6 & 73 \\
\hline $\begin{array}{l}\text { MANOEL DUTRA } \\
\text { (ANTIGA CONS. A. PRADO) }\end{array}$ & 22 & 1 & 10 & 3 & 4 & 4 & 44 \\
\hline MARIA JOSÉ & 17 & 2 & 8 & - & - & 2 & 29 \\
\hline $\begin{array}{l}\text { MONTE DE OURO } \\
\text { (ATUAL JOÃO PASSALACQUA) }\end{array}$ & 3 & - & - & - & - & 1 & 4 \\
\hline QUATORZE DE JULHO & 1 & - & 2 & - & - & 1 & 4 \\
\hline RUI BARBOSA & 24 & 1 & 10 & 2 & 2 & 4 & 43 \\
\hline SANTO AMARO & 15 & 3 & 20 & 3 & 2 & 2 & 45 \\
\hline SANTO ANTONIO & 19 & 1 & 27 & - & 4 & 19 & 70 \\
\hline SÃO DOMINGOS & 7 & 1 & 15 & - & 2 & 2 & 27 \\
\hline SÃO VICENTE & 3 & 3 & 5 & - & - & 1 & 12 \\
\hline $\begin{array}{l}\text { SARACURA GRANDE } \\
\text { (ATUAL NOVE DE JULHO) }\end{array}$ & 1 & 1 & - & - & - & - & 2 \\
\hline $\begin{array}{l}\text { SARACURA PEQUENA } \\
\text { (ATUAL DR. PLÍNIO BARRETO) }\end{array}$ & 1 & - & 5 & - & - & - & 6 \\
\hline $\begin{array}{l}\text { DO SOL } \\
\text { (ATUAL DR. LUÍS BARRETO) }\end{array}$ & 12 & - & 20 & - & 4 & 3 & 39 \\
\hline TREZE DE MAIO & 38 & 4 & 32 & - & 11 & 10 & 95 \\
\hline VALE DO ANDORRA $(*)$ & - & - & - & - & - & - & - \\
\hline $\begin{array}{l}\text { VALINHOS } \\
\text { (ATUAL MAJOR DIOGO) }\end{array}$ & - & - & - & - & - & - & - \\
\hline TOTAL GERAL & 242 & 20 & 208 & 46 & 31 & 68 & 615 \\
\hline
\end{tabular}

Tabela 36 - Tipologias, por localização

O predomínio de casas simples, térreas ou sobrados, construídas no alinhamento das ruas é nítido: 242 unidades; em seguida, vêm as casas em série, com

\footnotetext{
${ }^{235}$ Número total de casas a construir, independentemente do número de solicitações. Tabela elaborada a partir da Tabela 26, Solicitações originais e unidades (reais), a serem edificadas. Capítulo 2.
} 
208 unidades; e na seqüência, aparecem as casas de uso misto, com 68 unidades. Em número bem mais reduzido vêm as casas de fundos (20), as vilas (46) e os sobrados com dupla residência (31).

As ruas Treze de Maio, Santo Antonio, Major Diogo, Conselheiro Ramalho, Rui Barbosa, Manoel Dutra e Santo Amaro concentram o maior número de edificações, independentemente da tipologia. Juntas, essas ruas abrigam 425 ou 69,10\% dos 615 prédios construídos no bairro.

A concentração de prédios em algumas ruas e não em outras pode ser explicada pela extensão dessas vias. Daquelas citadas, a Manoel Dutra (assim como as ruas São Domingos, Conselheiro Carrão, São Vicente e Fortaleza) disposta em sentido transversal, é a rua mais curta. As outras estão dispostas longitudinalmente, atravessando todo o bairro, de Norte a Sul, sendo portanto as vias mais longas, como pode ser visto na Figura 78. A exceção fica por conta das ruas do Sol, João Passalacqua, Maria José e Abolição, que embora sejam longitudinais, percorrem trajetos mais curtos, apresentando um número menor de edificações.

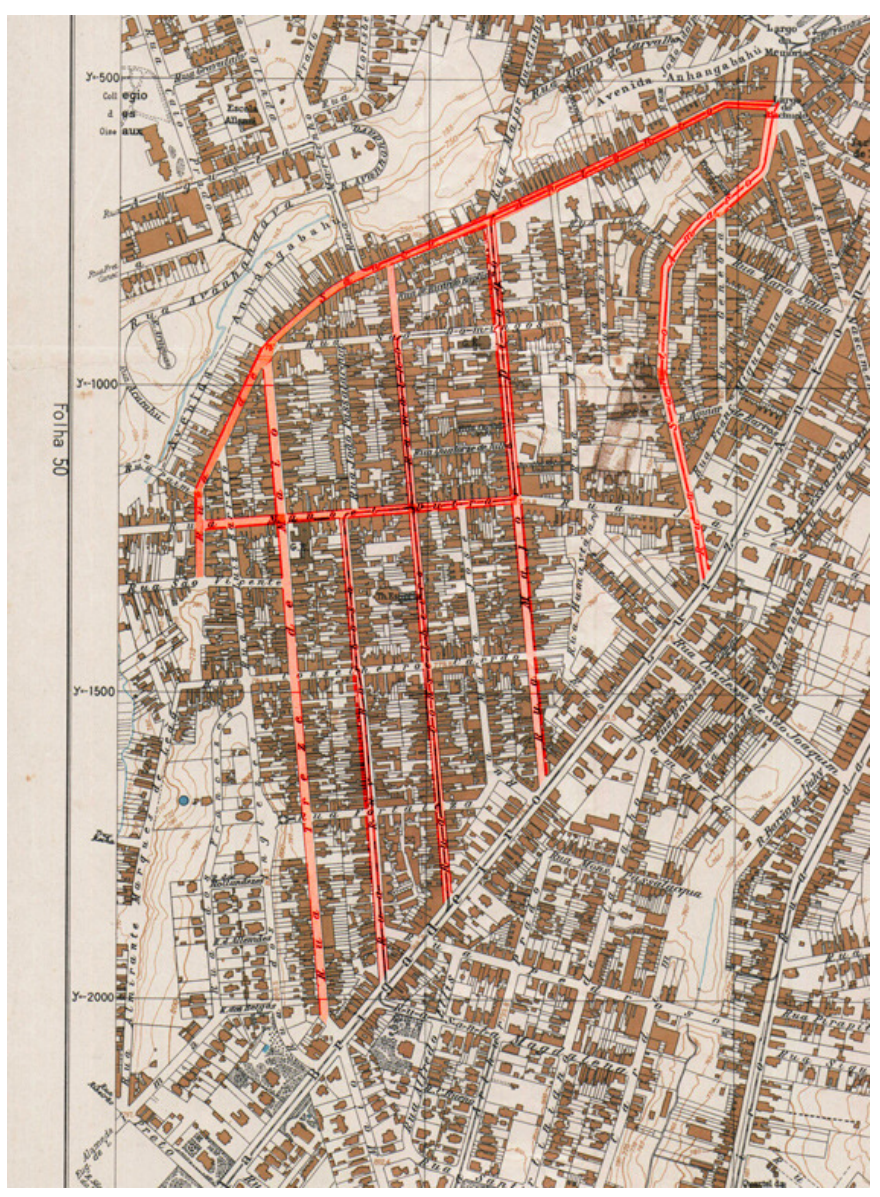

Figura 78 - Ocupação das ruas, conforme a maior concentração de prédios. Fonte: "Mappa Topográphico do Município de São Paulo (1930)”, SARA Brasil, Fl. 37. AHMWL. 
Para termos uma idéia mais aproximada da ocupação do bairro segundo as faixas de riqueza, por hipótese, acreditamos ser o número de cômodos um bom indicador. Por esse motivo é que, num segundo momento, elaboramos a Tabela 37, abaixo, onde estão organizadas as informações referentes ao número de cômodos de cada edificação, por localização.

\begin{tabular}{|c|c|c|c|c|c|c|}
\hline TIPOLOGIAS & $\begin{array}{c}\text { ATÉ 3 } \\
\text { CÔMODOS }\end{array}$ & $\begin{array}{c}4 \\
\text { CôMODOS }\end{array}$ & $\begin{array}{c}5 \\
\text { CôMODOS }\end{array}$ & $\begin{array}{c}6 \\
\text { CôMODOS }\end{array}$ & $\begin{array}{l}\text { MAIS DE } 6 \\
\text { CÔMODOS }\end{array}$ & $\begin{array}{c}\text { UNIDADES } \\
\text { RESIDENCIAIS } \\
\text { A CONSTRUIR }\end{array}$ \\
\hline CASAS SIMPLES & 78 & 51 & 43 & 35 & 35 & 242 \\
\hline $\begin{array}{l}\text { CASAS DE } \\
\text { FUNDO }\end{array}$ & 9 & 3 & 5 & 1 & 2 & 20 \\
\hline $\begin{array}{l}\text { CASAS EM } \\
\text { SÉRIE }\end{array}$ & 53 & 50 & 40 & 23 & 42 & 208 \\
\hline VILAS & 15 & 18 & 12 & 1 & - & 46 \\
\hline SOBRADOS & 7 & 4 & 9 & 3 & 8 & 31 \\
\hline CASAS MISTAS & 26 & 19 & 12 & 6 & 5 & 68 \\
\hline TOTAL & 188 & 145 & 121 & 69 & 92 & 615 \\
\hline
\end{tabular}

Tabela 37 - Tipologia e número de cômodos, por ocorrência

Para aprofundar a análise das informações fornecidas pela tabela, partimos do pressuposto que quanto menor o número de cômodos e mais simples a especialização dos espaços, mais pobres seriam seus ocupantes. Na medida em que se acrescentavam mais cômodos, e se introduziam espaços mais especializados, os moradores pertenceriam a estratos mais elevados. No Capítulo 2, distribuímos as informações disponíveis nos projetos segundo a tipologia adotada, o número de cômodos e os usos propostos. Ali constatamos que as casas que possuíam até 3 cômodos, assim como aquelas com 4 cômodos, eram bem simples, satisfazendo as necessidades básicas de seus moradores. As primeiras continham geralmente, sala (que à noite podia se transformar em dormitório), quarto (dormitório) e cozinha; as de 4 cômodos, dois quartos (ou dormitórios), sala e cozinha, ou ainda duas salas, um quarto e cozinha; ambas com a latrina localizada fora da edificação. As casas com 5 cômodos estavam a meio caminho, apresentando tendência a uma maior especialização e uma eventual "sofisticação". No geral, apresentavam duas salas (a sala de visitas e a sala de jantar ou varanda), dois quartos (ou dormitórios) e cozinha. Ocasionalmente, possuíam espaços mais valorizados socialmente, como o vestíbulo, o gabinete ou a sala de banho. Esta última só aparece com o avançar dos anos, já que até 1906 os serviços de água e esgoto ainda não estavam disponíveis para todo o bairro. As edificações com 6 cômodos ou mais de 6 cômodos pertenciam a moradores de um extrato social superior. As primeiras podiam apresentar - além dos usuais (dois) quartos (ou dormitórios), duas salas e cozinha -, despensas, vestíbulos, gabinetes, salas de banho, quartos para criada ou 
mesmo três quartos. As casas com mais de 6 cômodos, de uma maneira geral, contavam com duas salas, três quartos (ou dormitórios), quarto para criada, quarto para engomar, despensa, gabinete, etc. Não raramente, também podiam apresentar, além da sala de banho e/ou banheiro, uma latrina externa à edificação.

A seguir, analisaremos a distribuição das edificações pelas ruas do bairro, segundo o número de cômodos propostos. A primeira informação importante que a tabela nos fornece é a alta porcentagem de casas destinadas às camadas mais baixas da sociedade. As casas com até 3 cômodos (188 unidades) e aquelas com 4 cômodos (145 unidades) somam 333 unidades, perfazendo cerca de 54,14\% das construções da amostragem. As casas que possuem de 5 cômodos (121 unidades) a 6 cômodos (69 unidades), mais claramente destinadas às camadas médias, somam 190 unidades, aproximadamente $30,89 \%$ do universo das edificações para moradia a serem construídas. Por fim as casas com mais de 6 cômodos (92), totalizam 14,96\% do universo. Sem contarmos o caso dos cortiços (38), cujos ocupantes se situariam numa situação limite de pobreza, esses dados vêm confirmar nossas expectativas sobre o predomínio das camadas médias e baixas no bairro.

\begin{tabular}{|l|c|c|}
\hline $\begin{array}{c}\text { NÚMERO DE } \\
\text { CÔMODOS } \\
\text { PROPOSTOS }\end{array}$ & $\begin{array}{c}\text { UNIDADES } \\
\text { RESIDENCIAIS } \\
\text { A CONSTRUIR }\end{array}$ & $\%$ \\
\hline ATÉ 3 CôMODOS & 188 & $\mathbf{3 0 , 5 7}$ \\
\hline 4 CôMODOS & 145 & $\mathbf{2 3 , 5 8}$ \\
\hline 5 CôMODOS & 121 & $\mathbf{1 9 , 6 8}$ \\
\hline 6 CôMODOS & 69 & $\mathbf{1 1 , 2 1}$ \\
\hline + DE 6 CôMODOS & 92 & $\mathbf{1 4 , 9 6}$ \\
\hline TOTAL & $\mathbf{6 1 5}$ & $\mathbf{1 0 0 \%}$ \\
\hline
\end{tabular}

Tabela 38 - Percentual das casas a construir, por número de cômodos propostos

Como já nos referimos acima, no conjunto percebemos uma maior concentração de edificações nas ruas Treze de Maio, Santo Antonio, Major Diogo, Conselheiro Ramalho e Santo Amaro. Porém, se nos detivermos em cada uma delas, verificamos que dos totais por número de cômodos (com até 3, 4, 5, 6 e mais de 6 cômodos), aproximadamente, a metade está concentrada preferencialmente em determinadas ruas. 


\begin{tabular}{|c|c|c|c|c|c|c|}
\hline RUAS & $\begin{array}{l}\text { ATÉ } 3 \\
\text { CôMODOS }\end{array}$ & $\begin{array}{c}4 \\
\text { CôMODOS }\end{array}$ & $\begin{array}{c}5 \\
\text { CôMODOS }\end{array}$ & $\begin{array}{c}6 \\
\text { CôMODOS }\end{array}$ & $\begin{array}{c}\text { MAIS } \\
\text { DE } 6 \\
\text { CÔMODOS }\end{array}$ & $\begin{array}{c}\text { TOTAL DE } \\
\text { UNIDADES } \\
\text { RESIDENCIAIS } \\
\text { A CONSTRUIR } \\
\end{array}$ \\
\hline ABOLIÇÃo & 3 & 2 & 1 & 2 & - & 8 \\
\hline $\begin{array}{l}\text { CONSELHEIRO } \\
\text { CARRÃo }\end{array}$ & 13 & 10 & - & 2 & 3 & 28 \\
\hline CONSELHEIRO RAMALHO & 8 & 11 & 16 & 11 & 9 & 55 \\
\hline FORTALEZA & 14 & - & - & 2 & 1 & 17 \\
\hline $\begin{array}{l}\text { Jỗo PASSALÁCQUA } \\
\text { (ANTIGA MONTE DE OURO) }\end{array}$ & 5 & 1 & 4 & 4 & - & 14 \\
\hline $\begin{array}{l}\text { MAJOR DIOGO } \\
\text { (ANTIGA VALINHOS) }\end{array}$ & 14 & 12 & 30 & 2 & 15 & 73 \\
\hline $\begin{array}{l}\text { MANOEL DUTRA } \\
\text { (ANTIGA CONS. A. PRADO) }\end{array}$ & 16 & 13 & 7 & 4 & 4 & 44 \\
\hline MARIA JOSÉ & 13 & 8 & 3 & 4 & 1 & 29 \\
\hline $\begin{array}{l}\text { MONTE DE OURO } \\
\text { (ATUAL JOÃO PASSALÁCQUA) }\end{array}$ & - & 2 & 1 & 1 & - & 4 \\
\hline QUATORZE DE JULHO & 1 & - & - & 2 & 1 & 4 \\
\hline RUY BARBOSA & 12 & 16 & 9 & 4 & 2 & 43 \\
\hline SANTO AMARO & 7 & 7 & 9 & 5 & 17 & 45 \\
\hline SANTO ANTONIO & 16 & 17 & 16 & 9 & 12 & $\mathbf{7 0}$ \\
\hline SÃO DOMINGOS & 10 & 4 & 4 & 4 & 5 & 27 \\
\hline SÃO VICENTE & 10 & - & 1 & 1 & - & 12 \\
\hline $\begin{array}{l}\text { SARACURA GRANDE } \\
\text { (ATUAL } 9 \text { DE JULHO) }\end{array}$ & 1 & - & 1 & - & - & 2 \\
\hline $\begin{array}{l}\text { SARACURA PEQUENA } \\
\text { (ATUAL DR. PlíNIO BARRETO) }\end{array}$ & 3 & 2 & 1 & - & - & 6 \\
\hline $\begin{array}{l}\text { DO SOL } \\
\text { (ATUAL DR. LUÍS BARRETO) }\end{array}$ & 17 & 15 & 4 & 3 & - & 39 \\
\hline TREZE DE MAIO & 25 & 25 & 14 & 9 & 22 & 95 \\
\hline TOTAL & 188 & 145 & 121 & 69 & 92 & 615 \\
\hline
\end{tabular}

Tabela 39 - Número de cômodos, por localização

- As casas ocupadas pelas camadas mais pobres, possuindo até 3 cômodos, estavam localizadas preferencialmente nas ruas Treze de Maio, do Sol (atual Dr. Luís Barreto), Santo Antonio, Manoel Dutra e Fortaleza.

- As casas com 4 cômodos, dirigidas às camadas "médias baixas", localizavam-se nas ruas Treze de Maio, Santo Antonio, Rui Barbosa e do Sol (atual Dr. Luís Barreto).

- As casas com 5 cômodos, dirigidas às camadas "médias", localizavam-se nas ruas Major Diogo, Conselheiro Ramalho e Santo Antonio.

- As casas com 6 cômodos, "médias altas", localizavam-se nas ruas Conselheiro Ramalho, Santo Antonio e Treze de Maio.

- Casas com mais de 6 cômodos, de camadas "altas", localizavam-se nas ruas Treze de Maio, Santo Amaro e Major Diogo.

Desse panorama suscinto, concluímos que as ruas Treze de Maio e Santo Antonio agruparam todos os estratos sociais (das camadas baixas às camadas altas). Nas ruas Manoel Dutra, Maria José, Rui Barbosa, São Domingos, São Vicente e do Sol, as casas destinadas às camadas mais baixas são predominantes. As camadas médias, de maneira geral, ocupavam as ruas Conselheiro Ramalho, Major Diogo, Santo Antonio e 
Treze de Maio. Por fim, as ruas Treze de Maio, Santo Amaro e Major Diogo concentraram as residências ocupadas pelos estratos mais ricos.

Em seguida, analisaremos os cortiços, ocupados pelas camadas mais pobres do bairro, independente do número de cômodos que apresentavam. Nesse caso, decidimos abrir exceção quanto ao tipo de requerimento utilizado nas investigações. Até aqui nos utilizamos somente daqueles documentos voltados para novas edificações, porém, de acordo com a Tabela $34{ }^{236}$, reproduzida abaixo, se levássemos em consideração apenas as edificações que deram origem às habitações coletivas, teríamos apenas $\mathbf{1 6}$ casos, e estaríamos deixando de lado as $\mathbf{2 3}$ edificações referentes à grande maioria dos casos registrados nesta categoria. Por outro lado, o principal objetivo deste capítulo é analisar as formas de uso dos espaços e perfis dos seus usuários, entre os anos de 1881 e 1914, o que necessariamente, envolve a diversidade social ali contida e, portanto, a sociotopografia ali espacializada ${ }^{237}$. Dessa maneira, identificamos alguns requerimentos referentes a reformas e acréscimos nos imóveis.

\begin{tabular}{|l|c|c|}
\hline \multicolumn{1}{|c|}{$\begin{array}{c}\text { PROCESSOS E ORIGEM DA } \\
\text { IDENTIFICAÇÃO DOS CORTIÇOS }\end{array}$} & $\begin{array}{c}\mathbf{N}^{\circ} \\
\text { TOTAL }\end{array}$ & $\mathbf{\%}$ \\
\hline $\begin{array}{l}\text { REFORMAS E ACRÉSCIMOS } \\
\text { (INCLUSIVE UMA INTERVENÇÃO MUNICIPAL) }\end{array}$ & 23 & 58,98 \\
\hline NOVAS EDIFICAÇÕES PARA MORADIA & 10 & $\mathbf{2 5 , 6 4}$ \\
\hline $\begin{array}{l}\text { NOVAS EDIFICAÇÕES PARA COCHEIRA E } \\
\text { BARRACÕES }\end{array}$ & 3 & 7,69 \\
\hline $\begin{array}{l}\text { NOVAS EDIFICAÇÕES PARA INSTALAÇÃO DE } \\
\text { MANUFATURAS }\end{array}$ & 3 & 7,69 \\
\hline TOTAL & $\mathbf{3 9}$ & $\mathbf{1 0 0 \%}$ \\
\hline
\end{tabular}

Tabela 40 - Origem da Identificação de Cortiços e Habitações Coletivas

Ainda assim, os 39 possíveis cortiços e/ou habitações coletivas, identificados no capítulo anterior, são bem pouco significativos se pensarmos no panorama traçado por Haim Grünspun para o Bexiga na década de 1930, ou mesmo na realidade fixada no imaginário social sobre o bairro como espaço predominantemente "encortiçado". Tal como mencionado no Capítulo 2, no final das investigações, em 1914, o Bexiga ainda se encontrava em pleno processo de crescimento. A especulação imobiliária e o consequente adensamento populacional muito se intensificaram nos três últimos anos

\footnotetext{
${ }^{236}$ Tabela 34 - Origem da Identificação de Cortiços e Habitações Coletivas, Capítulo 2.

${ }^{237}$ LE GOFF, Jacques - “A nova sociedade urbana”, in O apogeu da cidade medieval, São Paulo: Martins Fontes, 1992, p. 94 a 123. Disponível em: http://groups.google.com.br/group/digitalsource. Consulta em 17/05/2009.
} 
da amostra, indicando que essa realidade ainda estava se configurando. De acordo com aquele autor, a região em direção ao vale do Saracura, recebia:

"[...] o nome genérico de Saracuras. A Saracura Grande e a Saracura Pequena, onde somente havia casebres e não casarões com escadarias.

As casas, mesmo, começavam no lado esquerdo das ruas Rocha, Manoel Dutra, Almirante Marques Leão, Santo Antonio e São Vicente. Neste lado baixo do bairro é onde se encontrava o maior número de cortiços, com escadarias sempre afundando para baixo" ${ }^{238}$.

Quando levantamos os emplacamentos realizados pela Câmara Municipal nas ruas do bairro, verificamos as seguintes informações:

a) Rua Rocha, arrolada pelo serviço de Emplacamentos em 02 de junho de 1919, contando naquela ocasião com sete imóveis emplacados.

b) Rua da Saracura Pequena, arrolada pelo serviço de Emplacamentos em 04 de junho de 1919, com 17 imóveis emplacados.

c) Rua Almirante Marques Leão, arrolada pelo serviço de Emplacamentos em 12 de novembro de 1924, com 12 imóveis emplacados.

Constatamos assim que essas vias somente foram reconhecidas num período posterior ao analisado por nós ${ }^{239}$. Por outro lado, em relação às ruas da Saracura Grande e Saracura Pequena (atual Dr. Plínio Barreto), por estarem localizadas fora da área selecionada para a pesquisa, não foram alvo de levantamentos sistematizados. Verificamos que dos onze requerimentos encontrados referentes às duas ruas, sete se relacionavam a cocheiras ou cômodos para depósito e/ou abrigo de pessoas que cuidavam dos respectivos terrenos. Portanto, é notório que ainda se tratava de uma área de ocupação rarefeita. Resta saber se os casebres e cortiços indicados por Grunspun foram construídos nos anos subsequentes a 1914, ou sempre estiveram lá e simplesmente não foram alvo de fiscalização e controle por parte das autoridades.

\footnotetext{
${ }^{238}$ GRÜNSPUN, Haim - Op. Cit, p. 21. Grifos nossos.

${ }^{239}$ Em relação à rua Rocha, encontramos na Série Obras Particulares um processo em nome de Demangos \& Cia., datado de 1909, onde o requerente solicita licença para construção de um galpão. Conforme o parecer do engenheiro responsável, de 20/02/1909, "não existe rua com essa denominação oficialmente". Cx. R1.

Conforme as informações obtidas junto à Seção de Logradouros, do AHMWL, as ruas Rocha e Saracura Pequena tiveram seus nomes oficializados pelo Ato $n^{\circ}$ 972, de 24 de agosto de 1916, sendo que a última somente viria a se chamar Dr. Plínio Barreto em 04 de novembro de 1965, através do Decreto nº 6257. Já a rua Almirante Marques Leão, antiga Saracura Grande, foi oficializada pela Lei $n^{\circ} 2181$, de 08 de março de 1919. Assim, ficamos sabendo que a rua da Saracura Grande, que acreditávamos corresponder apenas ao curso da atual Avenida Nove de Julho, também envolvia o percurso da atual rua Almirante Marques Leão.
} 


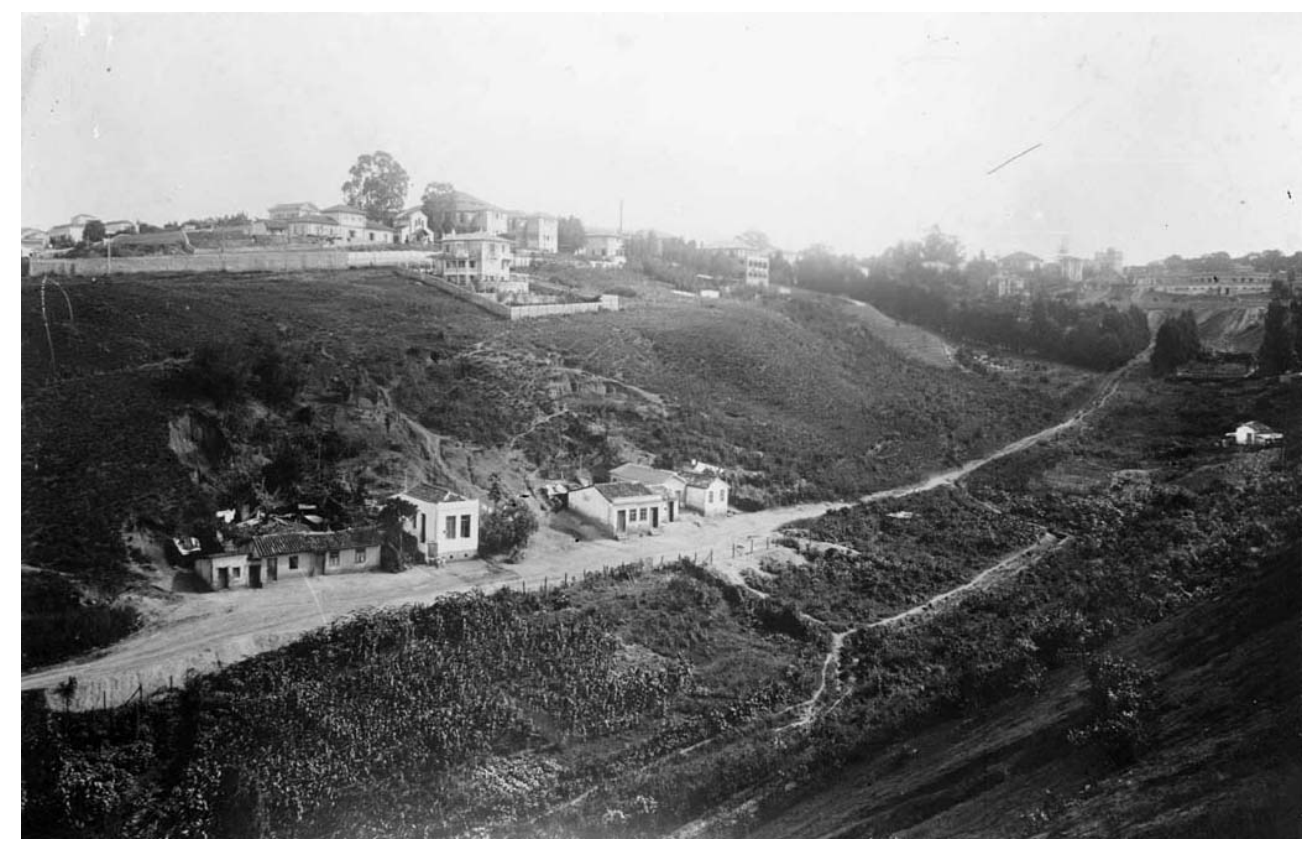

Figura 79 - Nesta imagem, vemos o córrego logo abaixo da rua da Saracura Grande, aparentemente em direção ao sul da cidade. A grande construção na parte de cima da foto, à esquerda, demonstra que a área já havia sido bastante desmatada. Porém, não é difícil imaginar como seria o lugar, anos antes. É visível que se tratava de perímetro suburbano, menos suscetível ao controle das autoridades municipais, facilitando a construção de moradias fora dos padrões construtivos. Foto: Autoria desconhecida, s/data. Fonte: Coleção SAN/DIM/DPH/SMC/PMSP.

Na análise sobre a tipologia dos cortiços do Bexiga, realizada no Capítulo 2, recorremos ao trabalho de Nicolau Sevcenko ${ }^{240}$ para termos uma idéia da disseminação desse tipo de habitação no bairro, para além dos anos estudados por nós. Os artigos de jornal analisados pelo autor (publicados entre 1919 e 1921) demonstraram que nossas expectativas estavam bem próximas da realidade. De outro lado, nossa hipótese sobre o aumento efetivo dos cortiços do Bexiga a partir dos anos 1920 e 1930 se confirma em certas áreas do bairro, com a presença de cortiços famosos. De acordo com Nabil Bonduki, por volta de 1920, “surgia a Vila Barros”, entre as ruas Japurá, Santo Amaro e Jacareí, “um labiríntico complexo de cortiços [...], onde se misturavam, em torno de um pátio irregular, diferentes tipos de cortiços e de espaços semipúblicos: "Navio Parado", "Pombal", "Vaticano" $e$ "Geladeira" ${ }^{241}$. Esses cortiços foram demolidos em 1948 e, em seu lugar, foi construído o edifício Japurá, com projeto de Kneese de Mello $^{242}$.

\footnotetext{
${ }^{240}$ SEVCENKO, Nicolau - Op. Cit.

${ }^{241}$ BONDUKI, Nabil - Origens da habitação social no Brasil, São Paulo: Estação Liberdade, 1998, p. 68-69.

${ }^{242}$ De acordo com GALESI e MALTA CAMPOS, o edifício Japurá, foi planejado pelo arquiteto Kneese de Mello, por iniciativa do IAPI-Instituto de Aposentadoria e Pensões dos Industriários. In: GALESI,
} 


\subsection{A Série Alvará e Licença}

A investigação dos processos contidos na Série Obras Particulares foi fundamental para sabermos como os diferentes estratos sociais se distribuíam no bairro do Bexiga. Todavia, em relação à identificação dos usuários, esses documentos foram de muito pouca utilidade. É claro que muitos dos proprietários viveram ou desenvolveram atividades produtivas nos imóveis edificados, mas como determinar isso com certeza? Fora isso, intuímos que grande parte dos imóveis destinava-se ao mercado locatício, o que nos leva a formular três perguntas:

a) quem de fato alugou essas casas?

b) quais os usos dados às construções?

c) como descobrir isso?

Através de Luciana Gennari tomamos conhecimento da Série Alvará e Licença ${ }^{243}$, no AHMWL. Fizemos os primeiros levantamentos para averiguação do material contido nesta Série e concluímos que realmente serviam aos nossos propósitos - a avaliação de pelo menos parte dos $\underline{\text { usuários }}$ - aqueles que exerceram atividades produtivas no bairro - e, em decorrência das atividades produtivas identificadas, os principais usos feitos dos espaços construídos.

Esta coleção contém, via de regra, os processos de solicitação de Alvará $e$ Licença para a abertura de negócios comerciais e/ou de serviços, entre 1906 e 1921. Antes de 1906, os livros trazem apenas os nomes dos requerentes, sem referência a endereços ou tipo de negócio para o exercício do qual se solicitava a licença. Pós 1906, os processos trazem além dos nomes dos requerentes, o endereço e tipo de negócio. Assim, decidimos trabalhar somente com o período de 1906 a 1914. Por outro lado, dado o grande número de informações existentes, optamos por um critério aleatório de seleção que de alguma forma abrangesse todo o período, a saber: 1906, 1907, 1910, 1911 e 1914.

René e CAMPOS, Candido Malta - "Edifício Japurá: pioneiro na aplicação do conceito de "unité d'habitation” de Le Corbusier no Brasil”, Portal Vitruvius, Arquitextos 031, dezembro/2002. Disponível em: http://www.vitruvius.com.br/arquitextos/arq031/arq031_03.asp.

${ }^{243}$ Esta Série está contida no Grupo Polícia Administrativa e Higiene (de 1906 a 1921), ainda em fase de identificação. In Guia Arquivo Histórico Municipal Washington Luís - 100 Anos (1907-2007), São Paulo: DPH, 2007, p. 33-34. 
De uma maneira geral, as solicitações contidas na Série Alvará e Licença se referem a:

- Abertura de novos negócios

- Renovação anual de licença

- Mudança de endereço do negócio

- Transferência para outro proprietário, no caso de venda do negócio

- Colocação de letreiro na fachada do estabelecimento

- Licença para funcionamento fora dos dias e horários previstos pela lei

- Licença para realização de festas religiosas nas ruas (aparentemente requisitadas por moradores do bairro)

À exemplo da Série Obras Particulares, elaboramos um banco de dados contendo os seguintes campos:

a) Data de entrada do requerimento

b) Endereço

c) Nome do requerente

d) Assunto (motivo da solicitação)

e) Histórico da solicitação

f) $\operatorname{Cota}\left(n^{\circ}\right.$ da caixa/Série/AHMWL)

\section{Usuários e principais usos}

Nos cinco anos selecionados, analisamos 221 processos. Este número, porém, não corresponde ao total de indivíduos ou pessoas jurídicas que realizaram alguma solicitação junto à municipalidade, já que a mesma pessoa podia fazer diferentes requerimentos, em diferentes momentos. Tendo em vista que nosso objetivo é a identificação dos usuários, independentemente do número de contatos realizados com o poder público, agrupamos todos os processos em que aparece o nome da mesma pessoa, no mesmo endereço ou em endereços diferentes. Dessa maneira chegamos a um total de 177 indivíduos e/ou pessoas jurídicas.

A primeira tentativa de identificação dos usuários/moradores foi apresentada na Tabela 41 - Moradores declarados, envolvendo os indivíduos que se declararam moradores nos endereços citados, chegando a $\mathbf{1 7}$ pessoas. 


\begin{tabular}{|c|c|c|c|c|c|}
\hline $\mathbf{N}^{\circ}$ & NOME & DATA & ENDEREÇO & ASSUNTO & HISTÓRICO \\
\hline 1 & ALFIO SCANDURRA & $12 / 04 / 1911$ & TREZE DE MAIO, 143 & $\begin{array}{l}\text { LICENÇA PARA } \\
\text { CAÇA }\end{array}$ & MORADOR NESTE ENDEREÇO, SOLICITA... \\
\hline 2 & ANTONIO ZICCARDI & $23 / 07 / 1907$ & SÃO DOMINGOS, 42 & $\begin{array}{l}\text { LICENÇA PARA } \\
\text { FOTÓGRAFO } \\
\text { AMBULANTE }\end{array}$ & $\begin{array}{l}\text { O SOLICITANTE, MORADOR DA RUA SÃO } \\
\text { DOMINGOS, } 42 \text {, DESEJANDO EXPLORAR O } \\
\text { RAMO DE FOTOGRAFIAS... }\end{array}$ \\
\hline 3 & CARMELA PETRONI & $15 / 01 / 1906$ & $\begin{array}{l}\text { CONSELHEIRO RAMALHO, } \\
194\end{array}$ & $\begin{array}{l}\text { SEM } \\
\text { IDENTIFICAÇÃO }\end{array}$ & $\begin{array}{l}\text { A REQUERENTE, ESTABELECIDA COM A } \\
\text { FAMÍLIA NESTE ENDERECCO E DESEJANDO } \\
\text { CONTINUAR COM O SEU RAMO DE } \\
\text { NEGÓCIOS, SOLICITA... }\end{array}$ \\
\hline 4 & $\begin{array}{l}\text { EUGENIO } \\
\text { GRADILONE }\end{array}$ & $05 / 02 / 1907$ & ABOLIÇÃO, 4 & $\begin{array}{l}\text { ABERTURA DE } \\
\text { JOGO DE BOLAS }\end{array}$ & $\begin{array}{l}\text { O REQUERENTE, DESEJANDO } \\
\text { ESTABELECER JOGO DE BOLAS, ANEXO À } \\
\text { SUA CASA DE RESIDÊNCIA, NESSE } \\
\text { ENDEREÇO, SOLICITA A LICENÇA... }\end{array}$ \\
\hline 5 & $\begin{array}{l}\text { FRANCISCO LUCITO E } \\
\text { NICOLA PICCA }\end{array}$ & $15 / 09 / 1911$ & $\begin{array}{l}\text { RUY BARBOSA, S/N } \mathrm{N}^{\circ} \mathrm{COM} \\
\text { CONS. RAMALHO }\end{array}$ & $\begin{array}{l}\text { LICENÇA PARA } \\
\text { REALIZAÇÃO DE } \\
\text { FESTA }\end{array}$ & $\begin{array}{l}\text { TENDO FEITO UM DEPÓSITO DE } 50 \$ 000, \\
\text { PARA REALIZAREM AS FESTAS E NSA. } \\
\text { SRA. DA PENHA, NOS DIAS } 7 \text { E } 8 \text { DO } \\
\text { CORRENTE, SOLICITAM A RESTITUIÇÃO... }\end{array}$ \\
\hline 6 & FRATELLI ZICCARDI & $06 / 02 / 1910$ & $\begin{array}{l}\text { CONSELHEIRO RAMALHO, } \\
202\end{array}$ & $\begin{array}{l}\text { ABERTURA DE } \\
\text { ATELIER } \\
\text { FOTOGRÁFICO }\end{array}$ & $\begin{array}{l}\text { OS IRMÃOS, MORADORES NESTE } \\
\text { ENDEREÇO, SOLICITAM LICENÇA P/ABRIR } \\
\text { O NEGÓCIO... }\end{array}$ \\
\hline 7 & $\begin{array}{l}\text { GIACOMO } \\
\text { COLAMASSARO }\end{array}$ & $01 / 04 / 1910$ & $\begin{array}{l}\text { CONSELHEIRO RAMALHO, } \\
219\end{array}$ & $\begin{array}{l}\text { ABERTURA DE } \\
\text { BOTEQUIM }\end{array}$ & $\begin{array}{l}\text { MORADOR NESTE ENDEREÇO E } \\
\text { DESEJANDO ABRIR UM BOTEQUIM PARA } \\
\text { VENDA DE VINHOS E BEBIDAS NA MESMA } \\
\text { RUA, SOLICITA... }\end{array}$ \\
\hline 8 & GIUSEPE FALCONE & $01 / 08 / 1907$ & TREZE DE MAIO, S/N ${ }^{\circ}$ & $\begin{array}{l}\text { LICENÇA PARA } \\
\text { REALIZAÇÃO DE } \\
\text { FESTA }\end{array}$ & $\begin{array}{l}\text { QUERENDO REALIZAR UMA FESTA NA R. } \\
13 \text { DE MAIO, BEXIGA, SOLICITA } \\
\text { AUTORIZAÇÃO PARA LEVANTAR UM } \\
\text { CORETO... }\end{array}$ \\
\hline 9 & JOSÉ CURIA & $12 / 01 / 1911$ & $\begin{array}{l}\text { SANTO AMARO, } 29 \\
\text { (ANTIGO 21) }\end{array}$ & $\begin{array}{l}\text { LICENÇA PARA } \\
\text { VENDA DE } \\
\text { FRUTAS, CARVÃO } \\
\text { E LENHA }\end{array}$ & $\begin{array}{l}\text { ESTABELECIDO NESTE ENDERECCO, E } \\
\text { DESEJANDO ABRIR O NEGÓCIO, SOLICITA } \\
\text { LICENÇA PARA ESTE FIM. }\end{array}$ \\
\hline 10 & JOSÉ R (?) DE MARIA & $15 / 07 / 1911$ & MAJOR DIOGO, 93 & $\begin{array}{l}\text { LICENÇA PARA } \\
\text { FUNCIONAMENTO } \\
\text { DE TIPOGRAFIA }\end{array}$ & $\begin{array}{l}\text { ESTABELECIDO COM "PEQUENÍSSIMA" } \\
\text { TIPOGRAFIA, NESTE ENDEREÇO, SOLICITA } \\
\text { ALVARÁ DE LICENÇA... } \\
\text { PEDIDO FOI DEFERIDO EM 21/JULHO, SOB } \\
\text { A ALEGAÇÃO DE QUE "PARECE NÃO } \\
\text { HAVER PERIGO, TANTO QUE } \underline{\text { O }} \\
\text { PROPRIETÁRIO MESMO É QUE RESIDE NOS } \\
\text { ALTOS". }\end{array}$ \\
\hline 11 & LUIZ DE DEDIO & $16 / 07 / 1910$ & $\begin{array}{l}\text { CONSELHEIRO RAMALHO, } \\
71\end{array}$ & $\begin{array}{l}\text { ABERTURA DE } \\
\text { QUITANDA }\end{array}$ & $\begin{array}{l}\text { MORADOR NESTE ENDEREÇO E } \\
\text { DESEJANDO ABRIR UMA QUITANDA DE } \\
\text { FRUTAS, SOLICITA... }\end{array}$ \\
\hline 12 & $\begin{array}{l}\text { MANOEL FERREIRA } \\
\text { SILVA }\end{array}$ & $06 / 09 / 1911$ & SARACURA PEQUENA,/No & $\begin{array}{l}\text { LICENÇA PARA } \\
\text { REALIZAÇÃO DE } \\
\text { FESTA }\end{array}$ & $\begin{array}{l}\text { DESEJANDO CONSTRUIR UM CORETO } \\
\text { PARA AS FESTAS QUE SE REALIZARÃO NO } \\
\text { DOMINGO, } 10 \text { DO CORRENTE, SOLICITA... }\end{array}$ \\
\hline 13 & NiCOLA CASTIGLi (?) & $31 / 12 / 1910$ & SÃO DOMINGOS, 64 & $\begin{array}{l}\text { RENOVAÇÃO DE } \\
\text { LICENÇA PARA } \\
\text { QUITANDA } \\
\end{array}$ & $\begin{array}{l}\text { MORADOR E ESTABELECIDO COM } \\
\text { QUITANDA DE FRUTAS NESTE } \\
\text { ENDEREÇO... }\end{array}$ \\
\hline 14 & PEDRO MAZZUCATO & $03 / 03 / 1911$ & LGO. DO RIACHUELO & $\begin{array}{l}\text { ABERTURA DE } \\
\text { BOTEQUIM }\end{array}$ & $\begin{array}{l}\text { MORADOR NESTE ENDEREÇO E } \\
\text { DESEJANDO ABRIR UM BOTEQUIM, } \\
\text { SOLICITA... }\end{array}$ \\
\hline 15 & RAPHAEL BASILE & $07 / 08 / 1907$ & SÃO DOMINGOS, 42 & $\begin{array}{l}\text { LICENÇA PARA } \\
\text { FOTÓGRAFO } \\
\text { AMBULANTE } \\
\end{array}$ & $\begin{array}{l}\text { O SOLICITANTE, MORADOR DA RUA SÃO } \\
\text { DOMINGOS, } 42 \text {, DESEJANDO EXPLORAR O } \\
\text { RAMO DE FOTOGRAFIAS... }\end{array}$ \\
\hline 16 & SALVADOR CHIRÉ & $19 / 01 / 1914$ & RUY BARBOSA, 90 & $\begin{array}{l}\text { LICENÇA PARA } \\
\text { QUITANDA }\end{array}$ & $\begin{array}{l}\text { MORADOR NESTE ENDEREÇO, QUERENDO } \\
\text { CONTINUAR COM O NEGÓCIO NESSE } \\
\text { LOCAL... }\end{array}$ \\
\hline 17 & SEBASTIÃO STANISCE & $29 / 04 / 1911$ & PIQUES, 55 & $\begin{array}{l}\text { LICENÇA PARA } \\
\text { CAÇA }\end{array}$ & $\begin{array}{l}\text { MORADOR NESTE ENDERECCO, SOLICITA } \\
\text { ALVARÁ DE LICENÇA E GUIA PARA CAÇA } \\
\text { NOS SUBÚRBIOS. }\end{array}$ \\
\hline
\end{tabular}

Tabela 41 - Moradores declarados

Nos três casos destacados em cinza, os requerimentos se referem a festas de rua, cuja organização provavelmente ficava a cargo de um morador mais rico que tivesse 
condições de fazer o depósito de 50\$000 réis necessários para cobrir eventuais danos que ocorressem. Por isso, num primeiro momento, consideramos os três requerentes como moradores.

Infelizmente, os $\mathbf{1 7}$ nomes passíveis de serem identificados como moradores significam apenas aproximados 9,60\% dos 177 requerentes, número insuficiente para ser generalizado para todo o universo. Ainda que acreditemos que boa parte dessas pessoas realmente residisse no bairro, qualquer afirmação neste sentido seria desprovida de fundamentos. Todavia, foram usuários, no sentido de que ali exerceram atividades produtivas. Nesse sentido, nossa análise daqui por diante será feita, basicamente, do ponto de vista do usuário/trabalhador.

Confrontamos os nomes obtidos nos pedidos de Alvará e Licença para abertura de negócios com os nomes fornecidos pelos requerimentos das Obras Particulares, fossem eles proprietários ou apenas requerentes ${ }^{244}$. Os nomes oriundos de ambas as fontes foram organizados num banco de nomes, tendo a preocupação de destacar as principais categorias originais - proprietários/requerentes e negociantes. Chegamos assim, a 20 nomes $^{245}$ comuns às duas categorias, relacionados na Tabela 42.

\begin{tabular}{|c|c|c|c|c|c|c|}
\hline $\begin{array}{l}\mathbf{N}^{\circ} \\
\text { REF. }\end{array}$ & AGENTE & ENDEREÇO & HISTÓRICO & CATEGORIA & FONTE & DATA \\
\hline \multirow[t]{2}{*}{$\mathbf{1}$} & AMILCARE CORRACIO & SANTO ANTONIO, 147 & $\begin{array}{l}\text { CONSTRUÇÃO DE CASA } \\
\text { C/ARMAZÉM }\end{array}$ & REQUERENTE & O.P. & $07 / 03 / 1900$ \\
\hline & AMILCARE CORASIO & SANTO ANTONIO, 141 & NEGÓCIO NÃO IDENTIFICADO & NEGOCIANTE & A. L. & $27 / 04 / 1906$ \\
\hline \multirow{2}{*}{2} & ANTONIO MUSTO & SANTO ANTONIO, 171 & QUITANDA & NEGOCIANTE & A. L. & $07 / 12 / 1911$ \\
\hline & ANTONIO MUSTO & SANTO ANTONIO, 209 & AUMENTO DE CÔMODOS & PROPRIETÁRIO & O.P. & $02 / 01 / 1914$ \\
\hline \multirow{3}{*}{3} & CAMILLO AMADIO & $\begin{array}{l}\text { SOL, } 4 \text { ESQUINA SANTO } \\
\text { ANTONIO }\end{array}$ & ACRÉSCIMO DE CÔMODOS & PROPRIETÁRIO & O.P. & $21 / 10 / 1913$ \\
\hline & CAMILLO AMADIO & $\begin{array}{l}\text { SOL, S/N } \\
\text { (ESQUINA SANTO } \\
\text { ANTONIO) }\end{array}$ & CONSTRUÇÃO DE 1 SOBRADO & $\begin{array}{l}\text { REQUERENTE E } \\
\text { PROPRIETÁRIO }\end{array}$ & O.P. & $18 / 03 / 1914$ \\
\hline & CAMILLO AMADIO & SOL, S/N & $\begin{array}{l}\text { LICENÇA P/DEIXAR MATERIAL } \\
\text { DE CONSTRUÇÃO NA CALÇADA }\end{array}$ & PROPRIETÁRIO & A. $\mathbf{L}$. & $05 / 05 / 1914$ \\
\hline \multirow{2}{*}{4} & $\begin{array}{l}\text { CATHARINA } \\
\text { ROMANIELLO } \\
\end{array}$ & $\begin{array}{l}\text { CONSELHEIRO RAMALHO, } \\
43\end{array}$ & JOGO DE BOLAS & NEGOCIANTE & A. L. & $27 / 03 / 1911$ \\
\hline & $\begin{array}{l}\text { CATARINA BONAMIELO } \\
\text { (?) }\end{array}$ & $\begin{array}{l}\text { CONSELHEIRO RAMALHO, } \\
60\end{array}$ & CONSTRUÇÃO DE 1 CASA & $\begin{array}{l}\text { REQUERENTE E } \\
\text { PROPRIETÁRIO }\end{array}$ & O.P. & $24 / 10 / 1912$ \\
\hline 5 & FRANCISCO LICITO & CONSELHEIRO CARRÃO, 51 & ABERTURA DE PORTÃO & PROPRIETÁRIO & O.P. & $11 / 05 / 1907$ \\
\hline
\end{tabular}

\footnotetext{
${ }^{244}$ Há casos em que o construtor é o requerente, sem que isso signifique que seja proprietário. Por outro lado, frequentemente, num mesmo processo, a mesma pessoa pode se enquadrar nas categorias proprietário e requerente. Como também há ocasiões em que indivíduos que aparecem desta maneira, podem aparecer também apenas como requerentes, ou apenas como proprietários. Levando em consideração a grande ocorrência de pessoas nessas condições é que incorporamos ao novo banco de dados, no Anexo 5, todos os requerentes e todos os proprietários.

${ }^{245}$ Se comparados ao total de $\mathbf{6 2 3}$ indivíduos (entre proprietários e requerentes) identificados nas Obras Particulares, 20 indivíduos são um número muito baixo, também não permitindo tirar maiores conclusões. Lá, o prazo de tempo investigado foi de trinta e um anos, enquanto que aqui foram apenas oito anos, contemplando um quarto do período proposto e perfazendo aproximadamente $3,21 \%$ daquele total. Se restringirmos os dados da Série Obras Particulares ao período investigado na Série Alvará e Licença, entre 1906 e 1914, teremos seis anos, com 258 indivíduos. A relação será de 20 moradores para 258 proprietários/requerentes, com um percentual de aproximadamente 7,75\%, ainda bastante baixo.
} 


\begin{tabular}{|c|c|c|c|c|c|c|}
\hline & FRANCISCO LICITO & CONSELHEIRO CARRÃO, 30 & $\begin{array}{l}\text { CONSTRUÇÃO DE CASA C/SALÃO } \\
\text { DE NEGÓCIO }\end{array}$ & $\begin{array}{l}\text { REQUERENTE E } \\
\text { PROPRIETÁRIO }\end{array}$ & O.P. & $23 / 08 / 1907$ \\
\hline & $\begin{array}{l}\text { FRANCISCO LOCITO E } \\
\text { NICOLA FICCO }\end{array}$ & $\begin{array}{l}\text { RUY } \\
\text { BARBOSA,C/C.RAMALHO }\end{array}$ & FESTA RELIGIOSA & NEGOCIANTE & A. L. & $30 / 07 / 1911$ \\
\hline & FRANCISCO LOSITO & CONSELHEIRO CARRÃO, 67 & REFORMA DE COCHEIRA & PROPRIETÁRIO & O.P. & 24/12/1914 \\
\hline \multirow{3}{*}{6} & JOÃO TERRACCIANO & Do SOL, 22 & SEM IDENTIFICAÇÃO & NEGOCIANTE & A. L. & $27 / 04 / 1906$ \\
\hline & JOÃO FERRACIANO & $\begin{array}{l}\text { SANTO ANTONIO, 242a } \\
\text { TINTA }\end{array}$ & $\begin{array}{l}\text { CONSTRUÇÃO DE } 1 \text { CASA } \\
\text { C/ARMAZÉM }\end{array}$ & PROPRIETÁRIO & O.P. & $10 / 01 / 1907$ \\
\hline & $\begin{array}{l}\text { JOÃO FERRACIANO (OU } \\
\text { TERRACIANO) }\end{array}$ & MANOEL DUTRA, 65 TINTA & $\begin{array}{l}\text { CONSTRUÇÃO DE } 2 \text { CASAS, UMA } \\
\text { C/COMÉRCIO }\end{array}$ & PROPRIETÁRIO & O.P. & $29 / 08 / 1913$ \\
\hline \multirow{15}{*}{7} & $\begin{array}{l}\text { JOAQUIM ANTUNES } \\
\text { DOS SANTOS } \\
\end{array}$ & $\begin{array}{l}\text { RUY BARBOSA, S/N } \\
\text { PEGADO AO } 27 \\
\end{array}$ & CONSTRUÇÃO DE 2 CASAS & REQUERENTE & O.P. & $10 / 04 / 1899$ \\
\hline & $\begin{array}{l}\text { JOAQUIM ANTUNES } \\
\text { DOS SANTOS } \\
\end{array}$ & $\begin{array}{l}\text { FORTALEZA, ESQUINA COM } \\
\text { RUY BARBOSA }\end{array}$ & ACRÉSCIMO DE COZINHA & REQUERENTE & O.P. & $15 / 06 / 1900$ \\
\hline & $\begin{array}{l}\text { JOAQUIM ANTUNES } \\
\text { (DOS SANTOS?) }\end{array}$ & $\begin{array}{l}\text { CONSELHEIRO RAMALHO, } \\
174\end{array}$ & CONSTRUÇÃO DE 1 CASA & REQUERENTE & O.P. & $14 / 03 / 1905$ \\
\hline & $\begin{array}{l}\text { JOAQUIM ANTUNES } \\
\text { DOS SANTOS }\end{array}$ & $\begin{array}{l}\text { FORTALEZA, S/No (JUNTO } \\
\text { AO 12) }\end{array}$ & CONSTRUÇÃO DE MURO & PROPRIETÁRIO & O.P. & $11 / 06 / 1906$ \\
\hline & $\begin{array}{l}\text { JOAQUIM ANTUNES } \\
\text { DOS SANTOS }\end{array}$ & FORTALEZA, JUNTO DO 12 & $\begin{array}{l}\text { CONSTRUÇÃO DE } 6 \text { CASAS, UMA } \\
\text { C/ARMAZÉM }\end{array}$ & $\begin{array}{l}\text { REQUERENTE E } \\
\text { PROPRIETÁRIO }\end{array}$ & O.P. & $18 / 07 / 1906$ \\
\hline & $\begin{array}{l}\text { JOAQUIM ANTUNES } \\
\text { DOS SANTOS }\end{array}$ & FORTALEZA, S/N ${ }^{\circ}$ & CONSTRUÇÃO DE 4 CASAS & $\begin{array}{l}\text { REQUERENTE E } \\
\text { PROPRIETÁRIO }\end{array}$ & O.P. & $28 / 08 / 1906$ \\
\hline & $\begin{array}{l}\text { JOAQUIM ANTUNES } \\
\text { DOS SANTOS }\end{array}$ & RUY BARBOSA, S/N & CONSTRUÇÃO DE 1 CASA & REQUERENTE & O.P. & $24 / 10 / 1906$ \\
\hline & $\begin{array}{l}\text { JOAQUIM ANTUNES } \\
\text { DOS SANTOS } \\
\end{array}$ & $\begin{array}{l}\text { RUY BARBOSA, } 83 \text { (TINTA) } \\
\text { PRÓXIMO RUA FORTALEZA }\end{array}$ & $\begin{array}{l}\text { ACRÉSCIMO DE COZINHA, } \\
\text { VARANDA E LATRINA } \\
\end{array}$ & PROPRIETÁRIO & O.P. & $22 / 01 / 1907$ \\
\hline & $\begin{array}{l}\text { JOAQUIM ANTUNES } \\
\text { DOS SANTOS }\end{array}$ & $\begin{array}{l}\text { CONSELHEIRO RAMALHO, } \\
\text { JUNTO AO } 204\end{array}$ & CONSTRUÇÃO DE 1 CASA & REQUERENTE & O.P. & $19 / 11 / 1907$ \\
\hline & $\begin{array}{l}\text { JOAQUIM ANTUNES } \\
\text { DOS SANTOS }\end{array}$ & $\begin{array}{l}\text { CONSELHEIRO RAMALHO, } \\
222\end{array}$ & $\begin{array}{l}\text { CONSTRUÇÃO DE } 2 \text { CASAS } \\
\text { CONSTRUÇÃO DE }\end{array}$ & $\begin{array}{l}\text { REQUERENTE E } \\
\text { PROPRIETÁRIO }\end{array}$ & O.P. & $17 / 12 / 1907$ \\
\hline & $\begin{array}{l}\text { JOAQUIM ANTUNES } \\
\text { DOS SANTOS }\end{array}$ & FORTALEZA, 7 E 10 & ALUGUEL DE COCHEIRA & PROPRIETÁRIO & A. $\mathbf{L}$. & $24 / 10 / 1911$ \\
\hline & $\begin{array}{l}\text { JOAQUIM ANTUNES } \\
\text { DOS SANTOS }\end{array}$ & $\begin{array}{l}\text { RUY BARBOSA, JUNTO AO } \\
143\end{array}$ & CONSTRUÇÃO DE 2 CASAS & PROPRIETÁRIO & O.P. & $20 / 01 / 1912$ \\
\hline & $\begin{array}{l}\text { JOAQUIM ANTUNES } \\
\text { DOS SANTOS }\end{array}$ & FORTALEZA, 13 & CONSTRUÇÃO DE 2 CASAS & $\begin{array}{l}\text { REQUERENTE E } \\
\text { PROPRIETÁRIO }\end{array}$ & O.P. & $26 / 01 / 1912$ \\
\hline & $\begin{array}{l}\text { JOAQUIM ANTUNES } \\
\text { DOS SANTOS }\end{array}$ & FORTALEZA, 11 & $\begin{array}{l}\text { CONSTRUÇÃO DE OFICINA } \\
\text { MARCENARIA }\end{array}$ & $\begin{array}{l}\text { REQUERENTE E } \\
\text { PROPRIETÁRIO }\end{array}$ & O.P. & $21 / 02 / 1912$ \\
\hline & $\begin{array}{l}\text { JOAQUIM ANTUNES } \\
\text { DOS SANTOS }\end{array}$ & $\begin{array}{l}\text { RUY BARBOSA, JUNTO AO } \\
143\end{array}$ & CONSTRUÇÃO DE MURO & $\begin{array}{l}\text { REQUERENTE E } \\
\text { PROPRIETÁRIO } \\
\end{array}$ & O.P. & $03 / 10 / 1912$ \\
\hline \multirow{3}{*}{8} & GIUSEPPE COFONE & RUY BARBOSA, 102 & CONSTRUÇÃO DE 1 CASA & PROPRIETÁRIO & O.P. & $31 / 05 / 1906$ \\
\hline & JosÉ COFFONE & $\begin{array}{l}\text { CONSELHEIRO RAMALHO, } \\
152 \mathrm{~A}\end{array}$ & JOGO DE BOLAS & NEGOCIANTE & A. L. & $19 / 01 / 1907$ \\
\hline & JOSÉ COFFONI & RUY BARBOSA, 124 & CONSTRUÇÃO DE 1 CASA & $\begin{array}{l}\text { REQUERENTE E } \\
\text { PROPRIETÁRIO }\end{array}$ & O.P. & $30 / 12 / 1913$ \\
\hline \multirow{2}{*}{9} & JOSÉ FALCONE & TREZE DE MAIO, 20 & ACRÉSCIMO /AÇOUGUE & PROPRIETÁRIO & O.P. & $11 / 08 / 1905$ \\
\hline & GIUSEPE FALCONE & $13 \mathrm{MAIO}, \mathrm{S} / \mathrm{N}^{\circ}$ & FESTA DE RUA & PROPRIETÁRIO & A. L. & $01 / 08 / 1907$ \\
\hline \multirow{3}{*}{10} & JosÉ TOSTO & M.DIOGO,43 & JOGO DE BOLAS & NEGOCIANTE & A. L. & $05 / 02 / 1910$ \\
\hline & JOSÉ TOSTA & MAJOR DIOGO, 49 & ACRÉSCIMO/ARMAZÉM & PROPRIETÁRIO & O.P. & $27 / 02 / 1913$ \\
\hline & JosÉ TOSTA & MAJOR DIOGO, 49 & REFORMA PARA COMÉRCIO & PROPRIETÁRIO & O.P. & $24 / 11 / 1913$ \\
\hline \multirow{4}{*}{11} & LEONARDO JACOBI & S.ANTONIO, 138 & AÇOUGUE & NEGOCIANTE & A. L. & $29 / 03 / 1911$ \\
\hline & LEONARDO JACOBI & SANTO ANTONIO, 148 & AUMENTO DE 3 CÔMODOS. & PROPRIETÁRIO & O.P. & $03 / 03 / 1914$ \\
\hline & LEONARDO JACOBI & SANTO ANTONIO, 148 & ACRÉSCIMO DE COZINHA. & PROPRIETÁRIO & O.P. & $05 / 05 / 1914$ \\
\hline & LEONARDO JACOB & SANTO ANTONIO, 148 & ACRÉSCIMO DE 1 QUARTO & PROPRIETÁRIO & O.P. & $06 / 07 / 1914$ \\
\hline \multirow[t]{2}{*}{12} & LUIZ DE ANGELIS & MAJOR DIOGO, 150 & $\begin{array}{l}\text { CONSTRUÇÃO DE CASA } \\
\text { C/ARMAZÉM }\end{array}$ & PROPRIETÁRIO & O.P. & $12 / 06 / 1901$ \\
\hline & LUIZ DE ANGELLO & MARIA JoSÉ,55 & JOGO DE BOLAS & NEGOCIANTE & A. L. & $17 / 01 / 1907$ \\
\hline \multirow{4}{*}{13} & $\begin{array}{l}\text { MANOELE PALADINE } \\
\text { (OU MANUEL) }\end{array}$ & $\begin{array}{l}\text { MANOEL DUTRA, } 15 \\
\text { (TINTA) }\end{array}$ & CONSTRUÇÃO DE 1 CASA & $\begin{array}{l}\text { REQUERENTE E } \\
\text { PROPRIETÁRIO }\end{array}$ & O.P. & $19 / 08 / 1899$ \\
\hline & MANOEL PALADINO & MANOEL DUTRA, 15 & QUITANDA & NEGOCIANTE & A. L. & $20 / 01 / 1911$ \\
\hline & PALADINE MANUELE & MANOEL DUTRA, 15 & QUITANDA & NEGOCIANTE & A. L. & $27 / 12 / 1911$ \\
\hline & MANOELE PALADINE & MANOEL DUTRA, 15 & $\begin{array}{l}\text { TRANSFORMAÇÃO DE JANELA } \\
\text { EM PORTA }\end{array}$ & PROPRIETÁRIO & O.P. & $08 / 02 / 1912$ \\
\hline \multirow{3}{*}{14} & NICOLA GIULIANO & $\begin{array}{l}14 \text { DE JULHO, } 36 \text { (ESQUINA } \\
\text { COM CONS. RAMALHO) }\end{array}$ & $\begin{array}{l}\text { CONSTRUÇÃO DE CASA } \\
\text { C/ARMAZÉM }\end{array}$ & PROPRIETÁRIO & O.P. & 18/04/1901 \\
\hline & NICOLAU JULIANO & $\begin{array}{l}\text { CONSELHEIRO RAMALHO, } \\
55\end{array}$ & $\begin{array}{l}\text { GÊNEROS ALIMENTÍCIOS E } \\
\text { BOTEQUIM }\end{array}$ & NEGOCIANTE & A. $\mathbf{L}$. & $18 / 05 / 1906$ \\
\hline & NICOLAU JULIANO & $\begin{array}{l}\text { CONSELHEIRO RAMALHO, } \\
71 \text { (COM } 14 \text { DE JULHO) }\end{array}$ & $\begin{array}{l}\text { TRANSFORMAÇÃO DE PORTAS } \\
\text { EM JANELAS }\end{array}$ & PROPRIETÁRIO & O.P. & $19 / 04 / 1912$ \\
\hline 15 & PAULO FRANCIULLA & CONSELHEIRO CARRÃO, 30 & INSTALAÇÃO DE ÁGUA E ESGOTO & PROPRIETÁRIO & O.P. & $11 / 09 / 1907$ \\
\hline
\end{tabular}




\begin{tabular}{|c|c|c|c|c|c|c|}
\hline & PAULO FRANCIULLO & $\begin{array}{l}\text { CONSELHEIRO RAMALHO, } \\
30\end{array}$ & QUITANDA & NEGOCIANTE & A. L. & $26 / 01 / 1911$ \\
\hline & PAULO FRANCIULLA & SOL, 64 & OFICINA DE MARCENARIA & $\begin{array}{l}\text { REQUERENTE E } \\
\text { PROPRIETÁRIO }\end{array}$ & O.P. & $08 / 11 / 1913$ \\
\hline \multirow{4}{*}{16} & ROCCO DE FRANCO & MONTE DE OURO, S/No & $\begin{array}{l}\text { CONSTRUÇÃO DE CASA } \\
\text { C/ARMAZÉM }\end{array}$ & $\begin{array}{l}\text { REQUERENTE E } \\
\text { PROPRIETÁRIO }\end{array}$ & O.P. & $28 / 03 / 1893$ \\
\hline & $\begin{array}{l}\text { ROCCO DE FRANCO (OU } \\
\text { ROQUE) }\end{array}$ & $\begin{array}{l}\text { CONSELHEIRO RAMALHO, } \\
35\end{array}$ & $\begin{array}{l}\text { ACRÉSCIMO DE QUARTO E } \\
\text { COZINHA }\end{array}$ & PROPRIETÁRIO & O.P. & $08 / 05 / 1900$ \\
\hline & ROCCO DE FRANCO & $\begin{array}{l}\text { CONSELHEIRO RAMALHO, } \\
\text { 37E }\end{array}$ & CONSTRUÇÃO DE 1 CASA & $\begin{array}{l}\text { REQUERENTE E } \\
\text { PROPRIETÁRIO }\end{array}$ & O.P. & $16 / 01 / 1905$ \\
\hline & ROCCO DE FRANCO & $\begin{array}{l}\text { CONSELHEIRO RAMALHO, } \\
35\end{array}$ & SECOS E MOLHADOS & NEGOCIANTE & A. L. & $12 / 04 / 1907$ \\
\hline \multirow{3}{*}{17} & TORBILLO ROSÁRIO & RUY BARBOSA,49 & SECOS E MOLHADOS & NEGOCIANTE & A. L. & $05 / 09 / 1906$ \\
\hline & ROSÁRIO TORBILLI & $13 \mathrm{DE}$ MAIO, $\left.\mathrm{S} / \mathrm{N}^{\circ}\right)$ & CONSTRUÇÃO DE MURO & PROPRIETÁRIO & O.P. & $26 / 02 / 1907$ \\
\hline & ROZÁRIO TORBILI & 13 DE MAIO, 101 & CONSTRUÇÃO DE 1 CASA & PROPRIETÁRIO & O.P. & $17 / 02 / 1914$ \\
\hline \multirow[b]{2}{*}{18} & SALVADOR CARUSO & MAJOR DIOGO,S/No & ABERTURA DE CINEMA & NEGOCIANTE & A. L. & $23 / 11 / 1911$ \\
\hline & SALVADOR CARUSO & $\begin{array}{l}\text { MAJOR DIOGO, } 41 \\
\text { (ESQUINA JACEGUAY) }\end{array}$ & $\begin{array}{l}\text { CONSTRUÇÃO DE } 1 \text { CINEMA } \\
\text { (CINEMA RECREIO) }\end{array}$ & $\begin{array}{l}\text { REQUERENTE E } \\
\text { PROPRIETÁRIO }\end{array}$ & O.P. & $10 / 12 / 1914$ \\
\hline \multirow{3}{*}{19} & $\begin{array}{l}\text { THOMAZO LUPPO (OU } \\
\text { THOMAZ) }\end{array}$ & RUY BARBOSA, 24 & CONSTRUÇÃO DE 1 CASA & $\begin{array}{l}\text { REQUERENTE E } \\
\text { PROPRIETÁRIO }\end{array}$ & O.P. & $25 / 02 / 1905$ \\
\hline & THOMAZO LUPPO & RUY BARBOSA, 24 & ACRÉSCIMO DE QUARTO & PROPRIETÁRIO & O.P. & $27 / 04 / 1907$ \\
\hline & THOMAZO LUPO & RUY BARBOSA, 38 & $\begin{array}{l}\text { MUDANÇA P/ O No } 37 \text { NA MESMA } \\
\text { RUA }\end{array}$ & NEGOCIANTE & A. $\mathbf{L}$. & $22 / 05 / 1911$ \\
\hline \multirow{4}{*}{20} & VICENTE DE FRANCO & $\begin{array}{l}\text { CONSELHEIRO RAMALHO, } \\
\mathrm{S} / \mathrm{N}^{\circ}\end{array}$ & ALINHAMENTO EDIFICAÇÃO & PROPRIETÁRIO & O.P. & 1890 \\
\hline & VICENTE FRANCO & $\begin{array}{l}\text { CONSELHEIRO RAMALHO, } \\
\mathrm{S} / \mathrm{N}^{\circ}\end{array}$ & CONSTRUÇÃO DE CASA C/VENDA & REQUERENTE & O.P. & $11 / 11 / 1895$ \\
\hline & VICENTE DE FRANCO & $\begin{array}{l}\text { CONSELHEIRO RAMALHO, } \\
39\end{array}$ & RECONSTRUÇÃO DE FACHADA & PROPRIETÁRIO & O.P. & $10 / 12 / 1900$ \\
\hline & VICENTE FRANCO & $\begin{array}{l}\text { CONSELHEIRO RAMALHO, } \\
62\end{array}$ & JOGO DE BOLAS & NEGOCIANTE & A. $\mathbf{L}$. & 20/01/1906 \\
\hline
\end{tabular}

Tabela 42 - Identificação dos nomes comuns às Séries "Obras Particulares" e "Alvará e Licença"

O esforço de organização dessas informações não foi inútil. Através do cruzamento destes dados com aqueles obtidos na Série Obras Particulares ampliamos nosso campo de visão acerca de alguns dos atores sociais que atuaram no bairro do Bexiga: usuários e proprietários.

\section{Atividades Produtivas}

A possibilidade de conhecimento e análise das atividades produtivas desenvolvidas no Bexiga foi a principal contribuição da Série Alvará e Licença para o nosso trabalho. Mesmo que a amostra investigada se restrinja à somente cinco anos, ela fornece um panorama amplo do que se fez para viver nesta parte da cidade. Através das solicitações de licença para qualquer tipo de atividade, percebemos os esforços empreendidos pelos atores sociais que ali viveram para ganhar o "pão de cada dia" e garantir, senão um futuro melhor, ao menos a sua sobrevivência diária. Por outro lado, a leitura dos textos - onde os solicitantes por vezes expunham seus pequenos dramas, seguida da leitura dos pareceres técnicos por vezes excessivamente frios e distantes, expõe frequentemente os embates entre as ações privadas e as ações do poder público, 
característicos desse momento de transição. De um lado, o poder público, cada vez mais empenhado em adaptar a vivência urbana aos princípios modernos da higiene e do controle social; de outro, os próprios requerentes, visando ampliar suas fontes de renda, ou simplesmente dar conta da sobrevivência.

Elaboramos a Tabela 43, contendo os tipos de negócios identificados e a quantificação dos mesmos, totalizando $\mathbf{1 7 6}$ atividades ${ }^{246}$. Essas atividades por sua vez, foram divididas em categorias diferenciadas, de forma a abarcarmos todas aquelas que envolvessem algum tipo de remuneração, a saber:

- Comércio alimentos

- Comércio/diversos

- Indústria

- Serviços manufatureiros

- Serviços/diversos

- Serviços de lazer

Procuramos agrupar os tipos de negócios que se realizaram nessas ruas por data de entrada da solicitação e pelo nome do requerente, independentemente do motivo do requerimento (para abertura da firma, renovação de licença, fechamento, etc.). Dessa maneira, conseguimos identificar quando se tratava do mesmo negócio, sob as mãos do mesmo proprietário, em diferentes momentos. Como o período abrangido por esta investigação envolveu a realização de duas mudanças na numeração das $\operatorname{casas}^{247}$, sempre que havia mais de um negócio em nome da mesma pessoa (porém com numeração diferente), esses números foram confrontados com o Índice de Emplacamentos, de forma a indicar se era o mesmo endereço/estabelecimento. Encontramos alguns casos que parecem significar a mudança para outro endereço, na mesma rua. Não é possível saber se realmente houve essa mudança ou se as numerações eram mesmo caóticas, renovando-se ao sabor da vontade dos proprietários e/ou usuários.

\footnotetext{
${ }^{246}$ Para efeitos do arrolamento e análise das atividades produtivas, excluímos o caso das duas instituições alemãs. Localizadas em outros bairros, tudo indica que a única relação dessas instituições com o bairro se dava através de sua provável sede social, à rua Treze de Maio ${ }^{\circ} 329$. Daí, a diferença entre o número de atividades produtivas (176) encontradas na Tabela 43 (pg.232)e os 177 usuários identificados na Tabela 46 - Tendência de ocupação étnica, por ano de ocorrência (pg.253).

${ }^{247}$ Conforme o Índice de Emplacamentos, do AHMWL, tais mudanças ocorreram basicamente, em 1908, 1909, 1911 e 1912. No geral, foram dois emplacamentos por rua, sendo que os anos contemplados variaram de rua para rua.
} 


\begin{tabular}{|c|c|c|}
\hline TIPO & NEGÓCIOS/ATIVIDADES & $\mathbf{N}^{\circ}$ REGISTROS \\
\hline \multirow{6}{*}{ COMÉrCio AlimENTOS } & AÇOUGUE & 10 \\
\hline & BOTEQUIM & 9 \\
\hline & LEITERIA & 1 \\
\hline & PADARIA & 3 \\
\hline & QUITANDA/DEPÓSITO DE FRUTAS & 76 \\
\hline & SECOS E MOLHADOS & 21 \\
\hline \multicolumn{2}{|l|}{ SUBTOTAL } & 120 \\
\hline \multirow{4}{*}{ COMÉRCIO DIVERSOS } & ARMARINHOS & 1 \\
\hline & FARMÁCIA & 1 \\
\hline & FOGOS DE ARTIFÍCIO & 4 \\
\hline & SEM IDENTIFICAÇÃO & 7 \\
\hline \multicolumn{2}{|l|}{ SUBTOTAL } & 13 \\
\hline \multirow{4}{*}{ FÁBRICA S } & FÁBRICA DE CAIXAS DE PAPELÃO & 1 \\
\hline & FÁBRICA DE MACARRÃO & 1 \\
\hline & FÁBRICA DE MAGNÉSIA EFERVESCENTE GRANULAR & 1 \\
\hline & TORREFAÇÃO DE CAFÉ & 2 \\
\hline \multicolumn{2}{|l|}{ SUBTOTAL } & 5 \\
\hline \multirow{6}{*}{$\begin{array}{l}\text { SERVIÇOS } \\
\text { MANUFATUREIROS }\end{array}$} & "ENDOURADOR" 248 & 1 \\
\hline & OURIVESARIA & 1 \\
\hline & SERRALHERIA & 3 \\
\hline & FOTOGRAFIA & 3 \\
\hline & FUNDIÇÃO DE METAIS & 1 \\
\hline & TIPOGRAFIA & 2 \\
\hline \multicolumn{2}{|l|}{ SUBTOTAL } & 11 \\
\hline \multirow{3}{*}{ SERVIÇOS DIVERSOS } & BARBEARIA & 2 \\
\hline & COCHEIRA & 1 \\
\hline & OFICINA DE ENGOMADEIRA & 1 \\
\hline \multicolumn{2}{|l|}{ SUBTOTAL } & 4 \\
\hline \multirow{6}{*}{ SERVIÇOS DE LAZER } & CAÇA (LICENÇA PARA) & 2 \\
\hline & CINEMA & 1 \\
\hline & COMPANHIA EQUESTRE & 1 \\
\hline & JOGO DE BOCHA & 17 \\
\hline & TEATRO & 1 \\
\hline & TIRO AO ALVO & 1 \\
\hline \multicolumn{2}{|l|}{ SUBTOTAL } & 23 \\
\hline \multicolumn{2}{|l|}{ TOTAL } & 176 \\
\hline
\end{tabular}

Tabela 43 - Atividades produtivas

A seguir, faremos uma breve análise de cada uma das cinco categorias relacionadas na Tabela 43.

a) Comércio (de alimentos e diversos) - Em relação a essa categoria, excetuando-se a loja de armarinhos, a farmácia, quatro comércios de fogos de artifício e as atividades sem identificação, encontramos $\mathbf{1 2 0}$ estabelecimentos voltados para alimentação. Esse número é bastante significativo, pois parece indicar que 68,18\% do total das atividades produtivas desenvolveu-se tendo em vista a satisfação das necessidades básicas das pessoas que viviam no lugar ou em zonas próximas. Desse total, não houve nenhum tipo de negócio mais especializado que pudesse atender uma clientela mais "sofisticada". Tudo indica que na maioria dos casos, tratava-se de pequeno comércio, claramente destinado às classes médias baixas que viviam no bairro

\footnotetext{
${ }^{248}$ No Dicionário Michaelis, não encontramos o termo “endourador”, somente “dourador”, que significa "aquele que executa qualquer processo de douração”.
} 
ou a classes mais abastadas dos bairros vizinhos. Exceção foram os estabelecimentos localizados no Largo do Piques (posterior Largo do Riachuelo), que provavelmente também atendiam os moradores do Centro.

Os açougues, os mais antigos datando de 1906 e 1907, funcionavam no Largo do Piques e na rua Santo Amaro. Os outros oito açougues, datados de 1910 e 1911, se distribuíam pelas ruas Manoel Dutra, Major Diogo, Maria José, Santo Antonio e Rui Barbosa.

\begin{tabular}{|c|c|c|}
\hline NEGÓCIOS/ATIVIDADES & $\begin{array}{c}\mathbf{N}^{\circ} \\
\text { ATIVIDADES }\end{array}$ & $\%$ \\
\hline COMÉRCIO (ALIMENTOS) & 120 & 68,18 \\
\hline COMÉRCIO (DIVERSOS) & 13 & 7,39 \\
\hline FÁBRICA S & 5 & 2,85 \\
\hline SERVIÇOS MANUFATUREIROS & 11 & 6,25 \\
\hline SERVIÇOS/ DIVERSOS & 4 & 2,27 \\
\hline SERVIÇOS DE LAZER & 23 & 13,06 \\
\hline TOTAL & 176 & $100 \%$ \\
\hline
\end{tabular}

Tabela 44 - Percentual das atividades produtivas

As quitandas mereceram uma análise mais acurada de nossa parte. No geral, foram identificadas $\mathbf{7 6}$ quitandas, número bastante alto para as dimensões do bairro e o período abrangido por nossas investigações na Série Alvará e Licença. Essa discrepância nos fez pensar na razão de tanta gente optar por esse tipo de negócio, afinal, às vezes, na mesma rua apareciam diversos estabelecimentos, competindo entre si. Aqui percebemos que estávamos utilizando um raciocínio contemporâneo, onde qualquer pessoa, a não ser que esteja no estado de miséria absoluta, pode adquirir uma geladeira a prazo. Não era o caso na época em questão, quando somente os muito ricos podiam se dar ao luxo de possuir geladeiras. De acordo com Carlos Lemos, no início do século XX, "Foi introduzida nos lares da burguesia a geladeira, verdadeiro cofre com dispositivos de isolamento térmico internos, revestidos de folha de Flandres, capazes de manter por quase 24 horas a pedra de gelo resfriado, conservando comidas" 249. Para a grande maioria das pessoas, o jirau se manteria como a forma de armazenamento de alimentos mais eficaz, enquanto a compra de alimentos poderia ser feita diariamente, na quitanda "ao lado" ou no bairro vizinho, cabendo aos donos das quitandas abastecerem-se nos estabelecimentos atacadistas da cidade, como o Mercado de São João e o Mercado da 25 de Março.

As vendas a varejo em São Paulo estiveram centralizadas, até meados do século XIX, na rua das Casinhas (atual rua do Tesouro) e, em seguida, na Ladeira do Carmo

${ }^{249}$ LEMOS, Carlos A. C. - Alvenaria burguesa, São Paulo: Nobel, 1985. p. 89-90. 
(atual Avenida Rangel Pestana). Desde aquele momento, diversas iniciativas foram empreendidas, por particulares e pela Câmara, no sentido de providenciar espaços especialmente destinados ao abastecimento urbano de alimentos: o Mercado de São João ou Mercado de Verduras, na atual Praça do Correio; o mercado da rua 25 de Março, conhecido como Mercado dos Caipiras, e substituído posteriormente pela versão mais moderna do Mercado Grande ${ }^{250}$; e o Matadouro Municipal, originalmente localizado na rua de Santo Amaro que, por problemas de higiene, foi transferido para o bairro de Vila Mariana, em $1887^{251}$. Entretanto, se os antigos espaços de abastecimento foram substituídos por outros mais modernos e mais aptos a satisfazer as necessidades da população em crescimento, a sua localização colocava outros problemas: a distância dos novos bairros situados nos subúrbios da cidade, dificultando o acesso dos seus moradores. Consequentemente, as necessidades diárias de abastecimento dessa população ficavam comprometidas. As feiras livres, tal como as conhecemos hoje, foram criadas somente em 1914, através de Ato do prefeito Washington Luís, sendo que a primeira foi instalada no Largo General Osório. Um ano depois, em 1915, havia sete feiras livres na cidade, uma delas na rua São Domingos, no bairro do Bexiga. Assim, é compreensível que a população moradora nos bairros periféricos buscasse outras alternativas para a compra de alimentos, sendo as quitandas uma opção viável.

Por outro lado, para as pessoas que necessitavam de um meio de vida que garantisse a subsistência e exigisse poucos investimentos, a exploração desse tipo de comércio parece ser uma possibilidade interessante, justificando assim a recorrência de tantos casos.

Embora a maior concentração de quitandas, entre 1906 e 1914, estivesse nas ruas Conselheiro Ramalho (17) e Santo Antonio (14), elas se distribuíam por todas as ruas do bairro, excetuando-se as ruas do Sol e da Saracura Pequena.

O mesmo se repetiu com os $\mathbf{2 1}$ armazéns de "secos e molhados", sendo aqui a preferência pelas ruas Conselheiro Ramalho e Rui Barbosa. Ficaram excluídas as vias menores, como as ruas da Abolição, do Sol, Fortaleza, São Domingos, São Vicente e Saracura Pequena.

\footnotetext{
${ }^{250}$ CAMPOS JR, Eudes - Mercados Públicos da São Paulo Oitocentista, in: Informativo Arquivo Histórico Municipal, jan-fev/2007, ano 2, no 10. Disponível em: http://www.fotoplus.com/dph/info10/index.html.

${ }^{251}$ MARTINS, Antonio Egydio - São Paulo antigo - 1554- 1910, São Paulo: Paz e Terra, 2003, p. 153.
} 
Das três únicas padarias, duas, datadas de 1906, estavam nos Largos do Piques e Riachuelo; a terceira, datada de 1911, na rua Conselheiro Ramalho. Acreditamos que estas quitandas, armazéns de secos e molhados e padarias não se limitassem a vender para o bairro, mas mediante o sistema de encomenda, entrega a domicílio, registro em caderneta - portanto "vendia fiado" - abasteciam os bairros mais ricos, vizinhos Morro dos Ingleses, Avenida Paulista e Paraíso, etc.

Já os botequins se destinavam a consumidores locais ou, situados em entroncamentos estratégicos, a transeuntes em direção ao Centro. Os donos de botequins parecem ter preferido a região mais antiga do bairro, o Largo do Riachuelo (ou o Largo do Piques ${ }^{252}$ ). Cinco desses botequins, nos anos de 1906 a 1911, estavam ali; um outro, de 1914, na rua 13 de Maio; e os outros dois, ambos de 1910, na Conselheiro Ramalho.

Por fim, a única farmácia (1907), como também a leiteria (1914), se instalaram naquela mesma rua.

Aqui cabe destacar a preferência geral pela rua Conselheiro Ramalho. Entre todas as ruas do bairro foi a que acolheu o maior número de estabelecimentos especificamente comerciais (42), seguida mais de perto apenas pela rua Santo Antonio, com 22 estabelecimentos. Em seguida, vinham a rua Rui Barbosa e o Largo do Riachuelo, cada uma com 15 e 17 casas de comércio, respectivamente. Este largo era praticamente o início do bairro, ao norte, e a sua preferência pode ser explicada pela antiguidade e pela proximidade do Centro da cidade. Aliás, é muito provável que o comércio ali alocado servisse principalmente os habitantes do Centro, mais do que aqueles do próprio Bexiga. De qualquer maneira, o grosso das atividades dedicadas ao comércio, principalmente de produtos alimentícios, estava distribuído por todo o bairro.

b) Indústria - Os cinco estabelecimentos de caráter industrial envolveram: duas torrefações de café ${ }^{253}$ (uma em 1911 e outra em 1914); uma fábrica de caixas de papelão, movida “à força elétrica” (1911); uma fábrica de “magnésia efervescente

\footnotetext{
${ }^{252}$ É necessário destacar que Largo do Piques e Largo do Riachuelo, foram, em momento sucessivos, o mesmo espaço. Apenas foram levantados separadamente porque assim estavam registrados nos documentos da Série Alvará e Licença, isso em praticamente todo o período investigado. Por outro lado, o largo do Piques não consta dos emplacamentos realizados entre 1908 e 1914. Não foi possível determinar o motivo desta ausência, já que pelo menos até 1911, processos de abertura de negócios ainda eram feitos com esse endereço.

${ }^{253}$ No início de nosso trabalho de investigação da Série Alvará e Licença, encontramos diversos documentos relativos a abertura de torrefações de café, para outros bairros da cidade. Estávamos então nos anos de 1906 e 1907, quando a riqueza gerada pelo café ainda era uma realidade e apresentava perspectivas potenciais de lucro a quem quisesse investir no ramo.
} 
granular" (1910); e uma fábrica de macarrão. Porém, o requerimento relativo à esta última, instalada na rua da Saracura Pequena, datado de março de 1910, dizia respeito à transferência do estabelecimento para o Largo da Memória, número 8A, por motivo não citado. Portanto, tratava-se de um negócio que estava saindo do bairro. As fábricas de caixas de papelão e de magnésia situavam-se no Largo do Riachuelo, dentro do perímetro central ${ }^{254}$. Assim, os únicos estabelecimentos fabris localizados dentro do bairro foram as torrefações de café. Não há como saber o porte desses empreendimentos, mas tudo leva a crer que fossem fábricas pequenas. De qualquer maneira, estas únicas iniciativas registradas só parecem confirmar a idéia de que o Bexiga estava longe de ser um bairro industrial. Idéia essa também comprovada se fizermos a comparação entre essas informações e aquelas fornecidas pela Série Obras Particulares. Ali, num prazo muito maior (31 anos), identificamos apenas 37 solicitações para edificação de prédios destinados a fábricas e manufaturas, numa proporção de aproximadamente 1,19 novos estabelecimentos por ano.

Estas fábricas, por menores que fossem, sempre implicavam em investimentos de maior monta. Obviamente, ao aplicar recursos nesse tipo de negócio devia haver por parte dos empreendedores a expectativa de que florescessem e frutificassem, a exemplo do que ocorria com imigrantes bem sucedidos em outros bairros da cidade. Todavia, a impressão que tivemos, a partir da ausência de solicitações de renovação de licença para funcionamento, é que se tratava de empreendimentos pouco promissores. Descontada a fábrica de macarrão, as restantes apresentaram um único requerimento, sendo três entre 1910 e 1911, e a quarta, em 1914, ano em que findamos as investigações. Acreditamos que se esses estabelecimentos tivessem prosperado, seus proprietários teriam solicitado a renovação de licença, o que não aconteceu, pelo menos até 1914.

c) Serviços - Dividimos esse setor em três categorias: 1) serviços manufatureiros, envolvendo algum tipo de elaboração manual até a obtenção do produto final; 2) serviços diversos, sempre que envolvessem trabalhos que não

\footnotetext{
${ }^{254}$ De acordo com o Art. $8^{o}$, da Lei $n^{o}$, de 14 de dezembro de 1900, temos a seguinte descrição do perímetro urbano da cidade de São Paulo: "O perímetro urbano a que se refere o Art. $1^{o}$ é o seguinte: rua da Figueira, esquina da avenida Rangel Pestana, ruas Santa Rosa, Paula Souza, via Tamanduatehy até a linha ingleza, por esta até as alamedas Antonio Prado, Barão de Limeira, Nothmann, rua das Palmeiras, largo de Santa Cecília, ruas d. Veridiana, Maria Antonia, Consolação, Major Diogo, Santo Amaro,

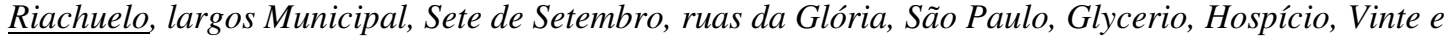
Cinco de Março, aterrado do Carmo até o ponto de partida”. Serie Obras Particulares. AHMWL.
} 
resultassem em produtos específicos, caso dos barbeiros, lavadeiras, etc.; e 3) serviços de lazer.

1) Os serviços manufatureiros somaram onze estabelecimentos:

- Um “endourador”, encontrado no ano de 1906, com oficina no Largo do Riachuelo $\mathrm{n}^{\circ} 23 \mathrm{~A}$.

- Uma ourivesaria, na rua Major Diogo, nº 53, em 1910.

- Três serralherias, sendo uma na rua Major Diogo nº 160, no ano de 1914; e duas, em nome da firma Xisto, Rizi \& Cia, nos anos de 1910 e 1911. Na primeira ocasião, o endereço fornecido era a rua Santo Antonio no 188 , e na segunda, o n 24 A da mesma rua. Na verdade, esses dois registros parecem indicar apenas a mudança de endereço do negócio.

- Uma oficina especializada na fundição do bronze e outros metais, na rua Conselheiro Ramalho, em 1911.

- Duas tipografias: uma, em 1907, no Largo do Riachuelo ${ }^{\circ}$ 25; e a outra, na rua Major Diogo ${ }^{\circ}$ 93, no ano de 1911.

- Dois fotógrafos ambulantes, em 1907: Antonio Ziccardi e Raphael Basile.

- Um ateliê fotográfico: o ateliê, cujo requerimento data de 1910, receberia o nome de dos fotógrafos Ziccardi.

Esses anos marcaram a expansão do mercado da construção civil na cidade em geral. Conforme Carlos Lemos, "grande parte dos materiais ditos de 'acabamentos' foi durante muitos e muitos anos importada, como [...] as ferragens em geral; chapas de cobre para confecção das calhas e condutores; chapas de zinco, de ferro zincado, lisas ou onduladas; [...] tubos e canos para as instalações hidráulicas; [...] colunas de ferro forjado ou fundido[... $]^{255}$.

Acreditamos que o bairro do Bexiga, embora em constante expansão desde os anos de 1880, não justificasse sozinho a presença das três serralherias ali encontradas. Provavelmente, estas não se destinassem exclusivamente ao bairro, mas à cidade como um todo, em plena fase de expansão.

O ourives, estabelecido na rua Major Diogo, deixa claro na sua solicitação de licença para funcionamento, que se tratava de "montar uma pequena 'auriveceria"”, deixando transparecer mais uma tentativa de acerto do que realmente uma certeza. $\mathrm{O}$ Bexiga não parecia ser exatamente o melhor lugar para se fabricar e vender objetos de

\footnotetext{
${ }^{255}$ LEMOS, Carlos - Alvenaria Burguesa, São Paulo: Nobel, 1985. p.36.
} 
ouro e prata, a não ser que essa produção se destinasse a consumidores de outras regiões da cidade.

As tipografias parecem responder às necessidades de uma sociedade em que o consumo de produtos "impressos" se expandia - pequenas publicações, folhetos, ou mesmo jornais para a colônia italiana. Exemplo disso podem ser as publicações relacionadas por Affonso de Freitas, no artigo "A imprensa periódica de São Paulo" ${ }^{256}$, onde o autor traçou o perfil dos jornais populares da cidade de São Paulo. Dentre as publicações dedicadas ao público italiano, destacamos aquelas cujas sedes se localizavam no Bexiga, ou nas suas proximidades. O jornal L'Avvenire, que "si publica per sottos crizione volontaria - esce quando puó” era uma publicação anarquista redigida em italiano e português, e de periodicidade irregular. O número citado pelo autor se referia especificamente ao $\mathrm{n}^{\mathrm{o}} 5$ do periódico, publicado em 13/01/1895, e apresentava a rua da Abolição $\mathrm{n}^{\mathrm{o}} 23$, como local de contato ${ }^{257}$. Já a sede do jornal socialista Avanti, em 1900, localizava-se no Largo da Memória ${ }^{\circ}$ 2, tendo se mudado posteriormente para a Ladeira do Ouvidor $\mathrm{n}^{\mathrm{o}} 3{ }^{258}$. Por fim, a revista popular Itália $e$ Brasile, “dedicada aos interesses do 'trabalho' e da 'imigração' rural”, entre 1909 e 1910, estava sediada à Avenida Brigadeiro Luiz Antonio $\mathrm{n}^{\mathbf{0}} 40{ }^{259}$. Freitas ainda cita duas publicações vinculadas a Escola Maria José. A primeira, O progresso do Bexiga, de 1900, se apresentava como "órgão defensor dos alunos da Escola Modelo Maria José, com especialidade do $4^{\circ}$ ao $5^{\circ}$ ano", com escritório e redação à rua Santo Antonio $\underline{n^{\circ} 111}$. Coincidentemente ou não o autor cita o número de $12 / 08 / 1905$, de um outro jornal, O Maria José - uma "publicação mensal dos alunos do Grupo Escolar Maria José, redigido por Alfredo Pujol Filho e Heitor Gonçalves” -, com sede na rua Pirapitingui $\mathrm{n}^{\text {o }} 22$, na Liberdade ${ }^{260}$. Com exceção do Avanti! ${ }^{261}$, com duração de aproximadamente 15 anos, pouco sabemos sobre o tempo de vida e o êxito dessas publicações. Tratava-se de publicações em sua maioria voltadas para a colônia italiana, fossem moradores do bairro ou não, que necessitavam do trabalho dos tipógrafos para

\footnotetext{
${ }^{256}$ FREITAS, Afonso de - “A imprensa periódica de São Paulo”. In Revista do Instituto Histórico Geográfico de São Paulo, vol. XIX, 1914. AHMWL.

${ }^{257}$ FREITAS, Afonso de - Op. Cit., p. 722.

${ }^{258}$ Op. Cit., p. 854.

259 Op. Cit., p. 1051

${ }^{260}$ Op. Cit., p. 860.

${ }^{261}$ Ver SCHMIDT, Benito Bisso - “Os partidos socialistas na nascente República”, in FERREIRA, Jorge e REIS, Daniel Aarão (Org.) - A formação das tradições. 1889-1945, Rio de Janeiro: Civilização Brasileira, 2007. p. 154.
} 
sua publicação. Nada garante que essas publicações tenham sido impressas nas tipografias citadas, porém se acrescentarmos a localização de suas redações no bairro ao fato de pelo uma delas ser de propriedade de italianos, esta poderia ser uma possibilidade.

De qualquer maneira, por parte dos proprietários da tipografia do Largo do Riachuelo - a Aristide Bellotto \& Cia. - havia a preocupação com a divulgação do negócio, já que pediam autorização para "propaganda” na fachada do prédio. Já José (?) de Maria, não se sabe há quanto tempo, se encontrava estabelecido com essa "pequeníssima tipografia”, na rua Major Diogo. Suas instalações "debaixo de um porão de 2 metros" deviam ser bem precárias, visto terem representado problema para ele obter o alvará de funcionamento.

Por fim, os fotógrafos podiam vender seus serviços em qualquer lugar da cidade. Constatamos que um dos dois indivíduos, em 1907, solicitou licença para exercer a profissão; três anos depois decidiu pela conveniência de se instalar num endereço fixo. Àquela altura talvez já tivesse se tornado conhecido no bairro o suficiente para garantir uma clientela que compensasse os gastos extras com aluguéis...

2) Serviços diversos - Entre os negócios voltados à prestação de serviços diversos, encontramos:

- Duas barbearias, ambas funcionando em 1910. A primeira, na rua Conselheiro Ramalho no 164; e a outra, na rua Major Diogo no 162.

- Uma cocheira, em 1911, na rua Fortaleza.

- Uma “oficina de engomadeiras", no Largo do Riachuelo n 52 A, no ano de 1910. Juntos, esses negócios totalizavam apenas quatro atividades, bem pouco se pensarmos que devem ter servido todo o bairro e adjacências, por um período de quatro anos.

Sobre a distribuição espacial desses serviços, temos que uma das barbearias ficava na rua Conselheiro Ramalho; a outra, na rua Major Diogo, paralela à primeira; a cocheira, localizava-se na rua Fortaleza, quase no final do loteamento; e a oficina de engomadeiras, no largo do Riachuelo, extremo norte e porta de entrada do bairro. De todos esses serviços, talvez os mais requisitados fossem as barbearias, e essas deviam bastar para a população residente no bairro. Quanto às "engomadeiras", instaladas no Largo do Riachuelo, o mais provável é que trabalhassem para as famílias que moravam no Centro ou bairros vizinhos - Morro dos Ingleses, Paraíso, Avenida Paulista, etc. Ademais, não podemos esquecer que estamos lidando com uma população de baixa 
renda, que dificilmente iria "mandar lavar e engomar roupa fora". Supomos sim, que as mulheres residentes no bairro prestassem esse tipo de serviço, o que se confirma a partir das informações fornecidas pelo memorialista Haim Grünspun. De acordo com o autor, na década de 1930, as lavadeiras já eram tradição antiga no Bexiga: “Esta era uma das profissões mais comuns do Bexiga: lavar roupa para fora. Quando as freguesas eram do próprio Bexiga ganhava-se uma miséria porque todos sabiam do preço. Mas quando as freguesas eram de fora do bairro, como Morro dos Ingleses ou Paraíso, dava para ganhar bem” ${ }^{262}$. Ao que parece, esse era um tipo de serviço possível de realizar sem que houvesse necessidade de licença da Prefeitura.

3) Serviços de lazer - Os espaços de lazer se restringiram basicamente aos $\mathbf{1 7}$ jogos de bocce, distribuídos principalmente entre 1907 e 1911. Curiosamente, não encontramos nenhuma referência a esse jogo em 1914, o que não significa que não fosse mais praticado. Armandinho do Bexiga ${ }^{263}$ mencionou a permanência desses espaços, já na década de 1940 e, ao que parece, geralmente instalados no fundo das cantinas. Nos nossos registros identificamos pelo menos três casos em que estava implícito que funcionariam nos "fundos do prédio", além de outros que falavam sobre estarem "junto ao negócio” principal. Esta prática deve ter sido usual: aproveitar a freguesia da quitanda ou do armazém para explorar um entretenimento. Tanto deve ter sido assim que a referência de Armandinho é bem explícita. Ao falar das cantinas, disse que "Bocha algumas tinham, outras não. A do 'Chico Jafalô' não tinha. Para ter bocha precisava ser grande e a maior parte eram pequenas” ${ }^{264}$. Mais adiante, ao citar Alcântara Machado, diz que o autor “[...] no Brás, Bexiga e Barra Funda, fala do Armazém Progresso. É a única coisa do Bixiga que ele cita nesse livro. O armazém existia mesmo. Era na Rua Abolição. Com bocha e restaurante no fundo, mas eu não cheguei a conhecer" ${ }^{265}$.

Não encontramos o jogo de bocha em oito dos logradouros investigados na Série Alvará e Licença, nas ruas Conselheiro Carrão, do Sol (atual Dr. Luís Barreto), Fortaleza, São Domingos, São Vicente, Saracura Pequena (atual Dr. Plínio Barreto), 13 de Maio e no Largo do Piques. No restante, entretanto, sempre havia pelo menos um

\footnotetext{
${ }^{262}$ GRÜNSPUN, Haim - Op. Cit.

${ }^{263}$ MORENO, Julio - Memórias de Armandinho do Bexiga, São Paulo: Editora SENAC São Paulo, 1996.

${ }^{264}$ MORENO, Op.cit., p.150.

${ }^{265}$ MORENO, Op.cit., p. 152.
} 
desses jogos, e chegamos a identificar até quatro casos numa mesma rua, a Conselheiro Ramalho.

As seis atividades de lazer restantes se restringiram a: uma Companhia Eqüestre, localizada na rua Major Diogo, cuja referência, de 1907, dizia respeito à mudança do negócio para a rua Teixeira Leite, localizada no Glicério; um "tiro ao alvo”, em 1914, com sede na rua Conselheiro Ramalho $\mathrm{n}^{\circ} 34$, que havia sido proibido pela polícia; o cinema Pavilhão Recreio, em 1911, na esquina da rua Major Diogo, com a Jaceguai; e dois pedidos de licença para "caça nos subúrbios" da cidade, ambos de abril de 1911. Não sabemos dizer se esse era um simples esporte ou se havia algum objetivo comercial na prática da caça. Na dúvida, mesmo correndo o risco de errar, optamos por classificar a atividade como "lazer".

Em 02 de abril de 1914 encontramos uma solicitação para a rua Conselheiro Ramalho $\mathrm{n}^{\mathrm{o}} 132$ em nome da firma Anselmo Pignatari \& Cia, onde o requerente "Desejando inaugurar o "Theatro Especial" com espetáculos cinematográficos e estando tudo de acordo com a lei, solicita o respectivo alvará de licença para pagamento dos impostos”. Já em 14 de agosto de 1912, localizamos na Série Obras Particulares, na rua Conselheiro Ramalho $\mathrm{n}^{\circ} 205$, um pedido de licença para ampliação de um "barracão para adaptá-lo a espetáculos cinematográficos, conforme a planta junta”, em nome de Salgado \& Cia. Quase duas décadas depois, é possível verificar na planta elaborada pela empresa SARA Brasil (1929-1930), a presença do Theatro Esperia, à rua Conselheiro Ramalho, entre as ruas Conselheiro Carrão e Manoel Dutra 266. A constatação de que pessoas, ainda que diferentes e em momentos diversos, tivessem se proposto a explorar a apresentação de "espetáculos cinematográficos" como forma de negócio num bairro habitado por segmentos mais pobres da população, nos dá a medida da popularidade e do interesse despertado por esse tipo de lazer. Mesmo que sejam espaços únicos e que o êxito do empreendimento não seja garantido, a permanência de um teatro naquela rua, no decorrer dos anos 1930, é significativa.

Por fim, havia as festas e, essas sim, parecem ter tido um papel significativo no lazer dos moradores do bairro. Os registros que encontramos sobre esses eventos datam

\footnotetext{
${ }^{266}$ Em relação ao Cinema Recreio, foi fundado por Salvador Caruso, e teve curta duração. De acordo com o pesquisador José Inácio Melo Souza, até pelo menos 1915, o projeto de Caruso foi alvo de constantes intervenções por parte da Diretoria de Obras. Em 1919, o terreno constava como local de um cinema demolido, permanecendo sem ocupação. Quanto ao Teatro Esperia, já estaria desativado em 1956, sendo reinaugurado como Teatro Bela Vista. Posteriormente, o prédio foi demolido, dando lugar ao Teatro Sérgio Cardoso, na Rui Barbosa, 153.
} 
de 1907 e 1911, e indicam que eram festas religiosas, realizadas em agosto e setembro, e dedicadas aos santos de devoção dos moradores do bairro ${ }^{267}$. Eram abertas para todos, sem distinção de classe. Parecem ter sido organizadas por iniciativa dos moradores mais ricos, pois implicavam em gastos com montagem de coretos e depósito em dinheiro para a Seção de Polícia e Higiene, tendo em vista cobrir eventuais incidentes que ocorressem. Temos por exemplo que, em 15 de setembro de 1911, após o término das festividades, Francisco Lucito e Nicola Picca encaminharam o seguinte pedido: “Os abaixo-assinados, tendo feito um depósito de 50\$000, para realizarem as festas nos dias 7 e 8, solicitam a restituição feita de acordo com as leis”. Nas três ocasiões em que identificamos referências às festas, elas se realizaram nas ruas Rui Barbosa, Saracura Pequena e 13 de Maio.

\footnotetext{
${ }^{267}$ Apenas a titulo de ilustração. Uma das festas realizadas em setembro, na esquina da rua Rui Barbosa com a Conselheiro Ramalho, com certeza era dedicada a Nossa Senhora da Penha. Acreditamos que a outra, realizada na rua da Saracura Pequena, fosse para a mesma santa, já que acontecia no mesmo mês. A terceira festa, realizada na rua 13 de Maio, no mês de agosto, provavelmente era em homenagem a Nossa Senhora da Achiropita, já que é nesse mês que se comemora o dia dessa santa.
} 


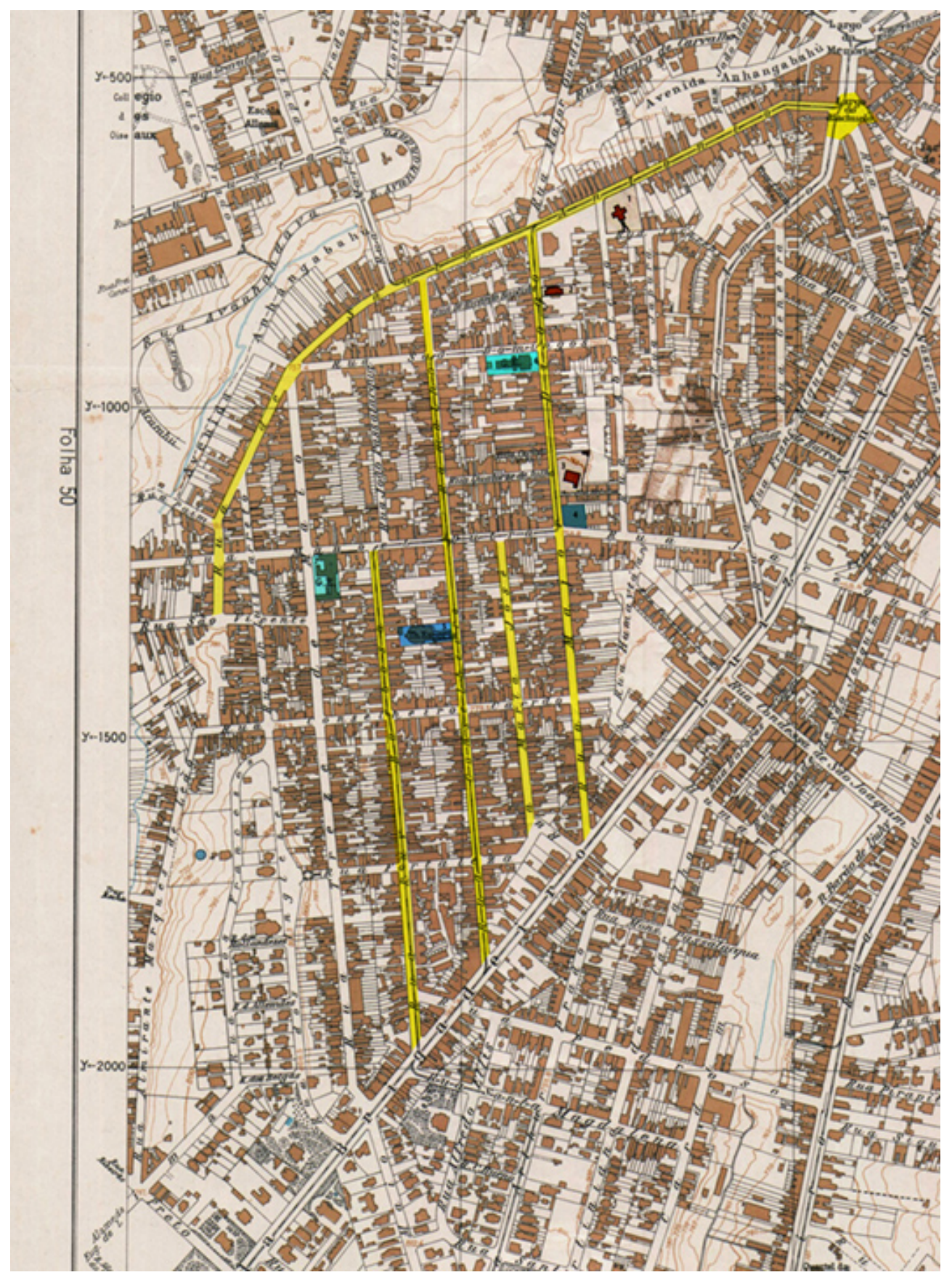

Figura 80 - Ruas com maior concentração das atividades produtivas. Nos destaques em vinho, azul e verde, os imóveis de localização confirmada.

1 -Residência do engenheiro Fernando de Albuquerque (posteriormente pertenceu à família Lee)

2 - Residência de D. Domiciana de Almeida Nogueira

3 - Residência de D. Yayá

4 - Cinema Recreio

5 - Teatro Especial (futuro Teatro Esperia)

6 - Grupo Escolar Maria José

7 - Grupo Escolar da Bela Vista

Fonte: Mappa Topográphico do Município de São Paulo, SARA Brasil (1930). Fl. 37. AHMWL.

As informações contidas na Série Alvará e Licença levantaram algumas questões que julgamos merecedoras de análise à parte. A primeira delas se refere às cocheiras. Nesta Série, o único registro dessa atividade relacionava-se à propriedade de Joaquim 
Antunes dos Santos, onde ele "Vem dizer que não se responsabiliza por nenhuma indústria colocada em suas propriedades - como sejam cocheiras, fornos para cozinha... bem como curtume e 'salga' de couros. Vem fazer este aviso a fim de "colectar" os inquilinos que exercem qualquer dessas profissões em sua propriedade". Essas informações, se cruzadas com aquelas das Obras Particulares, permitem concluir que esse tipo de edificação pode ter sido um bom negócio para Joaquim Antunes e outros. Nas Obras Particulares, além das solicitações de 11/07/1906 (na rua Fortaleza, junto ao $n^{\circ}$ 12) e de 17/12/1907 (Conselheiro Ramalho $n^{\circ} 222$ ), ambas em nome de Joaquim Antunes, e que se referiam à presença dessas edificações, identificamos um total de outras 43 , relacionadas à construção ou reforma.

Maria Luiza Ferreira de Oliveira ao falar sobre o exercício da profissão de cocheiro observou que esta "era uma profissão com mercado certo, na cidade que crescia, que demandava entregas cujos fluxos de mercadorias e pessoas só aumentavam” ${ }^{268}$. Dessa maneira, é factível que esse tipo de negócio também tenha sido explorado no Bexiga, fossem os espaços ocupados pelas cocheiras próprios ou alugados a terceiros.

Os registros arrolados na tabela abaixo demonstram claramente que, de 1891 a 1914, a construção de cocheiras manteve um ritmo intenso. A maior concentração foi na rua Major Diogo (dez cocheiras), seguida pelas ruas Conselheiro Ramalho, Rui Barbosa e Santo Antonio (cada uma com cinco cocheiras); rua 13 de Maio (quatro cocheiras); Conselheiro Carrão e Saracura Pequena (com três cocheiras); do Sol e Maria José (com duas cocheiras cada); e finalmente, Fortaleza, João Passalacqua, 13 de Maio e Saracura Grande (cada uma com uma cocheira).

A existência de diversos negócios no bairro sugere que muitos deles se utilizassem de animais para entrega, ou mesmo, para vender seus produtos como ambulantes. Os animais eram provavelmente guardados a noite nessas cocheiras.

Um velho costume, que pelo menos até alguns anos atrás ainda se encontrava em cidades do interior, era o da venda de leite in natura - uma carroça, puxada por um cavalo ou jumento, que ia pelas ruas, parando nas portas de quem quisesse comprar. Certamente esses leiteiros também foram usuais na cidade e no Bexiga. Aliás, entre os processos da Série Obras Particulares relativos às cocheiras encontramos um, de 22 de outubro de 1894, em nome de Joaquim Pereira, onde ele diz que "tendo de construir

\footnotetext{
${ }^{268}$ OLIVEIRA, Op.cit. p.46 e 47.
} 
uma 'cocheira para vacas', conforme planta junta, pede que a mesma seja aprovada". Devemos pensar que tais vacas se destinavam a fornecer leite ou seus derivados para os moradores do bairro e adjacências. Se assim era, provavelmente o próprio Joaquim fazia a entrega do leite.

\begin{tabular}{|c|c|c|c|}
\hline $\mathbf{N}^{\circ}$ & ENDEREÇO & DATA & $\begin{array}{c}\text { HISTÓRICO } \\
\text { SOLICITAÇÃO }\end{array}$ \\
\hline \multirow{4}{*}{4} & 13 DE MAIO, 93 (TINTA) & $10 / 10 / 1907$ & CONSTRUÇÃO \\
\hline & 13 DE MAIO, 95 & $09 / 10 / 1913$ & CONSTRUÇÃO \\
\hline & 13 DE MAIO, 102 & $20 / 10 / 1914$ & REFORMA \\
\hline & 13 DE MAIO, 127 & $22 / 06 / 1914$ & CONSTRUÇÃO \\
\hline \multirow{3}{*}{3} & CONSELHEIRO CARRÃO, S/N ${ }^{\circ}$ & $26 / 03 / 1894$ & CONSTRUÇÃO \\
\hline & CONSELHEIRO CARRÃO, 2 & $03 / 03 / 1896$ & CONSTRUÇÃO \\
\hline & CONSELHEIRO CARRÃO, 67 & $24 / 12 / 1914$ & REFORMA \\
\hline \multirow{5}{*}{5} & CONSELHEIRO RAMALHO, 21 & $13 / 11 / 1899$ & CONSTRUÇÃO \\
\hline & CONSELHEIRO RAMALHO, 75 & $12 / 09 / 1900$ & CONSTRUÇÃO \\
\hline & CONSELHEIRO RAMALHO, 173 & $01 / 12 / 1898$ & CONSTRUÇÃO \\
\hline & CONSELHEIRO RAMALHO, 204 & $28 / 03 / 1899$ & CONSTRUÇÃO \\
\hline & CONSELHEIRO RAMALHO, 222 & $17 / 12 / 1907$ & $\begin{array}{l}\text { TRANSFORMAÇÃO } \\
\text { EM } 2 \text { CASAS } \\
\text { OPERÁRIAS }\end{array}$ \\
\hline \multirow{2}{*}{2} & DO SOL, 63 TINTA & $16 / 11 / 1912$ & CONSTRUÇÃO \\
\hline & DO SOL, 65 & $29 / 03 / 1913$ & CONSTRUÇÃO \\
\hline 1 & FORTALEZA, JUNTO AO 12 & $11 / 06 / 1906$ & CONSTRUÇÃO \\
\hline 1 & JOÃO PASSALACQUA, 26 & $22 / 01 / 1912$ & CONSTRUÇÃO \\
\hline \multirow{10}{*}{10} & $\begin{array}{l}\text { MAJOR DIOGO (ANTIGA } \\
\left.\text { VALINHOS, } / \mathrm{S}^{\circ}\right)\end{array}$ & $30 / 06 / 1891$ & CONSTRUÇÃO \\
\hline & MAJOR DIOGO, $43 \mathrm{~T}$ & $30 / 01 / 1901$ & CONSTRUÇÃO \\
\hline & MAJOR DIOGO, 47 & $25 / 05 / 1895$ & CONSTRUÇÃO \\
\hline & MAJOR DIOGO, 50 & $22 / 09 / 1894$ & REFORMA \\
\hline & MAJOR DIOGO, PEGADO AO 72 & $11 / 01 / 1900$ & AUMENTO \\
\hline & MAJOR DIOGO, 74 & $14 / 02 / 1901$ & CONSTRUÇÃO \\
\hline & MAJOR DIOGO, 75 & $07 / 07 / 1905$ & CONSTRUÇÃO \\
\hline & MAJOR DIOGO, 83 & $07 / 08 / 1913$ & CONSTRUÇÃO \\
\hline & MAJOR DIOGO, 83 & $07 / 12 / 1914$ & CONSTRUÇÃO \\
\hline & MAJOR DIOGO, 124 & $29 / 07 / 1899$ & CONSTRUÇÃO \\
\hline \multirow{2}{*}{2} & MARIA JOSÉ, PEGADO AO 25 & $14 / 04 / 1899$ & CONSTRUÇÃO \\
\hline & MARIA JosÉ, 45 & $27 / 12 / 1914$ & REFORMA \\
\hline \multirow{5}{*}{5} & RUY BARBOSA, 38 & $04 / 05 / 1906$ & CONSTRUÇÃO \\
\hline & RUY BARBOSA, 39 & $27 / 08 / 1912$ & CONSTRUÇÃO \\
\hline & RUY BARBOSA, 53 & $08 / 06 / 1906$ & AUMENTO \\
\hline & RUY BARBOSA, 56 & $06 / 03 / 1899$ & CONSTRUÇÃO \\
\hline & RUY BARBOSA, 60 & $29 / 12 / 1914$ & CONSTRUÇÃO \\
\hline 1 & SANTO AMARO, 76 & $22 / 10 / 1894$ & CONSTRUÇÃO \\
\hline \multirow{5}{*}{5} & SANTO ANTONIO, JUNTO AO 24 & $23 / 06 / 1894$ & DEMOLIÇÃO \\
\hline & SANTO ANTONIO, 32 & $15 / 07 / 1899$ & CONSTRUÇÃO \\
\hline & SANTO ANTONIO, 32 TINTA & $21 / 10 / 1905$ & CONSTRUÇÃO \\
\hline & SANTO ANTONIO, 142 & $18 / 09 / 1899$ & CONSTRUÇÃO \\
\hline & SANTO ANTONIO, 204 & $26 / 06 / 1899$ & CONSTRUÇÃO \\
\hline \multirow{2}{*}{2} & SÃO DOMINGOS, 11 & $01 / 08 / 1906$ & CONSTRUÇÃO \\
\hline & SÃO DOMINGOS, 84 & $05 / 12 / 1914$ & CONSTRUÇÃO \\
\hline 1 & SARACURA GRANDE, 8D & $15 / 05 / 1900$ & CONSTRUÇÃO \\
\hline \multirow{3}{*}{3} & SARACURA PEQUENA, 48 & $06 / 08 / 1900$ & CONSTRUÇÃO \\
\hline & SARACURA PEQUENA, 64 & $15 / 01 / 1900$ & CONSTRUÇÃO \\
\hline & SARACURA PEQUENA, 72 & $30 / 01 / 1900$ & CONSTRUÇÃO \\
\hline 45 & \multicolumn{3}{|c|}{ INCLUÍDAS AS COCHEIRAS DE JOAQUIM ANTUNES DOS SANTOS. } \\
\hline
\end{tabular}

Tabela 45 - Cocheiras identificadas a partir da Série Obras Particulares - Processos de Construção e Reforma

Infelizmente, além dessa referência, encontramos apenas uma outra em que foi possível relacionar a presença da cocheira a algum tipo de negócio. Foi o caso do processo em nome de Domingos Albanez que em 5 de dezembro de 1914 ao solicitar a 
aprovação da planta para a construção de uma cocheira, dizia ser "residente com padaria na rua São Domingos, $n .84$ ”. Ora, a entrega de pão na porta das casas também era um costume comum.

Conseguimos localizar poucas referências além daquela de Maria Luiza Ferreira de Oliveira, que esclarecessem melhor os usos e funções das cocheiras na cidade. Sabemos sim, que se tratava de um momento em que carroças, carruagens e outros meios de transporte movidos à tração animal ainda eram de suma importância para o deslocamento de pessoas e mercadorias. A existência desse meio de transporte implicava na presença das cocheiras. Tanto era assim que o capítulo XVI do Código Sanitário de 1894 destinava-se inteiramente à regulamentação das condições de higiene de estábulos e cocheiras:

"Devem ser proibidas cocheiras e estábulos, nos pontos da cidade e povoações em que a população for densa, salvo os casos dos artigos 70 e 71 do capítulo $2^{\circ}$, com relação a cocheiras e estábulos particulares" ${ }^{269}$.

"Os estábulos deverão ser severamente fiscalizados para que não seja fornecido à população leite de má qualidade"270

A preocupação com as condições de higiene dos estábulos, manifesta no último artigo do Código Sanitário de 1894, poderia confirmar nossa dedução sobre Joaquim Pereira ser um leiteiro. Quanto à proibição de cocheiras e estábulos em áreas de "população densa", não sabemos se isso se aplicava ao Bexiga. As cocheiras estavam lá, portanto sua construção era autorizada. Não podemos esquecer que se tratava de um bairro, quase todo ele situado fora do perímetro urbano. Em 1913 e 1914, dado o grande número de novas edificações, o adensamento populacional já era um fato, contudo somente nesses anos foram construídas ou reformadas oito cocheiras. Por outro lado, os requerimentos não deixam claro qual a finalidade dessas construções, se para uso particular ou comercial. De qualquer maneira, acreditamos que boa parte delas tenha sido utilizada comercialmente ${ }^{271}$.

Afinal, em tempos de transporte de tração animal onde abrigar os animais? Seriam as cocheiras os "estacionamentos" da época, para aqueles que não dispusessem de espaço em seus imóveis para tanto?

\footnotetext{
${ }^{269}$ Actos do Poder Executivo, Decreto n.233, de 2 de março de 1894. Código Sanitário, Cap. XVI, Art. 335, p.97-98. Acervo do Arquivo Público do Estado de São Paulo.

${ }^{270}$ Código Sanitário. Op.cit., Art. 356.

${ }^{271}$ Acerca dos usos das cocheiras, a questão tem se mantido no decorrer de nosso trabalho para o projeto A Arquitetura da Cidade de São Paulo. O projeto envolve toda a cidade de São Paulo, entre 1906 e 1920, e ao longo desses anos a presença desse espaço é constante, sem que haja referências explícitas sobre a sua utilização.
} 
Nireu Cavacalti ${ }^{272}$ chamou a atenção para esta questão na cidade do Rio de Janeiro, no início do século XIX. Ao analisar a distribuição dos diferentes tipos de imóveis no Centro da cidade, verificou que:

"Os imóveis registrados nos livros da Décima Urbana de uso exclusivo para cocheira ou de uso misto - residencial ou comercial - eram muito poucos, apenas 52. Esse dado é um expressivo indicador do alto índice de urbanização já alcançado na época, da valorização dos terrenos e de seus imóveis localizados, sobretudo na área correspondente ao miolo da cidade do Rio de Janeiro. [...] Portanto, salvo nas 115 chácaras existentes no perímetro urbano - dotadas de pastagens e estrebarias e local para guarda dos equipamentos e veículos - possuir uma cocheira na área mais construída e central da cidade representava status social só compatível com o nível de negociantes de 'grosso trato'”.

Guardadas as devidas proporções, São Paulo dos anos 1900-1910 vivenciava um surto de urbanização semelhante àquele vivido pela cidade do Rio de Janeiro. Em vista disso, é compreensível que bairros fora do perímetro urbano, como o Bexiga, abrigassem este tipo de atividade.

Finalmente, em conversa que tivemos com Walter Taverna, proprietário de restaurantes na Bela Vista, e presidente do Centro de Memória do Bixiga, obtivemos a informação esclarecedora de que na época de sua infância, há cerca de 70 anos, as cocheiras ainda eram comuns no bairro. De acordo com Taverna, elas eram alugadas por seus proprietários a pessoas que possuíam carroças, funcionando como espaços de estacionamento para os veículos e local de guarda dos animais.

\footnotetext{
${ }^{272}$ CAVALCANTI, Nireu - O Rio de Janeiro setecentista: a vida e a construção da cidade da invasão
} francesa até a chegada da Corte, Rio de Janeiro: Jorge Zahar Ed., 2004. p. 268-269. 


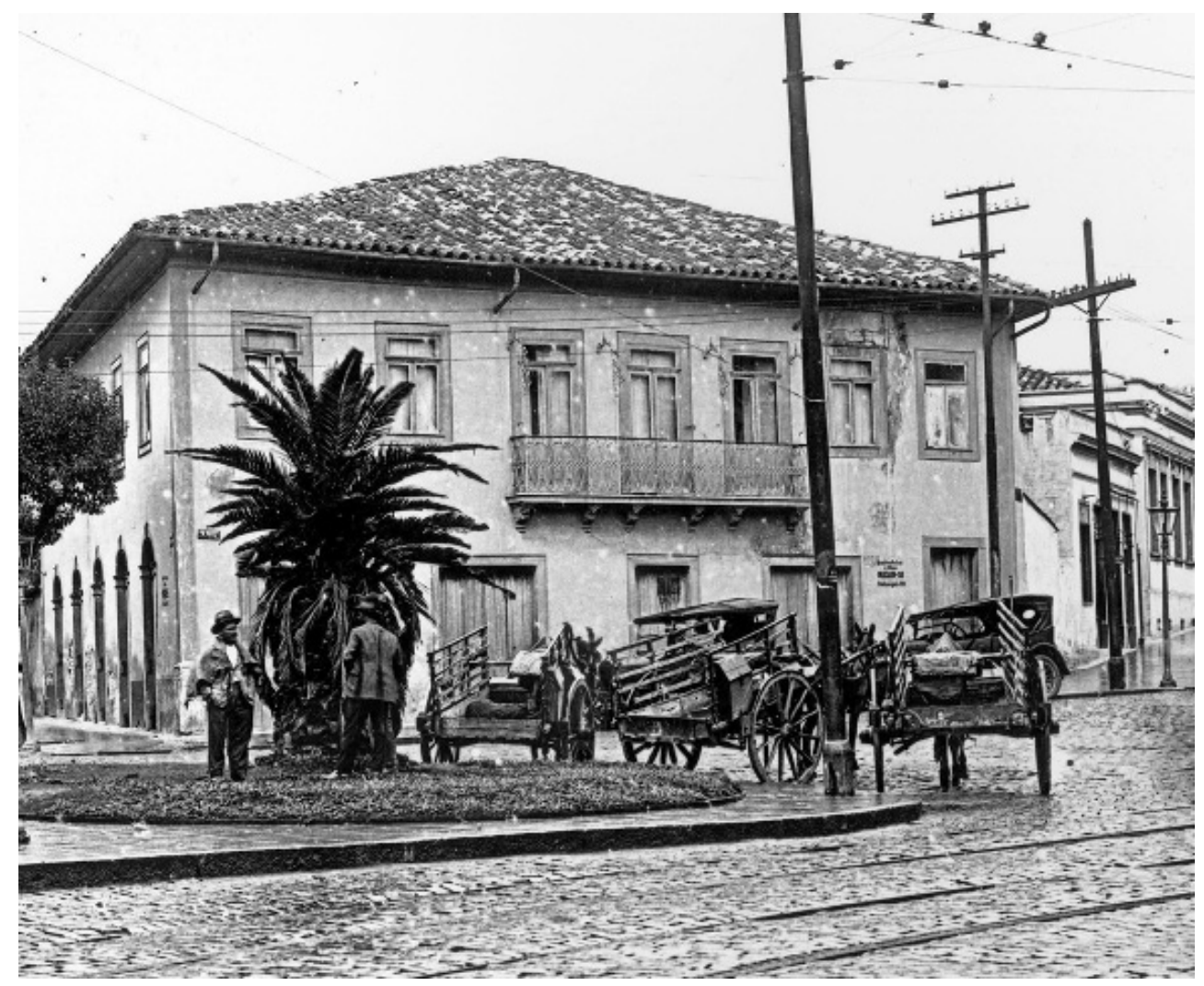

Figura 81 - Nesta imagem, destacamos um detalhe da fotografia do Largo do Riachuelo (ver Figura 56, Capítulo 2). Na fachada do sobrado, uma pequena placa traz o anúncio "MUDAM-SE”, referindo-se certamente, às carroças e aos cocheiros que conversam enquanto esperam o próximo cliente. Foto: Autoria desconhecida, 1926. Fonte: Acervo Fundação Energia e Saneamento.

A permanência de parte das pessoas ligadas a pequenos negócios na mesma rua ou nas imediações foi outro dado que nos chamou a atenção. Caso exemplar é o de Manoelle Paladine, que viveu e trabalhou na casa que construiu na rua Manoel Dutra ${ }^{\circ}$ 15. A casa foi edificada em 1899 e mereceu "transformação de janela em porta” (em 1912) para melhor adaptar a quitanda. O mesmo pode-se dizer de Nicola Giuliano. Em 1901, ele solicitou licença para construir uma “casa com armazém”, na rua 14 de julho, esquina com a Conselheiro Ramalho, e em 1906, pedia “alvará de transferência de negócio de gêneros alimentícios, do Mercado São João, para a rua Conselheiro Ramalho, 55”. Supomos que Giuliano já vivesse no Bexiga enquanto era comerciante naquele mercado e, naquele momento, por algum motivo, considerou oportuno transferir o negócio para perto de sua residência. Em 1912, ele voltou a procurar a Seção de $\operatorname{Obras}^{273}$, agora pedindo licença para transformar "portas em janelas",

\footnotetext{
273 De acordo com o Guia Arquivo Histórico Municipal Washington Luís - 100 anos 1907-2007, “com a organização do Poder Executivo Municipal sob a direção de um Prefeito (Lei $n^{\circ} 374$, de 19/12/1898), as
} 
exatamente naquela esquina onde edificara sua casa, em 1901. Tendo em vista conferirmos a correção da numeração dos endereços, consultamos o Índice de Emplacamentos, e constatamos que entre os emplacamentos realizados em 1908 e 1912, o número 55 tornou-se número 71. Assim, temos mais um personagem que permaneceu no mesmo imóvel por longo tempo.

Outro fato a se destacar é a relativa frequência de negócios abertos e fechados, bem como mudanças de endereços ou mesmo de donos. Entre as 168 atividades, detectamos pelo menos 20 casos de pedidos de baixa do negócio, transferências para outros donos, transferências para outros bairros e dez pedidos de transferência para o mesmo bairro, perfazendo aproximadamente $17,85 \%$ da amostra total. Esses dados indicam a instabilidade a que estavam sujeitos esses negócios, assim como a mobilidade física dos mesmos, fosse pelo fracasso do empreendimento, pelas dificuldades da localização ou ainda pelas dificuldades em se adaptar às exigências da lei. Entretanto, também encontramos o mesmo endereço, com o mesmo tipo de negócio, sendo ocupado por outro comerciante, às vezes num espaço de tempo de menos de um ano. Embora não houvesse registro formal dessas transferências de ponto, elas devem ter ocorrido. Pensamos que essa suposta informalidade de procedimentos se deva muito ao tipo de usuário que atuou no bairro, na maioria das vezes, de origem italiana. Italianos que chegavam à cidade, sozinhos ou com família, ali se instalavam no bairro, às vezes sendo acolhidos por familiares que haviam chegado antes, às vezes por conhecidos, mas sempre buscando recomeçar a vida através de algum tipo de atividade que possibilitasse a sobrevivência, e quem sabe, permitisse um futuro menos incerto. Maria Luiza Ferreira de Oliveira, ao analisar os grupos dos habitantes "mais pobres sem diversidades”, e principalmente dos “apenas remediados”, no período entre 1894 e 1901, apontou a intensa mobilidade que marcou a vida dessas pessoas na última década do século XIX. A autora ressalta que "nesse momento destacou-se a grande presença de imigrantes, com predomínio dos italianos" ${ }^{274}$, presença esta, totalmente confirmada no nosso bairro. Dessa maneira, é compreensível que se o negócio não estivesse dando certo, se passasse o "ponto" para outro interessado, indo em busca de outras possibilidades. Identificamos diversas situações dessa natureza. Generoso

antigas Intendências foram transformadas em Seções: Justiça, Polícia e Higiene, Obras e Finanças, todas elas subordinadas ao Prefeito”. AHMWL, São Paulo: DPH, 2007. p. 32.

${ }^{274}$ Segundo a autora, "aqueles que não tinham imóvel (oito casos, 30\%) concentraram seus esforços em negócios. Esse foi por exemplo, o caso de Conrado Mully sem bem de raiz, com dois contos investidos em uma tipografia. Todo o esforço ia para a moradia e/ou para o comércio”.OLIVEIRA, Op.cit., p.81-86. 
Rubino, em 10 de fevereiro de 1910, com quitanda instalada à rua Conselheiro Ramalho $\mathrm{n}^{\circ} 50$, encaminhou o aviso de encerramento do negócio, "tendo em vista não estar vendendo". Uma possível explicação para o fracasso de Generoso talvez fosse o grande número de quitandas na rua, um total de 16. Ernesto Mazzuco, em 17 de fevereiro de 1914, também proprietário de uma quitanda, agora localizada na rua Rui Barbosa $n^{\circ} 12$, solicitou baixa no negócio por "não poder arcar com as exigências da repartição sanitária”. Aqui é preciso lembrar a obrigatoriedade de pagamento de taxas a cada ação e/ou solicitação de licença que se fizesse junto aos órgãos responsáveis pelo bom funcionamento dos estabelecimentos. Eram várias as taxas a pagar: para a abertura do negócio; para a renovação anual da licença; para a mudança de endereço; para a mudança de dono; para a colocação de placas; e bem provável que também para o fechamento do negócio. Outro quitandeiro, Pietro Branca Leone, "tendo que retirarse para a Itália”, solicitou baixa no negócio da rua Santo Antonio $\mathrm{n}^{\circ} 176$, em 06/02/1911. Embora ele não explique o motivo da volta à Itália, esse caso nos remete ao trabalho de Zuleika Alvim, onde, ao estudar o processo de resistência do imigrante italiano à proletarização, no campo ou na cidade, abordou a questão da mobilidade geográfica e até do retorno ao país de origem, como uma das formas de resistência desse grupo ${ }^{275}$. Eram reais as dificuldades de adaptação aos padrões da cidade que se desenvolvia rapidamente, adotando políticas de controle por vezes consideradas invasivas e custosas. As tentativas malogradas de estabelecer um negócio eram fruto tanto da concorrência com inúmeras outras pessoas no bairro como da incapacidade de gerir esse negócio de forma racional e se, de fato, a grande maioria da população do Bexiga morava/trabalhava em imóveis alugados, cremos que nem sempre a renda auferida com o negócio fosse suficiente para todas as despesas, incluído aí o aluguel. Enfim, todos esses fatores podiam desfavorecer o investimento de parcos recursos no comércio ou qualquer outra atividade econômica que se empreitasse, impelindo o imigrante a buscar outras possibilidades ou mesmo a retornar à pátria onde, se também havia dificuldades, pelo menos haveria parentes com quem contar.

Mesmo levando em conta que a amostra investigada foi pequena, a verdade é que nesse período foram pouquíssimos os casos de pessoas que permaneceram com os

\footnotetext{
${ }^{275}$ A autora nos diz que "Para se analisar o que representou essa forma de resistência é preciso, novamente, recorrer aos antecedentes históricos do grupo imigrante, pois a mobilidade apresentada em São Paulo nada mais foi do que uma retomada do mesmo recurso adotado no país de origem. ALVIM, Zuleika. M.F. - Op. Cit. p.115-148.
} 
mesmos negócios por mais de dois anos. Entre eles: Raphael Fabiano, com uma quitanda na rua Major Diogo, nos anos 1910-14; Philomena Perrutti, com quitanda na rua Santo Antonio, nos anos 1910-14; Nicola Castigli, com quitanda na rua São Domingos, nos anos 1910-14; e finalmente, em 1907, um investimento no promissor ramo da fotografia. Nesse ano, encontramos duas solicitações, com textos exatamente iguais, em nome de Antonio Ziccardi e Raphael Basile, onde se diz que o "Morador da R. S. Domingos, 42, desejando explorar o ramo de fotografias, exibindo pelas ruas e praças da Capital aparelho fotográfico com tripé, solicita a licença”. Ambos eram fotógrafos e forneceram o mesmo endereço. Isso nos faz pensar nesses dois jovens, talvez recém chegados da Itália, que aprenderam o novo ofício, cheios de entusiasmo pelas perspectivas promissoras da profissão. Naquele momento ainda não se tratava exatamente de um "negócio", mas deve ter dado certo, porque em 1910 temos uma solicitação de licença, em nome de Fratelli Ziccardi, para abertura de um "ateliê" fotográfico na rua Conselheiro Ramalho $n^{\circ}$ 202. Bem, talvez não tenha dado tão certo, pois não encontramos mais nenhuma referência ao empreendimento, nem ao menos para a renovação anual da licença.

Já comentamos o fato do Bexiga abrigar negócios predominantemente voltados para a satisfação das necessidades básicas de seus moradores e vizinhança. Entre os 176 casos analisados, encontramos poucas fábricas, alguns espaços de prestação de serviços "gerais", algumas oficinas especializadas no manuseio de metais, mas principalmente um comércio generalizado de produtos alimentícios. Estas atividades aparentemente não excediam os limites do bairro. Os dados obtidos na Série Obras Particulares acrescentaram informações que confirmam esse quadro. Entre os $\mathbf{1 . 1 7 0}$ requerimentos analisados, identificamos 49 pedidos específicos para a construção de prédios destinados ao funcionamento de fábricas, manufaturas, comércio e serviços, bem pouco se pensarmos que isso envolveu um período relativamente longo, de $\mathbf{3 3}$ anos. Além desses casos, localizamos $\mathbf{7 1}$ requerimentos que envolviam licença para reforma e acréscimo em prédios de uso misto, ocupados por oficinas de costura ou alfaiataria, padarias e negócios não identificados, mas, sobretudo, por estabelecimentos denominados genericamente de armazéns. Na grande maioria desses casos, os projetos arquitetônicos demonstravam tratar-se basicamente de empreendimentos de pequeno porte.

Diversos projetos arquitetônicos se referem à instalação de algum tipo de negócio nos fundos de terrenos com "edificações existentes", utilizadas como moradia, 
e construídas no alinhamento. Acreditamos que isso confirme a hipótese de se tratar de pequenos negócios voltados para a satisfação de necessidades básicas dos moradores do bairro e vizinhança. Assim, as análises realizadas junto às fontes primárias parecem confirmar, se não a idéia do Bexiga como um bairro predominantemente residencial, como um bairro onde as atividades econômicas permeavam o cotidiano de seus habitantes.

De outro lado, a presença de negócios de pequeno e médio porte só vem reafirmar o que já havíamos constatado no caso dos proprietários: o predomínio, no bairro, dos segmentos médios e baixos da sociedade.

\section{Nacionalidades e etnias}

O memorialista Haim Grünspun, em seu trabalho Bexiga - Anatomia de um bairro, nos fala sobre os moradores do bairro na década de 1930, dizendo que "Na linha esquerda do bonde, a começar dos cortiços da Marques Leão, viviam na maioria italianos e seus descendentes, seguidos de mulatos, negros, espanhóis, fazendo a mescla brasileira do Bexiga." "276 O cenário traçado pelo autor se refere ao Bexiga dos anos 1930, distante aproximadamente vinte anos do nosso objeto de pesquisa. Entre 1914 e 1930 certamente muitas mudanças ocorreram, contudo, acreditamos que no período investigado tenham se esboçado as tendências que viriam a se concretizar anos mais tarde, configurando o bairro descrito por Grünspun.

Ao levantarmos os nomes dos atores sociais que efetivamente ocuparam o bairro, morando ou trabalhando, percebemos a presença maciça de italianos. Ao lado dos italianos, alguns indivíduos com outras origens: alemães, prováveis espanhóis, e certamente, portugueses.

Para aferirmos as dimensões dessa variedade de imigrantes, agrupamos os nomes desses indivíduos, por ordem alfabética e de acordo com suas prováveis nacionalidades. Como em diversos casos houve mais de um requerimento em nome da mesma pessoa, selecionamos os mais antigos, quando, hipoteticamente, esses atores sociais teriam entrado no cenário do Bexiga. Desse quadro, obtivemos as tendências de

\footnotetext{
${ }^{276}$ GRÜNSPUN, Haim - Op. Cit.
} 
ocupação durante os cinco anos investigados (1906, 1907, 1910, 1911 e 1914), descritos na tabela abaixo.

\begin{tabular}{|c|c|c|c|c|c|}
\hline \multirow{2}{*}{ ANO } & $\begin{array}{c}\text { BRASILEIROS } \\
\text { E/OU } \\
\text { PORTUGUESES }\end{array}$ & ITALIANOS & OUTROS & $\begin{array}{c}\text { NÃO } \\
\text { IDENTIFICADOS }\end{array}$ & $\begin{array}{c}\text { TOTAL } \\
\text { USUÁRIOS }\end{array}$ \\
\hline $\mathbf{1 9 0 6}$ & 3 & 21 & - & 4 & 28 \\
\hline $\mathbf{1 9 0 7}$ & 2 & 22 & - & 2 & 26 \\
\hline $\mathbf{1 9 1 0}$ & 4 & 44 & - & 1 & 49 \\
\hline $\mathbf{1 9 1 1}$ & 9 & 40 & 5 & 1 & 55 \\
\hline $\mathbf{1 9 1 4}$ & 2 & 15 & 1 & 1 & 19 \\
\hline TOTAL & $\mathbf{2 0}$ & $\mathbf{1 4 2}$ & $\mathbf{6}$ & $\mathbf{9}$ & $\mathbf{1 7 7}$ \\
\hline
\end{tabular}

Tabela 46 - Tendência de ocupação étnica, por ano de ocorrência

Embora durante todo o tempo se destaque uma maioria italiana, percebemos que nos anos de 1910 e 1911 houve um aumento considerável da sua presença. Isso tanto pode ser atribuído à entrada de novos imigrantes no bairro, como a um aumento do interesse em investir em algum tipo de negócio. Na investigação da Série Obras Particulares, que não contemplou os anos entre 1908 e 1911, constatamos um pico na presença dos italianos nos anos de 1912 (59 pessoas), 1913 (68 pessoas) e 1914 (65 pessoas), contra uma média de aproximadamente $\mathbf{1 5}$ pessoas para os outros anos. Assim, a tendência apontada naquele levantamento de aumento do número de italianos com interesses no bairro parece se confirmar na investigação aqui realizada, onde a "entrada" desses agentes praticamente dobrou.

\begin{tabular}{|l|c|c|}
\hline \multicolumn{1}{|c|}{ NACIONALIDADES } & $\begin{array}{c}\mathbf{N}^{\circ} \\
\text { USUÁRIOS }\end{array}$ & $\boldsymbol{\%}$ \\
\hline BRASILEIROS E/OU PORTUGUESES & 20 & 11,30 \\
\hline ITALIANOS & 142 & 80,22 \\
\hline OUTROS & 6 & 3,39 \\
\hline NÃO IDENTIFICADOS & 9 & 5,09 \\
\hline TOTAL & $\mathbf{1 7 7}$ & $\mathbf{1 0 0 \%}$ \\
\hline
\end{tabular}

Tabela 47 - Percentual de pessoas identificadas, por nacionalidade

De uma maneira geral, os nomes italianos ou de origem italiana significaram $80,22 \%$ do total de requerentes de licença para a abertura de novos negócios. Em seguida, mas muito longe, vieram os brasileiros e/ou portugueses, com 11,30\% da amostra (20 pessoas). Certamente, entre esses nomes que consideramos como "brasileiros e/ou portugueses" deve haver muitos portugueses, mas sua identificação é praticamente impossível. Se tomarmos o trabalho de Grunspun, de maneira geral, isso confirma o cenário traçado pelo autor para o Bexiga vinte anos mais tarde. Uma maioria italiana, permeada por alguns indivíduos alemães, judeus e espanhóis. Na realidade, entre os nove nomes de outras origens, encontramos duas instituições de origem alemã: a Associação Hospital Alemão e a Sociedade Escola Alemã Vila Mariana. De acordo com as referências encontradas sobre essas instituições: 
"Em 06 de janeiro de 1901, um grupo de funcionários da cervejaria Guanabara, posteriormente Brahma, na São Paulo antiga, num subúrbio, situado no bairro da Vila Mariana, fundam o colégio que teria a grande missão de ensinar os conhecimentos básicos e o alemão. Parte deste grupo já havia fundado, em 1897, o Hospital Alemão, atualmente Hospital Alemão Oswaldo Cruz, em cujas dependências foram realizadas muitas festas do Colégio, com o objetivo de angariar fundos para a sua ampliação $[\ldots] "{ }^{277}$

A Associação Hospital Alemão foi criada justamente com o intuito de construir um hospital que atendesse o grande contingente de imigrantes de língua alemã, reunindo austríacos, alemães e suíços ${ }^{278}$. Como vemos, tratava-se de entidades que concentravam pelo menos parte da colônia alemã na cidade e que possuíam na rua Treze de Maio $\mathrm{n}^{\circ}$ $329^{279}$ um espaço de convivência social.

As categorias outros e não identificados somam 15 pessoas $(8,48 \%)$. Além das duas instituições alemãs, há dois indivíduos com provável origem árabe, um de origem hispânica e outro de origem judaica.

As dificuldades de distinção entre usuários brasileiros e portugueses são as mesmas referentes à identificação dos negros. Em somente duas ocasiões tivemos a oportunidade de localizar nomes que indicassem uma provável origem africana. $\mathrm{Na}$ Série Obras Particulares encontramos os seguintes indivíduos: Tristão Antonio Congo, solicitando "alinhamento para edificação à casa contígua a que já possui”, na rua Vale do Andorra (início da atual rua Santo Antonio) s/no ${ }^{280}$ (1886); e Joaquim Mina, também pedindo “alinhamento para edificação”, no Caaguassú, antiga estrada de Santo Amaro 281 (1890). Nos dois casos, trata-se de possíveis antigos escravos, cujo nome denuncia sua origem. Após a República esses personagens desaparecem. Não sabemos até que

\footnotetext{
${ }^{277}$ Disponível em: http://www.colegiobenjamin.com.br.

${ }^{278}$ As informações sobre a Associação Hospital Alemão foram obtidas no Press Releases elaborado para a abertura da Exposição Histórica dos 110 Anos do Hospital Alemão Oswaldo Cruz, em comemoração aos 110 anos da entidade, e realizada entre setembro de 2007 e março de 2008. Disponível em: www.lvba.com.br/portugues/imprensa/release/haoc_0730.php.

${ }^{279}$ Sobre esta escola quase não encontramos informações. As únicas referências, encontradas em busca realizada na Internet, dizem respeito à propaganda nazista, por época da $2^{\mathrm{a}}$ Guerra Mundial, quando "marchinhas alemãs da Juventude Hitlerista [...] também eram cantadas pelos alunos da Escola Alemã de Vila Mariana”. In: DIETRICH, Ana Maria - Organização política e propaganda Nazista no Brasil (1930-1945). Adaptação das considerações finais de sua Dissertação de Mestrado. DIETRICH, Ana Maria, Caça às Suásticas, O Partido Nazista em São Paulo sob a mira polícia política. Departamento de História - USP, junho de 2001. Disponível em: http://www.cce.udesc.br/cem/simposioudesc/anais/st5/st5ana.doc

No entanto, localizamos informações sobre o Colégio Benjamin Constant, naquele bairro. Tendo em vista o histórico da escola, temos tudo para acreditar que se trata da mesma instituição. Tudo indica que o nome da entidade tenha sido alterado, justamente em função dos problemas políticos citados por Ana Maria Dietrich. Disponível em: http://www.colegiobenjamin.com.br/

${ }^{280}$ Obras Particulares, 21/05/1886, v. 24, p. 36. AHMWL.

281 Obras Particulares, 21/05/1890, v. 37, p. 77. AHMWL.
} 
ponto a Abolição da Escravidão e a mudança de regime político determinou a busca por novas identidades, através da mudança de nomes. De outro lado, é fato que muitos escravos e ex-escravos adotavam os nomes de seus proprietários e/ou patrões. Portanto, não temos como reconhecê-los, ainda que saibamos de sua presença no bairro e na cidade.

A presença de imigrantes brancos de quaisquer origens e brasileiros de origem africana, convivendo lado a lado, coloca uma questão relevante que merece ser pensada. De acordo com os autores que abordaram a questão racial naquele momento de transformações cruciais, a invisibilidade dos negros na cidade se reporta à intenção ideológica de branqueamento racial. Na introdução desta dissertação, já nos reportamos ao trabalho de Carlos José Ferreira dos Santos ${ }^{282}$; a ele podemos acrescentar outros, como Lilia M. Schwarcz e Paulo Cesar Xavier Pereira ${ }^{283}$, autores que embora sob perspectivas diferentes, pensaram a questão racial no Brasil, dos últimos anos do século XIX até, pelo menos, as duas primeiras décadas do século XX.

Para além da questão de fundo deste trabalho - a urbanização na cidade de São Paulo -, não há como ignorar a inserção da cidade num contexto mais abrangente. Se do ponto de vista econômico o Brasil se inseria na realidade mundial através da produção e exportação do café, por outro lado tratava-se também de se afirmar como entidade política, como um Estado/Nação, o que implicava em possuir uma identidade nacional própria. Assim, era preciso saber o que era a identidade nacional brasileira, e o que definiria esta nação. O país possuía uma história recente, cuja população distinguia-se pela mistura de raças, herança de um passado colonial que interessava esquecer, porém impossível de ignorar - tratava-se de solucionar o paradoxo entre a herança colonial e escravista e a aspiração à modernidade. Impunha-se a necessidade de elaboração da nacionalidade brasileira de acordo com os preceitos modernos europeus, assim como era

\footnotetext{
${ }^{282}$ SANTOS, Carlos José - Op. Cit. p. 42.

${ }^{283}$ Carlos José Ferreira dos Santos realizou esta análise do ponto de vista propriamente racial, ao buscar os vestígios “de outros sujeitos, os pobres, 'todos pretos ou quase pretos de tão pobres'”, não nos espaços visíveis representantes da "belle époque paulistana”, mas nas formas de sobrevivência e nas práticas culturais. SANTOS, Carlos José Ferreira dos - Op. Cit.

Lilian Moritz Schwarcz buscou compreender a maneira como os cientistas brasileiros, no final do século XIX, lidaram com a suposta degeneração racial, fruto da miscigenação empreendida ao logo da história brasileira. SCHWARCZ, Lilia Moritz - "Espetáculo da miscigenação”, in Estudos Avançados, São Paulo, v. 8, n. 20, 1994. Disponível em: <http://www.scielo.br.

Paulo César Xavier Pereira analisou a preferência por trabalhadores italianos na construção civil na cidade de São Paulo (1872 a 1914), em detrimento da mão de obra brasileira, in PEREIRA, Paulo César Xavier - São Paulo. A construção da cidade 1872-1914, São Carlos: RiMa/FAPESP, 2004.
} 
preciso estar de acordo com as práticas sociais e econômicas daquele modelo. Se por um lado os ideais republicanos convergiam para um regime político ideal, por outro lado, os ideais abolicionistas deveriam resgatar a idoneidade "moral" necessária sem, contudo, incorporar a população negra ou de origem negra ao imaginário nacional. Como resolver esse impasse? Se não era possível ignorar a multiplicidade de raças formadoras da sociedade nacional, estas deveriam ser incorporadas, mas de que maneira? Do ponto de vista do ideário europeu, a mistura de raças possuía uma conotação claramente negativa. Como bem analisado por Schwarcz, este foi um processo difícil de ser elaborado pelos intelectuais brasileiros que necessitaram "criar fórmulas próprias" para resolver a questão. A discussão foi assumida por diferentes grupos, cada qual se atendo a um aspecto da questão, mas sempre com o mesmo fim de determinar o que e como deveria ser a nação brasileira, ora com discursos que associavam a miscigenação à degeneração racial, ora atacando o problema das doenças endêmicas e a necessidade de saneamento das cidades através do controle das condições de higiene das moradias populares. Sob o ponto de vista de controle e regulamentação social é que juristas propuseram a adequação dos indivíduos e comunidades à idéia de Nação moderna, através de formas jurídicas de controle social, que mantivessem essa população sob tutela “(...) Ante a liberdade prometida pela abolição e a igualdade oferecida pela nova Constituição, parecia imperativo repensar a organização desse novo país (...) os homens não nascem iguaes absolutamente, suppõe-se uma igualdade presumida pela lei sem o que não haveria lei(... $)^{\prime \prime 284}$. Assim, a Abolição da Escravidão, condição fundamental para o Brasil inserir-se no contexto "modernizante", substituindo a mão de obra escrava pela do imigrante, também poderia solucionar a questão da mistura de raças. A introdução do imigrante branco, com o passar de algumas gerações, poderia engendrar um novo povo brasileiro - branco como convinha. Assim, a identidade nacional estaria assegurada, através do "desaparecimento" paulatino de quaisquer traços raciais ou culturais de origem africana.

É nesse contexto de busca da origem "ideal" e tentativa de escamoteamento da realidade que podemos melhor compreender a "invisibilidade" do negro na cidade de São Paulo e, particularmente, no Bexiga. A presença marcante do imigrante no bairro, comprovada pela nossa pesquisa, é um fato inquestionável. Resta então, buscar os sinais

\footnotetext{
${ }^{284}$ Grifo nosso. Artigo de 21/12/1920, publicado no Correio Paulistano, in, SCHWARCZ, Lilia Moritz Op. Cit.
} 
possíveis da presença negra. Os trabalhos de Paulo Kogurama, Maria Luiza F. de Oliveira e Maria Cristina Cortez Wissenbach indicam algumas pistas sobre a sua presença $^{285}$.

No trabalho desenvolvido por Kogurama ${ }^{286}$, localizamos um texto publicado pelo Correio Paulistano, em 03/10/1907, que vale a pena ser transcrito. O artigo, que dispensa qualquer comentário, se presta não somente a comprovar a presença negra na Saracura, como também a fornecer uma imagem das moradias ali existentes:

\section{"A Saracura}

É um pedaço da África. As relíquias da pobre raça impellida pela civilização cosmopolita que invadiu a cidade, ao depois de 88, foi dar alli naquela furna. Uma linha de casebres borda as margens do riacho. O Valle é fundo e estreito. Poças dagua esverdeada marcam os logares donde sahiu a argilla transformada em palacetes e residências de luxo.

Cabras soltas na estrada, pretinhos seminus fazendo gaiolas, chibarros de longa barba ao pé dos velhos de carapinha embranquecida e lábio grosso de que pende o cachimbo, dão áquele recanto uns ares do Congo.

[...] As casas são pequenas; as portas baixas. Há pinturas enfumaçadas pelas paredes esburacadas. A mobília, caixa velha e tóros de pau, sobre ser pobre, é sórdida.

E alli vão morrendo aos poucos - sacrificados pela própria liberdade que não souberam gozar, recosidos pelo álcool e estertorando nas angustias do brightismo que os dizima, eliminados pela evaporação antrhropologica da nova raça paulista - os que vieram dos navios negreiros, que plantaram o café, que cevaram este solo de suor e lágrimas, accumlados alli, como o rebutalho da cidade, no fundo lobrego de um valle' (grifo nosso).

A postura do cronista, em relação aos "que vieram dos navios negreiros", provavelmente refletisse a postura do próprio jornal e a idéia corrente sobre os negros: era gente que não soube usufruir a liberdade, deixando-se levar pelo alcoolismo e pelo brightismo e, que seria (fatalmente?) eliminada pela "nova raça paulista".

Se reportando a um período um pouco anterior, entre as décadas de 1860 e 1870, Maria Cristina Wissenbach, ao pesquisar os inquéritos policiais que envolviam negros (livres, escravos e libertos), identificou nos altos do Caaguassú, alguns desses personagens: Margarida de Azevedo Marques, casada com o lavrador liberto Sabino José da Graça; o escravo Antonio Mina "vivendo de seu ofício de roça”; o pedreiro

${ }^{285}$ KOGURAMA, Paulo - Conflitos do imaginário. A reelaboração das práticas e crenças afrobrasileiras na "metrópole do café". 1890-1920. São Paulo: Annablume/FAPESP, 2001. WISSENBACH, Maria Cristina Cortez - Sonhos africanos, vivências ladinas. Escravos e forros no Município de São Paulo. 1850-1880, dissertação de mestrado, Depto. de História/FFLCH.

${ }^{286}$ KOGURAMA, Paulo - Op. Cit. p. 210 a 212. 
Elias Palhares; o feitor Mestre Domingos; o sapateiro forro, José Sebastião Pereira; o “africano livre” Narcizo e "sua manceba” Maria Guilhermina ${ }^{287}$.

Maria Luiza F. de Oliveira, ao investigar os inventários post-mortem, entre 1850 e 1900, também identificou o Caaguassu como uma "área na cidade de concentração de ex-escravos, africanos, crioulos". Ela encontrou duas pessoas possuidoras de bens de raiz na região. Carolina Monteiro, africana liberta, falecida em 1877, que possuía "uma diminuta casa térrea de três cômodos, velha, de porta e janela, com cozinha atrás, avaliada por 30\$000, e um pequeno terreno de dez braças avaliado por $490 \$ 000$, situado no Caguassu”. A outra pessoa foi "Procópio Fernandes da Costa, africano, [...] casado com Joanna Africana Maria da Conceição”, cujo inventário constava de "uma sorte de terras no Lavapés [...], e uma casinha ou telheiro no morro do Caaguassu, (avaliado) por 220\$000” 288.

Foi exatamente no Caaguassú que, em 1890, localizamos Joaquim Mina, um dos dois casos de requerentes de origem africana registrados nas Obras Particulares. Conforme Wissenbach, essa foi uma das regiões em que ocorreu a formação de núcleos populacionais de negros, que muito rapidamente cederam lugar à expansão física da cidade, vindo a ser ocupados pelos setores mais ricos da sociedade local. Na região do Caaguassú foi aberta, em 1891, a Avenida Paulista. Assim, imaginamos por quanto tempo se manteve a edificação realizada por Joaquim Mina no ano anterior. Que destino terão tido ele e os outros personagens citados pela autora? Se fossem todos proprietários, terão vendido seus imóveis aos especuladores interessados na abertura da futura avenida? $\mathrm{Ou}$, se simples locatários, terão ido procurar abrigo nos cortiços do Bexiga e nos barrancos da Saracura, como atestou a crônica do Correio Paulistano?

Já Armandinho do Bixiga ${ }^{289}$ nos dá notícia mais recente, envolvendo a Saracura: "Existe uma parte, até hoje, que fica entre a Rua Rocha, a Rua Una e a Marquês Leão, que a gente chamava de Saracura, onde se localizavam muitos negros e portugueses. Tanto que foi lá que em 1930 nasceu o Vai Vai. [...] No Saracura, não existia mulato, era tudo negro, aqueles negros bem pretos, todos descendentes de escravos [...]”.

Infelizmente, testemunhos desse tipo e para essa região são raros. Contudo, acreditamos que os casos citados sejam bastante elucidativos em relação à presença negra no bairro do Bexiga e seus arredores. Ao apresentar duas áreas relativamente distantes, mas próximas em relação ao bairro, sugerem a possibilidade de escravos e ex-

\footnotetext{
${ }^{287}$ WISSENBACH, M. C. C. Op. Cit., p. 89.

${ }^{288}$ OLIVEIRA, M. L. F. Op. Cit., p. 125 a 128.

${ }^{289}$ MORENO, Júlio - Op. Cit., p. 87/88.
} 
escravos terem realizado movimentos em dois sentidos. O primeiro deles, em direção do Caaguassu, não se sabe exatamente a partir de quando, mas certamente, até a valorização daquelas terras, por volta dos anos 1890, quando teriam sido expulsos, dando lugar aos loteamentos da Avenida Paulista e da Vila América. O segundo, em direção do Saracura. Ali, também não podemos precisar o início da ocupação, mas as Figuras 82, 83 e 84 indicam a presença de cortiços e casebres em meio à vegetação e o córrego, pelo menos até os anos de 1930, quando da abertura da Avenida 9 de Julho. Na Figura 84, em especial, os dois ou três casebres localizados no centro da fotografia, acima da latrina, se assemelham bastante à descrição do cronista do Correio Paulistano, de 1907. As fotos não permitem a identificação de pessoas, mas tudo leva a crer que nesta área os negros realmente fossem predominantes. De outro lado, as imagens parecem confirmar nossa hipótese sobre a ausência dos fiscais da Diretoria de Obras nessa área do bairro: edificações esparsas, construídas sem uma aparente preocupação com as regras estabelecidas pela municipalidade.

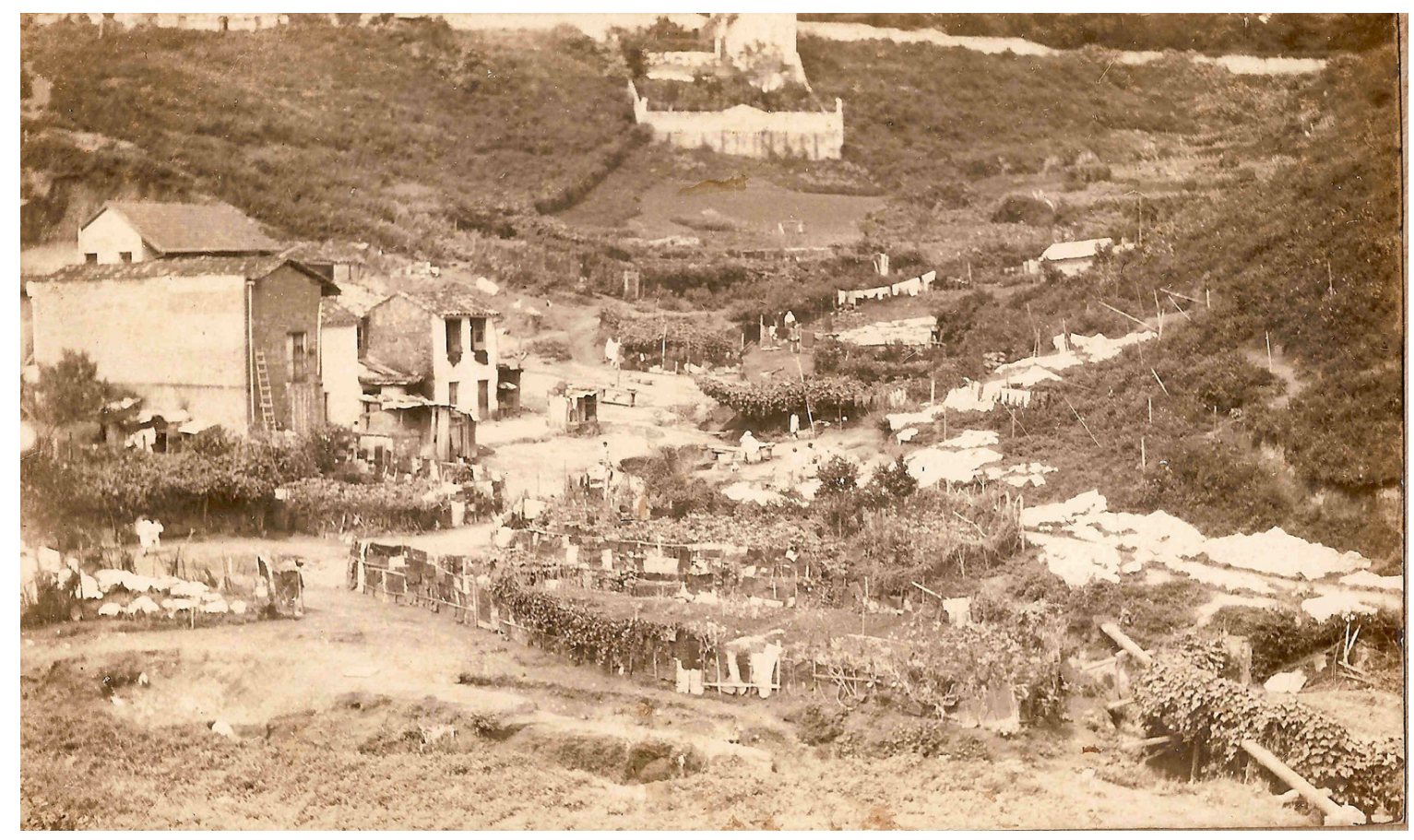

Figura 82 - Barrancos da Saracura Grande e um tipo de implantação que remete a um cenário rural: alguns casarões esparsos na paisagem; pequenos casebres aqui e ali; e quaradores de roupa a demonstrar novamente, a atividade predominante dessas mulheres como lavadeiras. Embora não haja identificação da data em que a foto foi feita, acreditamos que não ultrapasse a década de 1920. Foto: Geraldo Horácio de Paula Souza. S/data. Fonte: Centro de Memória da Saúde Pública/Faculdade de Saúde Pública/USP. 


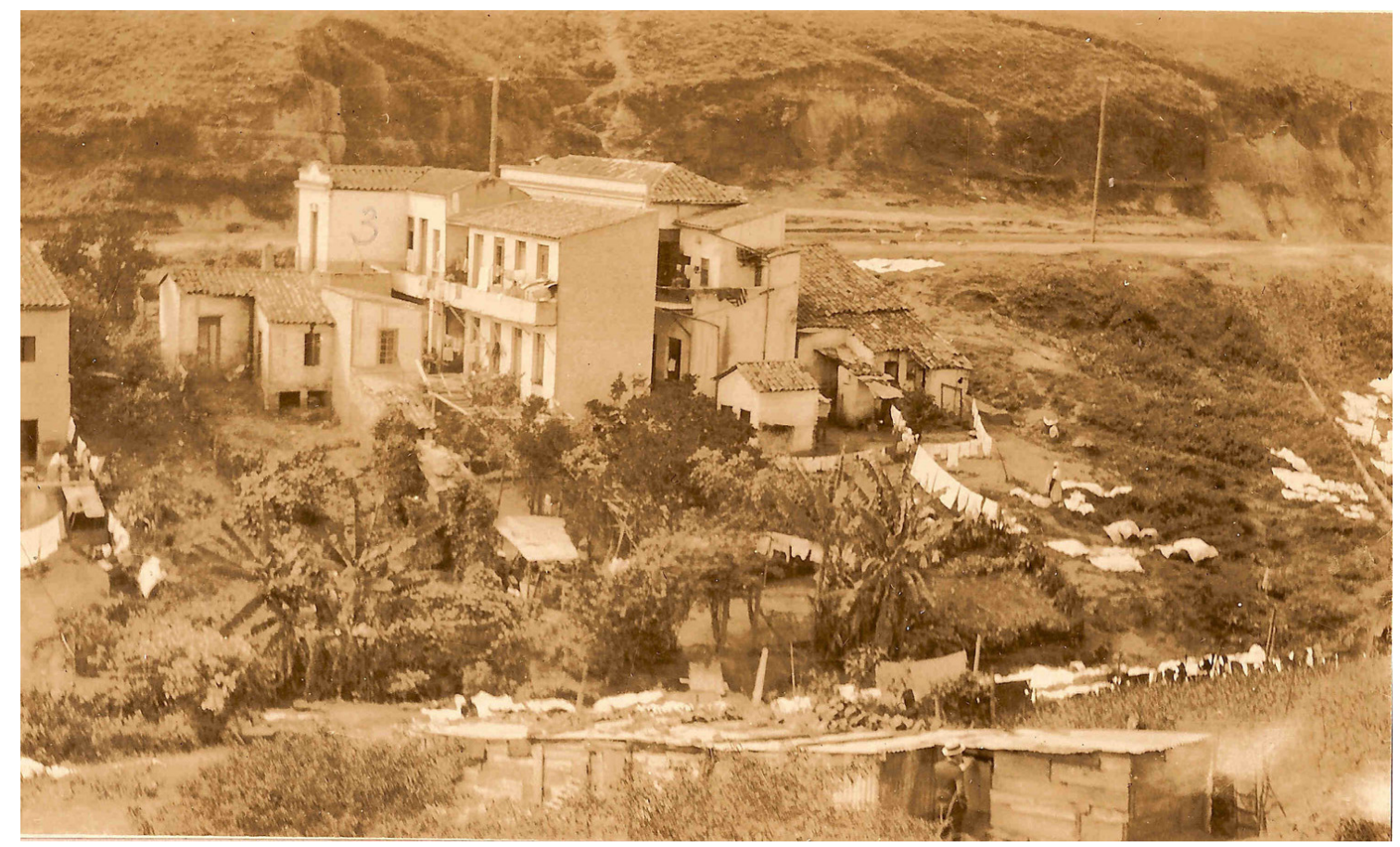

Figura 83 - Fundos de um cortiço localizado na Saracura Grande e roupas quarando, denunciando a atividade predominante dessas moradoras. Foto: Geraldo Horácio de Paula Souza. S/data. Fonte: Centro de Memória da Saúde Pública/Faculdade de Saúde Pública/USP.

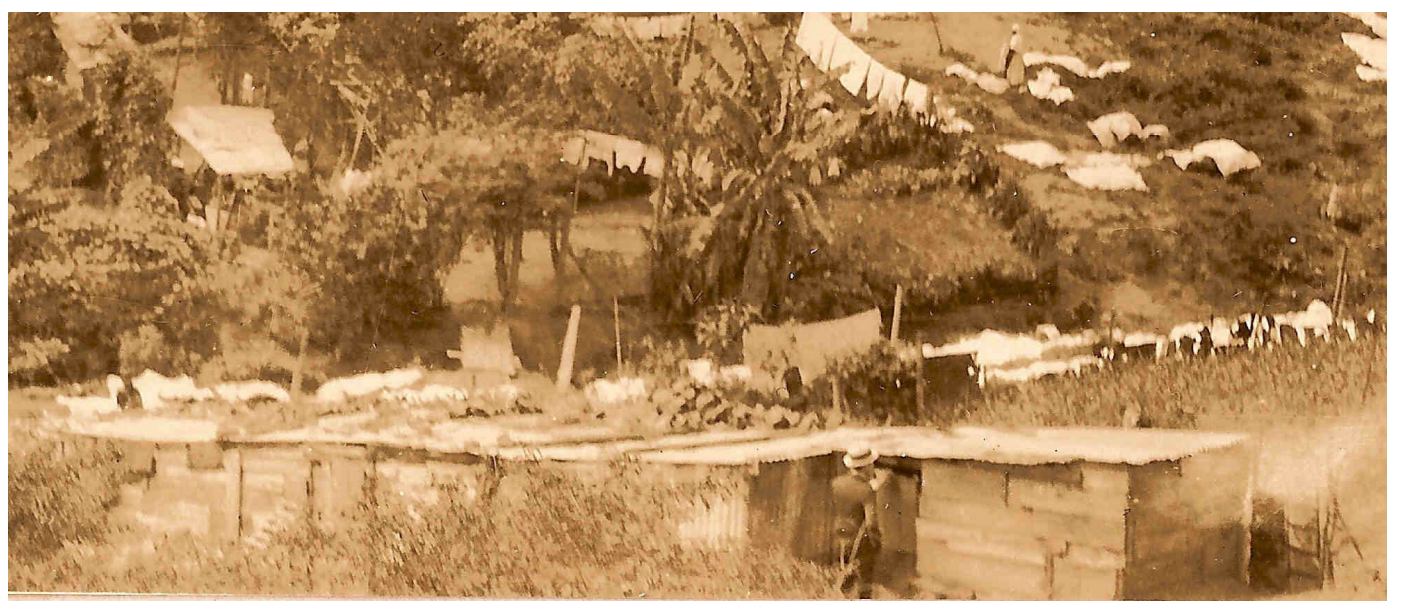

No detalhe, "estábulo improvisado com caixas de papelão”. Entre o estábulo e as roupas no varal, há um número razoável de cabeças de gado pastando, o que confere um ar bastante rural ao local. 


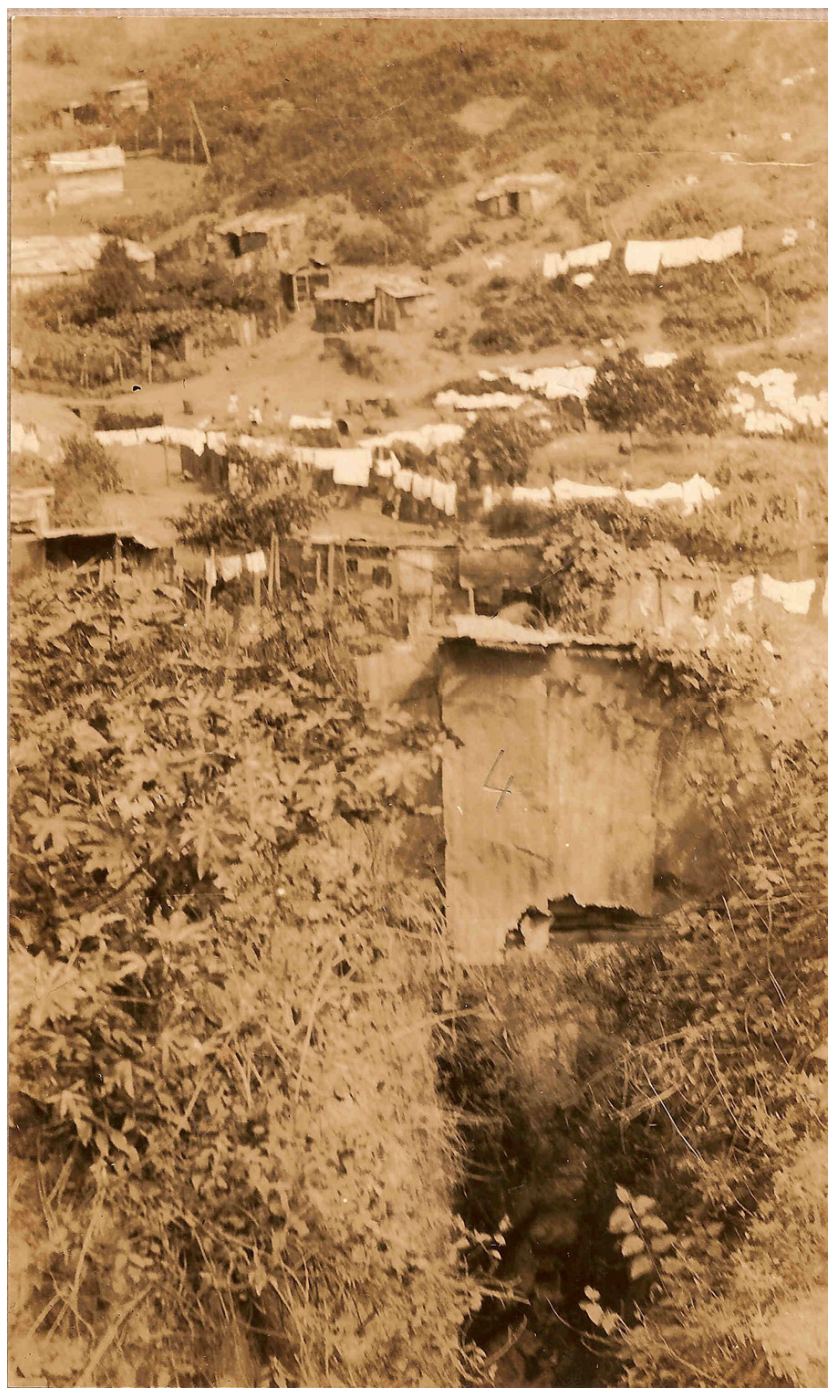

Figura 84 - Em primeiro plano, latrina na Saracura Grande abrindo-se sobre um rego d'água, denunciando a inexistência de esgoto na região. Logo acima, varais com roupa lavada e algumas casinhas construídas nas encostas, que novamente nos remetem a um cenário rural. Foto: Geraldo Horácio de Paula Souza. S/data. Fonte: Centro de Memória da Saúde Pública/Faculdade de Saúde Pública/USP.

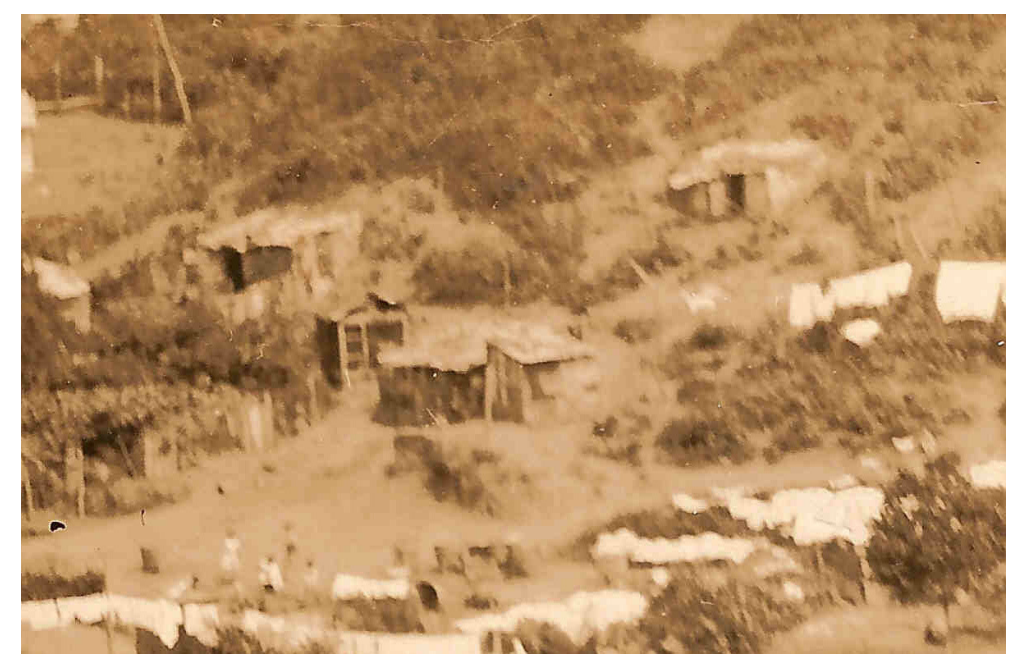

As casinhas, no destaque, remetem à descrição do cronista do jornal Correio Paulistano. 


\subsection{Alguns estudos de caso}

O diálogo entre as principais fontes primárias eleitas para este trabalho - as Séries Obras Particulares e Alvará e Licença, - foi enriquecido pela consulta ao Arquivo Aguirra, e pela consulta a alguns números do Almanaque Laemmert, ambos sob a guarda do Museu Paulista-USP. Em diversas ocasiões obtivemos nessas fontes complementares novas informações que ampliaram nosso conhecimento sobre diversos atores sociais, destacando alguns personagens que de alguma maneira estiveram presentes na construção da história do bairro do Bexiga.

\section{Vicente e Rocco de Franco}

Entre os usuários mais antigos do bairro do Bexiga estão Vicente e Roque de Franco. ${ }^{290}$ Vicente de Franco apresentou:

- Em 1890, pedido de “alinhamento para edificação" à rua Conselheiro Ramalho, s/nº $\mathrm{Na}$ avaliação do requerimento ficamos sabendo que o terreno "alinhará com os números 24 e 28 ”, e que "divide de um lado com o mesmo e de outro com Francisco Fulano”. Essas informações, além de indicarem o provável número 26 para o imóvel, demonstram que ele também era proprietário de um dos terrenos vizinhos.

- Em 11/11/1895, na condição de requerente, ele pediu licença para construir uma casa “com venda”, na mesma rua; então o alinhamento foi dado "pelas casas 44 e 40”, o que pode indicar a adoção do número $\underline{42}$ para o imóvel.

- Em 10/12/1900, “Precisando reconstruir a escada externa que acaba de desabar por efeito das chuvas, solicita licença para dar início as obras" na casa de sua propriedade, à rua Conselheiro Ramalho ${ }^{\circ} 39$.

- Finalmente, em $1906^{291}$, ele encaminhou à Seção de Polícia e Higiene uma "Solicitação de licença para abertura de jogo de bolas, vulgarmente chamado de "bocce", na rua Conselheiro Ramalho n 62.

Todos os endereços fornecidos por Vicente de Franco se localizavam na rua Conselheiro Ramalho, sendo que nas duas primeiras ocasiões, os imóveis receberam os

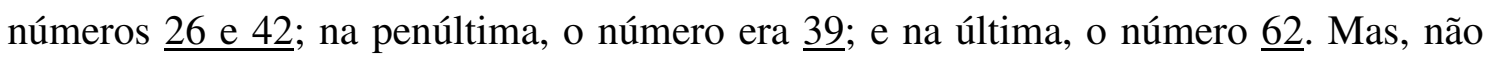
podemos esquecer que o imóvel localizado no número $\underline{24}$ ou no $\underline{28}$, também era de sua

\footnotetext{
${ }^{290}$ Obras Particulares, Processos de 1890, v.34, p. 189; 11/11/1895, v.81, p. 49; 10/12/1900, v.266, p. 91.

${ }^{291}$ Alvará e Licença, Processo de 20/01/1906, Cx. 695.
} 
propriedade. O primeiro emplacamento realizado pela Prefeitura foi apenas em 1908, em momento posterior às solicitações, portanto, é provável que realmente se tratasse de imóveis diferentes. Dessa maneira, a partir da constatação de diferentes requerimentos para edificações na mesma rua, podemos supor que, num primeiro momento, Vicente Franco tenha investido em imóveis de aluguel, posteriormente, resolvendo abrir seu próprio negócio, quando apresentou uma "Solicitação de licença para abertura de jogo de bolas, vulgarmente chamado de "bocce", no número 62, da rua Conselheiro Ramalho $^{292}$.

Já sobre Rocco (ou Roque) de Franco temos as seguintes informações:

- Em 1893, ele apresentou o primeiro requerimento junto à Seção de Obras ${ }^{293}$. O processo não possui um requerimento formal, apenas o projeto de uma casa contendo armazém, quarto, sala de jantar, cozinha, despensa e quintal, a ser construída na rua Monte de Ouro, s/n (atual rua João Passalacqua).

- Em 08/05/1900, o construtor Miguel Marzo projetou acréscimos para o imóvel: “tendo de construir uma cozinha e um quarto nos fundos da casa existente", de propriedade de Rocco de Franco, à rua Conselheiro Ramalho no $35^{294}$.

- Quase cinco anos depois, em 16/01/1905, o próprio Rocco requereu licença para a construção de "uma casinha entre duas existentes", na mesma rua Conselheiro Ramalho $\mathrm{n}^{\circ} 37 \mathrm{E}^{295}$.

- Finalmente, em 12/04/1907, Rocco apresentou à Seção de Polícia e Higiene, uma "solicitação de licença para instalação do negócio" de "secos e molhados", no número 35 da rua Conselheiro Ramalho ${ }^{296}$.

Vicente e Rocco de Franco estão entre os agentes que investiram no bairro nos primeiros dez anos do loteamento. O sobrenome comum e a proximidade dos endereços podem indicar que eram pessoas da mesma família. Se quisermos fazer conjecturas, o endereço citado por Rocco para a construção de casa com armazém localizava-se na rua Monte de Ouro, sem número. Essa, que foi a única rua diferente indicada por ele, é paralela à rua Conselheiro Ramalho. Assim, pode-se pensar que inicialmente se tratava de um único lote, com saída para as duas ruas. Independente dessa ser uma hipótese sujeita à confirmação, faz sentido pensarmos que a família "de Franco" tenha investido

\footnotetext{
${ }^{292}$ Alvará e Licença, Processo de 12/04/1907, Cx. 1907.

${ }^{293}$ Obras Particulares, Processo de 28/03/1893, v. 10.

${ }^{294}$ Obras Particulares, Processo de 08/05/1900, v.266, p. 82.

295 Obras Particulares, Processo de 14/01/1905. v.408, p. 79.

${ }^{296}$ Alvará e Licença, Processo de 12/04/1907, v.1907 (?).
} 
recursos na compra de terrenos numa mesma quadra no bairro do Bexiga. Num segundo momento, quando ambos já estavam estabelecidos, talvez vivendo das rendas auferidas com o aluguel das suas casas, cada um decidiu abrir seu próprio negócio. Porém, em processo de 21/11/1895, encontramos outro possível membro da mesma família, Nicolau de Franco ${ }^{297}$. Nesse processo, Nicolau solicitava licença para a construção de uma casa no número 42 da rua Conselheiro Ramalho, sob a responsabilidade do construtor Júlio Saltini. A interpretação da planta indica que esse não era o único terreno em nome de Nicolau; no quintal ao lado da casa a ser edificada havia uma outra casa existente, onde se lê que "pertence ao mesmo proprietário".

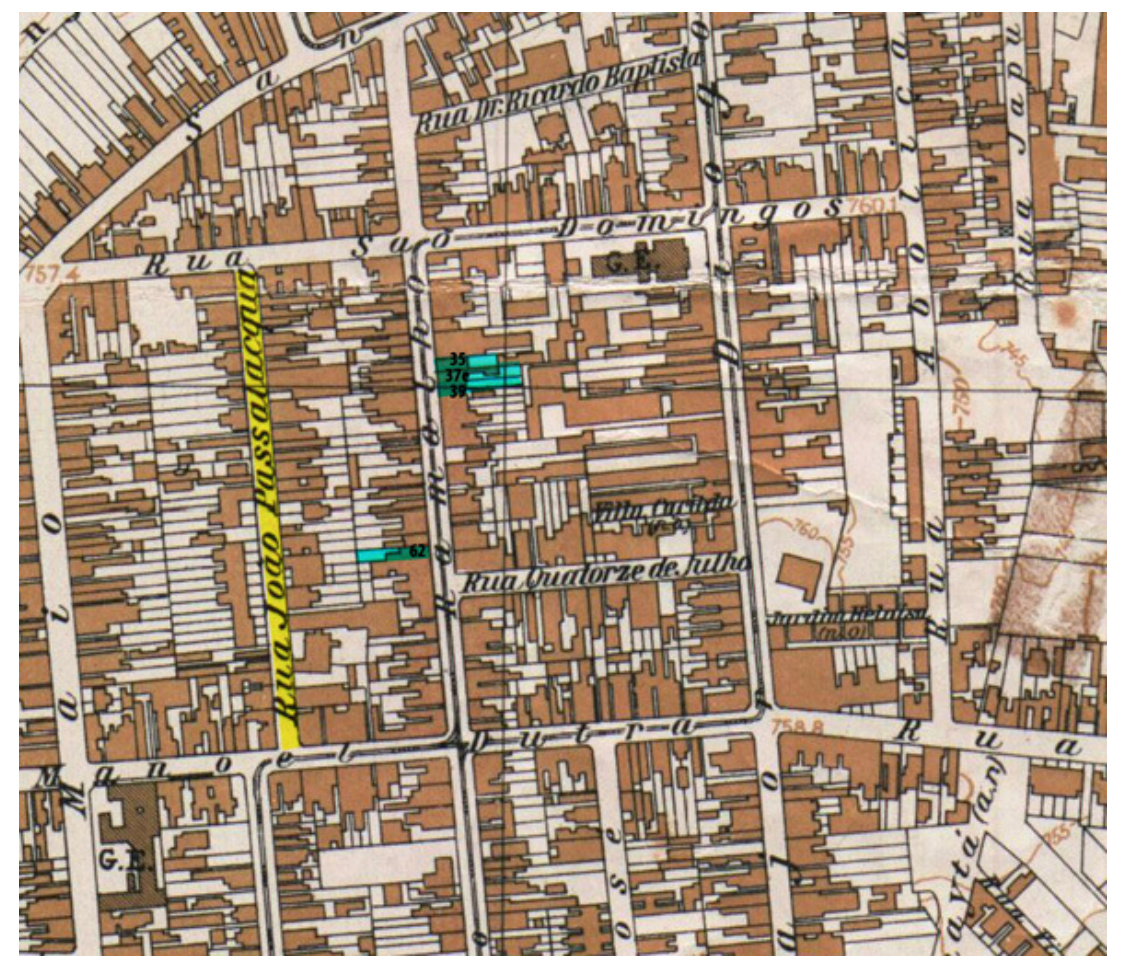

Figura 85 - Provável localização dos imóveis de propriedade dos irmãos de Franco. Fonte: SARA Brasil, 1930, Fl. 37. AHMWL.

No levantamento realizado no Arquivo Aguirra ${ }^{298}$, descobrimos que Rocco de Franco faleceu em 1935, aos 69 anos de idade. De acordo com o registro de

\footnotetext{
297 Obras Particulares, Processo de 21/11/1895. v.81.

${ }^{298}$ Trata-se de uma coleção de documentos organizada por João Baptista de Campos Aguirra, integrante do acervo do Serviço de Documentação Textual e Iconográfica, do Museu Paulista, da USP. De acordo com o artigo de Walter Pires para os Anais do Museu Paulista ${ }^{298}$, entre as atividades exercidas por Aguirra como pesquisador da história paulista, está o trabalho para a empresa Informação Aguirre. Informações sobre títulos de propriedades imobiliárias. Ao que indicam as palavras do autor, o trabalho naquela empresa "corresponde à atividade comercial e arquivística que passou a ser conhecida como Arquivo Aguirra”. Ainda conforme Walter Pires, a coleção envolve, entre outros documentos, uma coleção de fichas, mapas, cadastros, livros e fotografias.
} 
Aguirra, Rocco era viúvo de Rosa Franco. O conjunto de bens deixados pelo casal para os herdeiros constava de duas casas: uma casa na rua Conselheiro Ramalho $\mathrm{n}^{\circ}$ 51, no valor de 4.200.000 (?), e outra, na rua João Passalacqua nº 29.

\section{Manoele Paladine}

Manoele Paladine, ou Manoel Paladine, se destacou por ser um dos poucos personagens que jamais mudou de endereço. Nós o encontramos em quatro momentos diferentes entre 1899 e 1912. Na primeira ocasião, em 19/08/1899, solicitou licença para construir uma casa na rua Manoel Dutra $n^{\circ} 15$. O projeto apresentado era muito simples: uma casa de sala, quarto e cozinha ${ }^{299}$. Em 20/01/1911, doze anos depois, aparentemente já estabelecido com uma quitanda no mesmo endereço, solicitou alvará de licença e guia para "pagar o imposto do negócio", licença essa renovada no final do ano, quando "Desejando continuar com o negócio, neste endereço, solicita guia para pagamento do imposto do próximo ano" ${ }^{\text {300 }}$. Sua última aparição foi em 08/02/1912, quando entrou com o seguinte requerimento na Diretoria de Obras: "Desejando transformar uma janela da frente de seu prédio em porta, solicita guia para pagamento de imposto”. Essa transformação certamente tinha como objetivo abrir uma (ou outra) porta para a quitanda; o requerimento foi aprovado e a obra orçada em 150\$000. Manoel Paladine parece ter levado uma vida bem simples. Começou construindo um prédio de uso residencial com somente três cômodos e quintal. No decorrer dos treze anos investigados abriu um negócio na mesma casa, que não deve ter dado errado, já que renovou a licença pelo menos duas vezes. Não sabemos se em algum momento Paladine aumentou sua casa, se acrescentou cômodos no espaço disponível no quintal, ou se fez qualquer tipo de alteração no imóvel, além da "transformação da janela em porta". O fato de ter construído uma casa, adaptada posteriormente para acomodar um negócio, indica que também morou nela. Paladine certamente está entre os inúmeros proprietários que sobreviveram no bairro do Bexiga à custa de seu trabalho como pequeno comerciante.

\footnotetext{
${ }^{299}$ Alvará e Licença, Processo de 19/08/1899, v. 243, p. 107.

${ }^{300}$ Alvará e Licença, Processos de 20/01/1911, v. 721; e 27/12/1911, v. 722.
} 


\section{Carmela Petroni (ou Pedrone)}

O nome de Carmela se destacou porque, além de ter sido uma das poucas pessoas confirmadas como moradora do Bexiga, foi uma mulher que esteve à frente de seu negócio por mais de cinco anos. Em 15/01/1906, em requerimento entregue à Seção de Polícia e Higiene, ela dizia que "estabelecida com a família neste endereço e desejando continuar com o seu ramo de negócios, solicita a presença de cobrador para pagamento de imposto" ${ }^{301}$. Carmela se refere a "desejar continuar" com o negócio (não definido), o que significa que exercia a atividade há pelo menos um ano. Já nos referimos à obrigatoriedade de renovação anual da licença para os negociantes, e esse foi o caso daquele requerimento e dos outros dois entregues em 21/02/1910 e 21/02/1911. Entretanto, Carmela, em um determinado momento mudou seu negócio, do número 194 da rua Conselheiro Ramalho para o número 226 da mesma rua ${ }^{302}$, onde ainda estava em 1911. Não sabemos a que se deveu esta mudança: talvez Carmela fosse locatária da casa onde morava e trabalhava; talvez o proprietário tenha aumentado muito o valor do aluguel, levando-a a buscar uma casa mais barata; talvez o prédio não comportasse mais o negócio e a família... O caso é que buscou o novo imóvel nas proximidades do primeiro. Não encontramos seu nome entre os proprietários ou requerentes da Série Obras Particulares, o que pode indicar que realmente era uma simples locatária. O fato de ser uma mulher à frente do negócio é sugestivo, embora não fosse algo incomum: encontramos vinte e duas mulheres exercendo atividades comerciais de alguma espécie no bairro durante os anos investigados, aproximadamente $12,09 \%$ do total de 182 pessoas investigadas em nossa amostra.

Como já dissemos, uma fonte que se mostrou muito importante para elucidar sobre os atores sociais usuários do bairro foram os almanaques. No Almanaque Laemmert para o ano de 1909, encontramos algumas pessoas conhecidas. Foi o caso, por exemplo, de José Falcone, que consta como proprietário de um açougue, à rua Treze de Maio $\mathrm{n}^{\circ}$ 20, no subtítulo “Açougues" 303 . Já em 1905, instalado à rua Treze de Maio $\mathrm{s} / \mathrm{n}^{\mathrm{o}}$, Falcone, “desejando aumentar seu prédio, conforme a planta junta, solicita(va) a respectiva aprovação" ${ }^{304}$. A planta entregue por ele à Diretoria de Obras

\footnotetext{
${ }^{301}$ Alvará e Licença, Processo de 15/01/1906, Cx. 694.

${ }^{302}$ Consultamos o Índice de Emplacamentos, no AHMWL, para saber se no emplacamento realizado em 1908, o número correspondente ao endereço do negócio de Carmela havia mudado para 226, mas constatamos que não se tratava do mesmo endereço.

${ }^{303}$ Almanaque Laemmert, «Açougues », 1909, p. S19. Museu Paulista/USP.

${ }^{304}$ Obras Particulares, 11/08/1905, v. 425, p.134.
} 
apresentava uma casa composta de açougue (no alinhamento), seguido de dois quartos e despensa, além de corredor descoberto à direita. $\mathrm{O}$ acréscimo, cuja licença estava sendo solicitada, referia-se a uma sala de jantar e uma cozinha, a serem edificadas no prolongamento da construção. Anexa ao processo há uma declaração de que " $a$ construção destina-se à habitação de uma família”. Desses documentos, podemos deduzir que naquele momento Falcone estava ampliando a parte da casa utilizada para moradia de sua família. Já na Série Alvará e Licença descobrimos que, dois anos depois, em 1907, Giusepe Falcone, "querendo realizar uma festa na rua 13 de Maio, Bexiga, solicita autorização para levantar um coreto, assim como a guia para pagamento do imposto devido" ${ }^{305}$. Esse caso parece confirmar a hipótese que aventamos acima, sobre as festas de rua serem organizadas por pessoas de maiores posses. Tratava-se de alguém que estava estabelecido com negócio no bairro, desde antes de 1905, e que, certamente, possuía condições de arcar com as despesas da festa. Pudemos confirmar essa hipótese em outra pesquisa realizada no AHMWL, junto à mesma Série Obras Particulares, em outros logradouros não contemplados nesta investigação. Encontramos, no ano de 1907, uma solicitação em nome de Giusepe Falcone, para construção de seis casas em série, à rua Francisca Miquelina. Essa informação confirma que se tratava de pessoa de posses, e que Falcone foi mais um dos atores sociais do bairro que diversificou seus investimentos, seja como dono de açougue, seja como investidor no mercado imobiliário.

Outro personagem a constar no subtítulo "Açougues” foi José Toste (ou Tosta). Naquela ocasião, em 1909, o endereço do açougue era à rua Major Diogo $n^{\circ} 71^{306}$. Em 05 de fevereiro de 1910, José Tosta "desejando dar baixa do imposto do jogo de bolas neste endereço, devido ao fechamento em $1^{\circ}$ de janeiro, solicita baixa de lançamento" 307 . Em algum momento, Tosta abriu um "jogo de bolas" no número 43, na mesma rua Major Diogo, endereço bem próximo do açougue. Ao que parece, o negócio não deu certo, já que agora ele queria oficializar o fechamento. Três anos depois, em 27 de março de 1913, "querendo reformar e aumentar seu prédio, conforme a planta junta, solicita aprovação e alinhamento" 308 para o número 49 da rua Major Diogo. Embora a planta acusasse um armazém construído no alinhamento, seguido de quarto, sala e

\footnotetext{
305 Alvará e Licença, 01/08/1907, Cx.699.

${ }^{306}$ Almanaque Laemmert, «Açougues », 1909, p. S19. Museu Paulista/USP.

307 Alvará e Licença, 05/02/1910, Cx.713.

${ }^{308}$ Obras Particulares, 27/02/1913, Cx.M1.
} 
cozinha, a reforma do prédio implicava na transformação da antiga cozinha em quarto e no acréscimo de outro quarto e nova cozinha. Portanto, era uma reforma para moradia, só não se sabe se da sua própria residência ou de uma casa alugada a terceiros. Em 24 de novembro do mesmo ano ${ }^{309}$, Tosta voltou a solicitar licença para modificação do prédio, desta vez, para aumentar o espaço do armazém, a partir da incorporação de 1,50 metros do corredor lateral. Na verdade, a recorrência do nome de José Tosta na Série Obras Particulares, em endereço distinto daqueles fornecidos pelo Almanaque e pela Série Alvará e Licença, não significa necessariamente que ele tenha sido proprietário do “armazém” citado. Contudo, o situa como proprietário desse imóvel. De qualquer maneira, constatamos uma certa mobilidade no bairro, ainda que sempre na mesma rua.

Atuando no ramo das "Chapelarias" encontramos mais dois personagens interessantes: Adolpho Schritzmeyer e Antonio Brigante. O primeiro, estabelecido com a empresa Adolpho Schritzmeyer \& Cia. no Largo do Piques $\mathrm{n}^{\circ} 11^{310}$, e o segundo estabelecido como fabricante de "Chapéus para homem”, na rua Major Diogo $\mathrm{n}^{\circ} 78^{311}$. Conforme os registros da Série Obras Particulares, Antonio Brigante, em 18 de dezembro de $1912^{312}$, apresentou o seguinte requerimento para a rua Maria José $\mathrm{n}^{\mathrm{o}}$ 5: “desejando construir um prédio, conforme a planta junta, 25 metros retirados da rua, onde existe uma cocheira a ser demolida, solicita aprovação da mesma”. No parecer técnico elaborado pelo engenheiro responsável, no dia 24 de dezembro: "Existe um grande cortiço na parte do terreno, cuja frente dá para a rua Major Diogo e que não obedece ao padrão municipal”; por fim, temos que em 27 de dezembro o pedido foi indeferido. A julgar pelas descrições feitas pelo requerente e pelo engenheiro, tratava-se de um único lote, com saídas para as ruas Maria José e Major Diogo. Acreditamos que não seria mera coincidência se a saída para a rua Major Diogo fosse o mesmo endereço fornecido para a fábrica de "chapéus para homem", segundo o Almanaque Laemmert localizada à rua Major Diogo $\mathrm{n}^{\mathrm{o}} 78$, principalmente se levarmos em conta que a rua Maria José tem seu início quando a outra rua já está quase na metade de seu percurso.

Já Schritzmeyer é um nome bem mais conhecido. A família foi proprietária de uma das maiores fábricas de chapéus da cidade na última década do século XIX. De acordo com

\footnotetext{
${ }^{309}$ Obras Particulares, 24/11/1913, Cx.M1.

${ }^{310}$ Almanaque Laemmert, « Açougues », 1909, p. S34. Museu Paulista/USP.

${ }^{311}$ Almanaque Laemmert, «Açougues », 1909, p. S34. Museu Paulista/USP.

312 Obras Particulares, 18/12/1912, Cx. M1.
} 
Paula Beiguelman ${ }^{313}$, João Adolpho Schritzmeyer esteve entre os fabricantes de chapéus, cujos operários participaram dos movimentos grevistas entre 1896 e 1897. Embora não haja registros em nome da empresa na Série Alvará e Licença, julgamos que o fato da fábrica constar no Almanaque Laemmert justifique que o relacionemos aqui. Por outro lado, nós encontramos registros em nome de Adolpho Daniel Schritzmeyer na Série Obras Particulares em três ocasiões:

- Em 09/12/1905, quando o construtor José Kanz apresentou a seguinte solicitação de licença para a rua Conselheiro Ramalho $\mathrm{n}^{\circ}$ 18: "O proprietário da casa, desejando rebaixar o passeio para ficar no nível das guias, calçar a parede da frente e construir platibanda, solicita licença para montar andaime ${ }^{\text {314. }}$

- Em 12/03/1913, o próprio Adolpho Daniel requereu licença para “abertura de um portão no muro ao lado da casa 42, que faz frente para a rua (nova) João Adolpho”. O endereço fornecido foi à rua Santo Antonio, junto ao número $42^{315}$.

- Em 08/05/1913, Adolpho Daniel solicitou licença para construir “um barracão para oficina de carpintaria”, à "rua Sem Nome, na primeira travessa à direita da Santo Antonio ${ }^{, 316}$.

Em nenhuma dessas três ocasiões os endereços fornecidos são coincidentes com aquele do Almanaque Laemmert. A coincidência está nas três propriedades em nome de uma mesma pessoa, indicando que a família Schritzmeyer também investiu em imóveis no bairro.

Um outro nome encontrado no Almanaque Laemmert foi Luigi Russo. Em 12 de fevereiro de 1906, ele encaminhou à Seção de Polícia e Higiene um requerimento solicitando licença para abertura do negócio de “dourador”, no número 23 A do Largo do Riachuelo ${ }^{317}$. Três anos depois, ele já fazia propaganda do seu negócio no Almanaque $^{318}$, mantendo-se no mesmo endereço.

$\mathrm{O}$ fato desses indivíduos anunciarem no Almanaque Laemmert, anuário publicado na Capital Federal, parece dizer algo, se não sobre o êxito de seus negócios, certamente sobre a tentativa de acerto. Acima citamos exemplos de uma certa diversidade de prestadores de serviços, de pequenos e médios comerciantes, assim como

\footnotetext{
313 BEIGUELMAN, Paula - Os companheiros de São Paulo, São Paulo: Edições Símbolo, 1977, p. 19.

314 Obras Particulares, 09/12/1905, Cx. 428, p. 28.

315 Obras Particulares, 12/03/1913, Cx. S2.

${ }^{316}$ Obras Particulares, 08/05/1913, Cx. S2.

${ }^{317}$ Alvará e Licença, 12/02/1906, Cx. 695.

318 Almanaque Laemmert, 1909, p.S-40.
} 
de algumas fábricas e manufaturas. No subtítulo "Outros", encontramos referência à produção de diversos artigos: sabão, caixas de papelão, chapéus, velas, louças, cervejas, etc. Entretanto, as referências identificadas como "fábricas" possivelmente se definissem melhor como "manufaturas". A julgar pelos nomes dos proprietários dessas empresas, uma grande maioria era de origem italiana, mas o que mais nos chamou a atenção foi o fato de muitos deles estarem estabelecidos em ruas do Bexiga. Isso nos dá algumas indicações interessantes sobre as dimensões atingidas pela urbanização do bairro: o número expressivo de negociantes ali domiciliados e a diversidade de atividades produtivas, ainda que de pequeno e médio porte. Por outro lado, a busca por formas mais eficazes de divulgação de seus negócios, demonstra que esses negociantes estavam atentos às tendências modernizantes da época.

\subsection{Algumas Considerações}

Embora tenhamos buscado explorar ao máximo as possibilidades de análise de cada uma das fontes investigadas, o confronto entre as informações fornecidas por todas elas foi fundamental para nossa análise, ora viabilizando o aprofundamento de algumas questões, ora complementando informações às vezes apenas sugeridas por uma ou outra fonte. Ao permitir que traçássemos o perfil dos personagens atuantes e esboçássemos pelo menos parte do cenário de sua atuação, as diversas fontes possibilitaram as primeiras conclusões sobre a urbanização do bairro, apresentadas a seguir.

\section{Mapeamento da ocupação espacial do loteamento}

A abertura dos negócios significou a satisfação das necessidades de seus moradores e vizinhanças, principalmente no que diz respeito à alimentação, mas também à necessidade de pequenos serviços e de algum eventual lazer. $\mathrm{O}$ aumento dos serviços oferecidos, assim como a expansão dos mesmos pelas ruas do bairro, acompanhou o aumento da densidade populacional e dessa forma percebemos que com o passar dos anos as ruas do loteamento original foram sendo ocupadas pelas novas edificações destinadas à moradia e negócios. A levarmos em conta o mapa SARA Brasil, de 1930, na Figura 80, nessa época o arruamento do Bexiga estava praticamente completo, ainda que algumas ruas conservassem a nomenclatura antiga. 
Abaixo relacionamos, na Tabela 48, os principais logradouros correspondentes ao atual bairro da Bela Vista. Observe-se que as ruas destacadas com um asterisco, por se localizarem em pontos-limite do bairro, não foram objeto de nossa investigação.

\begin{tabular}{|c|c|}
\hline LOGRADOURO & NOMENCLATURA ANTIGA \\
\hline RUA ABOLIÇÃO & RUA ABOLIÇãO \\
\hline RUA ALMIRANTE MARQUES LEÃO & PARTE DA ANTIGA RUA DA SARACURA GRANDE \\
\hline PRAÇA DA BANDEIRA & LARGO DO PIQUES/RIACHUELO \\
\hline AV. BRIGADEIRO LUÍS ANTONIO (*) & (PROLONGAMENTO DA) RUA SANTO AMARO E CAAGUASSÚ \\
\hline RUA CONSELHEIRO CARRÃo & RUA CONSELHEIRO CARRÃO \\
\hline RUA CONSELHEIRO RAMALHO & RUA CONSELHEIRO RAMALHO \\
\hline RUA DR. LUIZ BARRETO & RUA DO SOL \\
\hline RUA DR. Plínio BARRETO & RUA DA SARACURA PEQUENA \\
\hline RUA DR. RICARDO BATISTA & TRAVESSA MAJOR DIOGO \\
\hline RUA FORTALEZA & RUA FORTALEZA \\
\hline RUA JACEGUAI (*) & (PROLONGAMENTO) DA RUA MANOEL DUTRA \\
\hline RUa JoÃo PaSSALACQUa & RUA MONTE DE OURO \\
\hline RUA MAJOR DIOGO & RUA DOS VALINHOS \\
\hline RUA MANOEL DUTRA & RUA CONSELHEIRO ANTONIO PRADO \\
\hline RUA MARIa JOSÉ & RUA MARIA JOSÉ \\
\hline AV. NOVE DE JULHO ( $)$ & RUA DA SARACURA GRANDE \\
\hline PRAÇA 14 Bis $(*)$ & LARGO SÃO MANOEL \\
\hline RUA QUATORZE DE JULHO & RUA QUATORZE DE JULHO \\
\hline RUA RUI BARBOSA & RUA RUI BARBOSA \\
\hline RUA SANTO AMARO & RUA SANTO AMARO \\
\hline RUA SANTO ANTONIO & RUA VALE DO ANDORRA \\
\hline RUA SÃO DOMINGOS & RUA SÃO DOMINGOS \\
\hline RUA SÃo VICENTE & RUA SÃO VICENTE \\
\hline RuA Treze de MaIo & RUA TREZE DE MAIO \\
\hline
\end{tabular}

(*) Logradouros não contemplados nas investigações.

Tabela 48 - Relação dos logradouros investigados com as antigas nomenclaturas

Em seguida, montamos a Tabela 49, contendo a distribuição do total das atividades nestas ruas, descontados os casos sem identificação da atividade. Aqui podemos observar em que medida os negócios abertos no bairro contribuíram para a sua ocupação e urbanização. Constatamos que a rua preferida pelos negociantes foi a Conselheiro Ramalho, reunindo 38 dos estabelecimentos $(22,22 \%$ do total de 171 estabelecimentos). Em seguida, vinham as ruas Santo Antonio e Major Diogo, a primeira com $22(12,87 \%)$ e segunda com 20 estabelecimentos (11,7\% do total). Atrás dessas vinham o Largo do Riachuelo, com 18 negócios, e a rua Rui Barbosa, com 14 negócios, $10,53 \%$ e 8,18 \% da amostra, respectivamente. Somente esses cinco logradouros reuniram 65, $05 \%$ dos negócios que funcionaram no bairro. Os 34,05\% restantes se distribuíram por outras 12 ruas do bairro, algumas ocupadas mais intensamente do que outras. 


\begin{tabular}{|c|l|c|c|}
\hline $\begin{array}{c}\mathbf{N}^{\circ} \\
\text { RUAS }\end{array}$ & \multicolumn{1}{|c|}{ RUA } & $\begin{array}{c}\mathbf{N}^{\circ} \text { DE } \\
\text { REGISTROS }\end{array}$ & $\%$ \\
\hline $\mathbf{1}$ & CONSELHEIRO RAMALHO & 38 & 22,22 \\
\hline $\mathbf{2}$ & SANTO ANTONIO & 22 & 12,87 \\
\hline $\mathbf{3}$ & MAJOR DIOGO & 20 & 11,70 \\
\hline $\mathbf{4}$ & LARGO DO RIACHUELO & 18 & 10,53 \\
\hline $\mathbf{5}$ & RUY BARBOSA & 14 & 8,18 \\
\hline $\mathbf{6}$ & SÃO DOMINGOS & 10 & 5,85 \\
\hline $\mathbf{7}$ & MANOEL DUTRA & 9 & 5,26 \\
\hline $\mathbf{8}$ & LARGO DO PIQUES & 7 & 4,10 \\
\hline $\mathbf{9}$ & SANTO AMARO & 7 & 4,10 \\
\hline $\mathbf{1 0}$ & MARIA JOSÉ & 7 & 4,10 \\
\hline $\mathbf{1 1}$ & 13 DE MAIO & 6 & 3,50 \\
\hline $\mathbf{1 2}$ & ABOLIÇÃO & 4 & 2,33 \\
\hline $\mathbf{1 3}$ & FORTALEZA & 3 & 1,76 \\
\hline $\mathbf{1 4}$ & CONSELHEIRO CARRÃO & 2 & 1,16 \\
\hline $\mathbf{1 5}$ & DO SOL & 1 & 1,16 \\
\hline $\mathbf{1 6}$ & SÃO VICENTE & 1 & 0,59 \\
\hline $\mathbf{1 7}$ & SARACURA PEQUENA & $\mathbf{1 7 1}$ & 0,59 \\
\hline & TOTAL & & $\mathbf{1 0 0 \%}$ \\
\hline
\end{tabular}

Tabela 49 - Distribuição das atividades econômicas

Se confrontarmos a planta do Bexiga (Figura 80) com a Tabela 48 veremos que o bairro se delineava a partir do largo do Riachuelo. Nesse largo nascia uma das ruas mais antigas da região, a Santo Antonio e a partir dela é que nasciam as ruas que iriam atravessar toda a extensão do bairro, até desembocarem na avenida Brigadeiro Luís Antonio. Entre elas, estavam justamente duas daquelas que concentraram o maior número de estabelecimentos, a Major Diogo e a Conselheiro Ramalho. A exceção fica por conta da Rui Barbosa que começava a partir da rua Manoel Dutra. O fato dessas ruas percorrerem o bairro de norte a sul dá uma medida de sua importância para a população local. Importância essa confirmada pela referência feita por Haim Grünspun, sobre o itinerário do bonde, durante os anos de 1930.

"[...] o bonde que vinha para a Conselheiro Ramalho e descia pela Rui Barbosa e Manoel Dutra nunca estava cheio[...]" e "Dai tinha que esperar o bonde [...], porque na rua Conselheiro Ramalho ele só subia e na rua Rui Barbosa ele só descia”319.

Assim temos um bonde que, provavelmente, saindo do Largo do Riachuelo, passasse pela rua Santo Antonio, entrasse na Conselheiro Ramalho, retornando em seguida pela rua Rui Barbosa. Em algum momento ele também andava pela rua Manoel Dutra, não sabemos se na ida ou na volta do percurso. Certo é que essas ruas configuravam corredores de acesso para quem entrava, saía, ou mesmo andava pelo bairro. Portanto, se estabelecer comercialmente em ruas de tráfego mais intenso devia ser promessa de bons negócios. Por outro lado, se a proximidade de locais de comércio

${ }^{319}$ GRÜNSPUN, Op.cit., ps.30 e 53. 
era um aspecto que valorizava os empreendimentos imobiliários, a proximidade de um meio de transporte como o bonde só podia elevar as possibilidades de ganho.

\section{Atuação dos órgãos oficiais em relação à abertura e fiscalização dos negócios}

Até meados de 1911, um dos anos selecionados para o levantamento na Série Polícia e Higiene, a facilidade com que essas solicitações eram deferidas faz pensar se uma das principais preocupações dos órgãos oficiais não seria a arrecadação dos impostos daí advindos, independente das condições de funcionamento dos estabelecimentos ou observância do Código Sanitário de 1894. Entretanto, nos levantamentos realizados no ano de 1914, já se faz clara uma fiscalização mais rígida, com o fechamento frequente daqueles negócios, sempre que não se adaptassem às normas de higiene. Exemplo disso é o processo, de 28 de janeiro de 1914, em nome de Ângelo Paladino, sobre a abertura de uma quitanda, dizendo que "Desejando estabelecer o negócio à rua Major Diogo, baixos do prédio que fica no canto da avenida Brigadeiro Luiz Antonio, para o que adaptou o lugar... de acordo com o Artigo 255 e seu parágrafo do Decreto $n^{\circ} 2141$, de 14 de novembro de 1911, pelo que solicita a respectiva licença...”. Cabe ainda ressaltar que, pelo menos parte dos negócios abertos no bairro, funcionavam nas próprias moradias de seus proprietários, ficando patente em algumas ocasiões, a preocupação dos fiscais com as condições de higiene dos estabelecimentos, como pode ser verificado no processo de 22 de fevereiro de 1911, em nome de Carmella Petroni, sobre a abertura de quitanda à rua Conselheiro Ramalho $\mathrm{n}^{\mathrm{o}} 226$, conforme o parecer do 'lançador',

“[...] trata-se de um depósito de bananas e não de uma quitanda. Ainda que o 'armazém' presta-se, mas, demolindo um sótão de madeira existente para não servir de dormitório [...].”

Como o período abrangido pela pesquisa envolveu um tempo relativamente longo (33 anos), no decorrer desse tempo o bairro sofreu não somente as transformações causadas pelo aumento da imigração e o crescente aumento populacional, como também o aumento do controle exercido pelo poder público, que, entre outras coisas, se deu através do emplacamento das ruas e casas do bairro. Como visto acima, cada processo aberto por um comerciante significava o aumento da arrecadação de impostos e era imperativo que a municipalidade identificasse exatamente quem eram e onde se localizavam os potenciais contribuintes. Esse foi um, dentre outros motivos, para que 
desde 1908 fossem realizados levantamentos periódicos das ruas da cidade, localizados no Índice de Emplacamento da Prefeitura (AHMWL), com a atualização dos registros dos nomes das ruas e da numeração dos prédios.

Por fim, a presença maciça de italianos, ao menos como usuários, deu um tom especial à cultura do bairro, até hoje marcante, embora não implicasse em novos hábitos de morar, já que as tipologias edilícias respeitaram os Códigos de Posturas e o Código Sanitário, seguindo padrões semelhantes em toda a cidade. 


\section{CONSIDERAÇÕES FINAIS}

De acordo com a definição de Roberto Mônaco (1991), “o valor da terra, depende da capacidade do solo de produzir rendas a partir do modo de produção vigente". Beatriz Bueno (2005/2008), ao constatar a presença de inúmeros imóveis de particulares, alugados a terceiros, no ano de implantação da Décima Urbana (1809), se refere ao papel da propriedade imobiliária na composição da riqueza, valor esse que naquele momento associava-se ao seu potencial "rentista". O crescente número de solicitações de datas de terras, encaminhadas à Câmara Municipal, desde 1850, vem atestar o incremento dessas práticas no decorrer da segunda metade do século XIX. O loteamento do bairro do Bexiga foi parte significativa do processo de expansão territorial e de transformação urbana de caráter capitalista que ocorreu na cidade, no qual o solo urbano adquiriu um valor inusitado no último quartel do século XIX.

No processo de sedimentação da nova ordem econômica, diferentes papéis foram representados por variados atores sociais, fossem eles oriundos da oligarquia cafeeira, fossem estrangeiros recém-chegados, fossem personagens urbanos anônimos. Cada um atuou de acordo com suas posses, mas sempre buscando auferir vantagens das mudanças políticas, econômicas e sociais então em curso.

Membros de reconhecidas famílias tradicionais como os Pais de Barros, os Souza Queiroz e os Prado, tiveram papéis decisivos nas mudanças econômicas e políticas. Além da atividade agroexportadora, eles atuaram em todas as frentes: na comercialização da produção agrícola, no setor financeiro (bancos), na introdução de infra-estrutura urbana, no exercício de cargos políticos e na especulação imobiliária. Sua atuação não se restringiu às iniciativas de grande porte, pois também investiram em empreendimentos populares, como bem demonstrado nos exemplos de Francisca de Paula de Souza e Mello, a "segunda" Baronesa de Limeira, e de Francisco Xavier Paes de Barros, o Barão de Tatuí, nas imediações do Bexiga.

Além dos membros da oligarquia, também atuaram no mercado imobiliário imigrantes possuidores de capital necessário para investir em terras e na construção de casinhas para aluguel, como Victor Nothmann, bem como investidores na indústria em gestação, como a família Clark, ou mesmo pessoas como Antonio José Leite Braga, certamente com menos "poder de fogo" do que o primeiro, mas igualmente interessado em desfrutar das possibilidades de lucro que a cidade oferecia. 
Atuaram assim imigrantes e brasileiros, muitos deles integrantes das camadas médias da sociedade urbana, para quem a modernidade colocava novas opções de inserção social, através da exploração de pequenos e médios negócios. Da mesma forma, os imigrantes destituídos de recursos, que encontraram na cidade em expansão não somente a possibilidade de sobrevivência, mas, sobretudo a oportunidade de conquistar um espaço social. Naquele momento, a atuação praticamente isolada do imigrante no mercado da construção civil, ao lado de certo espírito empreendedor, abriu perspectivas para a formação de um pecúlio através da compra de terrenos e da construção de moradias para locação. Foi o caso de construtores como Francisco Paulo Lambolha e Gregori Luigi. Isso, para não falar dos supostos brasileiros João Ferraz de Campos, Joaquim de Quadros Guimarães e Leopoldino Antonio dos Passos, todos eles comprovadamente proprietários de imóveis.

A abertura de negócios foi outra possibilidade explorada pelos imigrantes moradores do bairro do Bexiga, onde proliferaram armazéns, quitandas, manufaturas e oficinas de pequeno porte, ocupando os espaços possíveis. Os inúmeros pedidos de licença para "transformar janelas em portas" denunciam que a sala da frente da casa seria transformada em espaço para negócios. A instalação de fornos nos fundos das casas indica a existência de pequenas padarias, que poderiam estar associadas a uma quitanda ou a um armazém de "secos e molhados", assim como os barracões construídos nos fundos dos terrenos foram ocupados por fabriquetas de macarrão, ou ainda pelas oficinas. Oficinas essas que faziam de tudo um pouco: conserto de peças utilizadas no dia a dia, como máquinas de costura, carroças estacionadas nas cocheiras, ferragem dos animais, ou envolvidas no fabrico de gradis e portões utilizados nas construções, etc. Oficinas também funcionaram no espaço doméstico, não necessariamente no cômodo da frente, mas, frequentemente nos porões, utilizados por costureiras, alfaiates e sapateiros.

Embora não saibamos precisar os motivos, constatamos que no Bexiga o imigrante desempenhou papéis diversos daqueles encontrados em outros bairros, onde o cenário seria marcado pela associação dos elementos estrada de ferro/fábrica/operário. Zuleika Alvim (1986), ao estudar a história dos imigrantes italianos em São Paulo indicou que "é preciso estar atento aos valores próprios da sociedade pré-industrial e às diferenças regionais, que os faziam identificar-se como vênetos, calabreses, 
lombardos e outros, muito mais do que como italianos, já que isso influiu em sua integração na sociedade paulista” ${ }^{320}$. O Bexiga parece ter sido ocupado preferencialmente por calabreses que, supostamente, seriam adversos à disciplina imposta pela lógica industrial, preferindo o trabalho por conta própria, no qual eram seus próprios patrões. Embora esta seja uma afirmação fundamentada até certo ponto no senso comum, carece de investigação e análise aprofundada.

Ao lado dos espaços construídos ou adaptados a atividades produtivas, observam-se inúmeras construções destinadas à locação - diferentes tipologias serviram aos mais variados tipos de moradia (casas de fundo, vilas e sobrados, quando não o aproveitamento dos espaços disponíveis transformados em habitações coletivas ou cortiços). Tratava-se tanto de gente que usufruiu dos resultados do próprio trabalho, como Vicente e Rocco de Franco, José Falcone e José Tosta, como daqueles que exploraram a pobreza alheia, como parece ter sido o caso do Padre Paschoal Gazíneo, de José Maria Passalacqua e de Joaquim Antunes dos Santos. Enfim, aquele foi um momento de oportunidade para todos ou quase todos.

Identificar os papéis exercidos pelos atores sociais que atuaram na conformação do bairro do Bexiga, em todas as suas instâncias (como empreendedores, proprietários, construtores ou usuários), envolve a desmistificação desses mesmos papéis, assim como desse espaço urbano. É necessário compreender como se deu a inserção do imigrante no bairro, levando-se em conta a variedade de fatores que interagiram entre si, envolvendo ajustes com os próprios brasileiros. A forma como esses dois sujeitos se interrelacionaram, ora se associando, ora se hostilizando, poderá ajudar a compreender de que maneira foram incorporados no ideário de nação brasileira.

A integração dos imigrantes à sociedade local e ao espaço urbano não ocorreu de forma linear, dependendo de como conseguiram se inserir naquele contexto de transição. Carlos José Ferreira dos Santos (1998), ao se referir ao trabalho feminino e infantil nas indústrias têxteis cita documentos a partir dos quais infere que "além da qualificação técnica, os patrões [...] presumivelmente procuravam operários que pudessem incorporar a ordem do trabalho, os valores e os comportamentos que atendessem aos padrões sociais e culturais esperados”. Em praticamente todas as atividades desempenhadas pelos imigrantes não se levava em conta a possibilidade de

${ }^{320}$ ALVIM, Zuleika M. F. - Op. Cit., pg. 61. 
uso da mão de obra local (branca ou negra), considerada como atrasada, ignorante, tecnicamente desqualificada e não submissa. Assim, a inserção social do imigrante através do trabalho, na medida em que correspondia às expectativas, pode ter sido facilitada, pelo menos até o momento das primeiras greves, quando passaram a mostrar um engajamento político indesejado.

Se a crença na superioridade racial e cultural do estrangeiro significou para uma parcela da população a possibilidade de branqueamento, para o homem comum, especialmente para negros e mestiços pertencentes às camadas baixas da sociedade, na maioria das vezes significou uma disputa desigual pelo mercado de trabalho. De acordo com Carlos José Ferreira dos Santos (1998), esses segmentos, via de regra, se ocupavam dos serviços socialmente desvalorizados: eram cocheiros, lavadeiras, empregados domésticos, vendedores ambulantes, coletores de lixo, ou simplesmente viviam de "expediente".

Nossas investigações em busca de pistas da presença negra no bairro do Bexiga foram infrutíferas. Com exceção das duas únicas referências a esses atores sociais, não localizamos quaisquer outros indícios que confirmassem sua existência. Colocou-se então a pergunta: onde estavam e viviam os negros?

A resposta, ainda que parcial, foi localizada nos trabalhos de Maria Luiza Ferreira de Oliveira (2005), Maria Cristina Wissenbach (1989) e Paulo Kogurama (2001). Da mesma maneira que as profissões passíveis de serem exercidas por antigos escravos e seus descendentes foram aquelas desvalorizadas pelos segmentos médios da população, o mesmo aconteceu em relação ao espaço de viver e morar. Segundo os autores supracitados, restaram a esses personagens anônimos ocupar os espaços desocupados, pelo menos enquanto estes não se tornassem alvo da especulação imobiliária, como foi o caso do Caaguassú e do Saracura. Era apenas uma questão de tempo. Por fim, parecem ter restado os cortiços da rua Almirante Marques Leão e, alguns anos mais tarde, o complexo de cortiços da rua Japurá.

Dessa maneira, é compreensível que para esses sujeitos, ser preterido em favor do estrangeiro podia significar um olhar estigmatizante em relação aos primeiros, sendo de se supor que sua percepção em relação àqueles contivesse fortes ressentimentos, ainda que nem sempre claros. Atualmente, a noção do Bexiga como um "bairro tipicamente italiano" carrega implicitamente a idéia de bairro "branco", ainda que saibamos da presença do negro. O mesmo ideário que, entre as últimas décadas do século XIX e as primeiras do século $\mathrm{XX}$, fixou no imaginário paulista e nacional a 
cidade de São Paulo como locomotiva do progresso e paradigma de modernidade, de certa forma conseguiu estender à época contemporânea a invisibilidade do negro. Acreditamos que os ressentimentos entre brancos e negros foram em grande parte alimentados por essa invisibilidade, que por sua vez favoreceu o preconceito e a discriminação.

Entre os anos de 1912 e 1914, o bairro já dava sinais da proliferação das habitações coletivas e do processo de "encortiçamento" que viria a ocorrer nas décadas seguintes. A construção de barracões para oficinas e fabriquetas, casas de fundos ou mesmo vilas no interior dos terrenos (cujas áreas livres reduziam-se cada vez mais), a transformação de antigas cocheiras em residências, assim como os sobrados ocupados por duas residências, todos supostamente dentro dos parâmetros colocados pela legislação sanitária, ainda que a custa de embates contínuos entre proprietários e municipalidade, apontam para o aproveitamento exaustivo dos espaços ainda vazios. Por outro lado, as inúmeras intimações, multas e embargos, que por vezes envolviam um único processo, colocam em evidência o comportamento reincidente de proprietários e construtores, demonstrando a crescente perda de controle da situação por parte da Diretoria de Obras, frente ao acirramento da especulação imobiliária evidenciando a tendência do que iria ocorrer neste e noutros bairros populares da cidade nas próximas décadas.

Um olhar mais simplista sobre essa situação, baseado na assertiva de que o espaço construído no Bexiga teria se realizado aleatoriamente - movido pela vontade e pelo saber-fazer do imigrante italiano, orientado por suas próprias tradições culturais -, poderia até indicar que a contínua perda de controle do poder público sobre o ato de construir tivesse se originado dessas tradições, como se a "herança cultural" do inconsciente coletivo teimasse em orientar os procedimentos de proprietários e construtores quanto ao uso do espaço e à arquitetura praticada. No entanto, a construção e a apropriação do espaço urbano estavam agora, mais do que nunca, sujeitas às imposições da nova ordem higienista. Assim, acreditamos que a perda de controle se deva muito mais, de um lado, ao crescimento demográfico e a consequente demanda habitacional, e, de outro lado, ao despreparo da municipalidade em lidar com uma sociedade complexa, cujos atores sociais apresentavam necessidades e interesses conflitantes. 
Parte do resultado final deste trabalho se deve à busca de respostas às perguntas sugeridas pelas fontes primárias. A exploração de indícios deixados pelos documentos, que à primeira vista poderiam aparentar pouco significado, revelou aspectos esclarecedores acerca da atuação de determinados atores sociais e do próprio processo de urbanização do bairro. Foi como se jogássemos um instigante jogo de quebracabeças, onde peças soltas, aqui e ali, indicavam novas pistas. A investigação de cada uma delas permitiu, pouco a pouco, a montagem do cenário e a compreensão do enredo, assim como do papel de cada um dos personagens envolvidos. Fernando de Albuquerque foi um caso exemplar nesse sentido. Ao manipular as oportunidades oferecidas pelo momento histórico, ajudou a engendrar não apenas um bairro, mas a própria cidade. Dessa maneira, passou de mero personagem coadjuvante a protagonista de um momento histórico decisivo para a transformação de São Paulo.

Assim, concluímos que tão importantes quanto as hipóteses que nortearam nosso projeto inicial, foram as indagações e dúvidas decorrentes do trabalho de investigação e análise dos documentos. Ainda que tenhamos buscado levar às últimas consequências a desmistificação de certas personalidades, a compreensão do processo de encortiçamento de determinadas áreas e a obstinada invisibilidade do negro no bairro do Bexiga, a permanência dessas questões ainda no século XXI demonstra que sempre há novos caminhos a percorrer para a recuperação da memória urbana, e, quem sabe, para a compreensão dos seus caminhos e descaminhos contemporâneos. 


\section{BIBLIOGRAFIA}

ALAMBERT, Clara Correia d' e FERNANDES, Paulo Cesar Gaioto - "Bela Vista: a preservação e o desafio da renovação de um bairro paulistano”, Revista do Arquivo Municipal, no 204, São Paulo: DPH, 2006

ALVIM, Zuleika M. F. - Brava gente! Os italianos em São Paulo. 1870-1920, São Paulo: Brasiliense, 1986, $2^{\text {a }}$ Edição

ARQUIVO MUNICIPAL WASHINGTON LUÍS - Guia do Arquivo Histórico Municipal Washington Luís, São Paulo: DPH, 2007

AMERICANO, Jorge - “O Padre Gazineu”, São Paulo naquele tempo (1895-1915), São Paulo: Saraiva, 1957

BARBUY, Heloisa - A Cidade-Exposição. Comércio e cosmopolitismo em São Paulo, 1860-1914, São Paulo: Edusp, 2006

BEIGUELMAN, Paula - Os companheiros de São Paulo, São Paulo: Símbolo, 1977

BONDUKI, Nabil - Origens da habitação social no Brasil, São Paulo: Estação Liberdade/FAPESP, 1998

BRITTO, Iêda Marques - Samba na cidade de São Paulo(1900-1930): um exercício de resistência cultural, São Paulo: FFLCH/USP, 1986.

BUENO, Beatriz Siqueira - Aspectos do mercado imobiliário em perspectiva histórica. São Paulo (1908-1950), São Paulo: FAUUSP, 2008

CAMPOS JR., Eudes de Mello - Arquitetura paulistana sob o Império, tese de Doutorado, FAUUSP, 1996 - “A vila de São Paulo do Campo e seus caminhos”, In Revista do Arquivo Municipal - 30 anos de DPH, n 204, São Paulo, 2006. p. 28.

CASTRO, Márcio Sampaio de - Bexiga, um bairro afro-italiano: comunicação, cultura e construção de identidade étnica, Dissertação de Mestrado, ECA/USP, 2006

CAVALCANTI, Nireu - O Rio de Janeiro setecentista: a vida e a construção da cidade da invasão francesa até a chegada da Corte, Rio de Janeiro: Jorge Zahar, 2004

CHALHOUB, Sidney - Cidade febril: cortiços e epidemias na Corte imperial, São Paulo: Cia. das Letras, 1996

COMISSÃO DE PATRIMÔNIO CULTURAL DA USP - A casa de Dona Iaiá, São Paulo: Edusp/Imprensa Oficial, 2001

CORONA, Eduardo e LEMOS, Carlos A. C. - Dicionário da arquitetura brasileira, São Paulo: EDART, 1972 
CORREIA, Telma de Barros - A construção do habitat moderno no Brasil - 18701950, São Carlos: RiMa, 2004

DICK, Maria Vicentina de Paula do A. - A dinâmica dos nomes na cidade de São Paulo (1554-1897), São Paulo: ANNABLUME, 1996

EMPLASA - Memória Urbana: a grande São Paulo até 1940, São Paulo: Arquivo do Estado/IMESP, 2001 (3 v.)

GENNARI, Luciana Além - As casas em série do Brás e da Mooca: um aspecto da constituição da cidade de São Paulo, dissertação de Mestrado, FAUUSP, 2005

GRÜNSPUN, Haim - Anatomia de um bairro. O Bexiga, São Paulo: Cultura, 1979

INSTITUTO MOREIRA SALLES - Guilherme Gaensly e Augusto Malta: dois mestres da fotografia brasileira no Acervo Brascan. Exposição comemorativa da doação do Acervo Branscan ao IMS. Rio de Janeiro, São Paulo, Belo Horizonte, Poços de Caldas: IMS, 2003/2004.

KATINSKY, Julio Roberto - Um guia para a história da técnica no Brasil Colonia, FAUUSP, São Paulo, $2^{\text {a }}$ Edição, 1980

KOGURUMA, Paulo - Conflitos do imaginário: a reelaboração das práticas e crenças afro-brasileiras na 'Metrópole do Café' (1890-1920)”, São Paulo:

ANNABLUME/FAPESP, 2001

KUHL, Beatriz Mugayar - Arquitetura do ferro e arquitetura ferroviária em São Paulo, São Paulo: SEC/FAPESP/Ateliê, 1998

LÉFÈVRE, José Eduardo de Assis. De beco a avenida: A história da rua São Luiz. São Paulo: Edusp, 2006

LEPETIT, Bernard - Por uma nova história urbana, São Paulo: Edusp, 2001

LEMOS, Carlos A. C. - A República ensina a morar (melhor), São Paulo: Hucitec, 1999 - Alvenaria burguesa, São Paulo, Nobel: 1985 - Casa paulista, São Paulo: Edusp, 1999 - Cozinhas, etc., São Paulo: Perspectiva, 1976

LUCENA, Célia Toledo de - Bixiga, amore mio, São Paulo: Parnatz, 1981

MARINS, Paulo Cezar Garcez - Através da rótula: sociedade e arquitetura no Brasil, séculos XVII a XX, São Paulo: Humanitas/FFLCH/USP, 2001 - "Habitação e vizinhança: dimensões de uma privacidade possível”, in História da vida privada no Brasil, República: da Belle Époque à Era do Rádio, vol. 3, SEVCENKO, Nicolau (Org.), São Paulo: Cia. das Letras, 1998 
MARQUES, Gabriel - Ruas e tradições de São Paulo, São Paulo: Imprensa Oficial do Estado, 1966

MARTINS, Antonio Egydio - São Paulo antigo: 1554-1910, São Paulo: Paz e Terra, 2003

MARZOLA, Nádia - “Bela Vista”, in História dos Bairros de São Paulo, vol. 15, Depto. Patrimônio Histórico, Secr. da Cultura/Prefeitura de São Paulo, dez/1979 MIORANZA, Ciro - Dicionário dos sobrenomes italianos, v. 1, São Paulo: Escala, 1997.

MONACO, Roberto - As terras devolutas e o crescimento da cidade de São Paulo (1554 a 1930). Dissertação de Mestrado, FAUUSP, 1991.

MORENO, Julio - Memórias de Armandinho do Bexiga, São Paulo: Editora SENAC São Paulo, 1996

MORSE, Richard - Formação histórica de São Paulo, São Paulo: Difel, 1970

OLIVEIRA, Maria Luiza F. de - Entre a casa e o armazém: relações sociais e experiência da urbanização - São Paulo, 1850-1900, São Paulo: Alameda, 2005

PEREIRA, Paulo César Xavier - São Paulo. A construção da cidade 1872-1914, São Carlos: RiMa/FAPESP, 2004 - “A modernização de São Paulo no final do século XIX”, in SAMPAIO, Maria Ruth Amaral de (coord.) - Habitação e cidade, AUUSP/FAPESP, 1998

PIRES, Walter - Configuração territorial, urbanização e patrimônio: Colônia da Glória (1876-1904), dissertação de Mestrado, FAUUSP, 2003

REIS F $\mathrm{F}^{\mathrm{o}}$, Nestor Goulart - "Algumas experiências urbanísticas no início da República: 1890-1920”, in Cadernos de Pesquisa do LAP, n 1, São Paulo: FAUUSP, julago/1994

- "Cultura e estratégias de desenvolvimento”, in Cadernos de Pesquisa do LAP, $\mathrm{n}^{\circ} 23$, São Paulo: FAUUSP, jan-fev/1998

- “Habitação popular no Brasil: 1880-1920”, in Cadernos de Pesquisa do LAP, n 2, São Paulo: FAUUSP, set/1994 - Quadro da arquitetura no Brasil, São Paulo: Perspectiva, 1ª Edição, 1970

- Quadro da arquitetura no Brasil, São Paulo: Perspectiva, 10a. Edição, 2004 - São Paulo e outras cidades: produção social e degradação dos espaços urbanos, São Paulo: Hucitec, 1994 
- São Paulo - Vila, cidade e metrópole, FAPESP, CNPq, Prefeitura do Município de São Paulo, 2004

SAIA, Luís - Morada paulista, São Paulo: Perspectiva, 1978

SAINT-HILAIRE, Auguste de - Viagem à província de São Paulo, Belo Horizonte: Itatiaia; São Paulo: Edusp, 1976

SALIBA, Elias Thomé - "A dimensão cômica da vida privada na República”, in História da Vida Privada no Brasil, vol. 3, São Paulo: Cia. das Letras, 1998

SALMONI, Anita \& BENEDETTI, Emma - Arquitetura italiana em São Paulo, São Paulo: Perspectiva, 1981

SAMPAIO, Maria Ruth A. de - O papel da iniciativa privada na formação da periferia paulistana, São Paulo: Espaço e Debates, $\mathrm{n}^{\circ} 37$

SANT'ANNA, Nuto - São Paulo Histórico (Aspectos, Lendas e Costumes), v. I, Departamento De Cultura, São Paulo, 1937

SANTOS, Carlos José Ferreira dos - Nem tudo era italiano: São Paulo e a pobreza, 1890-1915, São Paulo: ANNABLUME, 1998

SEVCENKO, Nicolau - Orfeu extático na metrópole: São Paulo, sociedade e cultura nos frementes anos 20, São Paulo: Companhia das Letras, 1992

TOLEDO, Benedito Lima de - São Paulo: três cidades em um século, São Paulo: Duas Cidades, 1981

VAZ, Lílian Fessler - Uma história da habitação coletiva na cidade do Rio de Janeiro - Estudo da Modernidade através da moradia, Tese de doutorado apresentada à FAUUSP, 1994

VIEIRA, A. Paim - Chácara do Capão, Separata da Revista do Arquivo, $\mathrm{n}^{\circ}$ CXLVIII, São Paulo: Depto. de Cultura, 1952.

WISSENBACH, Maria Cristina Cortez - "Da escravidão à liberdade: dimensões de uma privacidade possível”, in História da Vida Privada no Brasil, v. 3, São Paulo: Cia. das Letras, 1998. - Sonhos africanos, vivências ladinas. Escravos e forros no Município de São Paulo. 1850-1880. Dissertação de Mestrado apresentada ao Departamento de História da FFLCH/USP, 1989. 


\section{SITES CONSULTADOS}

BUENO, Beatriz Siqueira - "Tecido urbano e mercado imobiliário em São Paulo: metodologia de estudo com base na Décima Urbana de 1809”, in Anais do Museu Paulista, v. 13, nº 1, São Paulo: Museu Paulista/USP, 2005. Disponível em: <http://redalyc.uaemex.mx/redalyc/html> Acesso em: 28/11/2009

CAMPOS, Cristina de - "A promoção e a produção das redes de águas e esgotos na cidade de São Paulo. 1875-1892”, in Anais do Museu Paulista, v. 2, juldez/2005. Disponível em: <http://redalyc.uaemex.mx/redalyc/html > Acesso em: 23/10/2007

CAMPOS JR., Eudes de Mello - “Casas e vilas operárias” in Informativo Arquivo Histórico Municipal, São Paulo: PMSP/SMC/DPH, 2 (10): jan-fev/2007 Disponível em: <http://www.arquivohistorico.sp.gov.br> Acesso em: 17/05/2009 - “Chalés paulistanos” in Anais do Museu Paulista, v. 16, n 1, São Paulo: Museu Paulista/USP, 2008. Disponível em: <http://redalyc.uaemex.mx/redalyc/html> Acesso em: 11/09/2008 - “Mercados Públicos da São Paulo Oitocentista”, in Informativo Arquivo Histórico Municipal, São Paulo: PMSP/SMC/DPH, 2 (10), jan/fev 2007. Disponível em: <http://www.arquivohistorico.sp.gov.br> Acesso em: 17/11/2008 - “Os Pais de Barros e a Imperial Cidade de São Paulo”. In Informativo Arquivo Histórico Municipal, São Paulo: PMSP/SMC/DPH, Disponível em: <http://www.arquivohistorico.sp.gov.br> Acesso em: $02 / 05 / 2009$ - "São Paulo antigo: plantas da cidade”, in Informativo Arquivo Histórico Municipal, São Paulo: PMSP/SMC/DPH, 4 (20): set-out/2008. Disponível em: <http://www.arquivohistorico.sp.gov.br> Acesso em: 22/05/2009

CASTELLUCCI, Aldrin A. S. - "Flutuações econômicas, crise política e greve geral na Bahia da Primeira República”. In Revista Brasileira de História, v.25, n.50. São Paulo, jul/dez 2005. Disponível em: <http://www.redalyc.uaemex.mx> Acesso em: 03/09/2009

CONPRESP/DPH/SMC/PMSP - Resolução 22/2002. Disponível em: 
<http://www.prefeitura.sp.gov.br/cidade/secretarias/cultura/conpresp> Acesso em: 23/10/2007

GALESI, René e CAMPOS, Candido Malta - “Edifício Japurá: pioneiro na aplicação do conceito de 'unité d'habitation' de Le Corbusier no Brasil”. In Portal Vitruvius, Arquitextos, $\mathrm{n}^{\circ}$ 031, dez/2002. Disponível em:

<http://www.vitruvius.com.br/arquitextos> Acesso em: 27/10/2009

LE GOFF, Jacques - "A nova sociedade urbana”, in O apogeu da cidade medieval, São Paulo: Martins Fontes, 1992. Disponível em: <http://www.gruoups.google.com.br/group/digitalsource>Acesso em 17/05/2009

MAKINO, Miyoko - “Ornamentação do Museu Paulista para o Primeiro Centenário: construção de identidade nacional na década de 1920”. In Anais do Museu Paulista, v. 10-11, no 11, São Paulo: Museu Paulista/USP, 2003. Disponível em: <http://redalyc.uaemex.mx/redalyc/html> Acesso em: 15/06/2007

MENDES, Ricardo - "Táxi - veículos de aluguel em São Paulo (1892-1930) e os marcos regulatórios”. In Informativo Arquivo Histórico Municipal, São Paulo: PMSP/SMC/DPH, 3 (13): jul/ago 2007. Disponível em: <http://www.arquivohistorico.sp.gov.br> Acesso em: 27/10/2009

OLIVEIRA, Cecília Helena Salles de - "Museu Paulista: espaço de evocação do passado e reflexão sobre a história" in Anais do Museu Paulista, v. 10-11, n 11, São Paulo: Museu Paulista/USP, 2003. Disponível em: <http://redalyc.uaemex.mx/redalyc/html> Acesso em: 15/06/2007

PIRES, Walter - “Arquivo Aguirra. Fonte documental sobre a formação territorial de São Paulo”, in Anais do Museu Paulista, v. 10-11, n 11, São Paulo: Museu Paulista/USP, 2003. Disponível em: <http://redalyc.uaemex.mx/redalyc/html> Acesso em: 17/11/2008

SCHWARCZ, Lilia Moritz - "Espetáculo da miscigenação", in Estudos Avançados, São Paulo, v. 8, n. 20, 1994. Disponível em: <http://www.scielo.br/scielo> Acesso em: 15/06/2007

SEMPLA - Histórico Demográfico do Município de São Paulo. Disponível em: <http://sempla.prefeitura.sp.gov.br/historico> Acesso em: 18/11/2009

VASCONCELOS, Maria da Penha e RODRIGUES, Jaime - “A fotografia como instrumento de trabalho do higienista (São Paulo, primeira metade do século XX)”. In História, Ciência e Saúde - Manguinhos, v.13, n.2, Rio de Janeiro, 
abr/jun 2006. Disponível em: <http://www.scielo.br/scielo> Acesso em: 23/11/2009

WISSENBACH, Maria Cristina Cortez - Bexiga. Referências afro-brasileiras no processo de urbanização de São Paulo (1870-1930), Relatório de pesquisa e de atividades para a FAPESP, Pós-doutorado, IFCH/UNICAMP, 2002. Disponível em: <http://www.unicamp.br/cecult/relat_tina.rtf> Acesso em: 17/04/2006 